\title{
Groundwater Flow and Tritium Migration from the SRS Old Burial Ground to Four Mile Branch
}

by

G. P. Flach

Westinghouse Savannah River Company

Savannah River Site

Aiken, South Carolina 29808

\section{MASTER}

DOE Contract No. DE-AC09-89SR18035

This paper was prepared in connection with work done under the above contract number with the U.S.

Department of Energy. By acceptance of this paper, the publisher and/or recipient acknowledges the U.S. Government's right to retain a nonexclusive, royalty-free license in and to any copyright covering this paper, along with the right to reproduce and to authorize others to reproduce all or part of the copyrighted paper. 
Groundwater Flow and Tritium Migration from the SRS Old Burial Ground to Fourmile Branch (U)

G. P. Flach, L. L. Hamm, M. K. Harris, P. A. Thayer, J. S. Haselow and A. D. Smits

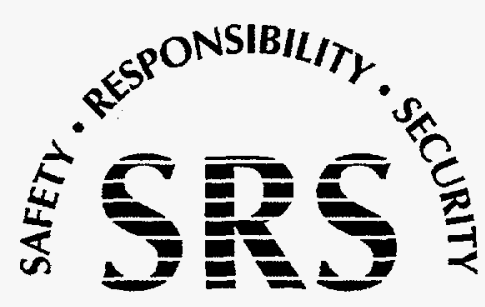




\section{DISCLAIMER}

This report was prepared as an account of work sponsored by an agency of the United States Government. Neither the United States Government nor any agency thereof, nor any of their employees, makes any warranty, express or implied, or assumes any legal liability or responsibility for the accuracy, completeness, or usefulness of any information, apparatus, product, or process disclosed, or represents that its use would not infringe privately owned rights. Reference herein to any specific commercial product, process, or service by trade name, trademark, manufacturer, or otherwise does not necessarily constitute or imply its endorsement, recommendation, or favoring by the United States Government or any agency thereof. The views and opinions of authors expressed herein do not necessarily state or reflect those of the United States Government or any agency thereof.

This report has been reproduced directly from the best available copy.

Available to DOE and DOE contractors from the Office of Scientific and Technical Information, P.O. Box 62, Oak Ridge, TN 37831; prices available from (615) 576-8401.

Available to the public from the National Technical Information Service, U.S. Department of Commerce; 5285 Port Royal Road, Springfield, VA 22161. 


\section{DISCLAMMER}

Portions of this document may be illegible in electronic image products. Images are produced from the best available original document. 
Groundwater Flow and Tritium Migration from the SRS Old Burial Ground to Fourmile Branch (U)

G. P. Flach, L. L. Hamm, M. K. Harris, P. A. Thayer, J. S. Haselow and A. D. Smits

Publication Date: April, 1996

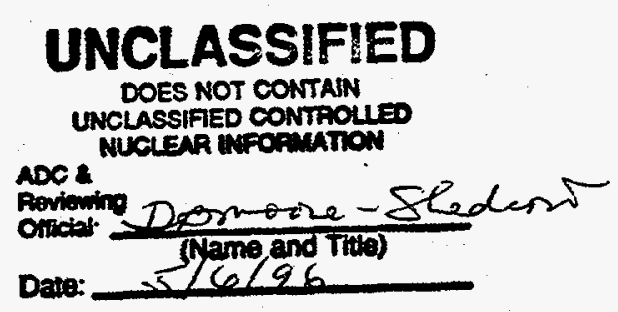

Westinghouse Savannah River Company Savannah River Site

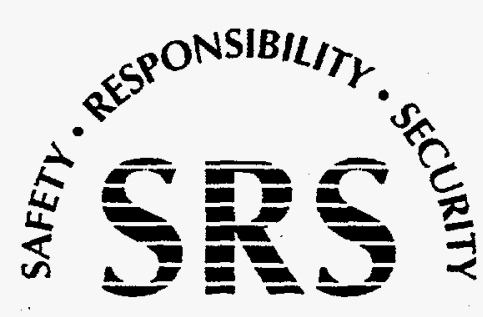
Aiken, SC 29808 
Groundwater Flow and Tritium Migration from the SRS Old Burial Ground to Fourmile Branch (U)

Authentication and Approvals:

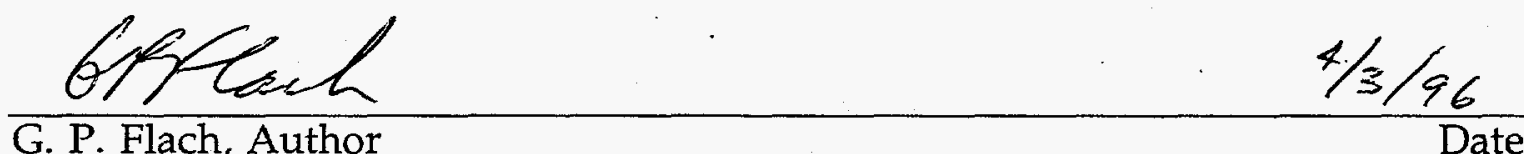

G. P. Flach, Author

Date

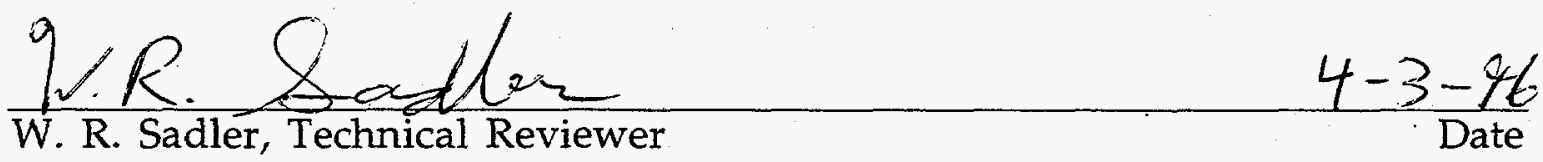

DBrnore-Sedur $5 / 6 / 96$ D. B. Moore-Shedrow, Manager, Environmental Sciences Section 


\section{Executive Summary}

The objectives of this investigation are twofold. The initial goal is to devise and demonstrate a technique for directly incorporating fine-scale lithologic data into heterogeneous hydraulic conductivity fields, for improved groundwater flow and contaminant transport model accuracy. The ultimate goal is to rigorously simulate past and future tritium migration from the SRS Old Burial Ground towards Fourmile Branch, to better understand the effects of various remediation alternatives such as no action and capping.

Large-scale variability in hydraulic conductivity is usually the main influence on field-scale groundwater flow patterns and dispersive transport, following the relative locations of recharge and discharge areas. Incorporating realistic hydraulic conductivity heterogeneity into flow and transport models is paramount to accurate simulations, particularly for contaminant migration. Sediment lithologic descriptions and geophysical logs typically offer finer spatial resolution, and therefore more potential information about heterogeneity, than other site characterization data.

In this study, a technique for generating a fine-scale, heterogeneous, threedimensional hydraulic conductivity field from sediment lithologic descriptions is presented. The approach involves creating a threedimensional, fine-scale representation of mud (silt + clay) fraction using a "stratified" interpolation algorithm. Mud fraction is then translated into horizontal and vertical conductivity using direct correlations derived from measured data and inverse groundwater flow modeling. Lastly, the fine-scale conductivity fields are averaged to create a coarser grid for use in groundwater flow and transport modeling.

The approach is demonstrated using a variably-saturated, finite-element groundwater flow model of the SRS Old Burial Ground. For this application, the technique improves estimates of large-scale flow patterns and dispersive transport, compared to a conventional approach for generating conductivity fields. The conductivity fields mimic actual lithologic data providing a more realistic picture of subsurface heterogeneity. Field-observed, preferential pathways for contaminant migration are replicated in the simulations without the need to artificially create zones of high conductivity.

In addition, a detailed, three-dimensional contaminant transport model of tritium migration from the Old Burial Ground to Fourmile Branch is developed. The transport model uses the groundwater velocity field from the flow model, and a detailed tritium source term. The tritium source varies spatially and temporally, and is reconstructed from burial and operations 
records. The model rigorously tracks and accounts for all tritium from burial through ultimate discharge to Fourmile Branch or decay. Transport simulations reproduce historical tritium discharges to Fourmile Branch and provide a more reliable forecast of future migration compared to previous analyses.

The total amount of tritium buried in the Old Burial Ground from approximately 1955 through 1972 is estimated to be 288 grams or 2.8 million Curies (decay-uncorrected). As of 1995, we estimate that $49 \%$ of this amount has decayed within waste forms, $45 \%$ has been released to the vadose zone, and $6 \%$ remains in waste forms. The estimated peak release rate to the vadose zone occurred in 1961 and has declined to $4 \%$ of the maximum in 1995. Spent melt crucibles appear to release tritium to the vadose zone at a much higher rate than other waste forms, on average. In the context of a first-order leaching and decay model, the leaching constant for spent-melts is about $0.341 \mathrm{yr}^{-1}$ compared to $0.029 \mathrm{yr}^{-1}$ for other waste forms, on average. Overall, $61 \%$ of the tritium inventory recorded in the COBRA database is buried in the west end of the Old Burial Ground and 39\% in the east end. However, $97 \%$ of the spent melts lie.in the east end.

The peak amount of tritium in the groundwater likely occurred in about $1972(600,000 \mathrm{Ci})$ and has declined to $41 \%$ of this maximum in 1995 . The tritium flux to Fourmile Branch is estimated to have peaked at about $4500 \mathrm{Ci}$ per year in 1992 (see figure below). A significant decline is expected in the near future without remediation. Simulated tritium plumes indicate that the source of tritium discharge to Fourmile Branch to-date is entirely from sources buried in the west end of the burial ground. The overall behavior of the predicted plumes is reasonably consistent with monitoring data.

The effects of capping the Old Burial Ground with a hypothetical, very low permeability cover are also shown in the figure. Code simulations indicate that tritium discharge to Fourmile Branch will be reduced by no more than about 300 Curies per year compared to uncapped conditions. The effect is small compared to the present discharge rate of about 4500 Curies per year. The reason is that most of the tritium originally present in solid radioactive waste burials has either decayed or migrated to groundwater below the water table. Tritium already in the groundwater is largely unaffected by capping. 


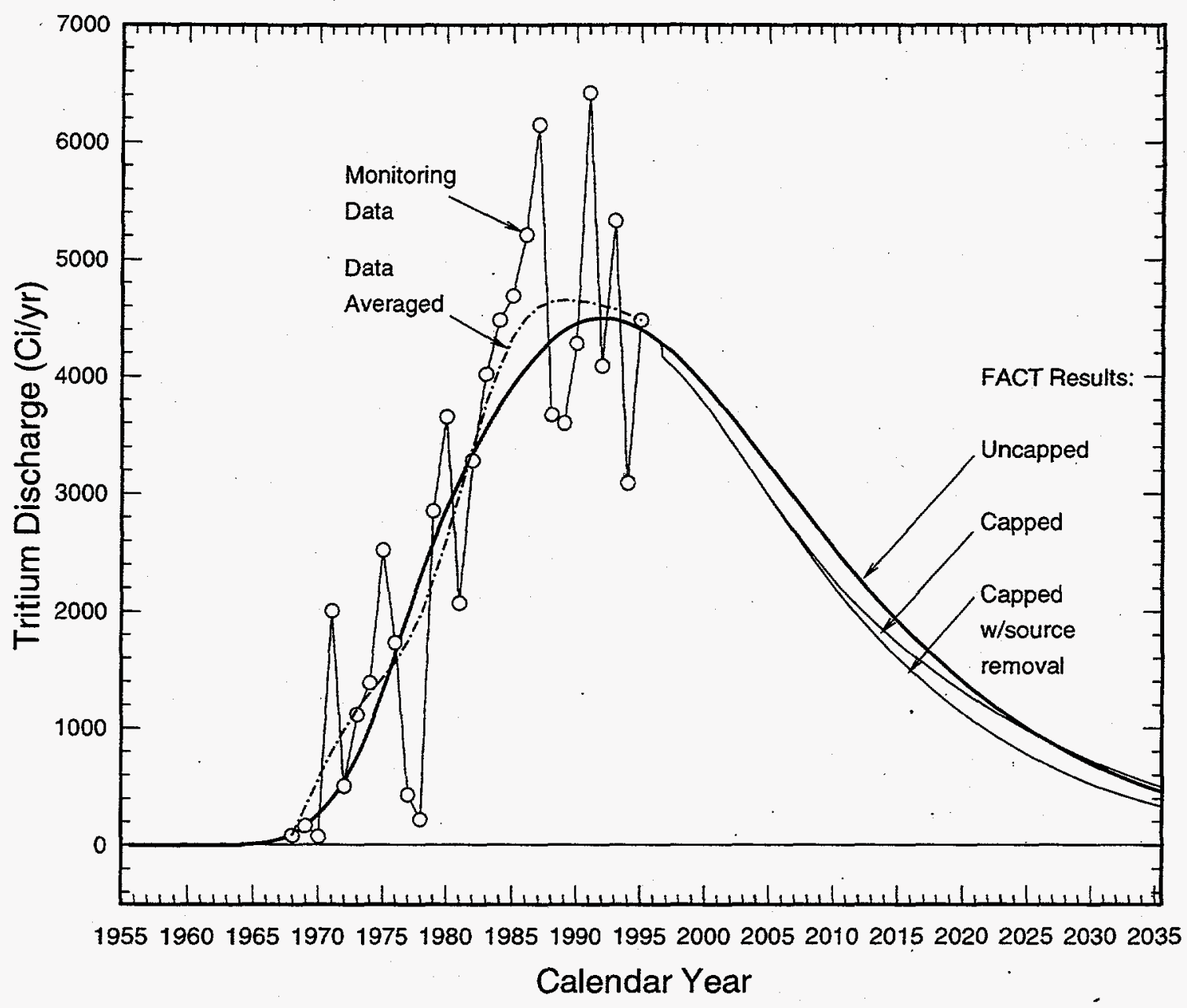




\section{Contents}

Executive Summary ..........................................................................................ii

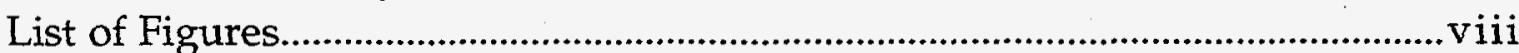

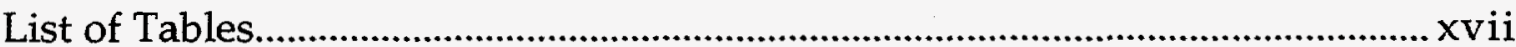

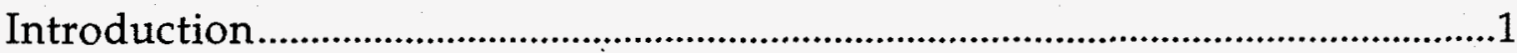

Characterizing hydrogeologic heterogeneity using lithologic data...................1

Simulating past and future Old Burial Ground tritium migration .................2

Report organization ....................................................................................................

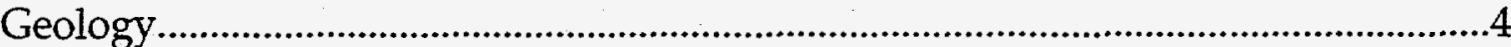

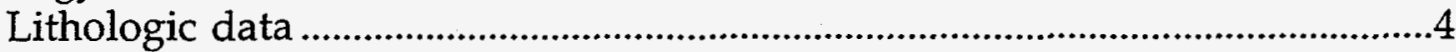

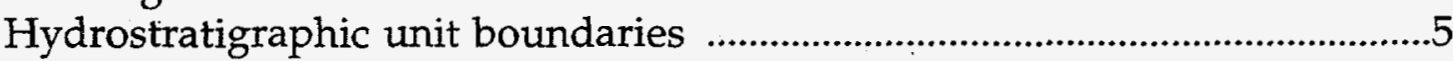

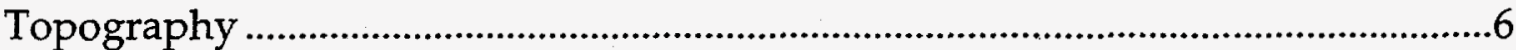

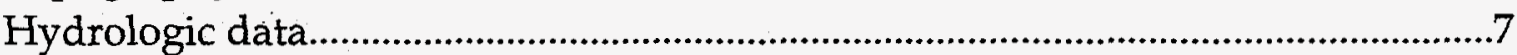

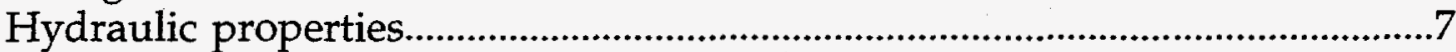

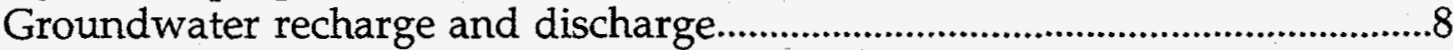

Hydraulic head data and potentiometric surfaces .................................................

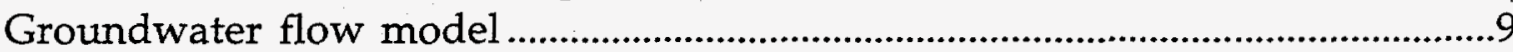

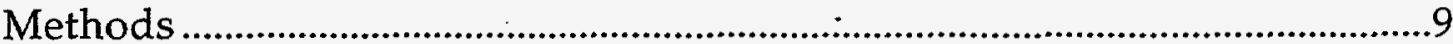

Three-dimensional interpolation of mud fraction data ............................10

Correlation of mud fraction to hydrologic properties ..................................11

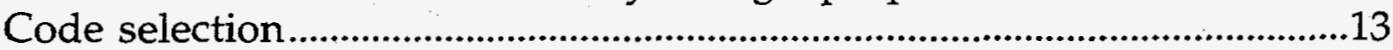

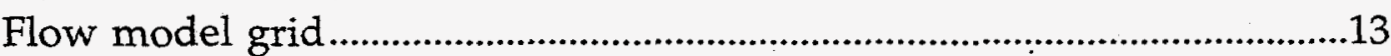

Transfer of hydrologic properties to flow model grid..................................14

Recharge and drain boundary conditions .....................................................15

Prescribed head and no flow boundary conditions .......................................17

Soil characteristic curves.............................................................................18

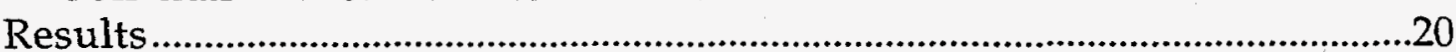

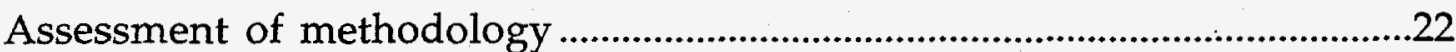

Flow modeling conclusions ............................................................................24

Tritium source characterization ...........................................................................24

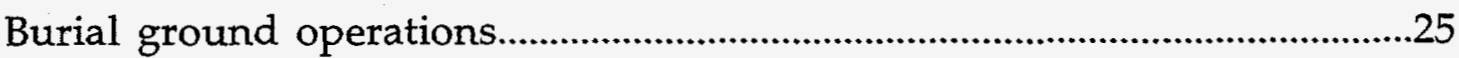

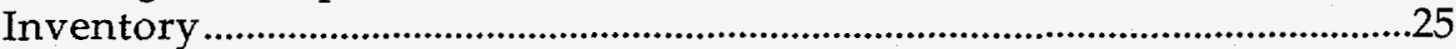

Waste form release mechanisms and rates....................................................26

Source term model.......................................................................................27

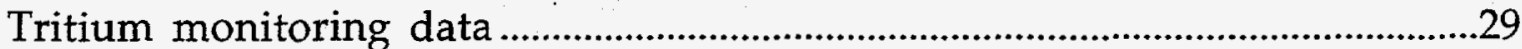

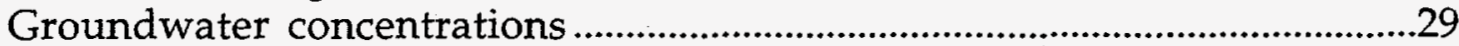

Discharge rate at Fourmile Branch ……............................................................

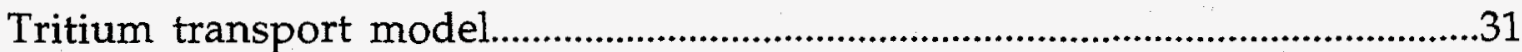

Transport parameters and calibration................................................................

Base case results and discussion .....................................................................32

No action results (reproduce past and predict no action future)...............32

Effect of capping... 


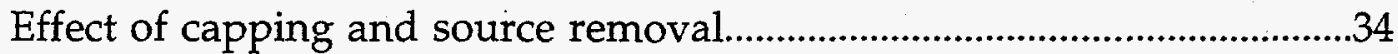

Sensitivity case results and discussion....................................................34

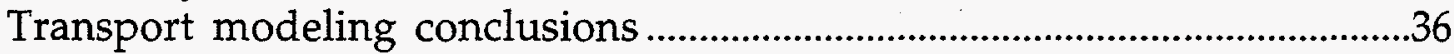

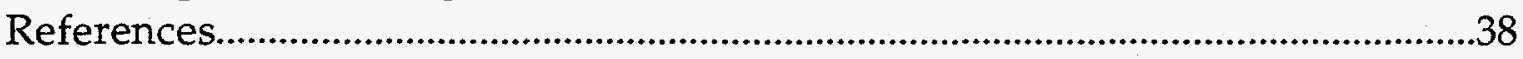

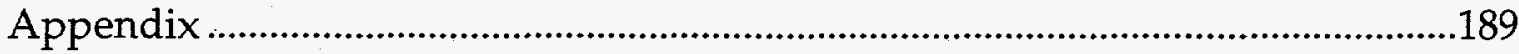




\section{List of Figures}

1 Location map of the Old Burial Ground showing the flow model domain and available sediment lithologic descriptions from 84 wells.

2 Lithostratigraphic and hydrostratigraphic nomenclature at the SRS (modified from Aadland et al., 1995)

3 Lithostratigraphic and hydrostratigraphic cross-section A-A' (Fig. 1)

4 Mud fraction probability distribution based on the cores listed in Table 2 .

5 Structure contour map for the top of the "tan clay" confining zone (feet above mean sea level); dots indicate locations where the "tan clay" confining zone is inferred to crop out

6 Thickness map for the "tan clay" confining zone (feet)

7 Structure contour map for the top of the Gordon confining unit (feet above mean sea level).

8 Thickness map for the Gordon confining unit (feet) .50

9 Structure contour map for the top of the Meyers Branch confining system (feet above mean sea level).

10 Contour plot of ground elevation (feet above mean sea level)

11 Water retention data and models for sandy sediment. .53

12 Water retention data and models for clayey sediment. .54

13 U. S. Geological Survey stream flow rate monitoring stations on Fourmile Branch.

14 Head contour map for the "upper" aquifer zone within the Upper Three Runs aquifer (feet above mean sea level). + denotes data, $\oplus$ pseudo-data.

15. Head contour map for the "lower" aquifer zone within the Upper Three Runs aquifer (feet above mean sea level). + denotes data, $\oplus$ pseudo-data 
16 Head contour map for the Gordon aquifer (feet above mean sea level). + denotes data, $\oplus$ pseudo-data.

17 Flowchart summarizing the methodology for creating a heterogeneous conductivity field from sediment lithologic descriptions

18 Flowchart summarizing the process chosen for creating a groundwater flow model using sediment core lithologic descriptions

19 Three-dimensional mud fraction variation within the flow model domain (Fig. 1) generated with EarthVision ${ }^{\circledR}$ 's minimum tension 3D gridding algorithm and a vertical influence factor of 0.01 . A total of 12,626 mud fraction values from the 84 cores depicted in Figure 1 were interpolated

20 Horizontal conductivity as a function of mud fraction. The data represent laboratory measurements of conductivity from undisturbed core samples and mud fraction measured by sieve analysis. The stair-step correlation line is the result of comparison to the data shown and inverse flow modeling.

21 Vertical conductivity as a function of mud fraction. The data represent laboratory measurements of conductivity from undisturbed core samples and mud fraction measured by sieve analysis. The stair-step correlation line is the result of comparison to the data shown and inverse flow modeling

22 Process for translating the fine-scale mud fraction grid into the coarser-scale flow model conductivity grid

23 Three-dimensional horizontal conductivity distribution on the flow model finite-element mesh

24 Three-dimensional vertical conductivity distribution on the flow model finite-element mesh

25 Combined recharge/drain boundary condition applied over the entire top surface of the flow model finite-element mesh.

26 Simulated three-dimensional hydraulic head distribution

27 Contour map of vertically-averaged "upper" aquifer zone hydraulic head 
28 Contour map of vertically-averaged "lower" aquifer zone hydraulic head

29 Contour map of vertically-averaged Gordon aquifer hydraulic head.

30 Contour map of "upper" aquifer zone head residuals 72

31 Contour map of "lower" aquifer zone head residuals.................................73

32 Contour map of Gordon aquifer head residuals.........................................74

33 Simulated three-dimensional saturation distribution................................75

$34 \quad$ Simulated recharge distribution..................................................................76

- 35 Three-dimensional pathlines originating from the Old Burial Ground projected onto a two-dimensional plane overlaying water saturation

36 Three-dimensional pathlines projected onto cross-section B-B in Figure 35 with mud fraction as the background .......................................78

37 Estimated pre-COBRA tritium burials relative to 1961 ...............................79

38 Estimated total annual tritium burials of all forms to the Old Burial Ground

39a Normalized spatial variation in tritium burials of all forms for the calendar year 1961

$39 \mathrm{~b}$ Normalized spatial variation in tritium burials of all forms for the calendar year 1962

39c Normalized spatial variation in tritium burials of all forms for the calendar year 1963

39d Normalized spatial variation in tritium burials of all forms for the calendar year 1964

39 e Normalized spatial variation in tritium burials of all forms for the calendar year 1965

$39 \mathrm{f}$ Normalized spatial variation in tritium burials of all forms for the calendar year 1966

$39 \mathrm{~g}$ Normalized spatial variation in tritium burials of all forms for the calendar year 1967 
$39 \mathrm{~h}$ Normalized spatial variation in tritium burials of all forms for the calendar year 1968

39i Normalized spatial variation in tritium burials of all forms for the calendar year 1969

$39 \mathrm{j}$ Normalized spatial variation in tritium burials of all forms for the calendar year 1970

40 Cumulative Curie content and volume of percolate for tritium lysimeter

41 Relative tritium release rate and cumulative released amount for spent melt waste forms

42 Relative tritium release rate and cumulative released amount for non-spent melt waste forms

43 Estimated total annual tritium burials of spent melts to the Old Burial Ground

44 Estimated total annual tritium burials of non-spent melts to the Old Burial Ground

45a Normalized spatial variation in tritium burials of spent melts for the calendar year 1961

45b Normalized spatial variation in tritium burials of spent melts for the calendar year 1962

45c Normalized spatial variation in tritium burials of spent melts for the calendar year 1963

45d Normalized spatial variation in tritium burials of spent melts for the calendar year 1964

45e Normalized spatial variation in tritium burials of spent melts for the calendar year 1965

$45 \mathrm{f}$ Normalized spatial variation in tritium burials of spent melts for the calendar year 1966

$45 \mathrm{~g}$ Normalized spatial variation in tritium burials of spent melts for the calendar year 1967

45h Normalized spatial variation in tritium burials of spent melts for the calendar year 1968 
$45 \mathrm{i}$ Normalized spatial variation in tritium burials of spent melts for the calendar year 1969

45j Normalized spatial variation in tritium burials of spent melts for the calendar year 1970 .

46a Normalized spatial variation in tritium burials of non-spent melts for the calendar year 1961

46b Normalized spatial variation in tritium burials of non-spent melts for the calendar year 1962.

46c Normalized spatial variation in tritium burials of non-spent melts for the calendar year 1963.

46d Normalized spatial variation in tritium burials of non-spent melts for the calendar year 1964.

46e Normalized spatial variation in tritium burials of non-spent melts for the calendar year 1965 .

$46 \mathrm{f}$ Normalized spatial variation in tritium burials of non-spent melts for the calendar year 1966.

$46 \mathrm{~g}$ Normalized spatial variation in tritium burials of non-spent melts for the calendar year 1967.

46h Normalized spatial variation in tritium burials of non-spent melts for the calendar year 1968 .

46i Normalized spatial variation in tritium burials of non-spent melts for the calendar year 1969.

46j Normalized spatial variation in tritium burials of non-spent melts for the calendar year 1970 .

47 Tritium accounting through time with respect to buried waste forms with $\mathrm{k}=0.029 \mathrm{yr}^{-1}$ for non-spent melts.

48 Tritium release rates with $\mathrm{k}=0.029 \mathrm{yr}^{-1}$ for non-spent melts

49 Locations of "upper" aquifer zone tritium concentration data for 1994

50 Two-dimensional contour plot of tritium concentration in the "upper" aquifer zone for 1994 based on monitoring data

51 Transient tritium concentration data for well BG-56 .120 
52 Annual tritium discharges to Fourmile Branch from the Old Burial Ground.

53 Tritium accounting through time with respect to the amount released to the vadose zone $\left(\mathrm{k}=0.029 \mathrm{yr}^{-1}\right.$ for non-spent melts, $23 \%$ porosity, $65 \mathrm{ft}$ dispersivity)

54 Comparison of predicted and measured tritium discharges to Fourmile Branch $\left(\mathrm{k}=0.029 \mathrm{yr}^{-1}\right.$ for non-spent melts, $23 \%$ porosity, $65 \mathrm{ft}$ dispersivity)

55 Simulated three-dimensional tritium concentration distribution for 1995

56a Contour plot of predicted "upper" aquifer zone tritium concentration for 1960 .

56b Contour plot of predicted "upper" aquifer zone tritium concentration for 1965 .

56c Contour plot of predicted "upper" aquifer zone tritium concentration for 1970 .

56d Contour plot of predicted "upper" aquifer zone tritium concentration for 1975 .

56e Contour plot of predicted "upper" aquifer zone tritium concentration for 1980 .

$56 \mathrm{f}$ Contour plot of predicted "upper" aquifer zone tritium concentration for 1985 .

$56 \mathrm{~g}$ Contour plot of predicted "upper" aquifer zone tritium concentration for 1990 .

$56 \mathrm{~h}$ Contour plot of predicted "upper" aquifer zone tritium concentration for 1995 .

$56 \mathrm{i}$ Contour plot of predicted "upper" aquifer zone tritium concentration for 2000

56j Contour plot of predicted "upper" aquifer zone tritium concentration for 2005 .

$56 \mathrm{k}$ Contour plot of predicted "upper" aquifer zone tritium concentration for 2010 . 
561 Contour plot of predicted "upper" aquifer zone tritium concentration for 2015.

57a Contour plot of predicted "lower" aquifer zone tritium concentration for 1960 .

$57 \mathrm{~b}$ Contour plot of predicted "lower" aquifer zone tritium concentration for 1965 .

57c Contour plot of predicted "lower" aquifer zone tritium concentration for 1970 .

57d Contour plot of predicted "lower" aquifer zone tritium concentration for 1975 .

57e Contour plot of predicted "lower" aquifer zone tritium concentration for 1980 .

$57 f$ Contour plot of predicted "lower" aquifer zone tritium concentration for 1985 .

$57 \mathrm{~g}$ Contour plot of predicted "lower" aquifer zone tritium concentration for 1990 .

$57 \mathrm{~h}$ Contour plot of predicted "lower" aquifer zone tritium concentration for 1995 .

$57 \mathrm{i}$ Contour plot of predicted "lower" aquifer zone tritium concentration for 2000 .

$57 \mathrm{j}$ Contour plot of predicted "lower" aquifer zone tritium concentration for 2005 .

$57 \mathrm{k}$ Contour plot of predicted "lower" aquifer zone tritium concentration for 2010 .

571 Contour plot of predicted "lower" aquifer zone tritium concentration for 2015 .

58a Contour plot of predicted Gordon aquifer tritium concentration for 1960

$58 \mathrm{~b}$ Contour plot of predicted Gordon aquifer tritium concentration for 1965

58c Contour plot of predicted Gordon aquifer tritium concentration for 1970 
$58 \mathrm{~d}$ Contour plot of predicted Gordon aquifer tritium concentration for 1975

$58 \mathrm{e}$ Contour plot of predicted Gordon aquifer tritium concentration for 1980

$58 \mathrm{f}$ Contour plot of predicted Gordon aquifer tritium concentration for 1985

$58 \mathrm{~g}$ Contour plot of predicted Gordon aquifer tritium concentration for 1990

$58 \mathrm{~h}$ Contour plot of predicted Gordon aquifer tritium concentration for 1995.

58i Contour plot of predicted Gordon aquifer tritium concentration for 2000

$58 \mathrm{j}$ Contour plot of predicted Gordon aquifer tritium concentration for 2005

$58 \mathrm{k}$ Contour plot of predicted Gordon aquifer tritium concentration for 2010

581 Contour plot of predicted Gordon aquifer tritium concentration for 2015

59 Simulated seepage face tritium concentrations for 1995

60 Map of low conductivity surface elements corresponding to engineered surfaces

61 Estimated effect of capping on tritium discharges to Fourmile Branch $\left(\mathrm{k}=0.029 \mathrm{yr}^{-1}\right.$ for non-spent melts, $23 \%$ porosity, $65 \mathrm{ft}$ dispersivity)

62 Tritium accounting through time with respect to buried waste form with $\mathrm{k}=0.17 \mathrm{yr}^{-1}$ for non-spent melts

63 Tritium release rates with $\mathrm{k}=0.17 \mathrm{yr}^{-1}$ for non-spent melts .165

64 Tritium accounting through time with respect to the amount released to the vadose zone $\left(\mathrm{k}=0.17 \mathrm{yr}^{-1}\right.$ for non-spent melts, $45 \%$ porosity, $300 \mathrm{ft}$ dispersivity) 
65 Comparison of predicted and measured tritium discharges to Fourmile Branch for no action and capping remedial alternatives $\left(\mathrm{k}=0.17 \mathrm{yr}^{-1}\right.$ for non-spent melts, $45 \%$ porosity, 300 $\mathrm{ft}$ dispersivity) 


\section{List of Tables}

1 Listing of core descriptions considered for the present study .................168

2 Cores used to define mud fraction probability distribution ....................169

3. Average mud fractions for sand, clayey sand, sandy clay and clay.........169

$4 \quad$ Hydrostratigraphic unit boundaries from Thayer et al. (1993)...............170

5 Fourmile Branch flow rates for date of minimum station 3 flow rate by water year.

6 Hydrologic parameters used in Old Burial Ground groundwater flow model

7 Summary of hydraulic head residuals between model and data (ft)

8 Documents relevant to tritium transport from the Old Burial Ground to Fourmile Branch

9 Outline of literature information relevant to tritium transport from the Old Burial Ground to Fourmile Branch

10 Comparison of groundwater tritium inventories estimated from monitoring data and predicted from transport modeling (base and sensitivity cases) 


\section{Introduction}

The objectives of this investigation are twofold. The initial goal is to devise and demonstrate a technique for directly incorporating fine-scale lithologic data into heterogeneous hydraulic conductivity fields, for improved groundwater flow and contaminant transport model accuracy. The ultimate goal is to rigorously simulate past and future tritium migration from the SRS Old Burial Ground towards Fourmile Branch, in order to better understand the effects of various remediation alternatives such as no action and capping.

The first phase of the project involves groundwater flow simulation using a fine-scale heterogeneous conductivity field, and is a feasibility study. Based on the success of the initial phase, tritium migration from the Old Burial Ground is then simulated in a second phase, using the groundwater flow field from the first phase.

\section{Characterizing hydrogeologic heterogeneity using lithologic data}

Groundwater flow and contaminant transport can be affected by many physical, chemical and microbiological factors. After the relative locations of recharge and discharge areas, large-scale variability in hydraulic conductivity is the dominant influence on field-scale groundwater flow patterns and dispersive transport, with other factors introducing second-order effects (Brusseau, 1994). Incorporating hydraulic conductivity heterogeneity into flow and transport models is paramount to accurate simulations in most situations, particularly for contaminant migration. For example, Poeter and Gaylord (1990) show how large-scale aquifer heterogeneity can influence, and in some cases dominate, contaminant transport at the DOE Hanford site through a series of computer simulations. They illustrate how a small but continuous geologic feature having one order magnitude higher conductivity than the surrounding media can have a dramatic effect on contaminant transport behavior (i.e.; greatly reduced transport times due to preferential pathways for groundwater flow).

Sediment lithologic descriptions and down-hole geophysical logs offer finer spatial resolution, and therefore more potential information about heterogeneity, than most other site characterization data. However, these data do not provide direct information about hydrogeologic properties and are viewed as "soft" hydrogeologic information. The emergence of powerful computing resources has enabled the routine use of spatially-dense, threedimensional (3D) "soft" hydrogeologic data in 3D flow and transport models. Methods for supplementing "hard" hydrogeologic data (e.g., pumping tests, 
slug tests, laboratory conductivity data), conventionally used to develop flow and transport models, with spatially-dense, $3 \mathrm{D}$ "soft" hydrogeologic data are a focus of this study. The integration of hard and soft data should reduce model uncertainty and the amount of field-scale hydrogeologic data required, because the available data is more fully utilized.

The SRS Old Burial Ground was selected as the waste site for development of a non-traditional groundwater flow and transport model that can guide ongoing RCRA and CERCLA surface and groundwater investigations (Fig. 1). The burial ground received solid radioactive and hazardous waste from approximately 1952 to 1972 . Primary groundwater contaminants include tritium, trichloroethylene (TCE) and tetrachloroethylene (PCE). The area is undergoing intense hydrogeological characterization for RCRA and CERCLA investigations (Westinghouse Savannah River Co., 1995). Hydrogeological characterization indicates that contaminant plumes emanating from the burial ground are migrating primarily to the south toward Fourmile Branch within the Upper Three Runs aquifer (Fig. 2). Although contaminant transport takes place mainly within this single hydrostratigraphic unit, the aquifer exhibits considerable field-scale heterogeneity, as indicated by a wideranging lithology and physical characteristics depicted in Figure 3. This heterogeneity and the present site focus on contaminant transport provide strong motivation for applying a technique that incorporates spatially-dense, 3D, "soft" hydrogeologic data into model conductivity fields.

Lithologic foot-by-foot descriptions of continuous drill core from 135 boreholes are available in the vicinity of the Old Burial Ground (Fig. 1). The fine vertical resolution of these data provide a great deal of information about aquifer heterogeneity. Tritium contamination provides an ideal tracer for assessment of the methodology (tritium is a conservative and unretarded contaminant). Three decades of tritium monitoring data are available in the form of groundwater concentrations and discharge rates to Fourmile Branch.

\section{Simulating past and future Old Burial Ground tritium migration}

Effective assessment of various remediation alternatives requires the capability of accurately and rigorously forecasting future tritium releases to Fourmile Branch. Existing models and analyses do not fully provide this capability due to deficiencies in modeling the source of tritium.

GeoTrans (1992) divided the Old Burial Ground into four zones, and within each zone applied a constant mass flux to the water table from 1952 to 1990. After 1990 the source was assumed to decay and the flux declined accordingly. The initial mass flux was derived by multiplying the maximum observed concentration in point of compliance (POC) wells over 15 quarters by the prevailing recharge rate. The assumed source results in grossly 
underestimated forecasts of tritium discharge rates to Fourmile Branch. For example, the predicted 1994 release to Fourmile Branch is only 13 Curies, two orders of magnitude lower than the monitoring data (3090 Curies; Arnett, et al., 1995). The effects of capping or other remedial alternatives were not assessed.

Looney et al. (1993) observed that annual Old Burial Ground tritium releases to Fourmile Branch between 1982 and 1992 were approximately constant with an average value of about 4500 Curies. They postulated that annual discharges would remain at about $4500 \mathrm{Ci}$ until at least the year 2010 . The basis for this estimate appears to be an assumption that the roughly constant annual discharges are the result of a steady flux to the water table from the burial ground vadose zone. In a follow-up study, Ref. 6 estimated the average annual tritium release since 1984 to be $5300 \mathrm{Ci}$ and the travel time between the burial ground and outcrop point to be 10 years. They assumed the relatively constant discharge rate to be the result of a constant tritium flux to the water table. Capping was predicted to essentially eliminate tritium releases to Fourmile Branch after 10 years had elapsed. Relative to the earlier forecast for no-action $(4500 \mathrm{Ci} / \mathrm{yr}$.), capping was therefore predicted to have a large impact. Ref. 2 supported this prediction with an $87 \%$ tritium flux reduction as a result of capping the Old Burial Ground. However, they did not predict tritium releases to Fourmile Branch with or without capping. The main weakness of these studies is the assumption of a constant tritium flux to the water table. More likely, leaching and radioactive decay continually deplete the source and result in a decreasing flux to the water table with time (burials ceased in 1972).

A detailed reconstruction of tritium burials and fine-scale, threedimensional, finite-element modeling are performed in the present study. By explicitly modeling the tritium inventory and associated waste release mechanisms, significantly improved and defensible forecasts are achieved for evaluating remedial alternatives.

\section{Report organization}

The remainder of this report, 1) summarizes the lithologic, hydrogeologic, topographic and hydrologic data used to construct a groundwater flow model of the Old Burial Ground, 2) details the development of the Old Burial Ground flow model through incorporation of detailed lithologic data, 3) develops a detailed tritium source model from burial records, operational history, and lysimeter tests, 4) summarizes tritium monitoring data, and 5) develops a transport model simulating past and future tritium migration from the Old Burial Ground to Fourmile Branch for no remedial action and two bounding capping scenarios. 


\section{Geology}

The study area is located in the Upper Atlantic Coastal Plain physiographic province in southwestern South Carolina (Fig. 1). The SRS is underlain by a southeast-dipping wedge of unconsolidated and consolidated sediment consisting of sand, mud, limestone, and gravel, which range in age from early Late Cretaceous (Cenomanian) to Holocene (Fallaw and Price, 1995). This study involves the Tertiary-aged sediment, principally the Eocene to Miocene sequence (Fig. 2). The Gordon aquifer, the Gordon confining unit and the Upper Three Runs aquifer are the hydrostratigraphic units of interest (Fig. 2).

The Gordon aquifer consists of unconsolidated sand and clayey sand of the Congaree Formation and, where present, the sandy parts of the underlying Williamsburg Formation. The sand is yellowish to grayish orange in color and is subrounded to well-rounded, moderately to poorly sorted, and medium to coarse-grained. The Gordon confining unit separates the Gordon and Upper Three Runs aquifers and is lithostratigraphically equivalent to the Warley Hill Formation. This unit is composed of fine-grained, silty and clayey sand, sandy clay and clay. The clay is stiff to hard and sometimes fissile. Zones of silica-cemented sand and clay, and calcareous sediment are common.

The Upper Three Runs aquifer includes all sediment from the ground surface to the top of the Gordon confining unit. Lithostratigraphically, the Upper Three Runs aquifer includes the Upland unit, Tobacco Road Sand, Dry Branch Formation, and Santee Formation (Fig. 2). The Upper Three Runs aquifer is divided by the "tan clay" confining zone into a "lower" aquifer zone and "upper" aquifer zone. The "lower" aquifer zone consists of a variety of lithologies including terrigenous sand and clay, calcareous skeletal sand, and sandy limestone. The "tan clay" confining zone contains light-yellowish tan to orange clay and sandy clay interbedded with clayey sand and sand. The "upper" aquifer zone is characterized by sand and clayey sand with minor intercalated clay layers. Gravelly layers are common.

\section{Lithologic data}

Data from detailed, foot-by-foot descriptions of continuous drill core from 84 boreholes are utilized in this study to define hydrologic properties. Figure 1 shows the areal distribution of the data in relation to the burial ground and Table 1 provides a listing. The core descriptions include data on core recovery; degree of induration; color; sedimentary structures; volume percent terrigenous gravel, sand, and mud; maximum and modal size of the terrigenous fraction; volume percent carbonate gravel, sand, and mud; volume percent cement; volume percent total carbonate sediment; sediment/rock name; grain sorting; volume percent porosity and dominant 
type; fossil types; and volume percent accessory constituents, including muscovite, glauconite, lignite, sulfides, and heavy minerals (Ref. 9). Rock/sediment name is deduced from down-hole geophysical logs for intervals of no recovery. The core description for OFS-3SB is provided in the appendix as a typical example (Table A1). From the overall core description, volume-percent terrigenous mud data are used to generate $3 \mathrm{D}$ conductivity fields.

For intervals of no core recovery, mud fraction values are defined as part of this investigation for sand (SD), clayey sand (CLSD), sandy clay (SDCL) and clay (CL), based on a statistical analysis of the intervals for which core was recovered. Mud content is first estimated based on gamma ray response (i.e., no recovery intervals are designated SD, CLSD, SDCL or CL). The cores listed in Table 2 are then used to generate a probability distribution function for mud content as shown in Figure 4. Table 3 lists the average mud fraction within the mud fraction ranges 0-25\% (SD), 25-50\% (CLSD), 50-75\% (SDCL) and $75-100 \%$ (CL) for the distribution shown in Figure 4. Note that the averages differ somewhat from the midpoints of the intervals. The values in Table 3 define mud fraction in no recovery intervals.

At least 135 core descriptions were available within the General Separations Area at the beginning of the study. These included the 127 cores listed in Ref. 8 and recent cores OFS-2SB through OFS-5SB, BGO-3A and BGO-51AA. Core descriptions known to be of good quality are listed in Table 1. Of these, 84 were used to grid mud fraction as indicated in the table. Those not used were too distant from the Old Burial Ground or not available in electronic form. Note that 30 cores lie within the groundwater flow model domain.

\section{Hydrostratigraphic unit boundaries}

Hydrostratigraphic surfaces are used to define the vertical discretization of the finite-element mesh and to compute the average properties of a unit. Ref. 8 produced an extensive series of hydrostratigraphic maps of the General Separations Area. The hydrostratigraphic unit boundaries or "picks" contained in Ref. 8 are adopted for the present study and listed in Table 4 .

Hydrostratigraphic surfaces in this study are created by triangulating the scattered data in Table 4 using the optimizing algorithm of Renka (1984) and choosing a linear basis function for each triangle. The two-dimensional interpolated surface honors each hydrostratigraphic pick and is continuous, but its derivatives are generally discontinuous along triangle edges and corners. Higher order basis functions, up to fifth order, were tested. Due to the irregularly distributed locations of the data, linear basis functions produce the best overall results from a physical perspective. The structure contour 
map for the top of the "tan clay" confining zone is presented in Figure 5; Figure 6 shows the thickness of the "tan clay" confining zone. The top of the "tan clay" confining zone appears to crop out near the confluence of the Farea outfall and Fourmile Branch based on the elevations of these features (dots in Fig. 5). Analogous plots are presented in Figures 7 and 8 for the Gordon confining unit. The structure contour map of the top of the Meyers Branch confining system is presented in Figure 9.

\section{Topography}

Ground elevations are available from U. S. Geological Survey Digital Elevation Model (DEM) data (U: S. Geological Survey, 1993a) and site topographic maps (Map 3302 and Environmental Restoration Dept. drawing GB0599). The Old Burial Ground lies within the New Ellenton SW 7.5minute series quadrangle. The associated DEM file contains ground elevation data in feet above mean sea level in Universal Transverse Mercator (UTM) coordinates on a uniform 30 meter by 30 meter grid. The data are transformed to site coordinates as follows:

- DEM import: Use Earthvision ${ }^{\circledR}$ v.1.2 (Dynamics Graphics Inc.) to import the USGS file into an EarthVision ${ }^{\circledR}$ binary 2D grid file.

- Grid export: Using the ev_export module of Earthvision ${ }^{\circledR}$, create an ASCII file of columnar $(x, y, z)$ data.

- UTM to geographic coordinates transformation: Use Earthvision ${ }^{\circledR}$ to convert the $(x, y)$ data from UTM coordinates to geographic coordinates (latitude-longitude).

- Geographic to site coordinates transformation: Use the SRPCOOR algorithm (Looney et al., 1987b) to convert the $(x, y)$ data from geographic to site coordinates.

Ground elevation is used to define the top surface of the finite-element mesh and thereby the head elevations at which surface drainage occurs. Therefore, accurate topography is especially important at seepage faces and stream channels. Interpolation of DEM data that straddle a stream channel typically results in an over-estimated elevation at the stream. To remedy this problem, the DEM data are augmented with $(x, y, z)$ stream coordinates digitized from site topographical maps to ensure the surface elevation grid is consistent with stream elevations. Stream coordinates and elevations for Fourmile Branch are taken from Map 3302 using the digitizer module of Earthvision ${ }^{\circledR}$. Because the map contour interval is 2 feet, stream elevations are available in 2 foot increments. Elevations for stream coordinates not on a contour line are defined by linear interpolation. Data for the F-area old and 
new outfalls are taken from Environmental Restoration Department drawing GB0599, which has a one foot contour interval. Again, elevations for stream coordinates not on a contour line are defined by linear interpolation. Stream elevation data resulting from this process are given in the appendix (Table A2).

A two-dimensional surface defining ground elevation in SRS site coordinates is created by approximating the scattered data using the minimum tension gridding algorithm implemented in EarthVision ${ }^{\circledR}$ v2.0. Figure 10 illustrates the resulting contour plot. The grid resolution is 100 feet by 100 feet, which is approximately the spacing of the DEM data.

\section{Hydrologic data}

Hydrologic data utilized for constructing the Old Burial Ground flow model are presented in this section. The hydrologic data needed include hydraulic conductivities, effective porosity, specific storage, soil characteristic curves, recharge, surface discharge and hydraulic head.

\section{Hydraulic properties}

Aadland et al. (1995) summarize the results of slug and pumping tests performed within the General Separations Area. Laboratory measurements of horizontal and vertical conductivity for sediments at the SRS are available from a number of sources (Bledsoe et al., 1990; Riha, 1993; Kegley et al., 1994; Aadland et al., 1995; Ref. 1). The conductivity data most useful to this study are those having an accompanying mud fraction measurement (e.g., sieve data). These data are listed in Table A3 (appendix) and used to correlate horizontal and vertical conductivities to mud fraction.

Effective porosity measurements for SRS soils range from 10 to $30 \%$ (Looney et al., 1987a) for the range of sand to clay, respectively. Looney et al. (1987a) recommend an average value of $20 \%$. Ref. 3 assumed a $20 \%$ effective porosity for aquifers and $30 \%$ for aquitards in their groundwater flow model of the General Separations Area.

Specific storage has no effect on steady-state groundwater flow, the focus of this study, but is required code input. Specific storage is defined as $S_{s}=\rho g(\alpha+\eta \beta)$ where $\alpha$ is soil compressibility, $\eta$ is porosity and $\beta$ is fluid compressibility. Based on Freeze and Cherry (1979, Table 2.5), a soil compressibility of $10^{-8} \mathrm{~m}^{2} / \mathrm{N}$ may be assumed for sand and $10^{-7} \mathrm{~m}^{2} / \mathrm{N}$ for clay. The resulting specific storages become $3 \times 10^{-5} \mathrm{ft}^{-1}$ for sand and $3 \times 10^{-4} \mathrm{ft}^{-1}$ for clay. 
Soil characteristic curves for relative permeability and water retention are needed to model unsaturated groundwater flow above the water table. A small set of water retention data from nearby $\mathrm{M}$-area is available for defining the water retention relationship (O'Brien and Gere Engineers, Inc., 1991). The data for $\mathrm{M}$-area sediment samples composed mainly of sand and gravel are plotted in Figure 11; Figure 12 shows the data for clayey sediment samples. Relative permeability data were not acquired by O'Brien and Gere Engineers, Inc. (1991). During technical review of this report, we became aware of soil property data for General Separations Area sediment samples (Ref. 10). These data are not used in the present study.

\section{Groundwater recharge and discharge}

Looney et al. (1987a) recommend an average annual recharge rate of 15 in/yr for the SRS. This value is supported by Parizek and Root (1986).

Stream baseflow can be estimated from U. S. Geological Survey monitoring station data at the locations shown schematically in Figure 13. Assuming runoff is negligible during low flow periods, baseflow between stations is the difference between station flow rates during these periods. Table 5 lists the stream flow rates for the date of the minimum flow rate at station 3 for the water year shown (U. S. Geological Survey, 1980-1993). Between stations 3 and 4 , the difference in average flow rate is $1.22 \mathrm{ft}^{3} / \mathrm{s}$ or $2.71 \times 10^{-4} \mathrm{ft}^{2} / \mathrm{s}$ over the $4500 \mathrm{ft}$ distance between stations. However, - the uncertainty in this estimate is very large; the sample standard deviation is 1.1 $\mathrm{ft}^{3} / \mathrm{s}$. The difference in average flow rates between stations 3 and 4 for all times (not just low flow) from water years 1973 through 1992 is $0.92 \mathrm{ft}^{3} / \mathrm{s}$ for a linear rate of $2.04 \times 10^{-4} \mathrm{ft}^{2} / \mathrm{s}$. The uncertainty in this estimate is not stated by the U. S. Geological Survey (1980-1993) but is relatively small because many years of daily values have been averaged. This latter result includes the effects of runoff in addition to baseflow, and yet is smaller than the previous estimate based on minimum flows. This nonphysical relationship is presumably a reflection of the large uncertainty in the $1.22 \mathrm{ft}^{3} / \mathrm{s}$ value that must be too high. Actual baseflow should not exceed $0.92 \mathrm{ft}^{3} / \mathrm{s}$ between stations 3 and 4.

\section{Hydraulic head data and potentiometric surfaces}

Well hydraulic head data and contour maps are needed to define boundary conditions and calibrate the groundwater flow model. Well inventory and field measurement data are available electronically from the Environmental Monitoring Section (EMS) database. The data are periodically published; for example see ESH-EMS-930261 "Environmental Protection Department's Well Inventory (U)" and ESH-EMS-930097 "The Savannah 
River Site's Groundwater Monitoring Program; Second Quarter 1993 (U)". Well coordinates and screen top and bottom elevations are contained in the well inventory database. Head data are taken from the EMS field measurement database. Head data from Burial Ground grid wells south of the Old Burial Ground taken in June 1994 are also available (Amidon, 1994a). The data are assigned to an aquifer unit based on the hydrostratigraphic picks summarized in the GSAWELLS.XLS file received from M. Amidon (1994b) (Ref. 8). Time-averaged well head data for the "upper" aquifer zone, "lower" aquifer zone and Gordon aquifers are tabulated in the appendix (Tables A4 through A6).

In the appendix, Tables A7 through A9 summarize the time-averaged data used to create head contour plots for the "upper" aquifer zone, "lower" aquifer zone and Gordon aquifers, respectively. Stream elevation data (Table A2) supplement well head data (Tables A4 through A6) wherever an aquifer zone or unit is exposed at the ground surface. Pseudo data were created for the "upper" and "lower" aquifer zones to correct deficiencies in the contour plots on the south side of Fourmile Branch which resulted from a lack of data in that region. Specifically, data were added on the south side of Fourmile Branch to raise hydraulic head to the point where the contour lines are approximately symmetric about the stream. Head contour plots created using EarthVision ${ }^{\circledR}$ are presented in Figures 14 through 16.

\section{Groundwater flow model}

Methods for generating a heterogeneous, 3D hydraulic conductivity field from estimated mud fraction (silt + clay sized material) are presented in this section. The techniques are then demonstrated for a finite-element groundwater flow model of the SRS Old Burial Ground. Model results are presented and discussed, and the methodology is assessed.

\section{Methods}

Figure 17 outlines the methodology used to generate heterogeneous hydraulic conductivity fields from lithologic descriptions. Mud fraction data are initially interpolated onto a 3D grid using an algorithm that preserves sharp vertical contrasts. The mud fraction grid is translated into horizontal $\left(\mathrm{K}_{\mathrm{h}}\right)$ and vertical conductivity $\left(\mathrm{K}_{\mathrm{v}}\right)$ fields using direct "correlations" of conductivity to mud fraction. Laboratory conductivity measurements on whole core and quantitative grain-size distribution data from sieve analyses are utilized as a guide for the development of the correlations. On the first pass, the correlations are based strictly on laboratory conductivity data. On subsequent passes, inverse flow modeling also influences the correlations through a feedback loop; that is, the correlations are adjusted to achieve better 
flow model results when compared to hydraulic head data and other targets. The fine-scale conductivity fields are transferred to the coarser groundwater flow model grid through arithmetic $\left(\mathrm{K}_{\mathrm{h}}\right)$ and harmonic $\left(\mathrm{K}_{\mathrm{V}}\right)$ averaging. The process is discussed below in more detail. Figure 18 illustrates the process for creating the overall groundwater flow model, including the steps shown in Figure 17.

\section{Three-dimensional interpolation of mud fraction data}

Boman et al. (1995) have demonstrated that relatively simple interpolation concepts can be used to successfully generate heterogeneous $3 \mathrm{D}$ conductivity fields for flow and transport models. They employed what can be termed successive inverse distance weighting (IDW) interpolation by horizontal layer, or "stratified IDW" in their terminology. The idea is to conceptually divide the subsurface into horizontal layers of uniform thickness. These layers are arbitrary and do not necessarily conform to formation boundaries or other geologic features. Within each layer, twodimensional inverse distance weighting is independently applied using only the subset of borehole data lying within that layer. With this stratified IDW approach, smoothing occurs in the horizontal plane while sharp vertical contrasts (if present) are preserved.

A similar effect can be achieved using the minimum-tension spline interpolation algorithm implemented in the EarthVision ${ }^{\circledR}$ software package (Version 2.0, Dynamics Graphics, Inc., Alameda, CA), by selecting a very small "vertical influence factor." The vertical influence factor is applied to data lying above and below the horizontal plane passing through the interpolation node of interest. By choosing a very small value, almost no weight is given to data above or below each interpolation node relative to data in the horizontal plane of that node. EarthVision ${ }^{\circledR}$ is chosen to generate a 3D mud fraction field from scattered core lithologic data.

Mud fraction values from the 84 boreholes depicted in Figure 1 are interpolated onto a $23 \times 23 \times 251$ grid of dimensions $11,000 \mathrm{ft} \times 11,000 \mathrm{ft} \times 250$ $\mathrm{ft}$. The areal dimensions correspond to the solid line box in Figure 1. The areal resolution is uniformly set to $500 \mathrm{ft}$ while the vertical resolution is uniformly set to $1 \mathrm{ft}$, the same as the raw data. In all, 12,626 mud fraction data points are employed. A vertical influence factor of 0.01 is selected to preserve vertical contrasts. Interpolated values of mud fraction are constrained to fall within the physical range of 0 to 1 to remedy under- and over-shoots between or beyond data. In a few locations lacking measured data, pseudo-data are added as control points to minimize extrapolation errors. Figure 19 illustrates the portion of the resulting 3D mud fraction representation contained within the flow model areal domain (dashed box in Figure 1) and cropped by the ground surface. The lithologic heterogeneity of the subsurface 
hydrostratigraphic units is easily recognized and corresponds with handcontoured lithofacies maps and cross-sections (e.g., Fig. 3) (Ref. 8). Note that the interpolation process preserves horizontal stratification of the sediments.

\section{Correlation of mud fraction to hydrologic properties}

Laboratory measurements of horizontal and vertical conductivity for sediments at the SRS (Table A3) are plotted as a function of mud fraction in Figures 20 and 21. The data show an overall trend of decreasing conductivity with increasing mud percentage, but exhibit a great deal of scatter. Estimated mud fractions are available for the entire length of all cores, whereas, sieve data are available primarily for transmissive well screen zones (10 to $30 \mathrm{ft}$ ). In order to utilize the most data, a direct correlation between conductivity and estimated mud fraction is chosen instead of a grain-size distribution data correlation. Kegley et al. (1994) and Lahm et al. (1995) demonstrated success using this approach. The initial conductivity-mud fraction correlations are developed based solely on the laboratory conductivity data. However, the resulting flow simulation does not generally match hydraulic head, average recharge and stream gain targets adequately. As such, the correlations are iteratively perturbed to improve flow results while maintaining consistency with the laboratory data. The stair-step functions shown in Figures 20 and 21 are the final outcome of this iterative flow model calibration process.

A stair-step functional form is chosen for two reasons. The interpolated mud fraction field shown in Figure 19 contains numerous regions where under- and over-shoots in the initial fit have been clipped by EarthVision ${ }^{\circledR}$ to lie within the specified physical range of zero to one. These initial under- and over-shoots are located between sparsely distributed data and at the fringes of the data (i.e., extrapolation errors). As a result the interpolated mud fraction field contains an artificially large number of values at or near zero and one. The flat portions of the stair-step functions tend to alleviate this problem by assigning the same conductivity to all mud fraction values in the vicinity of zero and one, respectively. Secondly, the stair-step functions provide the analyst very simple and direct control over conductivity values during model calibration when compared to other potential functional forms. A disadvantage of the correlations is the presence of unrealistically abrupt changes in conductivity. This deficiency is not serious however, because the abruptness is effectively smoothed out when the conductivity fields are translated to the coarser flow model grid through the averaging process discussed below.

In order to reduce the degrees of freedom during calibration to a reasonable number, restrictions are invoked early in the process. For the SRS burial ground application, the correlations were constrained such that the ratio of horizontal to vertical conductivity is three. This conductivity 
anisotropy ratio is suggested by the laboratory data of Bledsoe et al. (1990). Also, the junctions between steps of $0.1,0.25$, and 0.50 were held constant during final calibration. These choices yield four independent horizontal conductivity parameters spanning the ranges of 0.0 to $0.1,0.1$ to $0.25,0.25$ to 0.50 , and 0.50 to 1.0 . The flow model calibration process in this study is analogous to that performed for a conventional "layer cake" model, with horizontal conductivities within mud fraction ranges taking the place of hydrostratigraphic unit conductivities (or zonal conductivities within a unit).

Initially, properties were assigned throughout the model domain based solely on mud fraction, without regard to hydrostratigraphic unit or zone or depth of the sediments. However, preliminary groundwater flow simulations exhibited insufficient head differences. across the Gordon confining unit in comparison to field data. Also, this approach does not account for known variations in properties with depth for the same mud fraction. For example, sand in the Gordon aquifer tends to be coarser-grained than in the Upper Three Runs aquifer, and therefore more permeable (Ref. 8).

The three-dimensional mud fraction representation presented in Figure 19 apparently does not have enough horizontal continuity in the collection of clay layers at the elevation of the Gordon confining unit to produce a competent confining unit. Some of the core locations shown in Figure 1 do not have data at the depth of the Gordon confining unit. The areal data density may be insufficient to properly connect clay layers between cores. Accounting for dip would probably result in better continuity. Because fitting was done with a one foot vertical resolution, the dip would have to be known accurately to achieve a significantly better mud fraction representation. Another contributing factor may be that clay in the Gordon confining unit has a lower conductivity than clay at other depths. This idea is suggested by the Ref. 3 model. In the Ref. 3 model encompassing the F- and H-area seepage basins, the Gordon confining unit is about an order of magnitude less conductive than the "tan clay" confining zone. Assuming the average mud fraction is similar for both confining units, the Gordon confining unit would have a lower conductivity.

To accommodate these deficiencies, a hybrid approach is taken. Above the Gordon confining unit, conductivities are assigned by lithology (mud fraction). Below the top of the Gordon confining unit, conductivities are assigned by hydrostratigraphic unit (i.e. Gordon confining unit or Gordon aquifer). Porosity and specific storage are assigned by mud fraction everywhere. This approach accounts for property variation with depth by having separate functions above and below the top of the Gordon confining unit. Basically, detailed lithologic data is being employed in those areas where complex heterogeneities are known to exist, while the layered modeling approach is applied to areas suspected to be fairly uniform in the areal directions. It also compensates for insufficient continuity in Gordon 
confining unit mud fraction by assigning properties by unit rather than mud fraction at that depth.

\section{Code selection}

FACT, a variably-saturated 3D finite-element flow and transport code developed by SRTC, is chosen for flow simulation. FACT is a derivative of the SAFT3D and VAM3DCG codes developed by HydroGeoLogic, Inc. (Huyakorn et al., 1991; Huyakorn and Panday, 1992). The code solves Richard's equations. FACT assumes the hydraulic conductivity tensor is aligned with the principle axes of the porous media and its diagonal values are specified at the element centroids. In this study the porous media is assumed to be isotropic in the two horizontal directions, but anisotropic with respect to its vertical direction.

\section{Flow model grid}

To demonstrate the methodology, a finite-element mesh is selected that differs in extent, orientation, and spatial resolution from that of the mud fraction grid generated above. The extent of the flow model and its orientation relative to the mud fraction grid are shown in Figure 1 (dashed versus solid boxes). The mesh is rotated clockwise by an angle of $\theta=36.48^{\circ}$ relative to SRS site coordinates. The origin of the model coordinate system is located at 74,150 $\mathrm{N}$ and 50,000 $\mathrm{E}$ in SRS site coordinates. The coordinate transformation from model coordinates $(x, y)$ to site coordinates $(N, E)$ is

$$
\begin{aligned}
& N=-x \sin \theta+y \cos \theta+74,150 \mathrm{ft} \\
& E=x \cos \theta+y \sin \theta+50,000 \mathrm{ft}
\end{aligned}
$$

This domain captures the entire groundwater flow field from the Old Burial Ground to surface discharge at Fourmile Branch (Fig. 1), and aligns model boundaries with monitoring well clusters for increased boundary condition accuracy. The areal dimensions are $6760 \mathrm{ft} \times 5070 \mathrm{ft}$. Eight-noded rectangular "brick" elements, that are restricted to deformations only in the vertical direction, are used. The elemental dimensions in the areal extent are uniformly set to $130 \mathrm{ft}$ per side. The top of the mesh conforms to the ground surface while the bottom of the mesh conforms to the top of the highly competent Meyers Branch confining system (Fig. 2). In addition, two of the intermediate elemental surfaces coincide with the top of the "tan clay" confining zone and the top of the Gordon confining unit, respectively. Mesh nodal elevations for these stratigraphic surfaces are computed using linear triangular interpolation, while bicubic spline interpolation is used for the topographic surface. Vertical mesh refinement between adjoining surfaces is 
performed by quadratic vertical interpolation at each areal grid point. Element heights range from about 1 to $20 \mathrm{ft}$ with an average value around 10 $\mathrm{ft}$. The overall nodal dimensions of the flow grid are $53 \times 40 \times 30(52 \times 39 \times 29$ elements). The selected flow grid is much coarser than the mud fraction grid in the vertical direction, but finer in the areal directions.

\section{Transfer of hydrologic properties to flow model grid}

The process for translating the 3D mud fraction grid shown in Figure 19 into "composite" elemental conductivity defined over the 3D flow grid involves three steps and the creation of a fine-scale intermediate grid. First, while maintaining the $0.3 \mathrm{~m}(1 \mathrm{ft})$ vertical resolution of the mud fraction grid, mud fraction values are interpolated onto an intermediate grid whose areal grid points coincide with the element areal centroids of the flow grid. A natural bicubic spline interpolation is performed for each horizontal layer, independently. In the next step, mud fraction values defined on the resulting fine-scale intermediate grid are translated into "local" horizontal and vertical conductivities using the correlations shown in Figures 20 and 21. In the final step, these local conductivities on the fine-scale intermediate grid are vertically averaged over each finite-element (typically ten fine-scale layers per element). Figure 22 depicts the multi-step process discussed above starting from the fine-scale grid. During this last stage, composite conductivities (horizontal and vertical) are computed based on appropriate averaging (arithmetic and harmonic, respectively) where the local conductivities are assumed to reflect horizontal layering of aquifer materials that extend over the entire areal extent of each element. For a given finite-element these composite (horizontal and vertical) conductivities are expressed by

$$
\begin{aligned}
K_{h}^{\text {comp }}=\frac{\sum_{i=i b}^{i=i t}\left(K_{h} \xi \Delta z\right)_{i}}{\sum_{i=i b}^{i=i t}(\xi \Delta z)_{i}} \\
K_{v}^{\text {comp }}=\frac{\sum_{i=i b}^{i=i t}(\xi \Delta z)_{i}}{\sum_{i=i b}^{i=i t}\left(\xi \Delta z / K_{v}\right)_{i}}
\end{aligned}
$$

where

$$
i b \equiv \text { bottom fine-scale layer contained within element }
$$




$$
\begin{aligned}
\text { it } & \equiv \text { top fine-scale layer contained within element } \\
\Delta \mathrm{z}_{\mathrm{i}} & \equiv \text { vertical height of } \mathrm{i}^{\text {th }} \text { fine-scale layer } \\
\xi_{\mathrm{i}} & \equiv \text { fraction of } \mathrm{i}^{\text {th }} \text { fine-scale layer contained within element } \\
\mathrm{K}_{\mathrm{hi}} & \equiv \text { local horizontal conductivity of } \mathrm{i}^{\text {th }} \text { fine-scale layer } \\
\mathrm{K}_{\mathrm{vi}} & \equiv \text { local vertical conductivity of } \mathrm{i}^{\text {th }} \text { fine-scale layer } \\
\mathrm{K}_{\mathrm{h}}^{\mathrm{comp}} & \equiv \text { composite horizontal conductivity of element } \\
\mathrm{K}_{\mathrm{v}}^{\text {comp }} & \equiv \text { composite vertical conductivity of element }
\end{aligned}
$$

The resulting horizontal and vertical conductivity fields are shown in Figures 23 and 24 . In these figures, a wire-frame mesh outlines the finiteelement flow grid and the finite-element centroidal conductivity values have been linearly interpolated. Both conductivity fields are highly heterogeneous in the upper part of the aquifer system. At the ground surface low conductivity zones in the top layer of elements in the upper far corner of each grid are defined in order to model low infiltration zones corresponding to industrial and capped areas.

\section{$\underline{\text { Recharge and drain boundary conditions }}$}

The present methodology permits low permeability zones to crop out at the surface as shown in Figure 19 at several locations and reflected in Figures 23 and 24. These detailed features, together with a complex, a priori unknown seepline, make conventional manual specification of model recharge and drainage conditions a complicated and tedious process. Where low permeability zones crop out, a lower infiltration rate should be specified compared to the average recharge to prevent model hydraulic heads from significantly exceeding ground elevation. Physically, most rainfall runs off these low conductivity areas resulting in low infiltration and heads not exceeding ground elevation. Drain boundary conditions are needed wherever hydraulic head exceeds the ground elevation so that groundwater may properly discharge at the surface under these head conditions. Conversely, recharge boundary conditions should be specified wherever hydraulic head is below the ground surface. Because surface hydraulic heads are not generally known beforehand, a manual trial-and-error process is conventionally required to determine whether a drain or recharge boundary condition is appropriate, and if a recharge condition is needed, the appropriate local infiltration rate. 
Huyakorn et al. (1986) implemented an automated process for selecting a drain versus recharge boundary condition following Neuman et al. (1974) and Rulon (1984). The procedure involves a Picard iteration strategy imbedded in the flow code that switches between boundary condition types and also reduces infiltration as a seepline is approached. With this method convergence difficulties may arise for complex terrain and additional computational overhead is required to update boundary conditions during the iteration process.

The deficiencies expressed above can be eliminated by combining the concepts of recharge and drainage into a single boundary condition. The basic idea is that locally the surface is either recharging or draining the subsurface, and there should be a continuous transition between these conditions. Infiltration should occur for negative pressure head (water level below the ground surface) and aquifer discharge should occur for positive pressure head. Also, to be consistent with the continuity needs of the NewtonRaphson iterative solver employed in FACT, the overall function representing this "combined" recharge/drain boundary condition should also be continuous in its first derivative.

Figure 25 presents a combined recharge/drain boundary condition that meets the above criteria. When the water level is well below the ground surface, recharge occurs at the maximum rate permitted locally through user specification. As the pressure head approaches zero, recharge is smoothly reduced to zero. For positive pressure head, the surface drains the aquifer at a rate proportional to the pressure head. To the left of the transition zone, the combined recharge/drain boundary condition is exactly the same as the conventional recharge boundary condition. To the right of the transition zone, the combined recharge/drain boundary condition is identical to a typical drain boundary condition. The transition zone reflects a non-linear region connecting two limiting linear boundary conditions. The mathematical formulation for this function, as shown in Figure 25, is

$$
Q_{c}=\left\{\begin{array}{ccc}
Q_{R} & \text { for } & \psi \leq \frac{3}{2} \hat{\psi} \\
\frac{Q_{R}}{8}\left[7-2 x-x^{2}\right] & \text { for } & \frac{3}{2} \hat{\psi}<\psi<\frac{1}{2} \hat{\psi} \\
-M_{D} \psi & \text { for } & \frac{1}{2} \hat{\psi} \leq \psi
\end{array}\right.
$$

where

$$
\begin{gathered}
\psi=\mathrm{h}-\mathrm{z}_{\mathrm{c}} \\
\mathrm{Q}_{\mathrm{R}}=\mathrm{A}_{\mathrm{D}} \mathrm{R}_{\max }
\end{gathered}
$$




$$
\begin{gathered}
M_{D} \equiv A_{D}\left(\frac{K_{V}}{b}\right)_{D} \\
x \equiv 2\left(\frac{\hat{\psi}-\psi}{\hat{\psi}}\right) \\
\hat{\psi} \equiv-\frac{Q_{R}}{M_{D}}
\end{gathered}
$$

and

$$
\begin{aligned}
& \mathrm{h} \equiv \text { hydraulic head } \\
& \mathrm{z}_{\mathrm{C}} \equiv \text { elevation of combination boundary condition } \\
& \mathrm{Q}_{\mathrm{C}} \equiv \begin{array}{l}
\text { volumetric source or sink from combined effects of recharge } \\
\text { and drainage }
\end{array} \\
& \mathrm{R}_{\max } \equiv \text { maximum local recharge }(17 \mathrm{in} / \text { year in this study) } \\
& \psi \equiv \text { pressure head } \\
& \mathrm{A}_{\mathrm{D}} \equiv \text { area available for recharge and drainage (geometric area) } \\
&\left(\mathrm{K}_{\mathrm{V}} / \mathrm{b}\right)_{\mathrm{D}} \equiv \text { leakance coefficient }\left(18.2 \mathrm{yr}^{-1}\right. \text { in this study) }
\end{aligned}
$$

Equation (3) represents a two parameter model requiring the specification of the maximum local recharge rate $\left(R_{\max }\right)$ and the surface leakance coefficient $(\mathrm{K} / \mathrm{b})_{\mathrm{D}}$. The level of ponding along a seepage face can be adjusted by varying the magnitude of the surface leakance coefficient. Equation (3) is applied at every node over the entire top surface of the flow model in the present study. Seepage faces are automatically established during the iterative solution of the non-linear flow and boundary condition equations.

\section{Prescribed head and no flow boundary conditions}

Hydraulic head boundary conditions are derived from the head contour maps presented in Figures 14 through 16. Head is prescribed over each of the four vertical faces of the flow mesh, except for the ground surface nodes to avoid a conflict with the recharge/drain boundary condition just described. First, the head in each aquifer is defined at each node along all four edges of the areal flow mesh. This step is performed using Figures 14 through 16 and bicubic spline interpolation. Then, the hydrostratigraphic surfaces presented in Figures 5 through 9 are used to assign a specific head value to each node 
along the four vertical faces. For nodes residing completely within an aquifer (or aquifer zone), the head is assigned directly. For nodes within a confining unit, the head is interpolated between adjoining aquifer units and/or zones.

Monitoring wells indicate that groundwater flow through the burial ground starts at the east end and flows westward. Approaching the west end, the flow turns southward and discharges to the old F-area effluent ditch and Fourmile Branch near their confluence. The water table beneath the eastern end of the Old Burial Ground is relatively flat making it difficult to reproduce the known groundwater flow direction near the prescribed head boundaries in the model. No flow boundary conditions replace prescribed heads at selected "upper" aquifer zone nodes near the northeast corner of the mesh, to ensure westward flow at the east end of the burial ground. Specifically, these nodes are those on the east side with $j \geq 25$ and those along the north side with $\mathrm{i} \geq 45$. Without these modifications, groundwater tends to flow out the northeast corner of the model domain in conflict with the monitoring data. Ideally, the boundaries of the model would extend well beyond the east end of the Old Burial Ground in order to reduce the detrimental near-field effects of prescribed head boundary conditions. However, the main focus of this study is the southwest corner tritium plume and creating a fine-scale conductivity field. Expanding the model while keeping the number of computational nodes fixed would result in a coarser mesh and compromise modeling of the southwest plume.

\section{Soil characteristic curves}

The van Genuchten (1980) models for soil characteristic curves have a relatively strong physical basis and have been widely used. The equations for water retention-capillary suction and relative permeability are

$$
\begin{gathered}
S_{\mathrm{e}}=\frac{1}{\left[1+(-\alpha \psi) \frac{1}{1-\mathrm{m}}\right]^{\mathrm{m}}} \\
\mathrm{k}_{\mathrm{r}}=\mathrm{S}_{\mathrm{e}}^{1 / 2}\left[1-\left(1-\mathrm{S}_{\mathrm{e}}^{\frac{1}{\mathrm{~m}}}\right)^{\mathrm{m}}\right]^{2}
\end{gathered}
$$

where $S_{e}$ is the effective saturation defined by

$$
S_{e}=\frac{S_{w}-S_{w r}}{1-S_{w r}}
$$


and

$$
\begin{aligned}
\psi & \equiv \text { pressure head (negative in the unsaturated zone) } \\
\mathrm{k}_{\mathrm{r}} & \equiv \text { relative permeability } \\
\mathrm{S}_{\mathrm{W}} & \equiv \text { liquid saturation } \\
\mathrm{S}_{\mathrm{Wr}} & \equiv \text { residual saturation (may be empirically determined) } \\
\alpha, \mathrm{m} & \equiv \text { additional empirical parameters }
\end{aligned}
$$

Figures 11 and 12 show a fit of the M-area data of O'Brien and Gere Engineers, Inc. (1991) using the van Genuchten (1980) functional form. In Figure 11 for sandy samples, $\mathrm{S}_{\mathrm{wr}}=0.15, \alpha=3.68 \mathrm{ft}^{-1}$ and $\mathrm{m}=0.183$. For the clayey sample data in Figure 12, $\mathrm{S}_{\mathrm{wr}}=0.614, \alpha=1.28 \mathrm{ft}^{-1}$ and $\mathrm{m}=0.14$.

The van Genuchten form for water saturation as a function of capillary suction is continuous, but extremely abrupt at the transition between saturated and unsaturated conditions (Figures 11 and 12). This feature prevents or seriously hinders FACT code convergence to a reasonable head tolerance for this Old Burial Ground study. In addition, the relative permeability variation is also extremely abrupt and likewise contributes to convergence problems. As a remedy, the van Genuchten functional form for water retention is abandoned in favor of the less abrupt variation shown in Figures 11 and 12. Although the chosen function lacks the physical basis of the van Genuchten form, the widely scattered data are reasonably fit using this "pseudo-soil" property function. The equation defining the function is

$$
S_{w}=S_{w r}+\left(1-S_{w r}\right) e^{\alpha \psi}
$$

where

$$
\begin{aligned}
\mathrm{S}_{\mathrm{W}} & \equiv \text { liquid saturation } \\
\psi & \equiv \text { capillary suction pressure (negative in unsaturated zone) } \\
\mathrm{S}_{\mathrm{Wr}} & \equiv \text { residual saturation }(0.4) \\
\alpha & \equiv \text { empirical parameter }\left(0.07 \mathrm{ft}^{-1}\right)
\end{aligned}
$$

Likewise, the van Genuchten expression for relative permeability is discarded in favor of a less abrupt variation given by

$$
k_{r}=S_{e}^{3}
$$


where $S_{e}$ is as defined by equation (11) with $S_{w r}=0$ (i.e. $S_{e}=S_{w}$ ). Equation (13) has been proposed by Fatt and Klikoff (1959) and Verma et al. (1985) (Pruess, 1987). 'Site specific data would be needed to assess its validity for the present study.

Results

FACT groundwater flow simulation results for the Old Burial Ground are shown in Figures 26 through 36. The results were generated from the optimal conductivity fields depicted in Figures 23 and 24 and other hydrologic properties summarized in Table 6 . Figure 26 illustrates the 3D distribution of hydraulic head simulated by the flow model. Figures 27 through 29 show average hydraulic head within the "upper" aquifer zone, "lower" aquifer zone and Gordon aquifer, respectively. The root-mean-square residual between steady-state model and time-averaged measured hydraulic heads is $3.4 \mathrm{ft}$. Figures 30 through 32 illustrate head residuals in the "upper" aquifer zone, "lower" aquifer zone and Gordon aquifer, respectively. Table 7 presents summary statistics for each aquifer or aquifer zone. The appendix lists those wells inside the model domain which are used as targets (Table A10). Agreement in the Gordon aquifer is excellent. Residuals in the "upper" aquifer zone are increased, and show some spatial bias. Residuals in the central portion of the model tend to be low, and residuals in the northeast corner near the no flow boundaries are high. These biases are partly the result of an effort to achieve flow patterns more consistent with the conceptual model at the expense of higher head residuals, as discussed previously. The "lower" aquifer zone has an average head residual similar to the "upper" aquifer zone and also exhibits bias, especially in the vicinity of the H-area seepage basins and Fourmile Branch. Here the model head is low at the basin and high at Fourmile Branch.

Water saturation is shown in Figure 33 along the external faces of the mesh. A three-dimensional perspective was chosen to highlight the seepage face regions surrounding Fourmile Branch and the F-area outfall. The predicted seepline compares favorably with measured locations along Fourmile Branch.

The model recharge distribution is shown in Figure 34. Positive values represent infiltration while negative values represent drainage. The average recharge is $13.9 \mathrm{in} /$ year, which is less than the specified local maximum of 17 in/year because of the presence of seepage faces. This value is close to the 15 in/year recommended by Looney et al. (1987a). Areas of low recharge can be seen near the $\mathrm{F}$ - and $\mathrm{H}$-area seepage basins, because they were capped with low permeability materials. An area of low recharge can also be seen within the F-area separations complex due to the presence of engineered surfaces accounted for in the model. 
The total surface discharge is $1.5 \mathrm{ft}^{3} / \mathrm{s}$. The model domain contains about $5100 \mathrm{ft}$ of Fourmile Branch and the perennial portion of the F-area outfall is about $1400 \mathrm{ft}$. Assuming $2.04 \times 10^{-4} \mathrm{ft}^{2} / \mathrm{s}$ is a reasonable average linear rate based on monitoring data, baseflow does not exceed about $1.3 \mathrm{ft}^{3} / \mathrm{s}$ or 115,000 $\mathrm{ft}^{3} /$ day. Groundwater discharge along seepage faces goes towards both stream gain and evapotranspiration. Therefore, aquifer discharge should exceed stream gain and this is the case with the model.

Figure 35 shows 3D pathlines originating from the burial ground that have been projected onto a two-dimensional horizontal plane overlaying water saturation at the top surface. The pathlines start in the vadose zone at an elevation of $270 \mathrm{ft}$, corresponding to a burial depth of $20 \mathrm{ft}$ or less. The seeplines surrounding Fourmile Branch conform closely to field-observed locations. As illustrated, groundwater pathlines originating from the burial ground converge into a preferred pathway that terminates at the old F-area effluent ditch, consistent with contaminant monitoring data. In addition, local convergence of pathlines is observed in Figure 35 indicating the presence of finer-scale preferred pathways. Figure 36 shows similar 3D pathlines projected onto the cross-section B-B' in Figure 35 with mud fraction as the background. This cross-section coincides with the preferred pathway for groundwater flow from the burial ground and highlights vertical flow patterns. The example pathlines reveal a complex flow field resulting from heterogeneities incorporated into the conductivity field. Figure 36 shows that contaminant migration from the burial ground can be expected to follow multiple distinct pathways within the same aquifer, corresponding to regions of low mud content.

In a parallel effort, a conventional "layer-cake" flow model was created by assigning a uniform conductivity to each hydrostratigraphic unit. Comparison of the models revealed two advantages of the heterogeneous model. First, the models produced different large-scale flow patterns, despite yielding a similar average hydraulic head residual. As shown in Figure 35 for the heterogeneous model, groundwater flows westward in the eastern portion of the burial ground and flows southward at the west end. Westward flow through the burial ground in the heterogeneous model is caused by high mud content beneath the east end of the burial ground. Contaminant monitoring at perimeter wells confirms this overall flow pattern. The conventional "layer cake" model could not be made to behave in a similar manner using uniform layer properties, and indicated that groundwater flow is southward throughout the entire burial ground. The desired overall flow pattern could be achieved with the layer cake model by adding sufficient spatial variation to unit properties during model calibration. However, this process may be time-consuming compared to generating heterogeneity directly from mud fraction data. 
A second apparent benefit of the heterogeneous model is the presence of multiple parallel pathways available for contaminant transport, as noted above and shown in Figure 36. As discussed by Brusseau (1994) for example, contaminant dispersion is enhanced by aquifer heterogeneities at all scales. Heterogeneity produces a spatially varying velocity field that transports portions of the contaminant plume at different rates. Heterogeneity not explicitly incorporated into the flow and transport model must be accounted for through a separate mechanical dispersion term. The dispersivity value in this term is empirical and scale-dependent, and requires extensive monitoring data to define accurately. Fine-scale flow and transport models that capture as much aquifer heterogeneity as possible can reduce the magnitude and importance of the empirical dispersion term, leading to more accurate and reliable predictions. A direct, quantitative comparison of the conventional and heterogeneous models on this point was not possible, due to the significant differences in large-scale flow patterns between the models. That is, the large differences in advective behavior precluded a straightforward comparison of dispersive behavior. Qualitatively however, the heterogeneous model appeared to yield greater contaminant dispersion.

\section{Assessment of methodology}

The methodology presented here has proven effective in generating a heterogeneous conductivity field for an SRS burial ground flow and transport model. The conductivity fields mimic the actual lithologic data providing a more realistic picture of subsurface heterogeneity compared to traditional layered modeling approaches. The approach improves large-scale flow patterns and dispersive behavior compared to conventional methods. Fieldobserved, preferential pathways for contaminant migration are replicated in the model without the need to artificially create zones or channels of high conductivity. The concepts are general and can be applied to other sites. The resulting conductivity fields may be used with other finite-element or finitedifference groundwater codes. Nevertheless, improvements and extensions can and should be considered.

As evidenced by large data scatter in Figures 20 and 21 , there is much room for improvement in translating lithologic information into hydraulic conductivity. Utilizing additional information about grain size distribution would help, but the experience of Riha (1993) suggests that additional factors such as cementation, pore size distribution, bedding type, etc. should be considered as well.

It would be beneficial to incorporate laboratory conductivity measurements more directly into the process for generating a conductivity field. Presently, these data have only a weak influence on the final conductivity field through the conductivity versus mud fraction correlation 
(i.e., individual data points in Figures 20 and 21 have little effect on the correlation). The same can be said of other conductivity information, such as derived from slug and pumping tests. One solution would be to omit the mud fraction interpolation step, translate borehole mud fraction data to conductivity, augment these data with laboratory and in situ conductivity measurements, and interpolate the composite conductivity data set onto a 3D grid. Then laboratory and in situ conductivity measurements would have a strong local effect on the interpolated conductivity field, in addition to a global effect. Statistical weighting of the data based on estimated uncertainties would also improve the process.

A better understanding of the "stratified" EarthVision ${ }^{\circledR}$ interpolation algorithm is needed with regard to formation interconnectedness or continuity. We suspect, based on the groundwater flow modeling, that the interpolated mud fraction field displayed in Figure 19 underestimates confining zone continuity. There are many interpolated clay intervals in adjacent cores that appear to be slightly offset vertically but are actually connected. The "stratified" interpolation algorithm tends to not connect these intervals because they lie within different horizontal gridding layers. This problem is alleviated to some extent by vertical averaging during the transfer of fine-scale conductivity to the flow model grid: Also, harmonic averaging of vertical conductivities assumes perfect horizontal continuity within a grid element and slightly counteracts underestimation of continuity between elements. The conformal gridding option in EarthVision ${ }^{\circledR}$ could be used to achieve higher confining zone continuity by incorporating known variations in dip of strata into the gridding process. Selecting a coarser vertical resolution for the interpolated grid would increase interconnectedness, as would a larger vertical influence factor. These options would tend to blur vertical contrasts however, leaving conformal gridding as the preferred approach over changing the resolution.

Hydraulic head residuals within the Upper Three Runs aquifer are higher than desired. An objective of the study is to achieve noticeably lower head residuals in comparison to more traditional modeling approaches. One reason for some residuals being high is that all available head data are used as targets. These data include heads from the "SRL" grid wells south of the Old Burial Ground (CC, GG, M, Q S, U and $Y$ wells). Some of the SRL grid well heads appear to be inconsistent with surrounding data and produce very large residuals (e.g., U-13, Q-17, S-15). These data could be eliminated from the list of targets with justification. Eliminating these questionable targets would reduce the r.m.s. head residual. The large uncertainty in translating mud fraction into conductivity is undoubtedly another reason for some high residuals. Also, a global correlation between mud fraction and conductivity is used. Within the "lower" aquifer zone there is a bias to the distribution of residuals as noted above. In this case, the correlation should perhaps vary spatially to alleviate the bias. A spatially-varying correlation was not used in 
order to test the hypothesis that the correct spatial conductivity trends would be a natural outcome of basing conductivity on mud fraction data. While the hypothesis appears to be largely true, improvements can obviously be made.

\section{Flow modeling conclusions}

Based on the flow modeling results of this study we conclude:

- Fine-scale, heterogeneous, hydraulic conductivity fields can be successfully generated directly from lithologic data using the methods described herein.

- These hydraulic conductivity fields provide a more realistic picture of subsurface hydrologic heterogeneity than conventional "layer cake" modeling approaches.

- The approach improves large-scale flow patterns and dispersive behavior in groundwater flow and transport models. For the SRS burial ground application, field-observed, preferential pathways for contaminant migration are replicated without the need to artificially create zones of high conductivity.

\section{Tritium source characterization}

An extensive search for information relevant to Old Burial Ground tritium transport was conducted from approximately December 1994 to February 1995. This effort included a computerized literature search. Many site personnel were also "interviewed" for information and data including

E\&CSD: $\quad$ Mark Amidon, Joe Kanzleiter

SRTC/CPT: Lee Hyder

SRTC/ESS: Ken Dixon, Brian Looney, Chas Murphy, Ralph Nichols

SRTC/IWT: Jim Cook, Steve Serkiz, Elmer Wilhite

SW\&ER: Steve Mentrup, Joette Sonnenberg

among others. Table 8 lists the documents collected during the literature search and Table 9 outlines the overall knowledge base gained from the search. The works of Hyder (1993), Ref. 7 and Holcomb (1992) were especially useful starting points. Highlights of the information summarized in Table 9 are presented below. 


\section{Burial ground operations}

Figure 1 illustrates the study area and surroundings. The original site burial ground comprising 76 acres (Old Burial Ground) was designated in 1954 and probably received the first significant tritiated waste in late 1955 or early 1956 (Bebbington, 1990; Fenimore, 1964) coinciding with large-scale tritium production. The date of the first burial is-uncertain and may be as early as 1952. The last recorded burials were in 1972. Fenimore (1964) describes burial ground operations during the first 10 years. The COBRA burial records provide the best record of operations between 1961 and 1972 (Hyder, 1993). A potentially important event associated with the burial ground plumes is the repair to the eroded F-effluent ditch in 1980. This effort was designed to restore the tritium discharge point to its original location farther south from the burial ground.

\section{Inventory}

Tritium occurs in many buried waste forms such as spent melt crucibles, magnesium beds, equipment such as pumps and other hardware, and off-site sources (Hyder, 1993). Spent melt crucibles or "spent melts" were the main waste byproduct of the tritium extraction process. Lithium-aluminum target tubes and control rods were melted in steel crucibles to release tritium gas from the solid matrix. The gas was extracted under vacuum. Following the recovery of tritium gas, the molten material was considered "spent". . The melts were allowed to cool and solidify in the crucible. A crust of tritium-rich impurities typically formed at the top surface of the spent melt. Spent melts were then buried with no containment in the Old Burial Ground.

The COBRA database constitutes the main source of information about tritium burials. Hyder (1993) discusses the merits and problems (significant) of the database. The earliest COBRA tritium burial records begin in about March 1961. Therefore, there is a great deal of uncertainty about burials during the first several years of operation. Bebbington's (1990) descriptions of early reactor and tritium facility operations can be used to estimate early tritium burials as shown in Figure 37. Even for those years for which burial records were kept, there is considerable uncertainty in the buried inventory, because the recorded amounts are probably little more than guesses (Hyder, 1993; Wilhite, 1995). The estimated tritium content of spent melt crucibles is based on analysis and is probably within plus or minus $25 \%$. An estimate of total annual tritium burials based on Figure 37 and the COBRA records is shown in Figure 38 for the period of burial ground operation. Normalized spatial variations of tritium buried annually from 1961 through 1970 are shown in Figures 39a-j. 
Waste form release mechanisms and rates

Except for spent melts, the physical phenomena controlling tritium release from the various waste forms following burial are not known, much less quantified. For spent melt crucibles, a burial ground lysimeter study conducted over a 10 year period from 1974 to 1983 can be used to quantify the tritium release rate under past burial ground conditions. Figure 40 shows the cumulative tritium released from three Line 2 spent melt crucibles and lids with an estimated initial activity of 300-450 Ci (Ref. 5; Ref. 4). The physical phenomena involved in tritium release to the unsaturated zone (e.g. diffusion, dissolution, etc.) have not been identified, although some hypotheses have been advanced by Ref. 5 and Hyder (1993).

A release rate model for spent melts is constructed from the data shown in Figure 40 as follows. Because the physical phenomena controlling tritium release in the lysimeter study have not been identified, a simple first-order leaching model accounting for radioactive decay (also a first-order process) is adopted for data interpretation. The model is consistent with the assumption that the limiting step for mass transfer out of the waste form occurs across the boundary layer (film resistance). Under such conditions concentration gradients within the waste form are considered negligible. Defining the waste form as a control volume, the mass transfer equation for tritium reduces to the release model

$$
C_{t}=-k C-\lambda C
$$

where tritium reduction within the waste form is by either first-order radioactive decay or mass transfer into the water phase contained within the neighboring aquifer unit. Assuming a constant mass transfer coefficient (i.e. leaching constant) the analytical solution of equation (14) becomes

$$
C=C_{0} e^{-(k+\lambda) t}
$$

where

$$
\begin{aligned}
C & \equiv \text { average concentration in waste form } \\
C_{0} & \equiv \text { initial concentration in waste form } \\
\mathrm{k} & \equiv \text { leaching constant }\left(\mathrm{yr}^{-1}\right) \\
\lambda & \equiv \text { radioactive decay constant }\left(0.0564 \mathrm{yr}^{-1} \text { for tritium }\right)
\end{aligned}
$$


Based on this model, the cumulative quantities of tritium remaining in the source, lost through decay, and leached to the groundwater through time are, respectively,

$$
\begin{gathered}
Q_{\text {source }}=Q_{\text {initial }} e^{-(k+\lambda) t} \\
Q_{\text {decay }}=Q_{\text {initial }} \frac{\lambda}{k+\lambda}\left[1-e^{-(k+\lambda) t}\right] \\
Q_{\text {leached }}=Q_{\text {initial }} \frac{k}{k+\lambda}\left[1-e^{-(k+\lambda) t}\right]
\end{gathered}
$$

where $Q_{\text {initial }}$ is the initial quantity of buried tritium. The data shown in Figure 40 are reasonably well fit using parameter settings of $Q_{\text {initial }}=400 \mathrm{Ci}$ and $\mathrm{k}=0.341 \mathrm{yr}^{-1}$. Figure 41 illustrates the relative release rate and cumulative released amount for these parameter settings. Note that less than $86 \%$ of the initial inventory is ever released. The remainder decays within the spent melt. Also note that approximately $90 \%$ of the ultimate release occurs within the first 6 years.

The release rate for non-spent melts is assumed to take the same functional form as for spent melts for lack of a better alternative. Transport model calibration to tritium discharge data at Fourmile Branch indicates that non-spent melts release tritium at a much slower rate than spent melts. A value of $\mathrm{k}=0.029 \mathrm{yr}^{-1}$ is chosen for non-spent melts based on model calibration for the base case (defined later). Figure 42 illustrates the relative release rate and cumulative released amount for non-spent melts. For nonspent melts about $34 \%$ is ultimately released, while $66 \%$ decays within the waste form. More than 25 years are required to reach $90 \%$ of the total eventual release.

\section{Source term model}

Buried contaminants may be modeled in the variably-saturated FACT code as either point or distributed sources, with either concentration or mass flux prescribed. Tritium-bearing waste forms were buried throughout the Old Burial Ground from approximately 1955 through 1972. Therefore, the Old Burial Ground source term must vary spatially in accordance with the burial records, and temporally in accordance with burial times and the release rate model just described. The spatial variation is handled by assigning buried waste forms to the nearest FACT grid point. For the present application, a source term specified in terms of mass flux rather than concentration is convenient. 
A tritium source model defining the release rate from waste forms to the vadose zone as a function of time and space is constructed as follows. Tritiated waste forms are first segregated into spent melts and non-spent melts (i.e., all burials other than spent melts). Figures 43 and 44 show the estimated annual tritium burials for each type of waste and represent a subdivision of Figure 38. Likewise, Figures $45 a-j$ and $46 a-j$ illustrate the normalized spatial variation in tritium burials for spent melts and non-spent melts in burial ground coordinates, respectively. These figures are analogous to Figures $39 \mathrm{a}-\mathrm{j}$. For each waste form, the cumulative release rate for all sources buried at FACT areal node $x_{j}$ for years $\tau_{1}$ through $\tau_{n}$ is

$$
\begin{aligned}
H\left(t, x_{j}\right) & \equiv \sum_{i=1}^{n} F\left(\tau_{i}, x_{j}\right) \cdot G\left(t-\tau_{i}\right) \\
& =\sum_{i=1}^{n} T\left(\tau_{i}\right) \cdot S\left(\tau_{i}, x_{j}\right) \cdot G\left(t-\tau_{i}\right)
\end{aligned}
$$

where

$$
\begin{gathered}
T\left(\tau_{i}\right) \equiv \text { total annual buried amount in year } \tau_{i}, i=1, \ldots, n \\
S\left(\tau_{i}, x_{j}\right) \equiv \text { normalized spatial distribution at node } x_{j} \text { for year } \tau_{i} \\
\sum_{j=1}^{N} S\left(\tau_{i}, x_{j}\right)=1 \text { for } i=1, \ldots, n \\
F\left(\tau_{i}, x_{j}\right) \equiv T\left(\tau_{i}\right) \cdot S\left(\tau_{i}, x_{j}\right), \text { amount buried at node } x_{j} \text { in year } \tau_{i} \\
G(t) \equiv\left\{\begin{array}{cc}
k e^{-(k+\lambda) t} & t>0 \\
0 & t \leq 0
\end{array} \text { relative release rate for source buried at time } t=0\right.
\end{gathered}
$$

Figures 43 and 44 provide $T\left(\tau_{i}\right)$, Figures 45 and 46 essentially provide $S\left(\tau_{i}, x_{j}\right)$, and Figures 41 and 42 provide $G(t)$ for the spent melt and non-spent melt wastes, respectively. The total release rate is the sum of the contributions from spent melts and non-spent melts. Burial trenches are nominally 20 feet deep. The source term defined by equation (19) is applied to the second layer of nodes from the ground surface. Because the average FACT element height is 10 feet, this corresponds to a simulated burial depth of about 20 feet. The simulated source is therefore a few feet deeper than the actual source, because the average burial depth would be less than 20 feet. 
An overall account of the fate of tritium following burial is shown in Figure 47. The cumulative amount of tritium estimated to have been buried in the Old Burial Ground between 1955 and 1972 is $288 \mathrm{~g}$ or 2.8 million Curies. This estimate is deduced from COBRA records for the years 1961 to 1972 and from general descriptions of reactor and separation facility operations for earlier years as discussed earlier. Spent melt waste forms are estimated to account for $34 \%$ of the total decay-uncorrected tritium inventory. As of 1995, an estimated $49 \%$ of the tritium inventory has decayed within waste forms and $45 \%$ has been released to the vadose zone, leaving only $6 \%$ remaining within waste forms for the base case source term model. As can be seen from Figure 47 , an estimated $47 \%$ of the initial tritium inventory will ultimately be released to the vadose zone. Because $45 \%$ has already been released through 1995 , only an additional $2 \%$ will be released in the future.

Figure 48 shows the predicted rate of tritium release to the vadose zone, along with the discharge rate to Fourmile Branch at seeps to be discussed below. The peak release to the vadose zone is estimated to have occurred in about 1961 and has declined to only $4 \%$ of this maximum value in 1995 . Therefore, most of the initial buried tritium has either decayed in place or is migrating with groundwater toward Fourmile Branch.

\section{Tritium monitoring data}

Tritium monitoring data take two main forms: groundwater concentrations in monitoring wells and annual release amounts to Fourmile Branch. These are further discussed below.

\section{Groundwater concentrations}

Tritium concentration data are available from several sources. The Environmental Monitoring Section (EMS) electronic database contains concentrations for well series such as BG, BGO and HSB, and many of the OBG grid wells, as far back as 1979. Mark Amidon supplied data for the remaining OBG grid wells in electronic form. These data are published in various annual reports (see Table 8). All of the data are concentrated within the Old Burial Ground or its immediate vicinity. Valuable data taken at the F-effluent ditch seepline and between the burial ground and seepline discharge point have recently become available (Dixon and Rogers, 1993; Dixon et al., 1994; Dixon and Cummins, 1994; Ref. 1). All the data show considerable spatial and temporal variability, even within a single calendar year, making data interpretation difficult. To eliminate some of this noise, the data were annually averaged. The resulting number of annual average data from each source is listed below 


\begin{tabular}{rll}
3770 & EMS database \\
868 & IWT annual reports \\
157 & Cone Penetrometer data (Ref. 1) \\
33 & HydroPunch data (Ref. 1) \\
7 & Seepline (Dixon and co-workers) \\
\hline 4835 & TOTAL
\end{tabular}

The nearly 5000 annual average concentration data points were displayed in EarthVision ${ }^{\circledR}$ three-dimensional and Tecplot ${ }^{\circledR}$ two-dimensional images for various years, groups of years, and aquifer units during model development. Despite the large number of concentration data, the information appears to be insufficient to produce well defined plumes using computer interpolation. For example, the calendar year with the most spatial information is 1994. Figure 49 shows the location of "upper" aquifer zone tritium concentration data for 1994. A contour map of 1994 "upper" aquifer zone concentration is shown in Figure 50. The monitoring data alone are insufficient to fully define tritium plumes within the "upper" aquifer zone, as Figure 50 shows only isolated pockets of tritium contamination. Even less spatial resolution is available for the deeper aquifer zones. In addition, an attempt was made to generate meaningful tritium break-through curves using transient data from various individual wells. Figure 51 shows the results for BG-56, a typical example. The data exhibit too much variability to be effectively used on an individual basis for model calibration.

Instead, the data as a whole are used to ensure that predicted tritium plumes are more or less consistent with the data. The total quantity of tritium in the groundwater can be estimated from monitoring well data using the three-dimensional plume images mentioned above and the "Volumetrics" feature of EarthVision ${ }^{\circledR}$. Table 10 summarizes EarthVision ${ }^{\circledR}$ volumetrics calculations for various calendar years. The selected years offer more spatial information about the extent of plumes than earlier years. However, even the annually averaged concentration data from these years do not fully envelop the entire plume. For example, all of the wells within the Old Burial Ground are screened across the water table, but higher concentrations are probably now present at deeper elevations. The "Data" values in Table 10 probably underestimate the true mass because the full plume has not been considered due to an absence of data. Note that the data estimates show considerable variability from year to year. This behavior is a reflection of the large variability in individual well data mentioned above.

\section{Discharge rate at Fourmile Branch}

Fourmile Branch and its tributaries have been continuously monitored for tritium from 1968 to present. Annual monitoring reports (Table 8) summarize and interpret the data. The amount of tritium discharged to 
Fourmile Branch, which originated in the Old Burial Ground, can be estimated from these data as shown in Figure 52. The data represented in Figure 52 are a key target for the tritium transport model.

\section{Tritium transport model}

Once the tritium source term is defined, and given the velocity and water saturation fields from the flow model, development of a transient transport model is relatively simple as discussed next. Then, transport results for no action and two capping scenarios are presented.

\section{Transport parameters and calibration}

Based on model calibration the following transport parameter values are chosen for the base case:

Porosity (effective), $\phi$

Longitudinal dispersivity, $\alpha_{L}$ $65 \mathrm{ft}$

Release rate constant for non-spent melts, $\mathrm{k} 0.029 \mathrm{yr}^{-1}$

Half-life of tritium $12.3 \mathrm{yr}$

Time step size

$0.1 \mathrm{yr}$

Following standard transport modeling practice, an "effective" instead of total porosity is used for the base case to account for regions. of relatively immobile groundwater that are not effectively penetrated by the solute plume (de Marsily, 1986; Fetter, 1993). The value chosen is well within the guidelines set by Looney et al. (1987a). The dispersivity is relatively low compared to the recommendation of Looney et al. (1987a) probably because the highly heterogeneous hydraulic conductivity field employed in the present flow model alleviates the need for a large mechanical dispersion term. A dispersivity of $65 \mathrm{ft}$ also corresponds to a cell Peclet number of 2 . For maximum accuracy, the cell Peclet number should be less than or equal to 2 $\left(\mathrm{v} \Delta \mathrm{x} / \mathrm{D}=\Delta \mathrm{x} / \alpha_{\mathrm{L}} \leq 2\right)$, and this condition is satisfied with the present model. The release rate constant for non-spent melts was selected based primarily on comparison of predicted and measured tritium discharge to Fourmile Branch. This data reflects the overall system behavior. Preliminary simulations were performed at time step sizes of 1 year and 0.1 years. A time step of 0.1 years is judged sufficiently small to minimize the effects of time truncation errors. 


\section{Base case results and discussion}

Three future scenarios are considered: 1) no action, 2) capping with a hypothetical low permeability cover in mid-1996, and 3) capping and removal of the remaining source in mid-1996. Each simulation begins with a reproduction of past tritium migration from the first significant tritium burial (1955) to present (1996). The simulation continues 40 years into the future (2035) according to the selected remedial alternative. For the first capping scenario, the release rate of tritium to the vadose zone is assumed to be unaffected by capping (i.e., same as the no action case); tritium migration through the vadose zone is slowed by reduced infiltration however. For the second capping scenario, the tritium release rate is zero after capping. The actual tritium release rate after capping is bounded by these two cases.

\section{No action results (reproduce past and predict no action future)}

Figure 53 shows an overall accounting of tritium released to the vadose zone as a function of time based on FACT results. Tritium released to the vadose zone either decays in transit, discharges to surface water, migrates outside the model domain (negligible amount) or resides within the groundwater. In the simulation, the peak amount of tritium in the groundwater occurred in about 1972 and has declined to $41 \%$ of this value by 1995. Table 10 compares the predicted amount of tritium in groundwater shown in Figure 53 with estimates based on monitoring data and EarthVision ${ }^{\circledR}$ volumetrics calculations. The estimates based on well monitoring data are roughly half the code predictions. The discrepancy is most likely due to the fact that well monitoring data are not available below the water table within the burial ground where the bulk of tritium may be located. The values based on data may be missing a significant portion of the actual plume leading to a low estimate.

Figure 54 shows simulated tritium discharge to Fourmile Branch compared to monitoring data. The model predictions agree with the overall trend, but, do not reproduce the fine structure of the data. The cause of the data "noise" is unknown. The peak discharge is predicted to have occurred in 1992. A substantial decline in discharge to Fourmile Branch is predicted to occur over the next decade.

Figure 55 shows a cut-away of the three-dimensional tritium concentration for calendar year 1995. Tritium descends straight down through the vadose zone from buried waste to the water table at an average rate of about $12 \mathrm{ft} / \mathrm{yr}$ (17 in /yr local recharge divided by $23 \%$ porosity and $50 \%$ average saturation in the model). The plumes then move laterally toward Fourmile Branch (see Figure 36 too). From the southwest corner of the Old Burial Ground the total travel time to the seepline averages approximately 10 
to 15 years based on three-dimensional particle tracking. Two-dimensional contour maps of concentration within each aquifer zone/unit can be created from the three-dimensional results through vertical averaging.

Figures 56a-561 illustrate tritium concentrations in the "upper" aquifer zone on a 5 frequency from 1960 to 2015 . Two distinct plumes are identified corresponding to burials predominantly in the west and east ends of the Old Burial Ground. Observe that the plume emanating from the southwest corner of the Old Burial Ground contributes solely to the discharge at the Fourmile Branch seepline. This discharge is biased towards the west side of the F-effluent ditch. The east end plume contains more tritium than the southwest plume, but, is mostly confined to the areal bounds of the Old Burial Ground as it migrates slowly westward. Horizontal velocities in the eastern end of the Old Burial Ground are generally low.

Figures 57a-57 show tritium concentrations in the "lower" aquifer zone. Concentrations are lower as expected. The peak concentration lies beneath the Old Burial Ground in the mid-section. The plumes are slowly migrating toward Fourmile Branch.

Figures 58a-581 show Gordon aquifer concentrations, which are extremely low compared to the "lower" and "upper" aquifer zones (note the change in scale). Peak concentrations occur near the west end of the Old Burial Ground. The plumes are dispersing and slowly migrating west to northwest towards Upper Three Runs.

Finally, 1995 seepage face concentrations near the confluence of the F-area effluent ditch and Fourmile Branch are shown in Figure 59. Figure 59 illustrates concentration data at the surface of the three-dimensional concentration field depicted in Figure 55. Note that the scale has been reduced in Figure 59 to highlight the results in this area. The predicted values are consistent with the corresponding monitoring data.

\section{Effect of capping}

The second scenario involves placing a certain low permeability cover over the entire Old Burial Ground in mid-1996. The cap is created by changing the conductivity in the top layer of burial ground finite elements to $10^{-5} \mathrm{ft} / \mathrm{d}$, and reduces infiltration by a factor of $85 \mathrm{from} 17 \mathrm{in} / \mathrm{yr}$ to about 0.2 in/yr. Figure 60 shows the impacted surface elements. The figure also illustrates other engineered surfaces that are present throughout all three scenarios. The modeled cap is purely hypothetical and does not simulate any proposed design, but does offer significant insight into the general effect of capping. Tritium release rates from waste forms to the vadose zone are conservatively assumed to be unaffected by capping. 
The simulated effect of capping in mid-1996 is illustrated in Figure 61. As shown, tritium discharge to Fourmile Branch will be reduced by less than 300 Curies per year compared to uncapped conditions. The effect is small compared to the present discharge rate of about 4500 Curies per year. This outcome follows from the fact that most of the tritium originally present in solid radioactive waste burials has either decayed or migrated to groundwater below the water table. Tritium already in the saturated zone is largely unaffected by capping.

The immediate reduction in tritium discharge at the time of capping is the result of a slight reduction in average recharge over the entire model domain when burial ground infiltration is reduced from $17 \mathrm{in} / \mathrm{yr}$ to about $0.2 \mathrm{in} / \mathrm{yr}$. The reduced infiltration immediately slows groundwater. flow towards Fourmile Branch in the simulation, reducing the tritium flux. The smaller groundwater flow rate also causes additional radioactive decay while tritium is transported in the saturated zone. Reduced infiltration initially decreases the tritium flux from the vadose zone to the water table. As the tritium concentration builds in the vadose zone, the tritium flux to the water table increases and eventually exceeds that for the no action case. As a result, the discharge matches and then slightly exceeds tritium releases for the no action scenario some 30 years in the future.

\section{Effect of capping and source removal}

For the previous simulation, the tritium source term in the vadose zone is assumed to be unabated by a reduction in infiltration. Tritium release rates to the vadose zone may be affected by the infiltration rate. Reduced recharge would presumably decrease the release rate. To explore this possibility, the tritium release rates are set to zero coincident with capping as a second case. This assumption is equivalent to assuming the source is dug up and removed prior to capping. The present scenario and the preceding one bound the possible effects of capping. The former case maximizes the potential tritium source term while the present minimizes the source. The results of capping and source removal are shown in Figure 61. The two capping scenarios yield essentially identical results for the first 15 years while saturated zone groundwater presently between the burial ground and Fourmile Branch flushes through. From about 2010 onward, the present scenario continues to yield tritium discharges below the no action case.

Sensitivity case results and discussion

Unconnected pore space and dead-end pores are typically cited as the motivation for defining an effective porosity to be used instead of total porosity in solute transport modeling (de Marsily, 1986; Fetter, 1993). 
Unconsolidated Savannah River Site sediment probably contains very little unconnected pore space. Significant dead-end pore space is likely, but its mere presence does not justify using an effective porosity. For the natural groundwater flow rates at the Old Burial Ground, tritium has sufficient time to diffuse into relatively immobile water in dead-end pores. Therefore, water occupying dead-end pores participates in the transport of tritium. Unconnected pore space and dead-end pores cannot be used to justify use of an effective porosity well below total porosity for unconsolidated sediment beneath the SRS. However, larger scale heterogeneities do offer justification. The average vertical finite-element height in the model is about 10 feet. Interbedded sand and clay layers within the resolution of an average cell may effectively isolate portions of the groundwater from a passing tritium plume. In this case, a porosity value significantly less than the total porosity is appropriate for the base case considered above. Nevertheless, a second simulation using total porosity is now considered in case the $23 \%$ porosity value used for the base case is too low. The exercise also provides important information about the sensitivity of model results to calibration parameters.

The parameters selected for the sensitivity case following model calibration are

Porosity (total)

Longitudinal dispersivity

Release rate constant for non-spent melts

Half-life of tritium

Time step size
0.45

$300 \cdot \mathrm{ft}$

$0.17 \mathrm{yr}^{-1}$

$12.3 \mathrm{yr}$

$0.1 \mathrm{yr}$

Total porosity for SRS sediments ranges from about 0.4 to 0.6 (Looney et al., 1987a) with sands tending to have lower porosity than clays. A value of 0.45 is chosen because sands dominant the distribution of sediments (Figure 4). A larger dispersivity and release rate are needed to match the monitoring data at Fourmile Branch when compared to the base case. The reason is that the Darcy velocity from the flow simulation is the same for the base and sensitivity cases. The tritium mass flux near Fourmile Branch is the Darcy velocity times the solute concentration. The same concentration at the seepline is required regardless of specified porosity in order to preserve mass flux between the base and sensitivity cases. More tritium must be released to the vadose zone for a porosity of $45 \%$ to maintain the up-gradient concentration of tritium. This effect is accomplished by increasing the release rate of tritium from non-spent melt waste forms $\left(\mathrm{k}=0.17 \mathrm{yr}^{-1}\right.$ compared to $\left.0.029 \mathrm{yr}^{-1}\right)$. As indicated by Figure 62, the higher release rate for non-spent melts results in significantly higher releases of tritium to the vadose zone with less decay within the waste form, in addition to earlier release (see Figure 47 for the base case). Figure 63 shows the increased average release rate from all waste forms when compared to the base case (Figure 48). In addition, 
a larger dispersivity is needed to achieve the correct elapsed time for tritium break-through following burial.

The same three remediation scenarios considered for the base case are considered for the sensitivity case: 1) no action, 2) capping with a hypothetical low permeability cover, and 3) capping and removal of the remaining source. As before, each simulation begins with a reproduction of past tritium migration from the first significant tritium burial (1955) to present (1996), and continues 40 years into the future (2035) according to the selected remedial alternative.

Figures 64 and 65 summarize the "bottom line" results of the sensitivity study. The total amount of tritium in groundwater is significantly higher for the sensitivity case as illustrated by Figure 64 in comparison to Figure 53. Concentrations are roughly the same between the base and sensitivity cases. The higher inventory of tritium in groundwater is due to larger porosity rather than concentration. Figure 65 shows predicted discharges to Fourmile Branch for no action, capping, and capping with source removal. The sensitivity case results are very similar to the base case (Figure 61) for no remedial action. Capping is predicted to reduce tritium discharges by less than $150 \mathrm{Ci}$ compared to less than $300 \mathrm{Ci}$ for the base case. The reason is that virtually no tritium remains in the waste forms in 1996 compared to a small amount for the base case. Therefore capping has even less effect for the sensitivity case. The similarity of results for the base and sensitivity cases is the result of model calibration to 40 years of monitoring data in both cases. The monitoring data severely constrain the overall model and suggest the results for tritium discharge to Fourmile Branch have low uncertainty, despite large uncertainties in the source term.

\section{Transport modeling conclusions}

Based on the base case tritium source term and transport modeling results of this study we estimate:

- The total amount of buried tritium is approximately $288 \mathrm{~g}$ or 2.8 million $\mathrm{Ci}$ (decay uncorrected).

- Of this amount, $61 \%$ is buried in the west end of the Old Burial Ground and $39 \%$ in the east end. The east end contains $97 \%$ of the spent melts however.

- As of $1995,49 \%$ of buried tritium has decayed within waste forms, $45 \%$ has been released to the vadose zone, and $6 \%$ remains in waste forms. 
- Spent melts release tritium to the vadose zone at a much higher rate than other waste forms, on average. In the context of a first-order leaching and decay model, the leaching constant for spent-melts is about $0.341 \mathrm{yr}^{-1}$ compared to an average of $0.029 \mathrm{yr}^{-1}$ for non-spent melts.

- The peak release rate to the vadose zone occurred in 1961 and has declined to $4 \%$ of the maximum in 1995 .

- The peak amount of tritium in the groundwater occurred in $1972(600,000$ Ci) and has declined to $41 \%$ of this maximum by 1995

- The source of tritium discharge to Fourmile Branch to-date is entirely from sources buried in the west end of the burial ground. Groundwater velocities are low beneath the east end.

- The tritium flux to Fourmile Branch peaked at about $4500 \mathrm{Ci}$ per year in 1992.

- Tritium discharges to Fourmile Branch will significantly decline in the near future without remediation (Figure 61).

- Capping the Old Burial Ground with a hypothetical, very low permeability cover will reduce tritium discharge to Fourmile Branch by no more than about 300 Curies per year (Figure 61).

A sensitivity analysis using total porosity instead of effective porosity in the transport model suggests:

- The predictions of tritium discharge to Fourmile Branch appear to have low uncertainty. Despite large uncertainties in the source term, the calibrated model is tightly constrained by 40 years of monitoring data.

- The base case tritium source term model may over-estimate the amount of tritium remaining in waste forms. When the source term model is calibrated for transport with a porosity of $45 \%$ instead of $23 \%$, the release rate constant for non-spent melts is about $0.17 \mathrm{yr}^{-1}$ instead of $0.029 \mathrm{yr}^{-1}$. For $1995,22.2 \%$ of buried tritium has decayed within waste forms, $77.7 \%$ has been released to the vadose zone, and only $0.1 \%$ remains in waste forms for the higher release rate.

- The base case may under-estimate the amount of tritium in the groundwater. For the sensitivity case, the maximum groundwater inventory is $1,330,000 \mathrm{Ci}$ and occurs in 1973. However, groundwater concentrations are similar for both cases. 


\section{References}

Aadland, R. K., J. A. Gellici, and P. A. Thayer, 1995, Hydrogeologic framework of west-central South Carolina, South Carolina Department of Natural Resources, Water Resources Division Report 5, 200 p. +47 plates.

Arnett, M. W., A. R. Mamatey and D. Spitzer; eds., 1995, Savannah River Site environmental report for 1994, WSRC-TR-95-075.

Amidon, M. B., 1994a, personal communication.

Amidon, M. B., 1994b, personal communication.

Ref. 1 (deleted reference; contact an author for more information).

Bebbington, W. P., 1990, History of duPont at the Savannah River Plant, duPont, Wilmington, Delaware.

Bledsoe, H. W., R. K. Aadland and K. A. Sargent, 1990, Baseline hydrogeologic investigation - summary report (U), WSRC-TR-90-1010, 40 p. + appendices.

Boman, G. K., F. J. Molz and O. Guven, 1995, An evaluation of interpolation methodologies for generating three-dimensional hydraulic property distributions from measured data, Ground Water, v. 22, p. 247-258.

Brusseau, M. L., 1994, Transport of reactive contaminants in heterogeneous porous media, Reviews of Geophysics, v. 32, p. 285-313.

Ref. 2 (deleted reference; contact an author for more information).

de Marsily, G., 1986, Quantitative Hydrogeology, Academic Press, Orlando.

Dixon, K. L. and V. A. Rodgers, 1993, Results of the fourth quarter tritium survey of the F- and H-area seeplines: March 1993 (U), WSRC-TR-93526, Rev. 0. 
Dixon, K. L., V. A. Rodgers and B. B. Looney, 1994, Results of the quarterly tritium survey of Fourmile Branch and its seeplines on the $\mathrm{F}$ - and $\mathrm{H}$ areas of SRS: September 1993 (U), WSRC-TR-94-0286-E, Rev. 1.

Dixon, K. L., and C. L. Cummins, 1994, Quarterly sampling of the wetlands along the old F-area effluent ditch: May 1994 (U), WSRC-TR-94-365, Rev. 1.

Fatt, I. and W. A. Klikoff, 1959, Effect of fractional wettability on multiphase .flow through porous media, AIME Transactions, v. 216, p. 246.

Fallaw, W. C. and V. Price, 1995, Stratigraphy of the Savannah River Site and vicinity, Southeastern Geology, v. 35, p. 21-58.

Fenimore, J. W., 1964, Land burial of solid radioactive waste during a 10-year period, Health Physics, v. 10, p. 229-236.

Fetter, C. W., 1993, Contaminant Hydrogeology, MacMillan, New York.

Freeze, R. A. and J. A. Cherry, 1979, Groundwater, Prentice-Hall, Englewood Cliffs, New Jersey.

GeoTrans, 1992, Groundwater transport modeling of constituents originating from the Burial Grounds Complex, WSRC-TR-92-521 (WSRC author W. W. Pidcoe), October 30.

Ref. 3 (deleted reference; contact an author for more information).

Ref. 4 (deleted reference; contact an author for more information).

Ref. 5 (deleted reference; contact an author for more information).

Ref. 6 (deleted reference; contact an author for more information).

Holcomb, H. P., 1992, Transcription of a presentation by Dr. E. L. Albenesius, 'SRS Burial Ground Operation From a Historical Perspective' (U), WSRC-RP-92-349. 
Huyakorn, P. S. and S. Panday, 1992, VAM3DCG - variably saturated analysis model in three-dimensions with preconditioned conjugate gradient matrix solvers; documentation and user's guide; version 2.4, HydroGeoLogic, Inc., Herndon, Virginia, 274 p.

Huyakorn, P. S., S. Panday and T. Birdie, 1991, SAFT3D; Subsurface analysis finite element model for flow and transport in 3 dimensions; version 1.3; documentation and user's guide, HydroGeoLogic, Inc., Herndon, Virginia, $288 \mathrm{p}$.

Huyakorn, P. S., E. P. Springer, V. Guvanasen and T. D. Wadsworth, 1986, A three-dimensional finite-element model for simulating water flow in variably saturated porous media, Water Resources Research, v. 22, p. 1790-1808.

Hyder, M. L., 1993, Tritium in the burial ground of the Savannah River Site (U), WSRC-TR-93-316.

Ref. 7 (deleted reference; contact an author for more information).

Kegley, W. P., W. C. Fallaw, D. S. Snipes, S. M. Benson and V. Price, Jr., 1994, Textural factors affecting permeability at the MWD well field, Savannah River Site, Aiken, South Carolina, Southeastern Geology, v. 34, p. 139-161.

Lahm, T. D., E. S. Bair and F. W. Schwartz, 1995, The use of stochastic simulations and geophysical logs to characterize spatial heterogeneity in hydrogeologic parameters, Mathematical Geology, v. 27, p. 259-278.

Looney, B. B., M. W. Grant and C. M. King, 1987a, Estimation of geochemical parameters for assessing subsurface transport at the Savannah River Plant, DPST-85-904.

Looney, B. B., J. S. Haselow, C. M. Lewis, M. K. Harris, D. E. Wyatt and C. S. Hetrick, 1993, Projected tritium releases from F \& H Area seepage basins and the Solid Waste Disposal Facilities to Fourmile Branch (U), WSRC-TR-93-459.

Looney, B. B., J. T. Marsh, Jr. and D. W. Hayes, 1987b, Development of accurate standardized algorithms for conversion between SRP grid coordinates and latitude/longitude, DPST-87-724. 
Neuman, S. P., R. A. Feddes and E. Bresler, 1974, Finite element simulation of flow in saturated - unsaturated soils considering water uptake by plants: Report for Project ALO-5WC-77, Hydrodynamics and Hydraulic Engineering Laboratory, Technion, Hafia, Israel, 104 p.

O'Brien \& Gere Engineers, Inc., 1991, M Area Post Test Characterization Geotechnical Testing, File: 4998.007 \#2.

Parizek, R. R. and R. W. Root, Jr., 1986, Development of a groundwater velocity model for the Radioactive Waste Management Facility, Savannah River Plant, South Carolina, DPST-86-658.

Poeter, E. P. and D. R. Gaylord, 1990, Influence of aquifer heterogeneity on contaminant transport at the Hanford site, Groundwater, v. 28, p. 900909.

Pruess, K., 1987, TOUGH user's guide, Report No. LBL-20700, Lawrence Berkeley Laboratory.

Renka, R. J., 1984, Algorithm 624: Triangulation and interpolation at arbitrarily distributed points in a plane, ACM Trans. Math. Softw. v. 10, p. $440-442$.

Riha, B. D., 1993, Predicting saturated hydraulic conductivity for unconsolidated soils from commonly measured textural properties, $M$. S. Thesis, Clemson University, Clemson, S.C., 87 p.

Rulon, J., 1984, The development of multiple seepage faces along heterogeneous hillsides, Ph.D. Thesis, University of British Columbia, Vancouver, Canada, 161 p.

Ref. 8 (deleted reference; contact an author for more information).

U. S. Geological Survey, 1980-1993, Water Resources Data for South Carolina, Water Years 1980 and 1985-1993.

U. S. Geological Survey, 1993a, New Ellenton SW DEM file dated FEB-16-93 in header. 
van Genuchten, M. T., 1980, A closed-form equation for predicting the hydraulic conductivity of unsaturated soils, Soil Sci. Am. J., v. 44, p. 892-898.

Verma, A. K., K. Pruess, C. F. Tsang and P. A. Witherspoon, 1985, A study of two-phase concurrent flow of steam and water in an unconsolidated porous media, Paper presented at the 23rd ASME/AIChE National Heat Transfer Conference, Denver, Colorado, August.

Ref. 9 (deleted reference; contact an author for more information).

Westinghouse Savannah River Company, 1995, RCRA Part B permit renewal application (U), WSRC-IM-91-53, v. 7, Mixed Waste Management Facility (MWMF) postclosure, 530 p. + appendices.

Wilhite, E. L., 1995, personal communication, January 30.

Ref. 10 (deleted reference; contact an author for more information). 


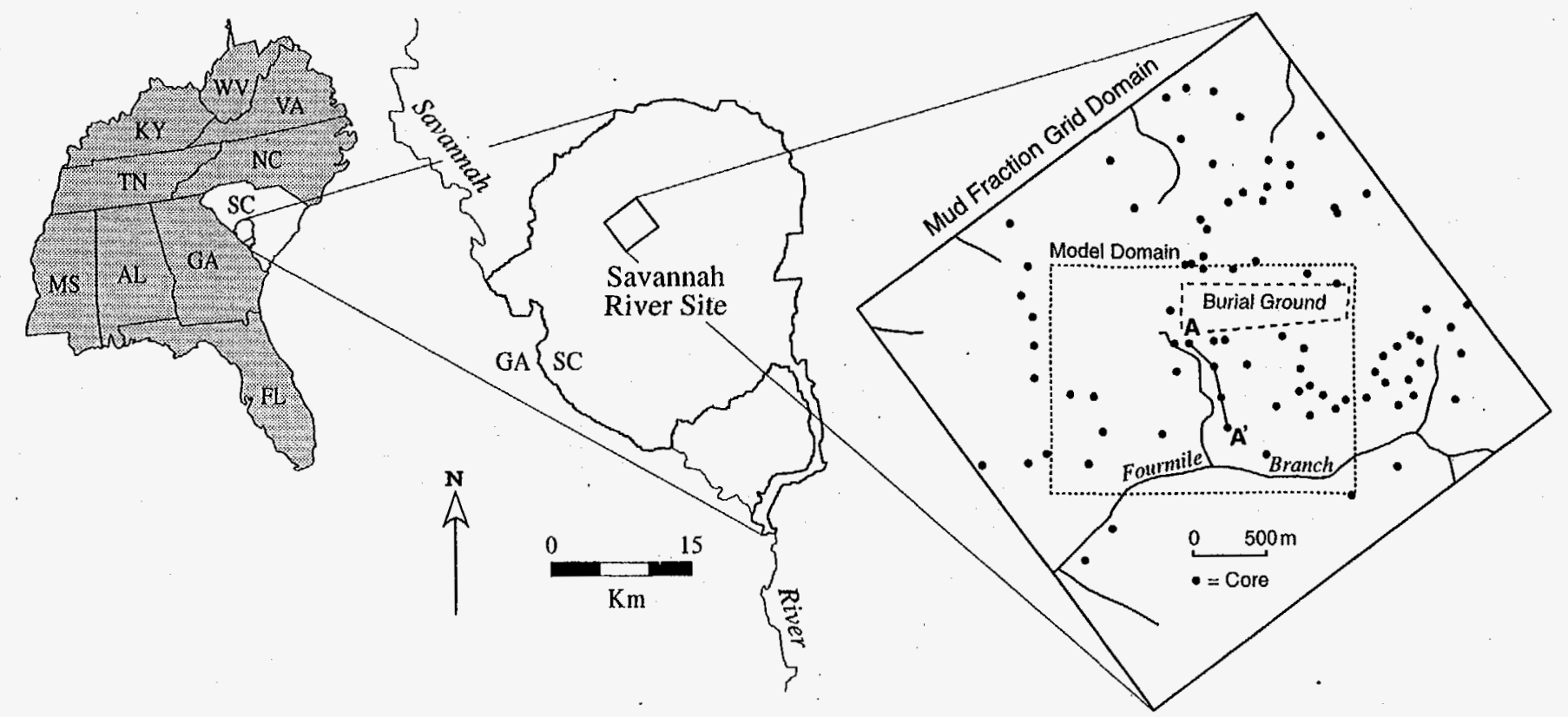

Figure 1. Location map of the Old Burial Ground showing the flow model domain and available sediment lithologic descriptions from 84 wells. 


\begin{tabular}{|c|c|c|c|c|c|c|}
\hline Epoch & \multirow{2}{*}{\multicolumn{3}{|c|}{$\begin{array}{c}\text { Rock-stratigraphic unit } \\
\text { Upland unit } \\
\end{array}$}} & \multicolumn{3}{|c|}{ Hydrogeologic unit } \\
\hline$\curvearrowright$ & & & & \multirow{6}{*}{ 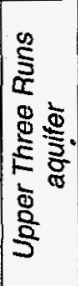 } & \multirow{3}{*}{$\begin{array}{l}\text { "upper" aquifer } \\
\text { zone }\end{array}$} & \multirow{8}{*}{ 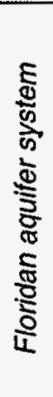 } \\
\hline \multirow{7}{*}{$\begin{array}{l}\stackrel{0}{\Phi} \\
8 \\
\stackrel{8}{8}\end{array}$} & \multirow{4}{*}{ 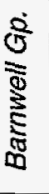 } & \multicolumn{2}{|c|}{ Tobacco Road Sand } & & & \\
\hline & & \multirow{3}{*}{$\begin{array}{l}\text { Dry } \\
\text { Branch } \\
\text { Fm. }\end{array}$} & $\begin{array}{l}\text { Inwinton } \\
\text { Sand Mbr. }\end{array}$ & & & \\
\hline & & & Griffins & & "tan clay" c. z. & \\
\hline & & & Landing Mbr. & & "Jower" aquifer & \\
\hline & \multicolumn{3}{|c|}{ Santee Formation } & & & \\
\hline & \multicolumn{3}{|c|}{ Warley Hill Formation } & \multicolumn{2}{|c|}{ Gordon confining unit } & \\
\hline & \multicolumn{3}{|c|}{ Congaree Formation } & \multicolumn{2}{|c|}{ Gordon aquifer } & \\
\hline \multirow{2}{*}{$\begin{array}{l}\stackrel{D}{d} \\
\delta \\
\frac{d}{\sigma} \\
0\end{array}$} & \multicolumn{3}{|c|}{ Williamsburg Formation } & \multirow{2}{*}{\multicolumn{3}{|c|}{$\begin{array}{l}\text { Meyers Branch } \\
\text { confining system }\end{array}$}} \\
\hline & \multicolumn{3}{|c|}{ Ellenton Formation } & & & \\
\hline
\end{tabular}

Figure 2. Lithostratigraphic and hydrostratigraphic nomenclature at the SRS (modified from Aadland et al., 1995). 


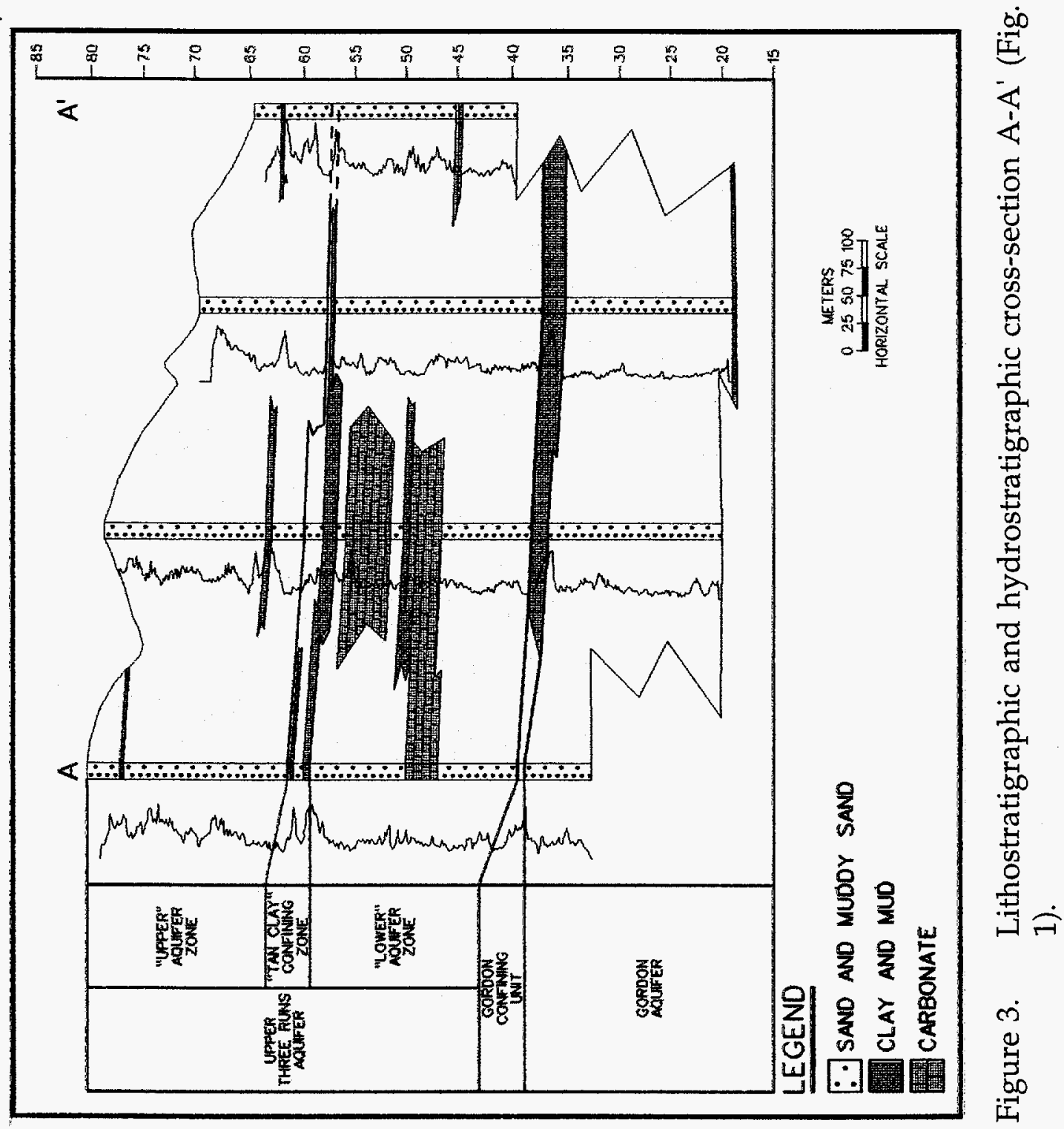




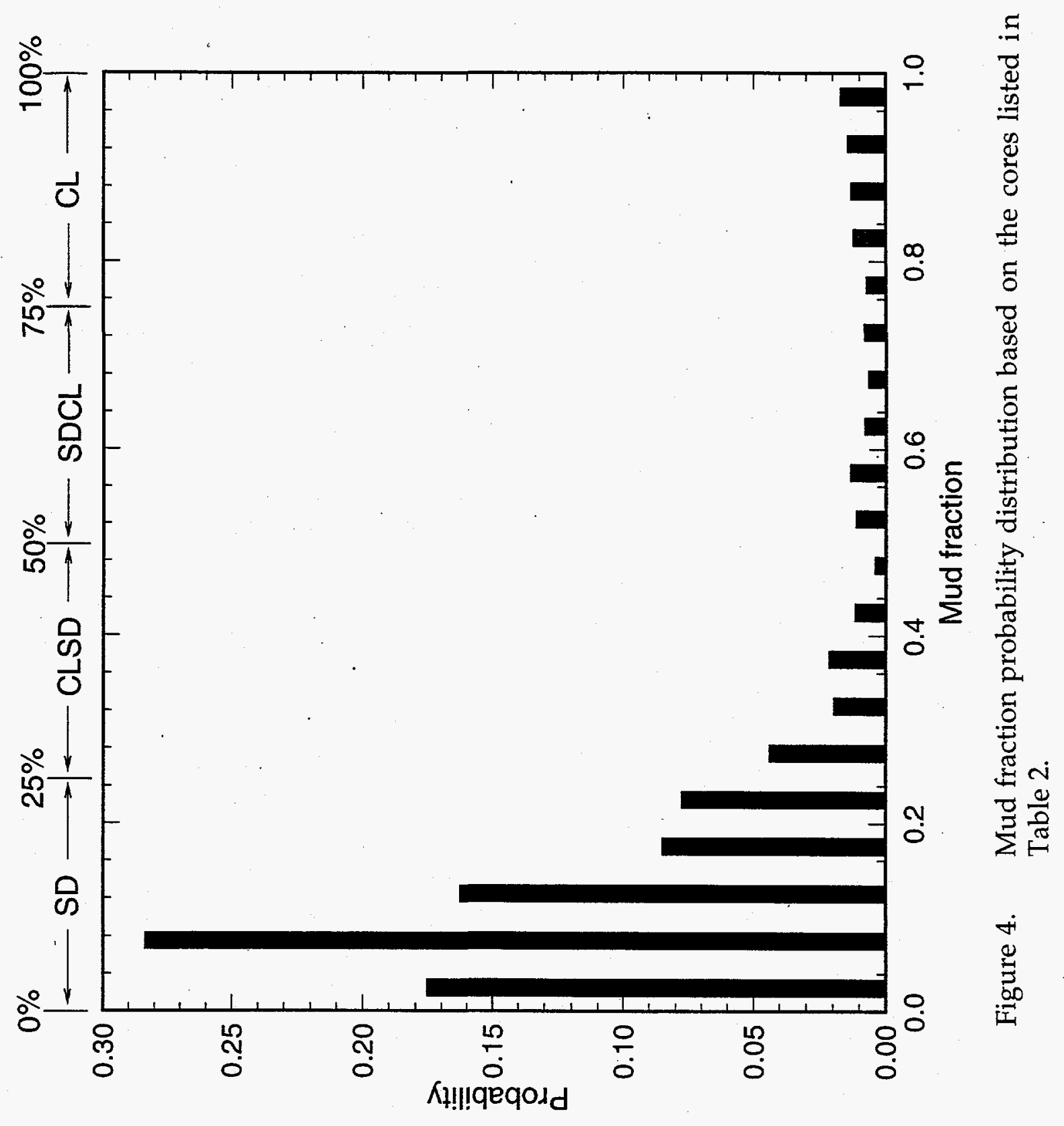




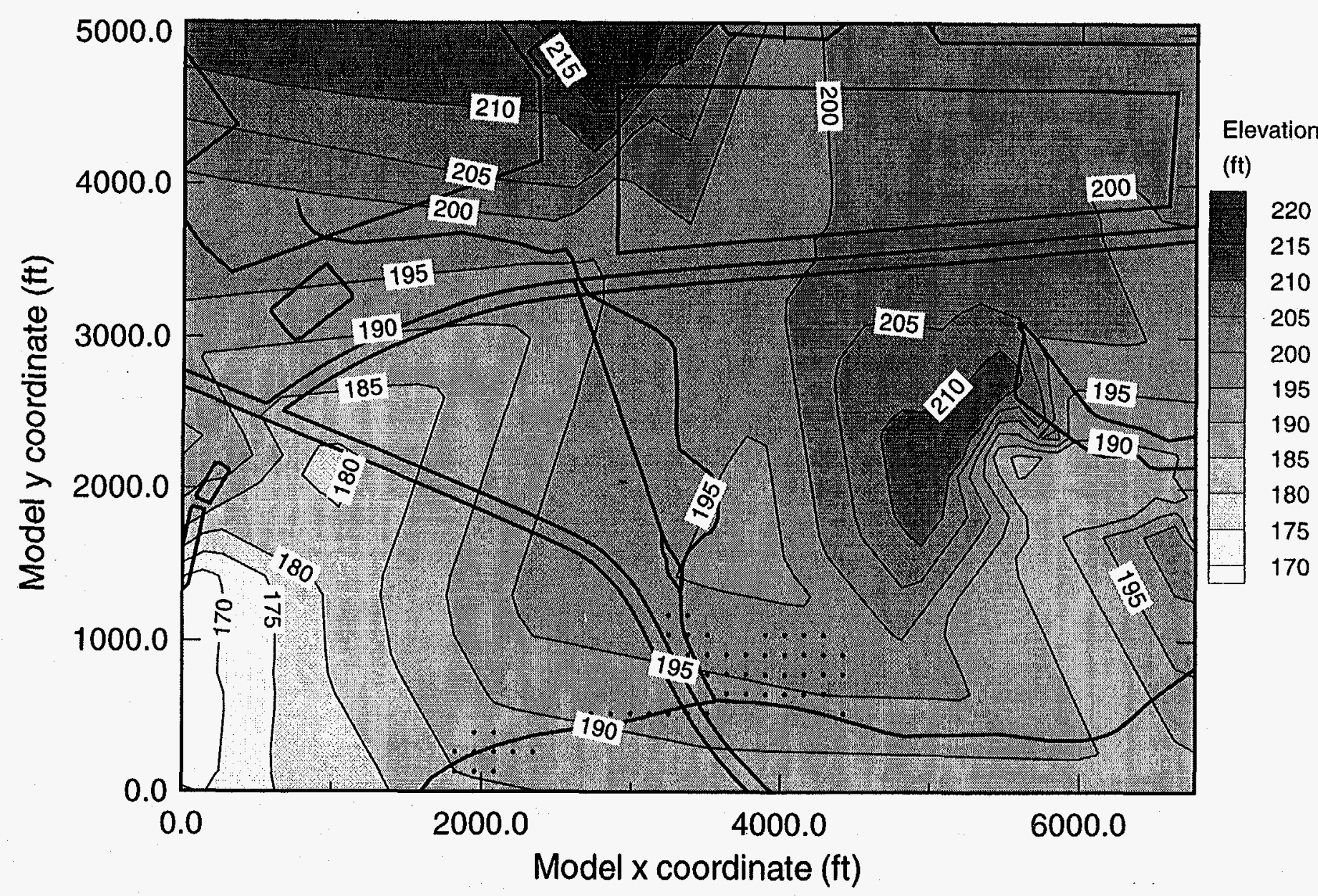

Figure 5. Structure contour map for the top of the "tan clay" confining zone (feet above mean sea level); dots indicate locations where the "tan clay" confining zone is inferred to crop out. 


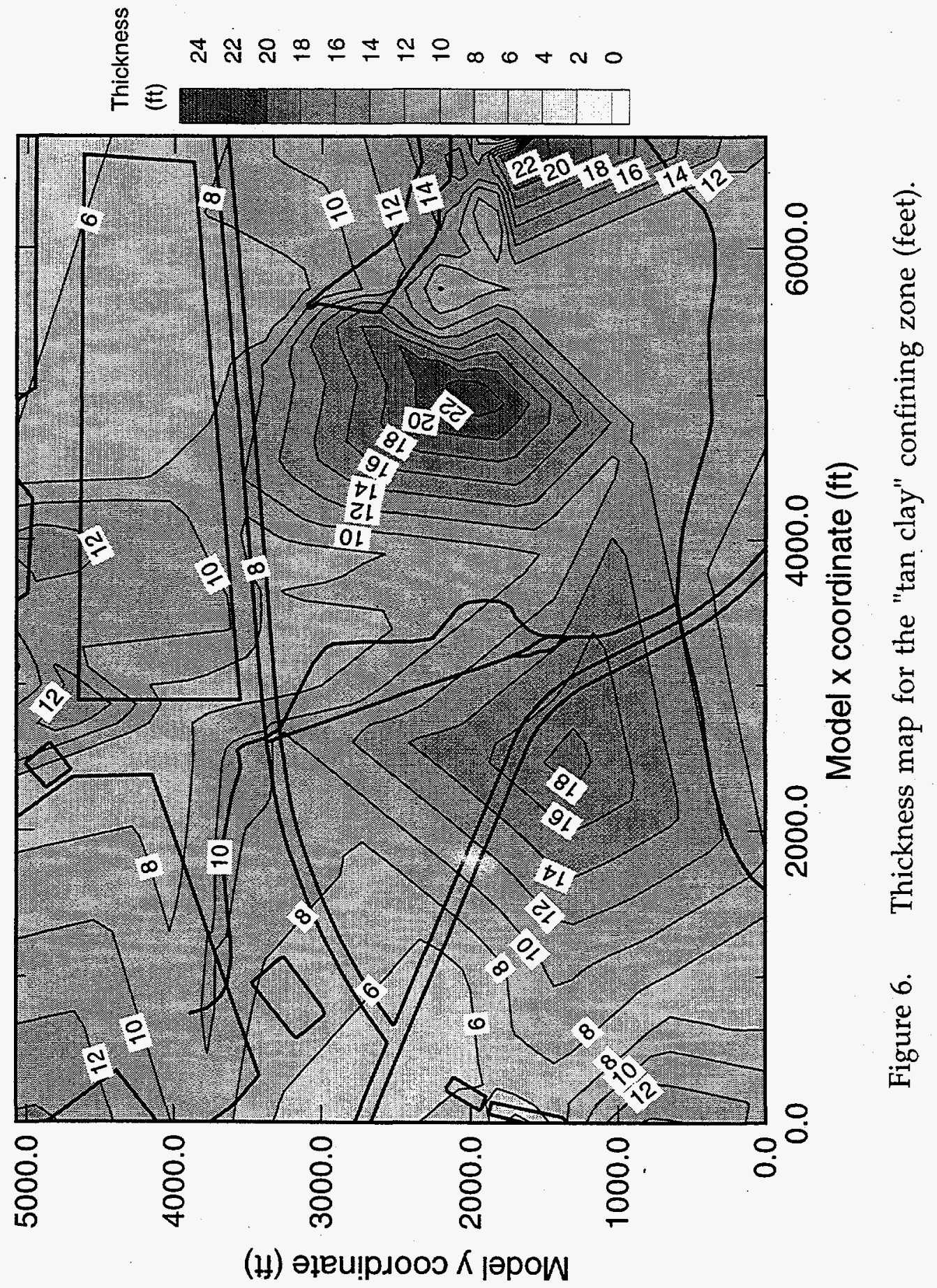




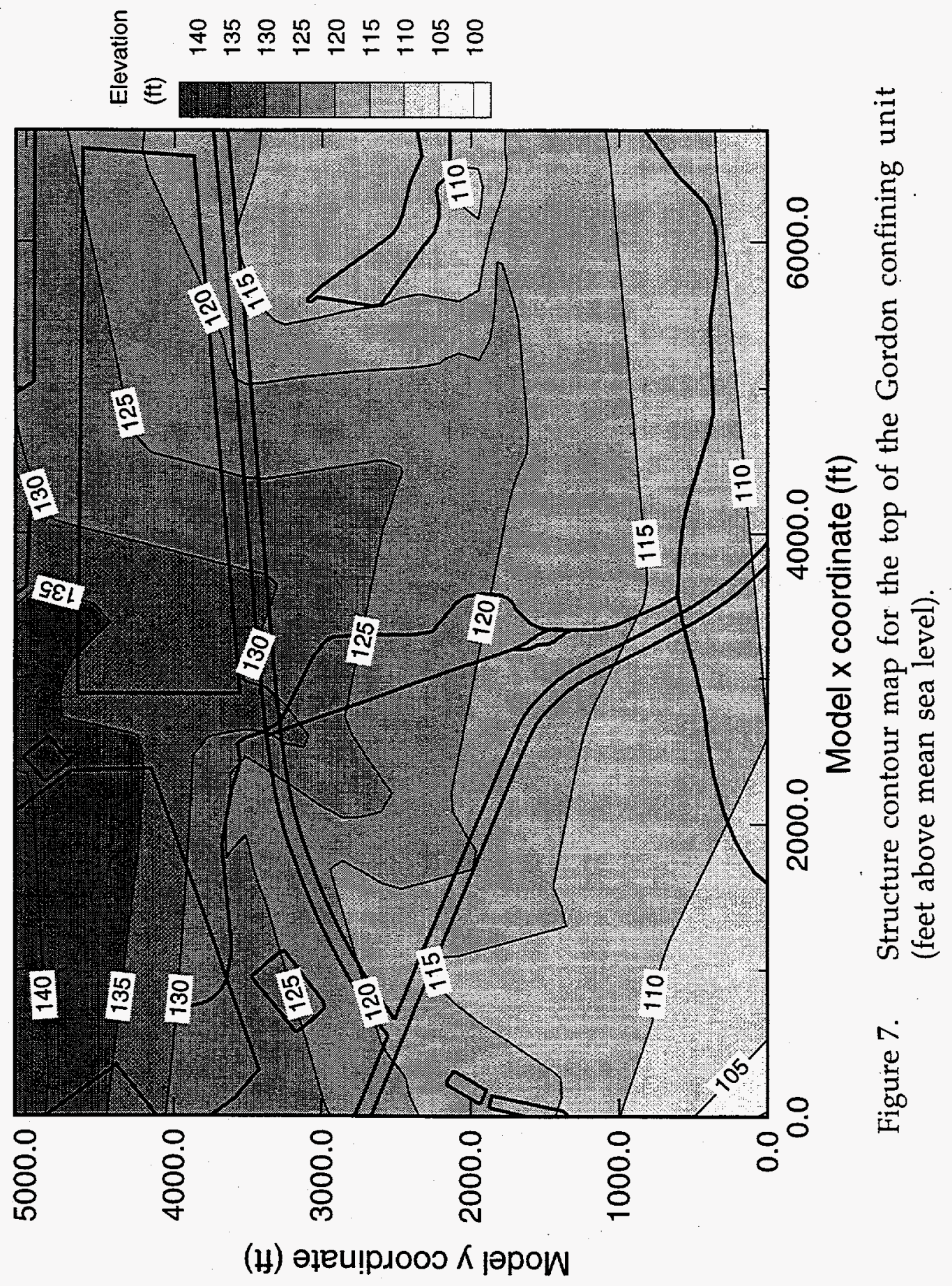




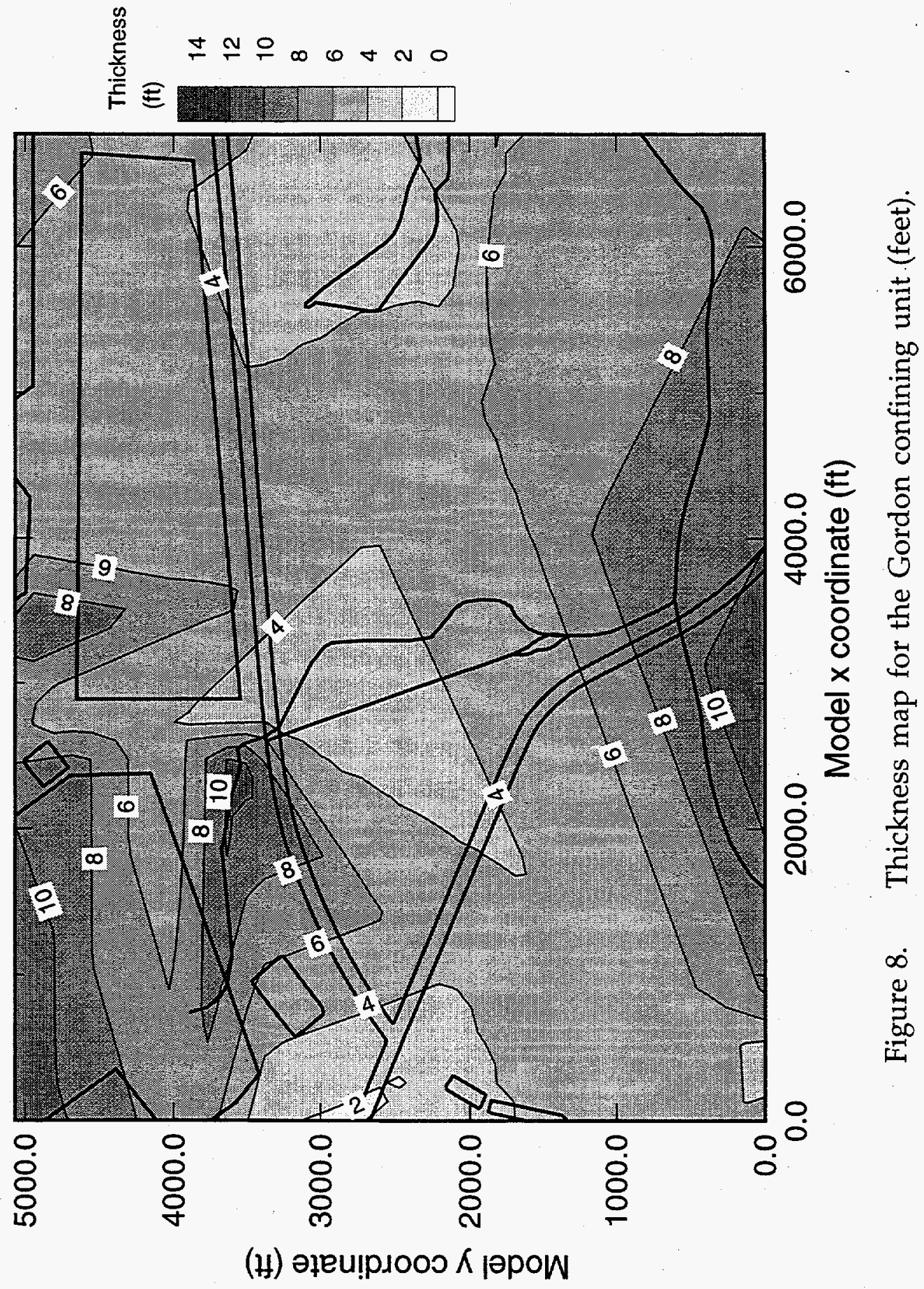




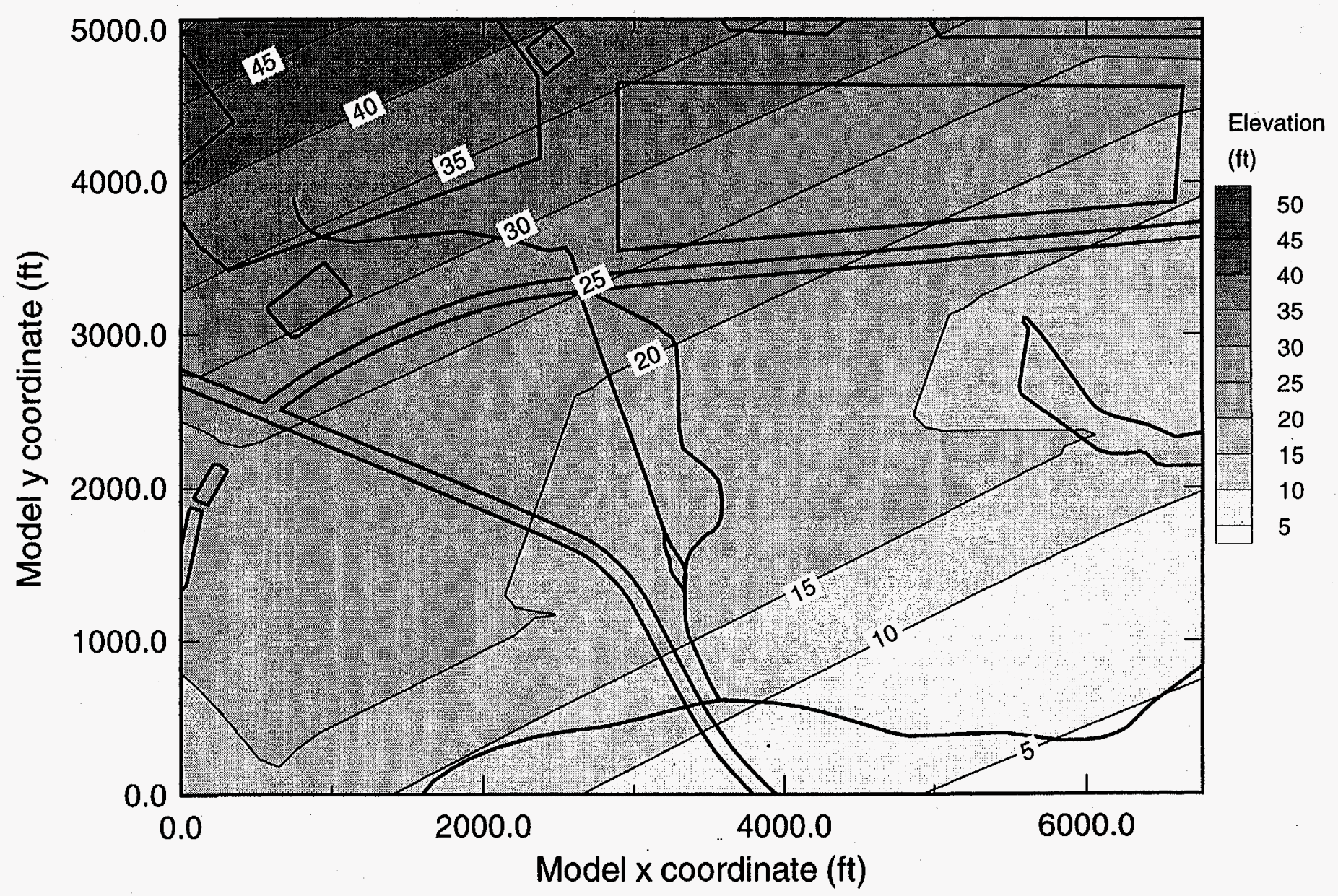

Figure 9. Structure contour map for the top of the Meyers Branch confining system (feet above mean sea level). 

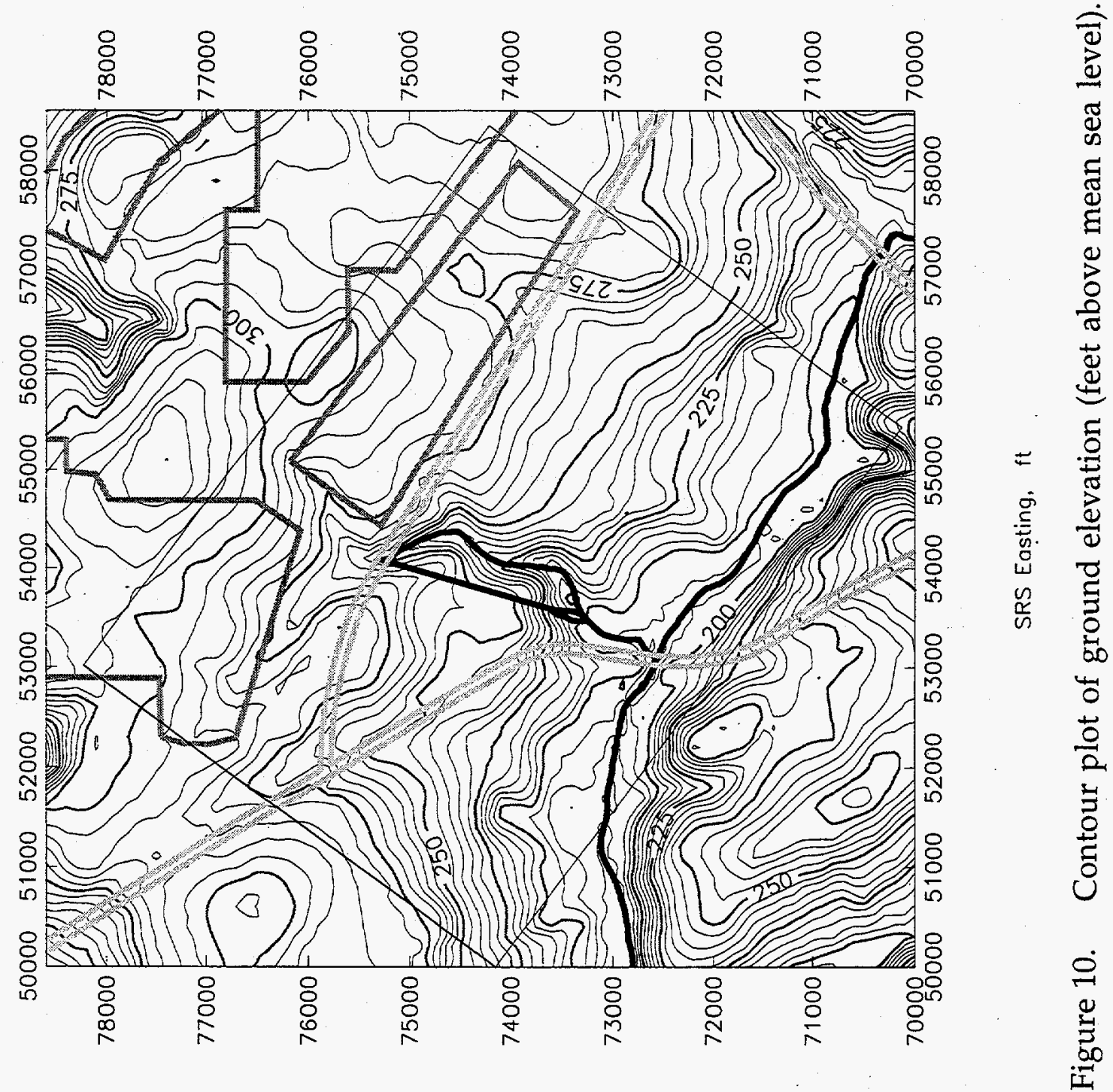

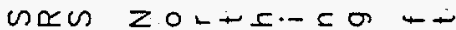




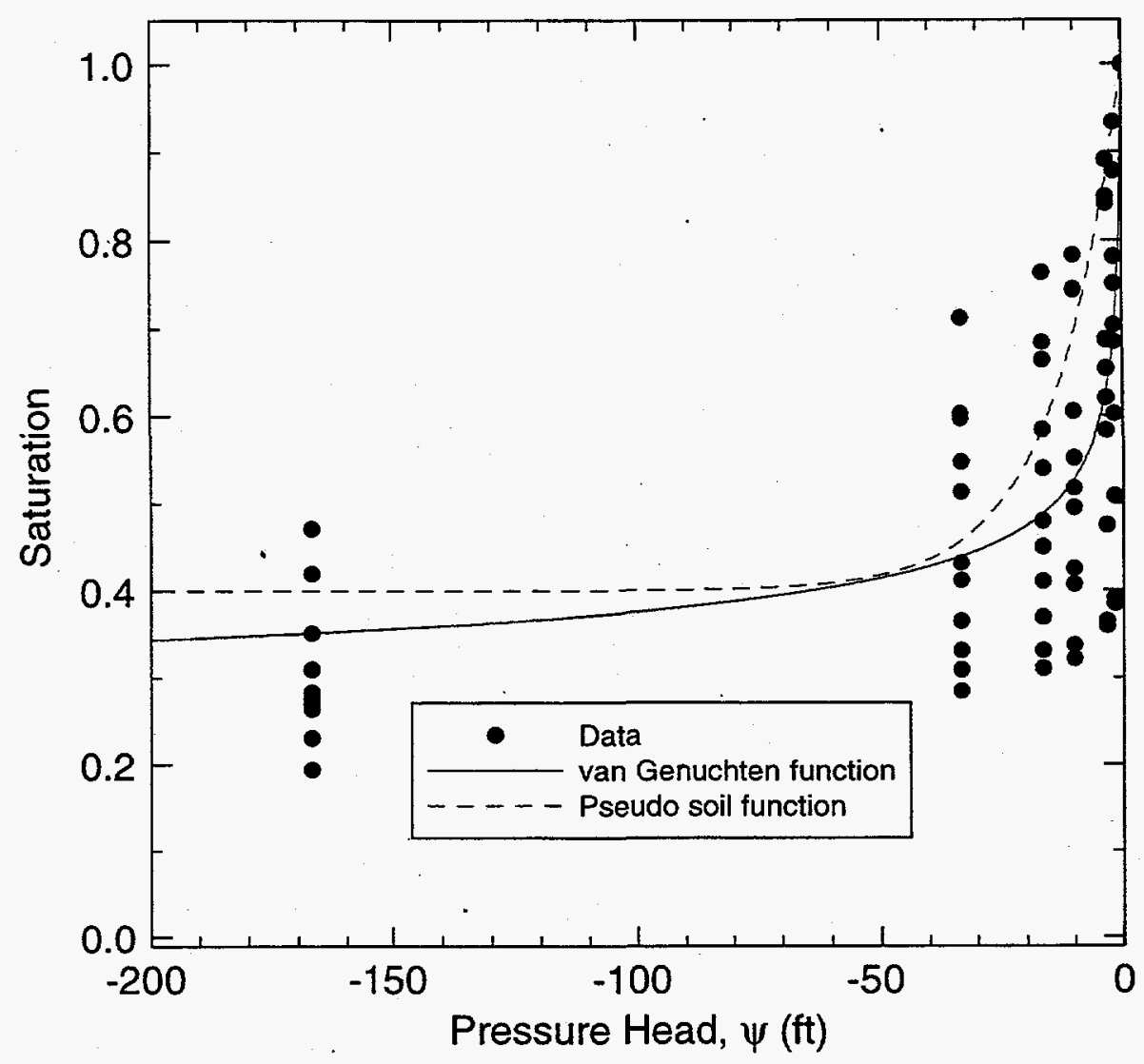

Figure 11. Water retention data and models for sandy sediment. 


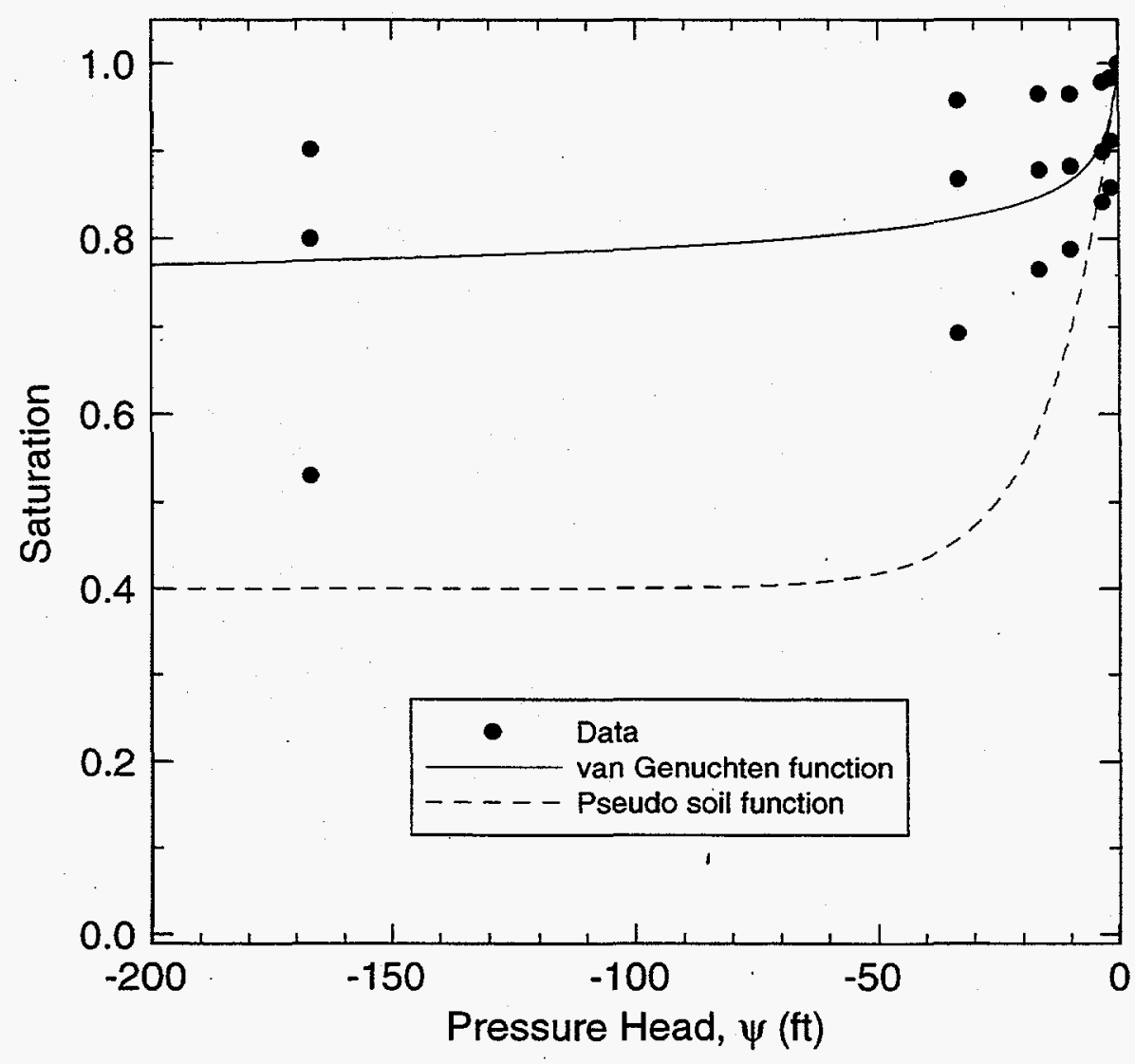

Figure 12. Water retention data and models for clayey sediment. 


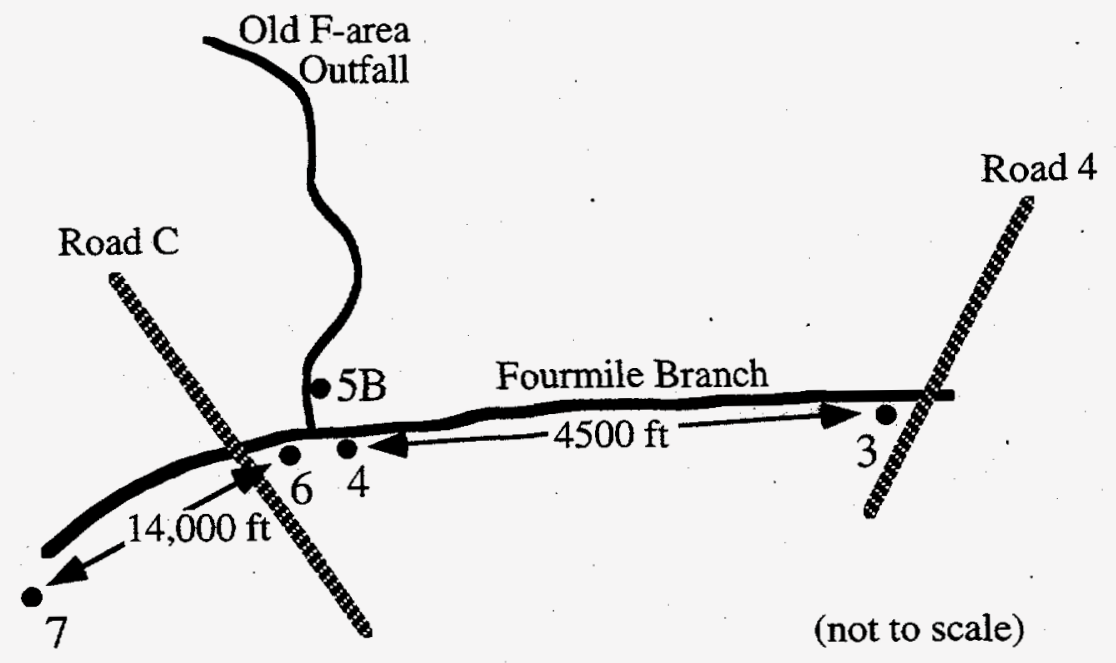

Figure 13. U. S. Geological Survey stream flow rate monitoring stations on Fourmile Branch. 


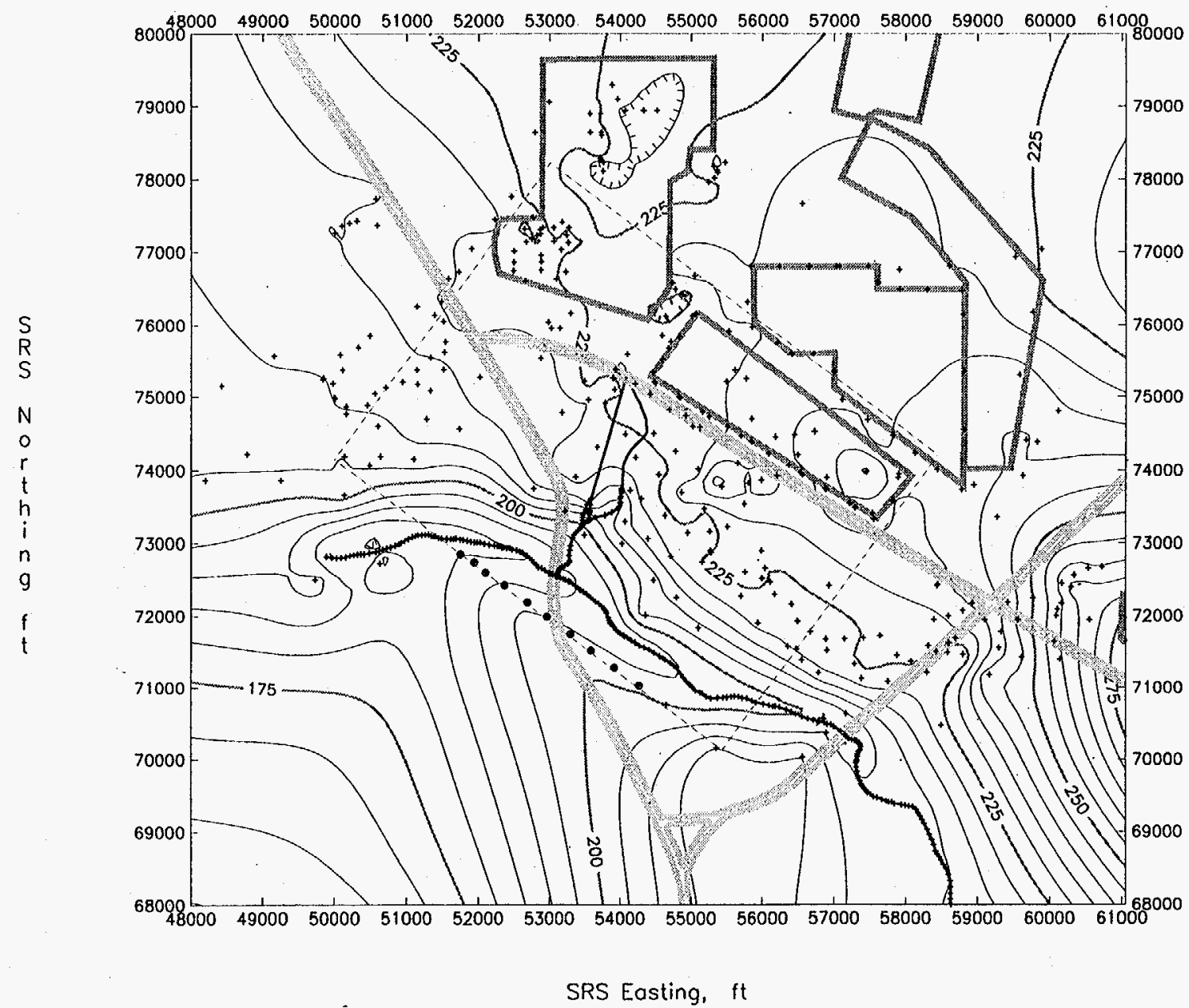

Figure 14. Head contour map for the "upper" aquifer zone within the Upper Three Runs aquifer (feet above mean sea level). + denotes data, $\oplus$ pseudo-data. 


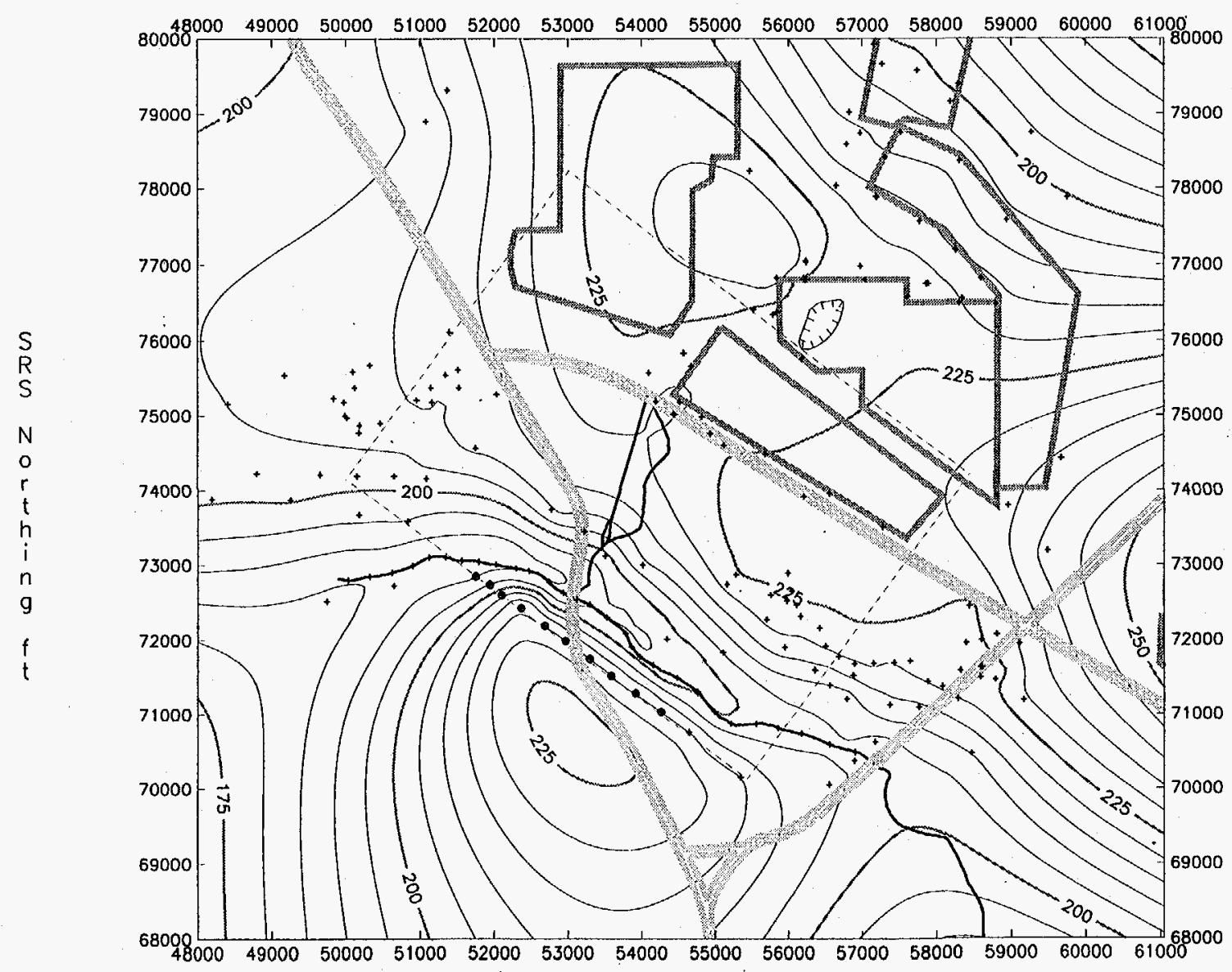

SRS Easting, ft

Figure 15. Head contour map for the "lower" aquifer zone within the Upper Three Runs aquifer (feet above mean sea level). + denotes data, $\oplus$ pseudo-data. 


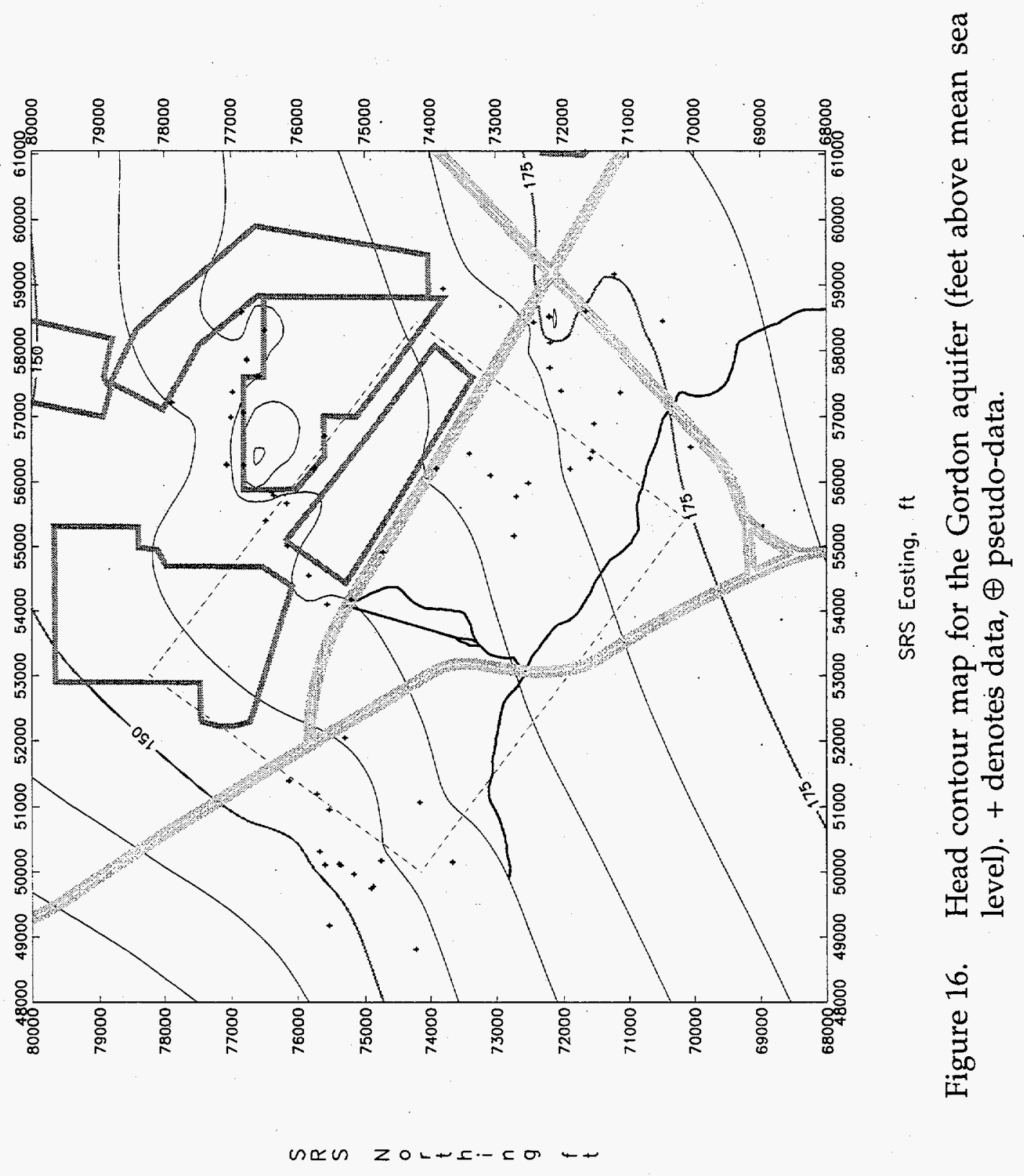




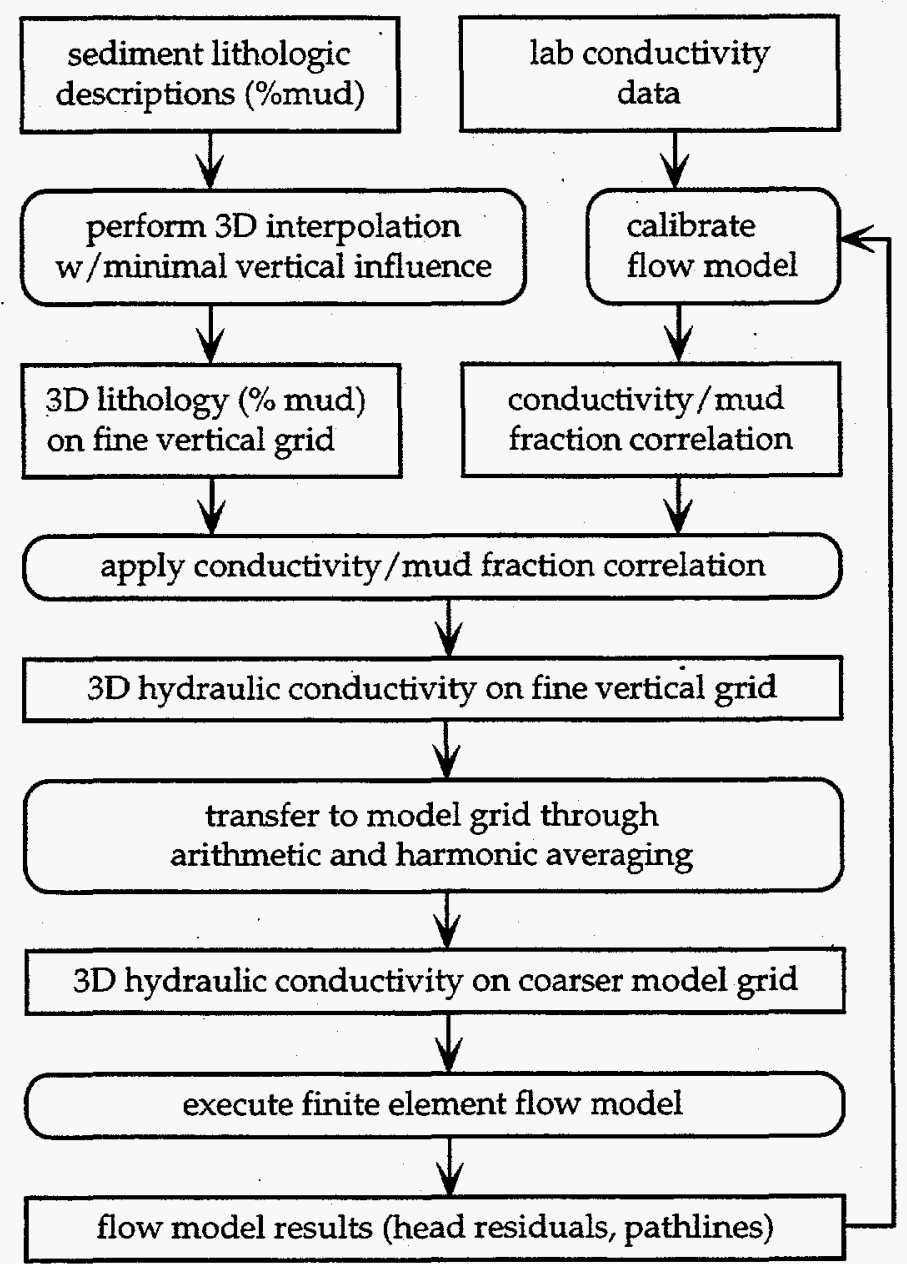

Figure 17. Flowchart summarizing the methodology for creating a heterogeneous conductivity field from sediment lithologic descriptions. 


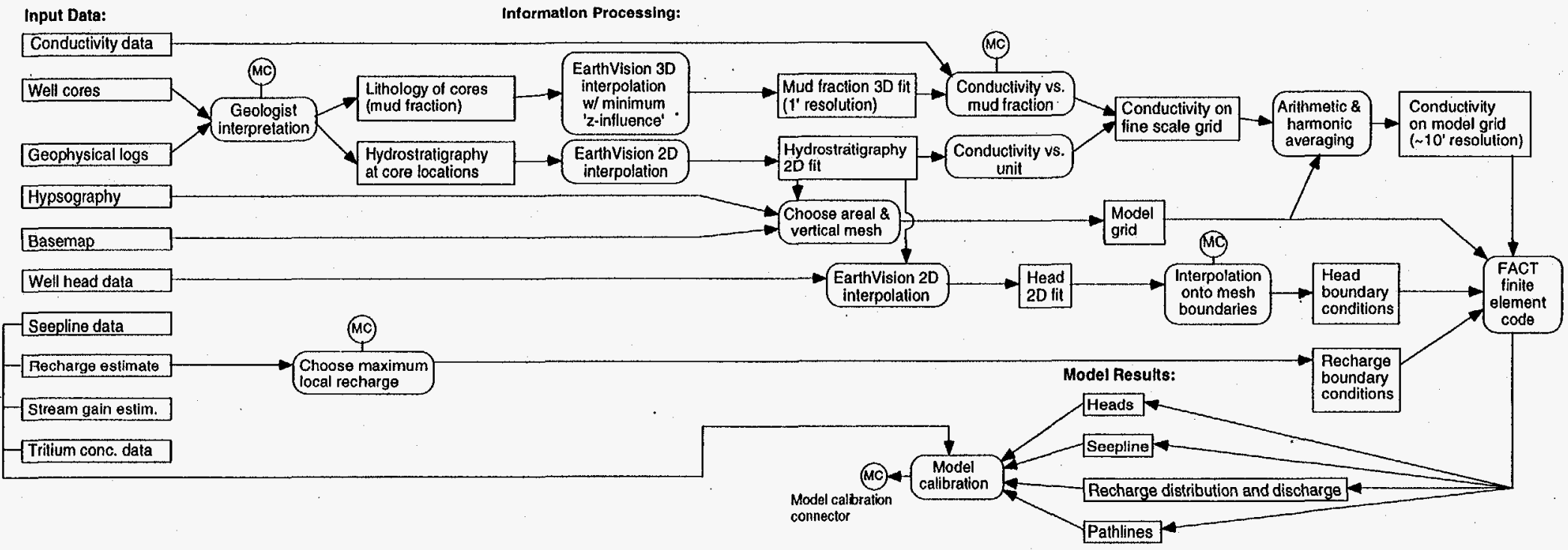

Figure 18. Flowchart summarizing the process chosen for creating a groundwater flow model using sediment core lithologic descriptions. 


\section{mud fraction}

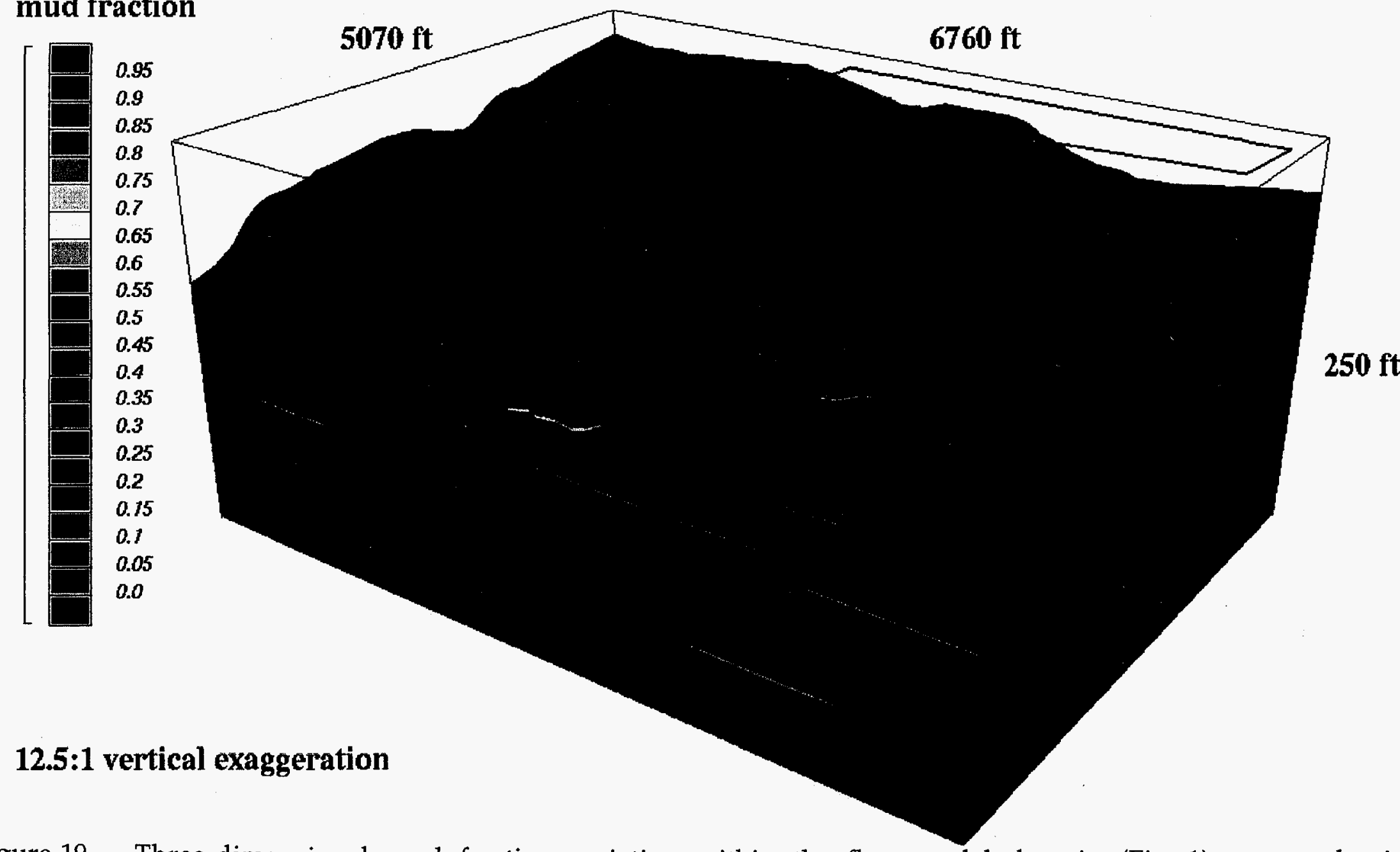

Figure 19. Three-dimensional mud fraction variation within the flow model domain (Fig. 1) generated with EarthVision ${ }^{\circledR}$ 's minimum tension 3D gridding algorithm and a vertical influence factor of 0.01 . A total of 12,626 mud fraction values from the 84 cores depicted in Figure 1 were interpolated. 


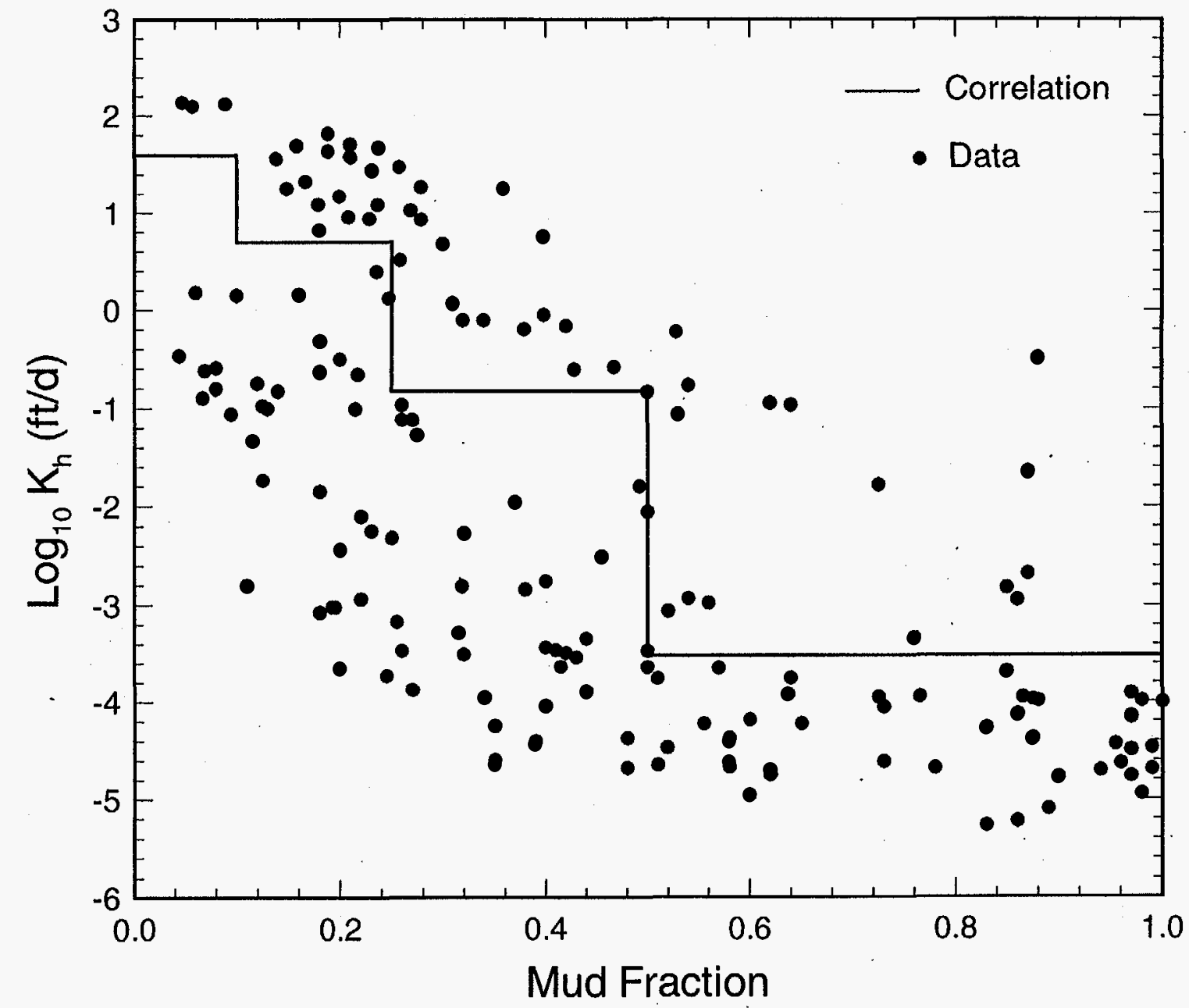

Figure 20. Horizontal conductivity as a function of mud fraction. The data represent laboratory measurements of conductivity from undisturbed core samples and mud fraction measured by sieve analysis. The stairstep correlation line is the result of comparison to the data shown and inverse flow modeling. 


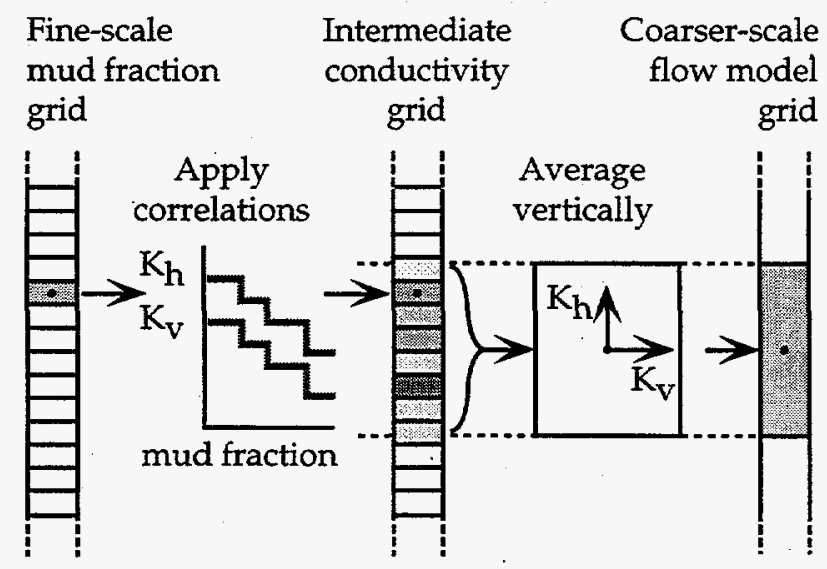

Figure 22. Process for translating the fine-scale mud fraction grid into the coarser-scale flow model conductivity grid. 


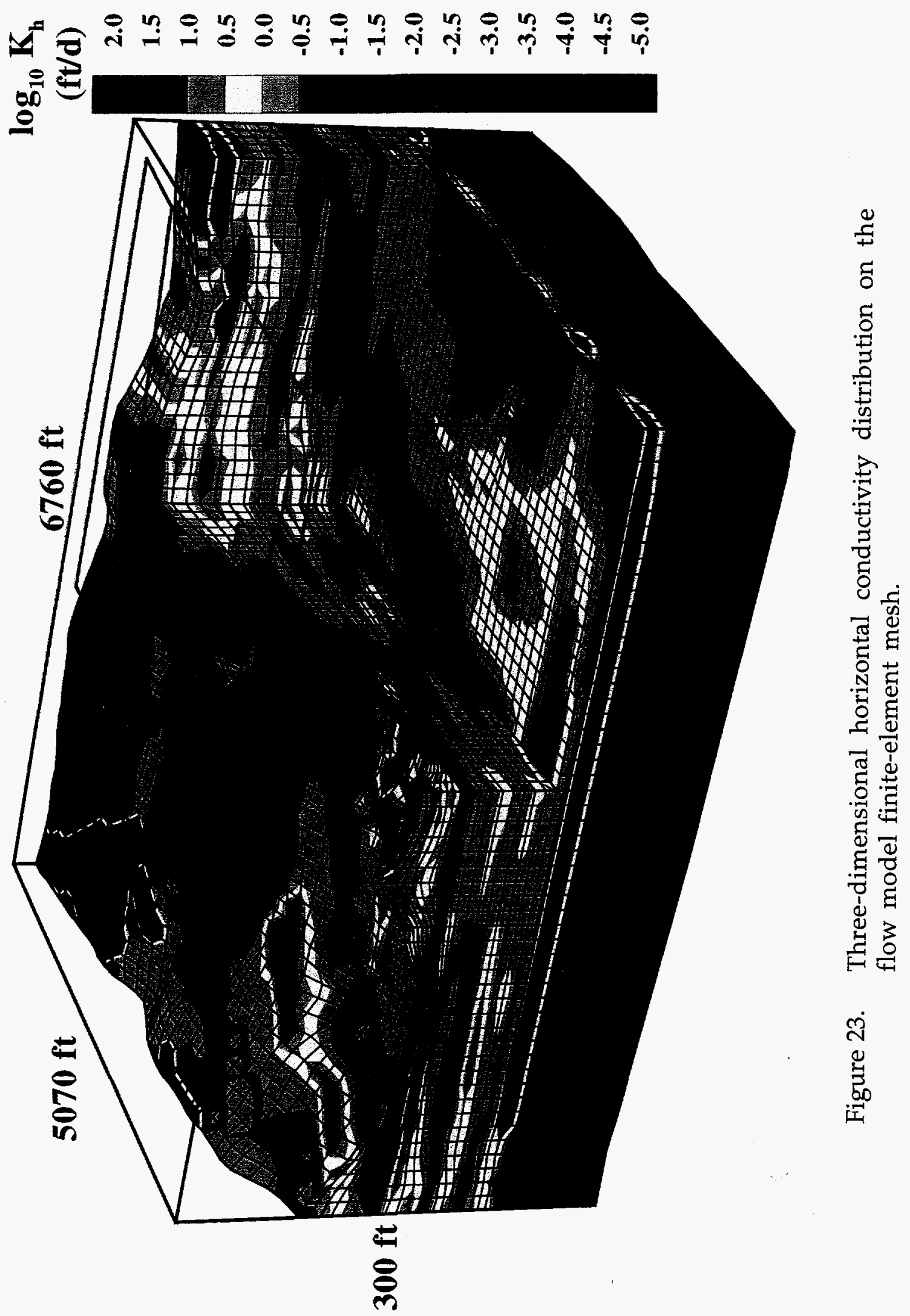




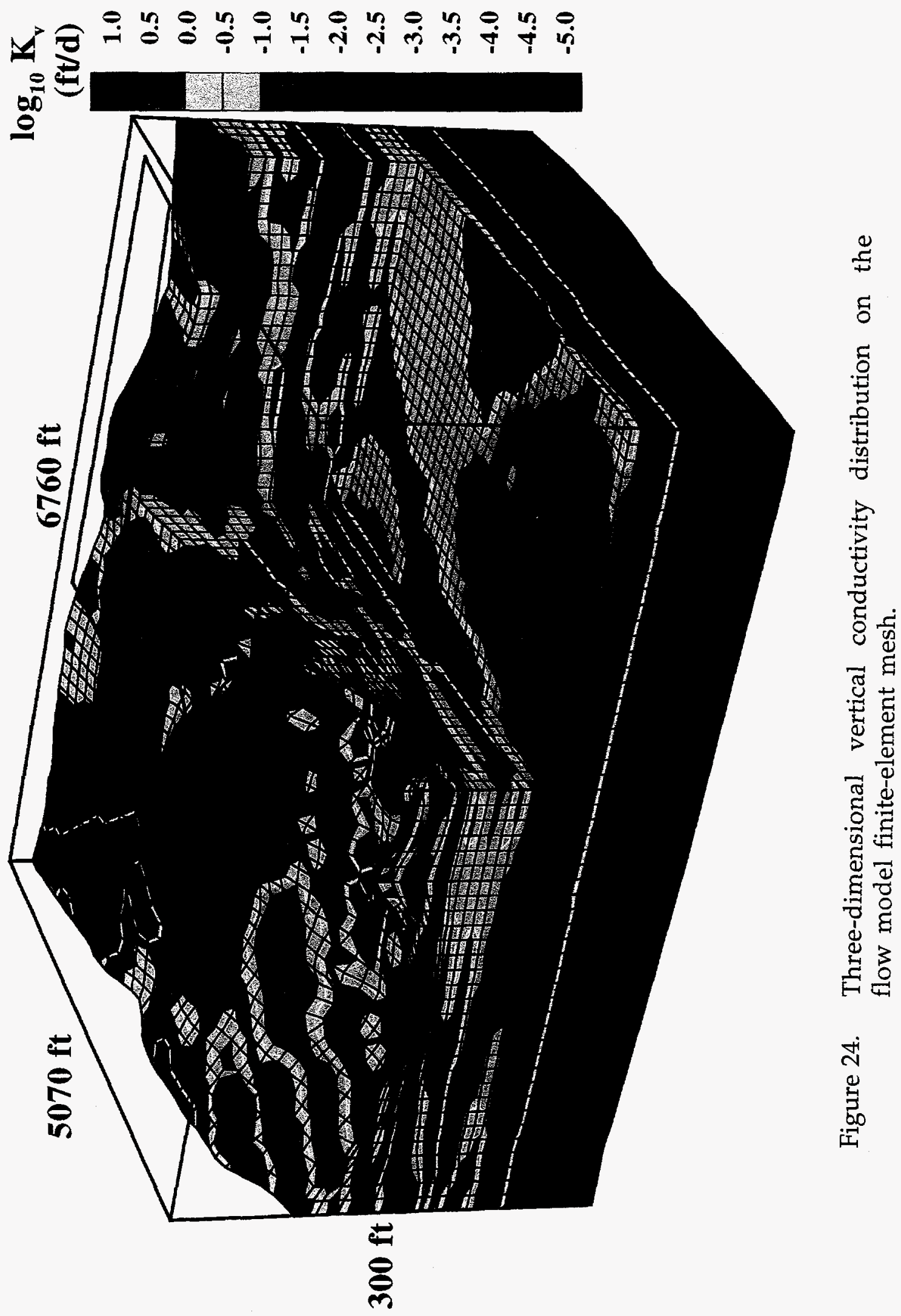




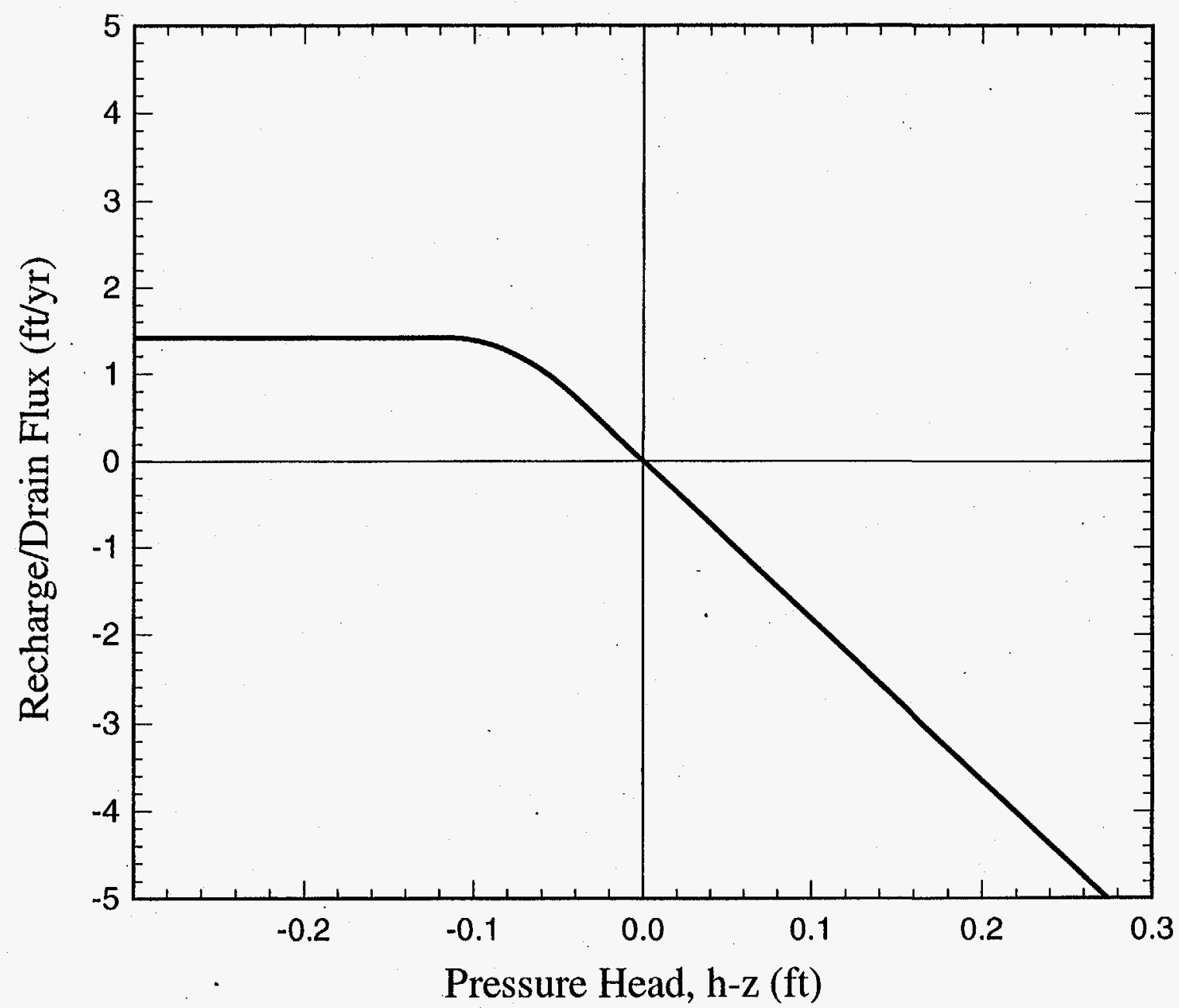

Figure 25. Combined recharge/drain boundary condition applied over the entire top surface of the flow model finite-element mesh. 


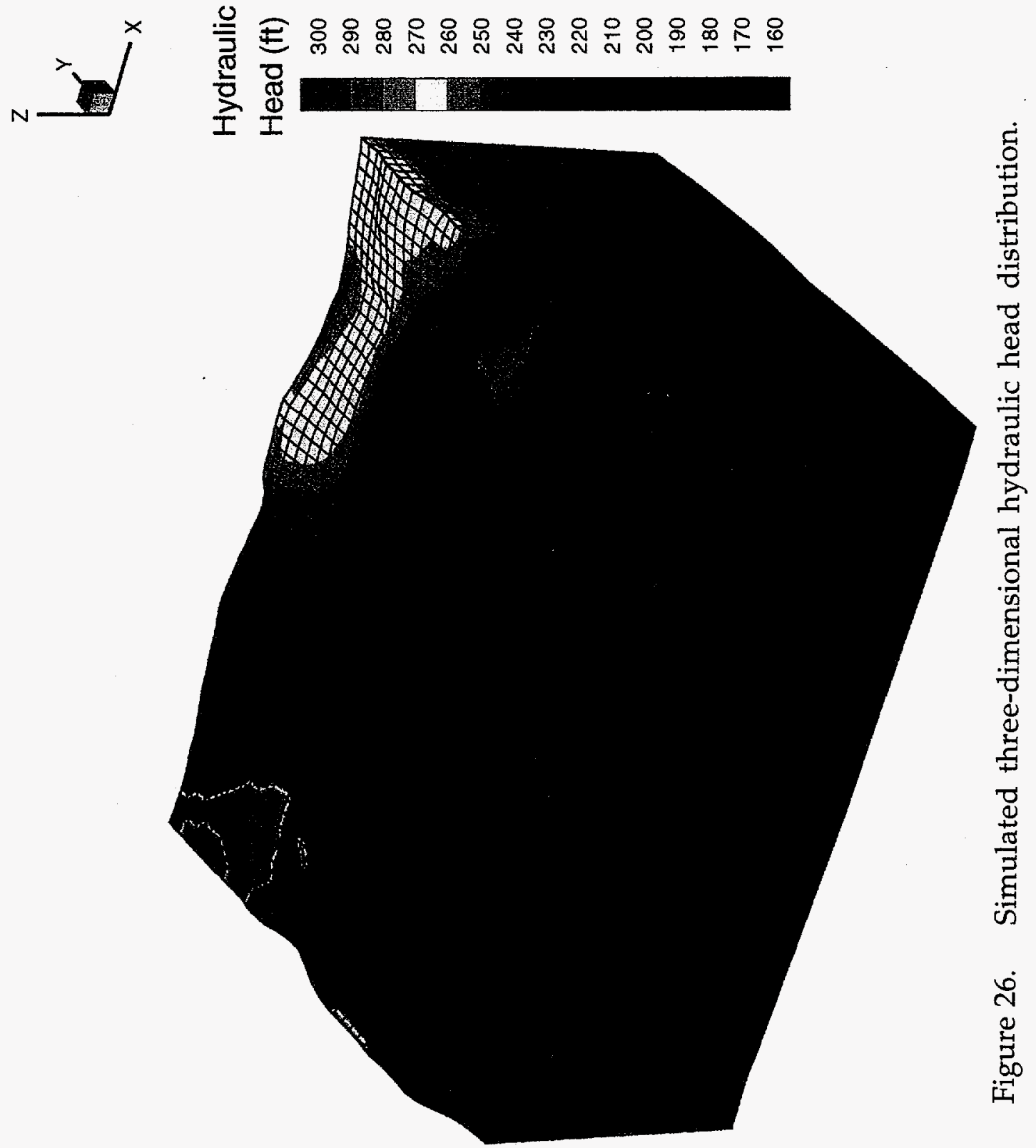




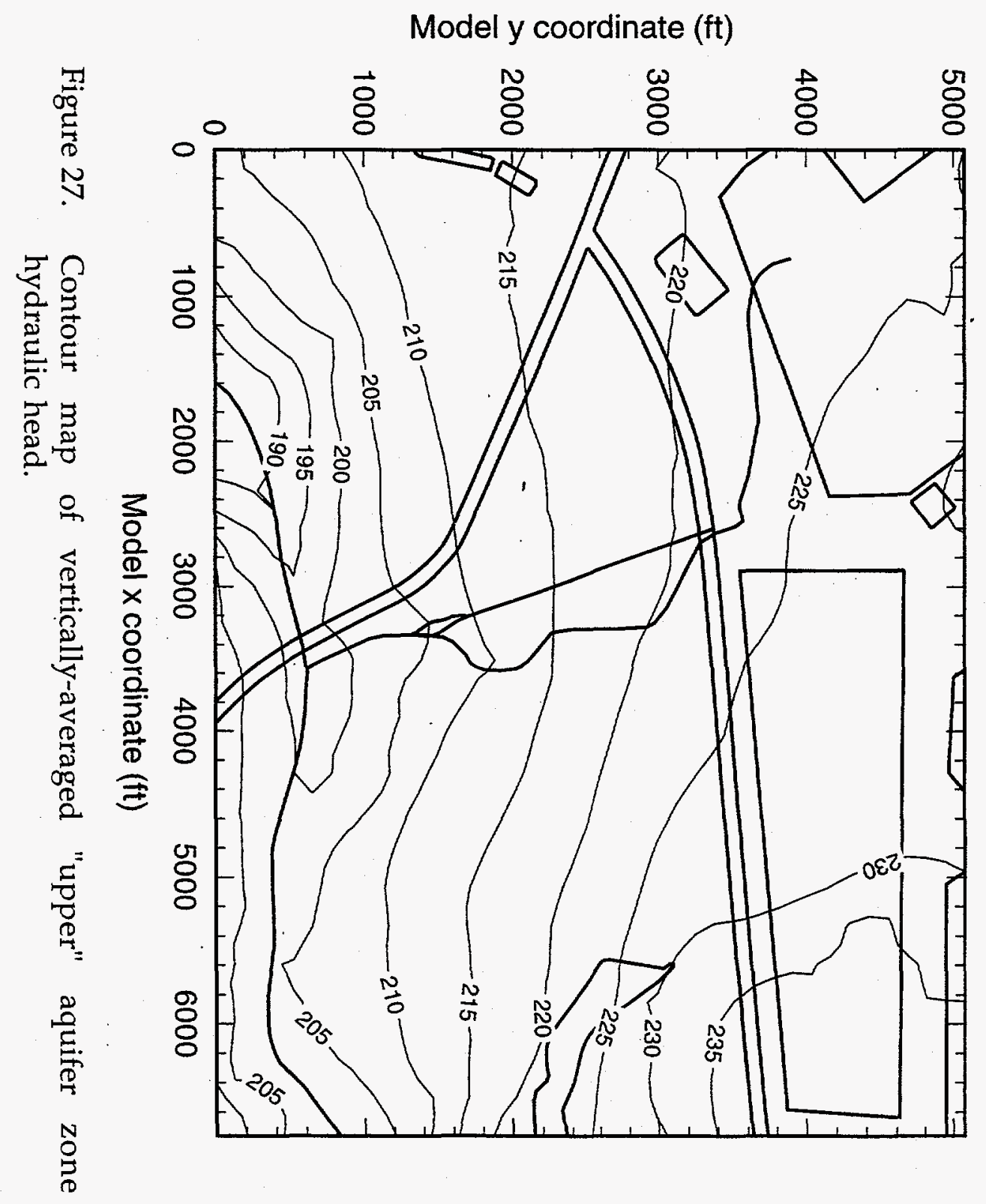




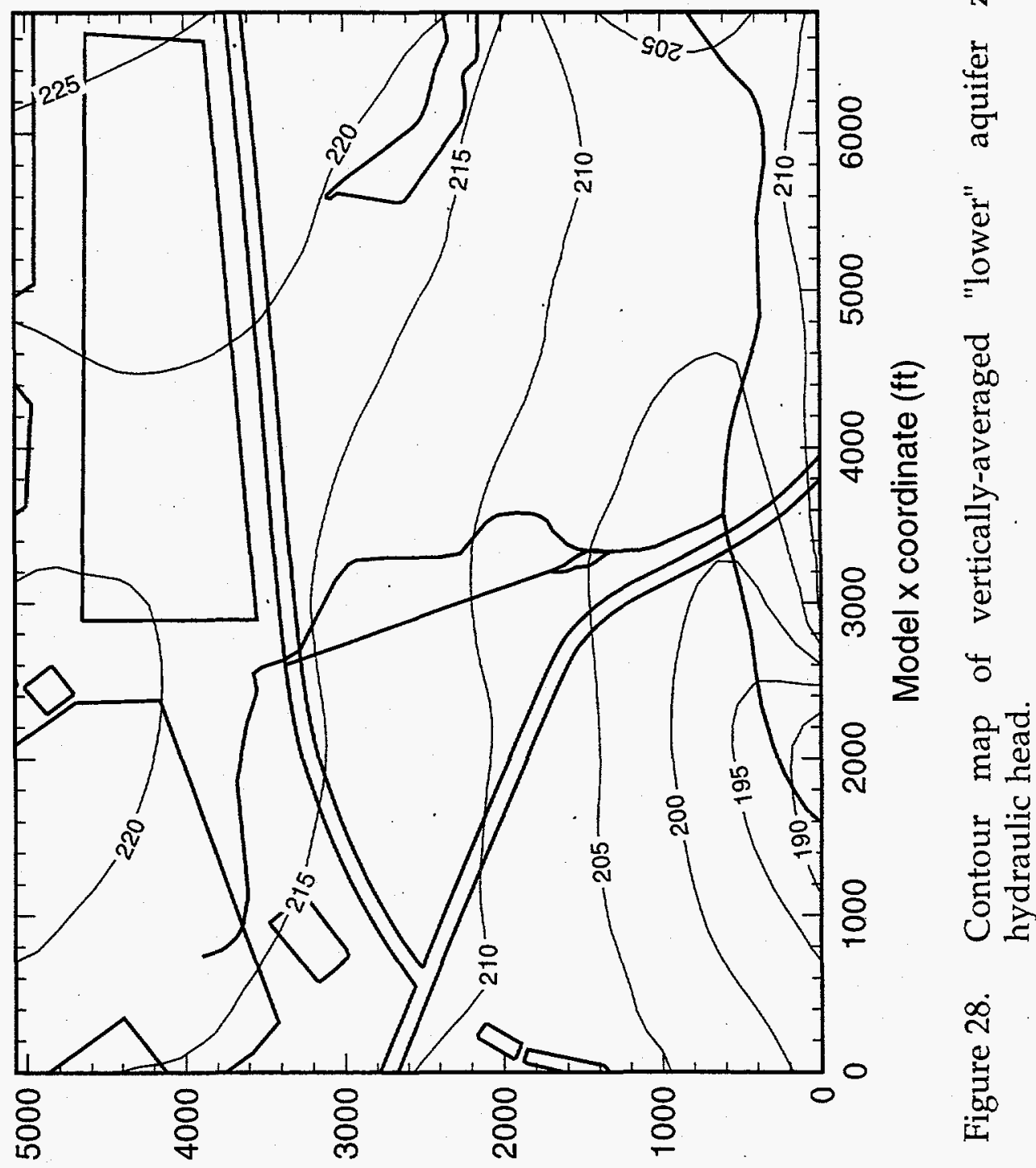

(н) әңеu!p 1000 К рәроW 


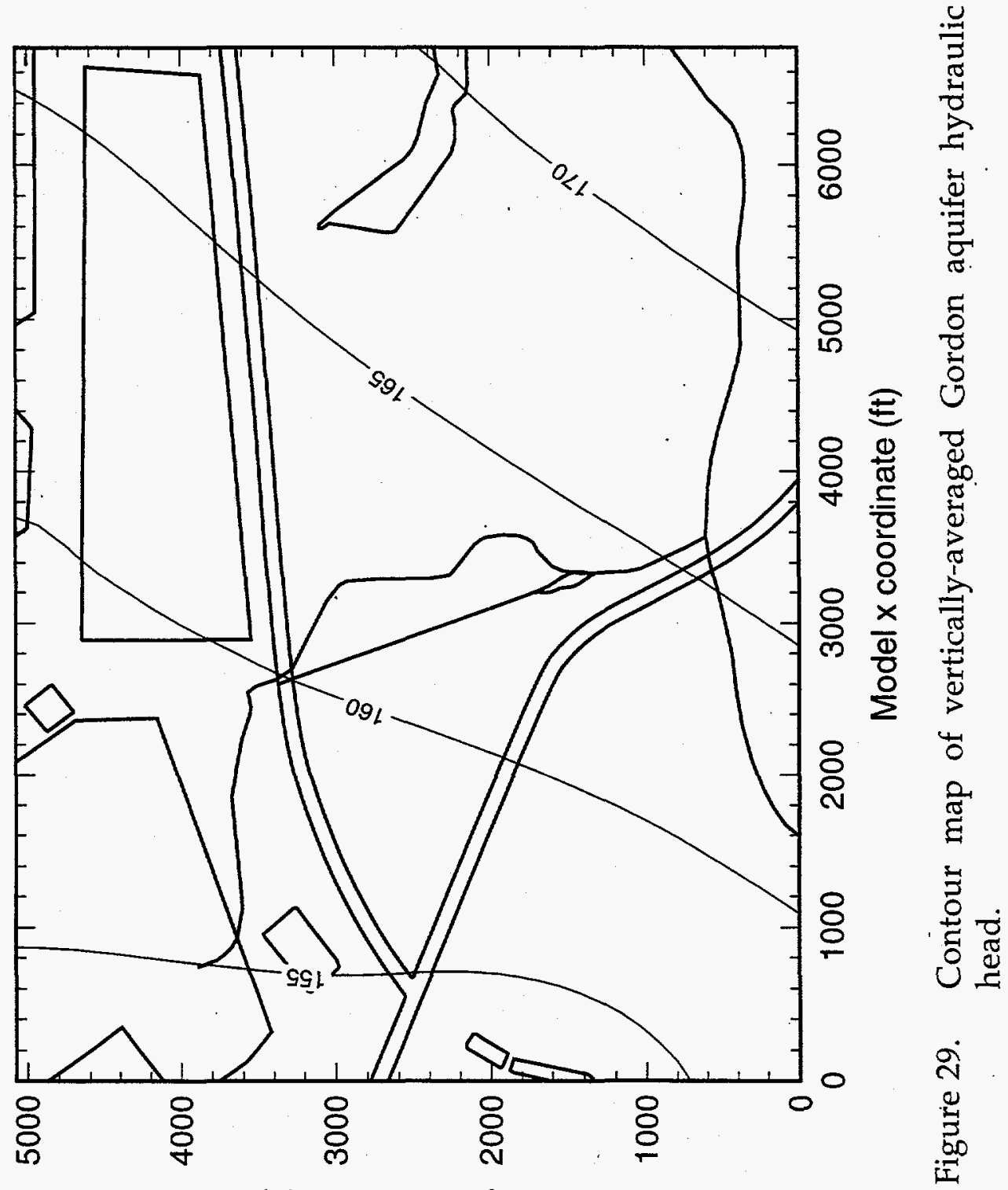

(ł) әңеu!p 1000 K lәроW 


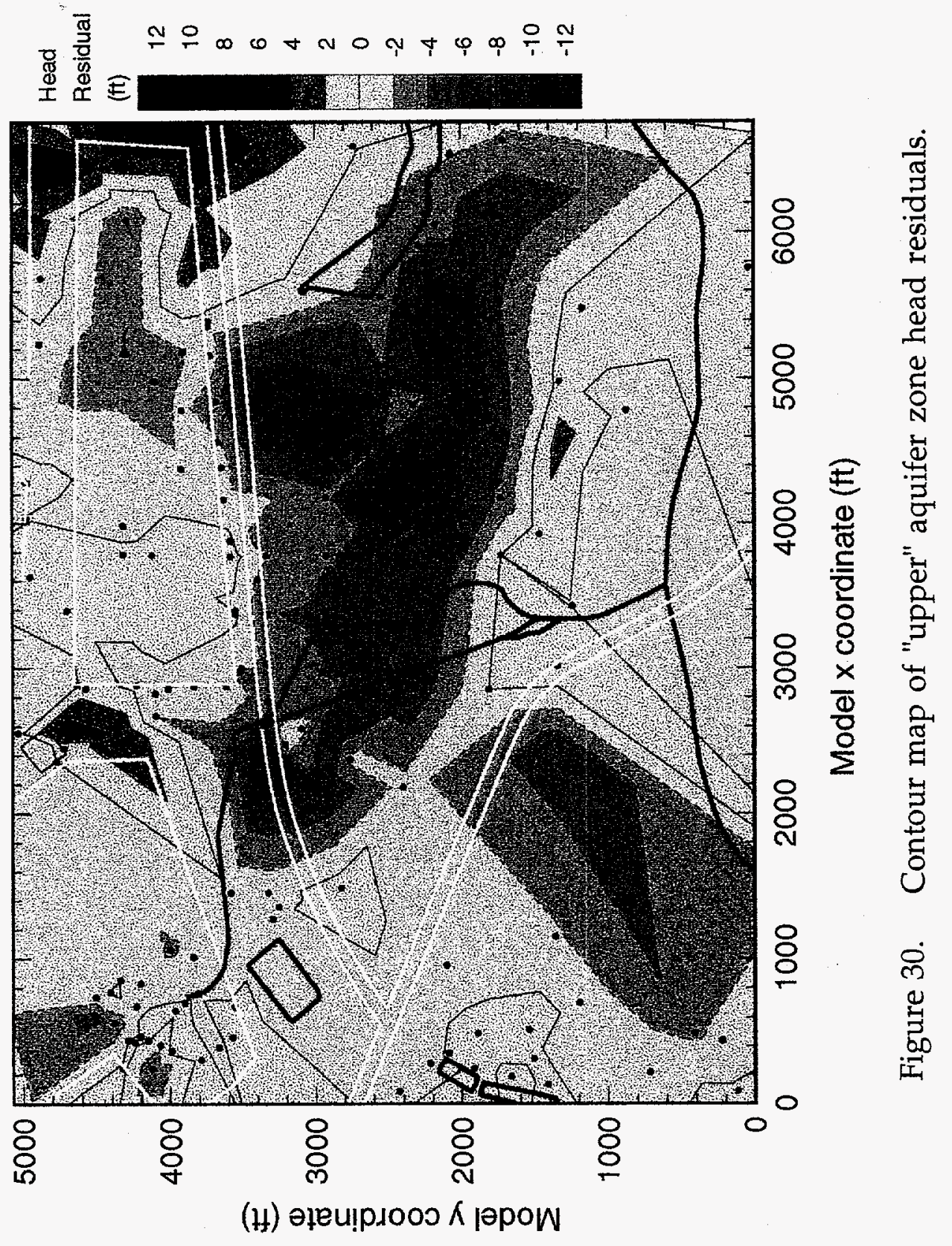




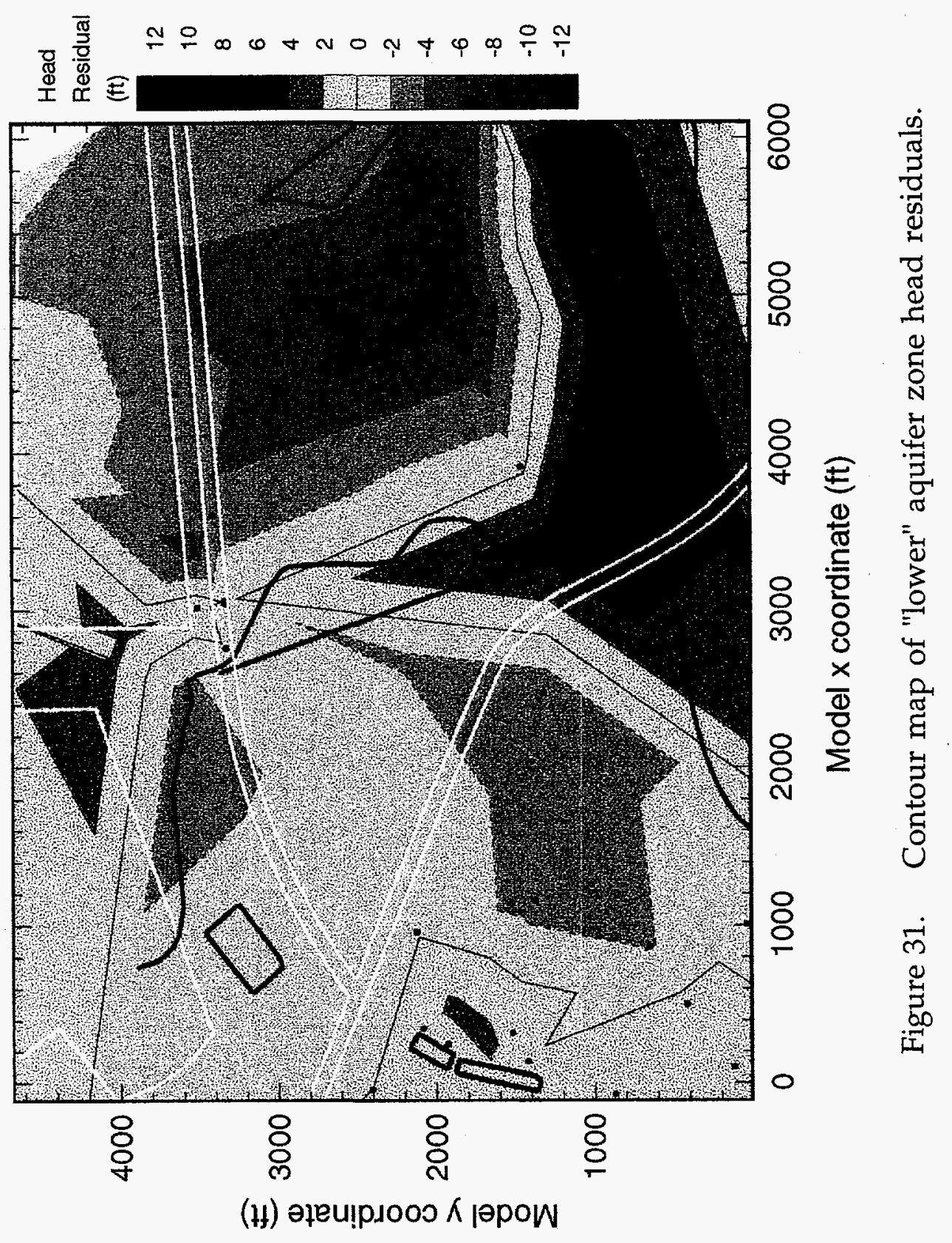




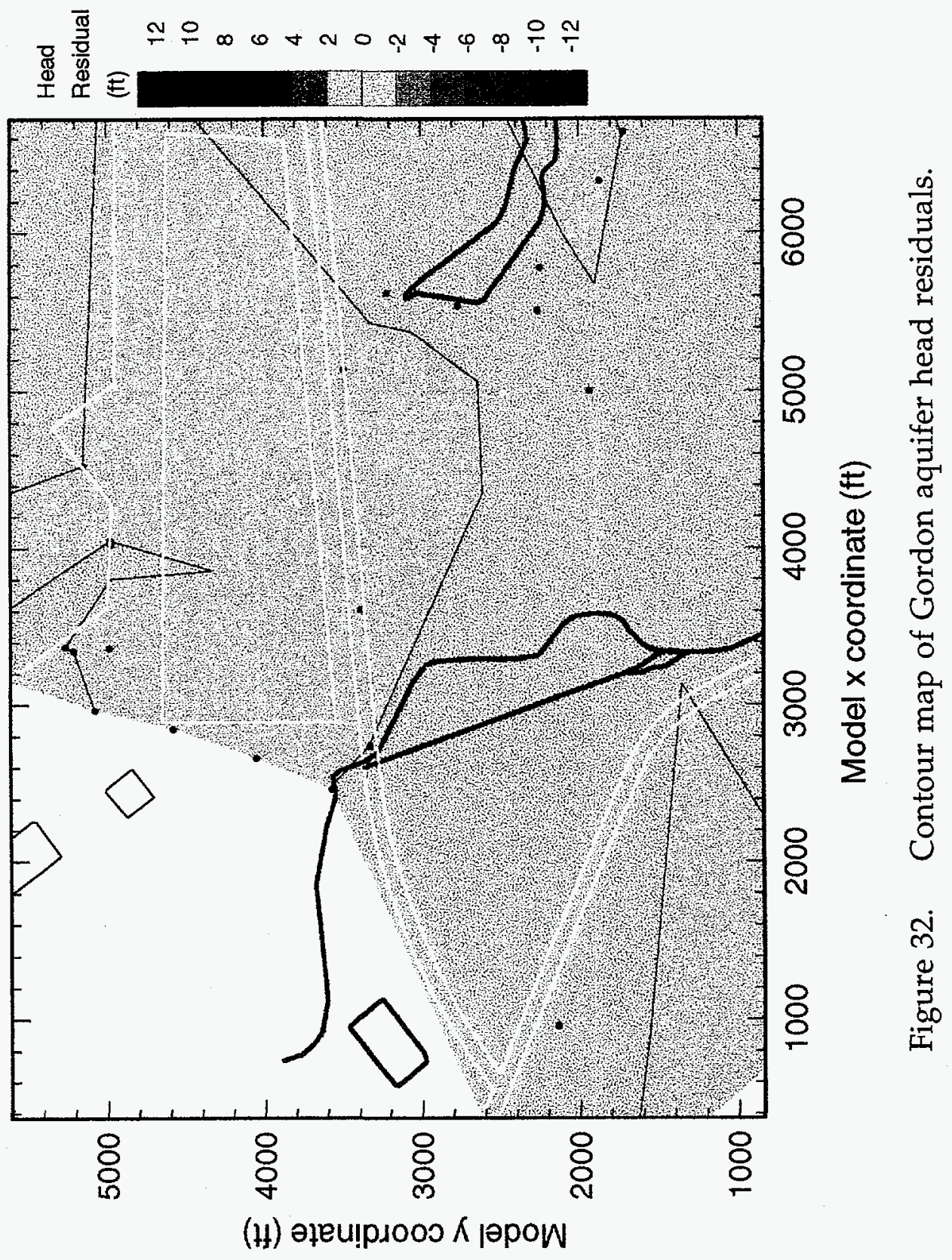




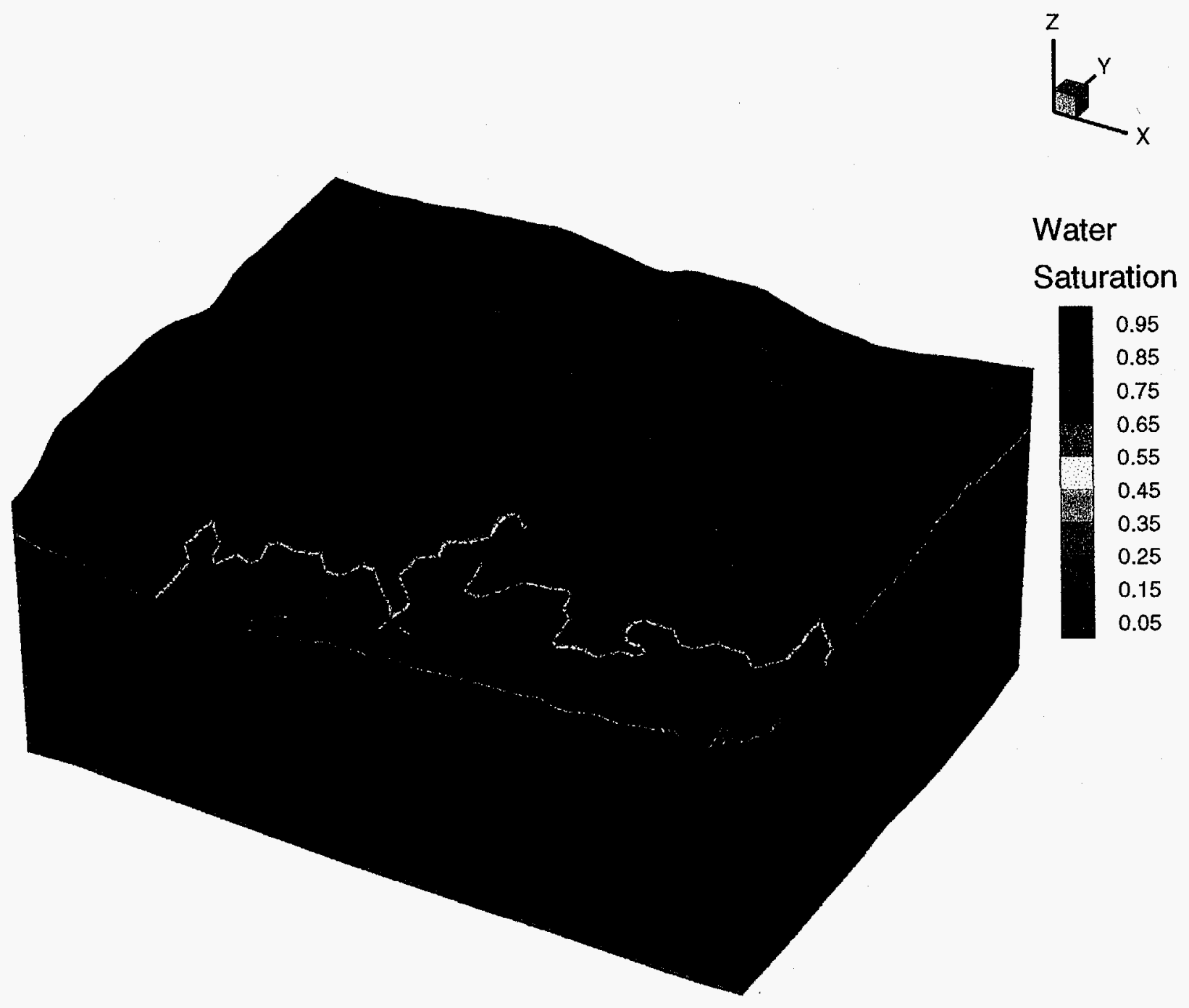

Figure 33. Simulated three-dimensional saturation distribution. 


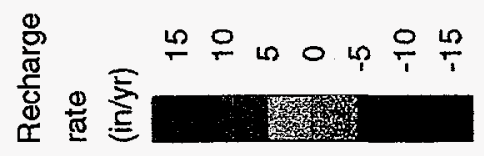

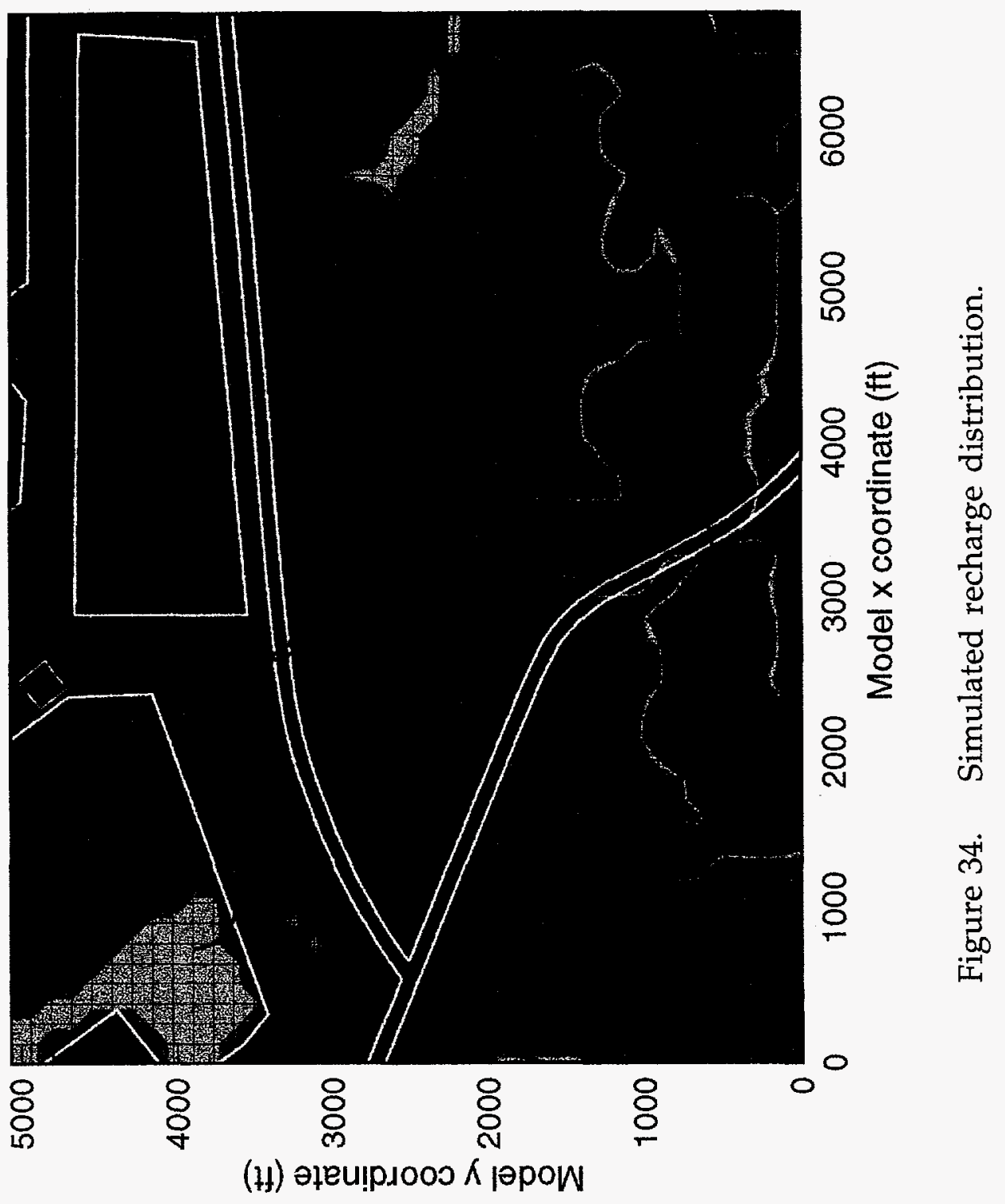




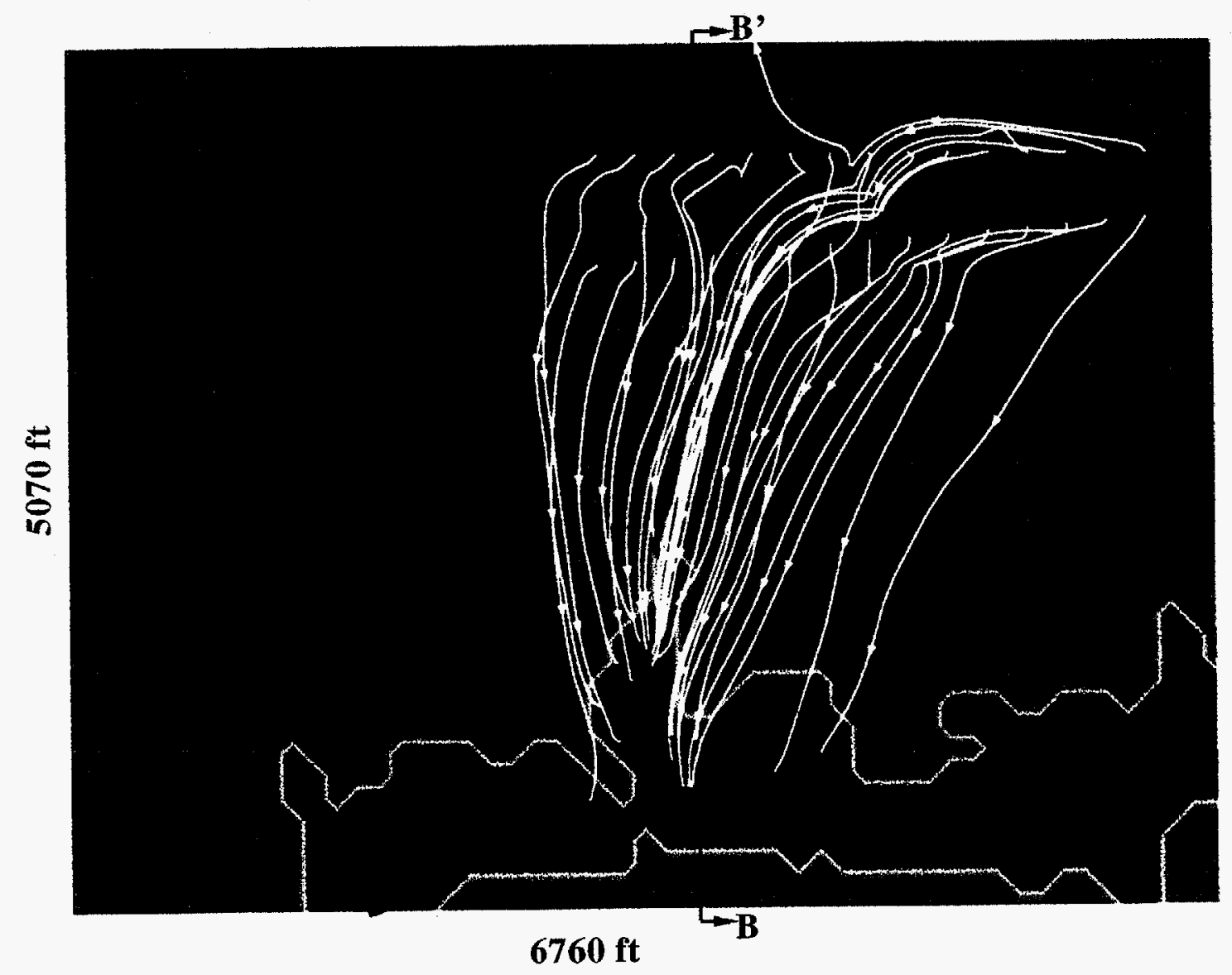

Figure 35. Three-dimensional pathlines originating from the Old Burial Ground projected onto a two-dimensional plane overlaying water saturation. 


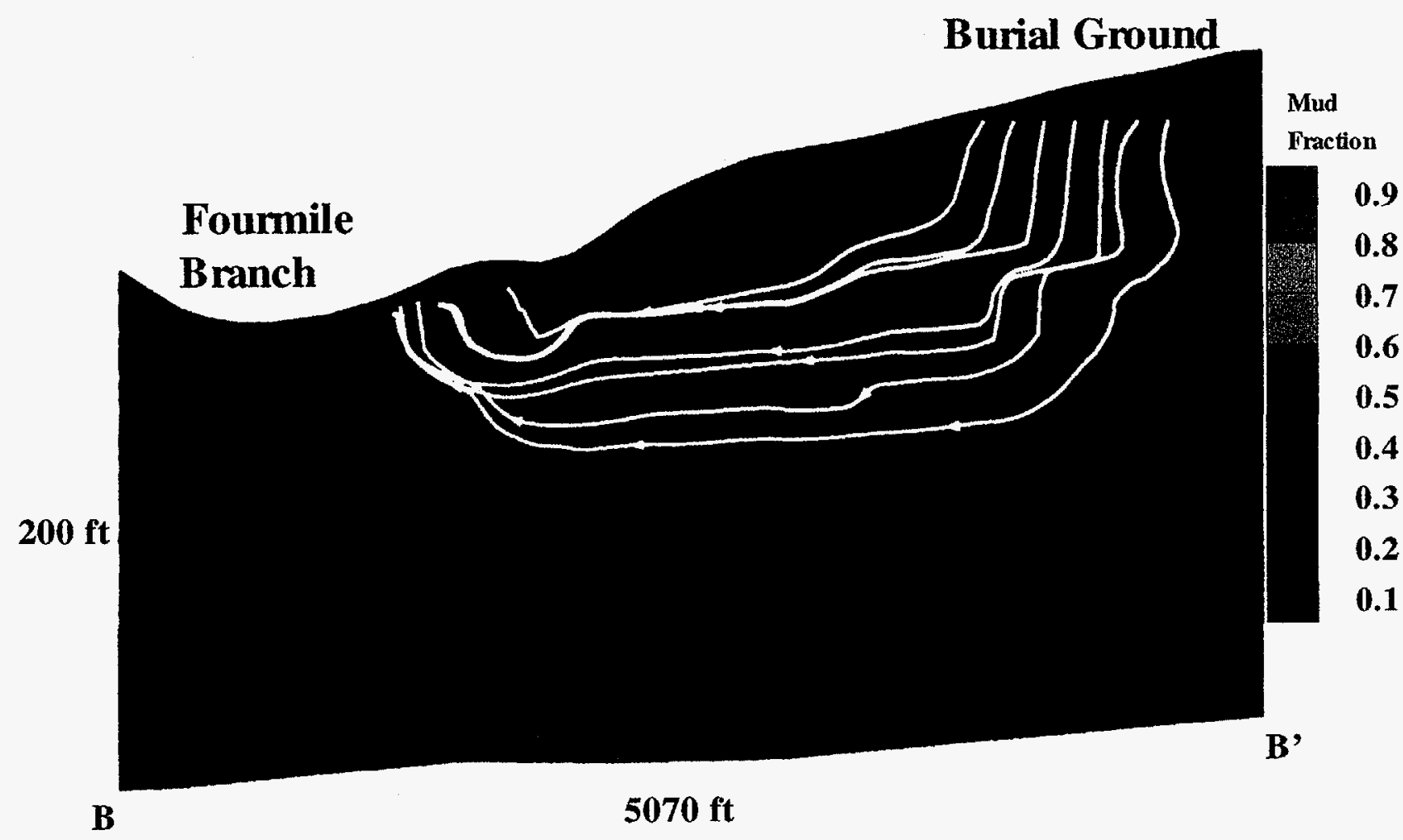

Figure 36. Three-dimensional pathlines projected onto cross-section B-B' in Figure 35 with mud fraction as the background. 


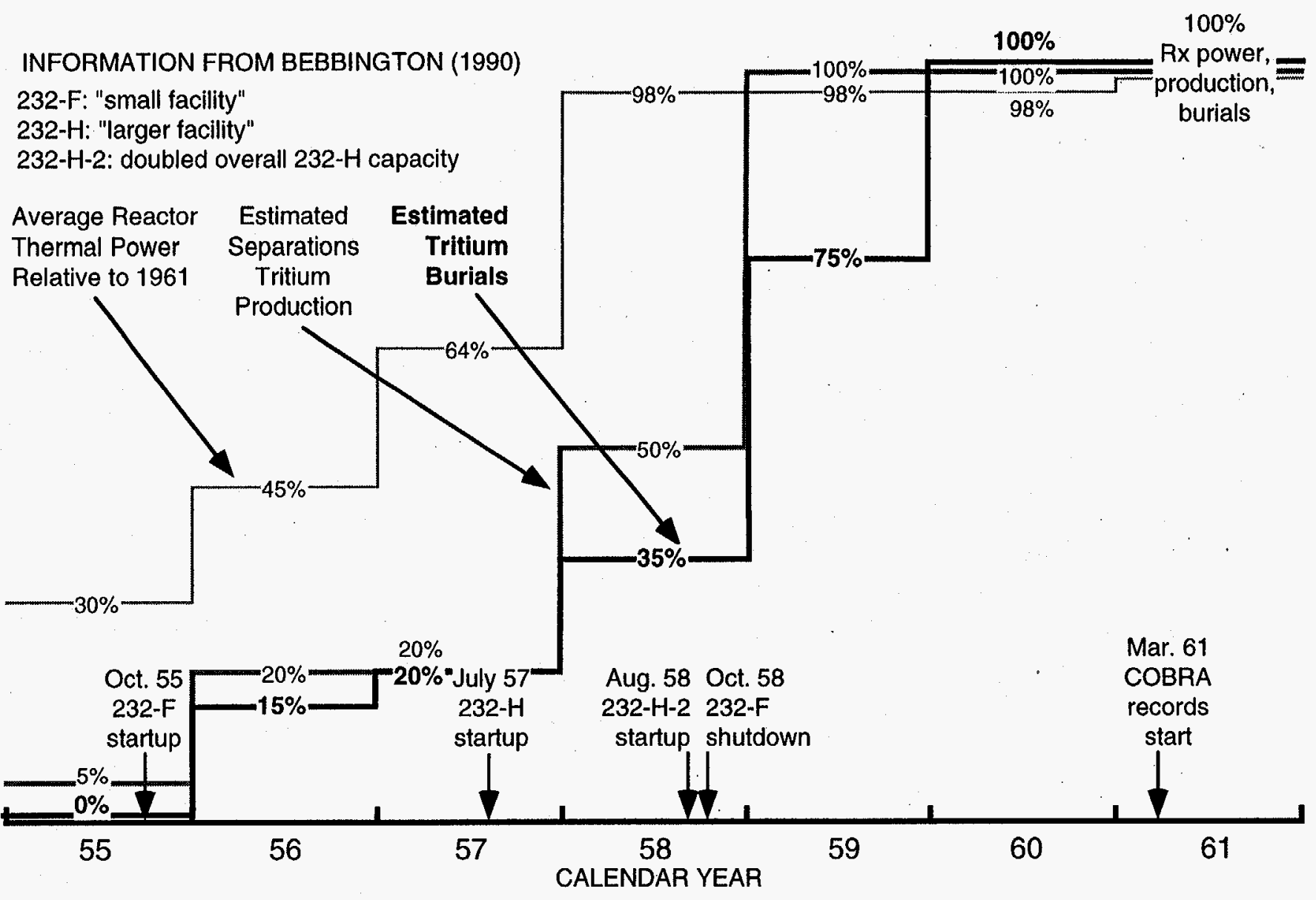

\section{BASIS FOR TRITIUM PRODUCTION ESTIMATES:}

$-100 \%$ value for $1959-60$ based on assumption that full production was reached with $232-\mathrm{H}-2$ startup

$.50 \%$ value for 1958 based on assumption that $232-\mathrm{H}-2$ doubled burials in 1959

- $20 \%$ value for $1956-57$ based on assumption that $232-\mathrm{H}$ has $50 \%$ more capacity than $232-\mathrm{F}$

$.5 \%$ value for 1955 is $20 \%$ prorated over the 3 months from Oct. to Dec.

-estimates are also consistent with average reactor power assuming all five reactors are operating from 1955-61

BASIS FOR TRITIUM BURIAL ESTIMATES

- 6 month delay assumed between production at separations facility and burial

-consistent with Table 2 of Hyder (1993), namely, sum of 1955-1960 burials divided by 1961 burials is 2.45 compared to 2.2 in Table 2

Figure 37. Estimated pre-COBRA tritium burials relative to 1961. 


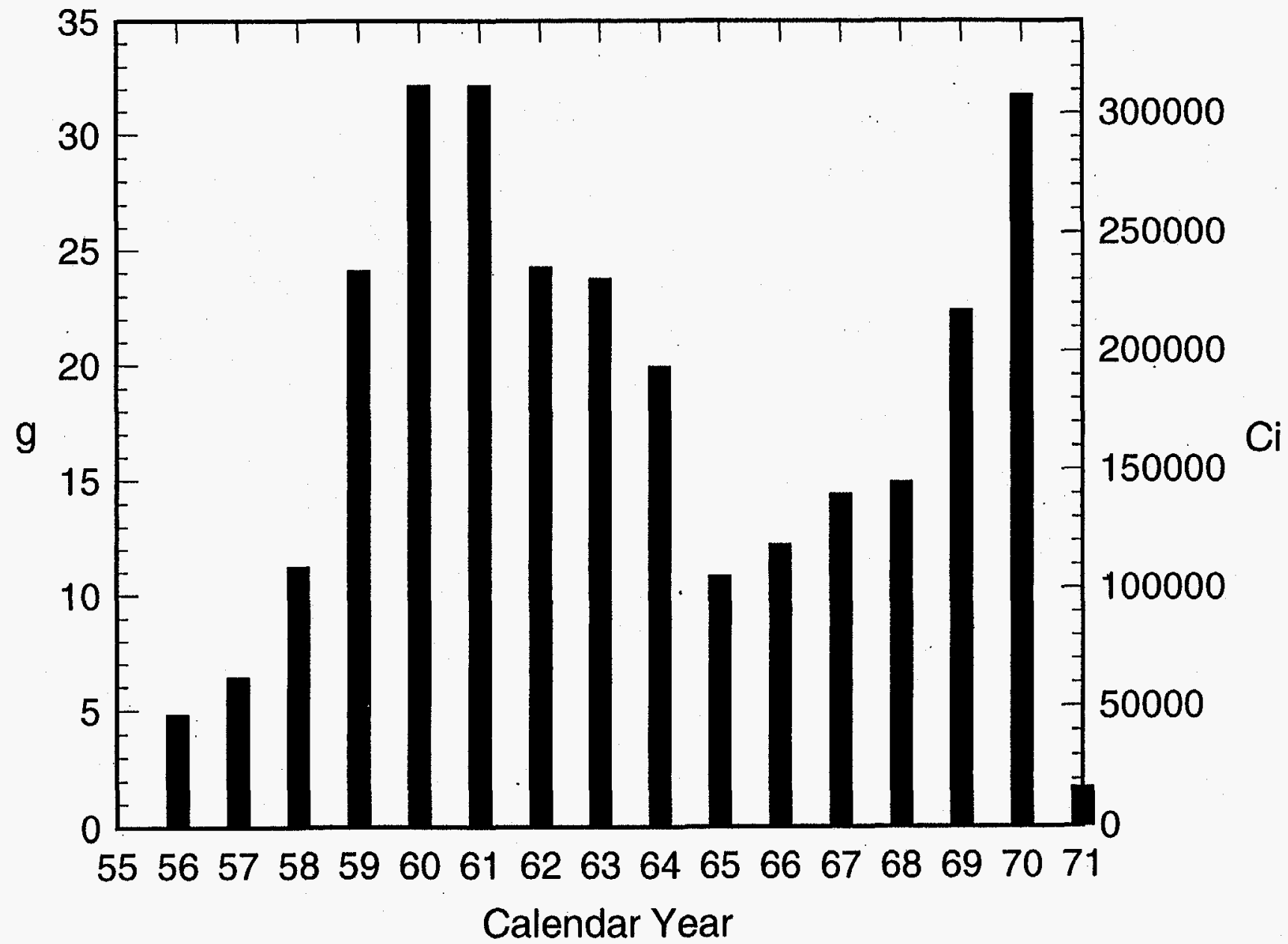

Figure 38. Estimated total annual tritium burials of all forms to the Old Burial Ground. 
North Coordinate, NC

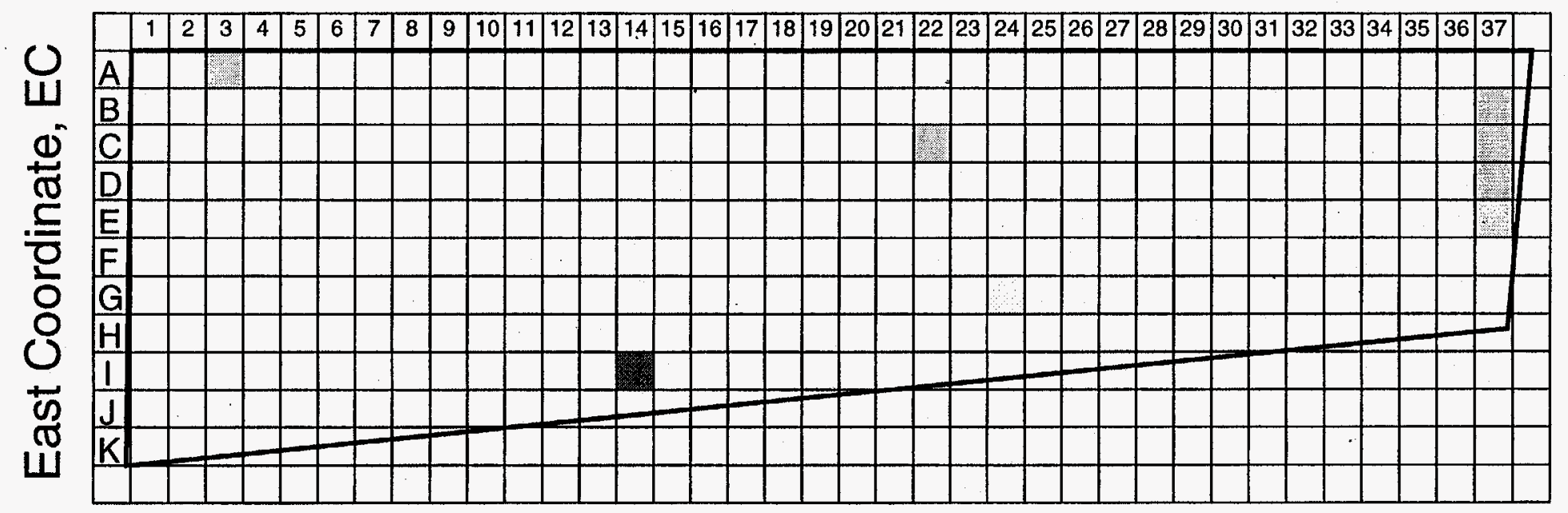

Figure 39a. Normalized spatial variation in tritium burials of all forms for the calendar year 1961. 


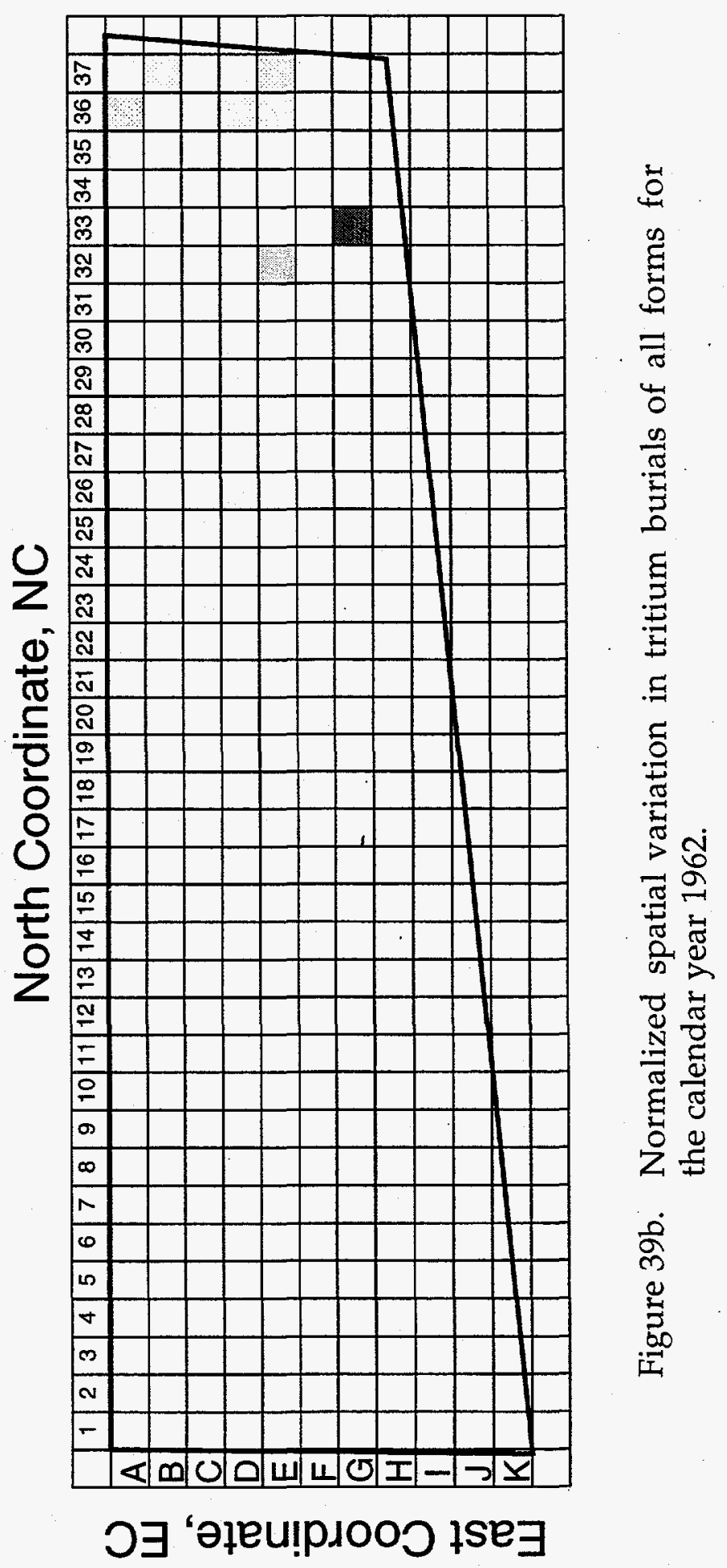




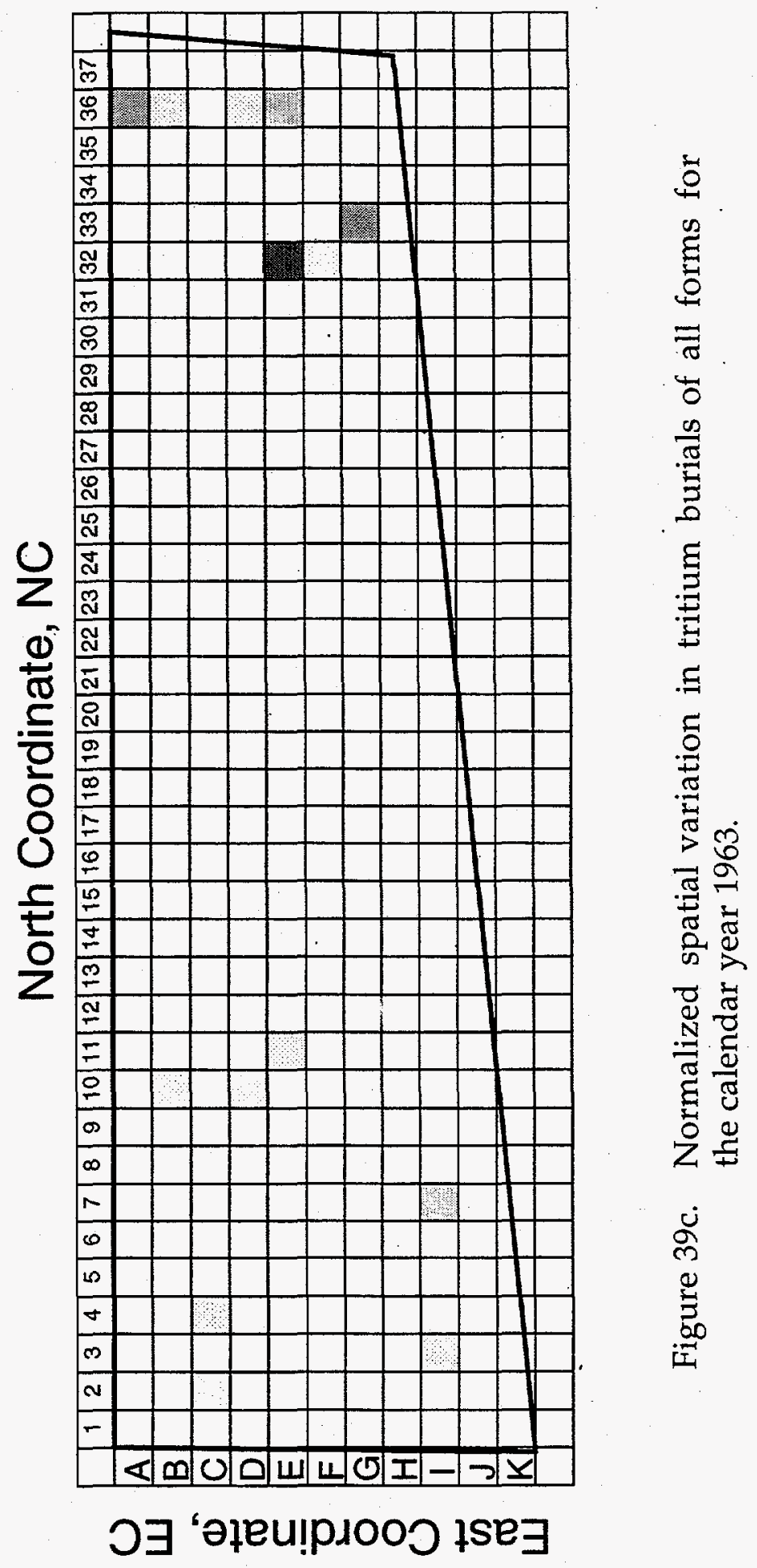




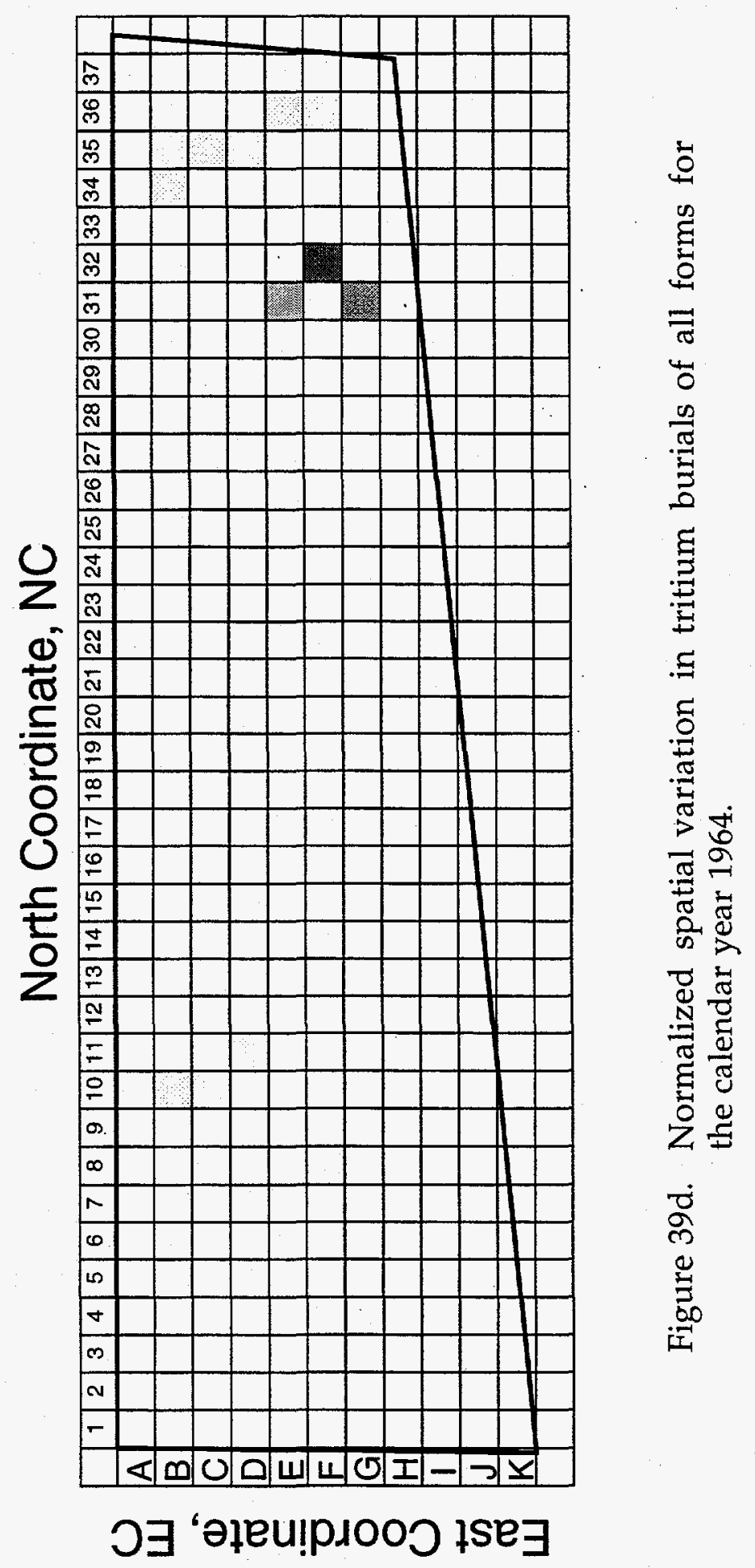




\section{North Coordinate, NC}

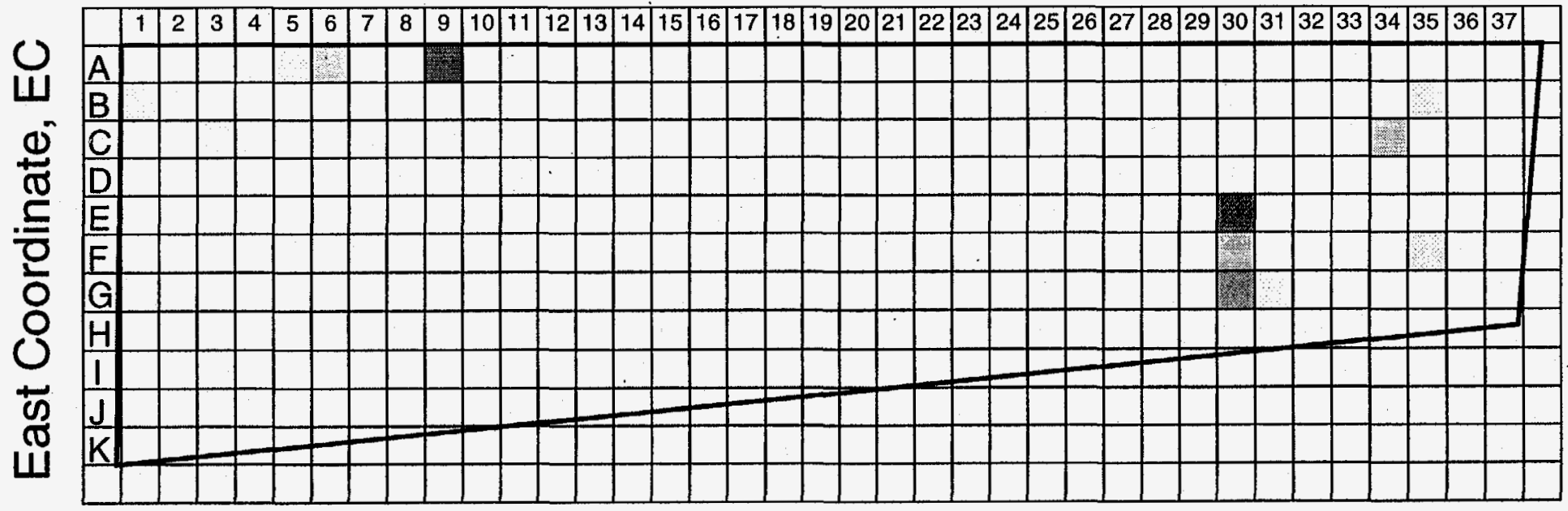

Figure 39e. Normalized spatial variation in tritium burials of all forms for the calendar year 1965 . 


\section{North Coordinate, NC}

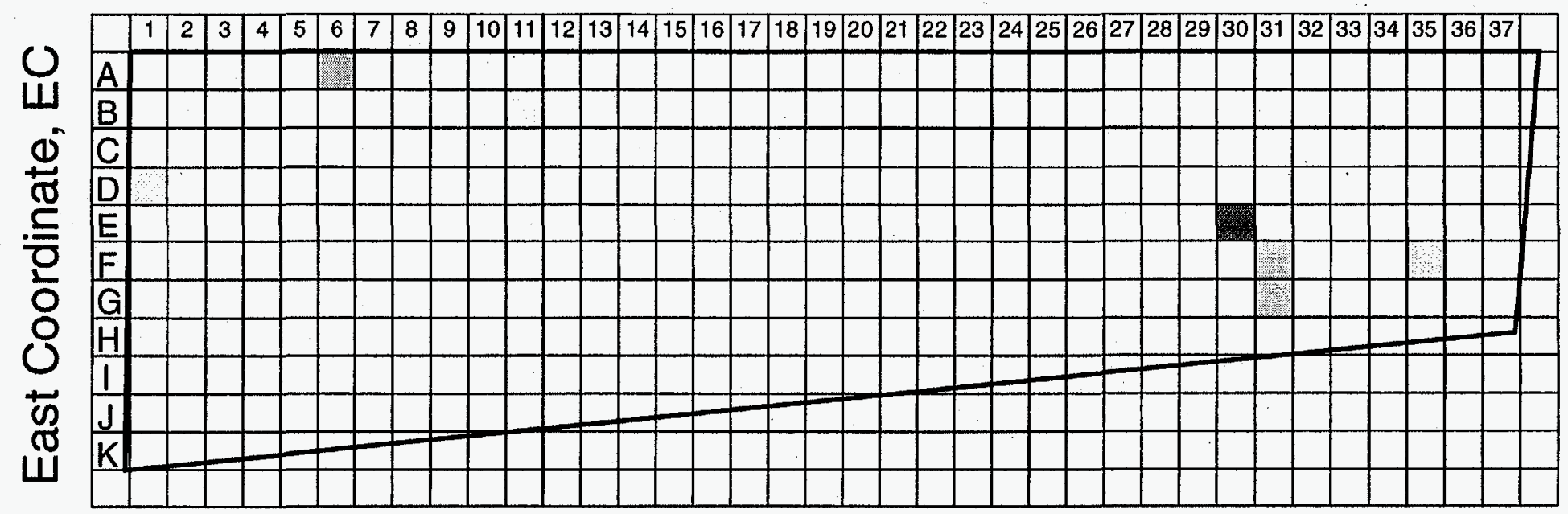

Figure 39f. Normalized spatial variation in tritium burials of all forms for the calendar year 1966. 


\section{North Coordinate, NC}

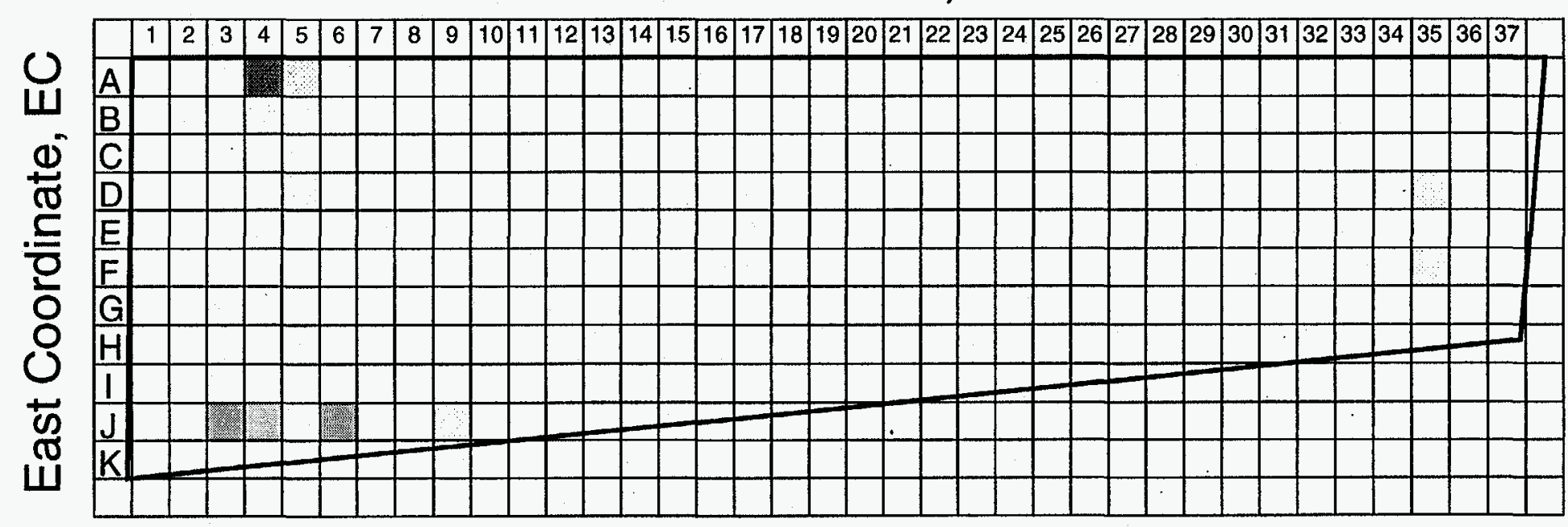

Figure $39 \mathrm{~g}$. Normalized spatial variation in tritium burials of all forms for the calendar year 1967. 


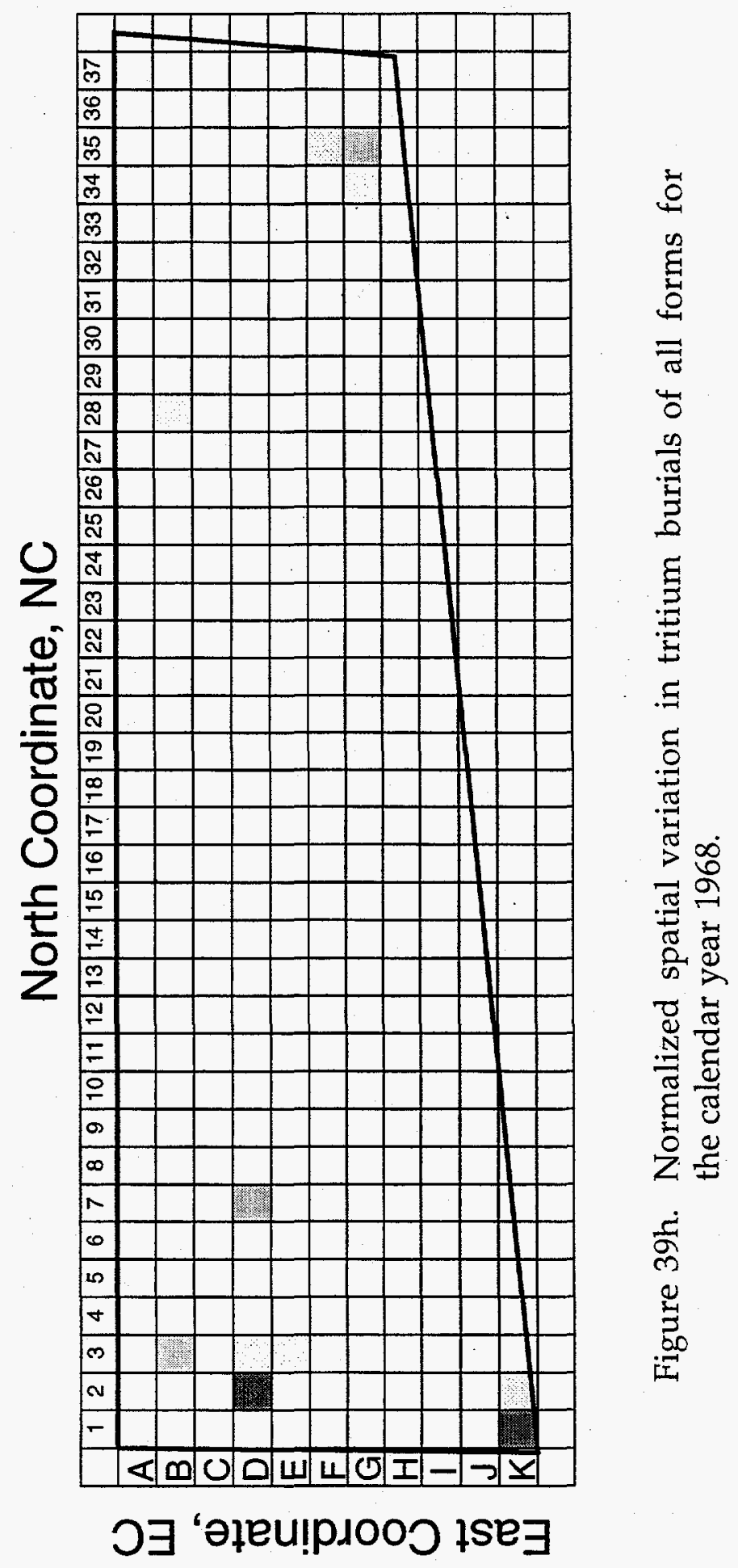




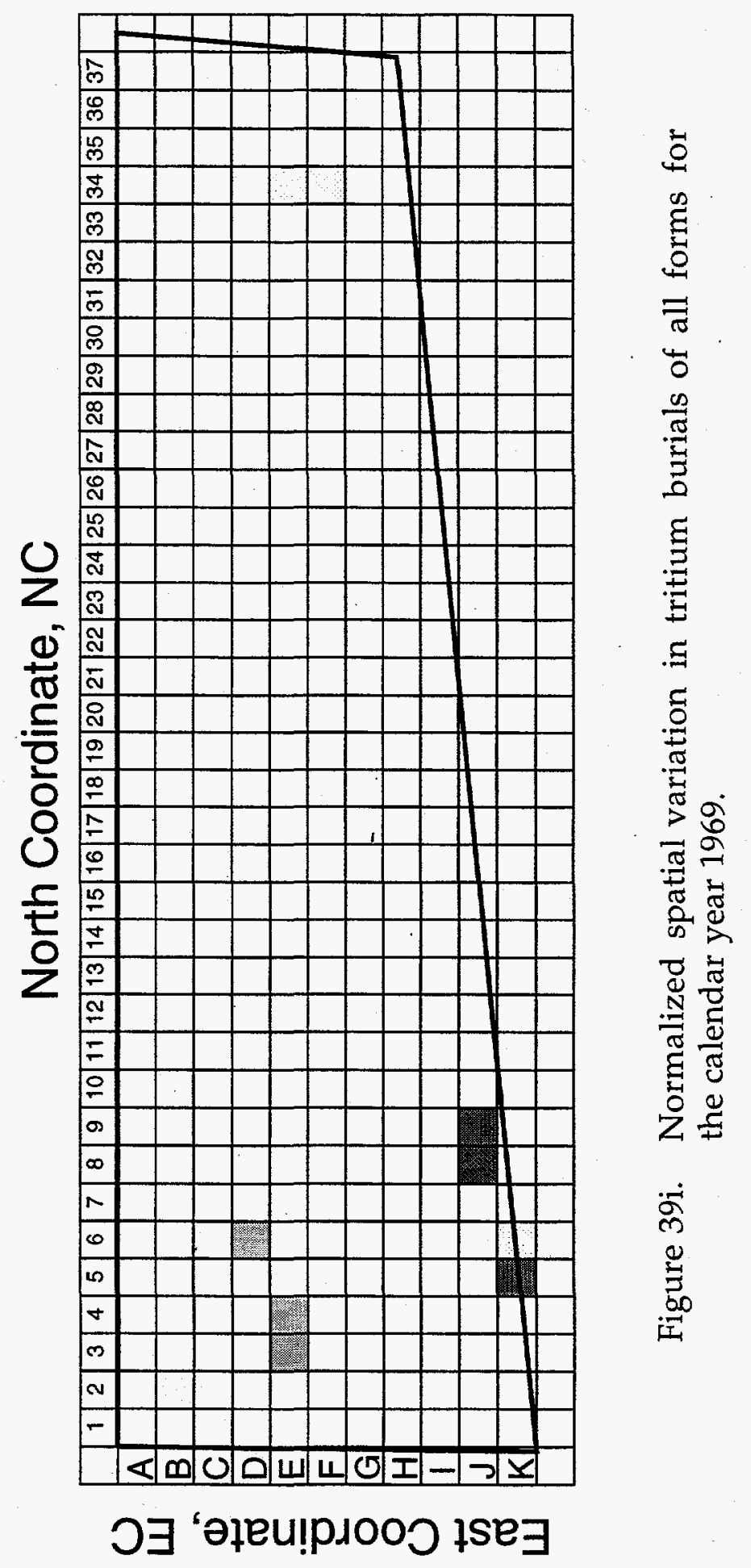




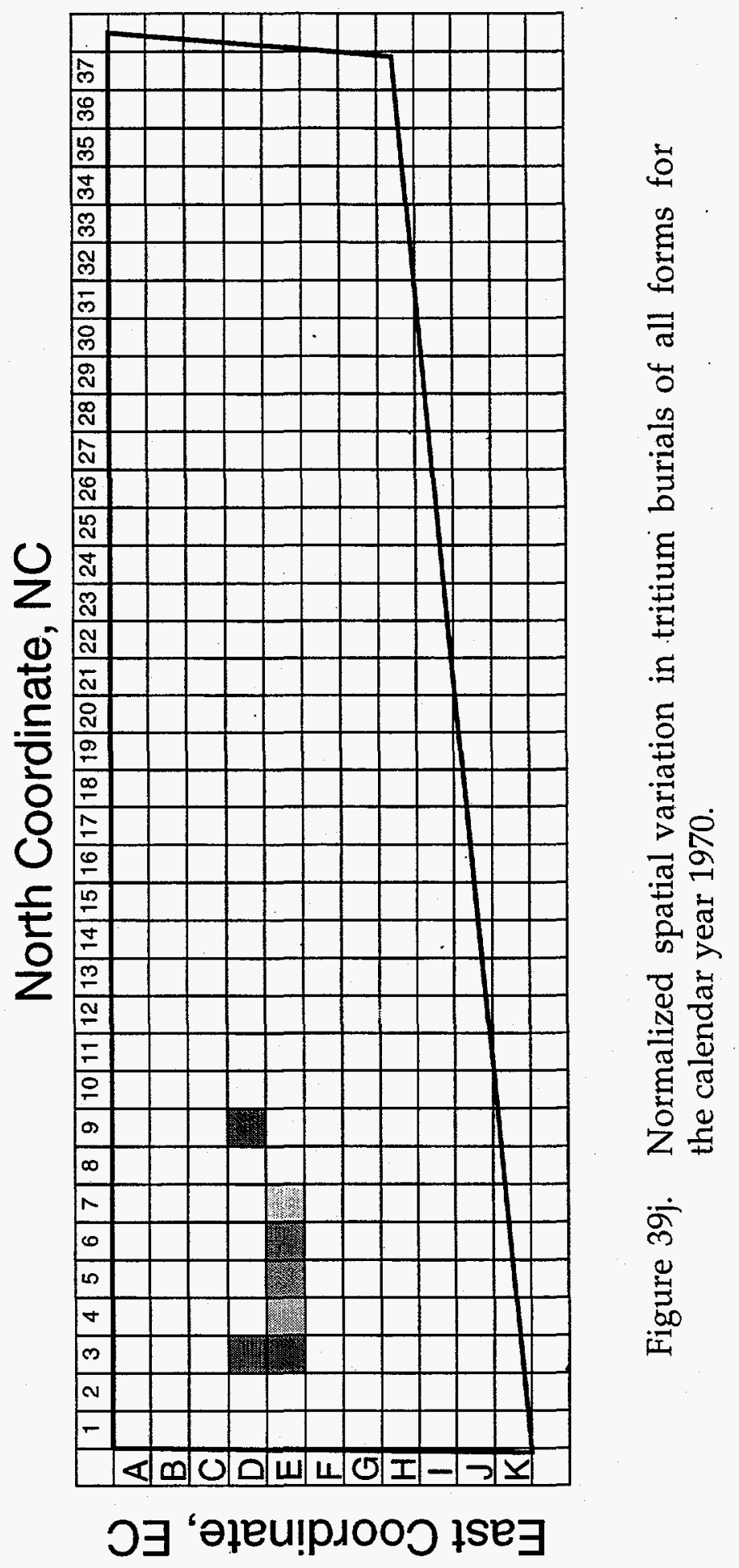




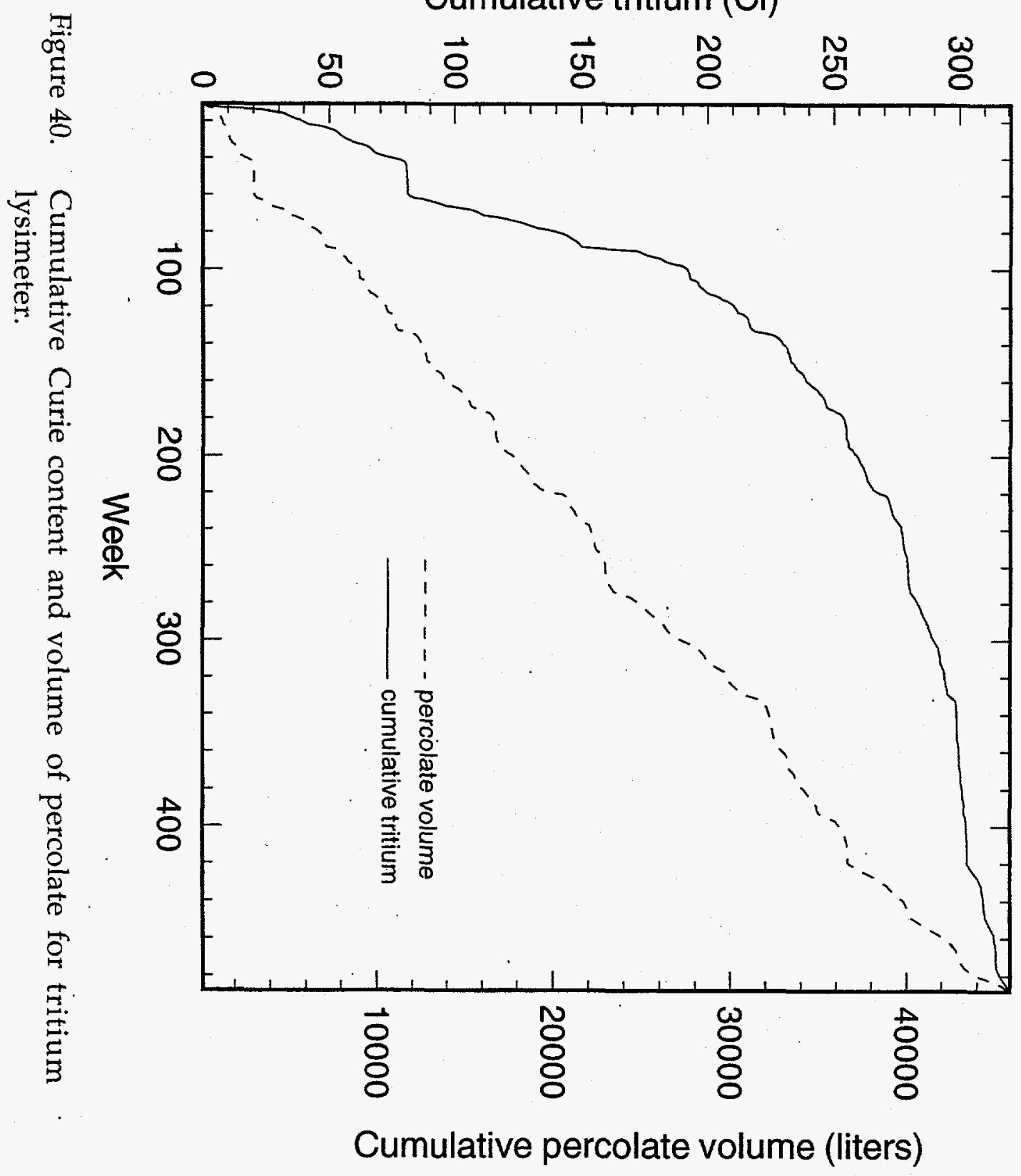




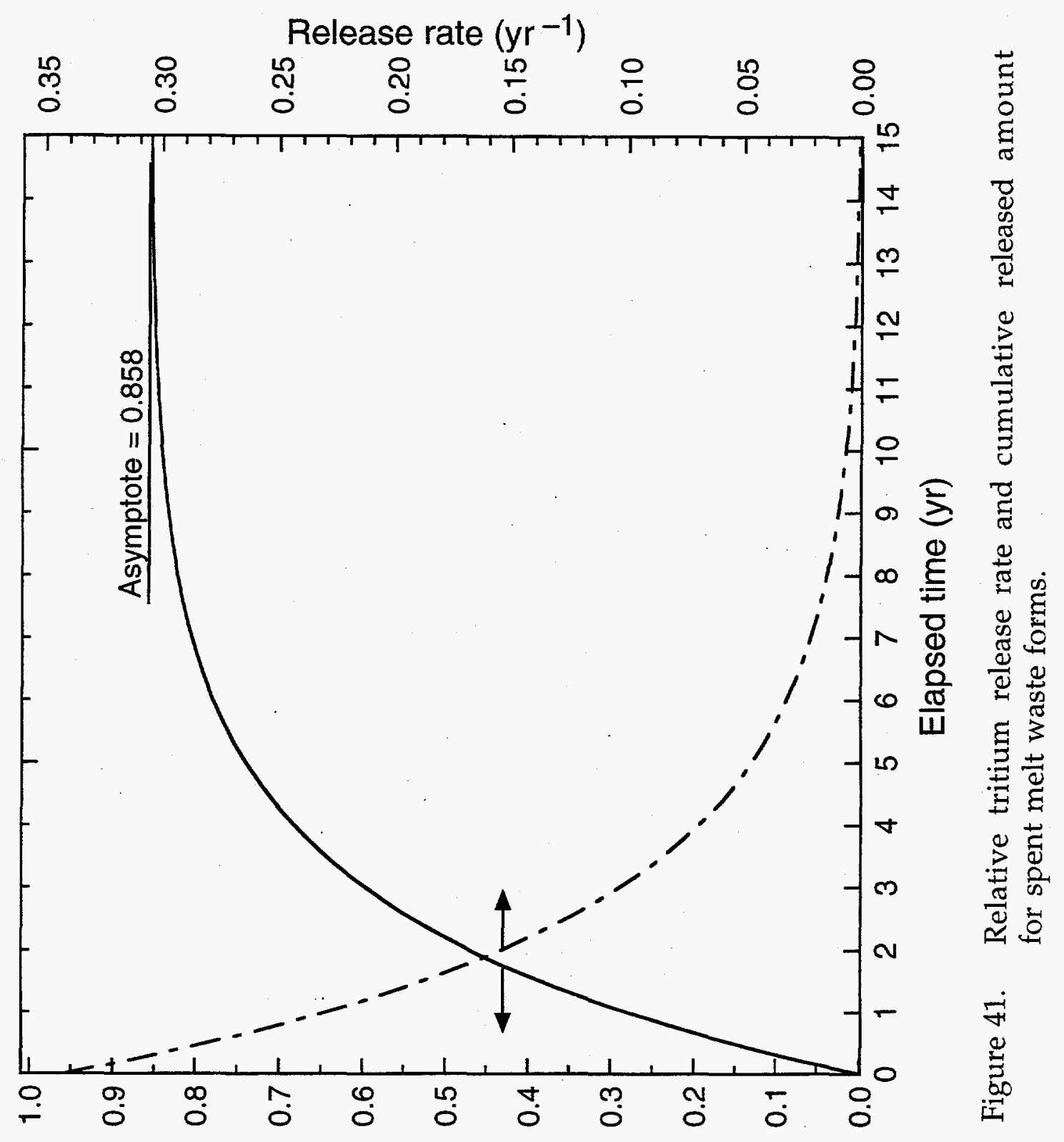

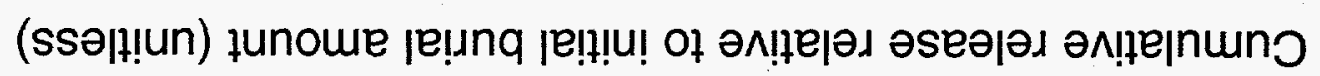




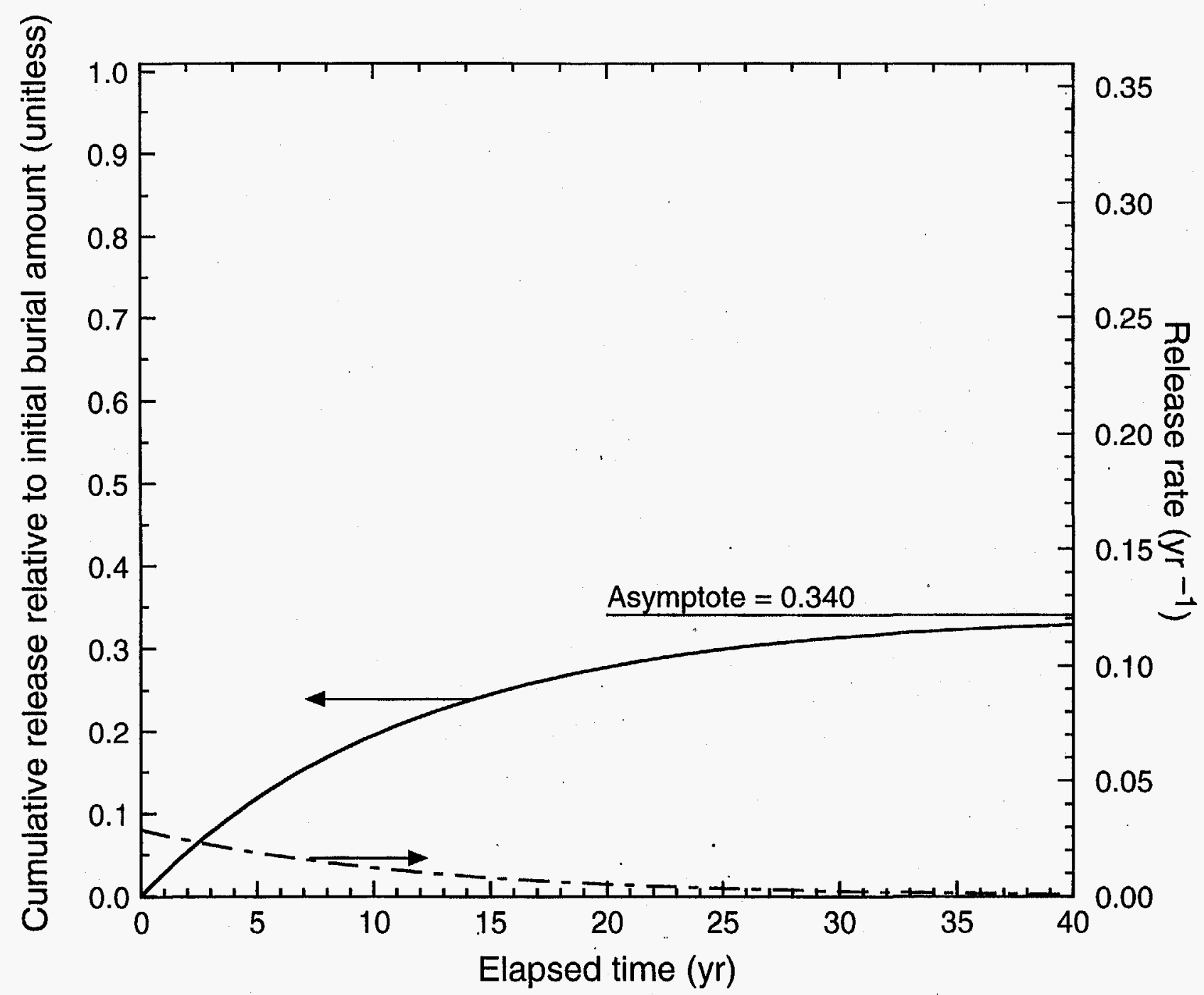

Figure 42. Relative tritium release rate and cumulative released amount for non-spent melt waste forms. 


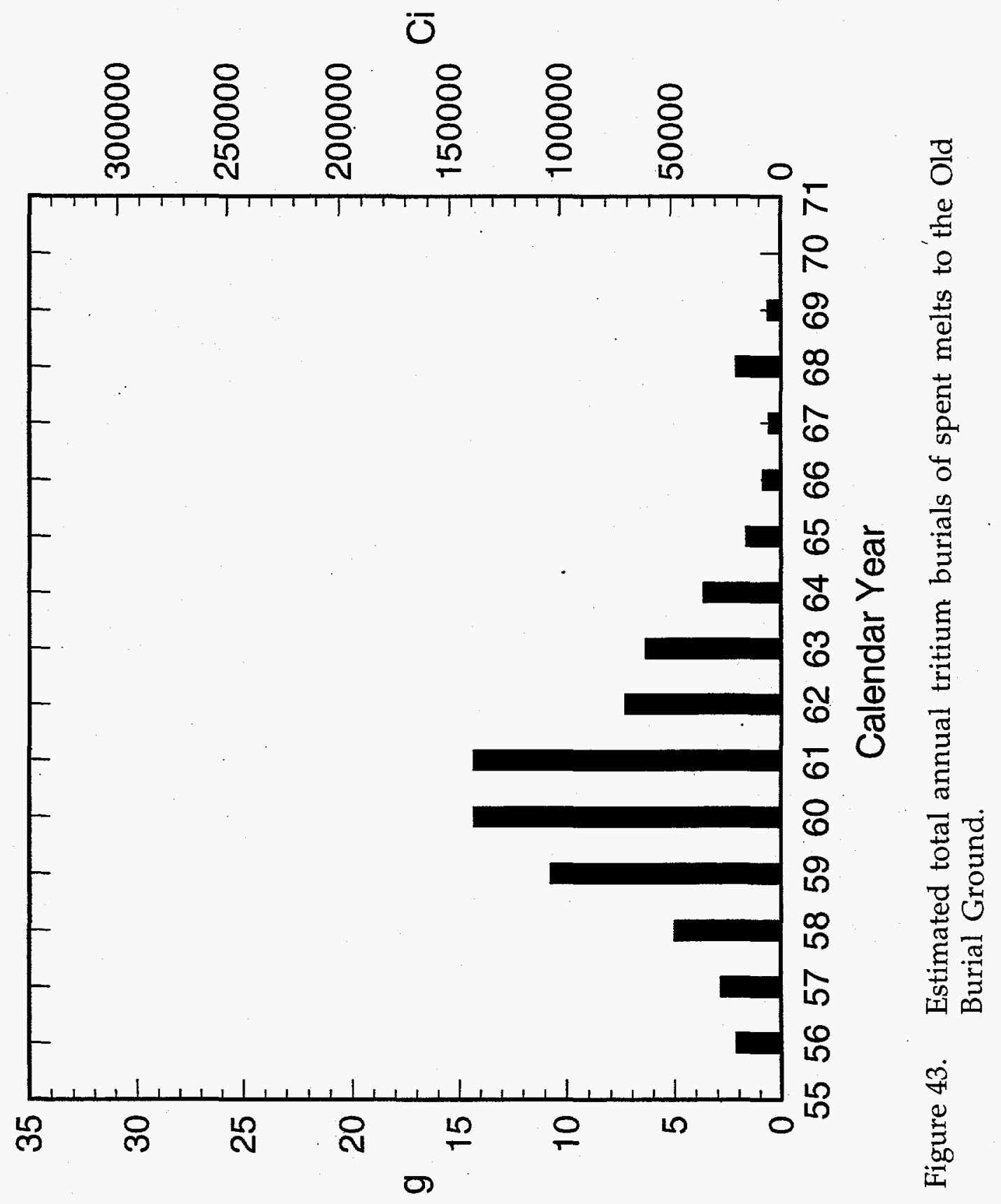




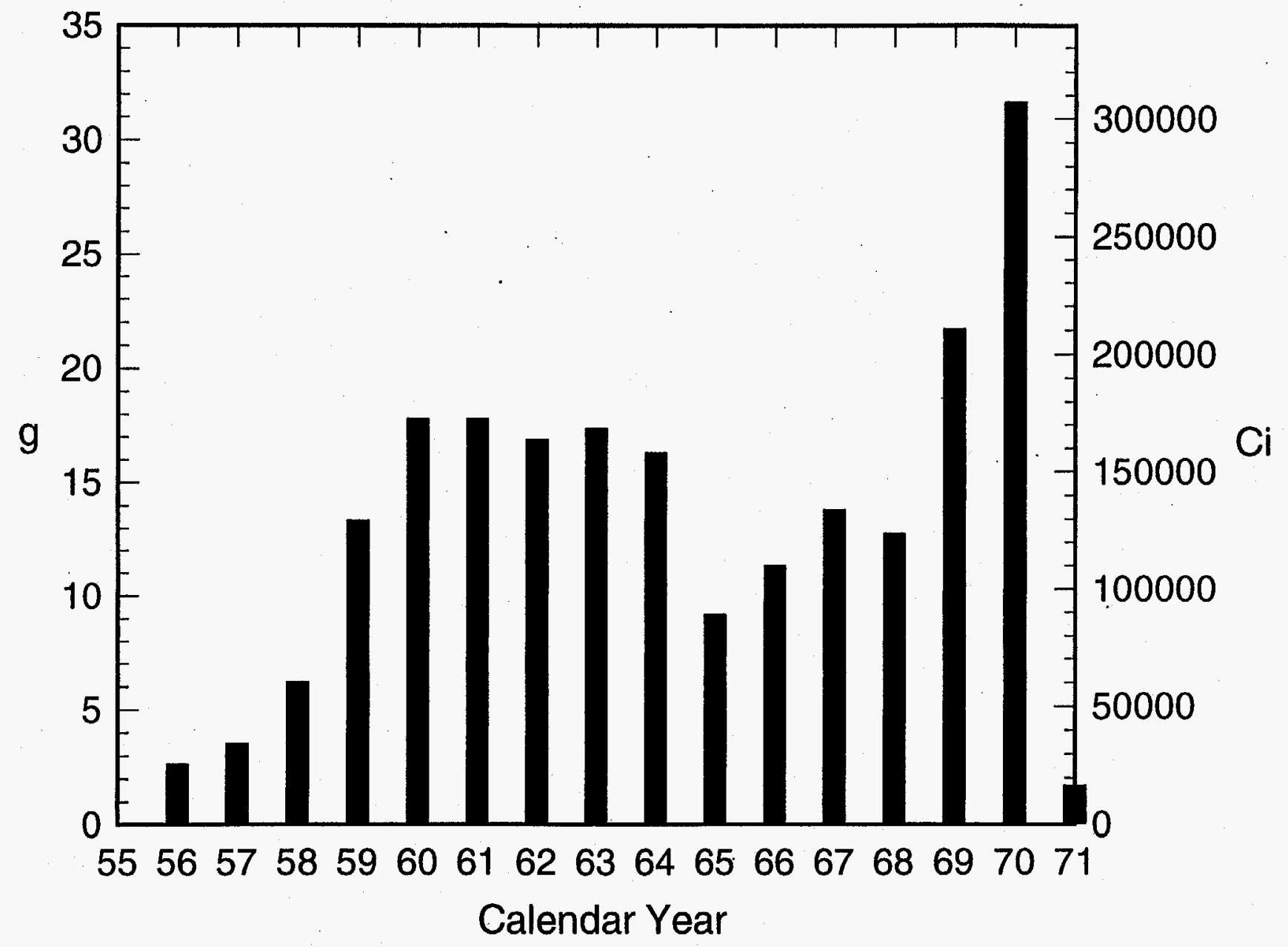

Figure 44. Estimated total annual tritium burials of non-spent melts to the Old Burial Ground. 


\section{North Coordinate, NC}

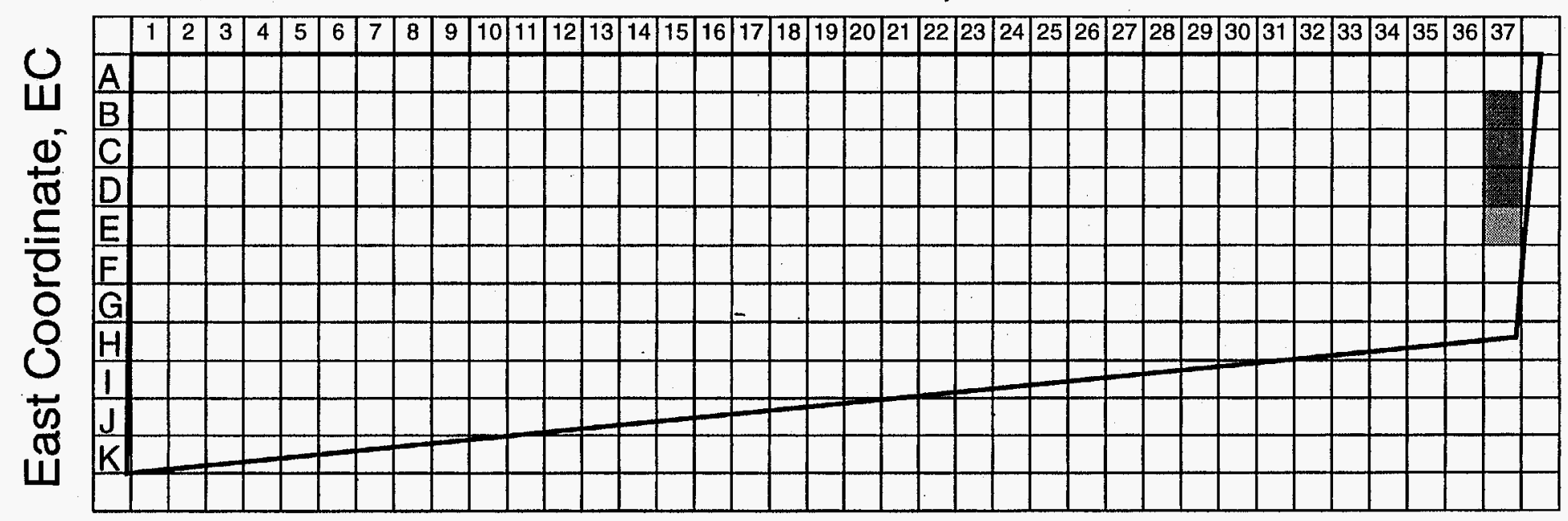

Figure 45a. Normalized spatial variation in tritium burials of spent melts for the calendar year 1961. 


\section{North Coordinate, NC}

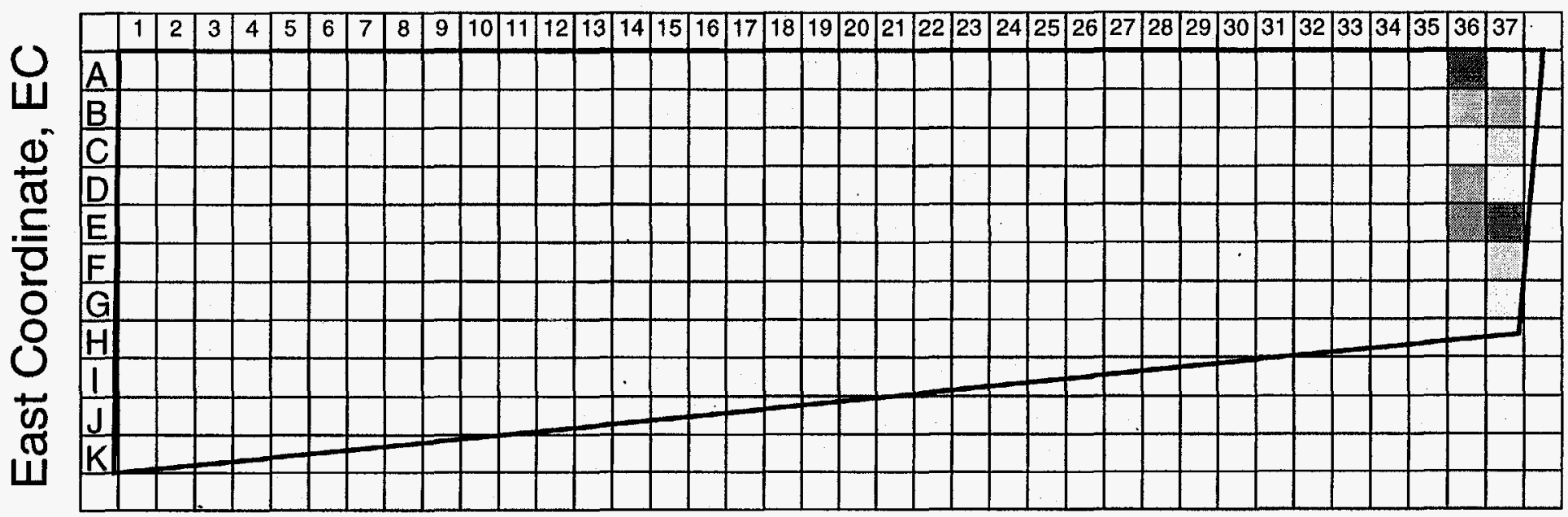

Figure 45b. Normalized spatial variation in tritium burials of spent melts for the calendar year 1962. 


\section{North Coordinate, NC}

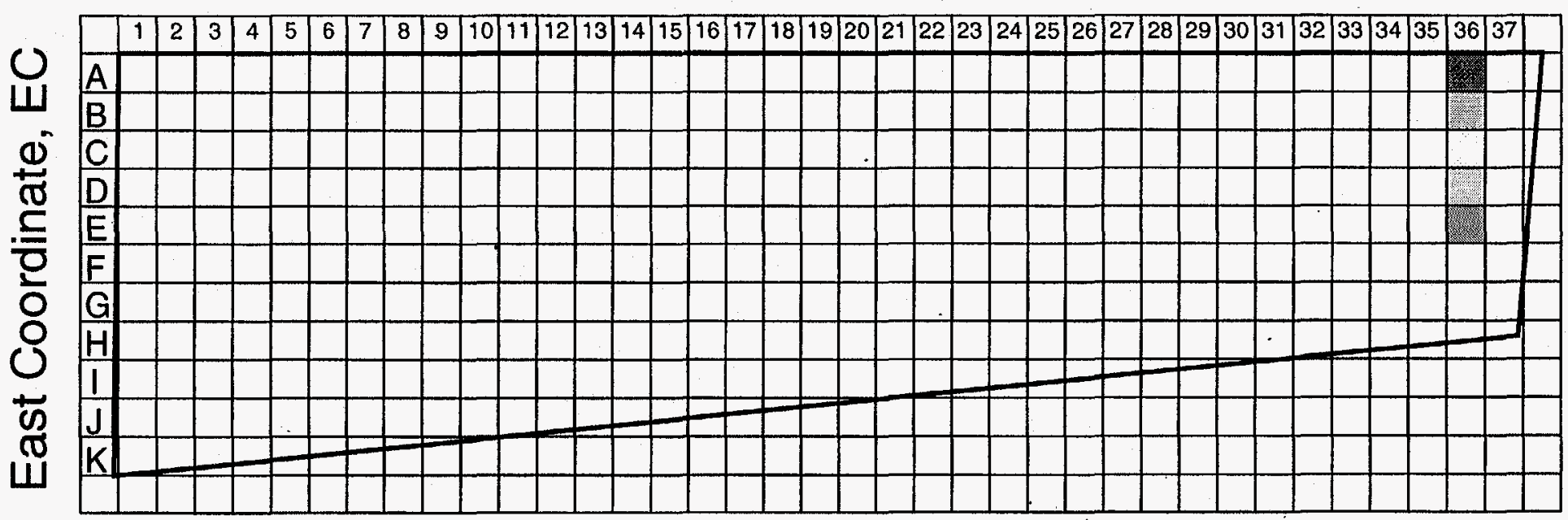

Figure 45c. Normalized spatial variation in tritium burials of spent melts for the calendar year 1963. 


\section{North Coordinate, NC}

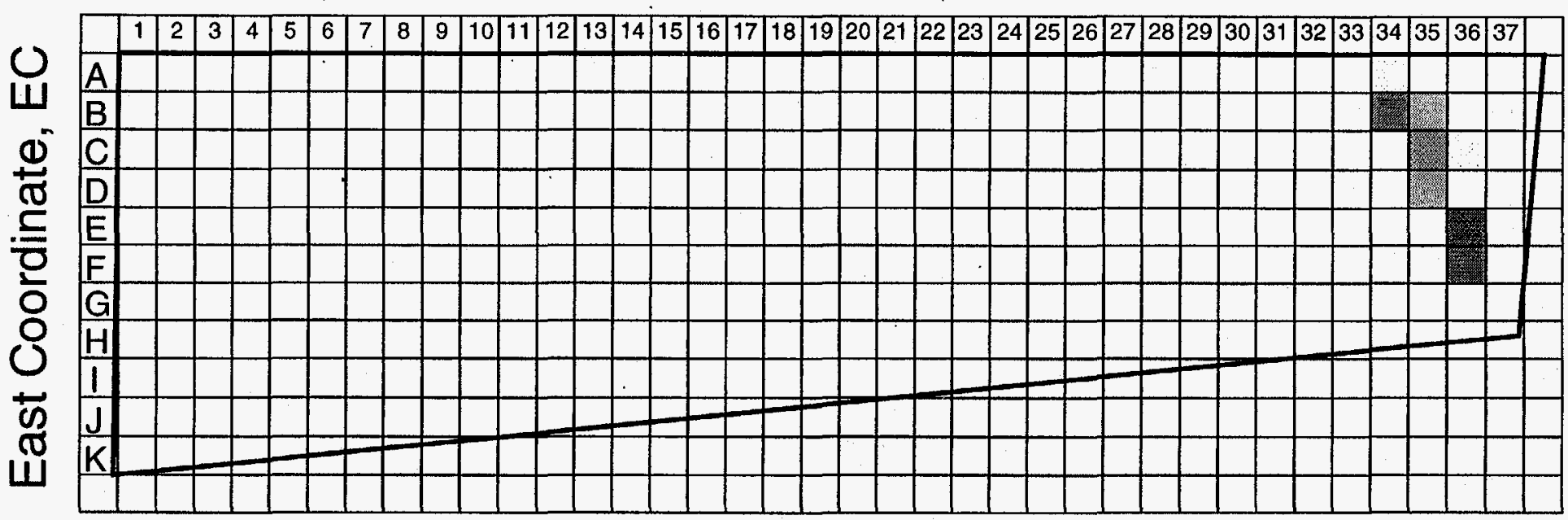

Figure $45 \mathrm{~d}$. Normalized spatial variation in tritium burials of spent melts for the calendar year 1964. 


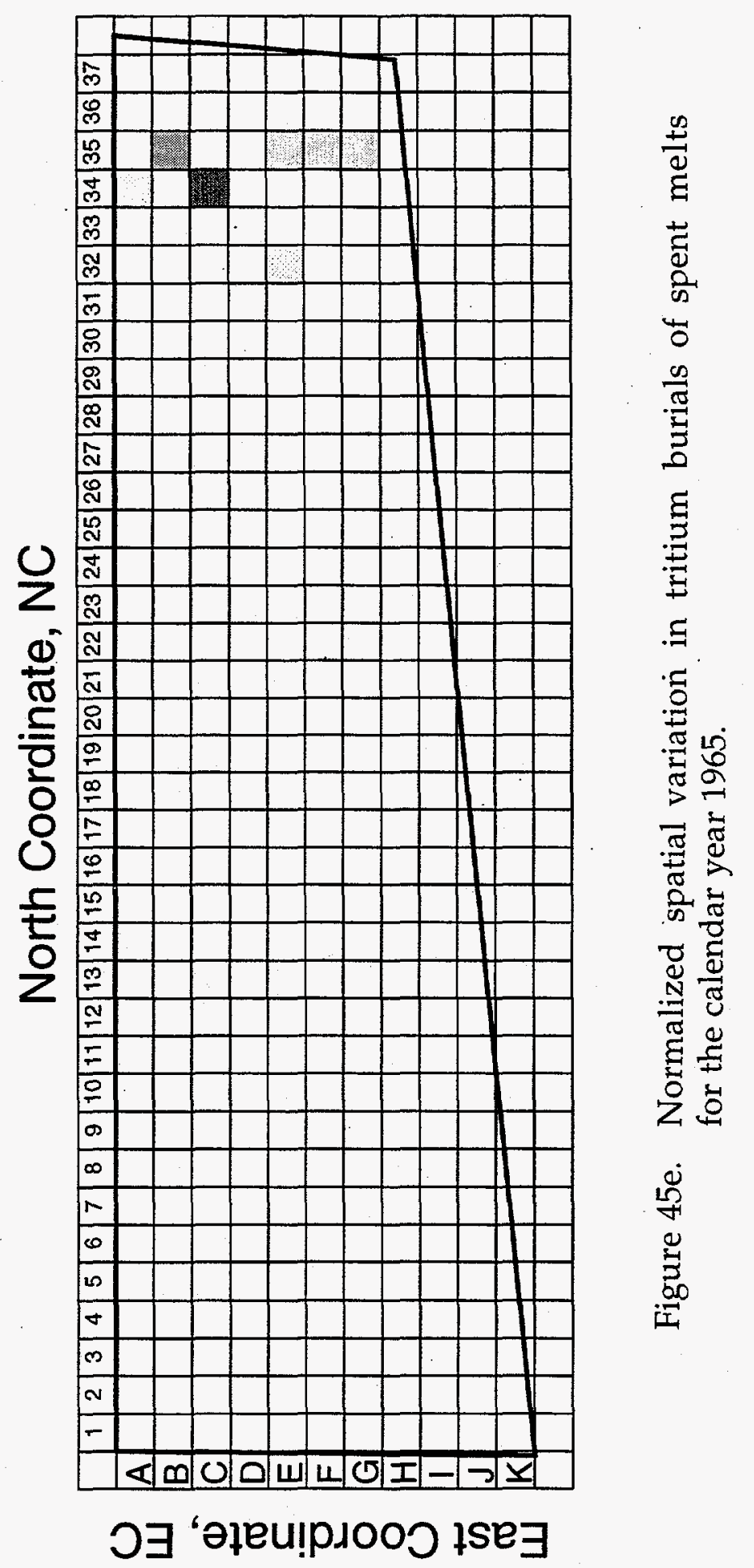




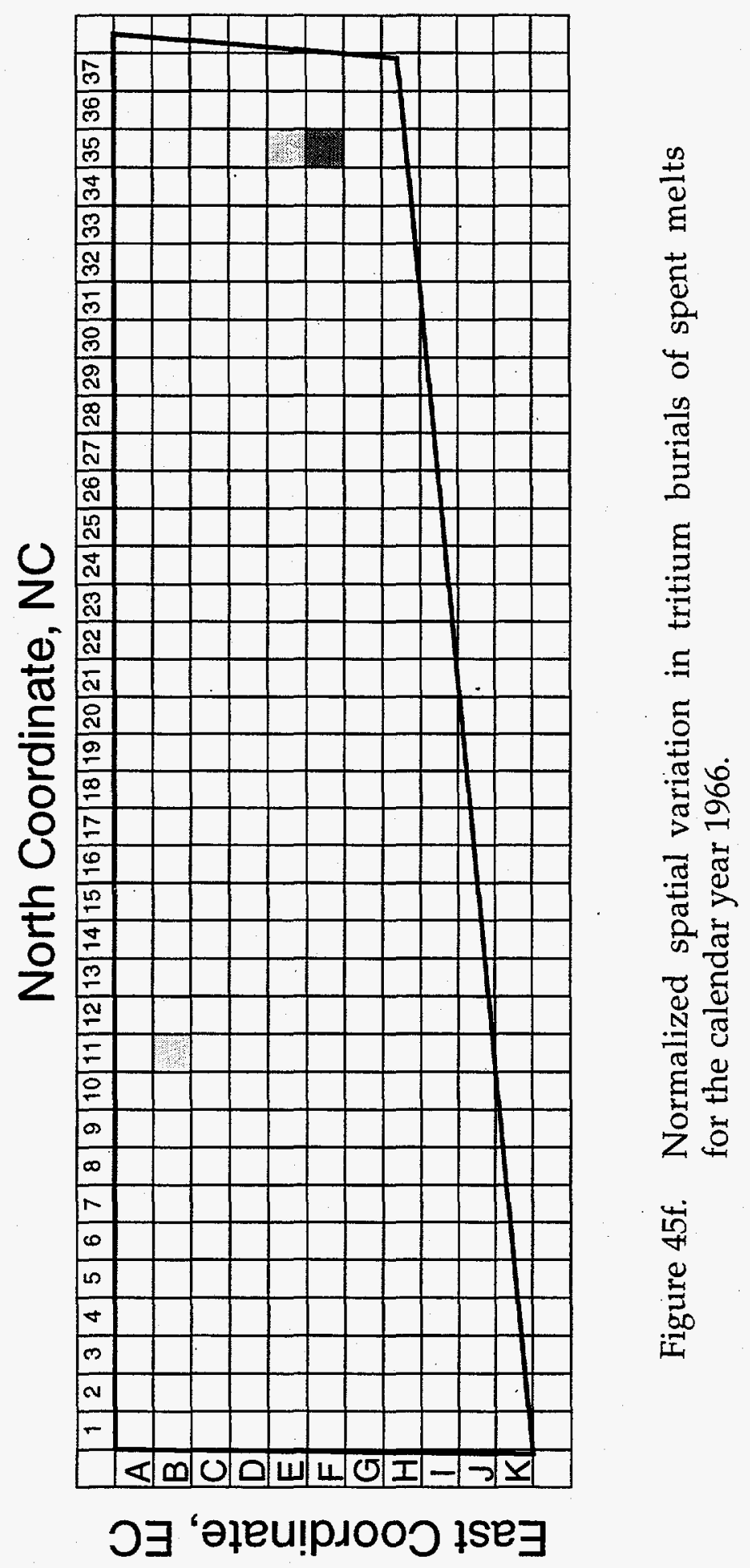


North Coordinate, NC

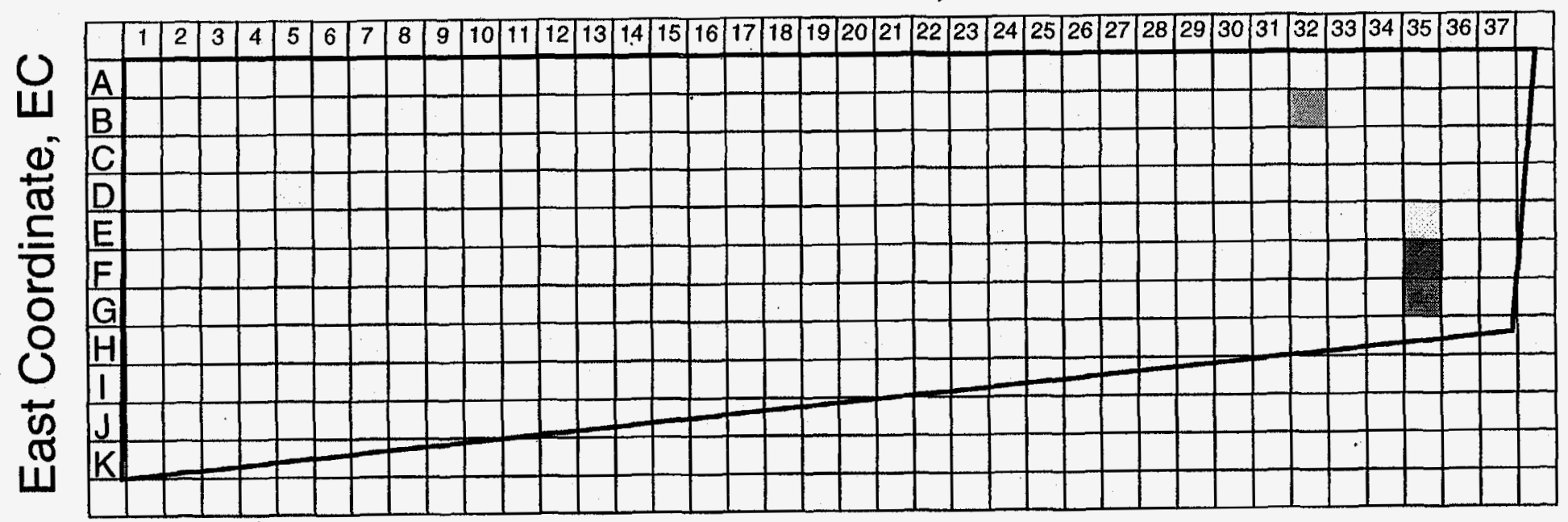

Figure 45g. Normalized spatial variation in tritium burials of spent melts for the calendar year 1967. 


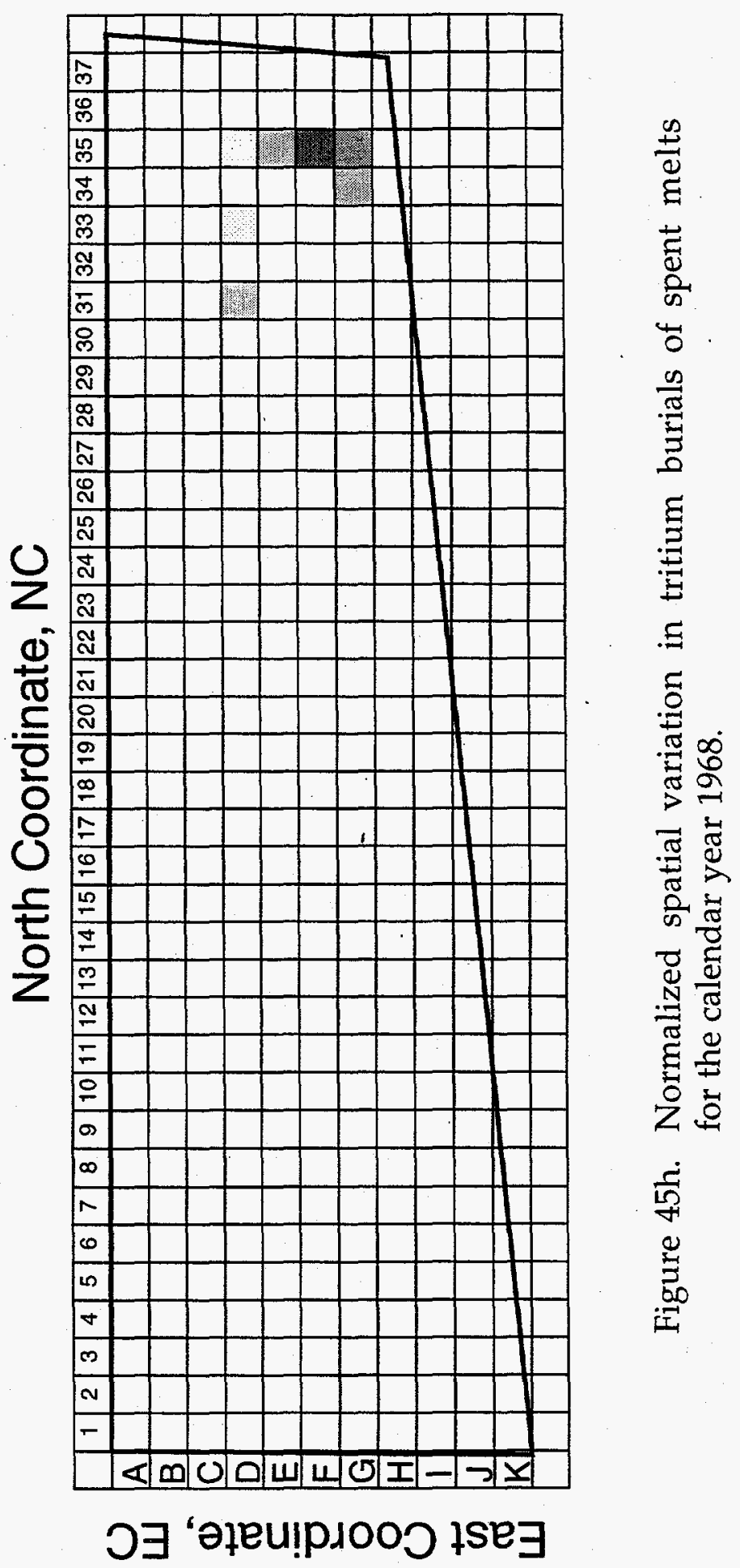




\section{North Coordinate, NC}

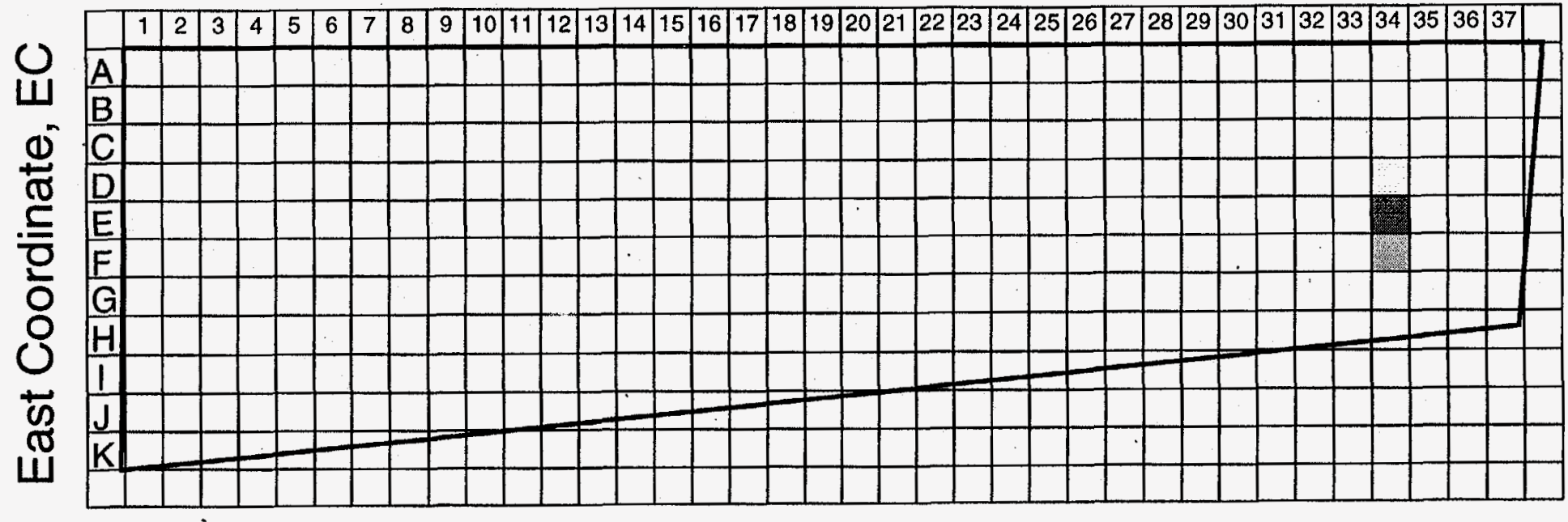

Figure 45i. Normalized spatial variation in tritium burials of spent melts for the calendar year 1969. 


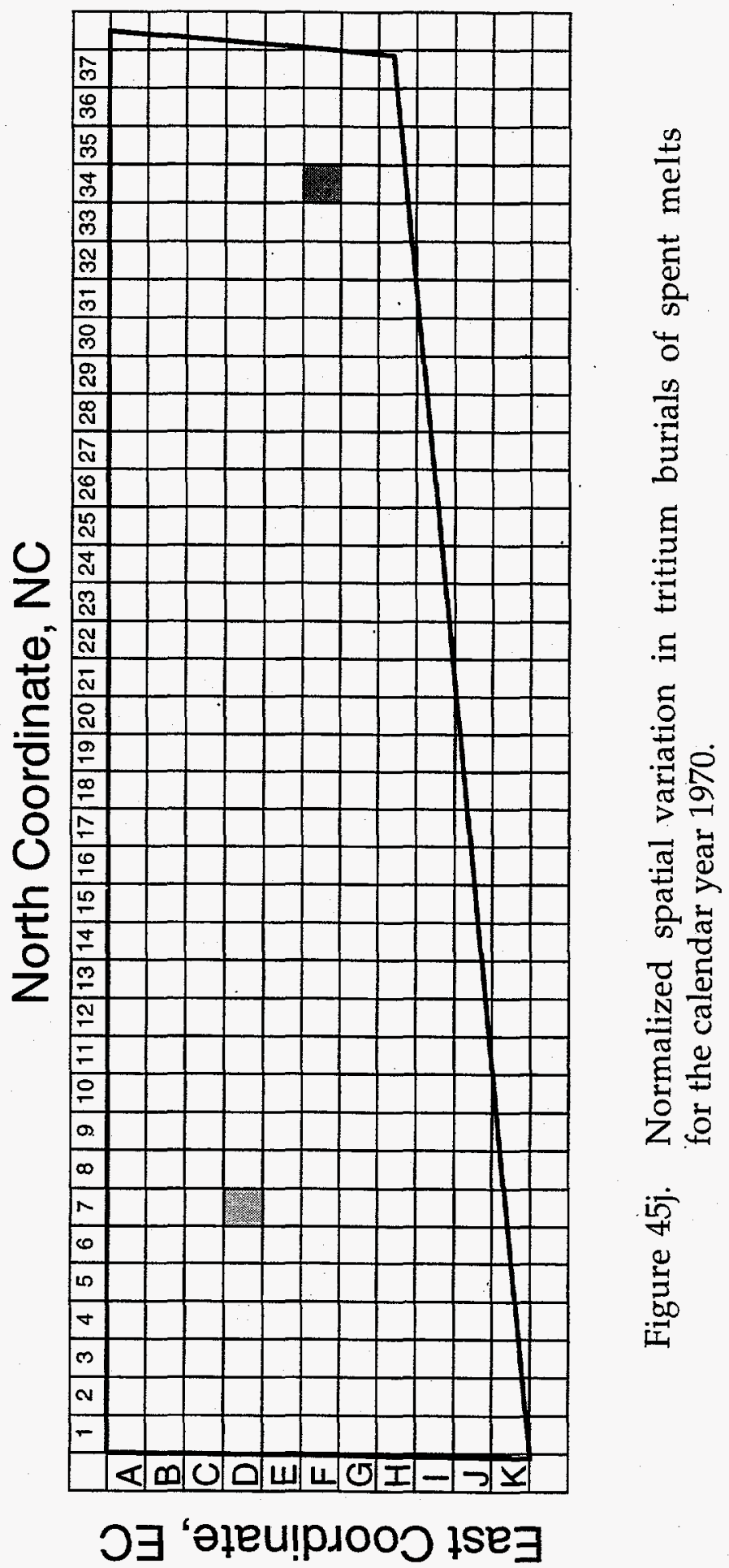




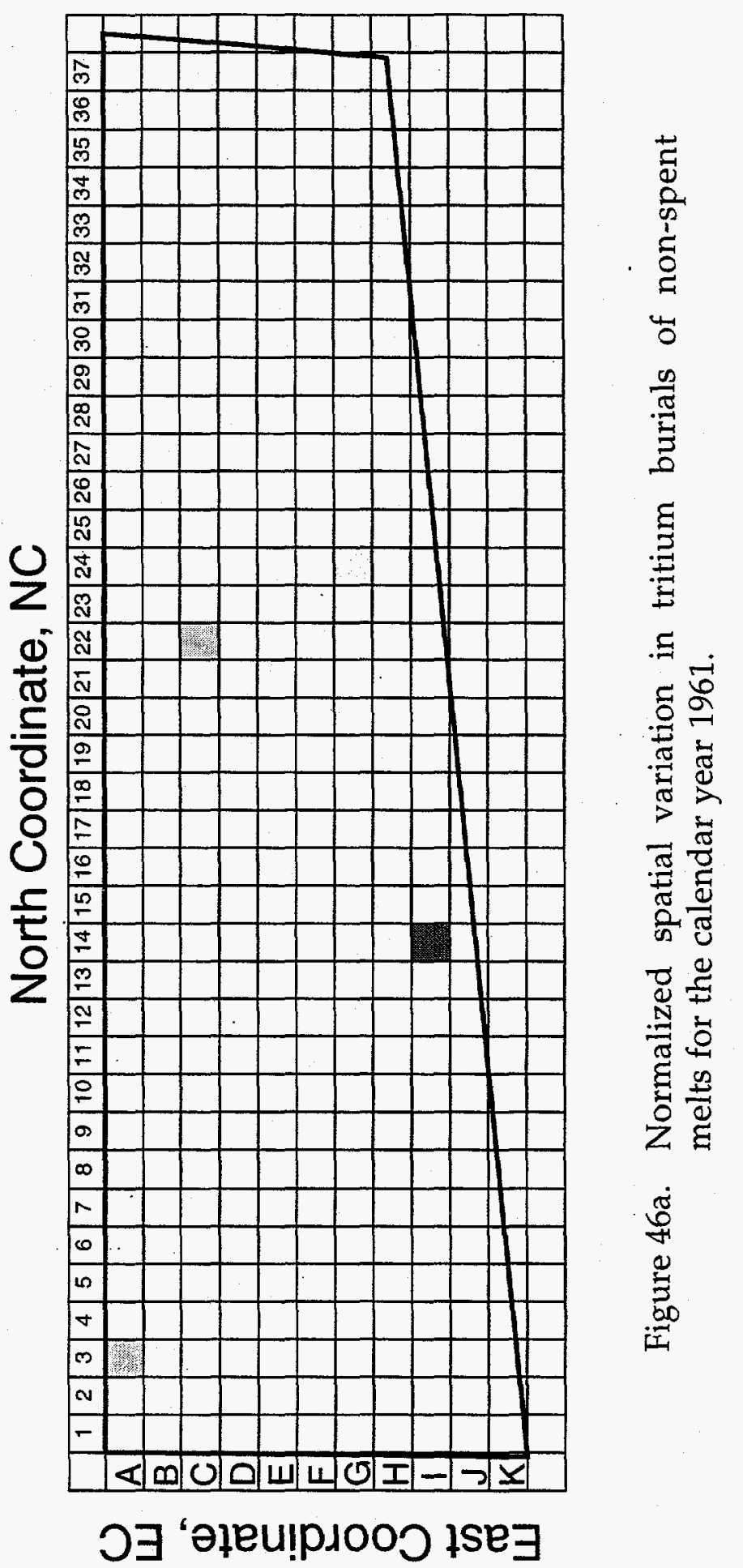


North Coordinate, NC

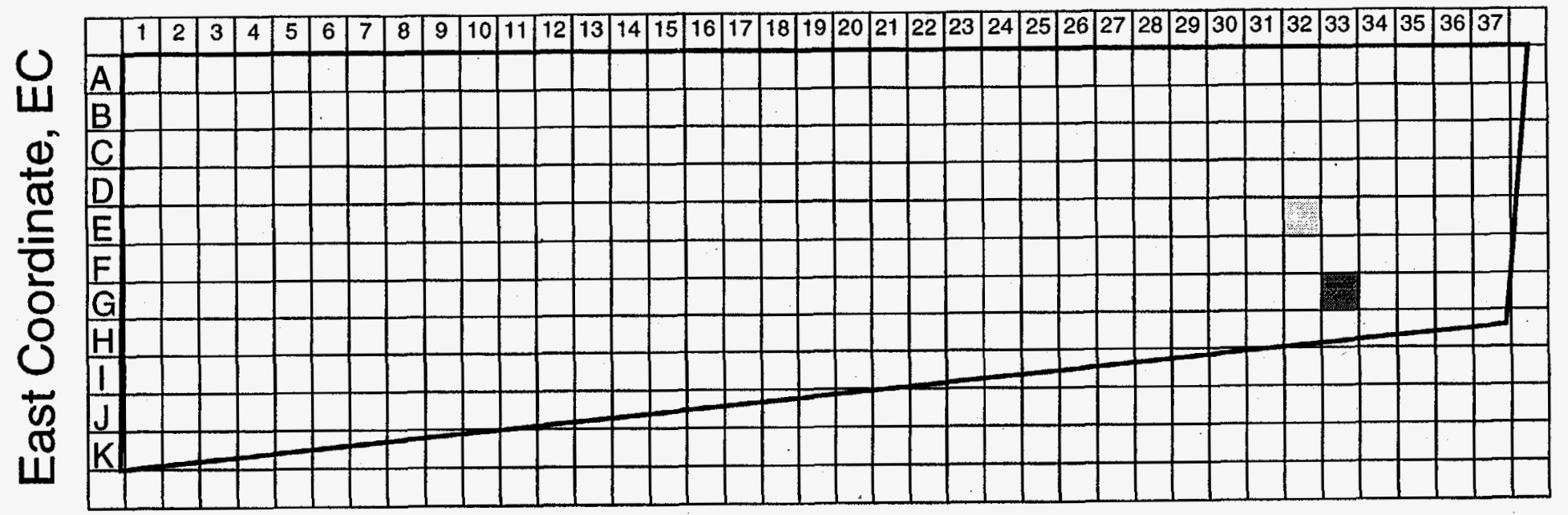

Figure 46b. Normalized spatial variation in tritium burials of non-spent melts for the calendar year 1962. 


\section{North Coordinate, NC}

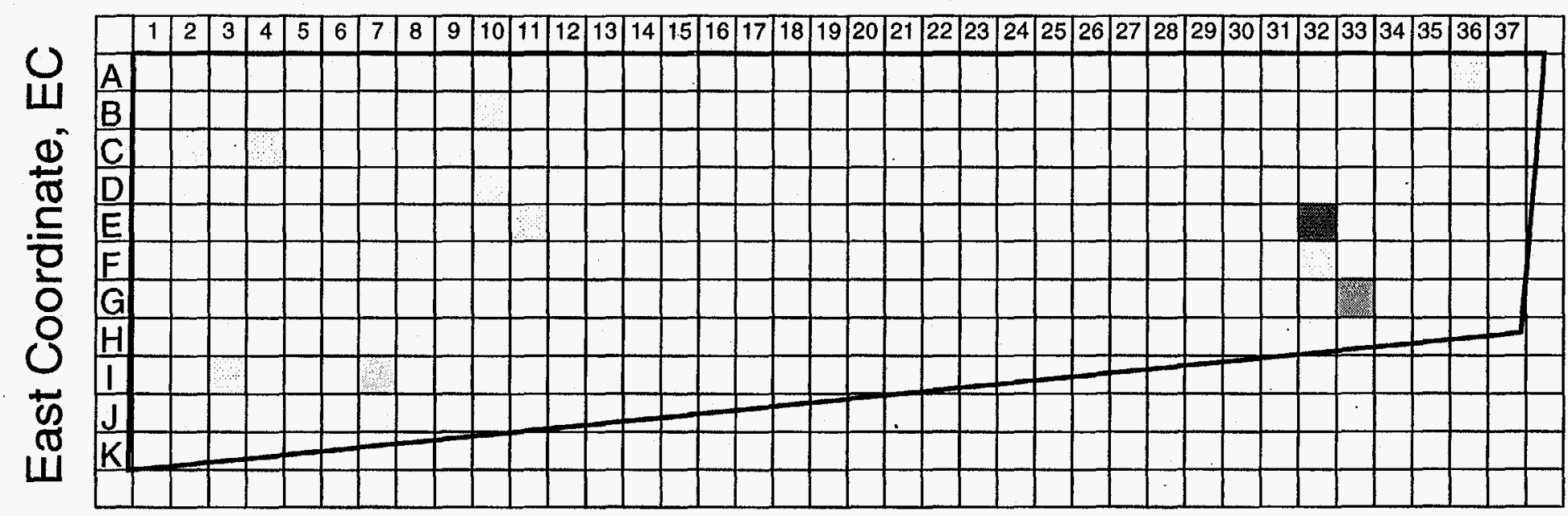

Figure 46c. Normalized spatial variation in tritium burials of non-spent melts for the calendar year 1963. 


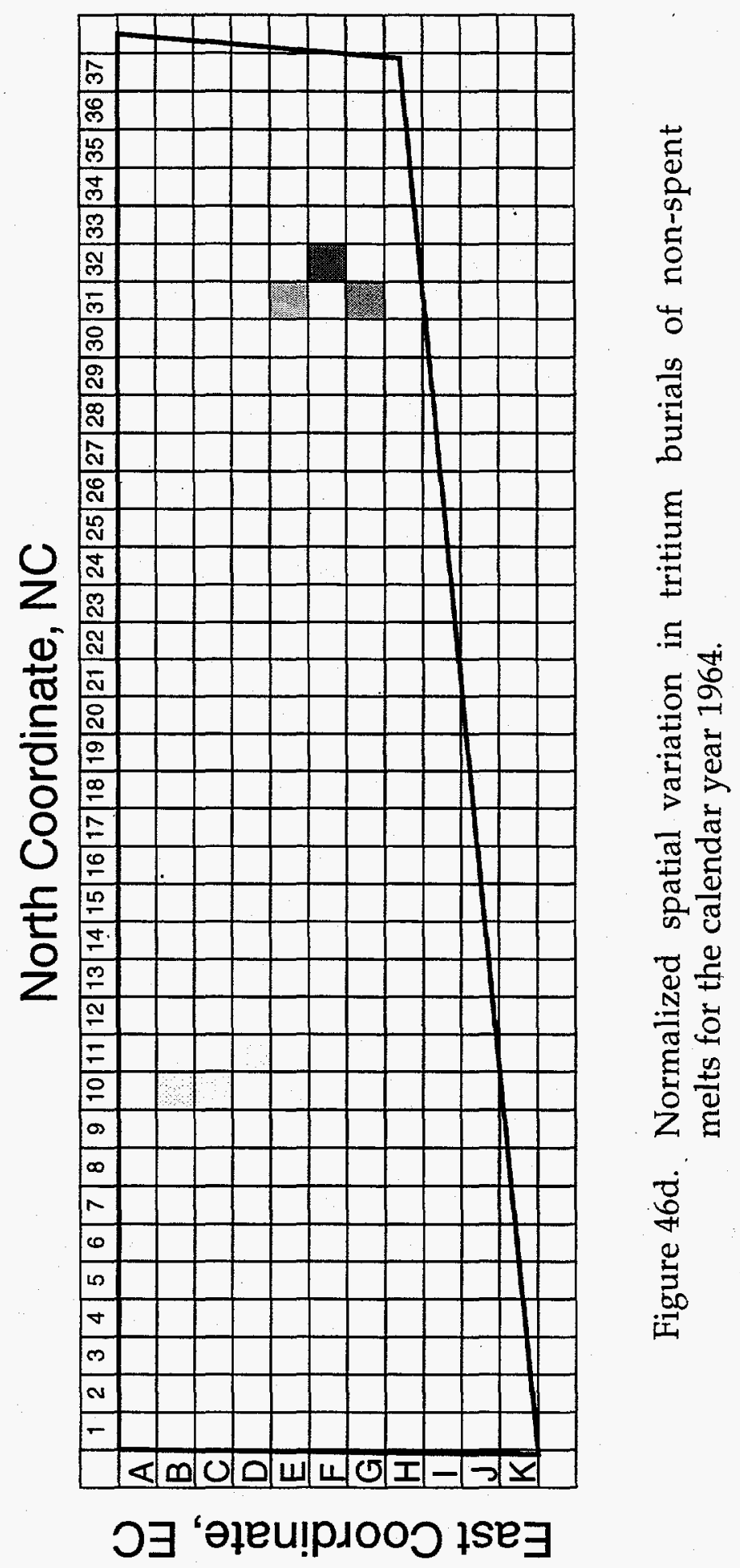




\section{North Coordinate, NC}

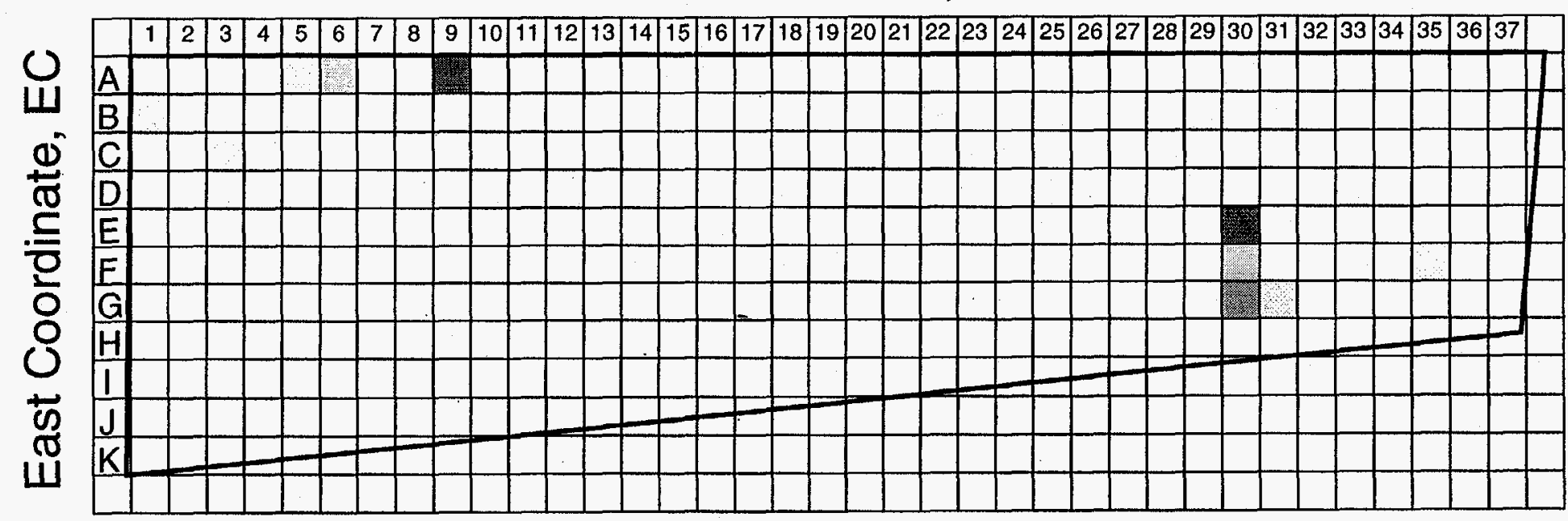

Figure 46e. Normalized spatial variation in tritium burials of non-spent melts for the calendar year 1965 . 


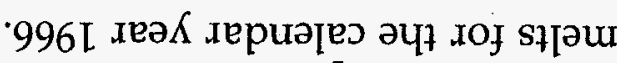

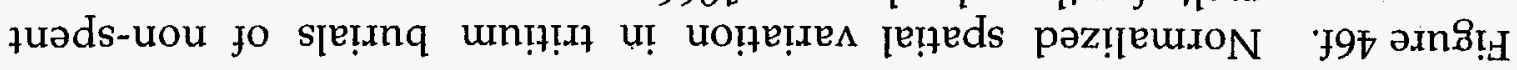

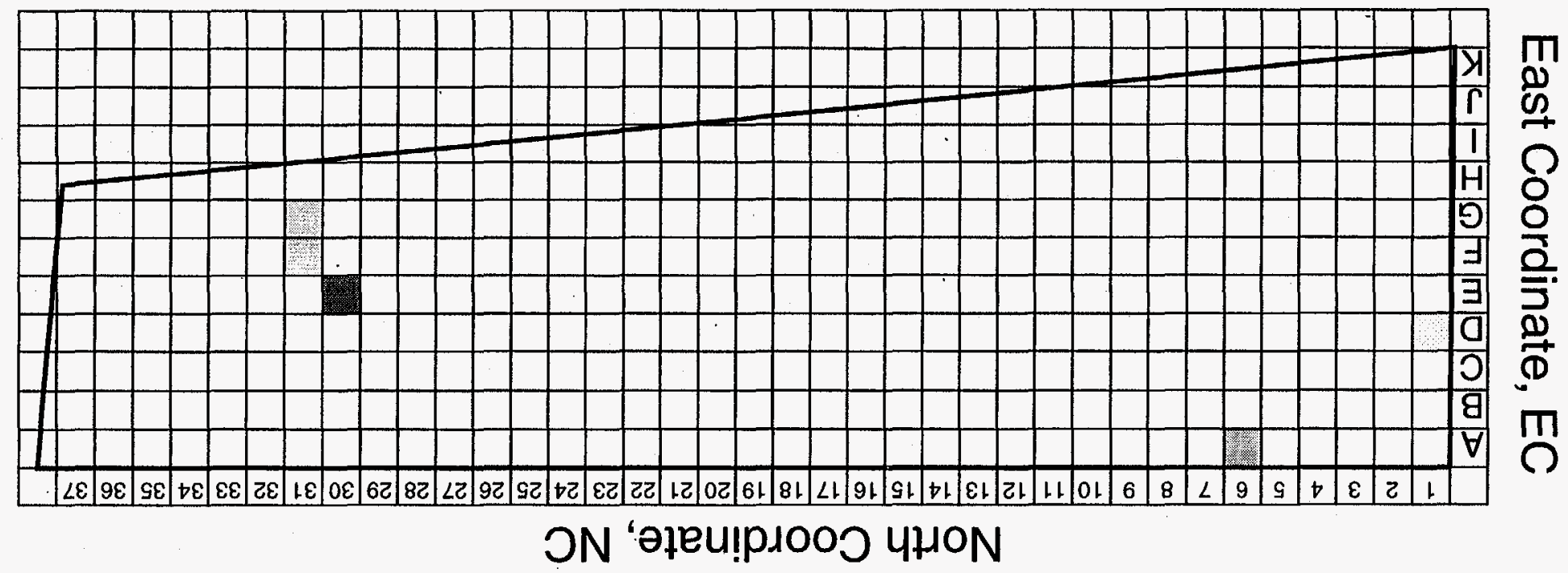




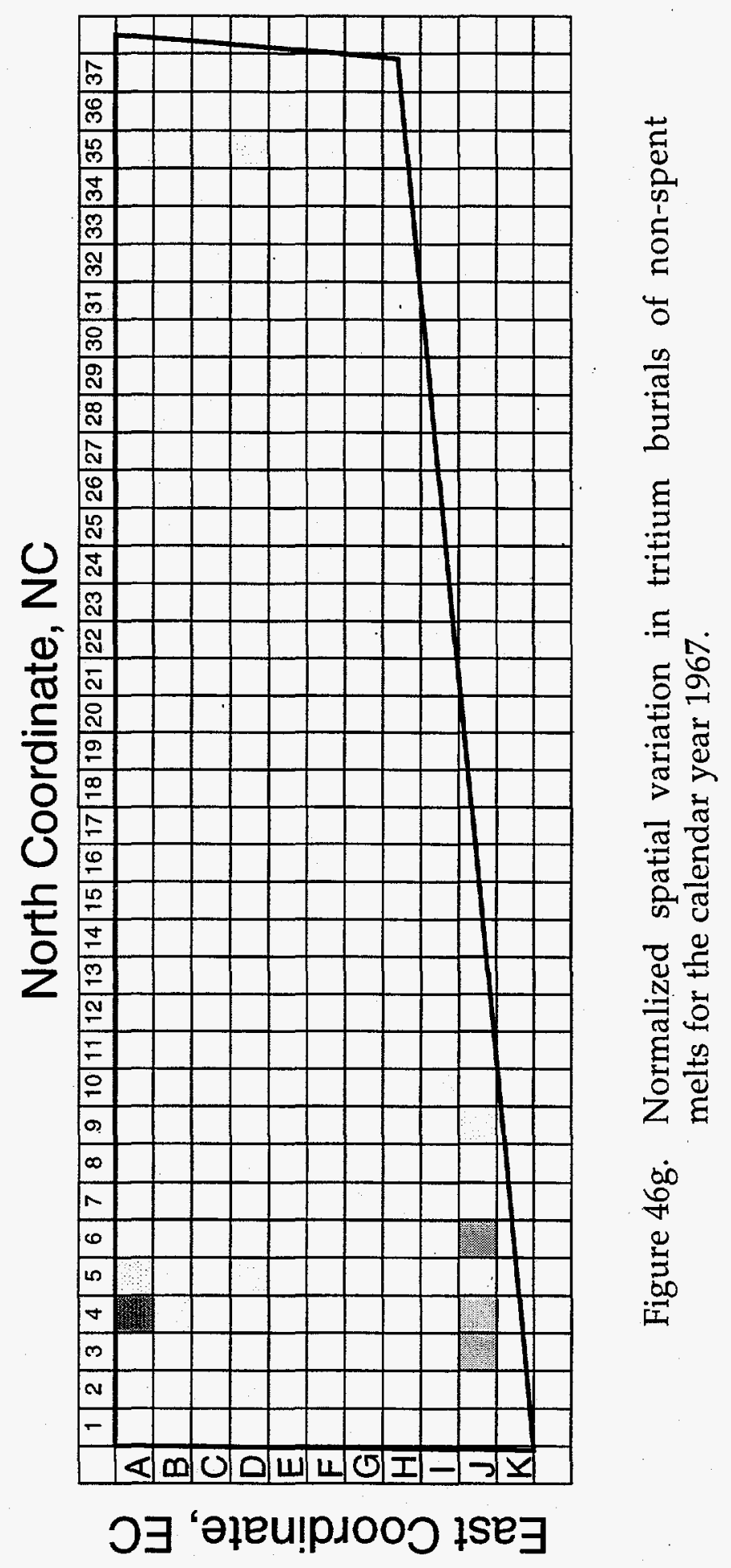




\section{North Coordinate, NC}

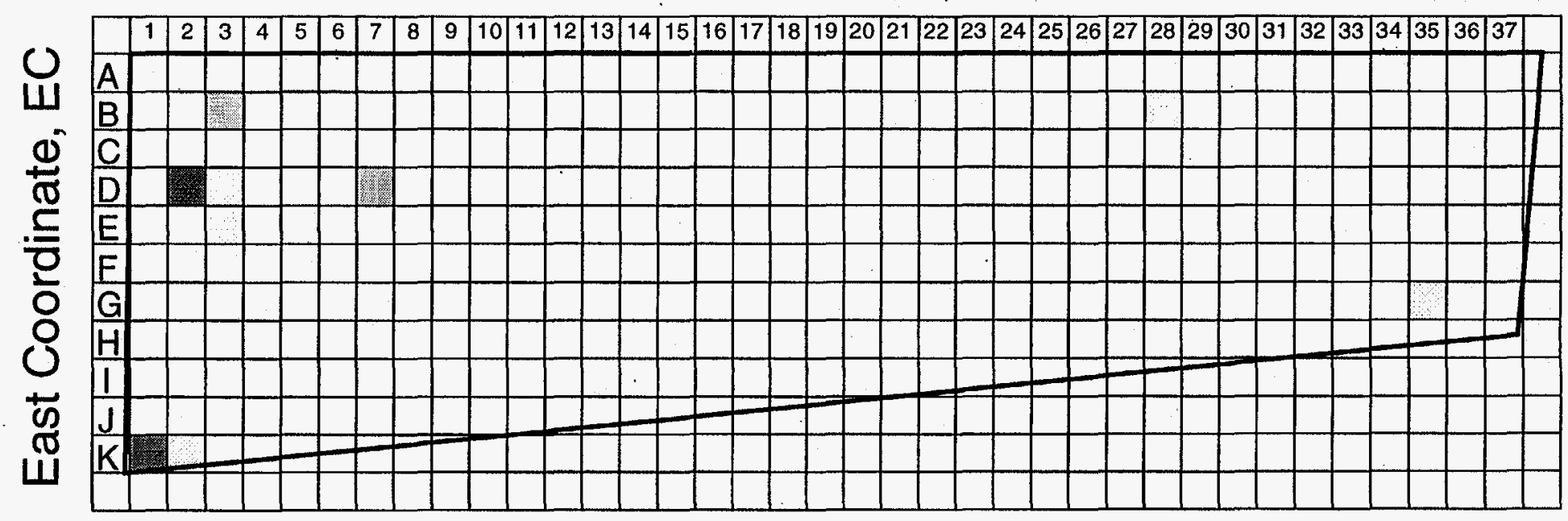

Figure 46h. Normalized spatial variation in tritium burials of non-spent melts for the calendar year 1968. 


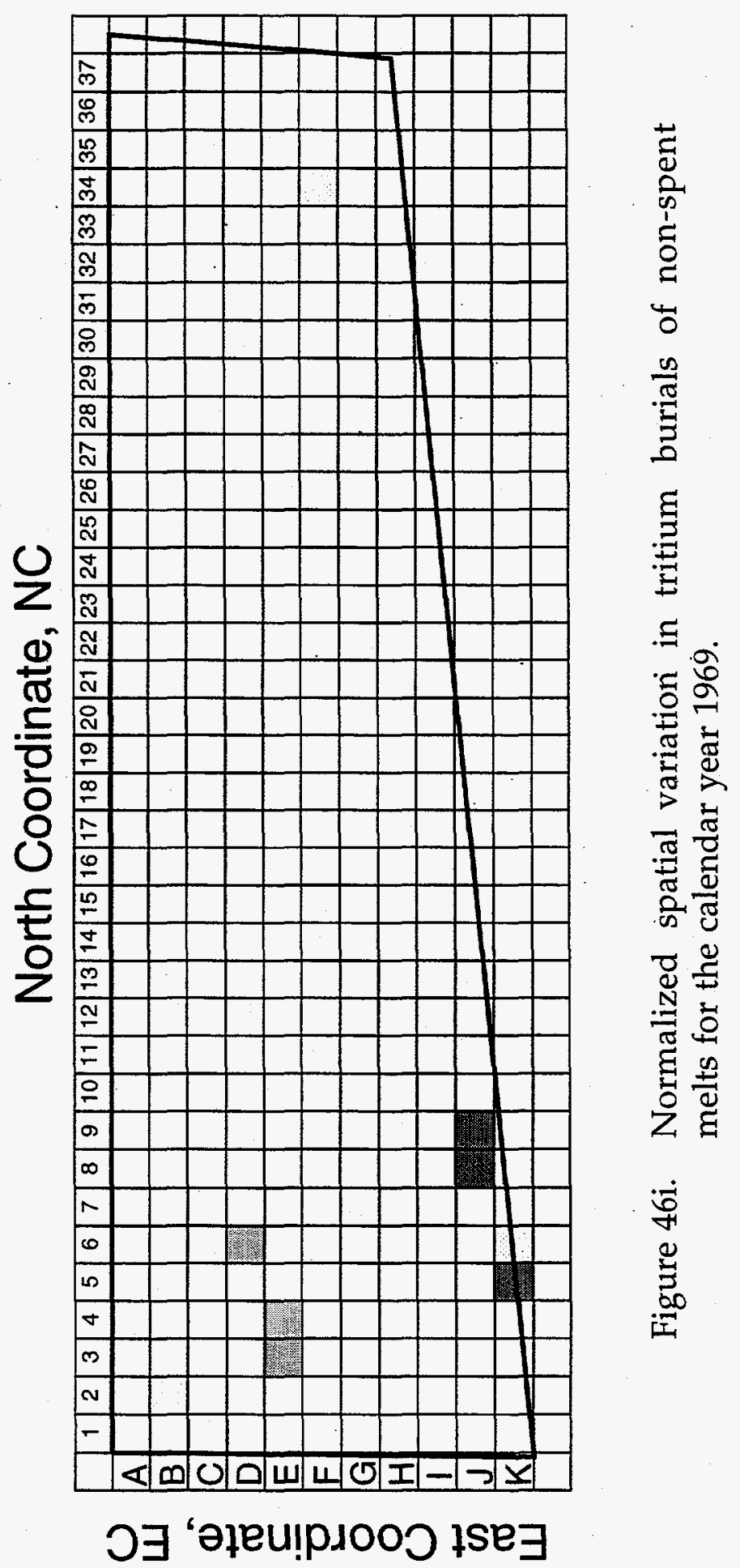




\section{North Coordinate, NC}

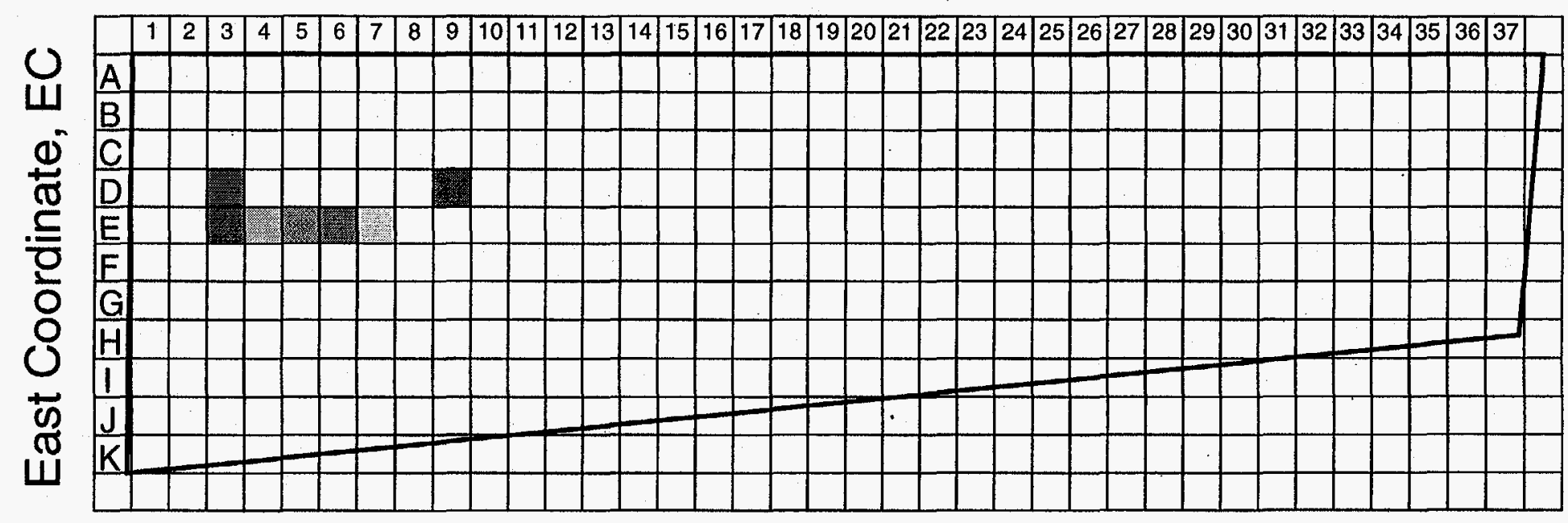

Figure 46j. Normalized spatial variation in tritium burials of non-spent melts for the calendar year 1970 . 


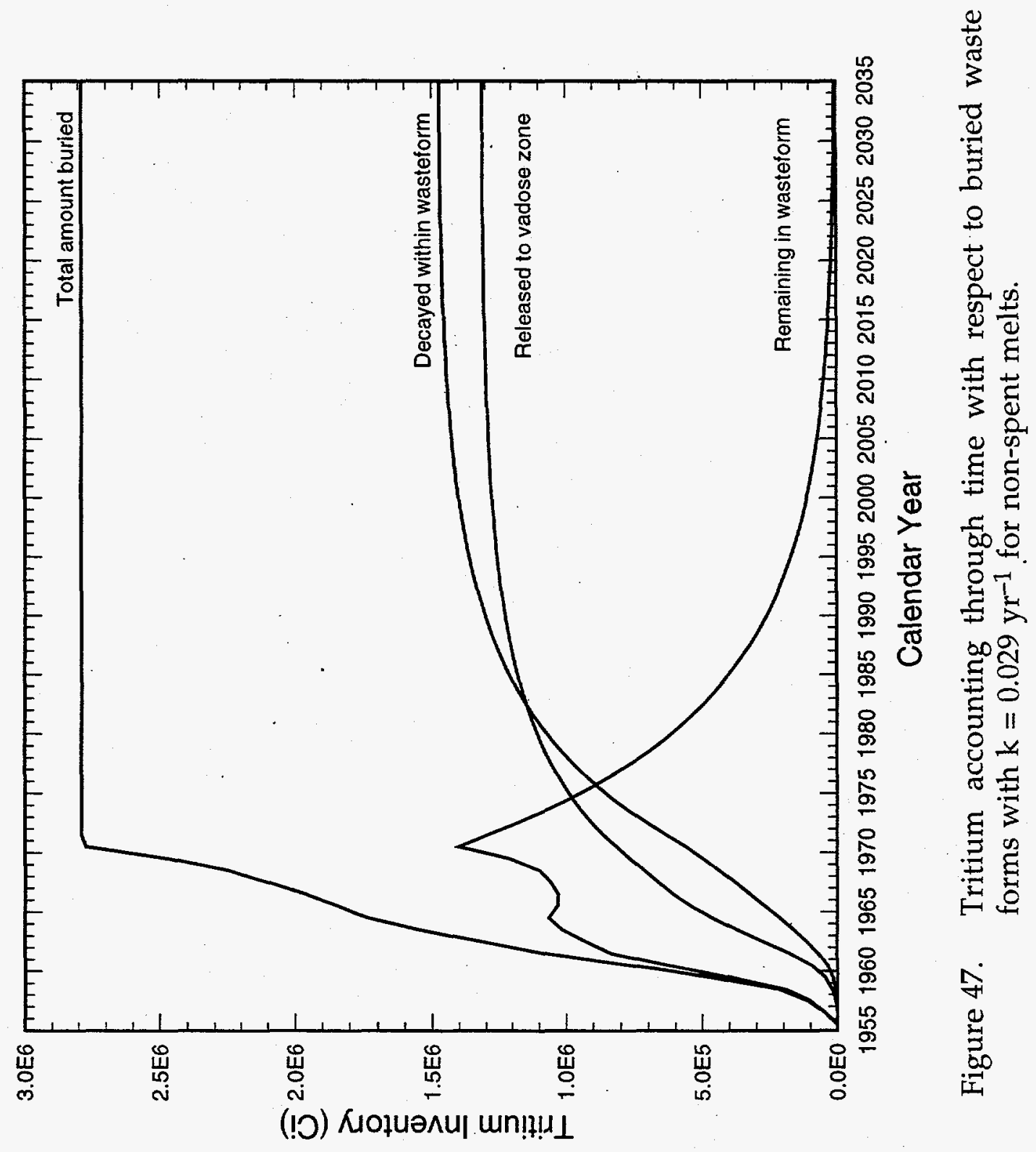




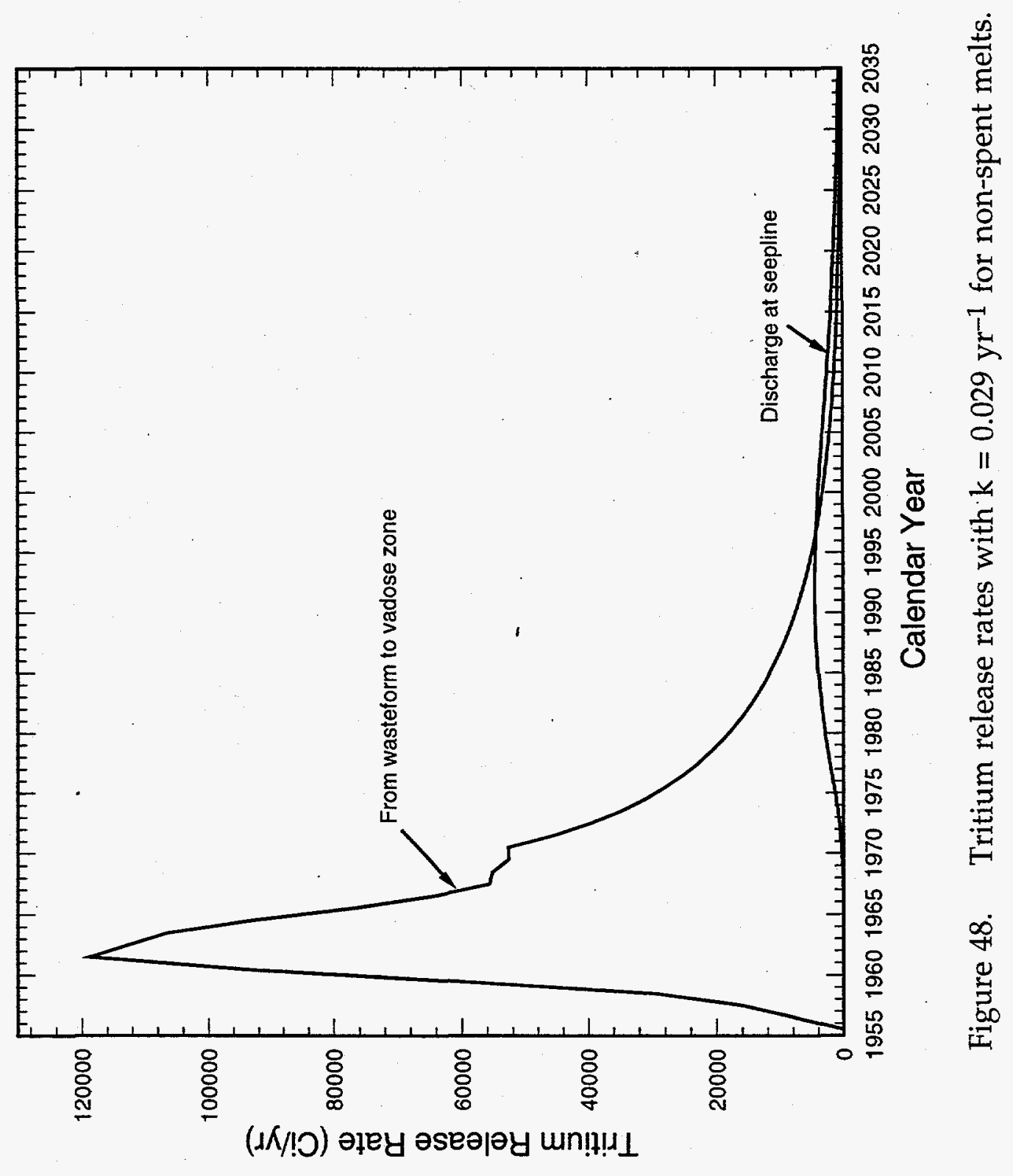




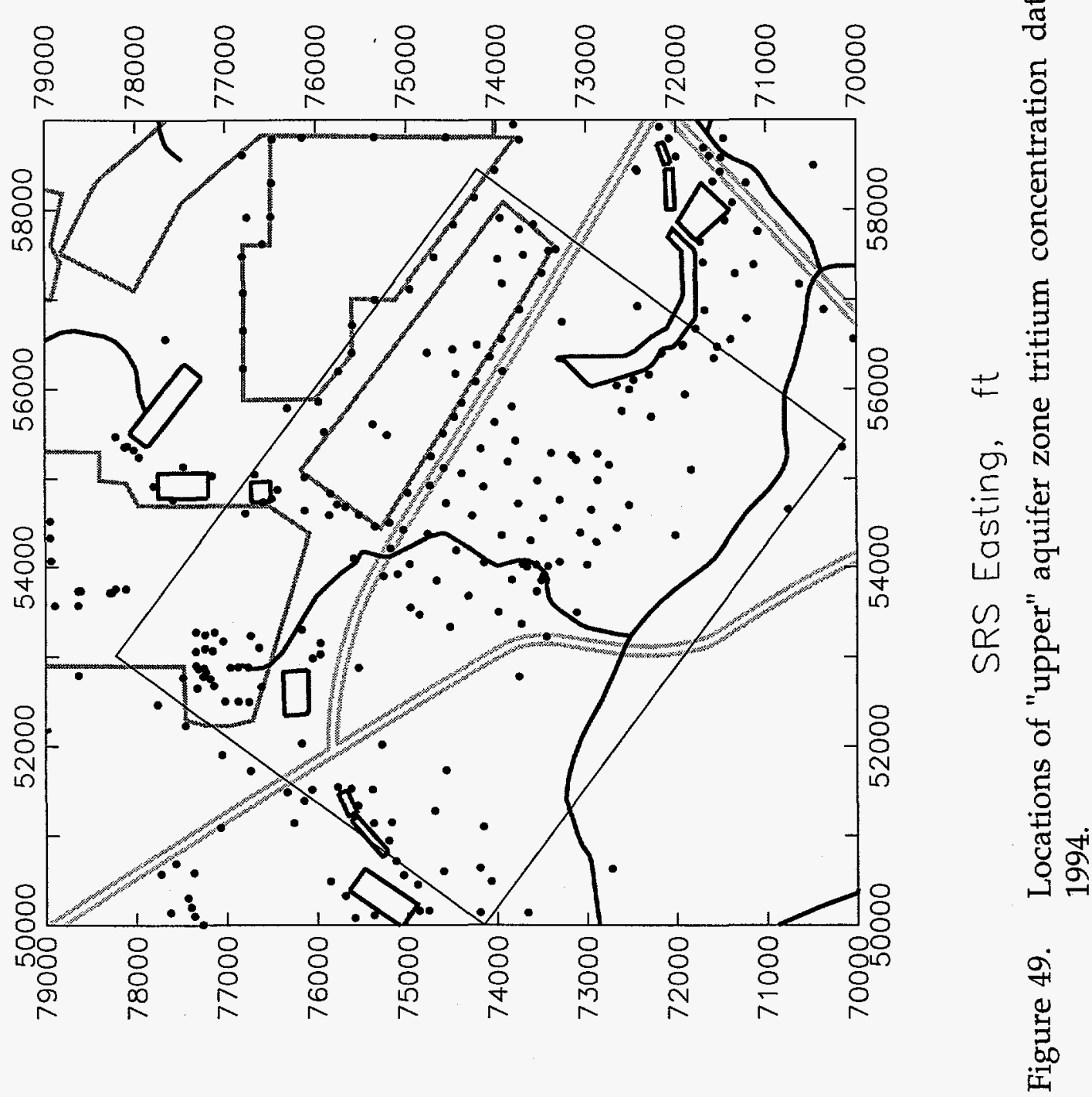

$\cos$ ZOL+ᄃ.- 


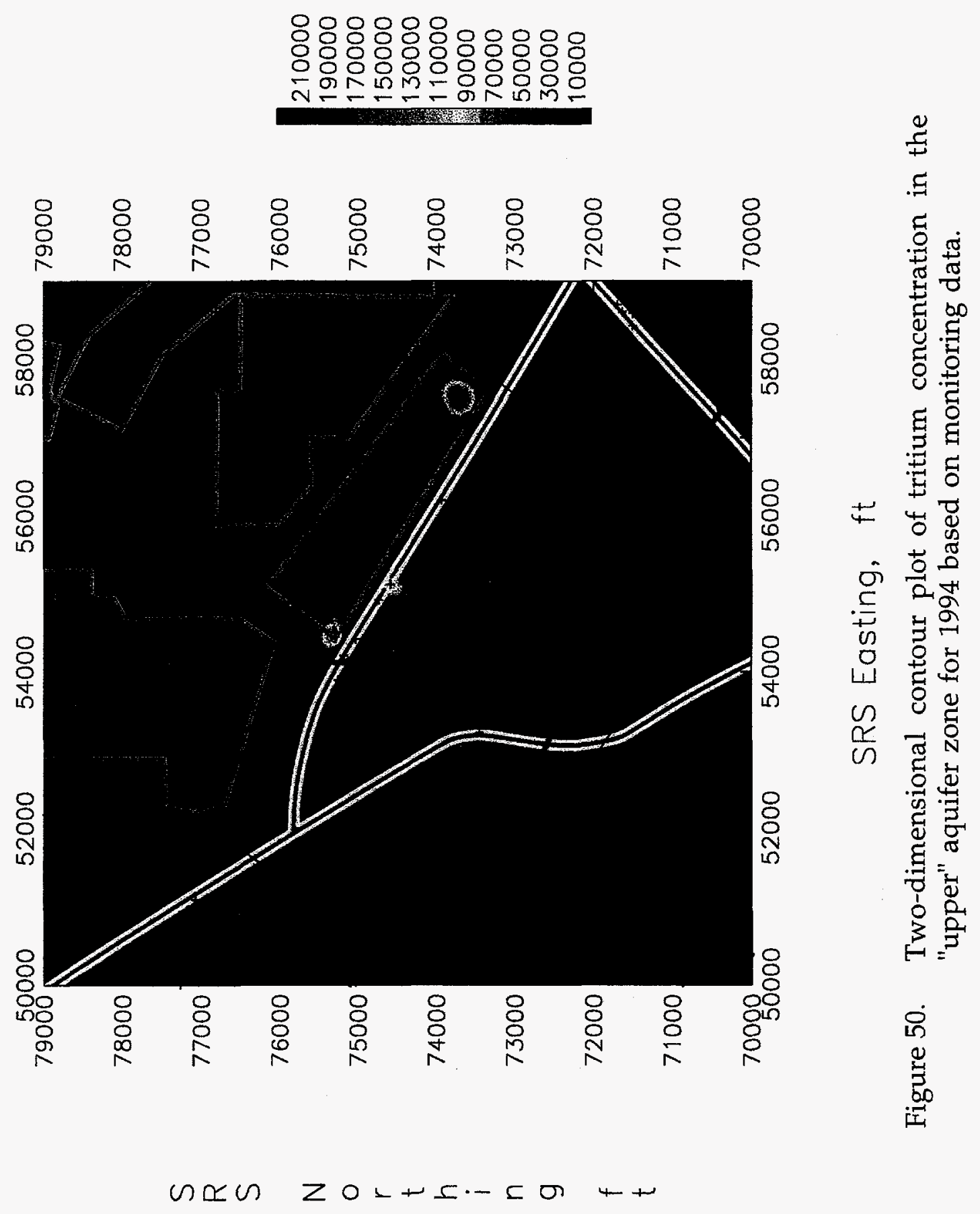


Tritium concentration $(\mathrm{pCi} / \mathrm{ml})$

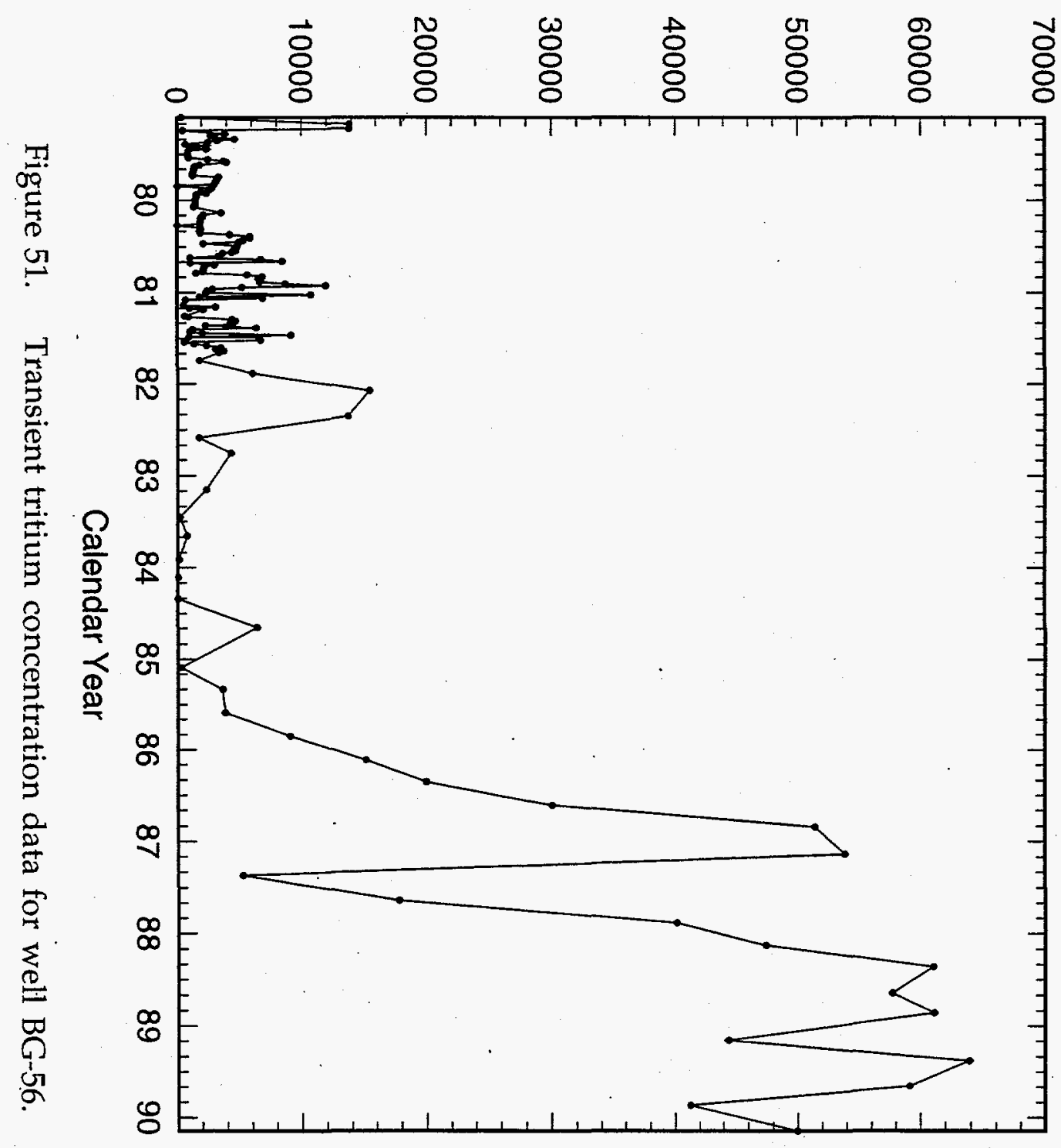




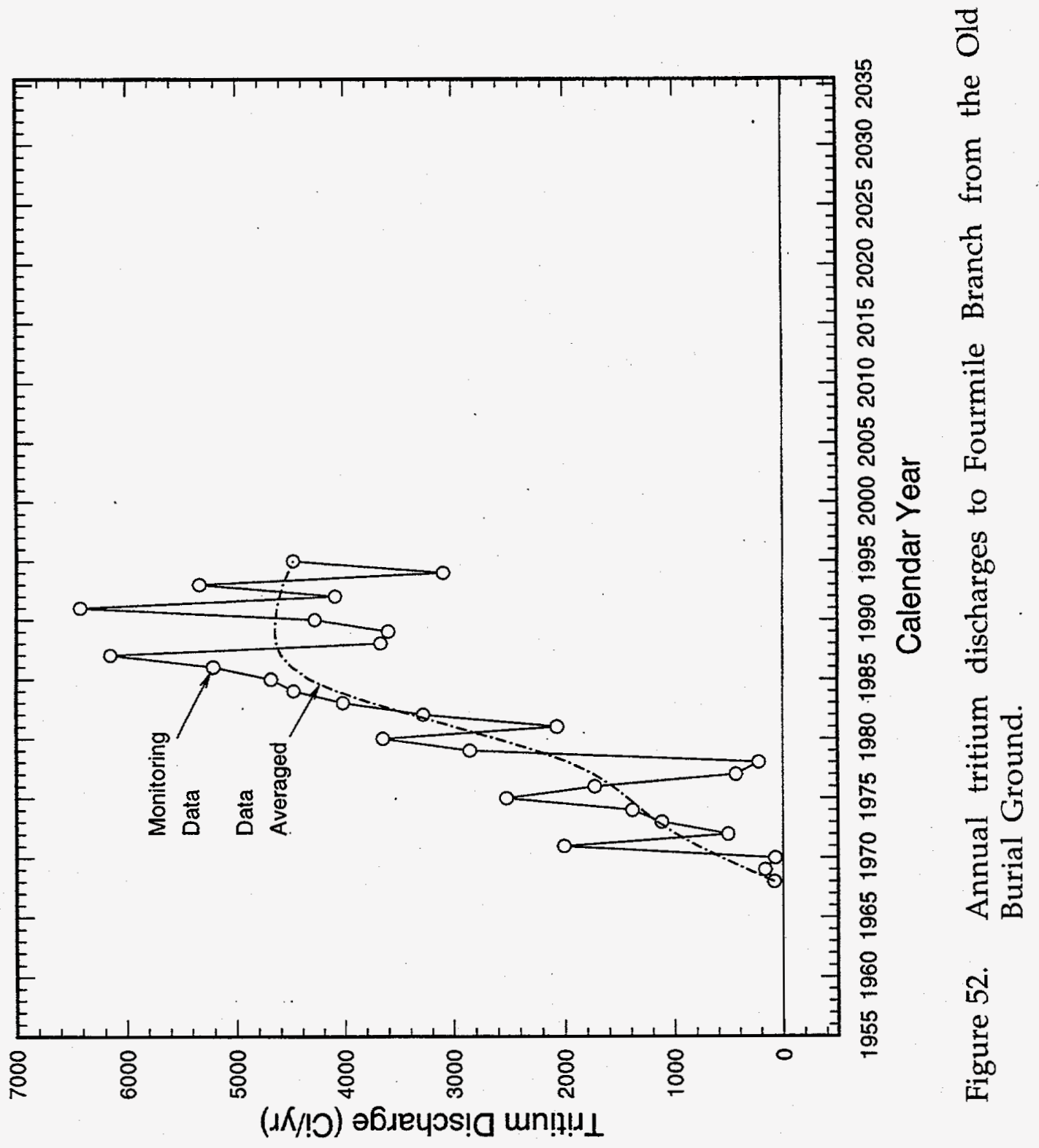




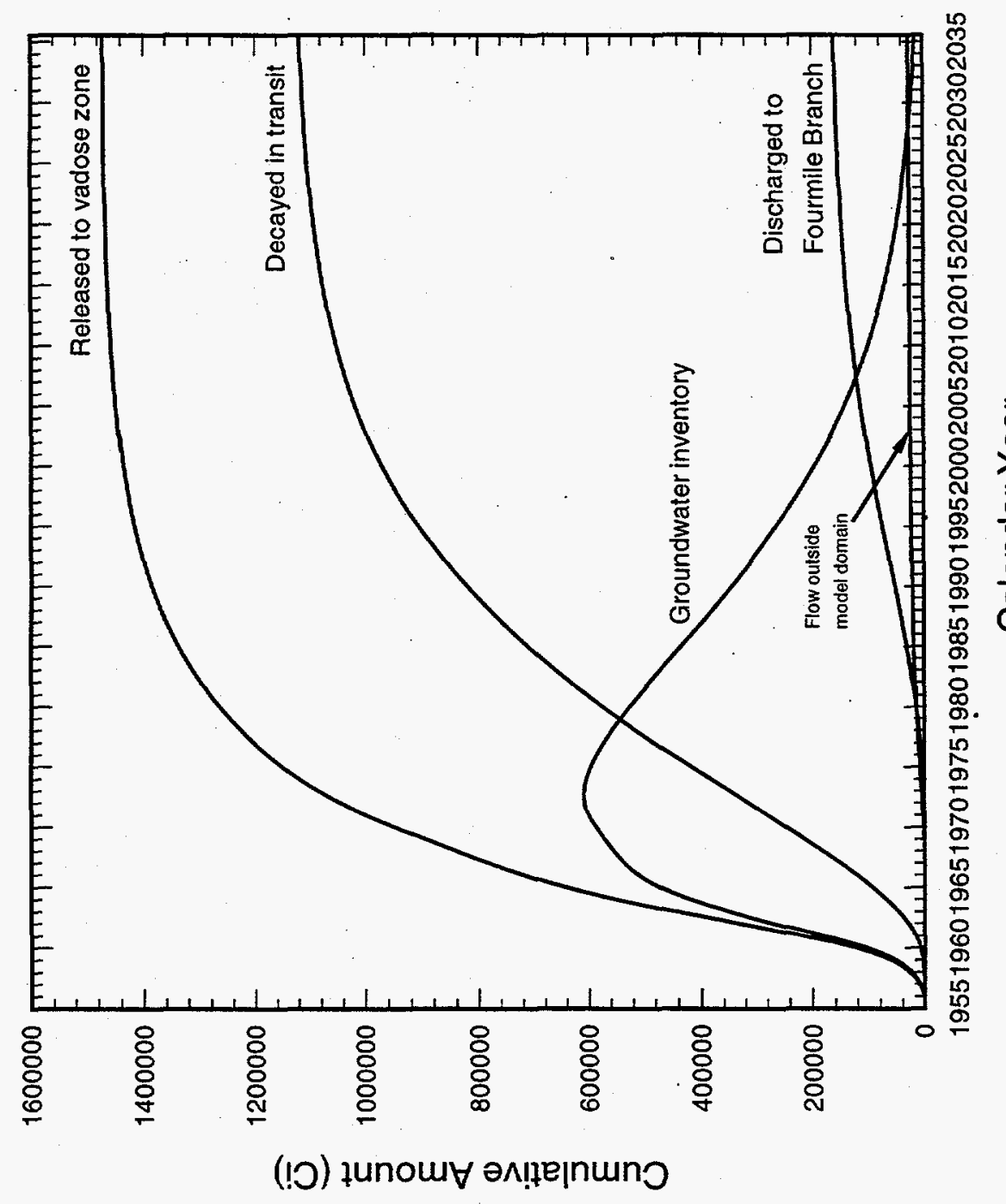

芯点

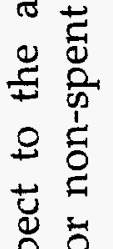

कू

$-5$

옹

ธั

छ 11

丰室

吾 号

N

, of

.

อ

号

어용

छ ซ్ర

武焉余

in

荘

诖 


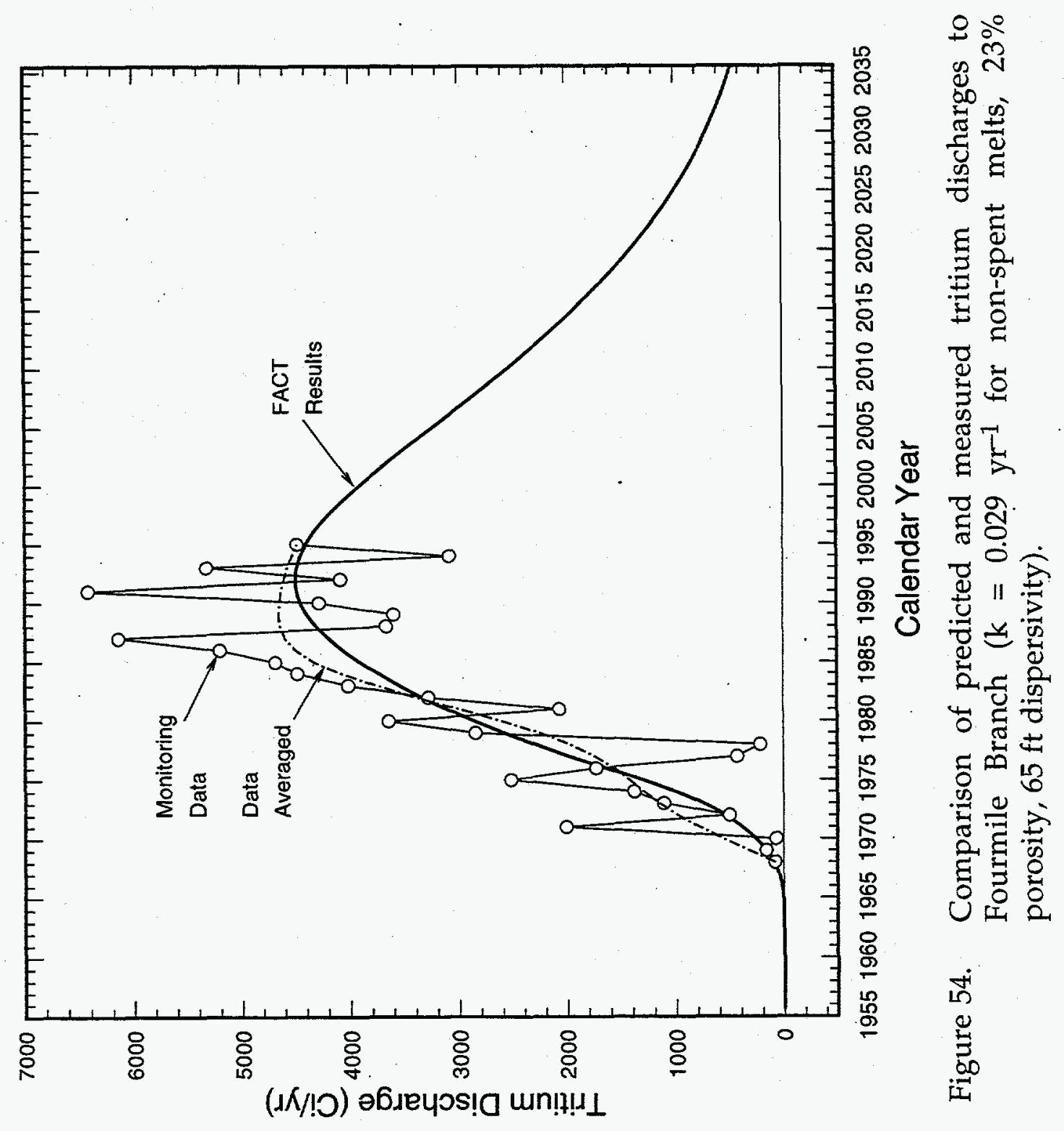




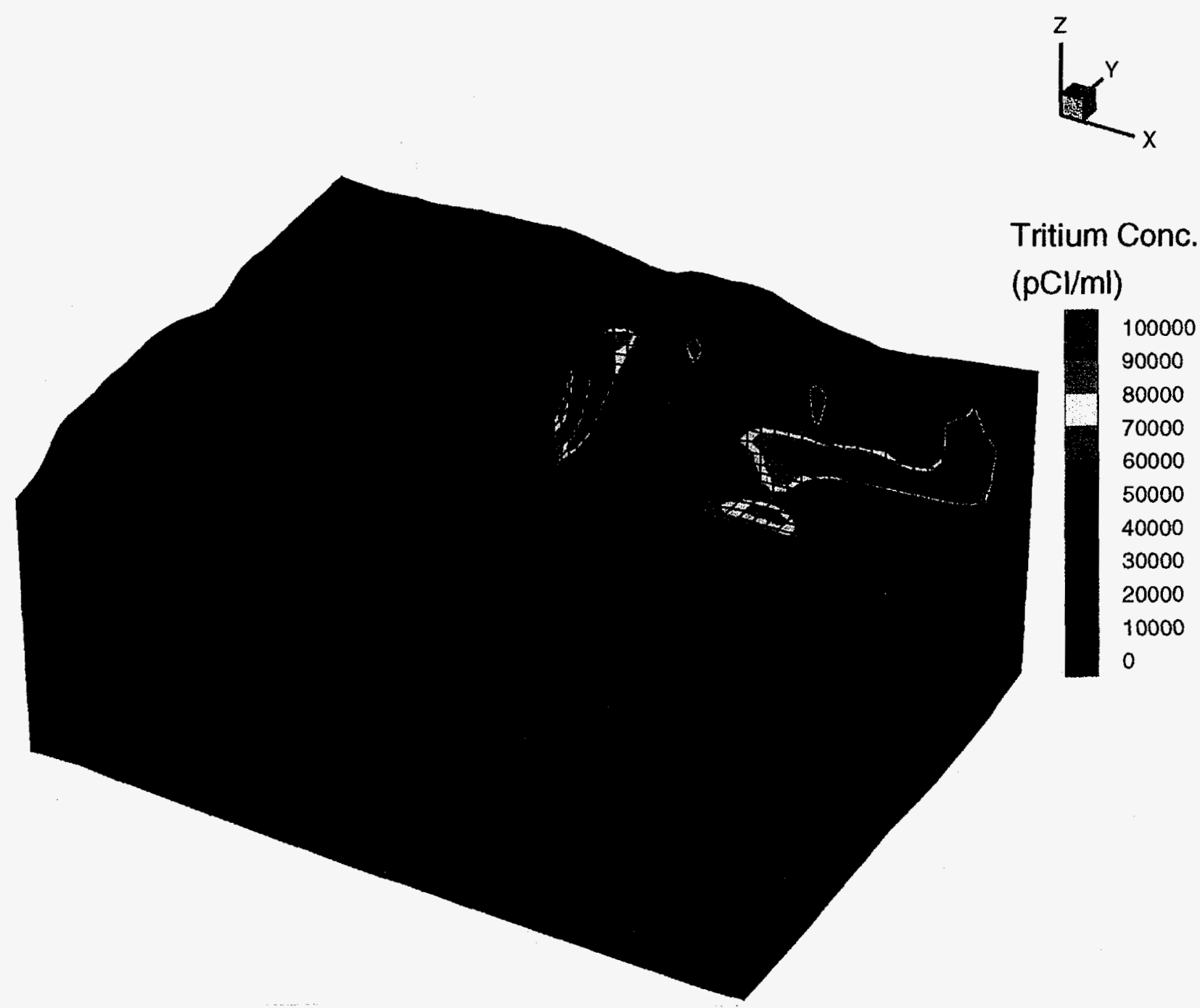

Figure 55. Simulated three-dimensional tritium concentration distribution for 1995. 


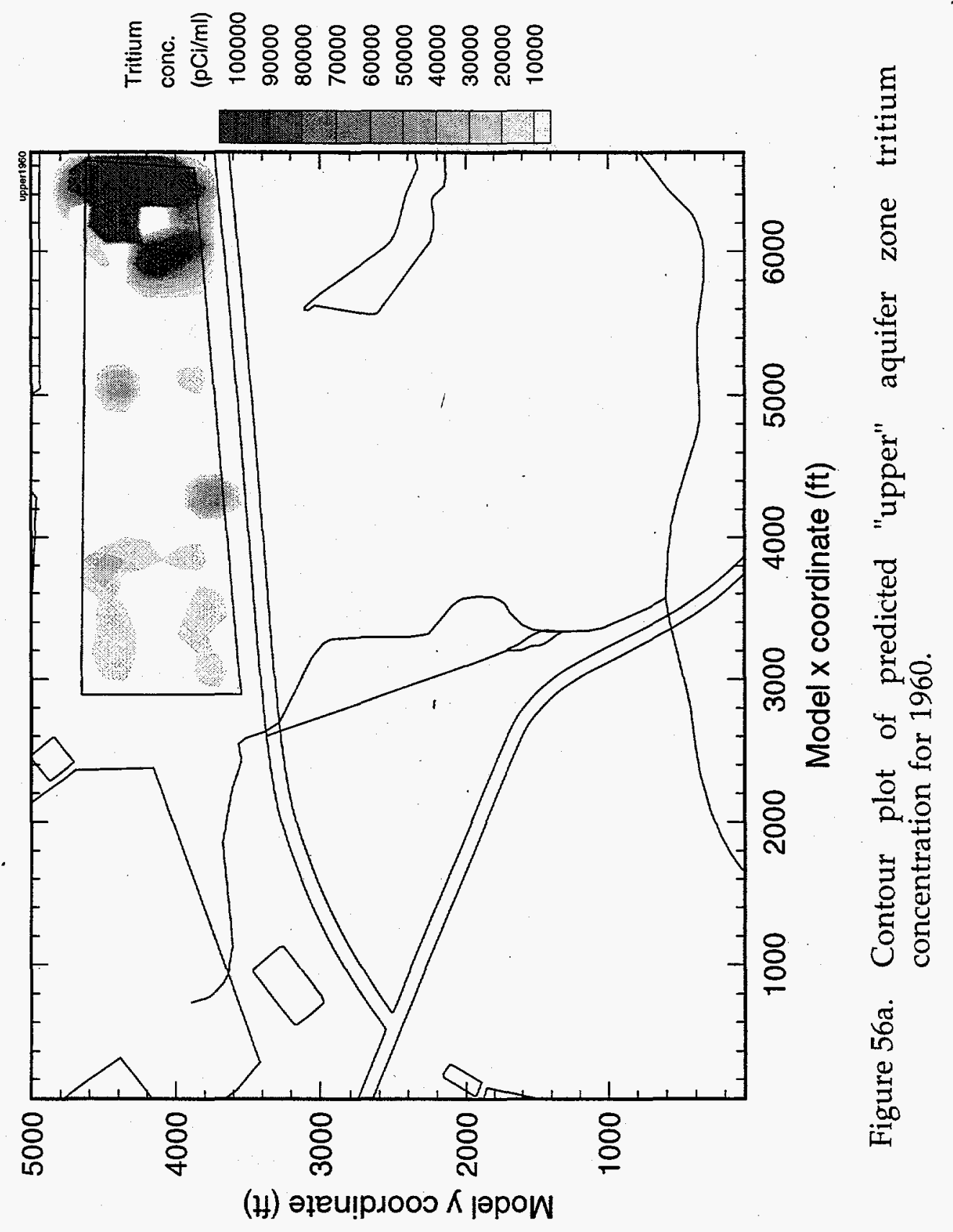




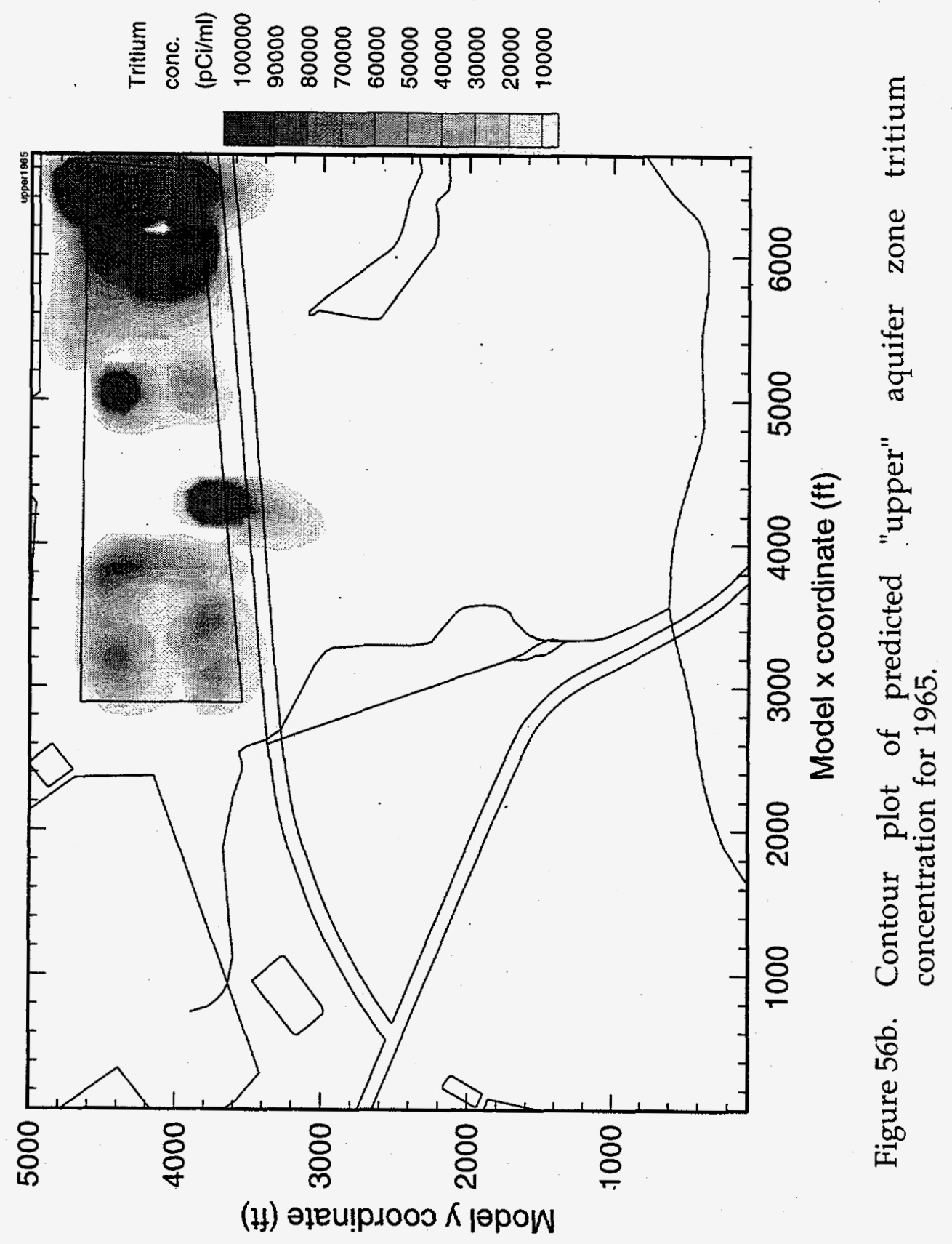




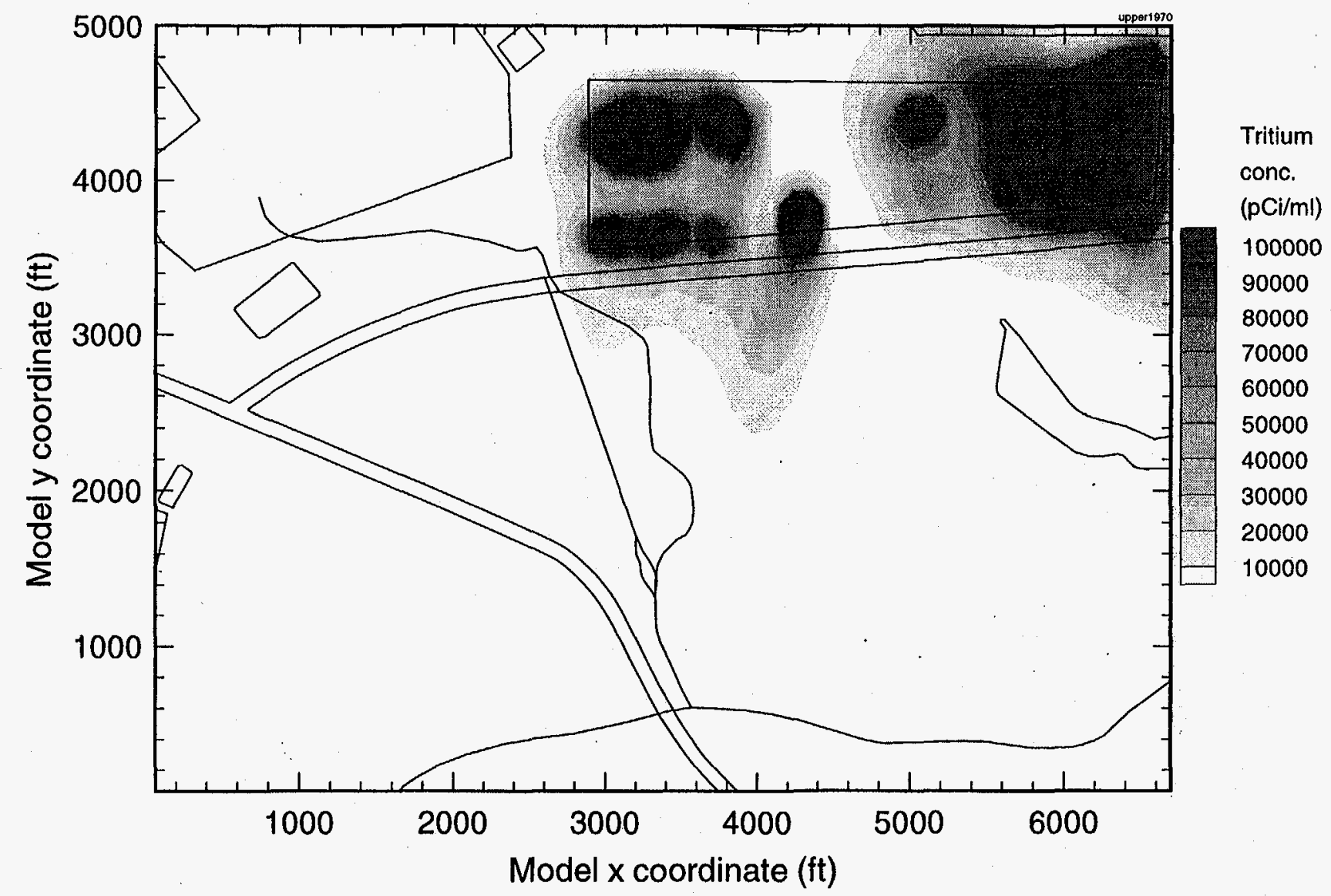

Figure 56c. Contour plot of predicted "upper" aquifer zone tritium concentration for 1970. 


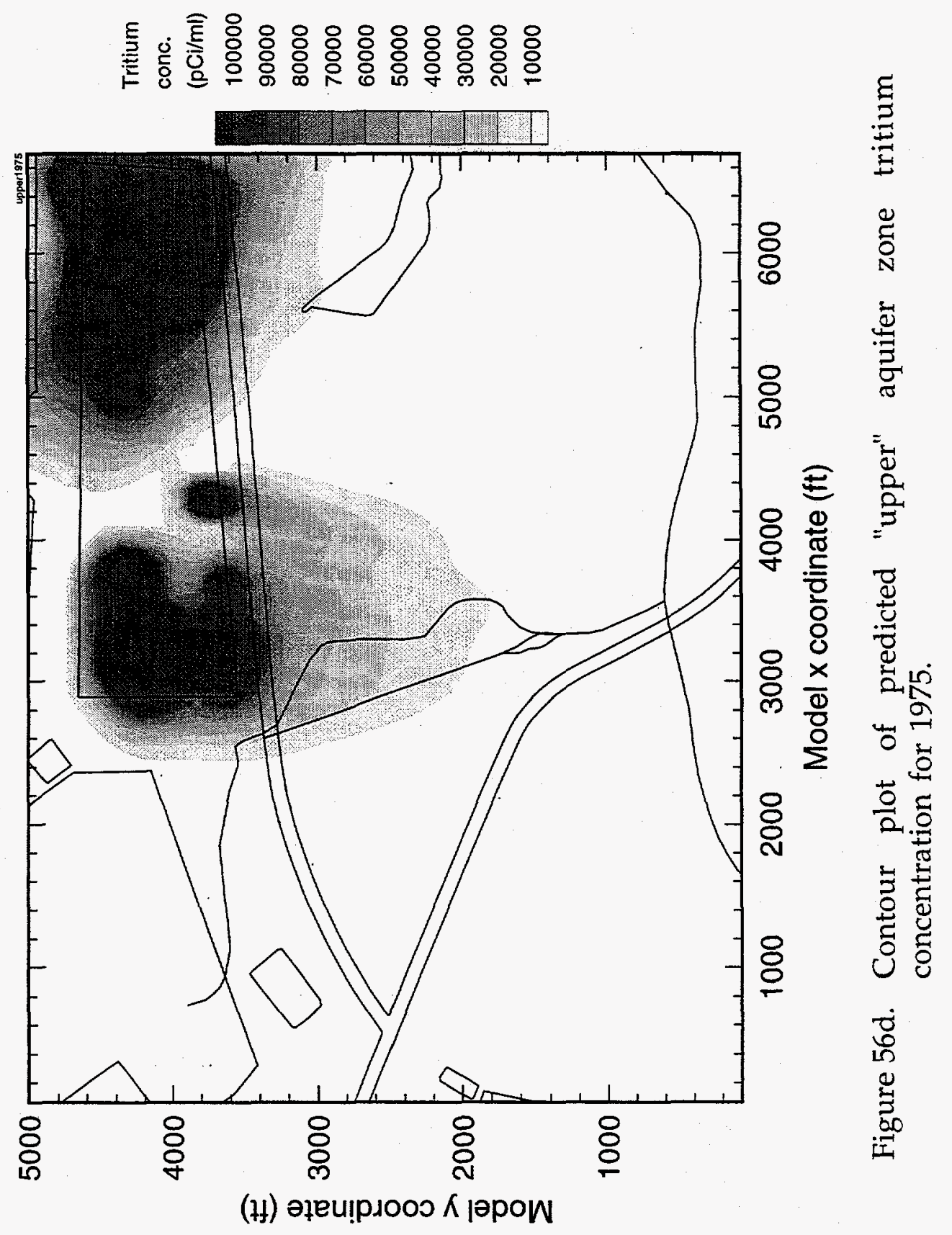




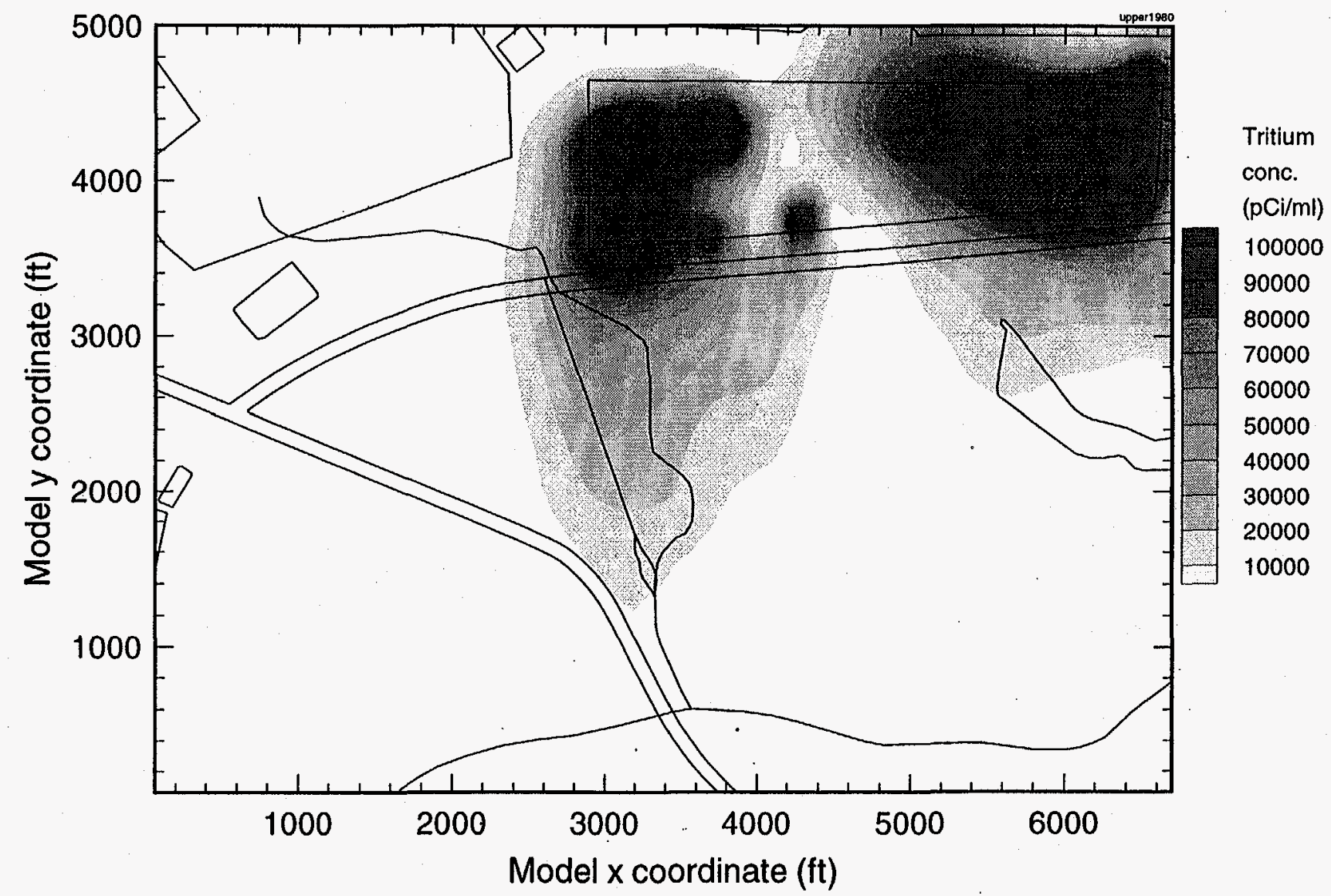

Figure 56e. Contour plot of predicted "upper" aquifer zone tritium concentration for 1980 . 


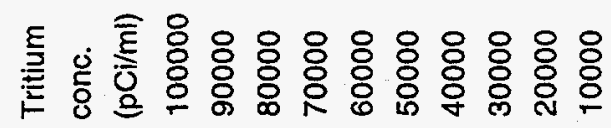

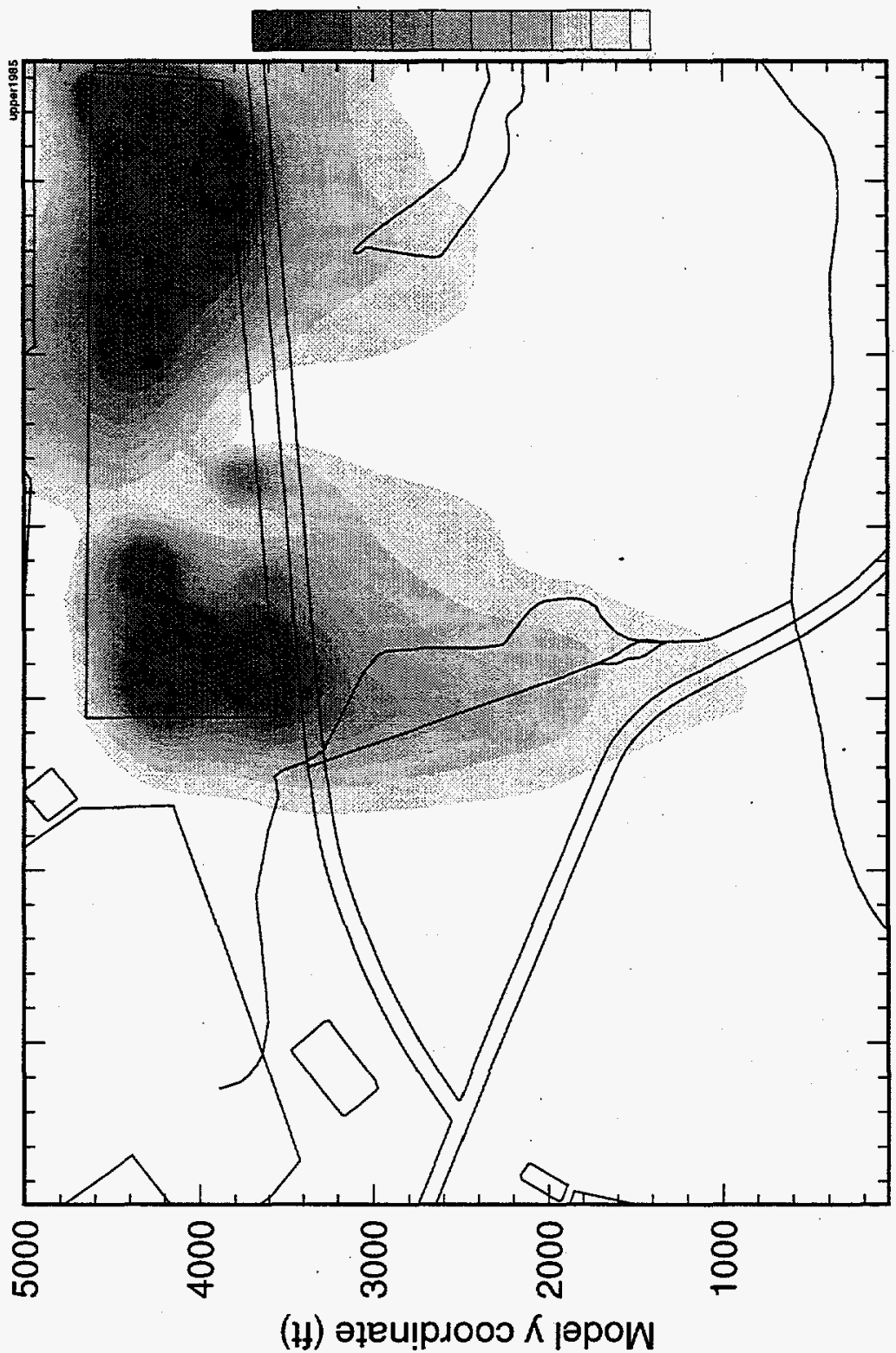

㤩

8

8

$8 \underset{8}{\stackrel{\Xi}{\sigma}}$

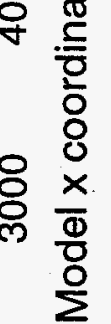

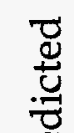

这

ธั。

용

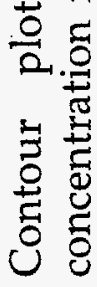

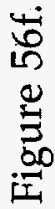

(ł) әұеu!p sоoо $\wedge$ рароW 


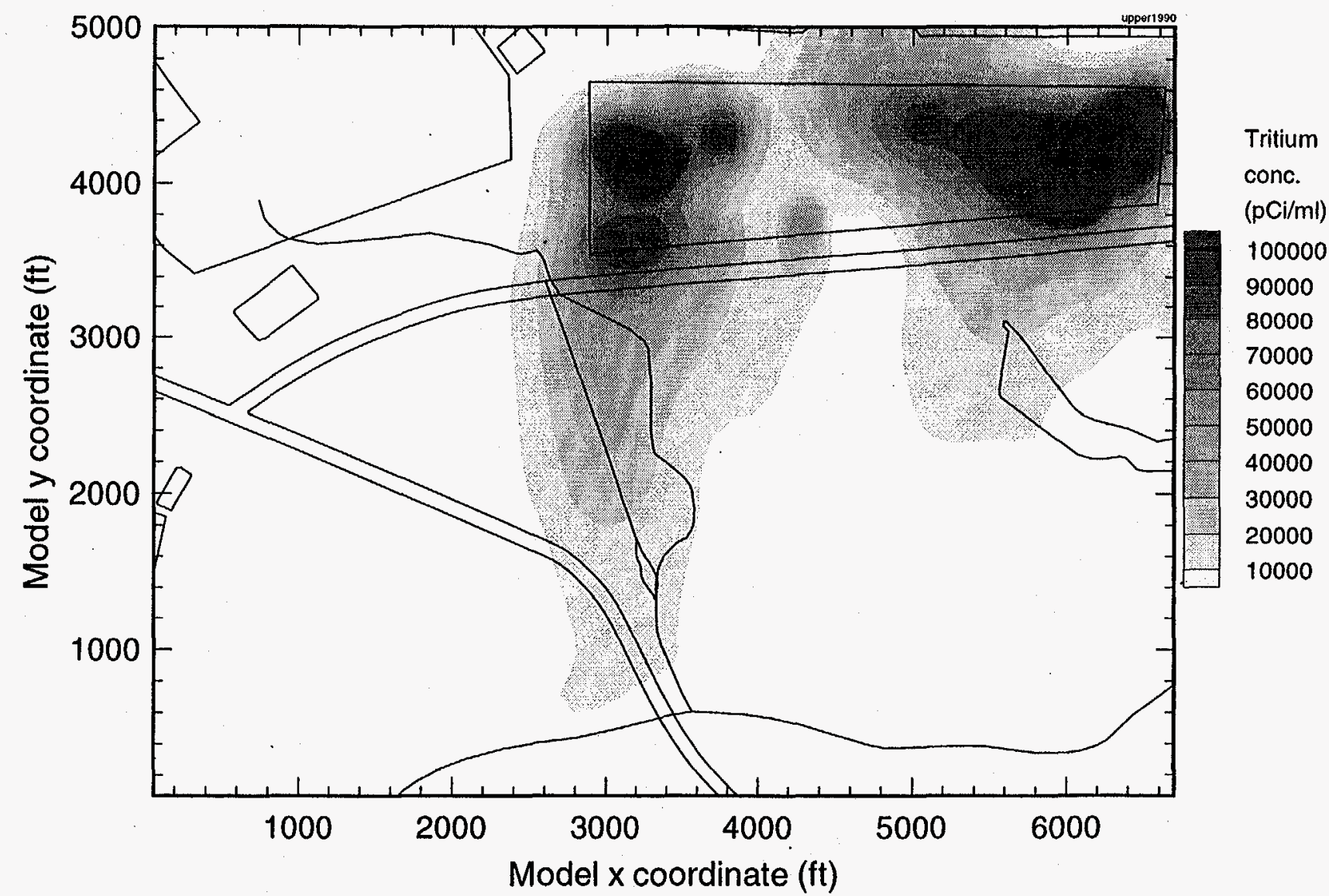

Figure 56g. Contour plot of predicted "upper" aquifer zone tritium concentration for 1990 . 


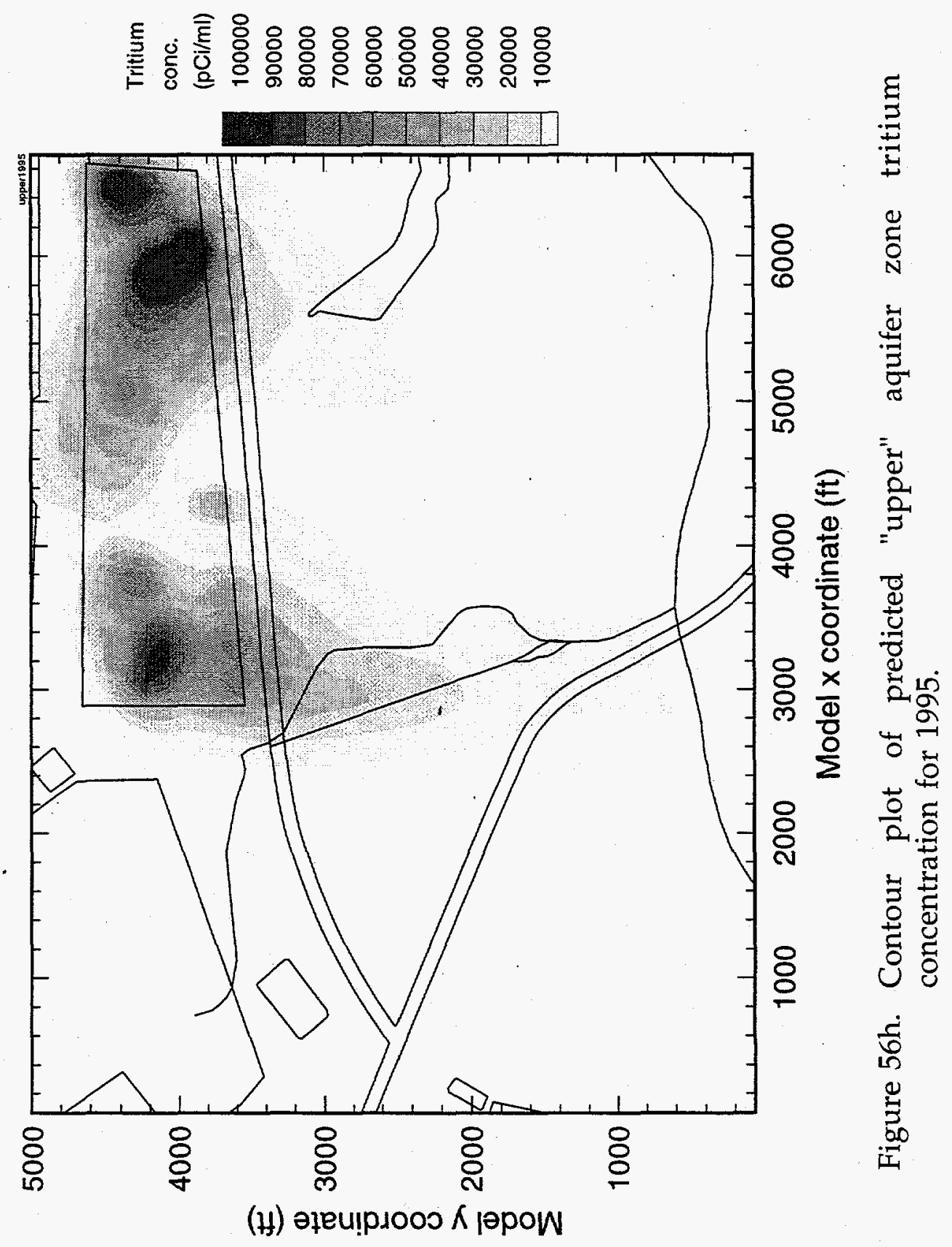




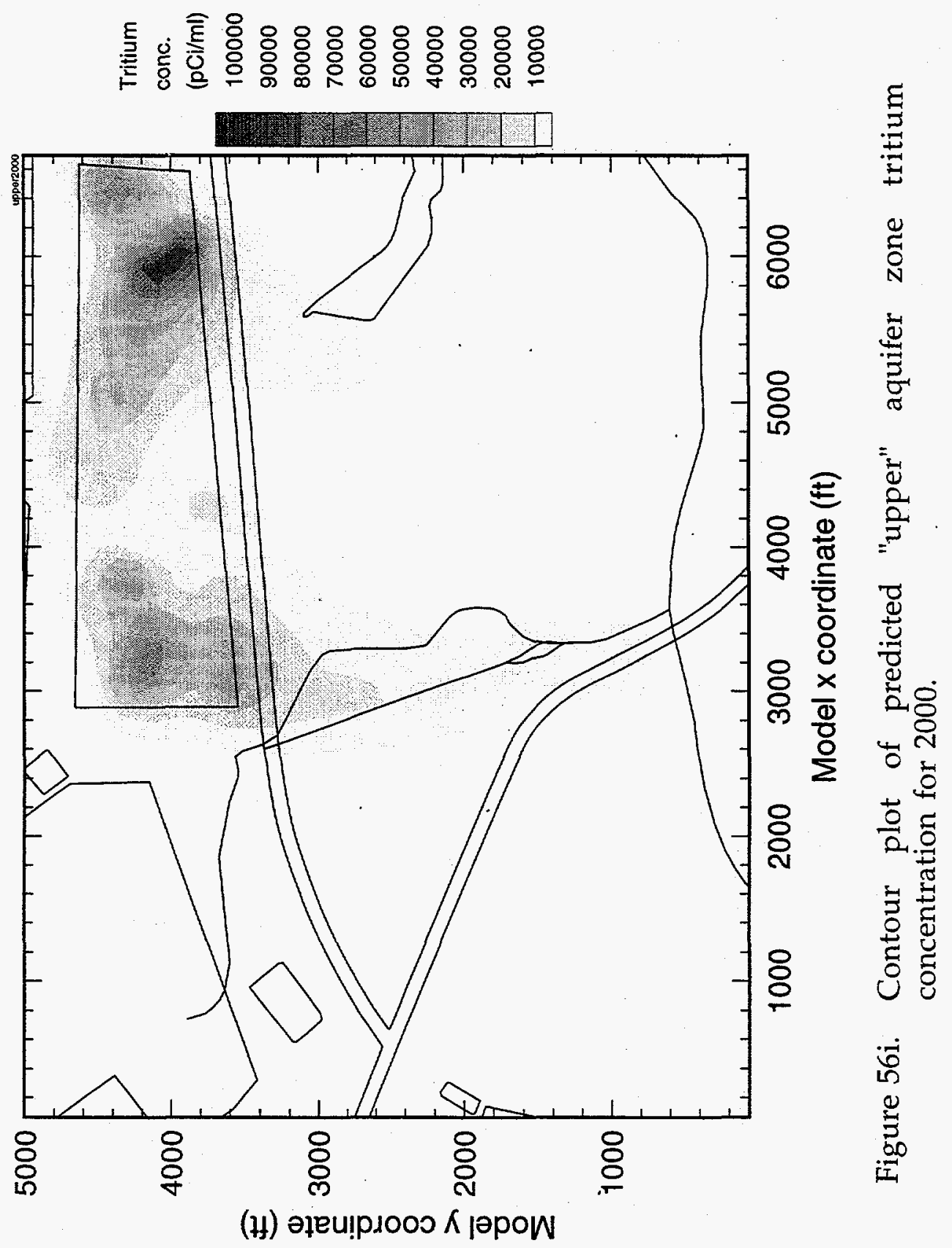




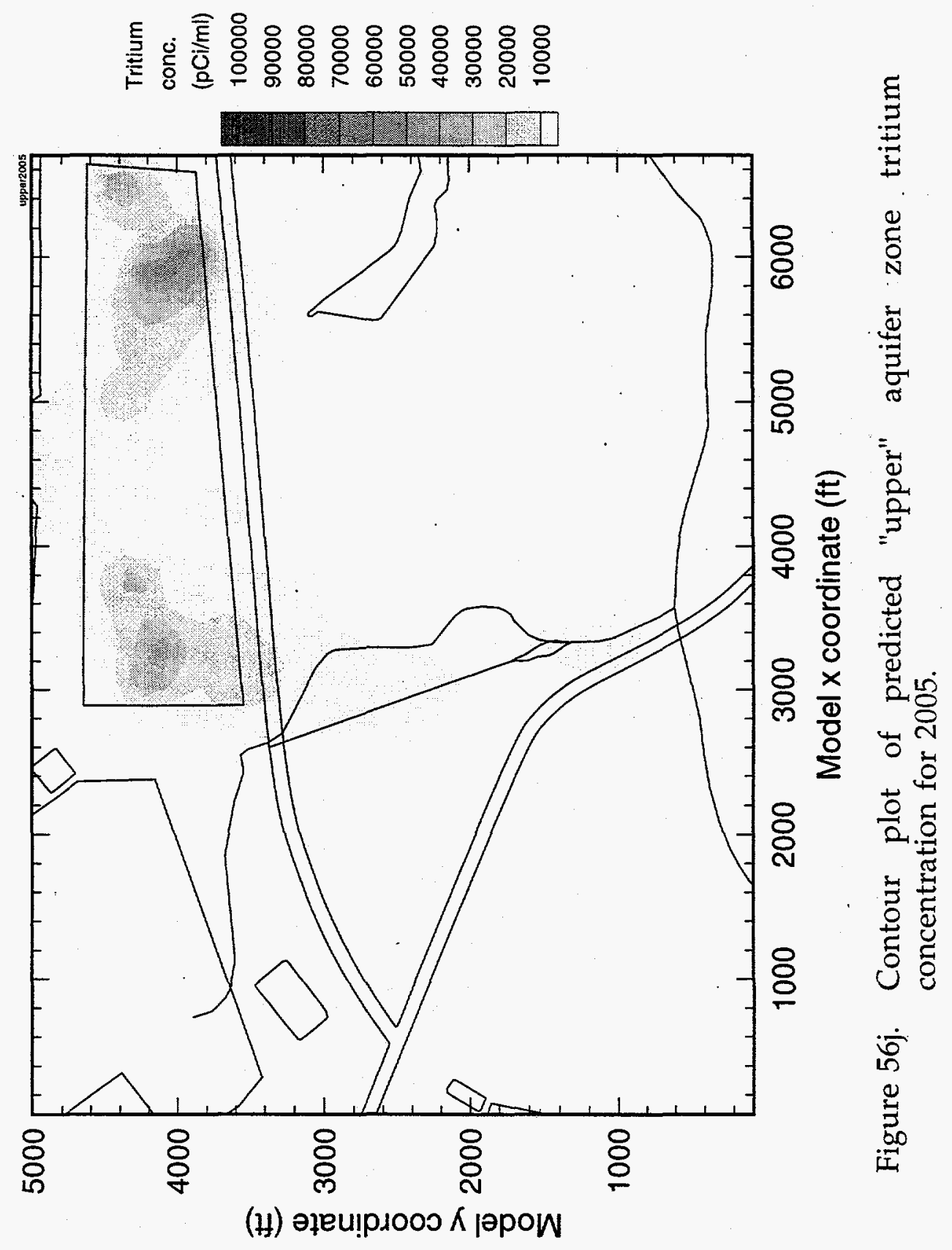




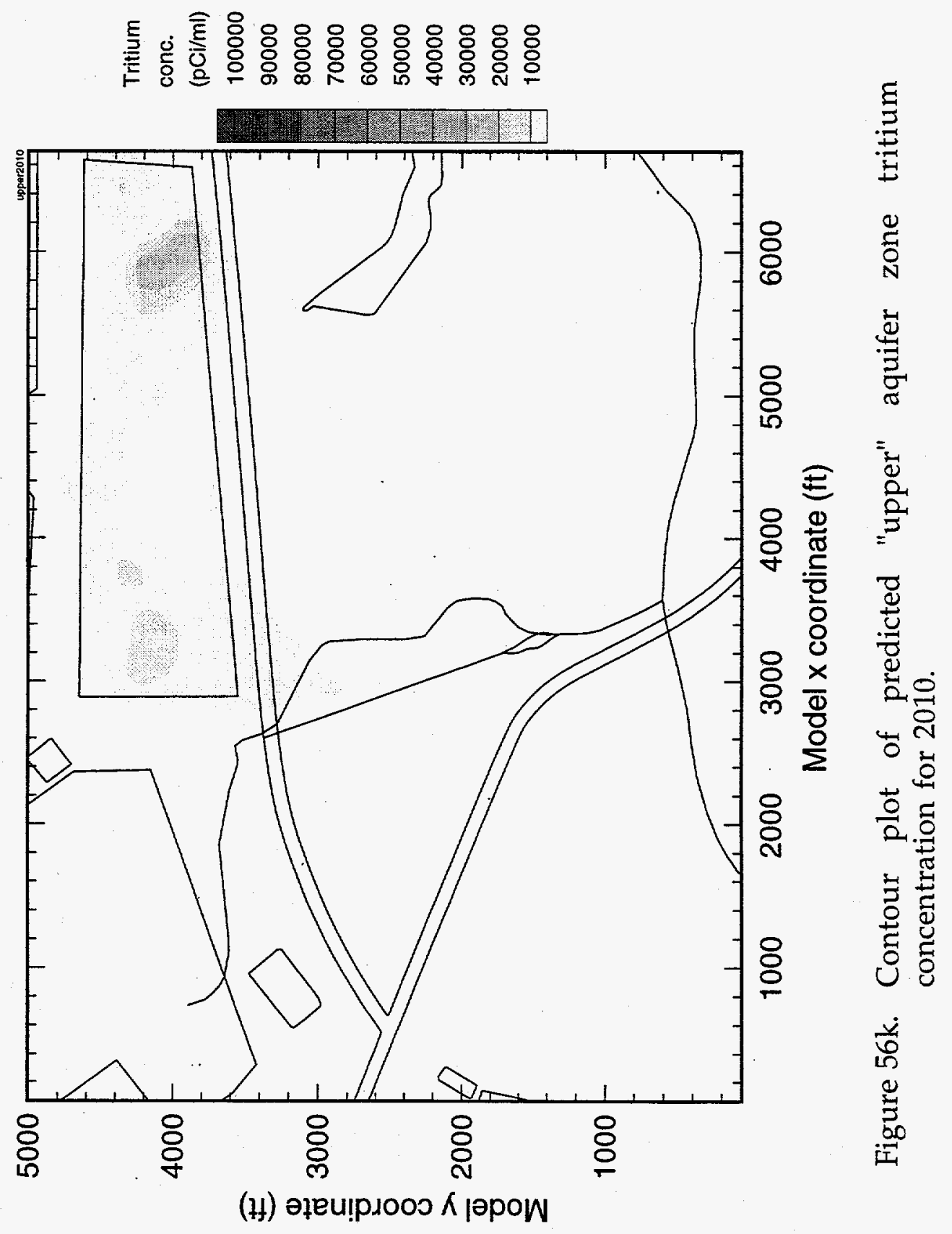




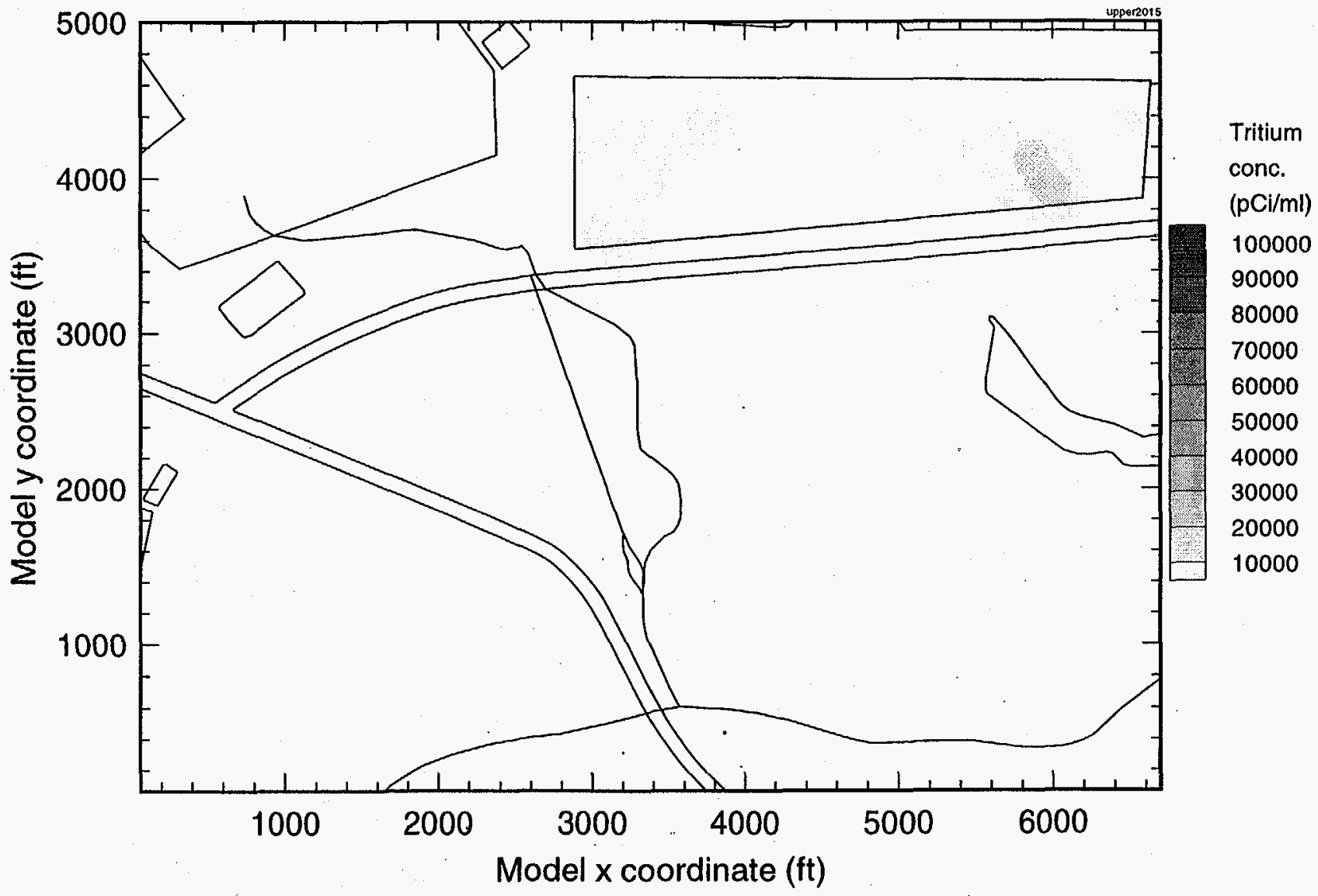

Figure 561. Contour plot of predicted "upper" aquifer zone tritium concentration for 2015 . 


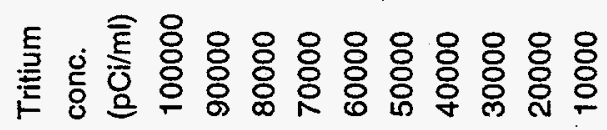

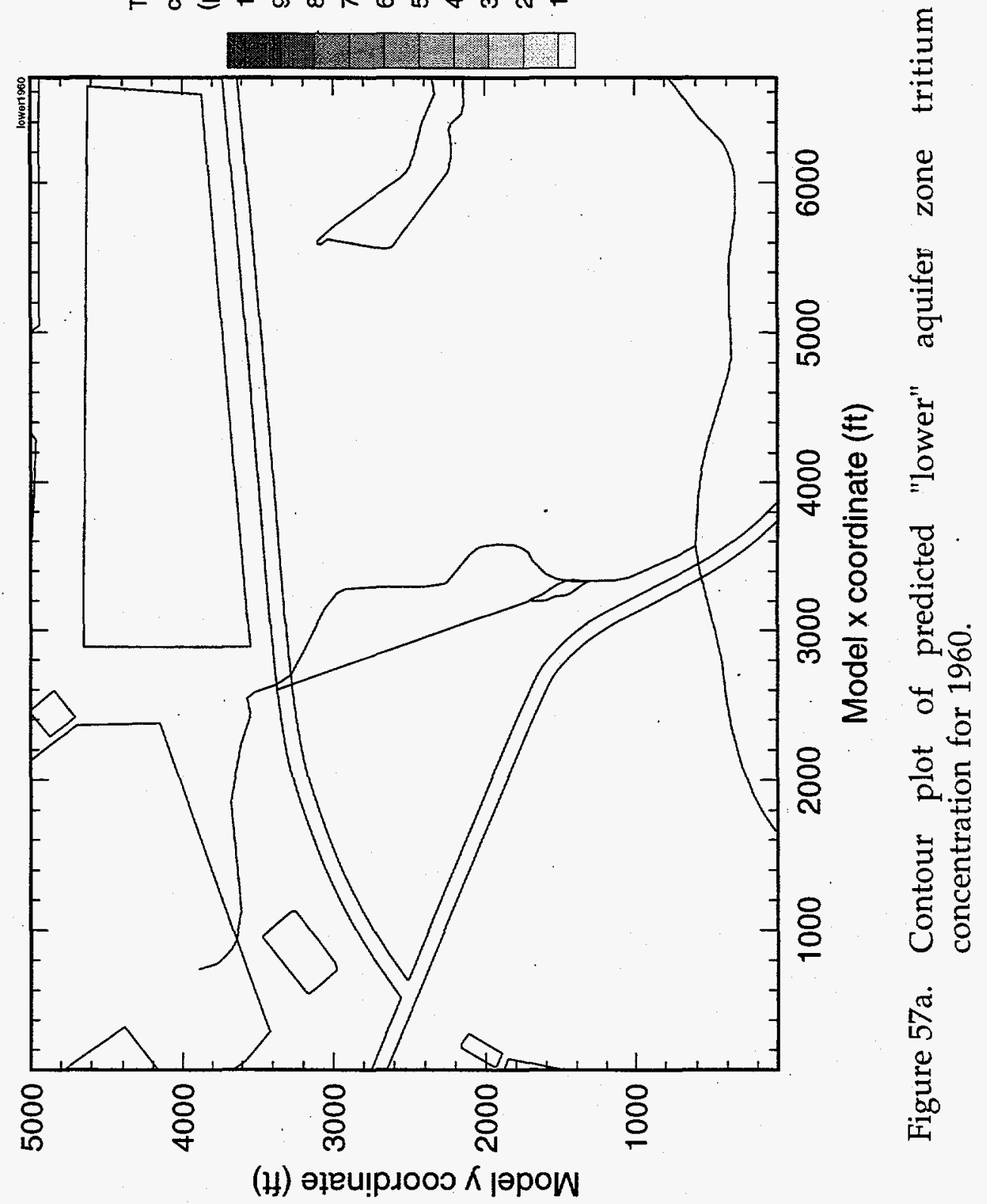




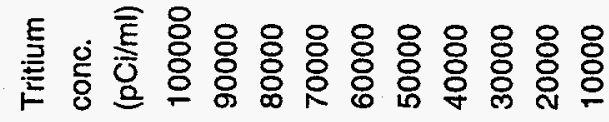

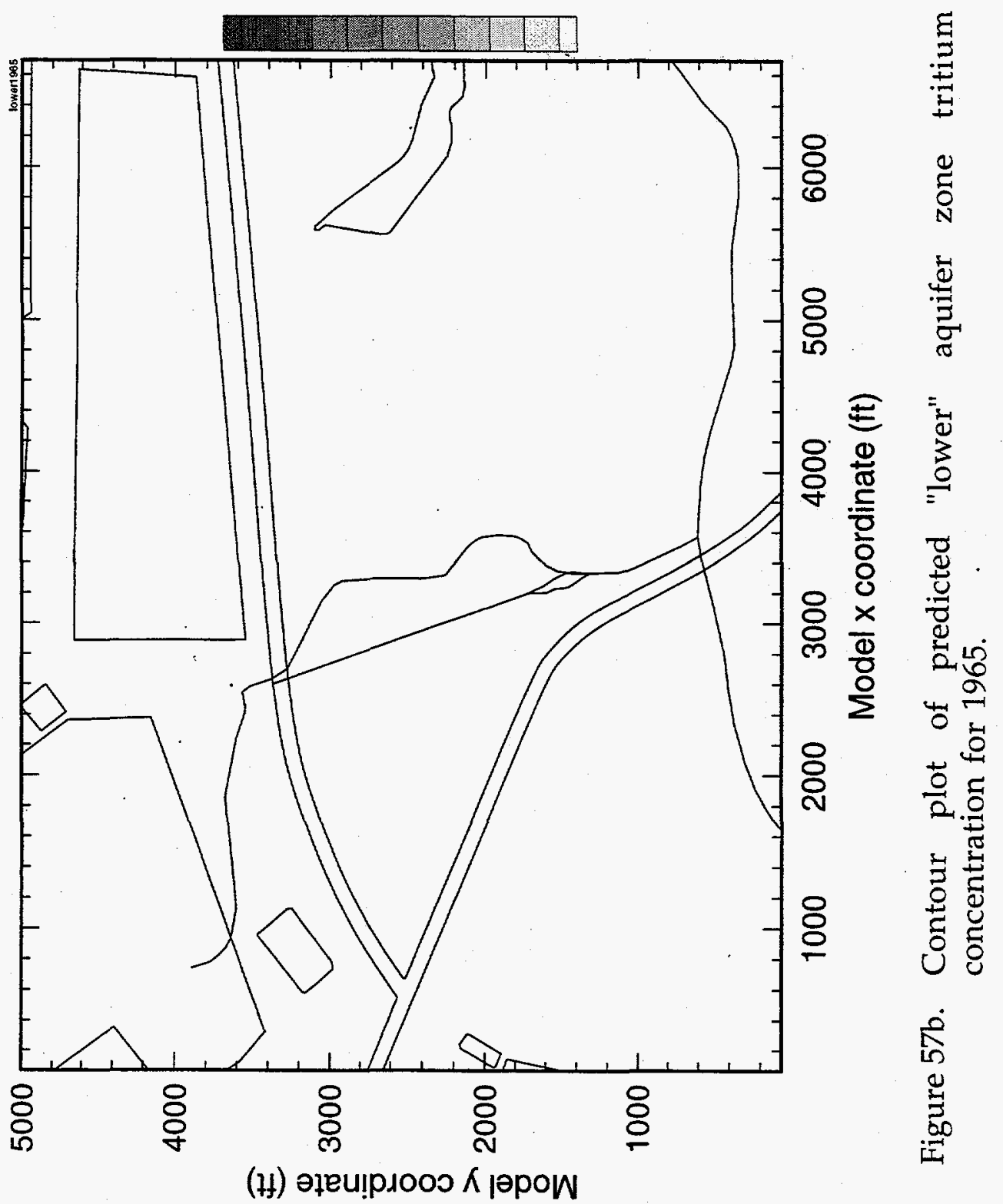




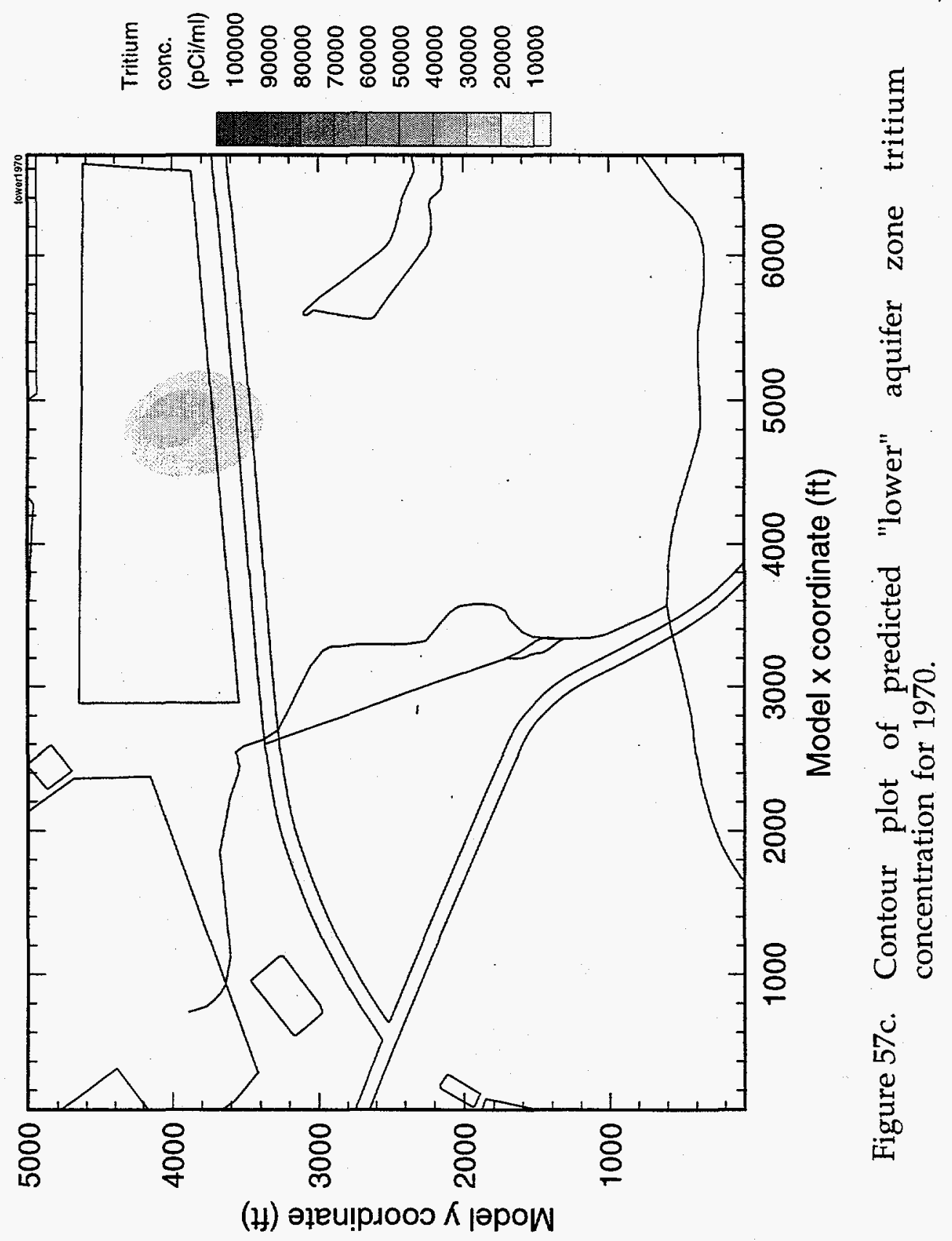




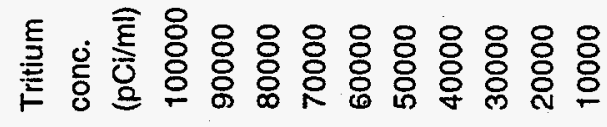

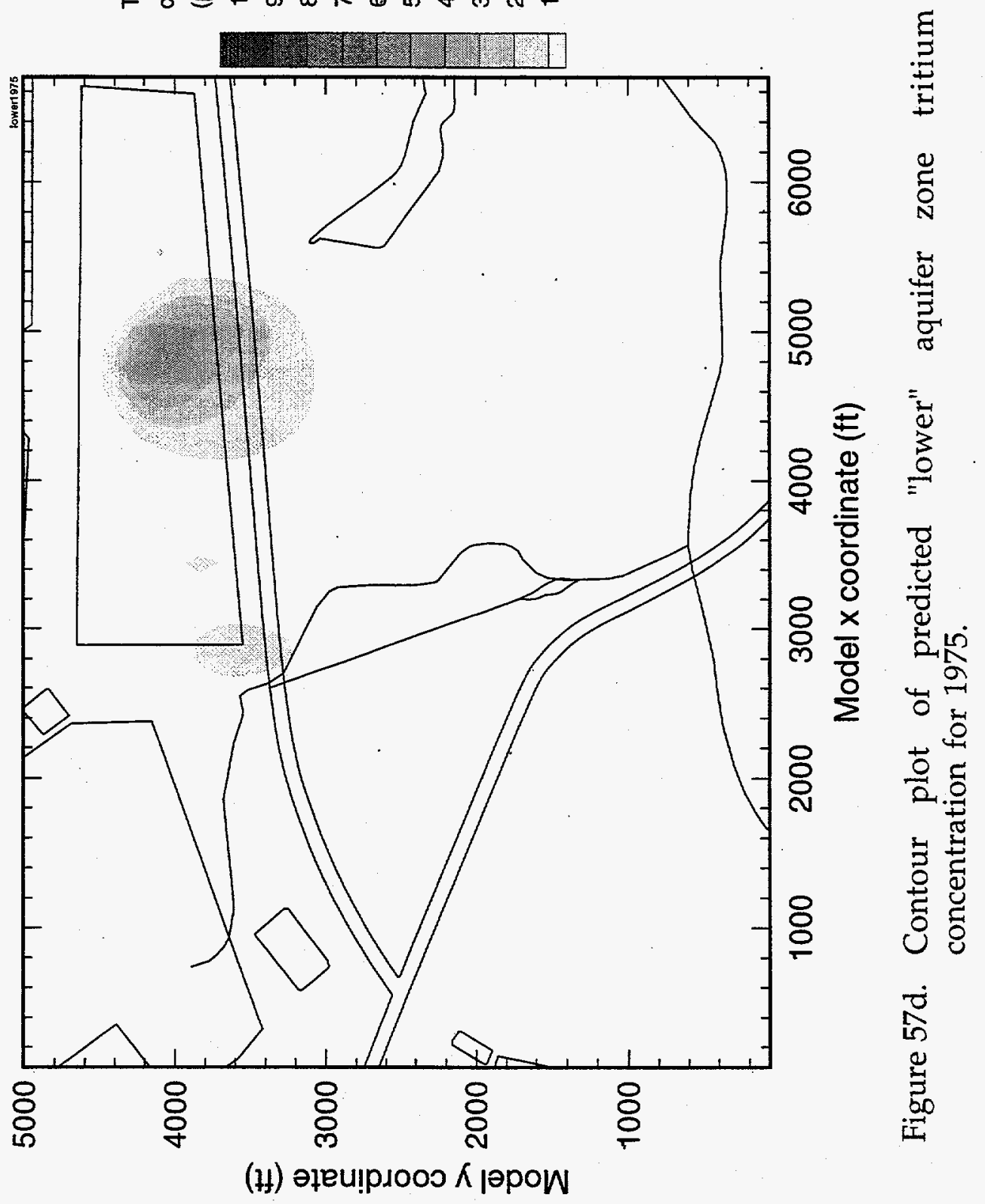




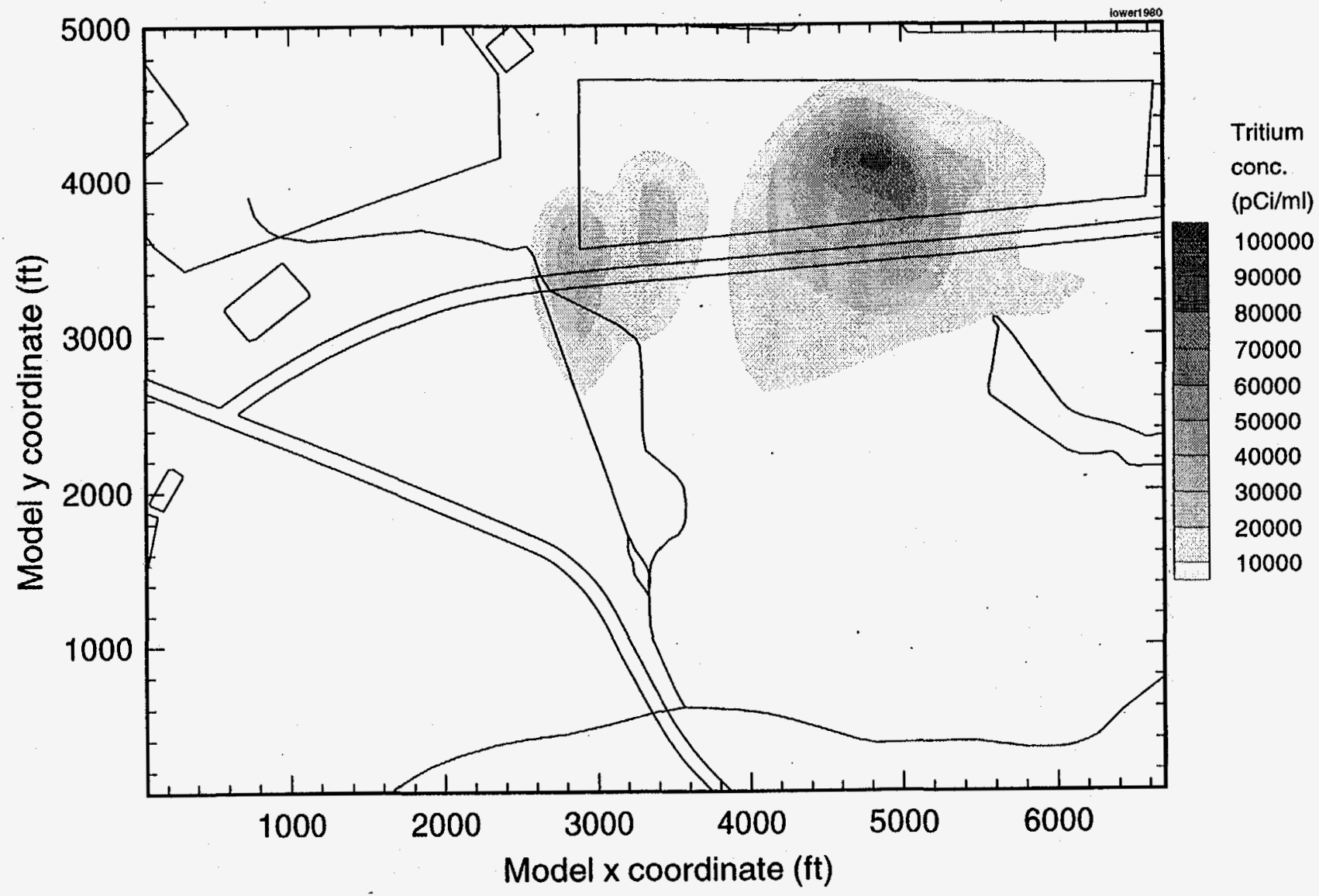

Figure 57e. Contour plot of predicted "lower" aquifer zone tritium concentration for 1980. 


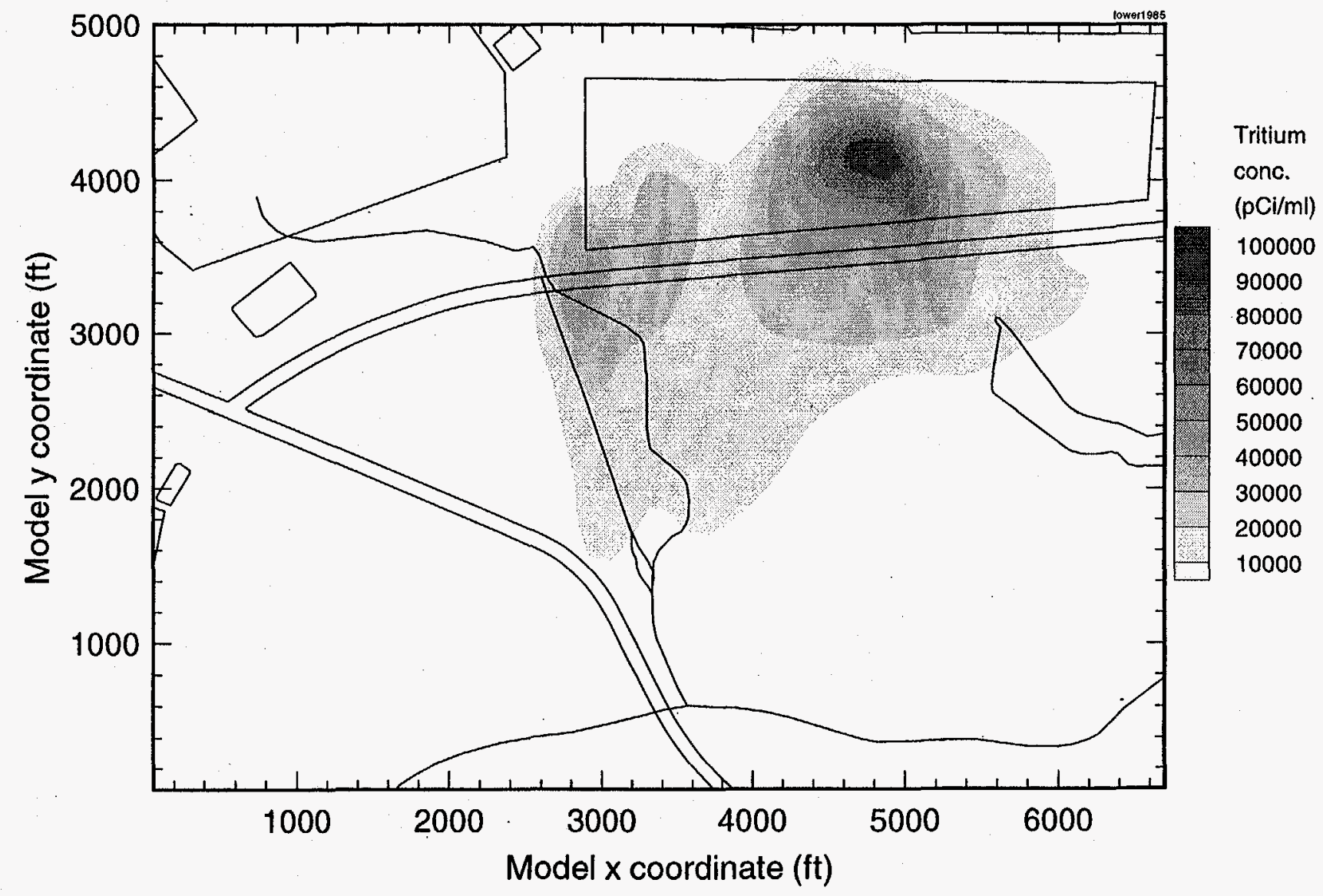

Figure 57f. Contour plot of predicted "lower" aquifer zone tritium concentration for 1985 . 


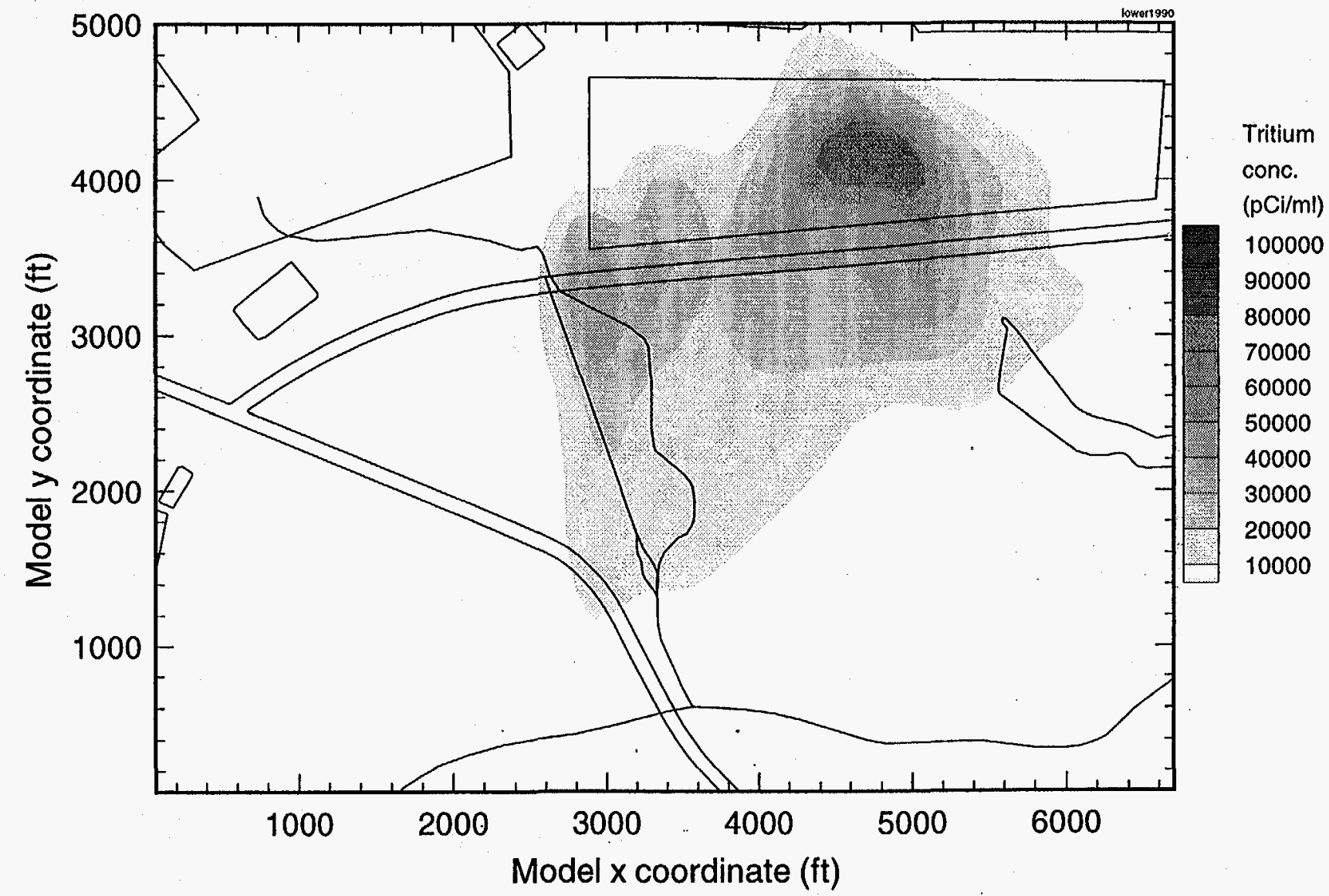

Figure 57g. Contour plot of predicted "lower" aquifer zone tritium concentration for 1990 . 


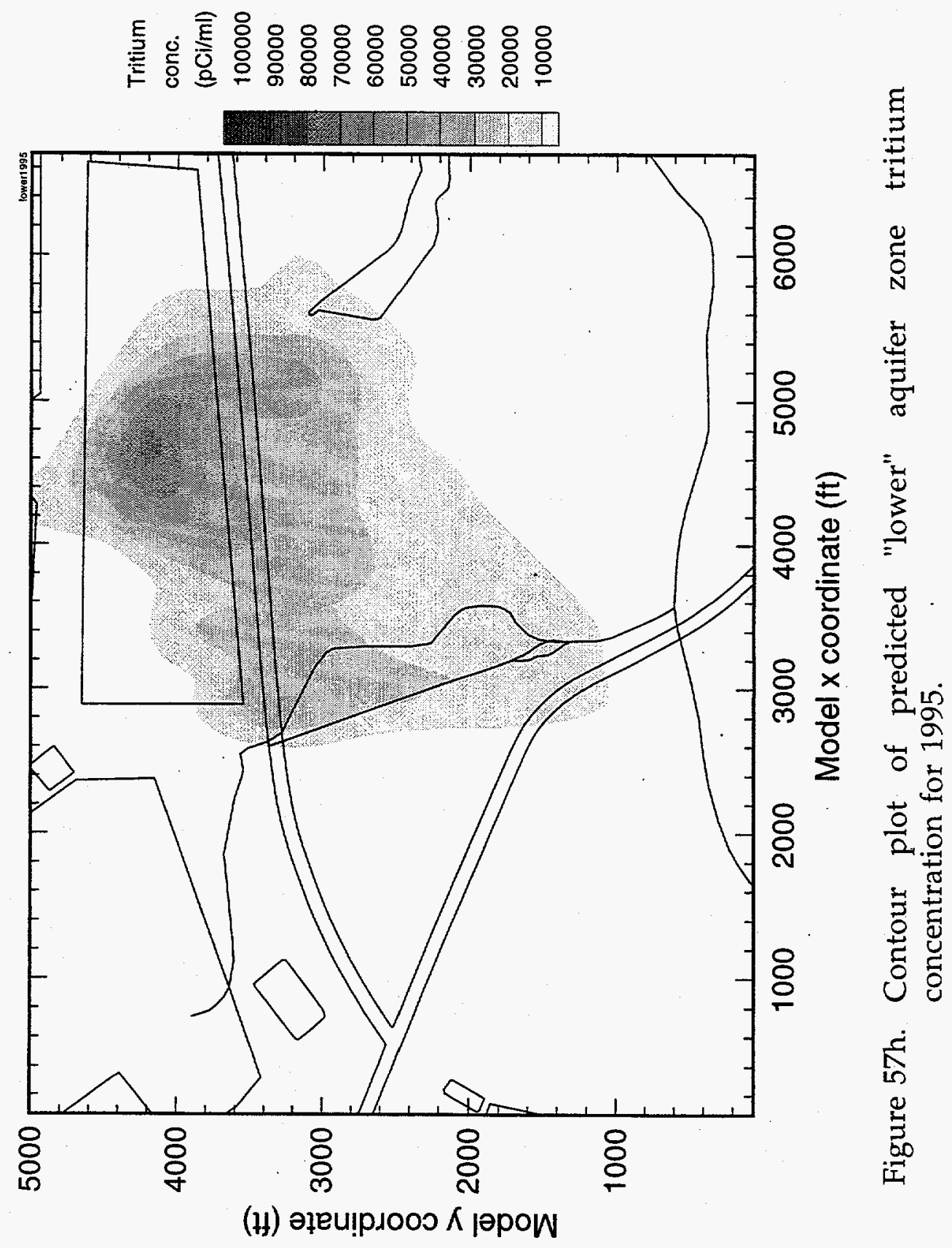




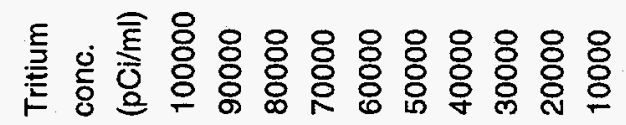

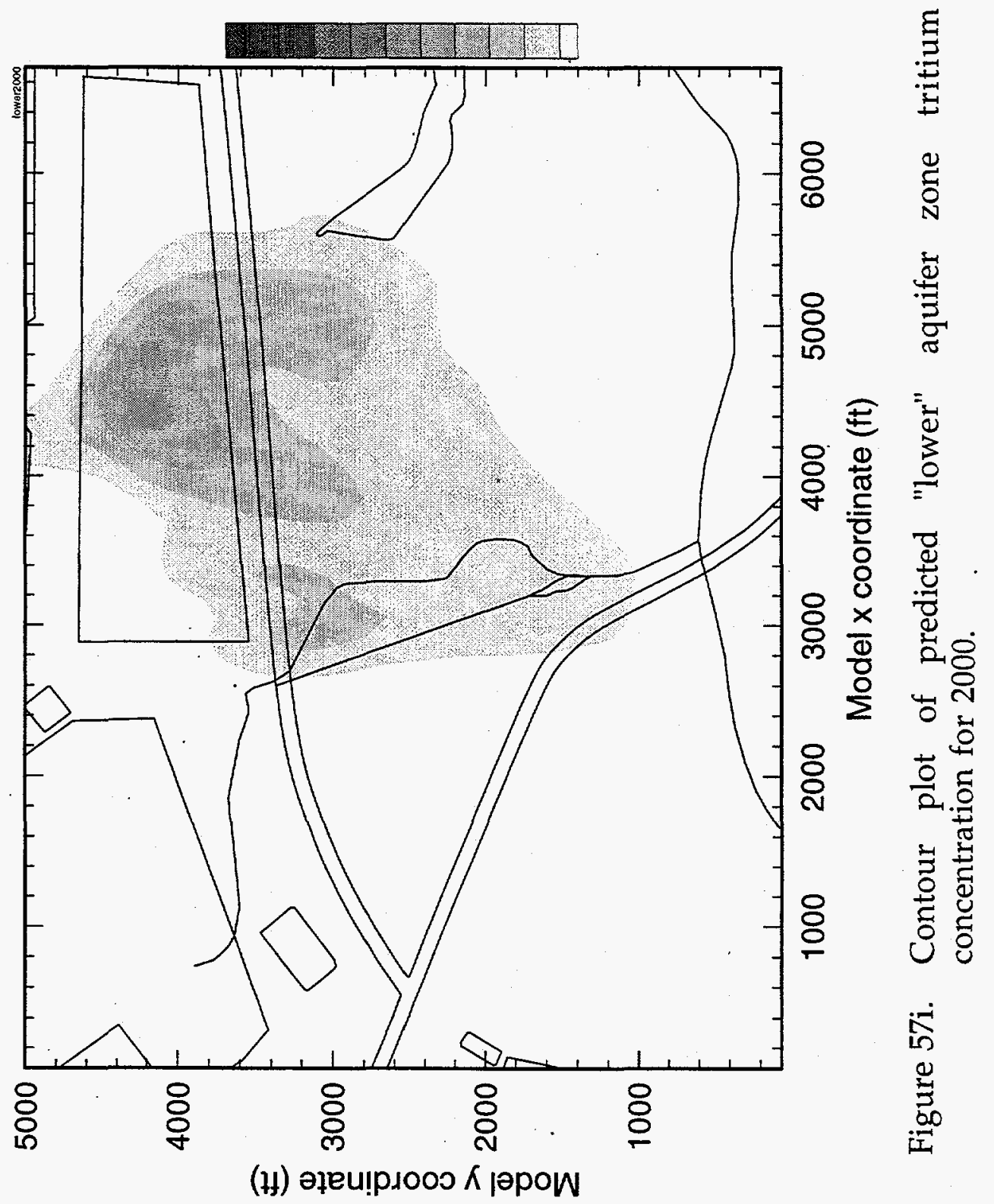




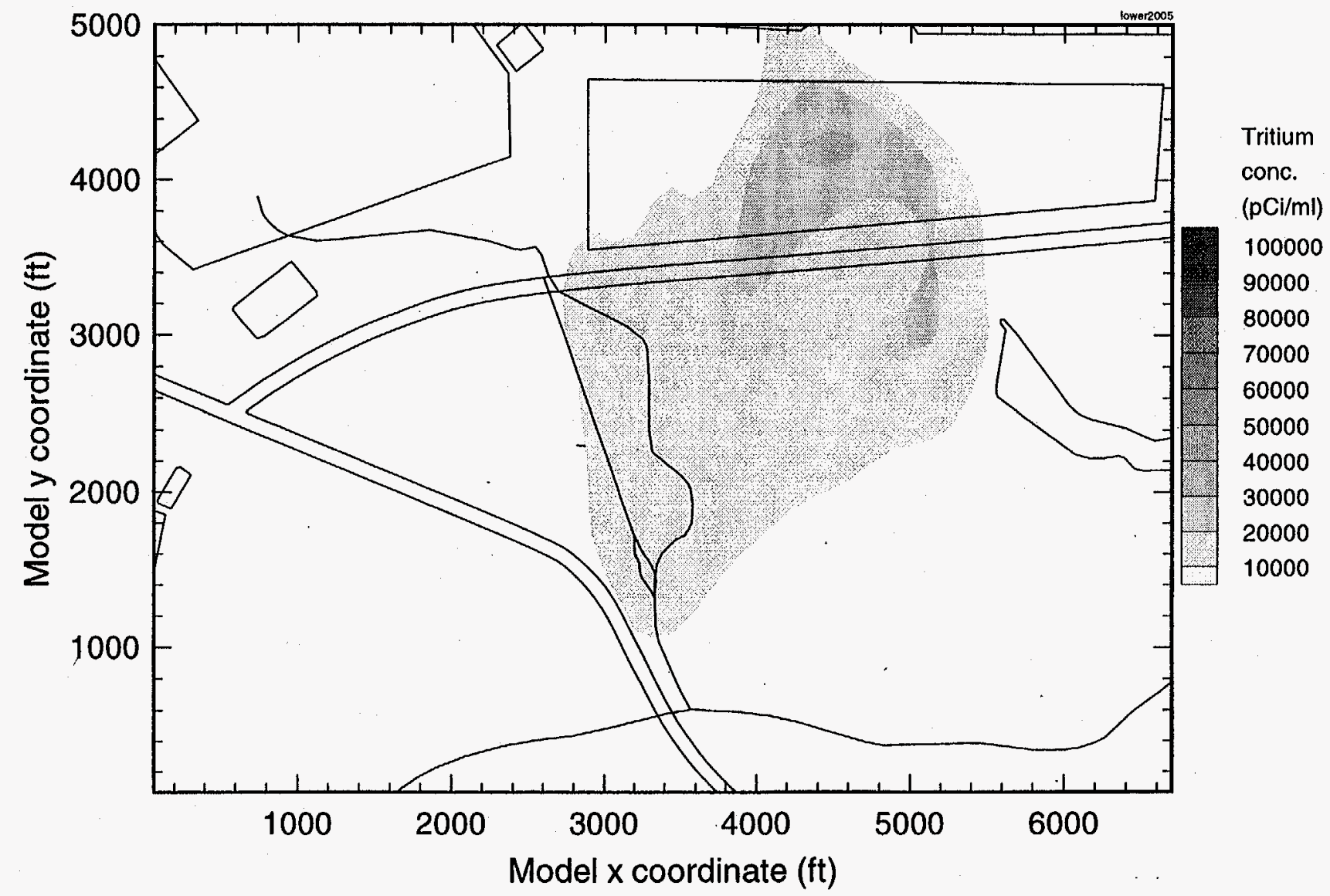

Figure 57j. Contour plot of predicted "lower" aquifer zone tritium concentration for 2005 . 


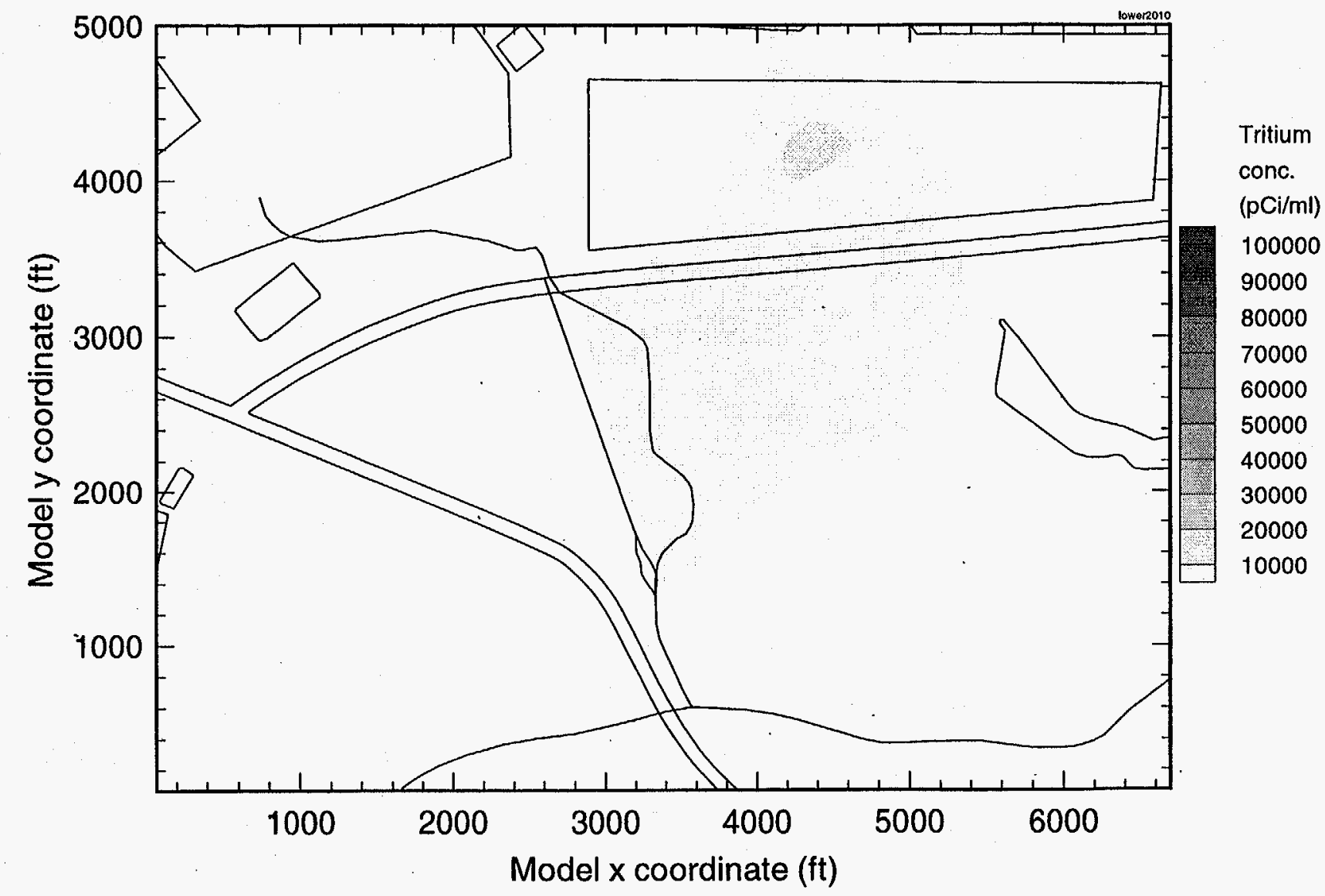

Figure 57k. Contour plot of predicted "lower" aquifer zone tritium concentration for 2010. 


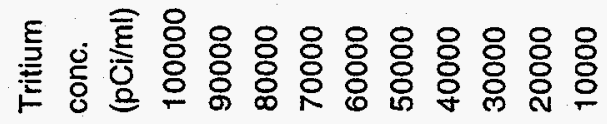

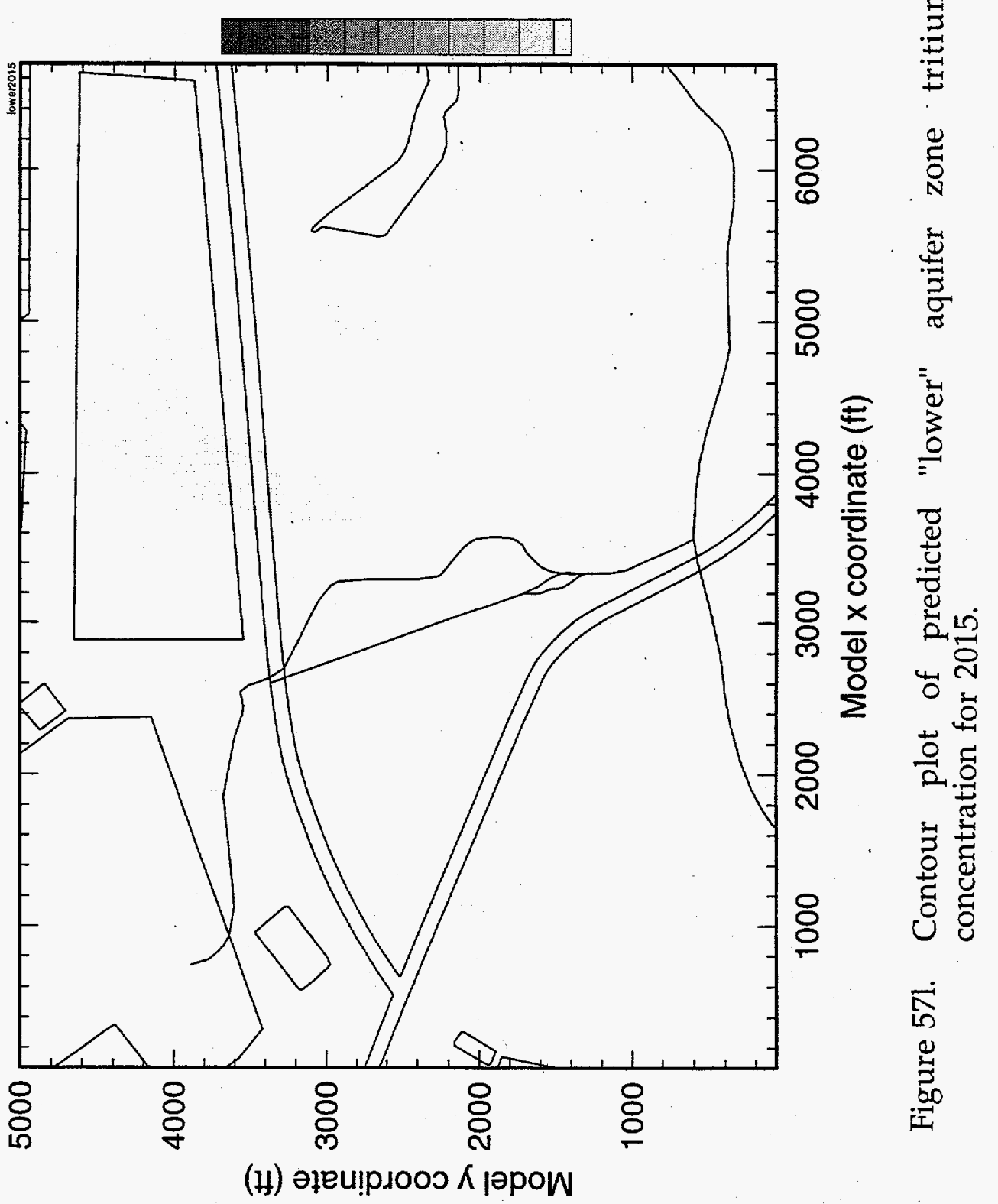




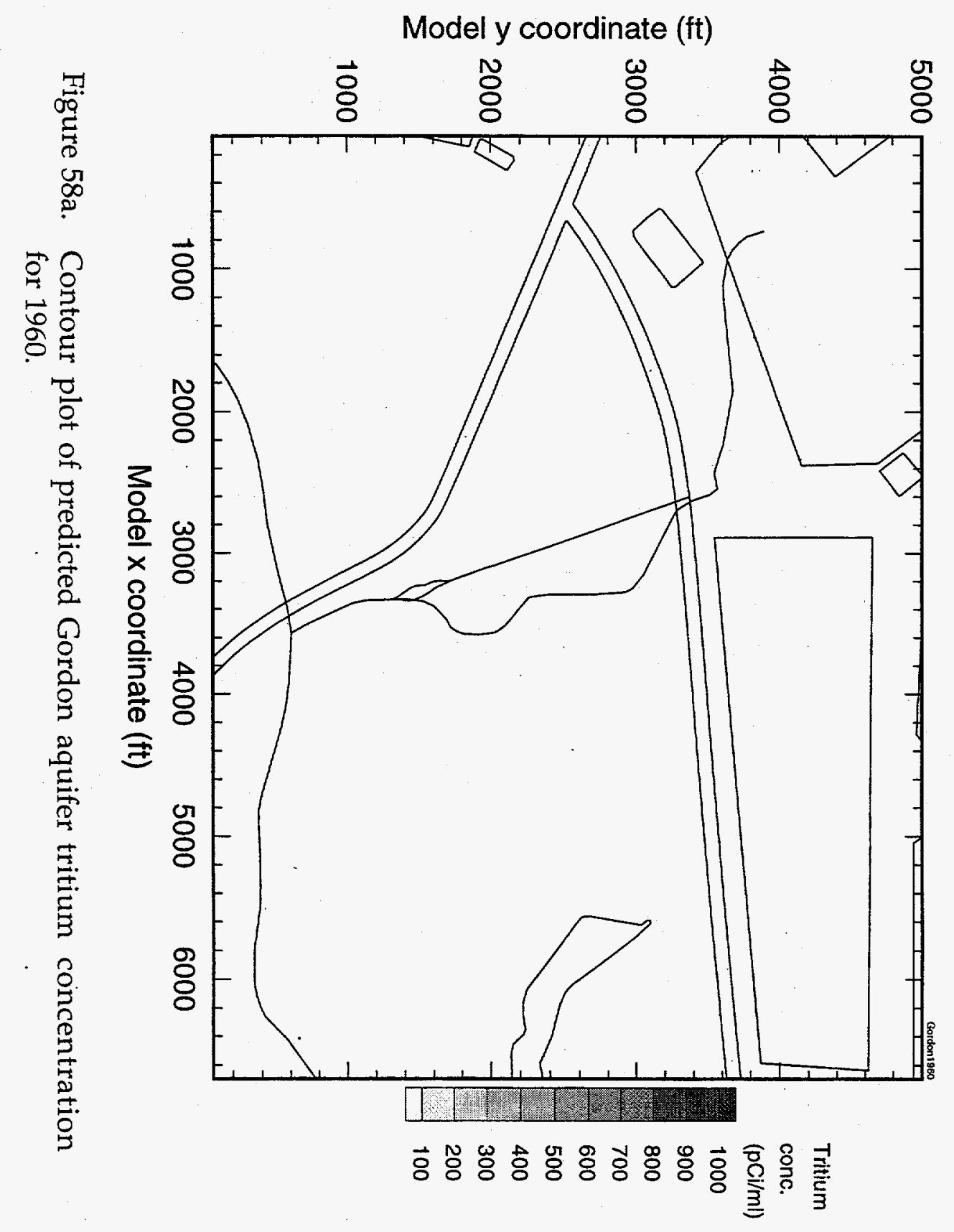




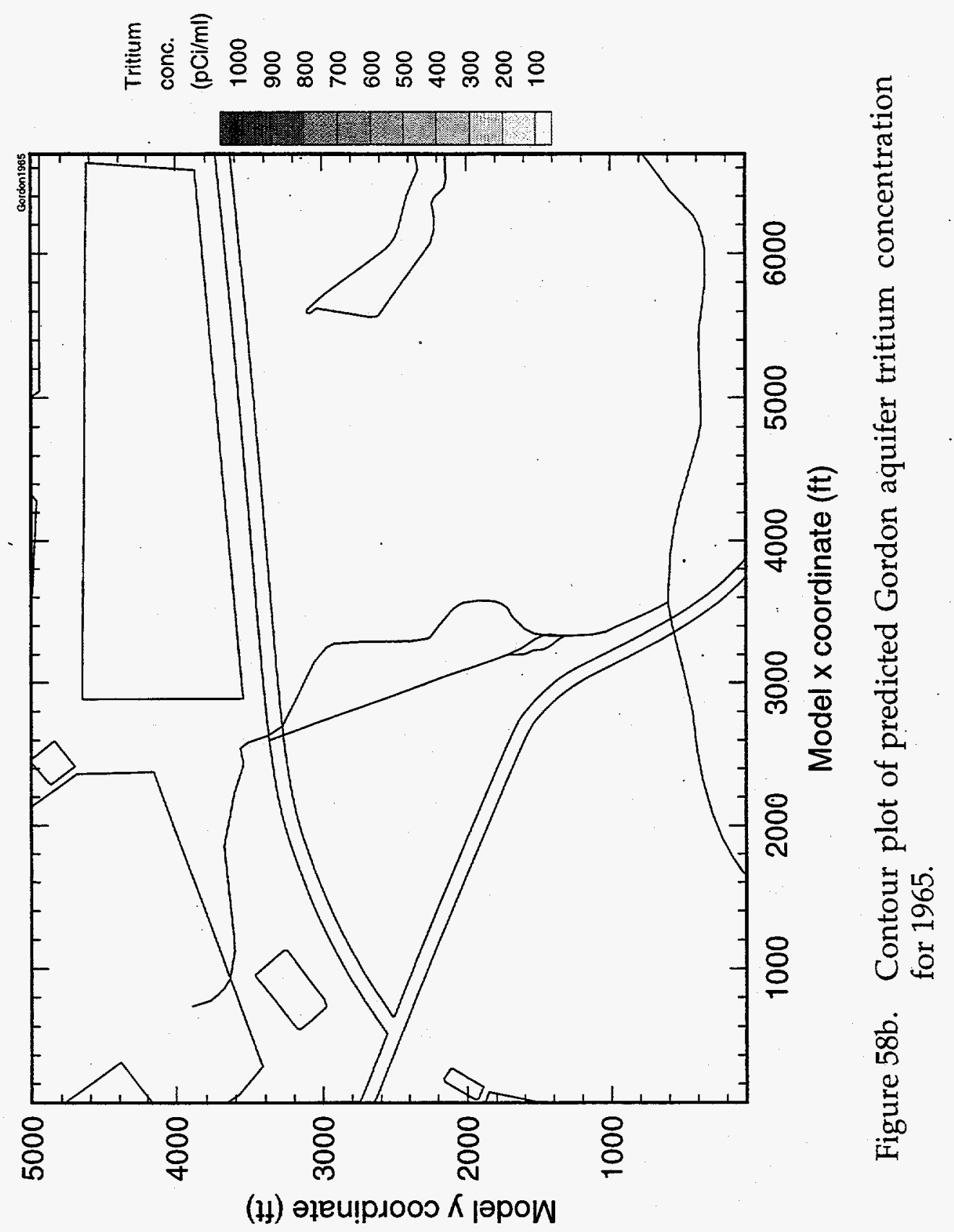




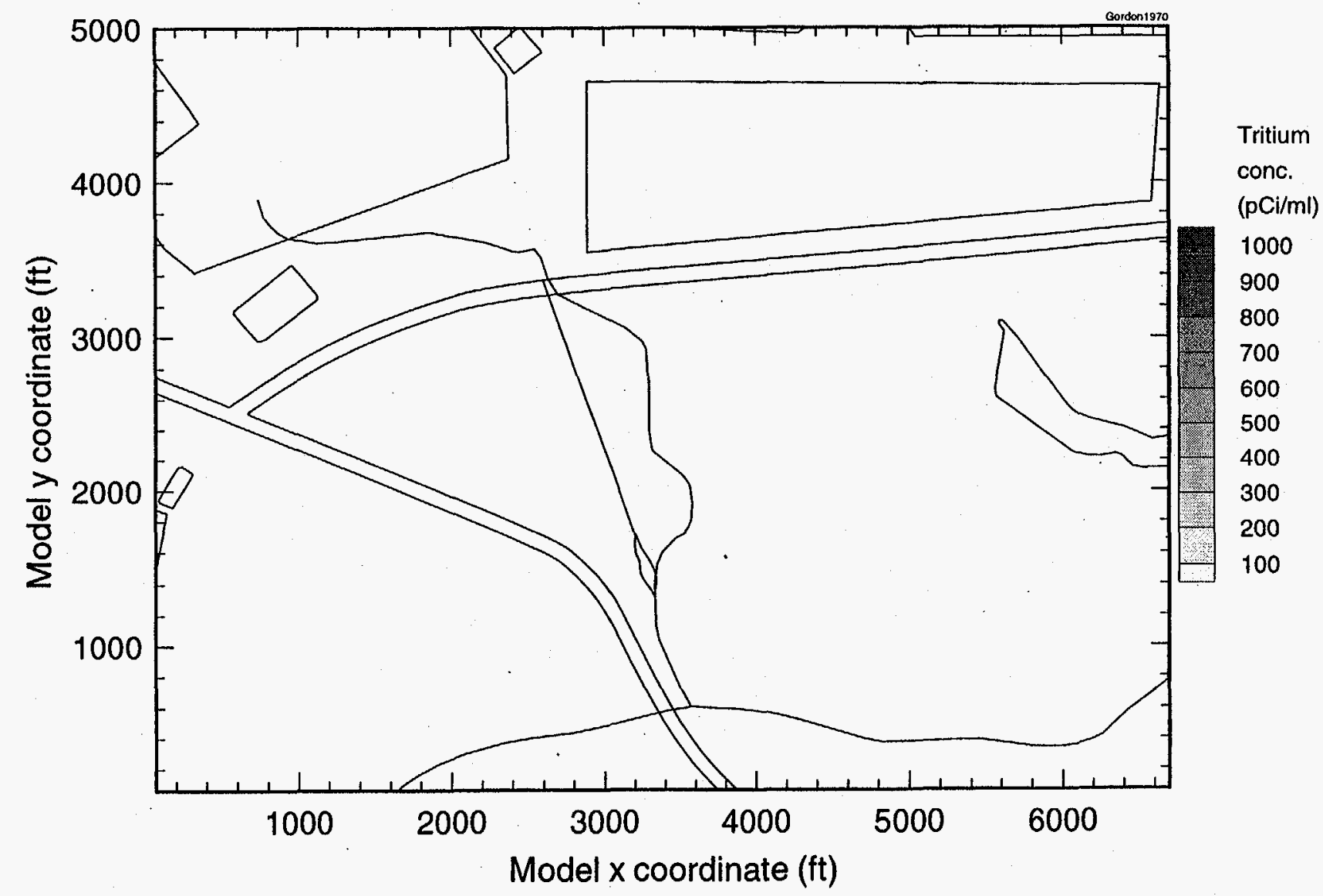

Figure 58c. Contour plot of predicted Gordon aquifer tritium concentration for 1970. 


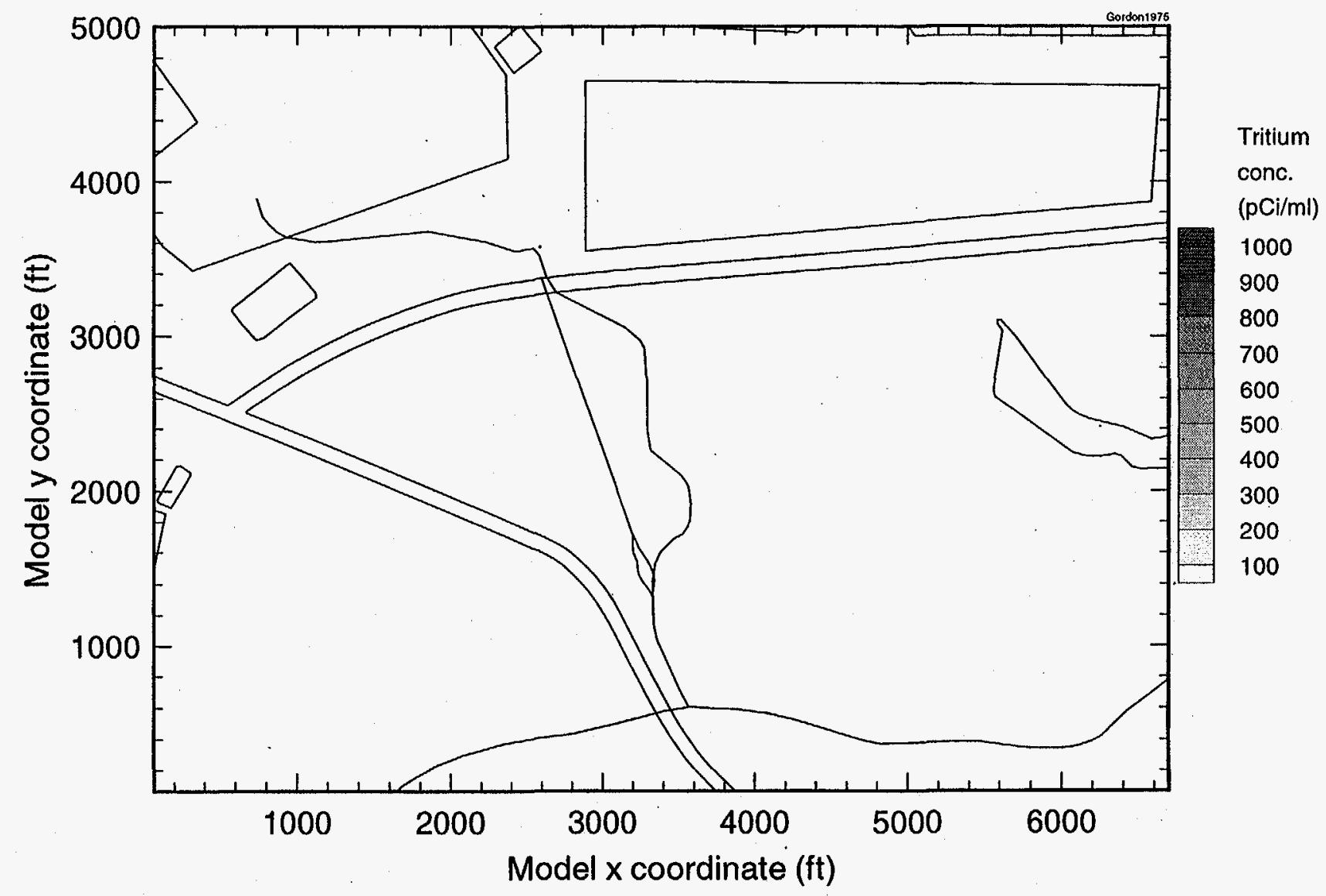

Figure 58d. Contour plot of predicted Gordon aquifer tritium concentration for 1975. 


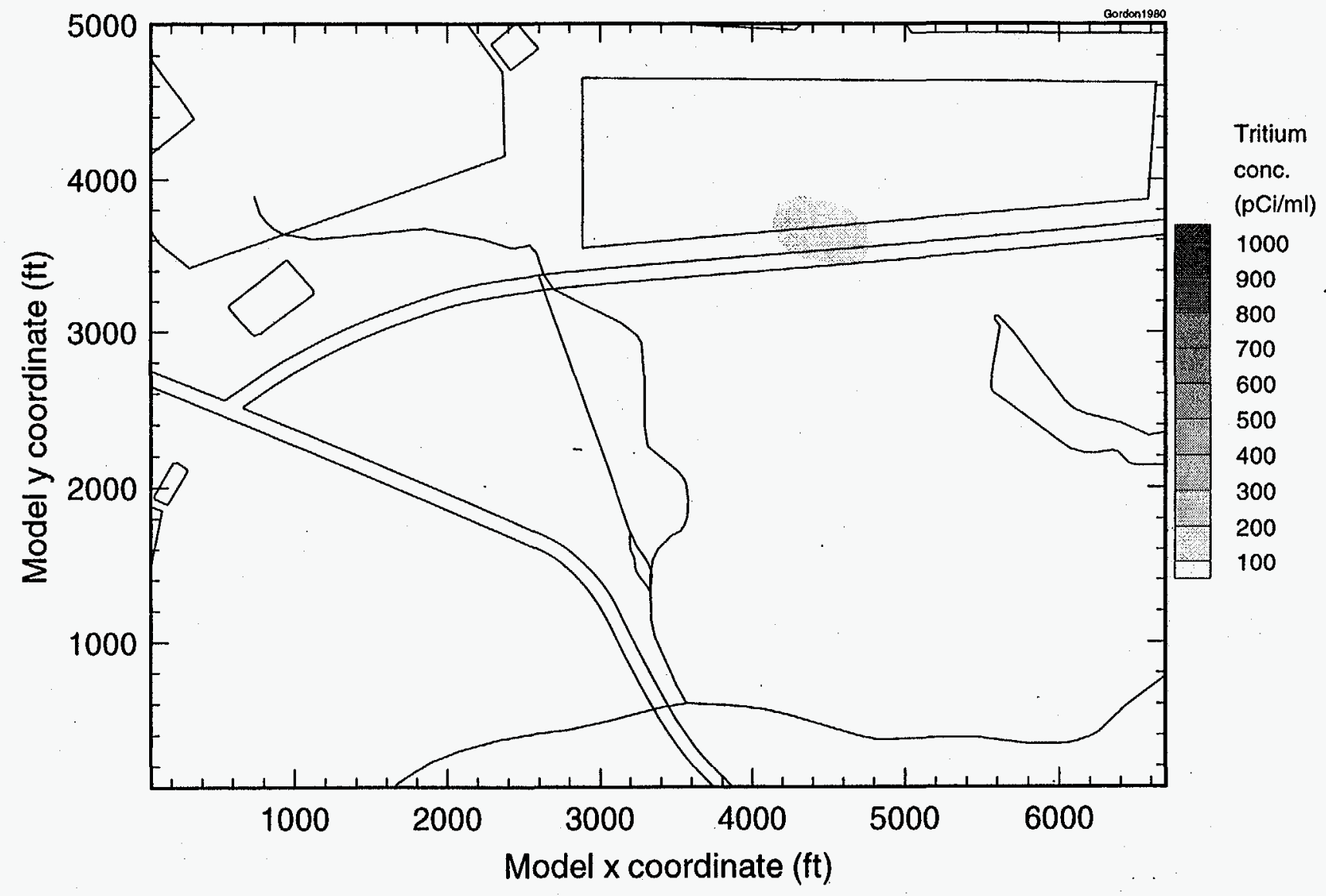

Figure 58e. Contour plot of predicted Gordon aquifer tritium concentration for 1980. 


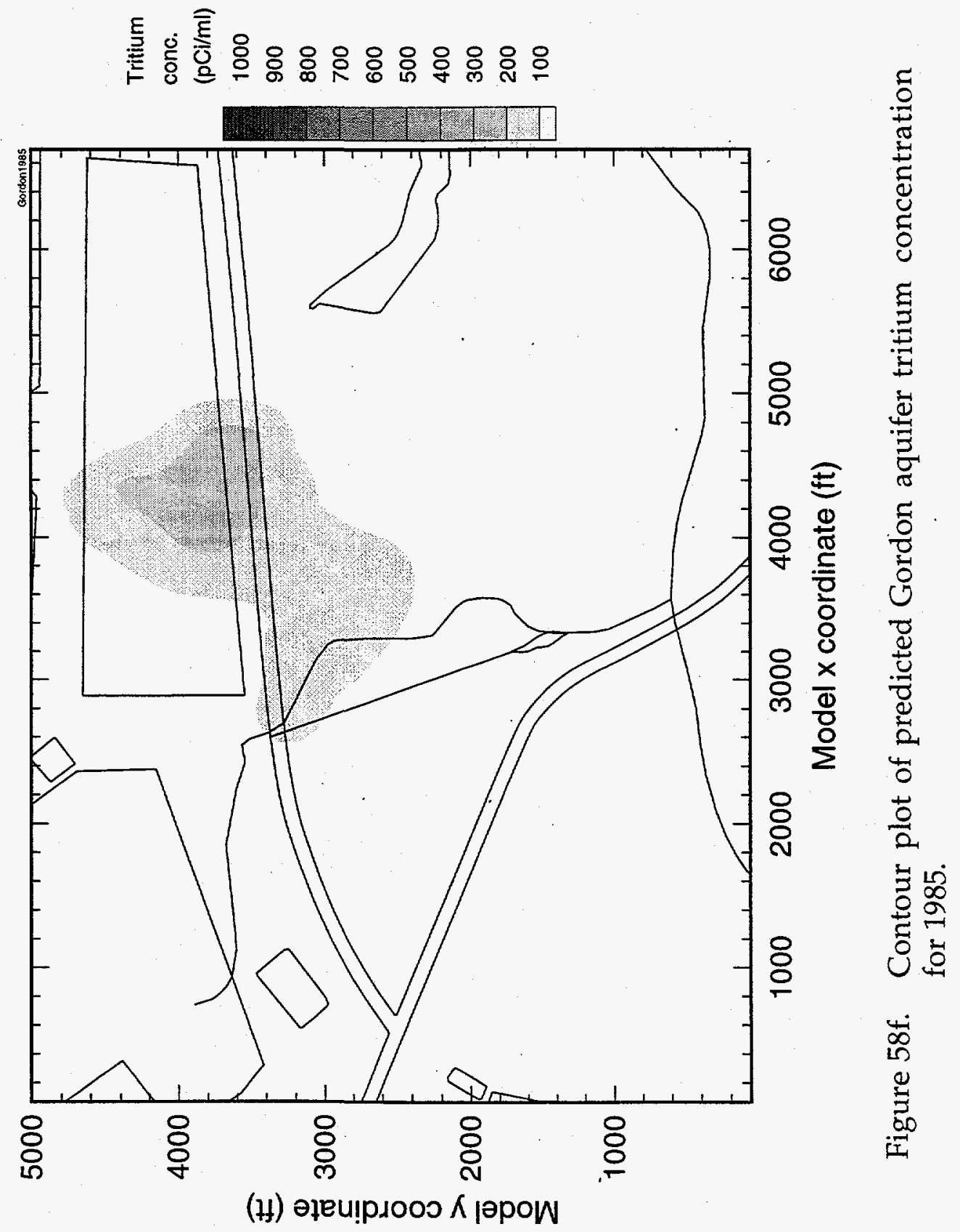




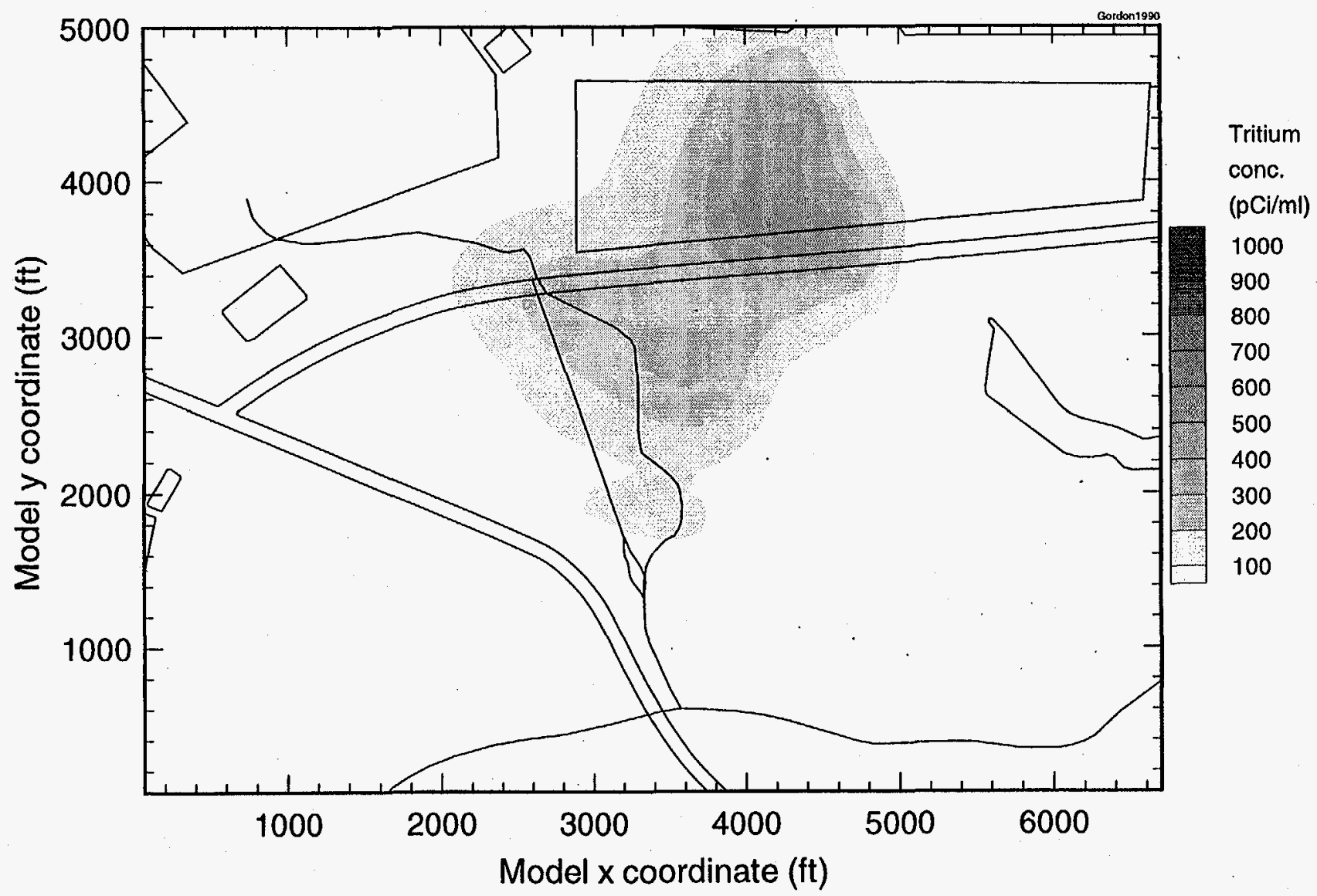

Figure 58g. Contour plot of predicted Gordon aquifer tritium concentration for 1990. 


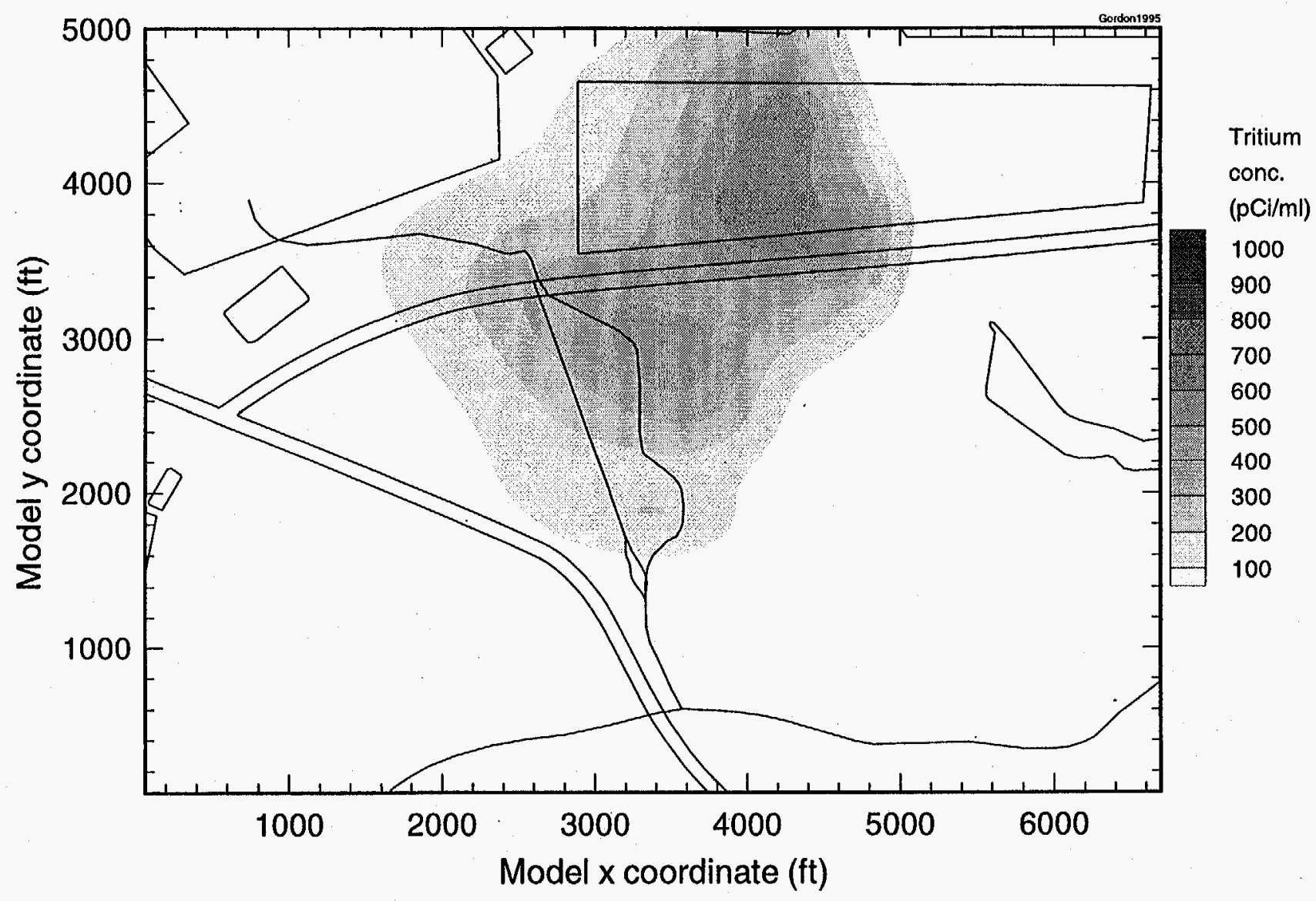

Figure 58h. Contour plot of predicted Gordon aquifer tritium concentration for 1995. 


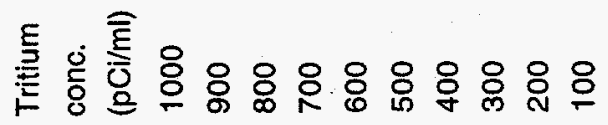

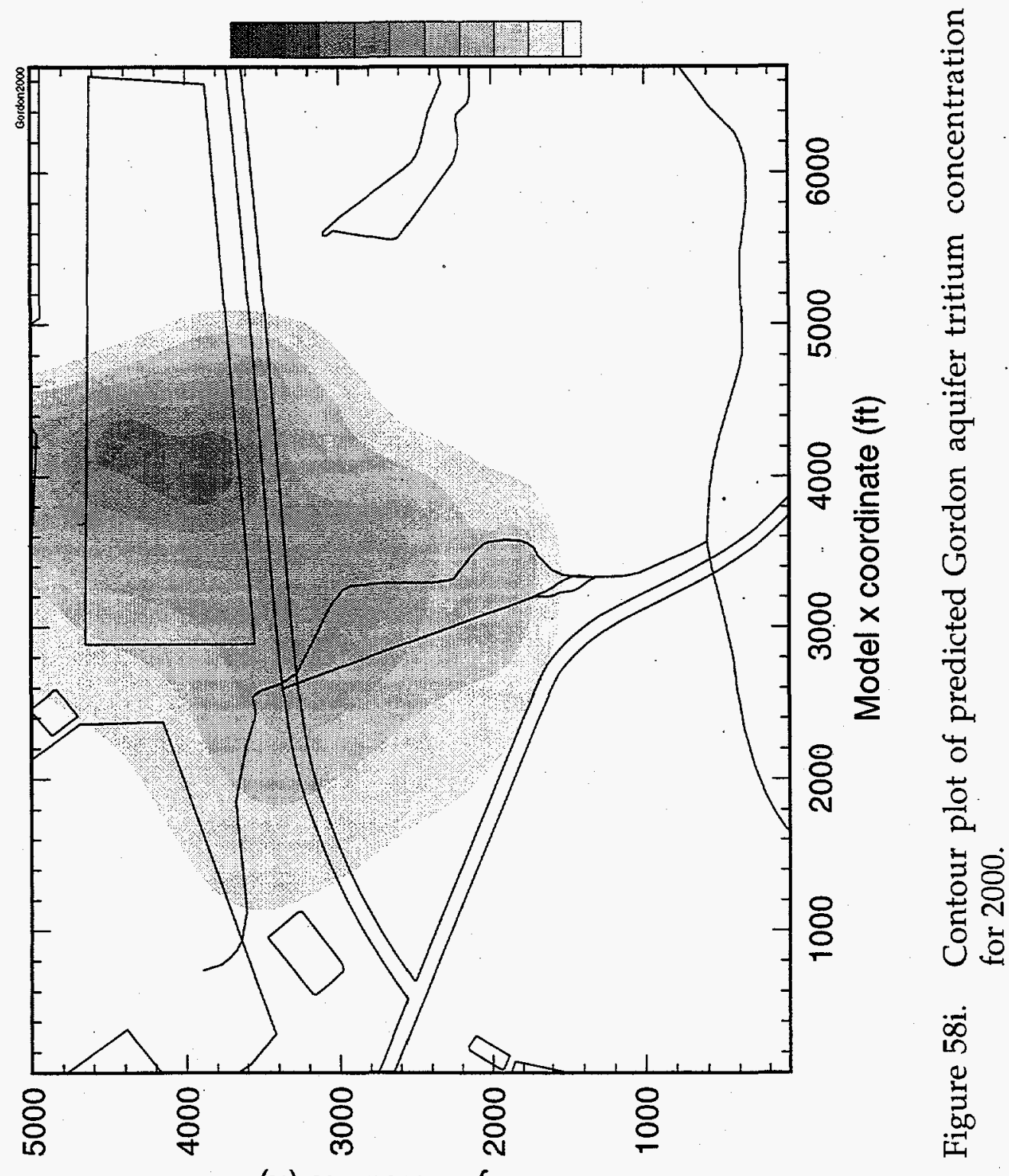

(H) әјеu!p 


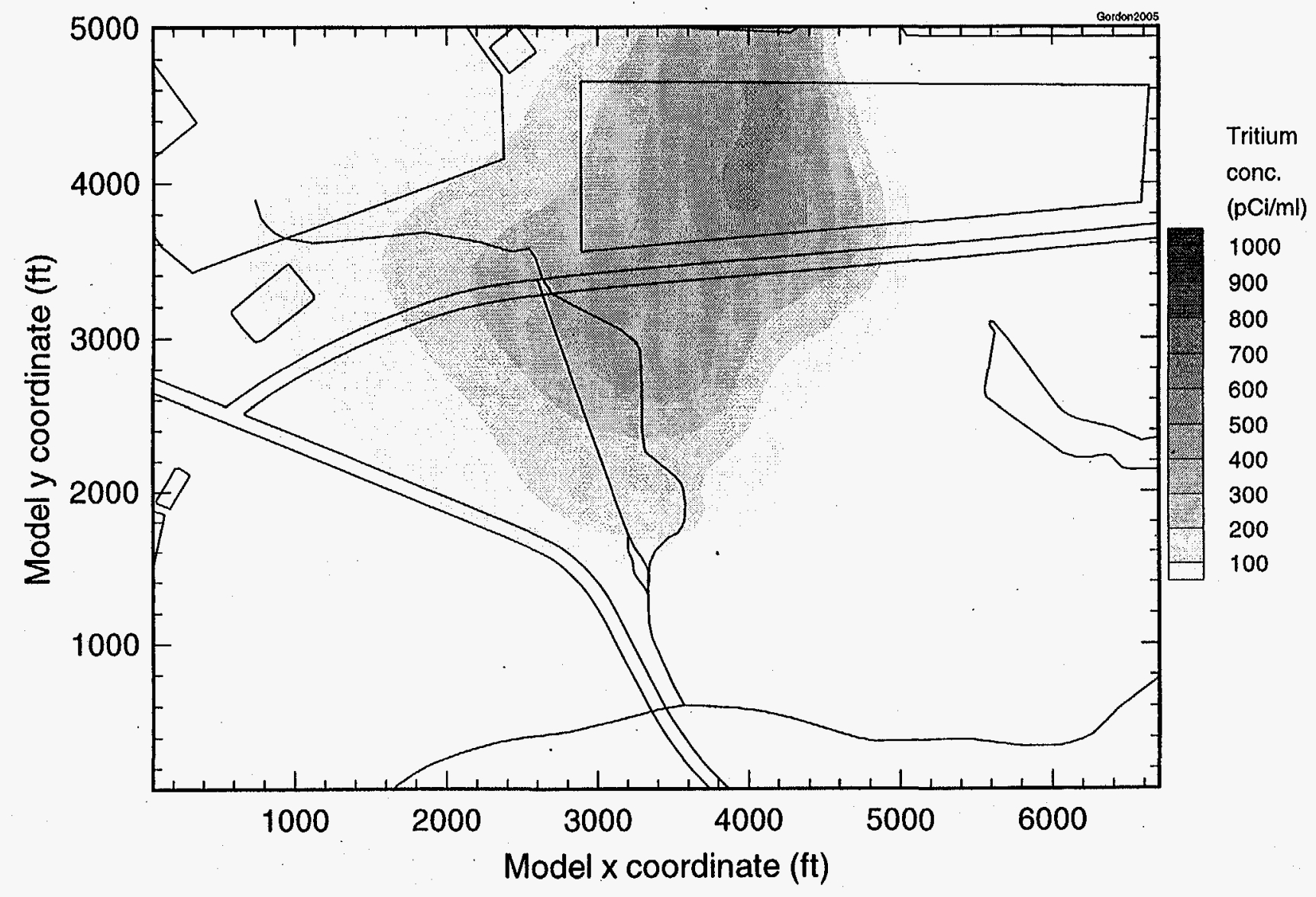

Figure 58j. Contour plot of predicted Gordon aquifer tritium concentration for 2005. 


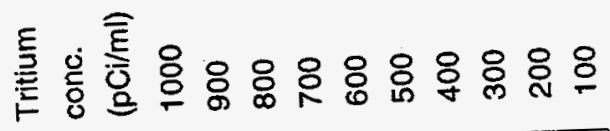

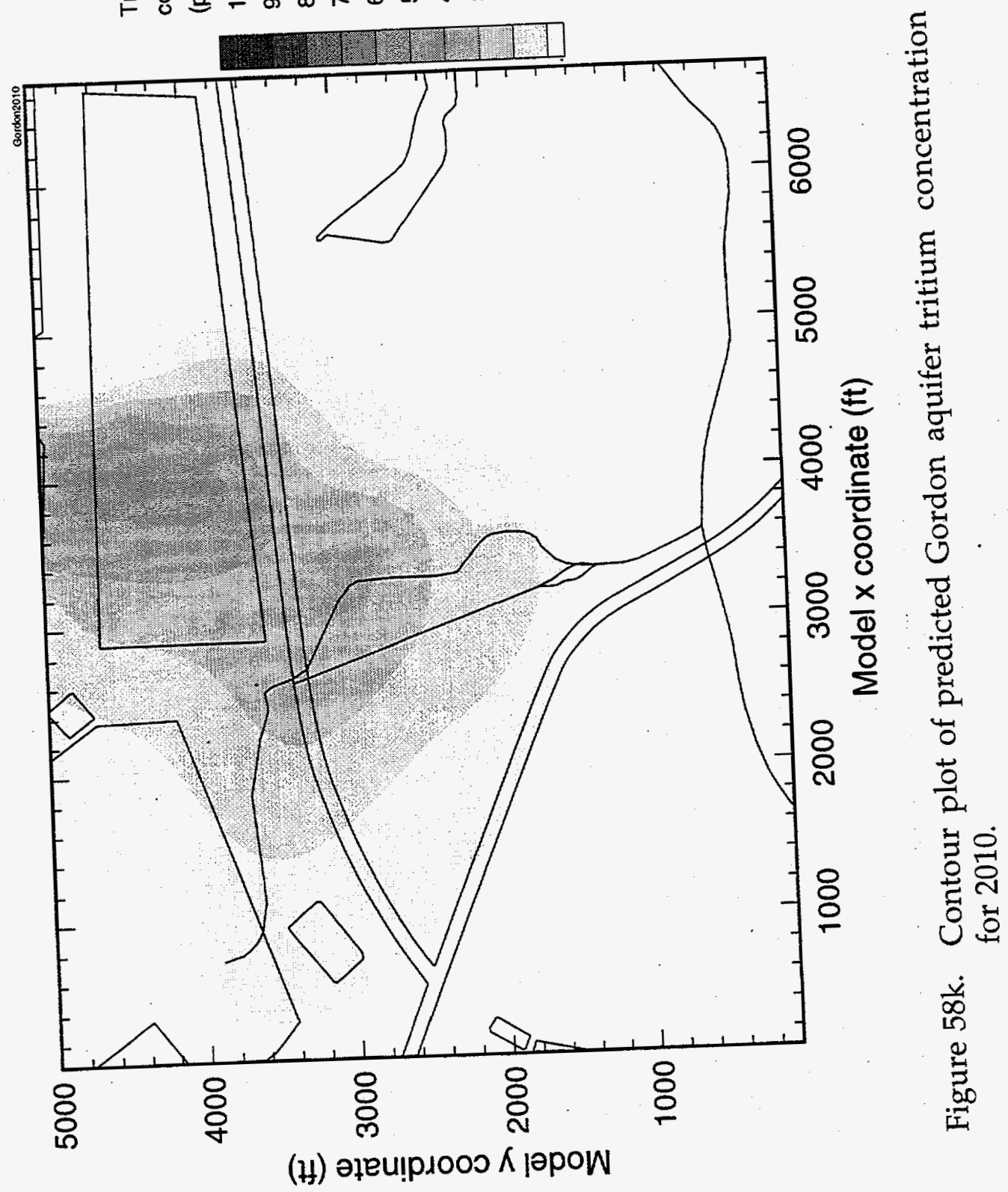




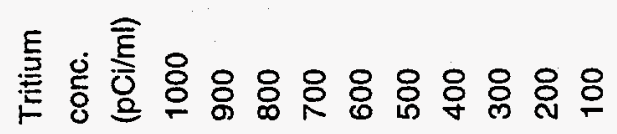

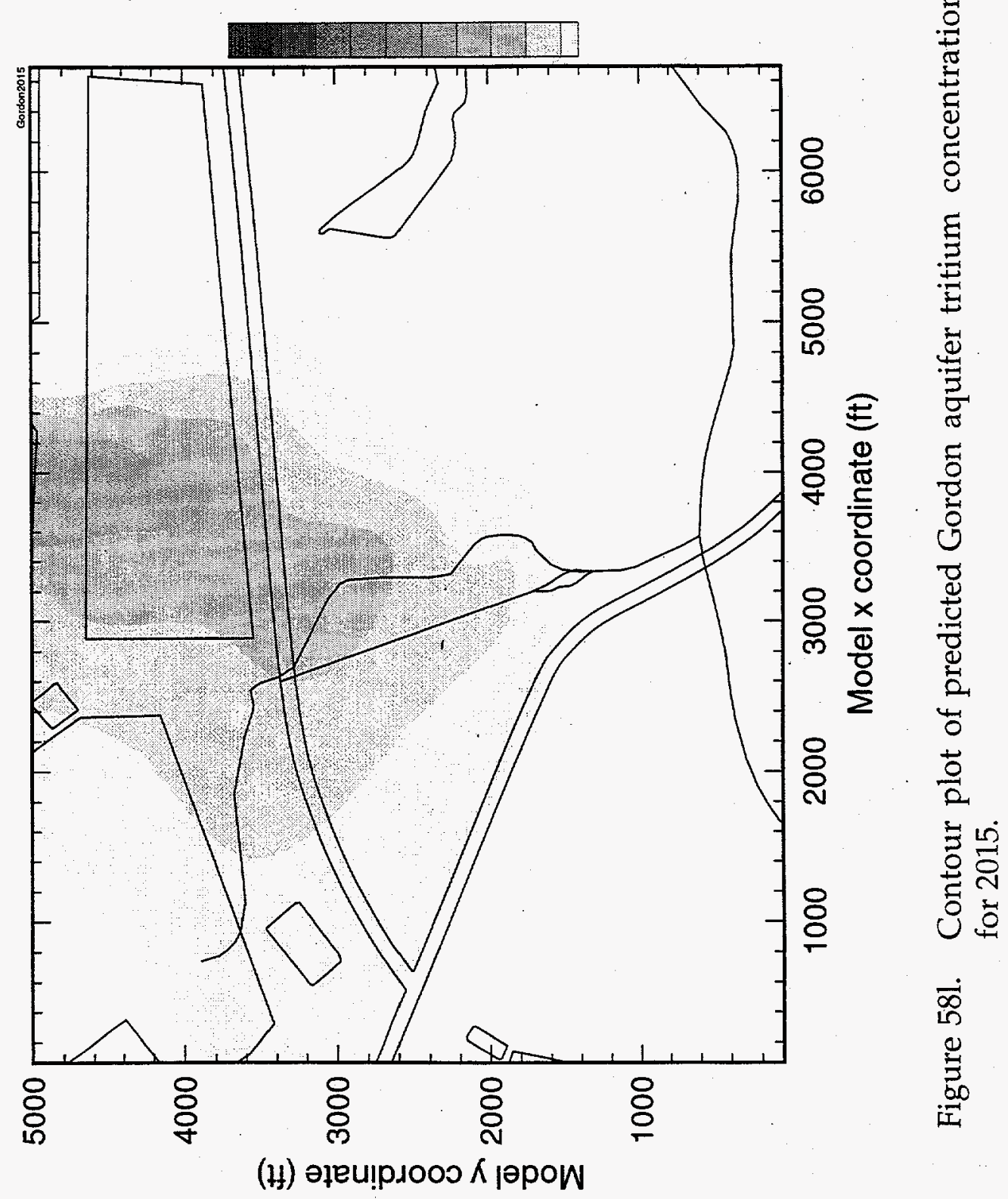




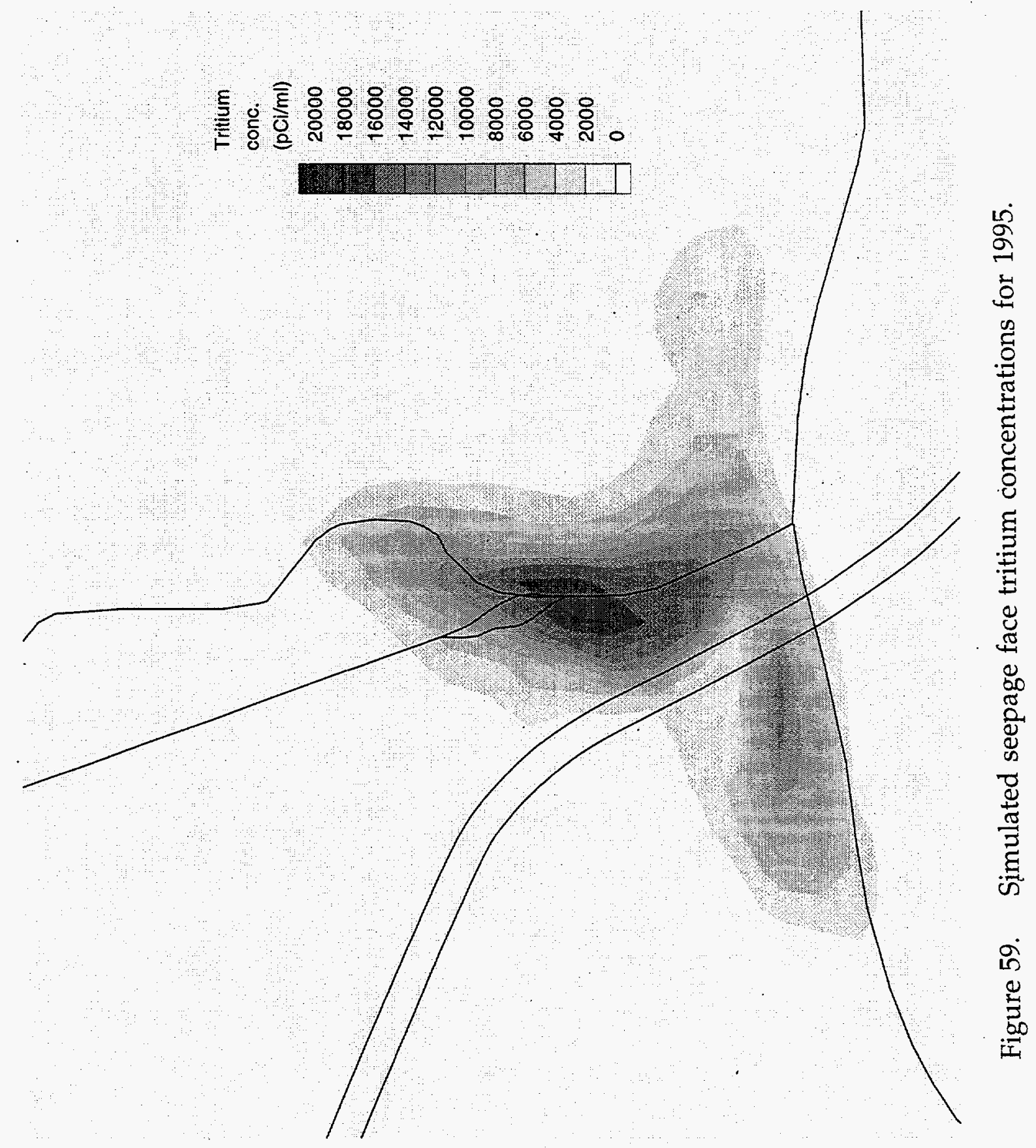




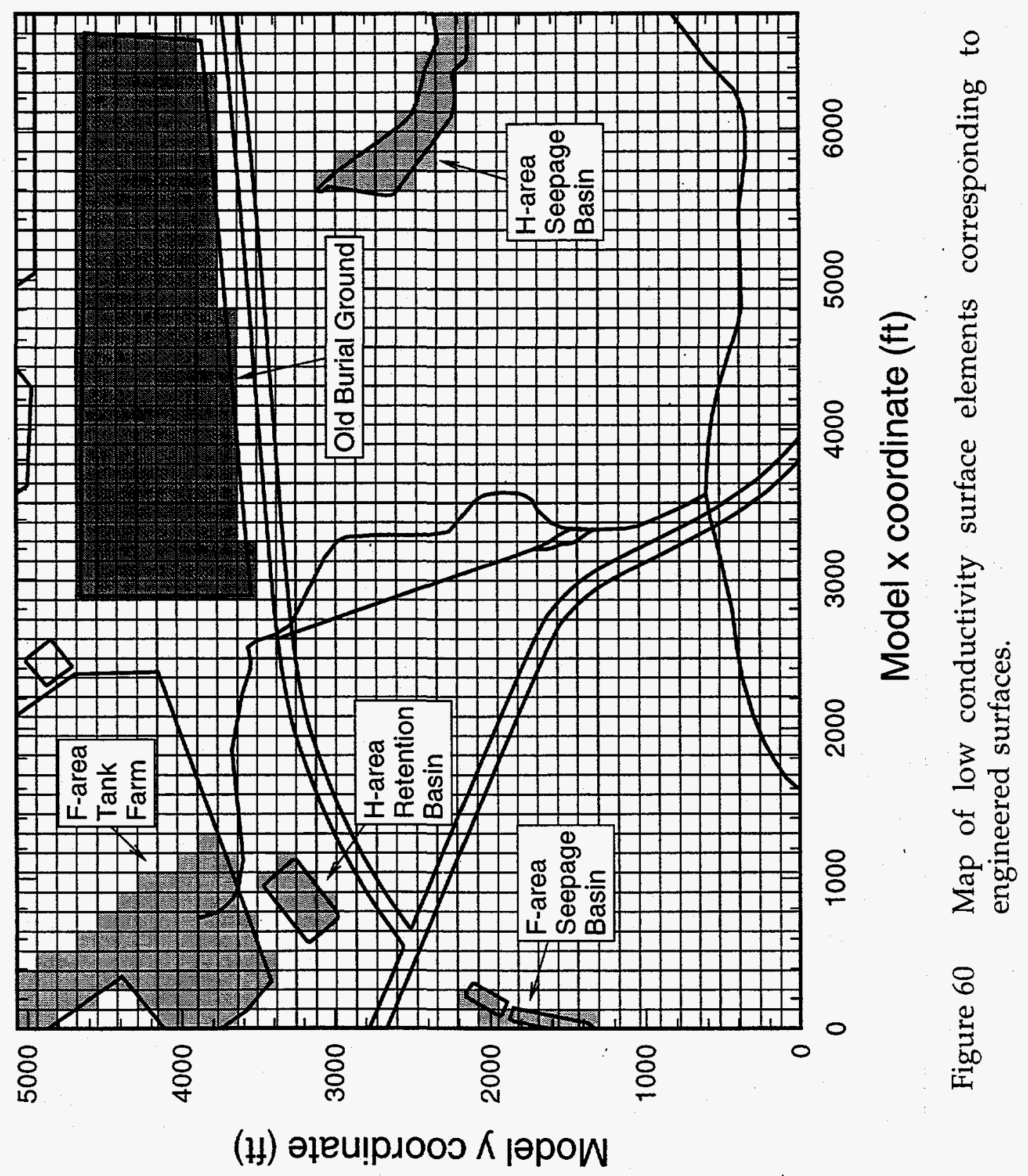




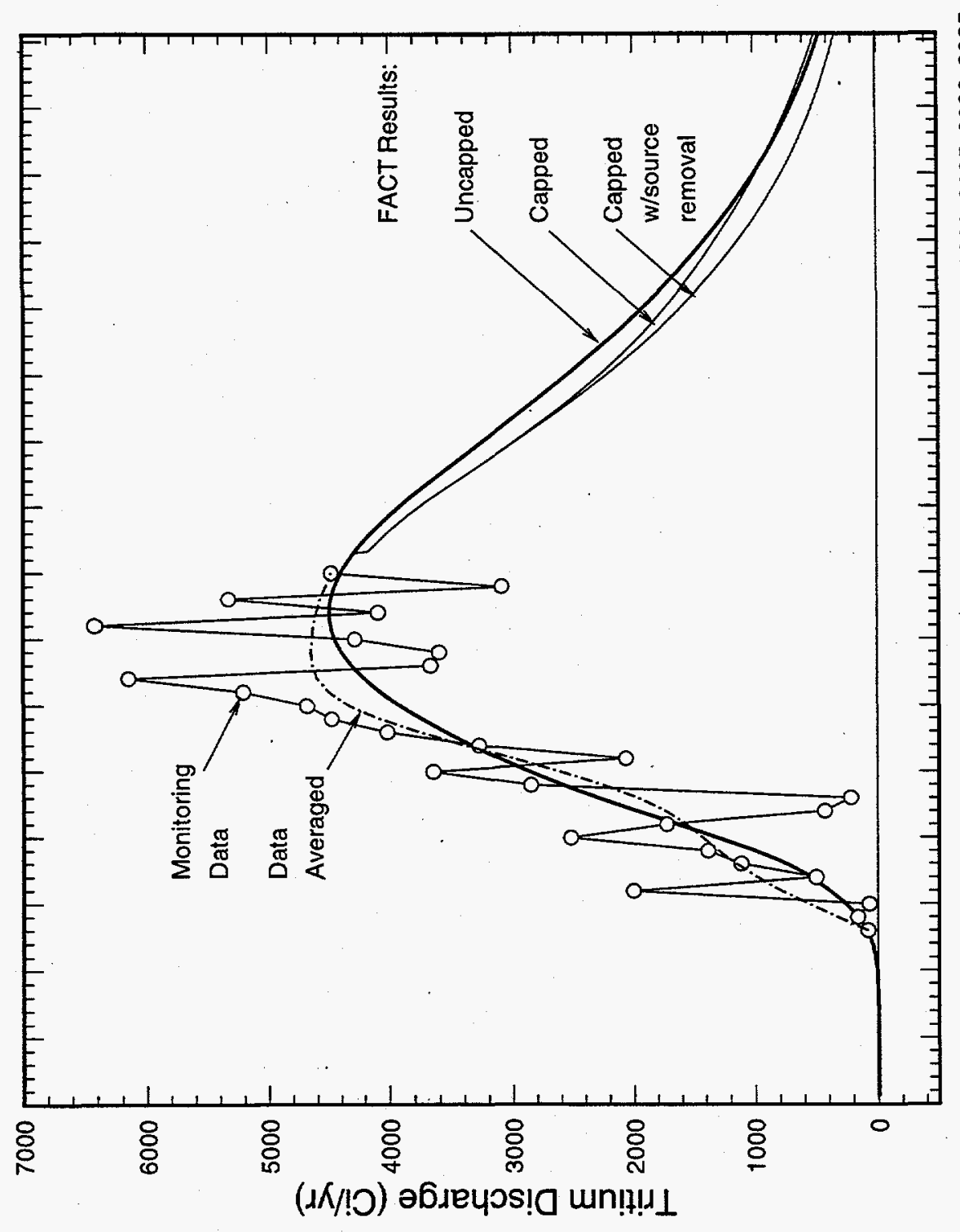

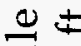

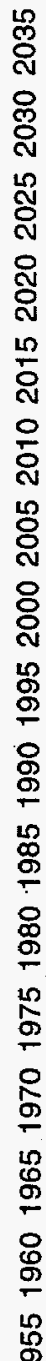

है

3

I

우

82

$\infty$

के

?

号

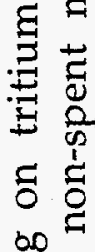

है

है।

ㄷำ

பீ

tै 11

드.

㱐

छ 气

ज范

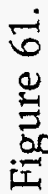




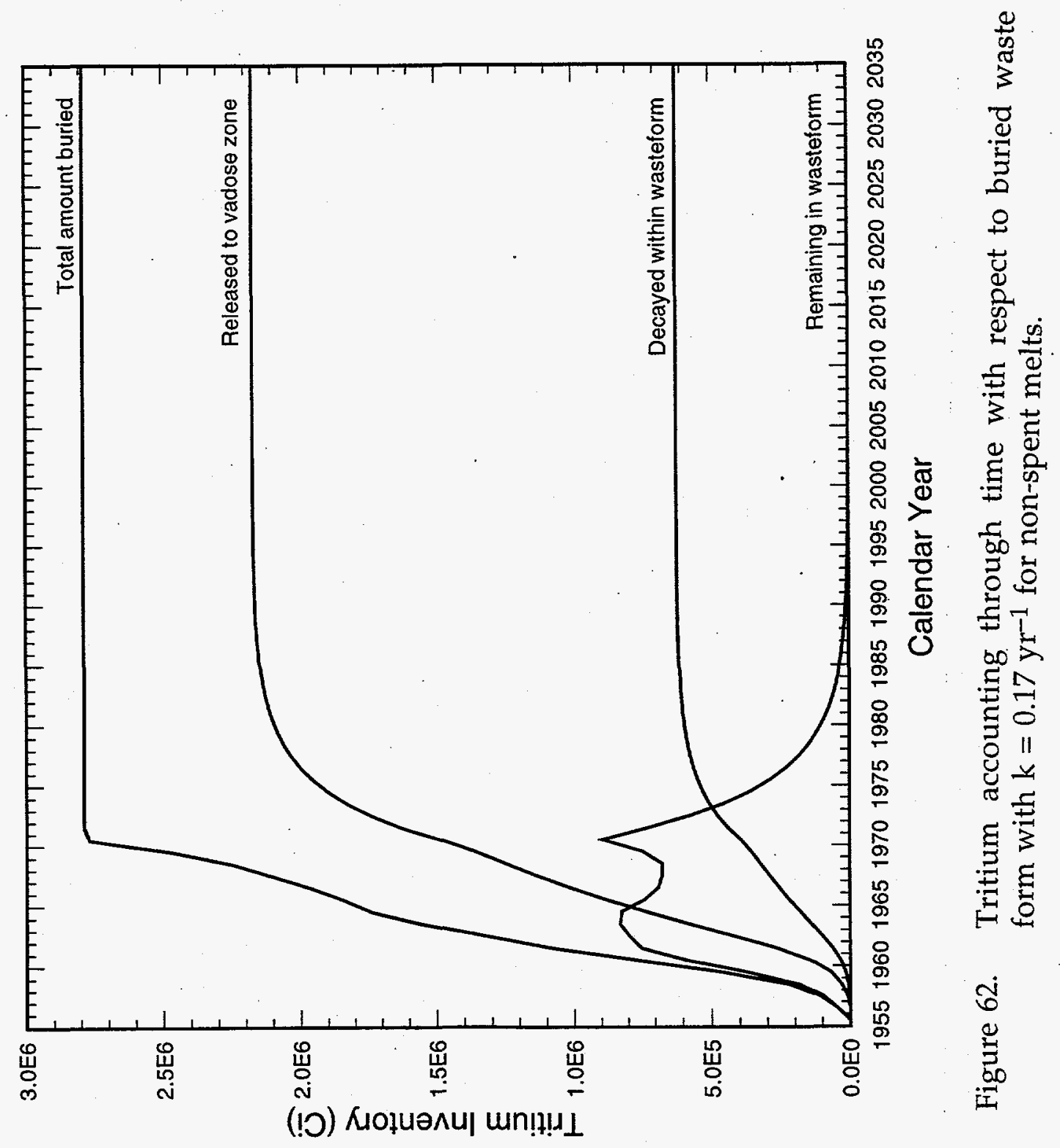




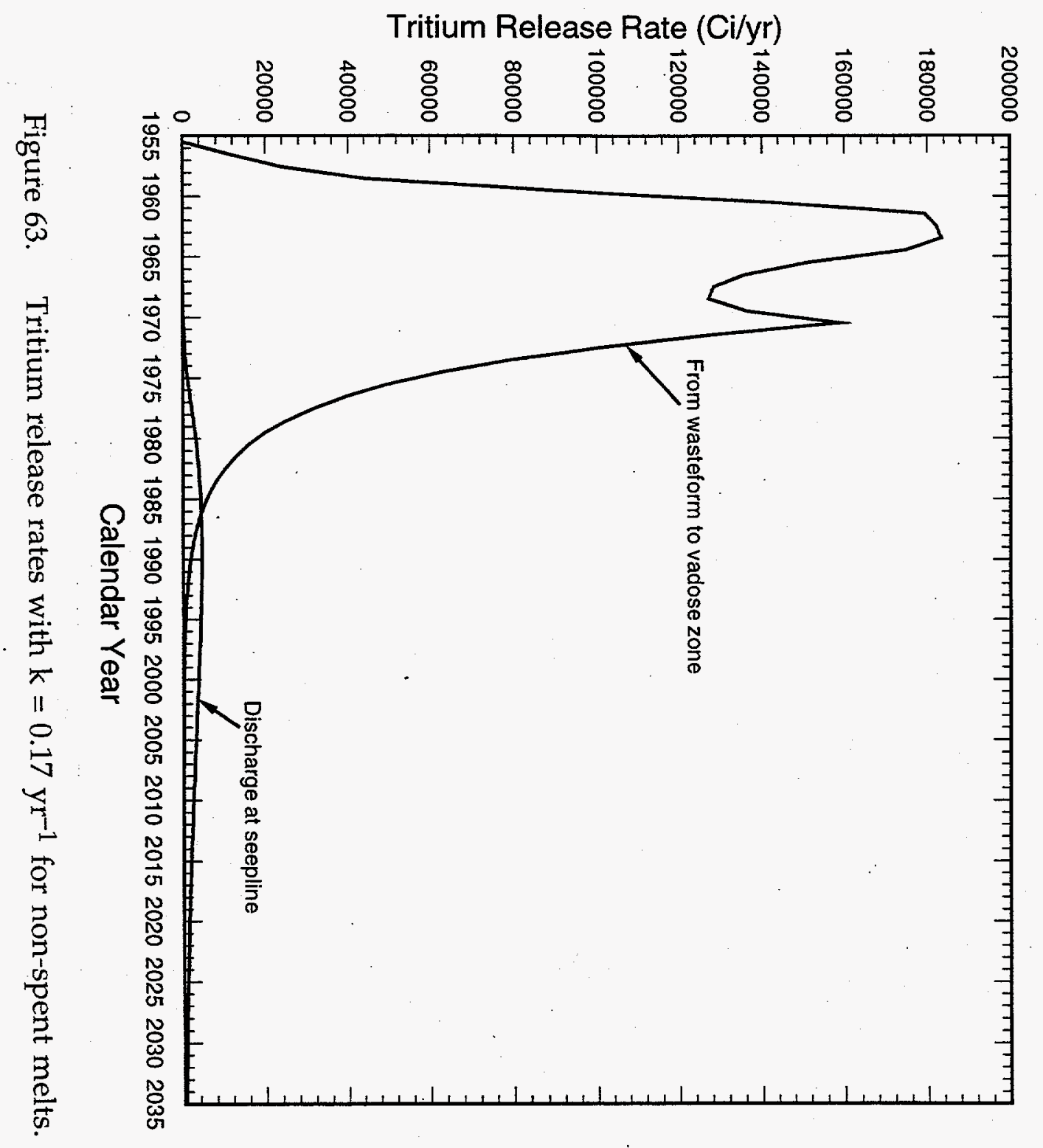




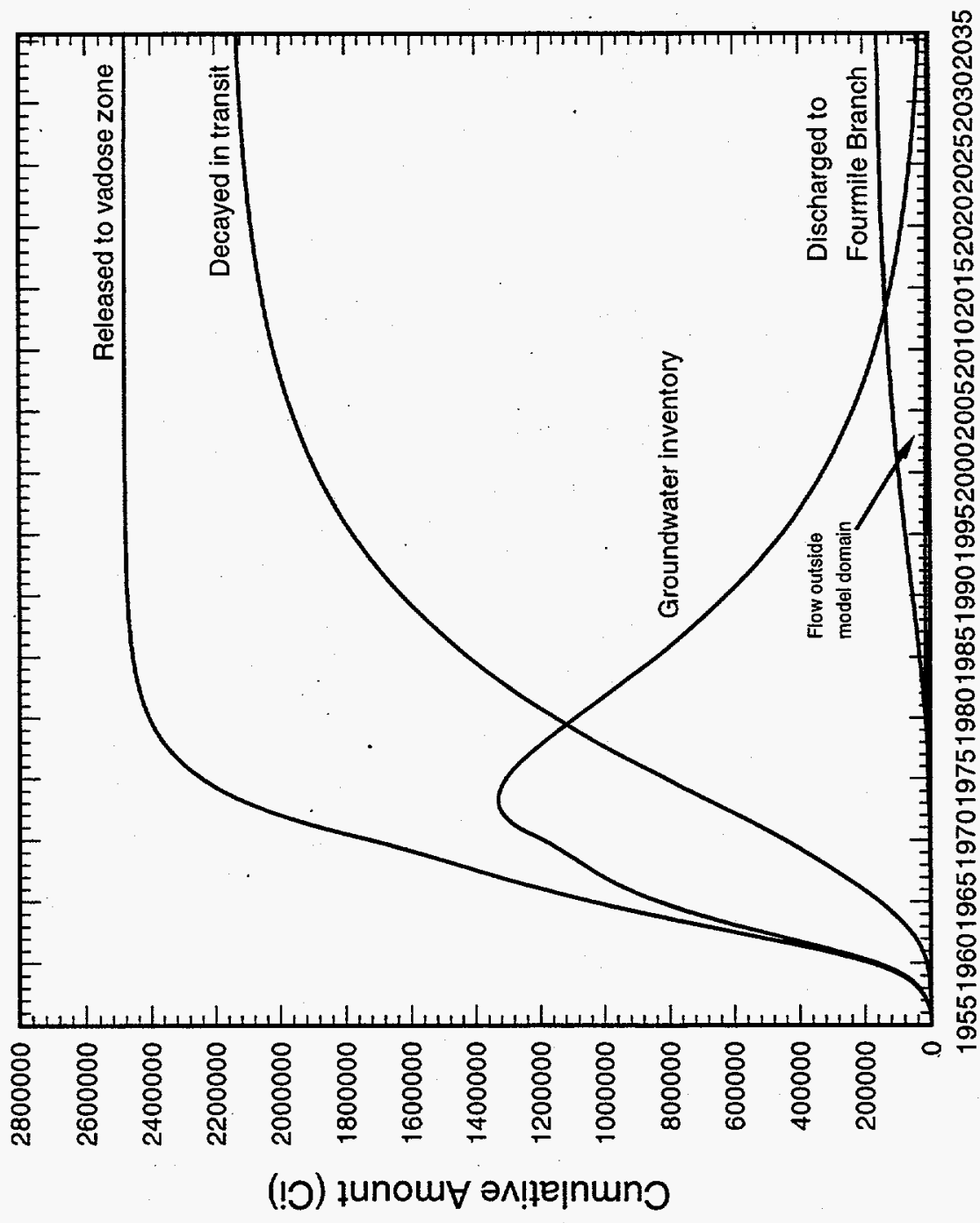

ङ

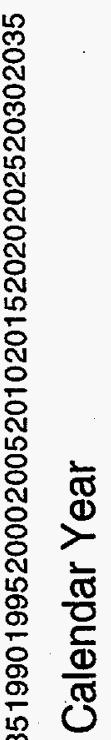

$\widetilde{\sigma}$

艺

$+\frac{1}{5}$

पु

웅

巴ٓ

돈

32

官 11

豆头实

兘艺

至

bo

.

苛

엉

웅

छ

$\exists$ \&

E엉

ษึ่

苟 


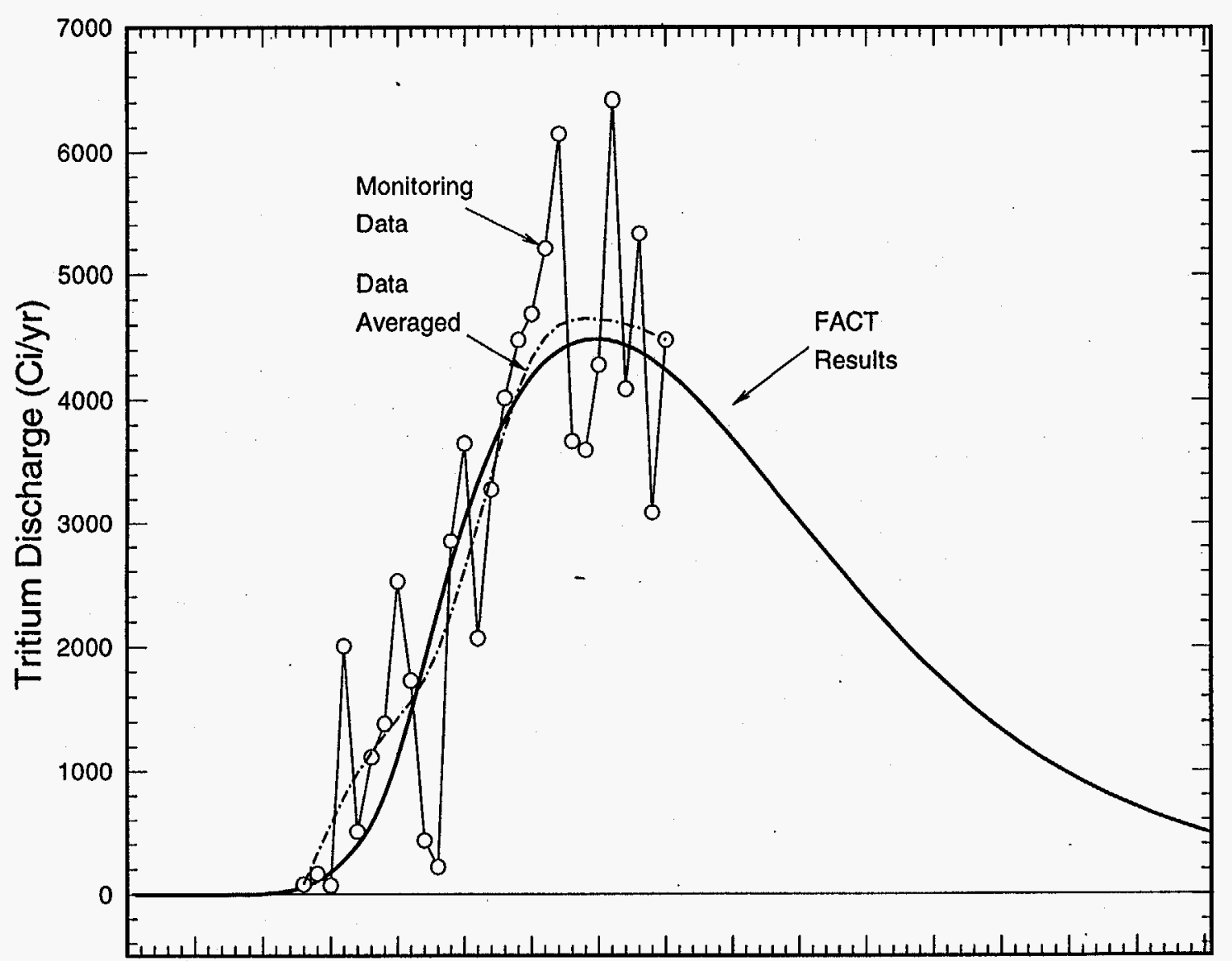

19551960196519701975198019851990199520002005201020152020202520302035

Calendar Year

Figure 65. Comparison of predicted and measured tritium discharges to Fourmile Branch for no action and capping remedial alternatives $\left(\mathrm{k}=0.17 \mathrm{yr}^{-1}\right.$ for non-spent melts, $45 \%$ porosity, 300 $\mathrm{ft}$ dispersivity). 
Table 1. Listing of core descriptions considered for the present study.

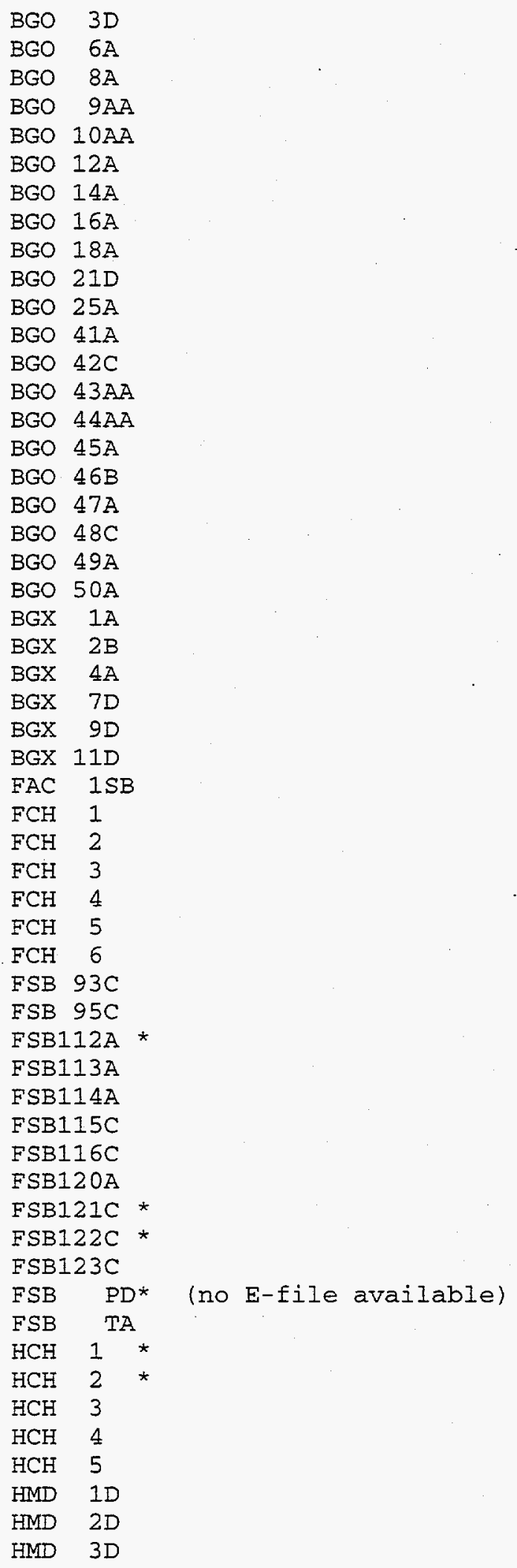

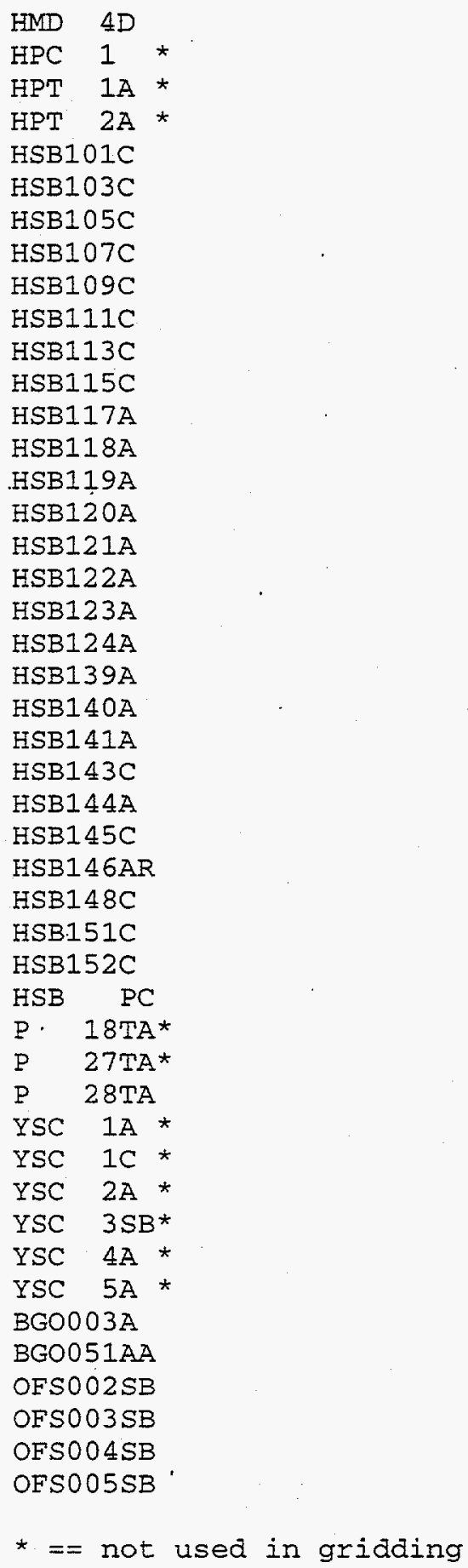


Table 2. Cores used to define mud fraction probability distribution function.

$\begin{array}{llllllll}\text { BG0009AA } & \text { BGO010AA } & \text { BG0041A } & \text { BGO042C } & \text { BGO043AA } & \text { BGO044AA } & \text { BGO045A } & \text { BGO046B } \\ \text { BG0047A } & \text { BGO048C } & \text { BG0049A } & \text { BGO050A } & \text { BGX001A } & \text { BGX002B } & \text { BGX004A } & \text { BGX007D } \\ \text { BGX009D } & \text { BGX011D } & \text { FAC001SB } & \text { FCH001 } & \text { FCH002 } & \text { FCH003 } & \text { FCH004 } & \text { FCH005 } \\ \text { FCH006 } & \text { FSBTA } & \text { FSB115C } & \text { FSB116C } & \text { FSB120A } & \text { FSB121C } & \text { FSB122C } & \text { FSB123C } \\ \text { HCH001 } & \text { HCH002 } & \text { HCH003 } & \text { HCH004 } & \text { HCH005 } & \text { HMD001D } & \text { HMD002D } & \text { HMD003D } \\ \text { HMD004D } & \text { HSB140A } & \text { HSB141A } & \text { HSB143C } & \text { HSB144A } & \text { HSB145C } & \text { HSB146A } & \text { HSB148C } \\ \text { HSB151C } & \text { HSB152C } & \text { P027TA } & \text { P028TA } & \text { BGO003A } & \text { BGO051AA } & \text { OFS002SB } & \text { OFS003SB } \\ \text { OFS004SB } & \text { OFS005SB } & & . & & & & \end{array}$

Table 3. Average mud fractions for sand, clayey sand, sandy clay, and clay.

\begin{tabular}{llrrr}
\multicolumn{2}{c}{$\begin{array}{c}\text { Soil } \\
\text { Label }\end{array}$} & & $\begin{array}{c}\text { \# Data } \\
\text { Points }\end{array}$ & $\begin{array}{c}\text { Average } \\
\text { Mud Fraction }\end{array}$ \\
& & & & \\
SD & 1 & & 7284 & 0.116 \\
CLSD & 2 & & 938 & 0.352 \\
SDCL & 3 & & 448 & 0.632 \\
CL & 4 & & 598 & 0.910
\end{tabular}


Table 4. Hydrostratigraphic unit boundaries from Thayer et al. (1993).

\begin{tabular}{|c|c|c|c|c|c|c|c|c|c|c|}
\hline No & Core & $=I D$ & $\begin{array}{l}\text { SRS } \\
\text { Northing } \\
\text { (ft) }\end{array}$ & $\begin{array}{l}\text { SRS } \\
\text { Easting } \\
\quad(f t)\end{array}$ & $\begin{array}{l}\text { "upper" } \\
\text { aquif. } \\
(f t)\end{array}$ & $\begin{array}{l}\text { "tan } \\
c I a y " \\
(f t)\end{array}$ & $\begin{array}{l}\text { "lower" } \\
\text { aquif. } \\
(f t)\end{array}$ & $\begin{array}{c}\text { Gordon } \\
\text { c.u. } \\
\text { (ft) }\end{array}$ & $\begin{array}{l}\text { Gordon } \\
\text { aquif. } \\
\text { (ft) }\end{array}$ & $\begin{array}{l}\text { Meyers } \\
\text { Branch } \\
(E t)\end{array}$ \\
\hline 1 & BGO & ID & 73737.9 & 58779.3 & 293 & NP & NP & NP & $\mathrm{NP}$ & $N P$ \\
\hline 2 & BGO & $3 D$ & 75351.3 & 58809.2 & 290.8 & $\mathrm{NP}$ & $N P$ & $\mathrm{NP}$ & NP & NP \\
\hline 3 & BGO & $5 C$ & 76476.9 & 58794.5 & 294.2 & 218.2 & 201.2 & NP & NP & $N P$ \\
\hline 4 & BGO & $6 \mathrm{~A}$ & 76487.2 & 58316.8 & 283.8 & 209.8 & 194.8 & 120.8 & 119.8 & NP \\
\hline 5 & BGO & $8 \mathrm{~A}$ & 76569 & 57618.3 & 281.3 & 213.3 & 199.3 & 130.3 & 120.3 & NP \\
\hline 6 & BGO & $9 A A$ & 76975.69 & 57371.94 & 282.8 & 223.8 & 210.8 & 134.8 & 124.8 & NP \\
\hline 7 & BGO & $10 \mathrm{~A}$ & 76805.18 & 57050.92 & 299.1 & 209.1 & 207.1 & 131.1 & 124.1 & $\mathrm{NP}$ \\
\hline 8 & BGO & 10AA & 76997.88 & 56990.54 & 298.8 & 218.8 & 206.8 & 129.8 & 125.8 & NP \\
\hline 9 & BGO & $12 \mathrm{~A}$ & 76804.63 & 56250.68 & 311.4 & 199.4 & 186.4 & 137.4 & 132.4 & NP \\
\hline 10 & BGO & $14 \mathrm{~A}$ & 76377.54 & 55838.32 & 300.2 & 220.2 & 212.2 & 133.2 & 127.2 & NP \\
\hline 11 & BGO & $16 \mathrm{~A}$ & 75756.95 & 56194.15 & 302.8 & 195.8 & 182.8 & 130.8 & 125.8 & NP \\
\hline 12 & BGO & $18 \mathrm{~A}$ & 75599.89 & 56699.67 & 292.9 & 204.9 & 198.9 & 130.9 & 125.9 & NP \\
\hline 13 & $\mathrm{BGO}$ & $21 D$ & 74688.53 & 57470.66 & 283 & NP & $\mathrm{NP}$ & $\mathrm{NP}$ & NP & NP \\
\hline 14 & BGO & $23 D$ & 74238.09 & 58132.96 & 287 & NP & $N P$ & $N P$ & $\mathrm{NP}$ & NP \\
\hline 15 & BGO & $25 \mathrm{~A}$ & 76158.5 & 55668.08 & 294.7 & 211.7 & 200.7 & 137.7 & 127.7 & NP \\
\hline 16 & BGO & $26 A$ & 76144.6 & 55014.2 & 285.1 & 219.1 & 205.1 & 133.1 & 129.1 & NP \\
\hline 17 & BGO & $27 \mathrm{C}$ & 75666.3 & 54671.4 & 273.9 & 198.9 & 191.9 & NP & NP & NP \\
\hline 18 & BGO & $29 A$ & 75560 & 54103.5 & 262.1 & 196.1 & 185.1 & 124.1 & 113.1 & NP \\
\hline 19 & BGO & $31 C$ & 74978 & 54816.2 & 271.1 & 198.1 & 188.1 & $\mathrm{NP}$ & NP & NP \\
\hline 20 & BGO & $33 \mathrm{C}$ & 74479.7 & 55681.4 & 277.4 & 200.4 & 191.4 & NP & NP & NP \\
\hline 21 & BGO & $35 \mathrm{C}$ & 73953.9 & 56545.7 & 271.4 & 204.4 & 197.4 & NP & NP & NP \\
\hline 22 & BGO & $37 \mathrm{C}$ & 73498.2 & 57279.2 & 284.3 & 199.3 & 191.3 & NP & $\mathrm{NP}$ & $\mathrm{NP}$ \\
\hline 23 & BGO & $41 \AA$ & 76469.52 & 55403.69 & 298.3 & 217.3 & 208.3 & 138.3 & 131.3 & NP \\
\hline 24 & BGO & $42 \mathrm{C}$ & 76404.71 & 55522.27 & 295.9 & 215.9 & 208.9 & NP & NP & NP \\
\hline 25 & BGO & $43 A A$ & 77066.01 & 56268.64 & 312.2 & 195.2 & 187.2 & 135.2 & 127.2 & NP \\
\hline 26 & BGO & $44 A A$ & 76757.02 & 57880.51 & 283.3 & 222.3 & 199.3 & 131.3 & 120.3 & NP \\
\hline 27 & BGO & $45 \mathrm{~A}$ & 75830.03 & 54550.14 & 276.9 & 206.9 & 200.9 & 133.9 & 129.9 & NP \\
\hline 28 & BGO & $46 \mathrm{~B}$ & 75012.1 & 54444.65 & 263.4 & 199.4 & 193.4 & 128.4 & 126.4 & NP \\
\hline 29 & BGO & $47 \mathrm{~A}$ & 74728.83 & 54914.04 & 264.8 & 19.7 .8 & 189.8 & 130.8 & 124.8 & NP \\
\hline 30 & BGO & $48 C$ & 74599.64 & 55124.38 & 274.7 & 197.7 & 191.7 & $\mathrm{NP}$ & $N P$ & NP \\
\hline 31 & BGO & $49 \mathrm{~A}$ & 73902.78 & 56205.08 & 269.1 & 201.1 & 192.1 & 119.1 & 115.1 & NP \\
\hline 32 & BGO & $50 \mathrm{~A}$ & 75201.16 & 54179.77 & 253.5 & 193.5 & 183.5 & 132.5 & 128.5 & NP \\
\hline 33 & $B G X$ & $1 \mathrm{~A}$ & 76831.89 & 58590.35 & 288.9 & 210.9 & 197.9 & 131.9 & 126.9 & NP \\
\hline 34 & BGX & $2 B$ & 77203.4 & 58256.5 & 289.2 & 216.2 & 198.2 & 140.2 & 127.2 & NP \\
\hline 35 & BGX & $4 A$ & 77879.2 & 57215.6 & 288.8 & 224.8 & 212.8 & 129.8 & 123.8 & NP \\
\hline 36 & $B G X$ & $7 D$ & 78349.3 & 58312.8 & 276.9 & 224.9 & 219.9 & 156.9 & 143.9 & NP \\
\hline 37 & BGX & $9 D$ & 76936 & 59522.1 & 277.4 & 207.4 & 202.4 & 139.4 & 131.4 & NP \\
\hline 38 & $B G X$ & $11 D$ & 75300.7 & 59581.4 & 273.6 & 192.6 & 176.6 & 125.6 & 116.6 & NP \\
\hline 39 & FAC & $1 S B$ & 78138 & 55243 & 312.2 & 224.2 & 217.2 & 149.2 & NP & NP \\
\hline 40 & $\mathrm{FCH}$ & 1 & 79488.82 & 52843.11 & 317 & 214 & 202 & 142 & 126 & 67 \\
\hline 41 & $\mathrm{FCH}$ & 2 & 78500 & 52599.59 & 288.6 & 212.6 & 196.6 & 141.6 & 129.6 & 57.6 \\
\hline 42 & $\mathrm{ECH}$ & 3 & 78059.22 & 52087.22 & 307.4 & 207.4 & 196.4 & 140.4 & 131.4 & 59.4 \\
\hline 43 & $\mathrm{FCH}$ & 4 & 77514.56 & 52021.03 & .297 .6 & 196.6 & 186.6 & 127.6 & 120.6 & 41.6 \\
\hline 44 & $\mathrm{FCH}$ & 5 & 76992.12 & 51667.65 & 284.2 & 196.2 & 191.2 & 129.2 & 128.2 & 36.2 \\
\hline 45 & $\mathrm{FCH}$ & 6 & 76410.33 & 51245.7 & 290.8 & 187.8 & 180.8 & 122.8 & 119.8 & 23.8 \\
\hline 46 & FSB & $76 \mathrm{~A}$ & 76131.9 & 51391.6 & 291.5 & ND & $\mathrm{ND}$ & 120.5 & 116.5 & NP \\
\hline 47 & FSB & $78 \mathrm{~A}$ & 74757.7 & 50172.8 & 270.5 & 162.5 & 146.5 & 104.5 & 99.5 & NP \\
\hline 48 & FSB & $79 A$ & 73664.5 & 50149.6 & 216.1 & 173.1 & 164.1 & 103.1 & 100.1 & 18.1 \\
\hline 49 & FSB & $87 \mathrm{~A}$ & 75601.7 & 50115.8 & 285.6 & 175.6 & 172.6 & 114.6 & 108.6 & $\mathrm{NP}$ \\
\hline 50 & FSB & $89 C$ & 75553.2 & 51345.2 & 279.1 & 186.1 & 180.1 & NP & $\mathrm{NP}$ & NP \\
\hline
\end{tabular}


Table 4. (cont'd)

\begin{tabular}{|c|c|c|c|c|c|c|c|c|c|c|}
\hline No & Core & ID & $\begin{array}{l}\text { SRS } \\
\text { Northing } \\
\text { (Et) }\end{array}$ & $\begin{array}{l}\text { SRS } \\
\text { Easting } \\
\text { (ft) }\end{array}$ & $\begin{array}{l}\text { "upper" } \\
\text { aquif. } \\
\text { (ft) }\end{array}$ & $\begin{array}{l}\text { "tan } \\
\text { clay" } \\
(\mathrm{ft})\end{array}$ & $\begin{array}{l}\text { "Iower" } \\
\text { aquif. } \\
\text { (ft) }\end{array}$ & $\begin{array}{c}\text { Gordon } \\
\text { c.u. } \\
(f t)\end{array}$ & $\begin{array}{l}\text { Gordon } \\
\text { aquif. } \\
\text { (ft) }\end{array}$ & $\begin{array}{l}\text { Meyers } \\
\text { Branch } \\
(\mathrm{ft})\end{array}$ \\
\hline 51 & FSB & $91 C$ & 75213.3 & 50953.5 & 277 & 168 & 161 & $\mathrm{NP}$ & NP & NP \\
\hline 52 & FSB & $93 C$ & 74897.3 & 50458.3 & 274 & 166 & 151 & NP & $\mathrm{NP}$ & NP \\
\hline 53 & FSB & $95 \mathrm{C}$ & 74971.7 & 50016.7 & 281.8 & 173.8 & 157.8 & NP & $\mathrm{NP}$ & $\mathrm{NP}$ \\
\hline 54 & FSB & $96 \mathrm{~A}$ & 74882.2 & 49778.7 & 277.7 & 166.7 & 153.7 & 108.7 & 100.7 & NP \\
\hline 55 & FSB & $97 \mathrm{~A}$ & 75171.2 & 49965.7 & 283.8 & 162.8 & 151.8 & 110.8 & 106.8 & NP \\
\hline 56 & FSB & $98 \mathrm{~A}$ & 75389.8 & $50121: 6$ & 280.7 & 171.7 & 159.7 & 108.7 & 106.7 & $\mathrm{NP}$ \\
\hline 57 & FSB & $99 A$ & 75675.6 & 50314.8 & 285.3 & 178.3 & 173.3 & 115.3 & 112.3 & NP \\
\hline 58 & FSBI & $.00 \mathrm{~A}$ & 75534.4 & 50958.4 & 283.8 & 184.8 & 182.8 & 117.8 & 113.8 & NP \\
\hline 59 & FSB1 & $.01 \mathrm{~A}$ & 75719 & 51191.3 & 282.9 & 190.9 & 182.9 & 118.9 & 115.9 & NP \\
\hline 60 & FSBI & $12 \mathrm{~A}$ & 74231.4 & 48809.1 & 227 & 164 & 144 & 103 & 98 & NP \\
\hline 61 & FSBI & $13 \mathrm{~A}$ & 74167.5 & 51068.1 & 221.3 & 178.3 & 171.3 & 109.3 & 104.3 & 22.3 \\
\hline 62 & FSB1 & $14 \mathrm{~A}$ & 75297.4 & 52046.6 & 250 & 178 & 173 & 114 & 110 & $\mathrm{NP}$ \\
\hline 63 & FSB1 & $-15 c$ & 72515.5 & 49736 & 205.8 & 180.8 & 164.8 & 100.8 & 85.8 & 5.8 \\
\hline 64 & FSBI & $.16 \mathrm{C}$ & 72725.5 & 50645.9 & 200.5 & 175.5 & 170.5 & $\mathrm{NP}$ & NP & $\mathrm{NP}$ \\
\hline 65 & FSB1 & $20 \mathrm{~A}$ & 75538.9 & 49175.7 & 278 & 181 & 165 & 112 & 110 & $\mathrm{NP}$ \\
\hline 66 & ESB1 & $21 \mathrm{C}$ & 75155.7 & 48413.1 & 254.4 & 173.4 & 162.4 & $\mathrm{NP}$ & NP & NP \\
\hline 67 & FSB1 & $22 \mathrm{C}$ & 73881.8 & 48195 & 216 & 164 & 148 & 104 & NP & $\mathrm{NP}$ \\
\hline 68 & FSB1 & $23 \mathrm{C}$ & 74566.7 & 51750.5 & 236.3 & 183.3 & 172.3 & $\mathrm{NP}$ & $\mathrm{NP}$ & $N P$ \\
\hline 69 & FSB & $\mathrm{PD}$ & 74549.2 & 49849.81 & 252.6 & $\mathrm{ND}$ & $\mathrm{ND}$ & $\mathrm{NP}$ & $\mathrm{NP}$ & NP \\
\hline 70 & FSB & TA & 75649.1 & 51658.3 & 275.4 & 191.4 & 187.4 & 117.4 & 115.4 & 24.4 \\
\hline 71 & $\mathrm{HC}$ & 12 & 73187 & 59504 & 287.3 & 195.3 & 190.3 & NP & $N P$ & $\mathrm{NP}$ \\
\hline 72 & $\mathrm{HCH}$ & 1 & 72796.39 & 60923.42 & 284.2 & 202.2 & 187.2 & 135.2 & 126.2 & 18.2 \\
\hline 73 & $\mathrm{HCH}$ & 2 & 72519.61 & 60091.79 & 270.9 & 195.9 & 179.9 & 130.9 & 122.9 & -0.1 \\
\hline 74 & $\mathrm{HCH}$ & 3 & 71998.82 & 59917.33 & 263.8 & 196.8 & 178.8 & 129.8 & 122.8 & $\mathrm{NP}$ \\
\hline 75 & $\mathrm{HCH}$ & 4 & 72449.59 & 59139.93 & 269.9 & 192.9 & 182.9 & 122.9 & 113.9 & $\mathrm{NP}$ \\
\hline 76 & $\mathrm{HCH}$ & 5 & 71810.36 & 59331.53 & 255 & 192 & 180 & 123 & 119 & -10 \\
\hline 77 & HMD & $1 D$ & 78731.7 & 56973.9 & 262.7 & 228.7 & 225.7 & 138.7 & 126.7 & $\mathrm{NP}$ \\
\hline 78 & HMD & $2 D$ & 79665.8 & 57269.7 & 259.3 & 222.3 & 216.3 & 143.3 & 138.3 & NP \\
\hline 79 & HMD & $3 D$ & 79578.7 & 57745.2 & 257.5 & 223.5 & 218.5 & 154.5 & .149 .5 & $\mathrm{NP}$ \\
\hline 80 & HMD & $4 D$ & 79160.4 & 58188.5 & 248.5 & 223.5 & 219.5 & 152.5 & 140.5 & NP \\
\hline 81 & HPC & 1 & 70395.4 & 62493.6 & 293.5 & 194.5 & 187.5 & 115.5 & 109.5 & 27.5 \\
\hline 82 & HPT & $1 \mathrm{~A}$ & 74847.1 & 60587 & 232.9 & ND & ND & 118.9 & 114.9 & 52.9 \\
\hline 83 & HPT & $2 \mathrm{~A}$ & 75061.8 & 60200.5 & 257.7 & $\mathrm{ND}$ & ND & 120.7 & 117.7 & 56.7 \\
\hline 84 & HSB & $65 A$ & 72436.2 & 58436 & 270.7 & 203.7 & 198.7 & 118.7 & 112.7 & NP \\
\hline 85 & HSB & $68 \mathrm{~A}$ & 71526.9 & 56892.1 & 247.4 & 198.4 & 193.4 & 116.4 & 110.4 & NP \\
\hline 86 & HSB & $69 A$ & 71549.4 & 56465.1 & 234.1 & 187.1 & 181.1 & 115.1 & 112.1 & NP \\
\hline 87 & HSB & $83 A$ & 71648.6 & 58606.1 & 234.9 & 194.9 & 187.9 & 113.9 & 103.9 & 11.9 \\
\hline 88 & HSB & $84 \mathrm{~A}$ & 71586.2 & 56359.1 & 226.4 & 204.4 & 180.4 & 118.4 & 110.4 & $\mathrm{NP}$ \\
\hline 89 & HSB & $85 \mathrm{~A}$ & 73791.9 & 58943.4 & 292.1 & 204.1 & 200.1 & 126.1 & 119.1 & NP \\
\hline 90 & HSB & $86 A$ & 72520.2 & 55985.9 & 260 & 185 & 178 & 112 & 109 & NP \\
\hline 91 & HSBI & $.01 C$ & 72001.9 & 58604.4 & 256.3 & 195.3 & 189.3 & $\mathrm{NP}$ & $\mathrm{NP}$ & NP \\
\hline 92 & HSBI & $.03 C$ & 71593.9 & 58323.6 & 245.2 & 195.2 & 181.2 & NP & NP & NP \\
\hline 93 & HSBI & $.05 \mathrm{C}$ & 71447.3 & 57883.8 & 247.2 & 190.2 & 183.2 & NP & NP & NP \\
\hline 94 & HSB1 & $.07 C$ & 71698.5 & 57432 & 258.3 & 198.3 & 190.3 & NP & NP & NP \\
\hline 95 & HSB1 & $09 C$ & 71684.8 & 56895.6 & 259.4 & 203.4 & 189.4 & NP & NP & NP \\
\hline 96 & HSBI & $11 \mathrm{C}$ & 71919.4 & 56501.9 & 253.7 & 187.7 & 170.7 & NP & $\mathrm{NP}$ & NP \\
\hline 97 & HSBI & $13 \mathrm{C}$ & 72312.3 & 56160.4 & 258.7 & 187.7 & 173.7 & NP & $\mathrm{NP}$ & NP \\
\hline 98 & HSBI & $15 C$ & 72653.2 & 56043.2 & 266.8 & 208.8 & 196.8 & $\mathrm{NP}$ & $\mathrm{NP}$ & NP. \\
\hline 99 & HSB1 & $17 \mathrm{~A}$ & 72733.6 & 55170.1 & 234.1 & 215.1 & 191.1 & 122.1 & 116.1 & NP \\
\hline 100 & HSB1 & $18 \mathrm{~A}$ & 72696.4 & 55775.6 & 245 & 183 & 173 & 119 & 114 & NP \\
\hline
\end{tabular}


Table 4. (cont'd)

\begin{tabular}{|c|c|c|c|c|c|c|c|c|c|c|}
\hline No & Core & $=I D$ & $\begin{array}{l}\text { SRS } \\
\text { Northing } \\
\text { (ft) }\end{array}$ & $\begin{array}{l}\text { SRS } \\
\text { Easting } \\
\text { (ft) }\end{array}$ & $\begin{array}{l}\text { "upper" } \\
\text { aquif. } \\
\text { (ft) }\end{array}$ & $\begin{array}{l}\text { "tan } \\
\text { clay" } \\
\text { (ft) }\end{array}$ & $\begin{array}{l}\text { "Lower" } \\
\text { aquif. } \\
\text { (ft) }\end{array}$ & $\begin{array}{l}\text { Gordon } \\
\text { c.u. } \\
\text { (ft) }\end{array}$ & $\begin{array}{l}\text { Gordon } \\
\text { aquif. } \\
\text { (ft) }\end{array}$ & $\begin{array}{l}\text { Meyers } \\
\text { Branch } \\
\text { (ft) }\end{array}$ \\
\hline 01 & HSB1 & $119 A$ & 73082.5 & 56100.2 & 254.8 & 212.8 & 194.8 & 114.8 & 110.8 & NP \\
\hline 02 & & $20 \mathrm{~A}$ & 73395.1 & 6431.9 & 266 & 203 & 196 & 112 & 110 & \\
\hline 103 & HSB] & $121 \mathrm{~A}$ & 72024.8 & 57389.6 & 272.3 & 197.3 & 184.3 & 113.3 & 109.3 & NP \\
\hline 104 & HSB1 & $122 \mathrm{~A}$ & 72195.9 & 57747.4 & 269.4 & 188.4 & 177.4 & 110.4 & 108.4 & NP \\
\hline 105 & HSB & $123 \mathrm{~A}$ & 72189.8 & 58124.8 & 262.3 & 194.3 & 184.3 & 112.3 & 106.3 & NP \\
\hline 106 & HSB] & $124 \mathrm{~A}$ & 72199.6 & 58514.6 & 263.9 & ND & ND & 121 & & $\mathrm{NP}$ \\
\hline 107 & HSB 1 & $139 A$ & 71127.4 & 57365.4 & 231.5 & 189.5 & 178.5 & 118.5 & 114.5 & NE \\
\hline 108 & HSB] & $140 \mathrm{~A}$ & 70050.3 & 56535.4 & 234 & 194 & 181 & 111 & 105 & NE \\
\hline 109 & HSB] & $141 \mathrm{~A}$ & 71213.6 & 59168.7 & 252.6 & 180.6 & & 118.6 & 12.6 & NP \\
\hline 110 & HSB] & $143 c$ & 73738.2 & 52773.2 & 220.1 & 198.1 & 179.1 & NP & NP & NP \\
\hline 111 & HSB & $144 \mathrm{~A}$ & 71892.1 & 56200.5 & 233.6 & 185.6 & 178.6 & 108.6 & 103.6 & NP \\
\hline 112 & HSB 1 & $145 \mathrm{C}$ & 71098.9 & 57769 & 233.7 & 183.7 & 174.7 & NP & NP & NE \\
\hline 113 & $\mathrm{HSB}$ & $146 \mathrm{AR}$ & 70478.9 & & & & & 121.6 & 111.6 & NP \\
\hline 14 & HSB & $148 \mathrm{C}$ & .70151 .5 & 4.2 & 248.9 & 186.9 & & NP & NP & NP \\
\hline 115 & HSB & $151 \mathrm{C}$ & 72997.9 & 54014.9 & 211.6 & 192.6 & 182.6 & NP & NP & NP \\
\hline 116 & HSB] & $152 \mathrm{C}$ & 72012 & 54346.7 & 212.1 & 198.1 & 186.1 & NP & NP & NP \\
\hline 117 & HSB & $T B$ & 72394 & 58696.1 & 267.1 & 207.1 & 199 & 110.1 & 106.1 & 9.1 \\
\hline 118 & $\mathrm{HSB}$ & PC & 72119.31 & 55650.03 & 227.8 & & & NP & $N$ & NP \\
\hline 119 & $\mathrm{P}$ & $18 \mathrm{TA}$ & 67576.5 & 47652.8 & 296.7 & 174.7 & 166.7 & 90.7 & 85 . & -17.3 \\
\hline 120 & $\mathrm{P}$ & $27 \mathrm{TA}$ & 70382 & 64022.9 & 274.1 & 180.1 & 169.1 & 129.1 & 127.1 & 49.1 \\
\hline 121 & $\mathrm{P}$ & $28 \mathrm{TA}$ & 79284.3 & 5441.1 & 285.2 & & & & & 63.2 \\
\hline 122 & YSC & $1 \mathrm{~A}$ & 78039.9 & 65438.93 & 268.9 & 209.9 & & & & $68: 9$ \\
\hline 123 & YSC & $1 \mathrm{C}$ & 78186.24 & 65855.46 & 272.5 & 214.5 & 212.5 & 163.5 & 156.5 & $\mathrm{NP}$ \\
\hline 124 & YSC & $2 A$ & 78311.53 & 66100.08 & 281.7 & 219.7 & 214.7 & 161.7 & 150.7 & NP \\
\hline 12 & YSC & $3 \mathrm{SB}$ & 77680 & 65920 & 277 & 211 & 205 & 149 & 140 & NP \\
\hline-2 & YSC & $4 \mathrm{~A}$ & 77050.08 & 65883.5 & 287.5 & 222.5 & 213.5 & 159.5 & 144.5 & 86.5 \\
\hline & isc & $5 A$ & & & & & & 136 & 128 & NI \\
\hline
\end{tabular}


Table 5. Fourmile Branch flow rates for date of minimum station 3 flow rate by water year.

\begin{tabular}{|c|c|c|c|c|c|c|c|}
\hline $\begin{array}{l}\text { Water } \\
\text { Year } \\
\text { (Oct.- } \\
\text { Sep.) }\end{array}$ & Date & $\begin{array}{l}\text { Station } 3 \\
\text { Flowrate } \\
\text { (cfs) }\end{array}$ & $\begin{array}{l}\text { Station } 4 \\
\text { Flowrate } \\
\text { (cfs) }\end{array}$ & $\begin{array}{l}\text { Station } \\
\text { 5B } \\
\text { Flowrate } \\
\text { (cfs) }\end{array}$ & $\begin{array}{l}\text { Station } 6 \\
\text { minus } \\
\text { Station } 4 \\
\text { Flowrate } \\
\text { (cfs) }\end{array}$ & $\begin{array}{l}\text { Station } 6 \\
\text { Flowrate } \\
\text { (cfs) }\end{array}$ & $\begin{array}{l}\text { Station } 7 \\
\text { Flowrate } \\
\text { (cfs) }\end{array}$ \\
\hline$\overline{93}$ & $9 / 16$ & 1.0 & - & - & - & - & - \\
\hline 92 & $7 / 15$ & 2.6 & 2.1 & 1.7 & 1.1 & 3.2 & 6.1 \\
\hline 91 & $10 / 5$ & 1.5 & 2.4 & 2.4 & 2.4 & 4.8 & 7.8 \\
\hline 90 & $8 / 11$ & 1.2 & 4.7 & 4.7 & 2.9 & 7.6 & 20. \\
\hline 89 & $9 / 19$ & 1.4 & 3.4 & 3.4 & 2.3 & 5.7 & 6.1 \\
\hline 88 & $8 / 10$ & 1.6 & 3.2 & 3.2 & 4.4 & 7.6 & 8.8 \\
\hline 87 & $8 / 23$ & 2.2 & 3.5 & 3.5 & 2.2 & 5.7 & 5.8 \\
\hline 86 & $10 / 20$ & 1.6 & 2.7 & 2.7 & 5.2 & 7.9 & 8.8 \\
\hline 85 & $5 / 20$ & 1.5 & 2.1 & 2.1 & 3.6 & 5.7 & 6.3 \\
\hline \multicolumn{8}{|l|}{84} \\
\hline \multicolumn{8}{|l|}{83} \\
\hline \multicolumn{8}{|l|}{82} \\
\hline \multicolumn{8}{|l|}{81} \\
\hline 80 & $7 / 14$ & 1.4 & 1.9 & - & & 5.0 & 6.9 \\
\hline averages & & $\begin{array}{l}1.67 \\
\end{array}$ & 2.89 & 2.93 & 3.01 & 5.91 & \\
\hline
\end{tabular}

cfs - cubic feet per second 
Table 6. Hydrologic parameters used in Old Burial Ground groundwater flow model.

\begin{tabular}{|c|c|c|c|c|c|c|}
\hline Property & $0 \leq \mathrm{mf} \leq 0.1$ & $\begin{array}{c}0.1 \leq \mathrm{mf} \leq \\
0.25\end{array}$ & $0.25 \leq \mathrm{mf} \leq 0.5$ & $0.5 \leq \mathrm{mf} \leq 1$ & $\begin{array}{c}\text { Gordon } \\
\text { confining } \\
\text { unit }\end{array}$ & $\begin{array}{l}\text { Gordon } \\
\text { aquifer }\end{array}$ \\
\hline $\begin{array}{l}\text { Horizontal } \\
\text { conductivity, } \\
\mathrm{K}_{\mathrm{h}}\end{array}$ & $40 \mathrm{ft} / \mathrm{d}$ & $5 \mathrm{ft} / \mathrm{d}$ & $\begin{array}{l}\mathrm{K}_{\mathrm{V}} \times \mathrm{R} . \\
(0.15)\end{array}$ & $\begin{array}{c}\mathrm{K}_{\mathrm{V}} \times \mathrm{R} \\
(0.0003)\end{array}$ & $3 \times 10^{-5} \mathrm{ft} / \mathrm{d}$ & $40 \mathrm{ft} / \mathrm{d}$ \\
\hline $\begin{array}{l}\text { Vertical } \\
\text { conductivity, } \\
\mathrm{K}_{\mathrm{V}}\end{array}$ & $\begin{array}{c}\mathrm{K}_{\mathrm{h}} / \mathrm{R} \\
(13.3 \mathrm{ft} / \mathrm{d})\end{array}$ & $\begin{array}{c}\mathrm{K}_{\mathrm{h}} / \mathrm{R} \\
(1.7 \mathrm{ft} / \mathrm{d})\end{array}$ & $0.05 \mathrm{ft} / \mathrm{d}$ & $0.0001 \mathrm{ft} / \mathrm{d}$ & $\begin{array}{c}\mathrm{K}_{\mathrm{h}} / \mathrm{R} \\
\left(1 \times 10^{-5} \mathrm{ft} / \mathrm{d}\right)\end{array}$ & $\begin{array}{c}\mathrm{K}_{\mathrm{h}} / \mathrm{R} \\
(13.3 \mathrm{ft} / \mathrm{d})\end{array}$ \\
\hline $\begin{array}{l}\text { Conductivity } \\
\text { ratio, } R\end{array}$ & 3 & 3 & - & 3 & 3 & 3 \\
\hline $\begin{array}{l}\text { Effective } \\
\text { porosity, } \eta\end{array}$ & 0.23 & 0.23 & 0.23 & 0.23 & 0.23 & 0.23 \\
\hline $\begin{array}{l}\text { Specific } \\
\text { storage, } S_{S}\end{array}$ & $3 \times 10^{-5}$ & $1 \times 10^{-4}$ & $2 \times 10^{-4}$ & $3 \times 10^{-4}$ & $\begin{array}{l}\text { assigned by } \\
\text { mud fraction }\end{array}$ & $\begin{array}{l}\text { assigned by } \\
\text { mud fraction }\end{array}$ \\
\hline
\end{tabular}

$\mathrm{mf} \equiv$ mud fraction 
Table 7. Summary of hydraulic head residuals between model and data $(\mathrm{ft})$.

Overall rms head (or conc) difference: 3.38

Upper Three Runs aquifer, "upper" zone

rms of (FACT-data) differences: avg of (FACT-data) differences:

3.426

avg of |FACT-data| differences:

$-1.389$

$\max$ of $\{F A C T-d a t a\}$ differences:

2.534

$-11.632$

Upper Three Runs aquifer, "lower" zone

rms of (FACT-data) differences:

avg of (FACT-data) differences:

3.865

avg of |FACT-data| differences:

$-1.561$

max of \{FACT-data\} differences:

3.095

$-9.083$

Gordon aquifer

rms of (FACT-data) differences:

0.659

avg of (FACT-data) differences:

$-0.081$

avg of |FACT-data| differences:

0.539

max of \{FACT-data\} differences: 
Table 8. Documents relevant to tritium transport from the Old Burial Ground to Fourmile Branch.

\begin{tabular}{|c|c|c|c|}
\hline Doc No. & Author(s) & Title & Comments \\
\hline \multicolumn{4}{|l|}{ GENERAL: } \\
\hline $\begin{array}{l}\text { Health Physics, v10, } \\
229-236,1964\end{array}$ & J. W. Fenimore & $\begin{array}{l}\text { Land burial of solid radioactive waste during a } \\
10 \text {-year period }\end{array}$ & $\begin{array}{l}\text { Good information about first } 10 \text { years of } \\
\text { operation. Scrap metals have radionuclides } \\
\text { dispersed throughout the metal leaving little } \\
\text { for leaching. Process equipment } \\
\text { decontaminated before burial. Results of a } \\
\text { tracer study. }\end{array}$ \\
\hline DPST-70-460 & $\begin{array}{l}\text { J. C. Corey and J. H. } \\
\text { Horton }\end{array}$ & Savannah River Plant burial ground practices & Good general discussion of operations. \\
\hline DP-1366 & $\begin{array}{l}\text { J. H. Horton and J. C. } \\
\text { Corey }\end{array}$ & $\begin{array}{l}\text { Storing solid radioactive wastes at the } \\
\text { Savannah River Plant }\end{array}$ & 1975 grid well tritium concentration data. \\
\hline DPST-77-300 & $\begin{array}{l}\text { J. W. Fenimore and R. } \\
\text { L. Hooker }\end{array}$ & $\begin{array}{l}\text { The assessment of solid low-level waste } \\
\text { management at the Savannah River Plant }\end{array}$ & $\begin{array}{l}\text { Average and maximum tritium concentration } \\
\text { data for BG well series, } 1956 \text { to } 1974 \text {, which } \\
\text { indicate more or less background? Source of } \\
\text { tritium is said to be the spent melts. }\end{array}$ \\
\hline DPST-82-725 & J. W. Fenimore & $\begin{array}{l}\text { The burial ground as a containment system: } 25 \\
\text { years of subsurface monitoring at the } \\
\text { Savannah River Plant facility }\end{array}$ & $\begin{array}{l}\text { Results of } 1957-1970 \text { tracer study in southwest } \\
\text { corner (p. 20, Figure 10). Between burial } \\
\text { ground and F-effluent highest concentration is } \\
64000 \mathrm{pCi} / \mathrm{ml} \text { and is } 6000 \mathrm{pCi} / \mathrm{ml} \text { at outcrop } \\
\text { (THESE ARE PROBABLY } \sim 1980 \\
\text { MEASUREMENTS!) (p. } 49 \text { ). } 850 \mathrm{Ci} / \mathrm{yr} \text {. } \\
\text { discharge to F-effluent. }\end{array}$ \\
\hline
\end{tabular}


Table 8. $\quad$ (cont ${ }^{\prime} \mathrm{d}$ )

\begin{tabular}{|c|c|c|c|}
\hline DPST-83-829 & $\begin{array}{l}\text { J. A. Stone and E. J. } \\
\text { Christensen eds. }\end{array}$ & $\begin{array}{l}\text { Technical summary of groundwater quality } \\
\text { protection program at the Savannah River } \\
\text { Plant, vol. II - radioactive waste }\end{array}$ & $\begin{array}{l}200 \text { ? } 850 \text { ? } \mathrm{Ci} / \text { yr. discharge to F-effluent. } \\
\text { Results of soil coring done between burial } \\
\text { ground and F-effluent. Tritium concentration } \\
\text { in BG wells for } 1980 \text { and 1981. BGC wells for } \\
\text { 1980-1982. }\end{array}$ \\
\hline DPST-85-694 & $\begin{array}{l}\text { W. J. Jaegge, N. L. } \\
\text { Kolb, B. B. Looney, I. } \\
\text { W. Marine, O. A. } \\
\text { Towler and J. R. Cook }\end{array}$ & Radiactive waste burial grounds & $\begin{array}{l}2 \mathrm{~m} / \mathrm{yr} \text { flow rate in unsaturated zone (p. } 27) \text {. } \\
\text { Results of } 57-70 \text { tracer study in southwest } \\
\text { corner (p. } 35 \text { ). }\end{array}$ \\
\hline WSRC-RP-90-1140 & WSRC & $\begin{array}{l}\text { RFI/RI workplan for the old radioactive burial } \\
\text { ground, bldg. number } 643-G(U)\end{array}$ & Tritium plume shown in Figure 2-21. \\
\hline duPont, 1990 & W. P. Bebbington & History of duPont at the Savannah River Site & Early operations described. \\
\hline \multicolumn{4}{|c|}{$\begin{array}{l}\text { BURIAL GROUND } \\
\text { INVENTORY: }\end{array}$} \\
\hline WSRC-TR-93-316 & M. L. Hyder & $\begin{array}{l}\text { Tritium in the burial ground of the Savannah } \\
\text { River Site (U) }\end{array}$ & $\begin{array}{l}\text { Summary including hypotheses for spent mel } \\
\text { release mechanism. }\end{array}$ \\
\hline WSRC-RP-91-709 & J. R. Cook & Radionuclide inventory of $\mathrm{E}$ area $(\mathrm{U})$ & $\begin{array}{l}\text { Total tritium estimated at } 172 \mathrm{~g} \text {. This estimate } \\
\text { does not include burials past 1970; including } \\
\text { these gives } 205 \mathrm{~g} \text {. }\end{array}$ \\
\hline \multicolumn{4}{|l|}{$\begin{array}{l}\text { DISCHARGE TO } \\
\text { FOUR MILE } \\
\text { BRANCH: }\end{array}$} \\
\hline WSRC-RP-93-459 & $\begin{array}{l}\text { B. B. Looney, J. S. } \\
\text { Haselow, C. M. Lewis, } \\
\text { M. K. Harris, D. E. } \\
\text { Wyatt and C. S. } \\
\text { Hetrick }\end{array}$ & $\begin{array}{l}\text { Projected tritium releases from F \& H area } \\
\text { seepage basins and the Solid Waste Disposal } \\
\text { Facilities to Fourmile Branch (U) }\end{array}$ & $\begin{array}{l}\text { Discharge to FMB data (Table 2). Projected } \\
\text { discharge. }\end{array}$ \\
\hline see below & & Annual monitoring reports, 1968 to present & \\
\hline
\end{tabular}


Table 8. (cont'd)

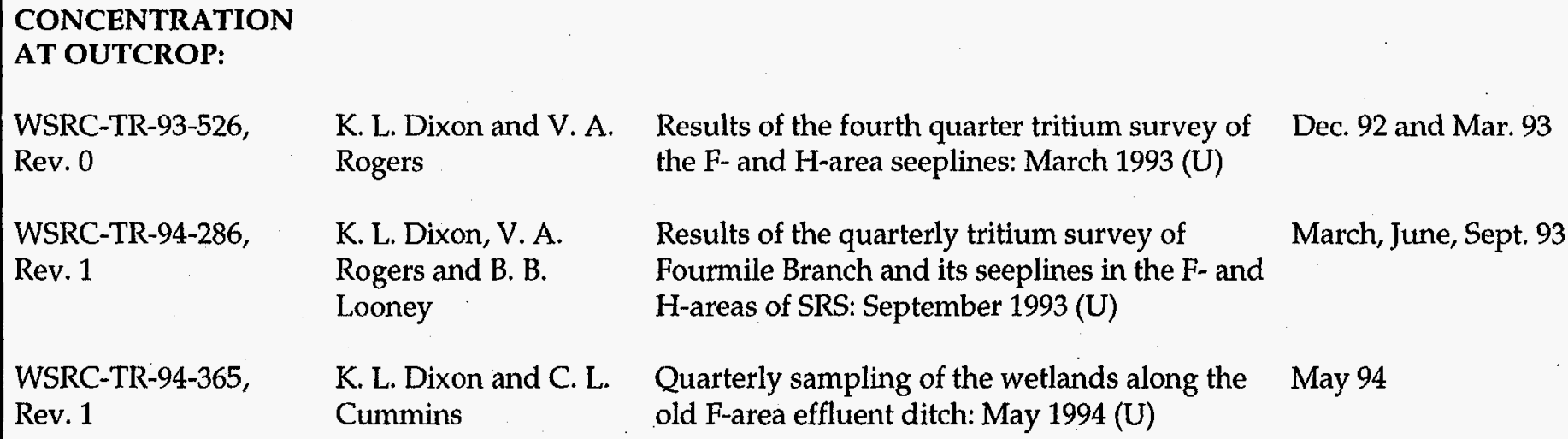

WSRC-TR-93-526,

Rev. 0

L. Dixon and V. A.

Rogers

Results of the fourth quarter tritium survey of

the F- and H-area seeplines: March 1993 (U)

WSRC-TR-94-286,

K. L. Dixon, V. A.

Rev. 1

Rogers and B. B.

Looney

Results of the quarterly tritium survey of

Fourmile Branch and its seeplines in the F- and

H-areas of SRS: September 1993 (U)

WSRC-TR-94-365,

K. L. Dixon and C. L.

Rev. 1

Cummins

Quarterly sampling of the wetlands along the old F-area effluent ditch: May 1994 (U)

Dec. 92 and Mar. 93

March, June, Sept. 93

May 94

Radionuclides in 643G ground water - 1973-76 OBG grid well data and interpretation; 452000 gal pumped from $\mathrm{G} 21$. $300 \mathrm{pCi} / \mathrm{ml}$ peak background. $60 / 40$ split between west and east. Hypothesis that waste forms in west end leach tritium

Radioactivity trends in Burial Grounds wells 1975-1976

year percolation time?

Annual summary of burial ground grid well assays -1977

Annual summary of burial ground grid well assays -1978

Annual summary of burial ground grid well assays - 1979 
Table $8 . \quad$ (cont'd)

DPST-81-643 J. W. Fenimore

DPST-83-1033

DPST-84-605

DPST-85-353

Stone Weimorts
R. H. Emslie, P. M.

Weimorts and J. A.

R. H. Emslie and P.M. Subsurface monitoring of groundwater at the

J. A. Stone and P. M.

Weimorts
Annual summary of burial ground grid well assays -1980

Subsurface monitoring of groundwater at the SRP burial grounds: 1981-1982 summary of grid well assays SRP burial grounds: 1983 summary of grid well assays

Subsurface monitoring of groundwater at the SRP burial ground: 1984 summary of grid well assays
OBG grid well data and interpretation. F-effluent repair completed Nov. 1980. Detailed description of repair.

OBG grid well data and interpretation. Second coring of tritium plume at repair site.

OBG grid well data and interpretation. G-34 now dominant.

OBG grid well data and interpretation. References soil coring done by G21 (G21A,B,P?).

\section{OBG}

GROUNDWATER

FLOW:

DPST-76-265 J. W. Fenimore $\quad$ 643-G ground water flow path

DPST-79-265

E. L. Albenesius and

J. W. Fenimore
Tritium migration from the burial ground to Four Mile Creek - Reappraisal of flow paths and travel times
Grid wells southwest of OBG indicate discharge to eroded F-effluent drainage instead of Fourmile Branch. Repairs recommended.

Summary of logic leading to stream repair. $\sim 1000 \mathrm{Ci} /$ yr discharge around 1979. Repair predicted to practically eliminate discharges. Without repair maximum discharge predicted to be $4000 \mathrm{Ci} / \mathrm{yr}$. Tracer tests are described.

\section{OFFSITE PAPERS:}

DP-MS-68-23
J. W. Fenimore
Tracing soil moisture and groundwater flow at the Savannah River Plant 
Table 8. (cont'd)

\begin{tabular}{|c|c|c|c|}
\hline DP-MS-75-25 & R. H. Hawkins & $\begin{array}{l}\text { Migration of tritum from a nuclear waste } \\
\text { burial site }\end{array}$ & $\begin{array}{l}\text { Early discussion of spent melt immersion and } \\
\text { lysimeter experiments. }\end{array}$ \\
\hline DP-MS-82-61 & $\begin{array}{l}\text { J. A. Stone, J. W. } \\
\text { Fenimore, R. H. } \\
\text { Hawkins, S. B. Oblath } \\
\text { and J. P. Ryan Jr. }\end{array}$ & $\begin{array}{l}\text { Shallow land burial of solid low-level } \\
\text { radioactive wastes - } 30 \text { years of experience at } \\
\text { the Savannah River Plant }\end{array}$ & Summary document. Kd's. \\
\hline DP-MS-83-89 & $\begin{array}{l}\text { J. A. Stone, S. B. } \\
\text { Oblath, R. H. } \\
\text { Hawkins, R. H. } \\
\text { Emslie, J. P. Ryan Jr. } \\
\text { and C. M. King }\end{array}$ & $\begin{array}{l}\text { Migration studies at the Savannah River Plant } \\
\text { shallow land burial site }\end{array}$ & $\begin{array}{l}\text { Overview of subsurface monitoring, } \\
\text { lysimeters, soil-water chemistry. }\end{array}$ \\
\hline DP-MS-84-82 & $\begin{array}{l}\text { J. A. Stone, S. B. } \\
\text { Oblath, R. H. } \\
\text { Hawkins, R. H. } \\
\text { Emslie, S. L. Hoeffner } \\
\text { and C. M. King }\end{array}$ & $\begin{array}{l}\text { Radionuclide migration studies at the } \\
\text { Savannah River Plant humid shallow land } \\
\text { burial site for low-level waste }\end{array}$ & $\begin{array}{l}\text { Soil cores around G-21 indicate that most } \\
\text { tritium does NOT arise near G-21 but from } \\
\text { more distant and easterly sources (G-34 area?). } \\
\text { Spent melts have released most of tritium and } \\
\text { plume has moved far from source. Kd's. }\end{array}$ \\
\hline DP-MS-85-86 & $\begin{array}{l}\text { J. A. Stone, S. B. } \\
\text { Oblath, R. H. } \\
\text { Hawkins, M. W. } \\
\text { Grant, S. L. Hoeffner } \\
\text { and C. M. King }\end{array}$ & $\begin{array}{l}\text { Waste migration studies at the Savannah River } \\
\text { Plant burial ground }\end{array}$ & Mainly discusses the various lysimeter studies. \\
\hline \multicolumn{4}{|c|}{$\begin{array}{l}\text { TRITIUM } \\
\text { LYSIMETERS: }\end{array}$} \\
\hline DPST-81-548 & R. H. Hawkins & $\begin{array}{l}\text { Tritium released from spent melts by water } \\
\text { immersion }\end{array}$ & $\begin{array}{l}\text { Immersion test results. References basis for } \mathrm{Ci} \\
\text { content of spent melts. }\end{array}$ \\
\hline DPST-85-384 & $\begin{array}{l}\text { M. W. Grant and R. H. } \\
\text { Hawkins }\end{array}$ & Results of the spent melt lysimeter experiment & $\begin{array}{l}\text { Results, hypotheses and conclusions at } \\
\text { experiment completion. }\end{array}$ \\
\hline DPSTN-4363 & M. W. Grant & duPont Lab Notebook issued 19Apr85 & $\begin{array}{l}\text { Contains raw data from spent melt lysimeter } \\
\text { experiment. }\end{array}$ \\
\hline
\end{tabular}


Table 8. (cont'd)

WSRC-TR-91-597 A. D. Yu and J. R. An estimation of tritium inventory limits for Cook the E-area vaults $(\mathrm{U})$

Contains a fit to the tritium lysimeter data using a leaching model. See Figure 4 and Appendix B.

\section{SS DIFFUSIVITY:}

J. Nucl. Mat., v43, 119- J. H. Austin and T. S. Tritium diffusion in 304- and 316-stainless 125,1972 Elleman steels in the temperature range 25 to $222 \mathrm{C}$

J. Nucl. Mat., v211, $156-167,1994$

A. Roustila, N. Kuromoto, A. M. Brass and J. Chene

Quantitative analysis of tritium distribution in austenitic stainless steels welds

See Figure 4.

See page 160.

Nucl. Tech., v26, 192- M. R. Louthan Jr., J. A. Tritium absorption in Type 304L stainless steel 200,1975 Donovan and G. R.

Caskey Jr.

J. Nucl. Mat., v73, 77- P. M. Abraham, T. S. 88,1978 Elleman and $\mathrm{K}$. Verghese

J. Nucl. Mat., v85\&86, J. A. Swansiger and R. 335-339, $1979 \quad \therefore \quad$ Bastasz

J. Nucl. Mat., v85\&86, 257-269, 1979

V. A. Maroni and E. H. Van Deventer

Diffusion and trapping of tritium in grainboundaries of $304 \mathrm{~L}$ stainless steel

Not useful.

SRL data and correlation for SS.

-

Tritium and deuterium permeation in stainless Not useful. steels: influence of thin oxide films

Materials considerations in tritium handling systems

\section{AL/LI DIFFUSIVITY}

J. Nucl. Mat., v116,

$141-146,1983$

J. Nucl. Mat., v120,

267-271, 1984
M. Nakashima, $M$. Saeki, Y. Aratono and

E. Tachikawa

M. Saeki, M.

Nakashima, Y.

Aratono and $\mathrm{E}$.

Tachikawa
Diffusivity of tritium in $\mathrm{Li}-\mathrm{Al}$ alloys

See Figure 4. 


\section{UNSATURATED \\ ZONE:}

Soil Sci, v100, n6, 377383, 1965

Hawkins

water table

Soil Sci. Soc. Proc.

C. C. Haskell and R.

v28, 725-728, 1964

H. Hawkins

D2O-Na24 method for tracing soil moisture movement in the field

DPST-75-218 J. H. Horton $\quad \begin{aligned} & \text { Soil moisture flow as related to the burial of } \\ & \text { solid radioactive waste }\end{aligned}$
solid radioactive waste

Referenced in DPST-75-218.

Referenced in DPST-75-218.

"water flows in the unsaturated soil column at a rate of about 7 feet per year $(3,4)$ ".

\section{ANNOTATED}

BIBLIOGRAPHY:

\begin{tabular}{lll} 
Q-ESR-E-00001 & $\begin{array}{l}\text { J. P. Kanzleiter and T. } \\
\text { E. Rehder }\end{array}$ & $\begin{array}{l}\text { Mixed Waste Management Facility (MWMF) } \\
\text { Old Burial Ground (OBG) source control } \\
\text { technology \& inventory study (U) }\end{array}$ \\
\hline
\end{tabular}

\section{HISTORICAL}

INFORMATION:

140 ct80 memo

duPont, 1990

WSRC-RP-92-349 anonymous

W. P. Bebbington

H. P. Holcomb "a condensed history of SRP from 1950 to 1975"

History of duPont at the Savannah River Plant

Transcription of a presentation by Dr. E. L. Albenesius, "SRS burial ground operation from a historical perspective" (U) 
Table 8. (cont'd)

\begin{tabular}{|c|c|c|}
\hline WSRC-RP-89-1229 & $\begin{array}{l}\text { E. G. Orebaugh and R. } \\
\text { M. Wallace }\end{array}$ & $\begin{array}{l}\text { Quantification of hazards associated with the } \\
\text { decay storage/disposal of tritium crucibles }\end{array}$ \\
\hline \multicolumn{3}{|l|}{$\begin{array}{l}\text { ANNUAL } \\
\text { MONITORING } \\
\text { REPORTS: }\end{array}$} \\
\hline $\begin{array}{l}\text { DPSP-61-25-4 (deleted } \\
\text { version) }\end{array}$ & $\begin{array}{l}\text { Works Technical } \\
\text { Department }\end{array}$ & $\begin{array}{l}\text { Health physics regional monitoring } \\
\text { semiannual report, July through December } \\
1960\end{array}$ \\
\hline $\begin{array}{l}\text { DPSP-62-25-2 (deleted } \\
\text { version) }\end{array}$ & $\begin{array}{l}\text { Works Technical } \\
\text { Department }\end{array}$ & $\begin{array}{l}\text { Health physics regional monitoring } \\
\text { semiannual report, January through June } 1961\end{array}$ \\
\hline $\begin{array}{l}\text { DPSP-62-25-9 (deleted } \\
\text { version) }\end{array}$ & $\begin{array}{l}\text { Works Technical } \\
\text { Department }\end{array}$ & $\begin{array}{l}\text { Health physics regional monitoring } \\
\text { semiannual report, July through December } \\
1961\end{array}$ \\
\hline $\begin{array}{l}\text { DPSP-63-25-3 (deleted } \\
\text { version) }\end{array}$ & $\begin{array}{l}\text { Works Technical } \\
\text { Department }\end{array}$ & $\begin{array}{l}\text { Health physics environmental monitoring } \\
\text { semiannual report, January through June } 1962\end{array}$ \\
\hline $\begin{array}{l}\text { DPSP-63-25-10 } \\
\text { (deleted version) }\end{array}$ & $\begin{array}{l}\text { Works Technical } \\
\text { Department }\end{array}$ & $\begin{array}{l}\text { Health physics environmental monitoring } \\
\text { semiannual report, July through December } \\
1962\end{array}$ \\
\hline DPSPU-64-11-12 & $\begin{array}{l}\text { Works Technical } \\
\text { Department }\end{array}$ & $\begin{array}{l}\text { Health physics regional monitoring annual } \\
\text { report, } 1963\end{array}$ \\
\hline DPST-66-302 & C. Ashley & $\begin{array}{l}\text { Environmental monitoring at the Savannah } \\
\text { River Plant annual report - } 1965\end{array}$ \\
\hline DPST-67-302 & C. Ashley & $\begin{array}{l}\text { Environmental monitoring at the Savannah } \\
\text { River Plant annual report - } 1966\end{array}$ \\
\hline DPST-69-302 & C. Ashley & $\begin{array}{l}\text { Environmental monitoring at the Savannah } \\
\text { River Plant annual report - } 1968\end{array}$ \\
\hline
\end{tabular}

Talks about the decision to plug crucibles with epoxy. 
Table 8. (cont'd)

\begin{tabular}{|c|c|c|}
\hline DPST-70-302 & C. Ashley & $\begin{array}{l}\text { Environmental monitoring at the Savannah } \\
\text { River Plant annual report - } 1969\end{array}$ \\
\hline DPST-71-302 & C. Ashley & $\begin{array}{l}\text { Environmental monitoring at the Savannah } \\
\text { River Plant annual report - } 1970\end{array}$ \\
\hline DPSPU-72-302 & C. Ashley & $\begin{array}{l}\text { Environmental monitoring at the Savannah } \\
\text { River Plant annual report - } 1971\end{array}$ \\
\hline DPSPU-73-302 & $\begin{array}{l}\text { C. Ashley and C. C. } \\
\text { Zeigler }\end{array}$ & $\begin{array}{l}\text { Environmental monitoring at the Savannah } \\
\text { River Plant annual report - } 1972\end{array}$ \\
\hline DPSPU-74-302 & $\begin{array}{l}\text { C. Ashley and C. C. } \\
\text { Zeigler }\end{array}$ & $\begin{array}{l}\text { Environmental monitoring at the Savannah } \\
\text { River Plant annual report - } 1973\end{array}$ \\
\hline DPSPU-75-302 & $\begin{array}{l}\text { C. Ashley and C. C. } \\
\text { Zeigler }\end{array}$ & $\begin{array}{l}\text { Environmental monitoring at the Savannah } \\
\text { River Plant annual report - } 1974\end{array}$ \\
\hline DPSPU-76-302 & $\begin{array}{l}\text { C. Ashley and C. C. } \\
\text { Zeigler }\end{array}$ & $\begin{array}{l}\text { Environmental monitoring at the Savannah } \\
\text { River Plant annual report - } 1975\end{array}$ \\
\hline DPSPU-77-302 & $\begin{array}{l}\text { C. Ashley and C. C. } \\
\text { Zeigler }\end{array}$ & $\begin{array}{l}\text { Environmental monitoring at the Savannah } \\
\text { River Plant annual report }-1976\end{array}$ \\
\hline DPSPU-78-302 & $\begin{array}{l}\text { C. Ashley and C. C. } \\
\text { Zeigler }\end{array}$ & $\begin{array}{l}\text { Environmental monitoring at the Savannah } \\
\text { River Plant annual report - } 1977\end{array}$ \\
\hline DPSPU-79-302 & $\begin{array}{l}\text { C. Ashley and C. C. } \\
\text { Zeigler }\end{array}$ & $\begin{array}{l}\text { Environmental monitoring at the Savannah } \\
\text { River Plant annual report - } 1978\end{array}$ \\
\hline DPSPU-80-302 & $\begin{array}{l}\text { C. Ashley, C. C. } \\
\text { Zeigler, P. A. Culp } \\
\text { and D. L. Smith }\end{array}$ & $\begin{array}{l}\text { Environmental monitoring at the Savannah } \\
\text { River Plant annual report - } 1979\end{array}$ \\
\hline DPSPU-81-302 & $\begin{array}{l}\text { C. C. Zeigler, P. A. } \\
\text { Culp and D. L. Smith }\end{array}$ & $\begin{array}{l}\text { Environmental monitoring at the Savannah } \\
\text { River Plant annual report - } 1980\end{array}$ \\
\hline
\end{tabular}


Table 8. (cont'd)

DPSPU-82-302

DPSPU-83-302

DPSPU-84-302

DPSPU-85-302

DPSPU-86-30-1

DPSPU-87-30-1

DPSPU-88-30-1

WSRC-RP-89-59-1

WSRC-IM-90-60

WSRC-IM-91-28
C. Ashley and C. C. Zeigler

C. Ashley, P. C.

Padezanin and C. C. Zeigler

C. Ashley, P. C.

Padezanin and C. C. Zeigler

C. C. Zeigler, I. B.

Lawrimore and W. E.

O'Rear

C. C. Zeigler, I. B.

Lawrimore, E. M.

Heath and J. E. Till

C. C. Zeigler, E. M.

Heath, L. B. Taus and

J. L. Todd

S. C. Mikol, L. T.

Burckhalter, J. L.

Todd and D. K.

Martin

H. A. Davis, D. K. Martin and J. L. Todd

C. L. Cummins, D. K. Martin and J. L. Todd

C. L. Cummins, D. K. Martin and J. L. Todd
Environmental monitoring at the Savannah River Plant annual report - 1981

Environmental monitoring at the Savannah

River Plant annual report - 1982

Environmental monitoring at the Savannah

River Plant annual report - 1983

Environmental monitoring at the Savannah

River Plant annual report - 1984

U.S. Department of Energy Savannah River Plant environmental report, annual report for 1985

U.S. Department of Energy Savannah River Plant environmental repor, annual report for 1986

U.S. Department of Energy Savannah River Plant environmental report, annual report for 1987

Savannah River Site environmental report for $1988(\mathrm{U})$

Savannah River Site environmental report for 1989 (U)

1990 Savannah River Site environmental report (U) 
Table 8. (cont'd)

\begin{tabular}{|c|c|c|c|}
\hline WSRC-TR-92-186 & $\begin{array}{l}\text { M. W. Arnett, L. K. } \\
\text { Karapatakis, A. R. } \\
\text { Mamatey and J. L. } \\
\text { Todd }\end{array}$ & $\begin{array}{l}\text { Savannah River Site environmental report for } \\
1991 \text { (U) }\end{array}$ & . \\
\hline WSRC-TR-93-75 & $\begin{array}{l}\text { M. W. Arnett, L. K. } \\
\text { Karapatakis and A. R. } \\
\text { Mamatey }\end{array}$ & $\begin{array}{l}\text { Savannah River Site environmental report for } \\
1992\end{array}$ & \\
\hline WSRC-TR-94-77 & M. W. Arnett & $\begin{array}{l}\text { Savannah River Site environmental data for } \\
1993\end{array}$ & \\
\hline $\begin{array}{l}\text { ESH-EMS-95-251, } \\
\text { Rev. } 1\end{array}$ & C. W. Worley & $\begin{array}{l}\text { Fourth quarter } 1994 \text { tritium inventory in } \\
\text { Savannah River Site streams and the Savannah } \\
\text { River (U) }\end{array}$ & \\
\hline \multicolumn{4}{|l|}{ DRAWINGS: } \\
\hline S5-6-308 & & Burial ground trench layout, sheet no. 1 & Western portion. \\
\hline S5-6-309 & & Burial ground trench layout, sheet no. 2 & Central portion. \\
\hline S5-6-310 & & Burial ground trench layout . & Eastern portion. \\
\hline
\end{tabular}


Table 9. Outline of literature information relevant to tritium transport from the Old Burial Ground to Fourmile Branch.

-Operations

-"burial ground used continuously since 1953" (DPST-70-460)

-Designated 1954 (140ct08 memo)

-Pre-COBRA operation (Fenimore Health Physics paper)

-Trenches are 20 feet deep with minimum of 4 feet of soil cover (DPST-70-460)

-F-effluent repair (DPST-81-643)

- Inventory

$-452 \mathrm{k}$ gallons pumped from G21. (Fenimore report)

-Total amounts

- Spatial and temporal distribution

-SWC tracer study implications (DPST-82-725)

BEBBINGTON CHRONOLOGY:

- "Initial construction included a small facility (232-F) in F Area and a larger facility (232-H) in H Area..." (p. 38)

- "In October of 1955, the facility for extracting tritium from irradiated targets started up." (p. 53)

-"By 1955, however, defense needs required greater production of tritium..." (p. 66)

-see reactor power figures, pp. 69-70. Roughly linear increase

between 1954 and 1958 .

-"The first small facility for the recovery of tritium from irradiated lithium-aluminum control-rod slugs started up in 232-F building in October 1955. In July 1957 a larger tritium facility began operation in 232-H. In 1958 the capacity of 232-H was doubled." (p. 72)

- "In 1956, construction resumed in H Area of a tritium separations facility $(232-\mathrm{H})$... By the end of the year the second tritium production line in $232-\mathrm{H}$ was operating." (p. 112) CONFLICT!

- "Tritium continued to be separated and purified in both 232-F and 232-H until August of 1958 when a new, higher-capacity separations line, 232-H-2, went into service. In October the F-Area tritium facility was shut down permanently. Later it was found possible to operate with $232-\mathrm{H}-2$ alone." (p. 113)

-Drawings

-Release mechanism( $s$ )

-Tritium lysimeter data

- Diffusion models and parameters

-Hyder's hypothesis - sources in west and east (WSRC-TR-93-316)

-Fenimore's hypothesis - sources in west and east (Fenimore doc.)

-Albenesius' hypothesis - spent melts are source (WSRC-RP-92-349)

-Groundwater concentrations

-Grid wells

-BG, BGO, etc. (EMS database)

-Cone penetrometer and HydroPunch

- Seepline

-Max $64000 \mathrm{pCi} / \mathrm{ml}, 6000$ at seepline in -1980 (DPST-82-725)

-Estimated 1980 and 1981 plume boundaries

(DPST-83-829 \& WSRC-RP-90-1140)

-Considerable stratification, higher concentrations deeper,

$90 \%$ below well screen (DPST-79-45.2, DPST-85-353, DP-MS-84-82)

-Discharge to F-effluent ditch

-Stream monitoring data (Annual monitoring reports, 1968-93)

$-850 \mathrm{Ci} / \mathrm{yr}$. estimate around 1980?' (DPST-82-725)

-Projected discharges (WSRC-RP-93-459) 
Table 10 Comparison of groundwater tritium inventories estimated from monitoring data and predicted from transport modeling (base and sensitivity cases).

\begin{tabular}{|c|c|c|c|}
\hline Calendar year & Monitoring data & $\begin{array}{c}\text { Transport model } \\
\text { base case } \\
\left(10^{3} \mathrm{C}\right)\end{array}$ & $\begin{array}{c}\text { Transport model } \\
\text { sensitivity case } \\
\left(10^{3} \mathrm{C}\right)\end{array}$ \\
\hline 1973 & 4 & 608 & 1329 \\
\hline 1974 & 21 & 602 & 1317 \\
\hline 1975 & 25 & 592 & 1291 \\
\hline 1976 & 82 & 580 & 1255 \\
\hline 1977 & 77 & 566 & 1213 \\
\hline 1978 & 256 & 551 & 1166 \\
\hline 1979 & 73 & 535 & 1117 \\
\hline 1980 & 111 & 517 & 1066 \\
\hline 1981 & 92 & 500 & 1014 \\
\hline 1982 & 50 & 481 & 963 \\
\hline 1983 & 42 & 463 & 912 \\
\hline 1984 & 95 & 444 & 863 \\
\hline 1985 & 149 & 426 & 815 \\
\hline 1986 & 204 & 408 & 769 \\
\hline 1987 & 424 & 389 & 725 \\
\hline 1988 & 233 & 371 & 682 \\
\hline 1989 & 99 & 354 & 642 \\
\hline 1990 & 187 & 336 & 604 \\
\hline 1991 & 177 & 320 & 567 \\
\hline 1992 & 35 & 303 & 533 \\
\hline 1993 & 39 & 287 & 500 \\
\hline 1994 & 52 & 272 & 469 \\
\hline & & & \\
\hline
\end{tabular}




\section{Appendix}

\section{List of Tables}

A1 Lithologic description of OFS-3SB core....................................................190

A2 Stream coordinate and elevation data for Fourmile Branch and F-area outfalls

A3 Laboratory hydraulic conductivity as a function of mud fraction for SRS Tertiary-aged sediments

A4 Time-averaged well hydraulic head data for the "upper" aquifer zone within the Upper Three Runs aquifer

A5 Time-averaged well hydraulic head data for the "lower" aquifer zone within the Upper Three Runs aquifer

A6 Time-averaged well hydraulic head data for the Gordon aquifer..........217

A7 Hydraulic head data used to create a head contour map for the "upper" aquifer zone (Figure 14).

A8 Hydraulic head data used to create a head contour map for the "lower" aquifer zone (Figure 15)

A9 Hydraulic head data used to create a head contour map for the Gordon aquifer (Figure 16).

A10 Hydraulic head targets used to calibrate flow model and residuals......239 
Table A1. Lithologic description of OFS-3SB core.

Column headings are defined as follows:

$\begin{array}{lll}\text { Heading } & \text { Top elevation } & \\ \text { UAT } & \text { "upper" aquifer zone } & \text { ("upper" aquifer top) } \\ \text { UAB } & \text { "tan clay" confining zone } & \text { ("upper" aquifer bottom) } \\ \text { LAT } & \text { "lower" aquifer zone } & \text { ("lower" aquifer top) } \\ \text { LAB } & \text { Gordon confining unit } & \text { ("lower" aquifer bottom) } \\ \text { GAT } & \text { Gordon aquifer } & \text { (Gordon aquifer top) } \\ \text { GAB } & \text { Meyers Branch confining system } & \text { (Gordon aquifer bottom) }\end{array}$

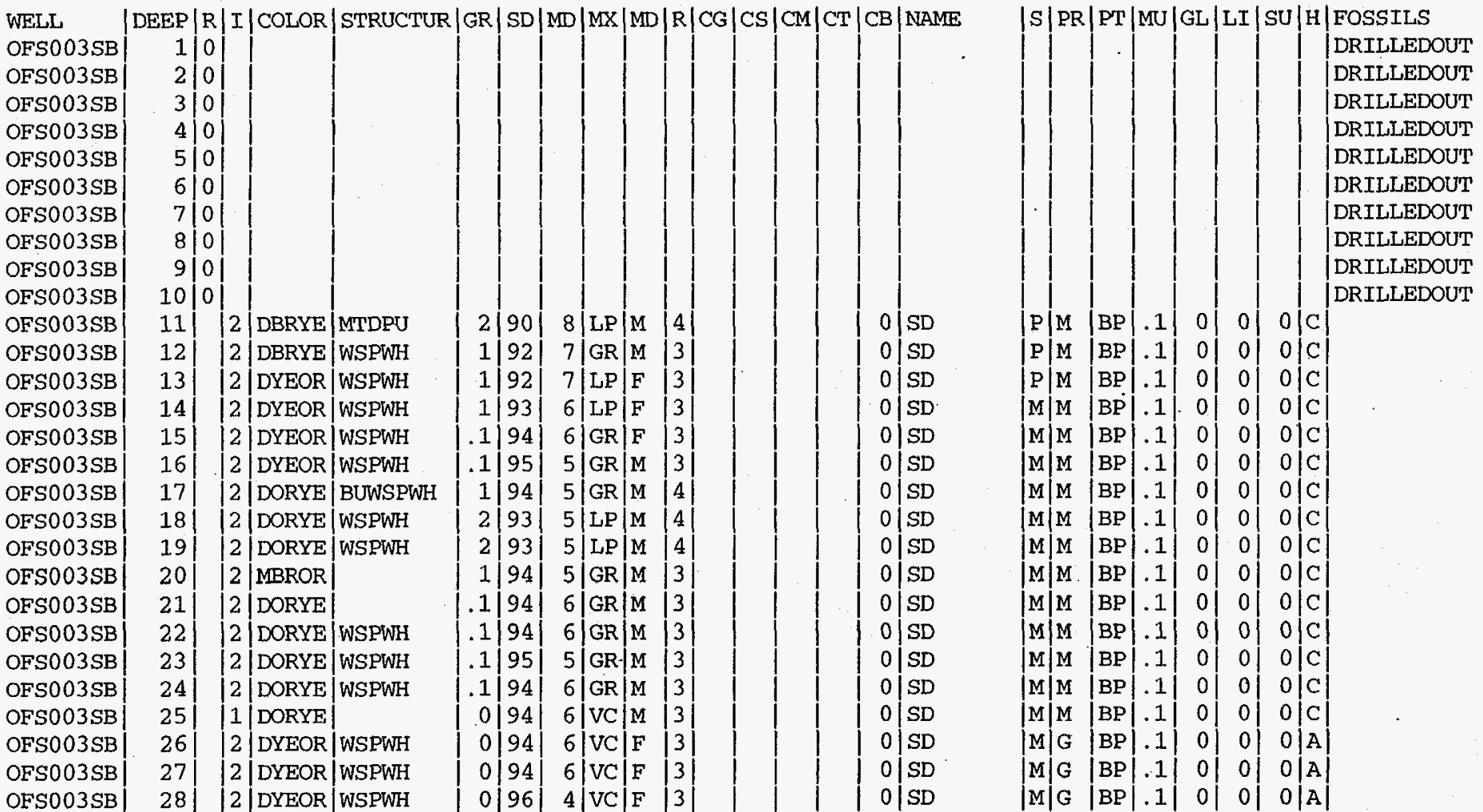


Table A1. (cont'd)

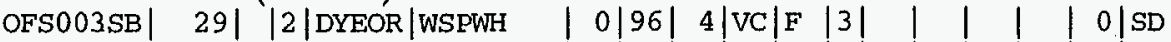

(1)

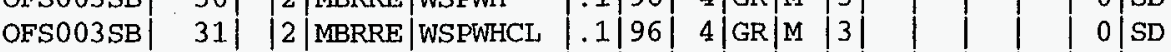

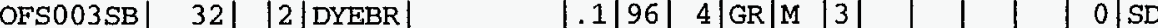

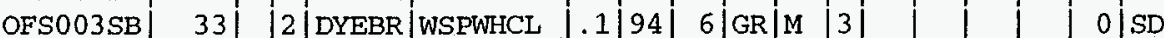

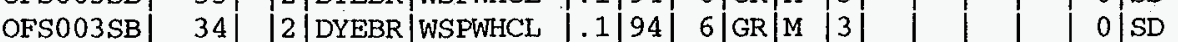

\begin{tabular}{ll|l|l|l|l|l|l|l|l|l|l|l|l|l|l|} 
&
\end{tabular}

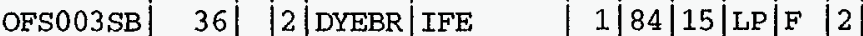

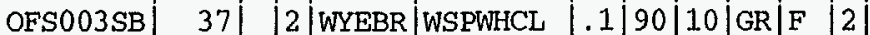

\begin{tabular}{l|l|l|l|l|l|l|l|l|l|l|l|l|} 
OFS003SB & 38 & 2 & MYEBR IWHCL & $\mid .1$ & 85 & 15 & GR & M & 3
\end{tabular}

OFS003SB $\quad 39 \mid$ |2|DYEOR |WSPWHCL $1.1|85| 15 \mid$ GR $|M| 3 \mid$

\begin{tabular}{ll|l|l|l|l|l|l|l|l|l|l|l|l|} 
OFS003SB & 40 & 2 & DYEOR IWHCL & 2 & 68 & 30 & GR & M & 3 \\
\hline
\end{tabular}

\begin{tabular}{ll|l|l|l|l|l|l|l|l|l|l|l|l|l|} 
&
\end{tabular}

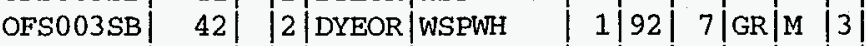

\begin{tabular}{ll|l|l|l|l|l|l|l|l|l|l|l|l|l|} 
&
\end{tabular}

\begin{tabular}{ll|l|l|l|l|l|l|l|l|l|} 
OFS003SB & 44 & 2 & 1 & DYEOR & WSPWH & $1 / 92$ & $7 / G R$ & M & 3
\end{tabular}

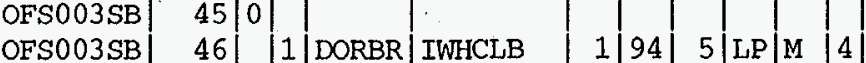

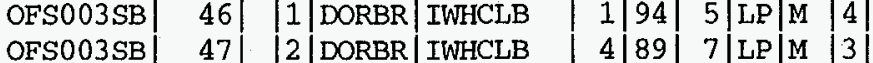

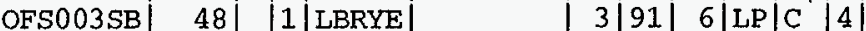

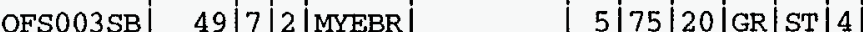

OFS003SB 5010

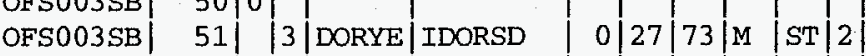

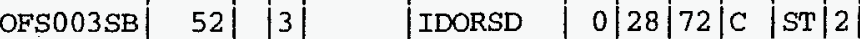

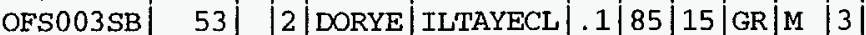

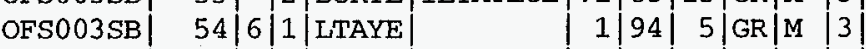

OFS003SB $55|0|$

OFS003SSB $\quad 56 \mid 0$

OFS003SB $57 \mid 0$

OFS003SB 5810

OFS003SB $\quad 59|4| 2 \mid$ LTAYE

OFS003SB 60 |0

OFS003SB $61|1|$ DBROR

OFS003SB 62 1 1 DYEOR ILTACL

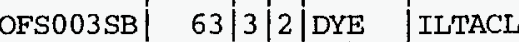

OFS003SB

OFS003SB

OFS003SB

OFS003SB

OFS003SB

OFS003SB

OFS003SB

OFS003SB

OFS003SB

OFS003SB
$64|0|$

$65 \mid 0$

66 6 2 2 DYEOR IDTACL

$67|0|$

68 2 DBROR

69 2 DTA IDORSD

111

$0|60| 40|\mathrm{C}| \mathrm{ST}|3|$

1 1 94 5 GR M 3

$.1|90| 10 / U P|M| 3 \mid$

$.1|60| 40|\mathrm{GR}| \mathrm{M}|3|$

$1|79| 20|\mathrm{GR}| \mathrm{M}|3|$

$\left.2|88| 10\right|_{\mathrm{GR}} \mathrm{C}_{\mathrm{C}}$

$0|45| 55 \mid C$ IST 3

0.15 85 C

$0|10| 90|\mathrm{M}| \mathrm{CL}|3|$

71) 3 DYETA FS

$0|15| 85|\mathrm{M}| \mathrm{CL}|3|$

73| 2 |DBRYE|IFSTACL | 2 |68|30|GR|C $|4|$

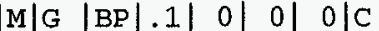

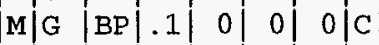

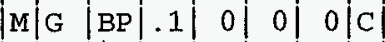

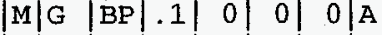

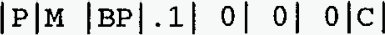

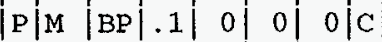

$|\mathrm{P}| \mathrm{M}|\mathrm{BP}| .1 \mid$\begin{tabular}{lll|l}
0 & 0 & $0 \mid \mathrm{C}$
\end{tabular}

\begin{tabular}{l|l|l|l|l|l|l|l|}
$\mathrm{P} \mid \mathrm{P}$ & $\mathrm{BP}$ & .1 & 0 & 0 & 0 & $\mathrm{R}$
\end{tabular}

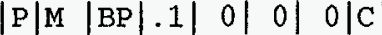

\begin{tabular}{|l|l|l|l|l|l|l|l|l}
$\mathrm{P} \mid \mathrm{M}$ & $\mathrm{BP}$ & 1 & 0 & 0 & $0 \mid \mathrm{R}$
\end{tabular}

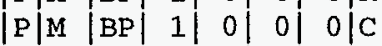

\begin{tabular}{l|l|l|l|l|l|l|l|l}
\hline $\mathrm{P}$ & $\mathrm{P}$ & $\mathrm{BP}$ & 1 & 0 & 0 & 0 & $\mathrm{C}$
\end{tabular}

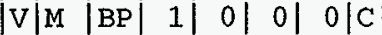

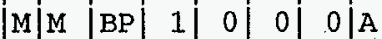

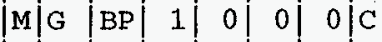

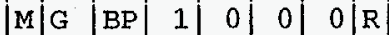

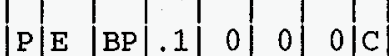

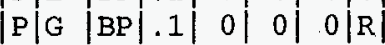

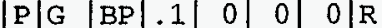

\begin{tabular}{ll|l|l|l|l|l|l}
\hline P & $\mathrm{P}$ & $\mathrm{BP}$ & .1 & 0 & 0 & 0 & $\mathrm{R}$ \\
\hline
\end{tabular}

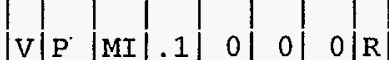

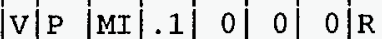

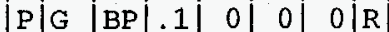

$|\mathrm{M}| \mathrm{E}|\mathrm{BP}| \mathrm{1}|\mathrm{0}| \mathrm{0}|\mathrm{0}| \mathrm{R}$

$0 \mid S D$

$0 \mid S D$

SD

SD

$\mathrm{SD}$

$0 /$ CLSD

SD

0 SD.

$0 / \mathrm{SD}$

$0 \mid$ CLSD

CLSD

SD

$0 \mid S D$

SD

$0 \mid S D$

$0 \mid$ SDCL

$0 \mid \mathrm{CL}$

$0 / \mathrm{CL}$

$0 \mid \mathrm{CL}$

o/CLSD

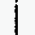

IVI

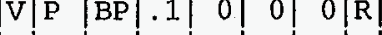

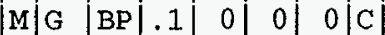

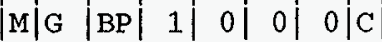

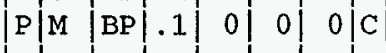

- 1 ISHELBYTUBE

M|M

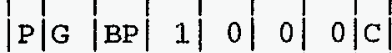

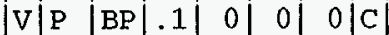

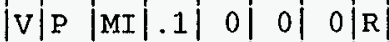

$|V| P|M I| .1 \mid$\begin{tabular}{llll} 
& 0 & 0 & $0 \mid R$ \\
\hline
\end{tabular}

V|P $|\mathrm{MI}| .1 \mid$\begin{tabular}{lll|l|l} 
& 0 & 0 & 0 & $\mathrm{R}$ \\
\hline
\end{tabular}

$|\mathrm{P}| \mathrm{P}|\mathrm{BP}| .1 \mid \begin{array}{llll}0 & 0 \mid & 0 \mid \mathrm{C}\end{array}$ 
Table A1. (cont'd)

OFS003SB $\quad 74|5| 2 \mid$ MBRGN|WSPBKGN $|.1| 80|20| G R|M| 3|0| 99|0| 0|.1|$ SD $\quad|\mathrm{P}| \mathrm{M}|\mathrm{BP}| .1|0| 0|0| 0|\mathrm{C}|$

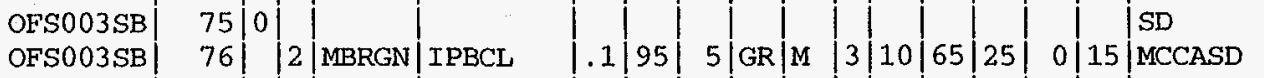

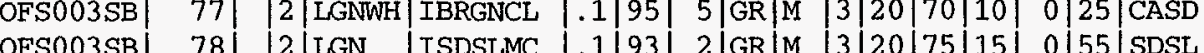

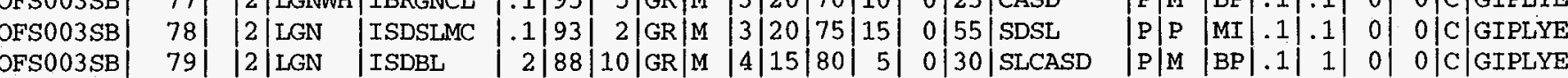

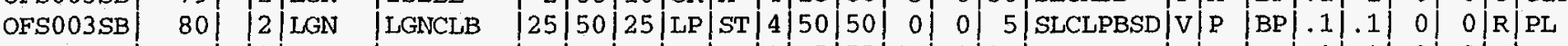

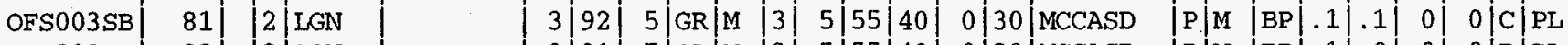

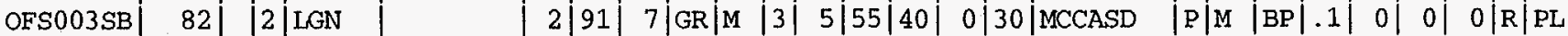

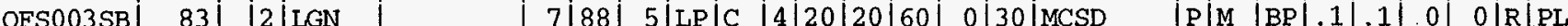

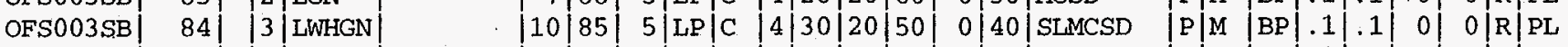

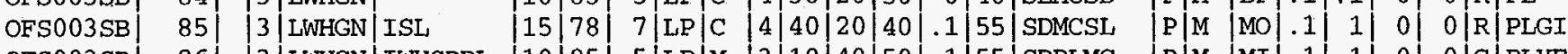

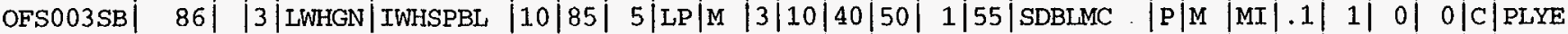

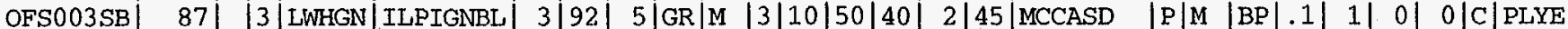

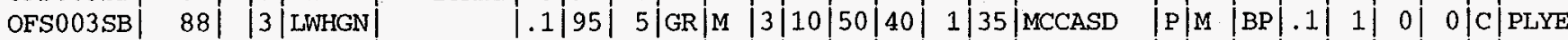

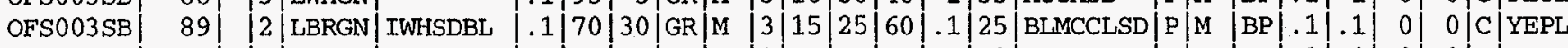

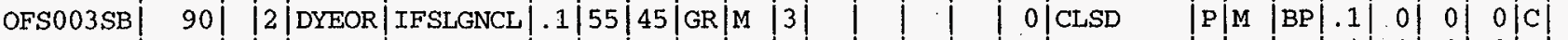

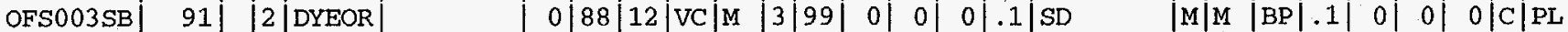

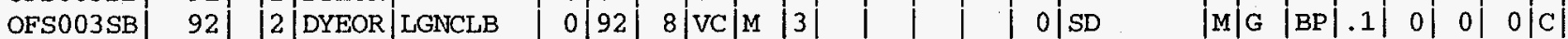

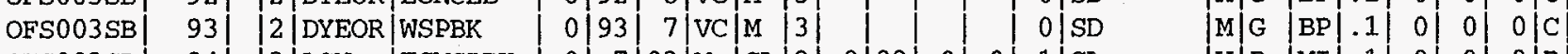

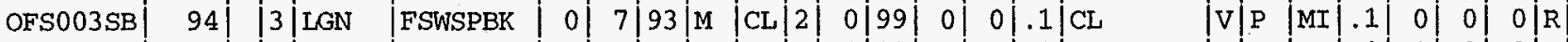

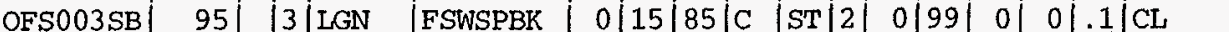

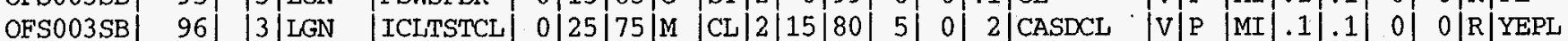

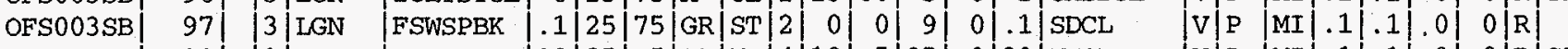

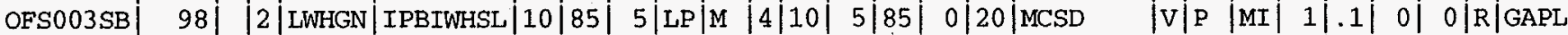

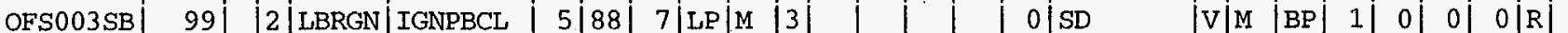

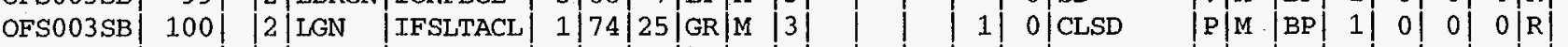

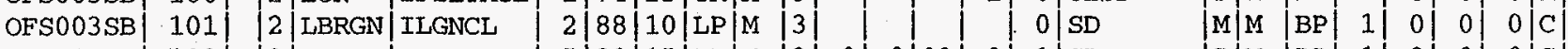

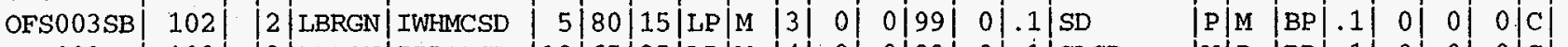

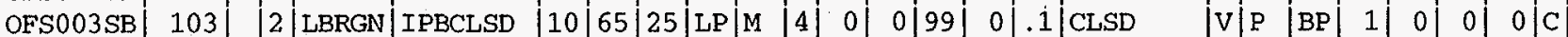

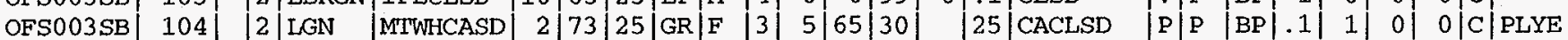

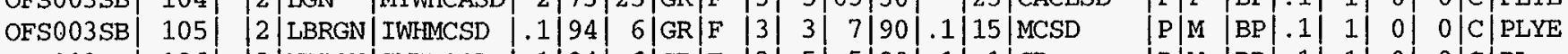

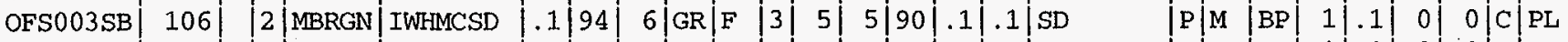

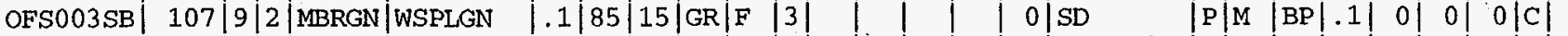

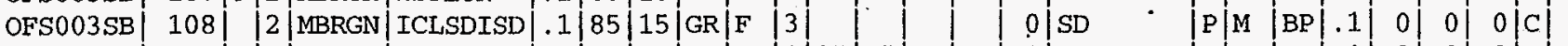

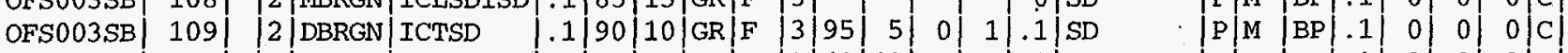

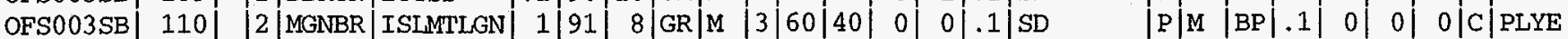

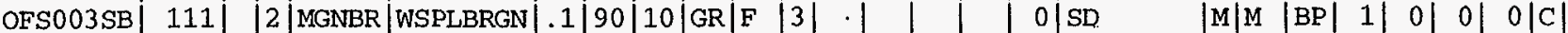

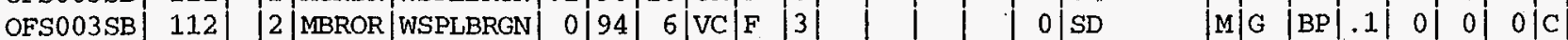

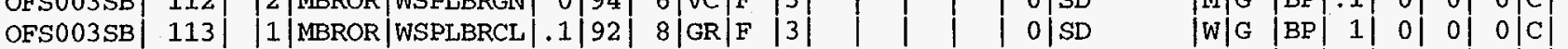

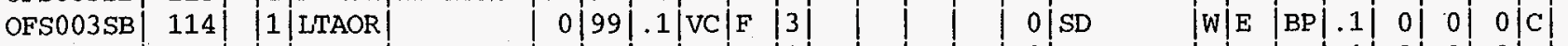

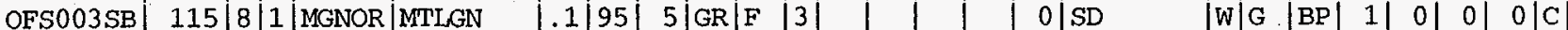

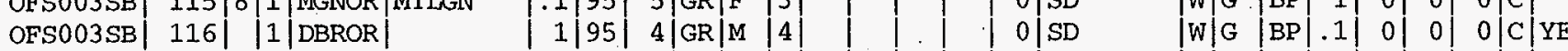

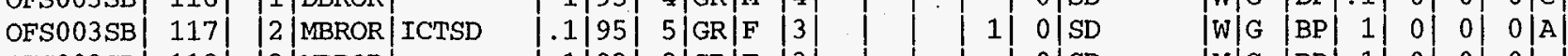

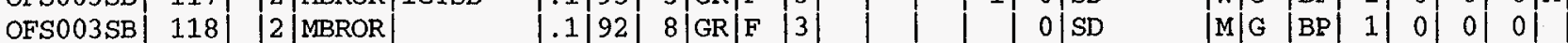


Table A1. (cont'd)

OFS003SB $119 \mid$ | 2 |MBROR|WSPGNGY

OFS003SB 12010

OFS003SB 121 (2) 2 DBROR/WSPWHCL $1.1 / 90 \mid 10 / \mathrm{GR} / \mathrm{M} / 4$

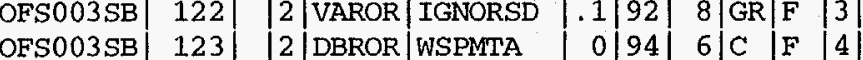

OFS003SB 124 |0।

OFS003SB $125|0|$

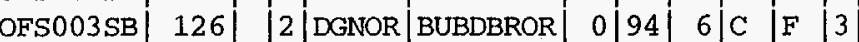

OFS003SB $127 / 9|2| D G N O R$

OFS003SB $128 \mid$ |2|DGNOR

OFS003SB $129|4| 3 \mid$ DGNOR |ICTSD

OFS003SB $130|0|$

OFS003SB 131 | 1 MBROR

OFS003SB $132|2| \mathrm{MBROR} \mid$

OFS003SB $133 \mid$ | 2 |MBROR

\begin{tabular}{ll|l|l|l|l|l|l|l|l|l|l|l|l|} 
&
\end{tabular}

OFS003SB $\quad 135|3| 2 \mid$ DBROR $/$ MTLBRGN

OFS003SB $136 / 0 \mid$

OFS003SB $137|0|$

OFS003SB 138| |2|MGYGN

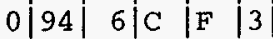

$0|96| 4|\mathrm{C}| \mathrm{F}|3|$

$0|90| 10|\mathrm{C}| \mathrm{F}|3|$

$1|95| 4|G R| C|4|$

$1|95| 4|\mathrm{GR}| \mathrm{C}|4|$

1 74 $25|\mathrm{GR}| \mathrm{F}$

$1|59| 40 \mid$ GR $|F| 2 \mid$

\begin{tabular}{|l|l|l|l|l|l|}
2 & 68 & 40 & $\mathrm{GR}$ & $\mathrm{ST}$ & 3
\end{tabular}

\begin{tabular}{l|l|l|l|l|l|l|l|l|l|l|l|l|l|l|l|l|l|l|l|} 
&
\end{tabular}

OFS003SB 140 O0।

OFS003SB 141\%|

OFS003SB 142 O

OFS003SB 143 | 1 DBROR BDORBR

OFS00.3SB 144 | 1 |MYEOR

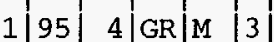

$0|99| 1|C| F|3|$

OFS003SB 145 |1|LORTA|ILGNGYSD 1 1|99|.1|GR|M |4

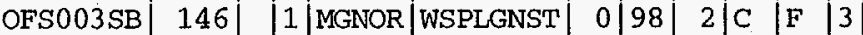

\begin{tabular}{l|l|l|l|l|l|l|l|l|l|l|l|l|l|l|l|} 
OFS003SB & 147 & 2 & DORYE & BMORBLBR & 0 & 99 & 1 & $\mathbf{C}$ & $\mathbf{F}$ & 3
\end{tabular}

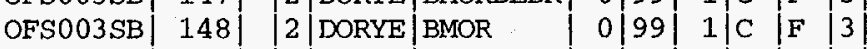

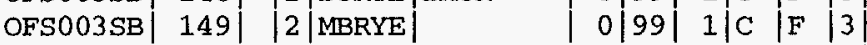

OFS003SB $150|\quad 2|$ MBRYE $|\quad 0| 99|1| C|F| 3 \mid$

OFS003SB $151|2|$ MBRYE $\quad$ |.1|97| 3/GR/F 2

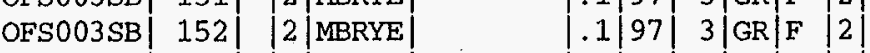

\begin{tabular}{ll|l|l|l|l|l|l|l|l|l|l|l|l|l|l|} 
OFS003SB & 153 & 2 & DORYE & BLGY & |.1|99| & 1 |GR & F & 2
\end{tabular}

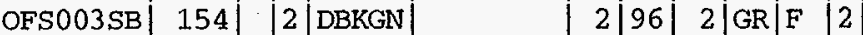

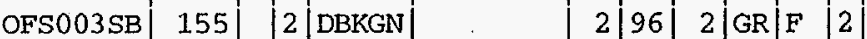

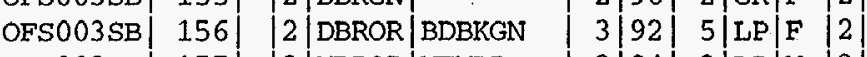

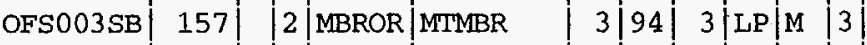

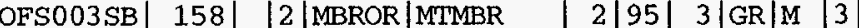

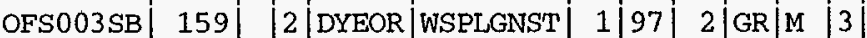

OFS003SB 160| |1|MTAOR| |1|98| 1 GR/M $|3|$

OFS003SB $161|1|$ MTAOR $\quad$ |.1|98| 2 |GR|M $|3|$

OFS003SB $162|1|$ MTAOR $\quad 00|99| 1|\mathrm{VC}| \mathrm{M} \mid 3$

OFS003SB $163 \mid$ | 1 |MTAOR
$0|99| 1|V C| M|3|$
I $0 \mid S D$

$0 \quad \mathrm{SD}$

$0 \mid S D$

$0 . \mathrm{SD}$

SD

SD

$0 / S D$

$0 \mid \mathrm{SD}$

1) $0 / \mathrm{SD}$

SD

$0 \mid$ SD

$0 \mid \mathrm{SD}$

$0 \mid \mathrm{SD}$

$1010 /$ CLSD

3) $0 /$ CLSD

CLSD

CLSD

0 SD

SD

SD

$0 . \mathrm{SD}$

$0 \mid S D$

$0 \mid \mathrm{SD}$

$0 \mid \mathrm{SD}$

$0 \mid S D$

$0 \mid \mathrm{SD}$

$0 \mid \mathrm{SD}$

$0 \mid S D$

$0 \mid S D$

$0 \mid \mathrm{SD}$

$0 \mid S D$

$0 / \mathrm{SD}$

이 SD

$0 \mid$ SD

O) SD

$0 \mid S D$

$0 \mid S D$

$0 / \mathrm{SD}$

$0 \mid S D$

0 SD

$0 \mid \mathrm{SD}$

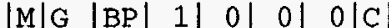

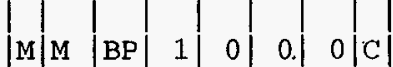

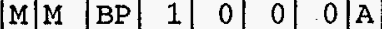

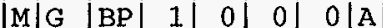

W/G WI

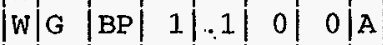

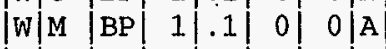

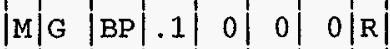

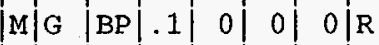

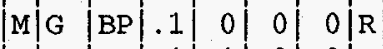

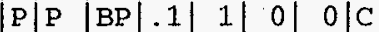

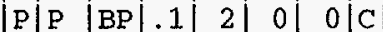

11191 I SHELBYTUBE

\begin{tabular}{llll|l|l|l|l}
\hline$P$ & $P$ & $B P$ & 1 & 2 & 0 & 0 & \\
\hline
\end{tabular}

IW|G

1111111

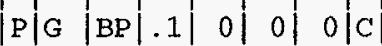

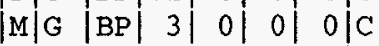

$|W| \mathrm{E}|\mathrm{BP}| .1 \mid \begin{array}{llll}0 & 0 & 0 & 0 \mid \mathrm{C}\end{array}$

W $G$ BP 3 (

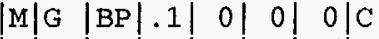

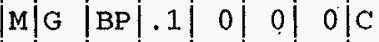

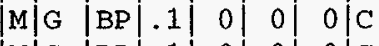

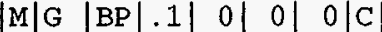

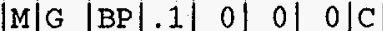

$|\mathrm{M}| \mathrm{G}|\mathrm{BP}| .1 \mid$ o| $0 \mid \begin{array}{lll} & 0 \mid \mathrm{C}\end{array}$

IM|G |BP|.1| $0 \mid$\begin{tabular}{lll}
0 & $0 \mid \mathrm{C}$ \\
\hline
\end{tabular}

P E E

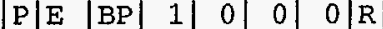

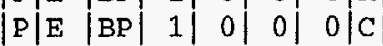

$|P| E|B P| .1|0| 0|0| 0|C|$

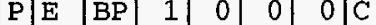

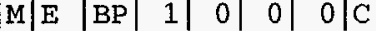

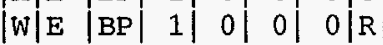

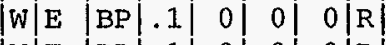

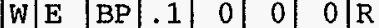

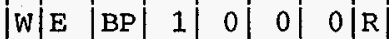


Table A1. (cont'd)

OFS003SB| 164| |1|MTAOR| OFS003SB $165|0|$

OFS003SB $166|2| 1 \mid$ MBROR

OFS003SB $167|0|$

OFS003SB 168| 1 DTAOR

OFSO03SB 169 | 1 DTAOR

OFS003SB $170|\quad 1|$ DTAOR

OFS003SB 171 1 DYEOR

OFS003SB 172 | 1 |DYEOR

OFS003SB 173 | 1 |DYEOR

OFSO03SB 174| 1 |DYEOR |

OFSO03SB 1750

OFSO03SB $176 \mid$ |1|DYEOR|DORCLB

OFS003SB 177| 1.DYEOR

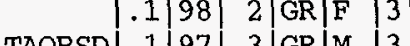

OFS003SB $179|0|$

OFS003SB 180|0

OFS003SB 181 1 MORYE

OFSO03SB 182 | 1 |MORYE

OFSO03SB 183 | 1 MORYE

OFSO03SB 184 |2|MORYE

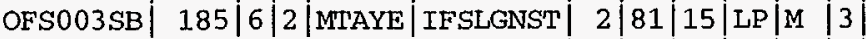

OFS003SB $186 \mid 0$

OFS003SB 187|0 |

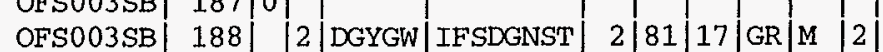

OFSO03SB $189 \mid$ |2|DGYGW|DGYCLB $11|94|$ 5|LP|M |2|

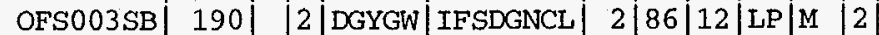

OFS003SB 1910

OFS003SB $192|0|$

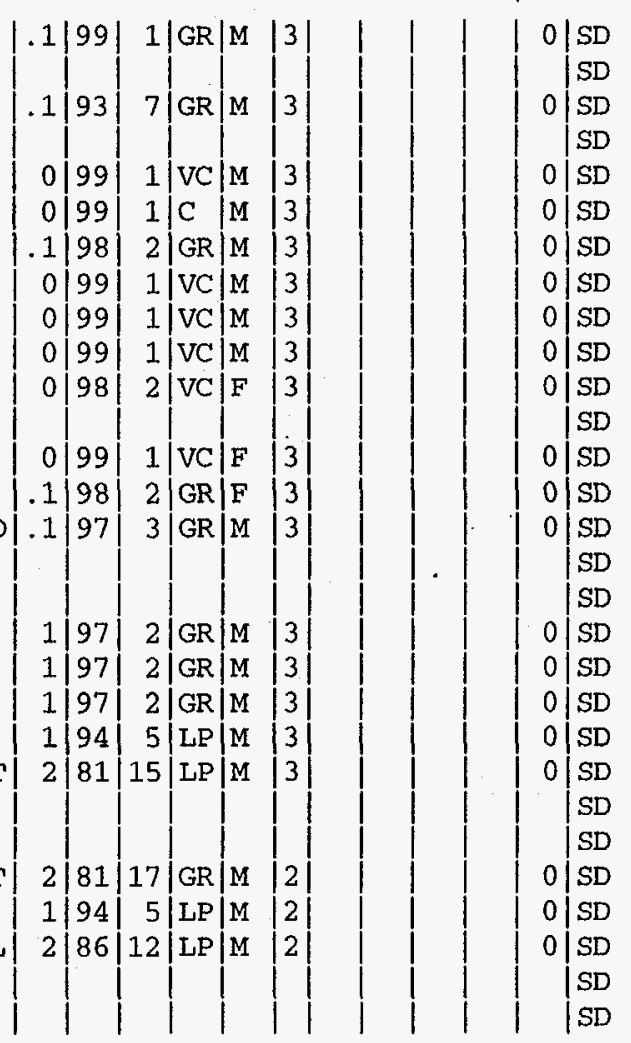

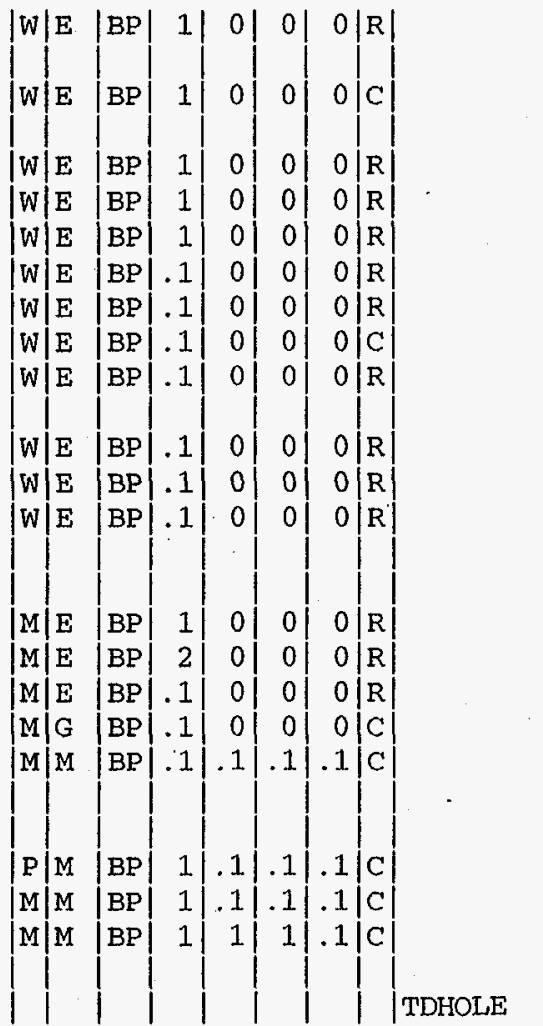


Table A2. Stream coordinate and elevation data for Fourmile Branch and F-area outfalls.

\begin{tabular}{lccc} 
Stream & $\begin{array}{c}\text { SRS East } \\
\text { Label }\end{array}$ & $\begin{array}{c}\text { SRS North } \\
(\text { ft) }\end{array}$ & $\begin{array}{c}\text { Elevation } \\
(f t)\end{array}$ \\
\hline 4Mile_Br & 49884.0 & 72820.2 & 180.0 \\
4Mile_Br & 49963.2 & 72807.8 & 180.1 \\
4Mile_Br & 50029.3 & 72800.3 & 180.3 \\
4Mile_Br & 50094.4 & 72804.4 & 180.4 \\
4Mile_Br & 50156.5 & 72814.8 & 180.5 \\
4Mile_Br & 50213.9 & 72829.3 & 180.6 \\
4Mile_Br & 50266.4 & 72845.2 & 180.7 \\
4Mile_Br & 50312.7 & 72847.3 & 180.8 \\
4Mile_Br & 50359.3 & 72852.2 & 180.9 \\
4Mile_Br & 50404.7 & 72852.2 & 181.0 \\
4Mile_Br & 50481.1 & 72869.6 & 181.1 \\
4Mile_Br & 50570.8 & 72884.1 & 181.3 \\
4Mile_Br & 50615.8 & 72896.9 & 181.4 \\
4Mile_Br & 50670.4 & 72916.1 & 181.5 \\
4Mile_Br & 50729.8 & 72931.6 & 181.6 \\
4Mile_Br & 50781.0 & 72948.4 & 181.7 \\
4Mile_Br & 50847.4 & 72971.2 & 181.8 \\
4Mile_Br & 50896.9 & 72994.3 & 181.9 \\
4Mile_Br & 50926.4 & 73005.5 & 182.0 \\
4Mile_Br & 50974.7 & 73032.5 & 182.1 \\
4Mile_Br & 51021.0 & 73058.6 & 182.2 \\
4Mile_Br & 51076.3 & 73086.1 & 182.3 \\
4Mile_Br & 51118.2 & 73101.0 & 182.4 \\
4Mile_Br & 51156.1 & 73111.9 & 182.4 \\
4Mile_Br & 51209.5 & 73113.9 & 182.5 \\
4Mile_Br & 51254.2 & 73116.1 & 182.6 \\
4Mile_Br & 51301.0 & 73117.6 & 182.7 \\
4Mile_Br & 51341.6 & 73101.1 & 182.8 \\
4Mile_Br & 51373.5 & 73094.0 & 182.8 \\
4Mile_Br & 51403.9 & 73091.6 & 182.9 \\
4Mile_Br & 51442.9 & 73074.4 & 183.0 \\
4Mile_Br & 51488.1 & 73063.5 & 183.1 \\
4Mile_Br & 51559.4 & 73057.5 & 183.2 \\
4Mile_Br & 51616.1 & 73055.1 & 183.3 \\
4Mile_Br & 51653.2 & 73057.8 & 183.4 \\
4Mile_Br & 51685.0 & 73062.6 & 183.4 \\
4Mile_Br & 51747.9 & 73052.1 & 183.6 \\
4Mile_Br & 51788.8 & 73046.8 & 183.6 \\
4Mile_Br & 51843.4 & 73032.0 & 183.7 \\
4Mile_Br & 51895.0 & 73023.1 & 183.8 \\
4Mile_Br & 51944.1 & 73011.2 & 183.9 \\
4Mile_Br & 51982.2 & 73008.6 & 184.0 \\
4Mile_Br & 52022.8 & 73008.2 & 184.1 \\
4Mile_Br & 52085.0 & 72993.5 & 184.2 \\
4Mile_Br & 52149.6 & 72979.0 & 184.3 \\
4Mile_Br & 52225.0 & 72969.6 & 184.4 \\
4Mile_Br & 52263.9 & 72959.8 & 184.5 \\
4Mile_Br & 52296.2 & 72960.0 & 184.6 \\
4Mile_Br & 52329.5 & 72945.9 & 184.6 \\
4Mile_Br & 52365.2 & 72944.7 & 184.7 \\
4Mile_Br & 52398.7 & 72934.2 & 184.7 \\
4Mile_Br & 52439.4 & 72932.9 & 184.8 \\
& & &
\end{tabular}


Table A2. (cont'd)

\begin{tabular}{|c|c|c|c|}
\hline $\begin{array}{l}\text { Stream } \\
\text { Label }\end{array}$ & $\begin{array}{l}\text { SRS East } \\
\text { (ft) }\end{array}$ & $\begin{array}{c}\text { SRS North } \\
(\mathrm{ft})\end{array}$ & $\begin{array}{c}\text { Elevation } \\
\text { (ft) }\end{array}$ \\
\hline $4 \mathrm{Mile}$ (Br & 52472.9 & 72918.5 & 184.9 \\
\hline 4Mile_Br & 52537.9 & 72904.4 & 185.0 \\
\hline $4 \mathrm{Mile}$ & 52584.6 & 72891.5 & 185.1 \\
\hline $4 \mathrm{Mile} B \mathrm{Br}$ & 52619.1 & 72874.2 & 185.1 \\
\hline $4 \mathrm{Mile}$ _Br & 52679.8 & 72832.6 & 185.3 \\
\hline $4 \mathrm{Mile}$ _Br & 52747.9 & 72774.8 & 185.4 \\
\hline 4Mile_Br & 52776.4 & 72737.6 & 185.5 \\
\hline 4Mile_Br & 52819.9 & 72699.6 & 185.6 \\
\hline $4 \mathrm{Mile} \mathrm{Br}$ & 52847.2 & 72675.8 & 185.7 \\
\hline $4 \mathrm{Mile \_ Br}$ & 52890.9 & 72658.5 & 185.7 \\
\hline 4Mile_Br & 52936.6 & 72630.3 & 185.8 \\
\hline 4Mile_Br & 52995.8 & 72593.8 & 186.0 \\
\hline $4 \mathrm{Mi}$ le_Br & 53019.6 & 72583.0 & 186.0 \\
\hline 4Mile_Br & 53045.9 & 72575.7 & 186.2 \\
\hline 4Mile_Br & 53084.2 & 72564.0 & 186.6 \\
\hline 4Mile_Br & 53122.8 & 72540.2 & 187.0 \\
\hline $4 \mathrm{Mi} l e \_\mathrm{Br}$ & 53163.8 & 72527.4 & 187.4 \\
\hline 4Mile_Br & 53198.7 & 72513.9 & 187.7 \\
\hline 4Mile_Br & 53230.4 & 72500.8 & 188.0 \\
\hline 4Mile_Br & 53270.5 & 72484.4 & 189.1 \\
\hline $4 \mathrm{Mile}=\mathrm{Br}$ & 53300.4 & 72471.1 & 190.0 \\
\hline 4Mile_Br & 53365.3 & 72423.0 & 190.2 \\
\hline $4 \mathrm{Mi} I \mathrm{E} \_\mathrm{Br}$ & 53422.6 & 72372.8 & 190.3 \\
\hline 4Mile_Br & 53442.4 & 72354.9 & 190.4 \\
\hline $4 \mathrm{Mile} B \mathrm{Br}$ & 53480.7 & 72340.3 & 190.4 \\
\hline $4 \mathrm{Mile} \mathrm{Br}$ & 53529.7 & 72301.9 & 190.6 \\
\hline $4 \mathrm{Mile} B \mathrm{Br}$ & 53585.3 & 72258.2 & 190.7 \\
\hline $4 \mathrm{Mile} B \mathrm{Br}$ & 53652.3 & 72204.3 & 190.9 \\
\hline $4 \mathrm{Mile} B \mathrm{Br}$ & 53697.4 & 72172.5 & 191.0 \\
\hline 4Mile_Br & 53741.1 & 72133.4 & 191.1 \\
\hline $4 \mathrm{Mile} \mathrm{Br}$ & 53780.8 & 72088.7 & 191.2 \\
\hline 4Mile_Br & 53796.6 & 72069.9 & 191.3 \\
\hline 4Mile_Br & 53803.6 & 72040.7 & 191.3 \\
\hline 4Mile_Br & 53832.5 & 71977.4 & 191.4 \\
\hline $4 \mathrm{Mile} \mathrm{Br}$ & 53841.1 & 71943.6 & 191.5 \\
\hline $4 \mathrm{Mi} I \mathrm{Mr}$ & 53860.6 & 71911.3 & 191.6 \\
\hline 4Mile_Br & 53863.9 & 71899.7 & 191.6 \\
\hline $4 \mathrm{Mile} B \mathrm{Br}$ & 53884.0 & 71886.7 & 191.7 \\
\hline 4Mile_Br & 53900.2 & 71857.0 & 191.7 \\
\hline $4 \mathrm{Mi} l e \_B r$ & 53942.3 & 71808.9 & 191.8 \\
\hline 4Mile_Br & 53976.6 & 71778.1 & 191.9 \\
\hline $4 \mathrm{Mil} l{ }_{-} \mathrm{Br}$ & 54002.5 & 71758.8 & 192.0 \\
\hline $4 \mathrm{Mi} I e \_B r$ & 54043.1 & 71735.9 & 192.1 \\
\hline 4Mile_Br & 54060.4 & 71721.0 & 192.2 \\
\hline 4Mile_Br & 54099.0 & 71701.8 & 192.3 \\
\hline $4 M i l e \_B r$ & 54156.8 & 71663.4 & 192.5 \\
\hline 4Mile_Br & 54213.0 & 71634.9 & 192.7 \\
\hline 4Mile_Br & 54272.0 & 71591.5 & 192.9 \\
\hline 4Mile_Br & 54343.1 & 71563.3 & 193.1 \\
\hline 4Mile_Br & 54409.3 & 71534.9 & 193.3 \\
\hline 4Mile_Br & 54479.6 & 71493.9 & 193.5 \\
\hline $4 \mathrm{Mile}$ Br & 54555.6 & 71446.2 & 193.7 \\
\hline $4 \mathrm{Mile} B \mathrm{Br}$ & 54605.3 & 71415.0 & 193.9 \\
\hline
\end{tabular}


Table A2. (cont'd)

\begin{tabular}{|c|c|c|c|}
\hline $\begin{array}{l}\text { Stream } \\
\text { Label }\end{array}$ & $\begin{array}{c}\text { SRS East } \\
\text { (ft) }\end{array}$ & $\begin{array}{c}\text { SRS North } \\
(\mathrm{t} t)\end{array}$ & $\begin{array}{c}\text { Elevation } \\
\text { (ft) }\end{array}$ \\
\hline Mile_Br & 54633.1 & 71395.7 & 194.0 \\
\hline $\mathrm{Mile} \mathrm{Br}$ & 54705.9 & 71347.9 & 194.3 \\
\hline ile_Br & 54762.3 & 71307.2 & 194.6 \\
\hline Mile_Br & 54793.7 & 71285.1 & 194.7 \\
\hline Mile_Br & 54855.2 & 71193.5 & 195.1 \\
\hline Aile_Br & 54889.4 & 71144.6 & 195.3 \\
\hline Mile_Br & 54935.9 & 71089.0 & 195.6 \\
\hline Mile_Br & 54989.8 & 71037.5 & 195.9 \\
\hline Iile_Br & 55013.0 & $71014: 5$ & 196.0 \\
\hline Mile_Br & 55061.7 & 70959.2 & 196.2 \\
\hline AMile_Br & 55126.7 & 70934.2 & 196.5 \\
\hline Iile_Br & 55159.8 & 70917.8 & 196.7 \\
\hline Iile_Br & 55215.6 & 70874.7 & 196.9 \\
\hline lile_Br & 55280.0 & 70848.4 & 197.2 \\
\hline ile_Br & 55372.3 & 70857.5 & 197.5 \\
\hline Iile_Br & 55450.6 & 70862.4 & 197.8 \\
\hline lile_Br & 55498.7 & 70863.0 & 198.0 \\
\hline Iile_Br & 55557.6 & 70871.5 & 198.1 \\
\hline Iile_Br & 55603.8 & 70880.6 & 198.2 \\
\hline Mile_Br & 55659.9 & 70875.0 & $198: 3$ \\
\hline lile_Br & 55713.8 & 70852.4 & 198.4 \\
\hline ile_Br & 55782.9 & 70848.1 & 198.5 \\
\hline ile_Br & 55859.7 & 70814.2 & 198.6 \\
\hline ile_Br & 55912.6 & 70790.3 & 198.7 \\
\hline ile_Br & 56015.1 & 70771.7 & 198.9 \\
\hline Iile_Br & 56090.8 & 70749.1 & 199.0 \\
\hline lile_Br & 56143.7 & 70735.9 & 199.1 \\
\hline ile_Br & 56177.0 & 70737.8 & 199.2 \\
\hline Iile_Br & 56234.0 & 70721.8 & 199.3 \\
\hline ile_Br & 56330.0 & 70688.2 & 199.4 \\
\hline lile_Br & 56400.8 & 70660.8 & 199.6 \\
\hline Iile_Br & 56463.6 & 70629.9 & 199.7 \\
\hline Iile_Br & 56555.9 & 70592.3 & 199.9 \\
\hline Iile_Br & 56634.3 & 70562.1 & 200.0 \\
\hline ile_Br & 56712.4 & 70542.6 & 200.2 \\
\hline Iile_Br & 56793.6 & 70519.6 & 200.5 \\
\hline Iile_Br & 56865.3 & 70507.2 & 200.6 \\
\hline ille_Br & 56906.4 & 70491.2 & 200.8 \\
\hline ile_Br & 56954.6 & 70484.6 & 200.9 \\
\hline$i l e \_B r$ & 56993.1 & 70458.7 & 201.0 \\
\hline ile_Br & 57092.5 & 70386.0 & 201.4 \\
\hline ile_Br & 57149.5 & 70338.1 & 201.6 \\
\hline ile_Br & 57171.6 & 70317.5 & 201.6 \\
\hline le. $\mathrm{Br}$ & 57205.8 & 70287.9 & 201.8 \\
\hline ile_Br & 57249.5 & 70271.1 & 201.9 \\
\hline le_Br & 57287.6 & 70266.0 & 202.0 \\
\hline ile_Br & 57309.4 & 70257.2 & 202.1 \\
\hline ile_Br & 57322.4 & 70242.9 & 202.2 \\
\hline $4 \mathrm{Mile}$-Br & 57353.6 & 70227.2 & 202.3 \\
\hline 4Mile_Br & 57361.0 & 70205.9 & 202.5 \\
\hline ile_Br & 57370.3 & 70178.8 & 202.7 \\
\hline ile_Br & 57366.4 & 70141.3 & 203.0 \\
\hline Mile_Br & 57359.6 & 70127.9 & 203.1 \\
\hline
\end{tabular}


Table A2. (cont'd)

\begin{tabular}{|c|c|c|c|}
\hline $\begin{array}{l}\text { Stream } \\
\text { Iabel }\end{array}$ & $\begin{array}{c}\text { SRS East } \\
\text { (ft) }\end{array}$ & $\begin{array}{c}\text { SRS North } \\
\text { (ft) }\end{array}$ & $\begin{array}{c}\text { Elevatio } \\
\text { (ft) }\end{array}$ \\
\hline Mile_Br & 57341.9 & 70107.2 & 203.2 \\
\hline ile_Br & 57330.0 & 70070.4 & 203.5 \\
\hline ile_Br & 57325.5 & 70039.9 & 203.7 \\
\hline ile_Br & 57317.1 & 69997.5 & 204.0 \\
\hline ile_Br & 57314.1 & 69982.7 & 204.1 \\
\hline ile_Br & 57305.0 & 69951.2 & 204.2 \\
\hline ile_Br & 57309.5 & 69899.4 & 204.4 \\
\hline ile_Br & 57318.6 & 69840.3 & 204.7 \\
\hline ile_Br & 57329.0 & 69773.8 & 205.0 \\
\hline ile_Bx & 57339.4 & 69739.5 & 205.1 \\
\hline ile_Br & 57361.8 & 69707.9 & 205.3 \\
\hline Lle_Br & 57376.4 & 69663.2 & 205.5 \\
\hline ile_Br & 57390.7 & 69643.3 & 205.6 \\
\hline ile_Br & 57408.3 & 69624.4 & 205.7 \\
\hline ile_Br & 57422.9 & 69599.6 & 205.8 \\
\hline ile_Br & 57447.1 & 69577.4 & 205.9 \\
\hline ile_Br & 57456.1 & 69563.2 & 206.0 \\
\hline ile_Br & 57471.1 & 69544.1 & 206.0 \\
\hline ile_Br & 57516.6 & 69519.2 & 206.2 \\
\hline ile_Br & 57551.2 & 69490.2 & 206.3 \\
\hline ile_Br & 57603.3 & 69477.5 & 206.4 \\
\hline Le_Br & 57668.6 & 69451.4 & 206.5 \\
\hline $1 e \_\mathrm{Br}$ & 57729.7 & 69426.7 & 206.7 \\
\hline Lle_Br & 57765.0 & 69415.5 & 206.7 \\
\hline ile_Br & 57805.5 & 69410.8 & 206.8 \\
\hline ile_Br & 57843.9 & 69392.5 & 206.9 \\
\hline Lle_Br & 57939.8 & 69374.1 & 207.1 \\
\hline ile_Br & 57992.1 & 69368.5 & 207.2 \\
\hline ile_Br & 58043.2 & 69353.3 & 207.3 \\
\hline le_Br & 58097.9 & 69345.3 & 207.4 \\
\hline Ie_Br & 58145.1 & 69312.3 & 207.6 \\
\hline ile_Br & 58174.9 & 69265.3 & 207.7 \\
\hline le_Br & 58201.5 & 69217.7 & 207.8 \\
\hline le_Br & 58230.9 & 69163.8 & 207.9 \\
\hline le_Br & 58260.3 & 69114.8 & 208.0 \\
\hline Le_Br & 58301.1 & 69033.0 & 208.2 \\
\hline lle_Br & 58328.3 & 68965.3 & 208.4 \\
\hline Le_Br & 58364.6 & 68892.5 & 208.6 \\
\hline Ie_Br & 58392.6 & 68824.5 & 208.7 \\
\hline ile_Br & 58416.4 & 68737.0 & 208.9 \\
\hline Ie_Br & 58438.7 & 68695.9 & 209.1 \\
\hline ile_Br & 58472.3 & 68657.1 & 209.2 \\
\hline $1 e \_B r$ & 58492.1 & 68611.0 & 209.3 \\
\hline le_Br & 58531.2 & 68551.2 & 209.4 \\
\hline Ie_Br & 58567.9 & 68490.5 & 209.6 \\
\hline Ie_Br & 58597.2 & 68415.0 & 209.8 \\
\hline le_Br & 58622.8 & 68330.8 & 210.0 \\
\hline Ile_Br & 58626.5 & 68244.6 & 210.2 \\
\hline ile_Br & 58626.3 & 68151.2 & 210.5 \\
\hline le_Br & 58624.3 & 68075.4 & 210.7 \\
\hline ile_Br & 58632.7 & 68006.0 & 210.9 \\
\hline Ie_Br & 58643.2 & 67964.6 & 211.0 \\
\hline ile_Br & 58681.6 & 67926.2 & 211.2 \\
\hline
\end{tabular}


Table A2. (cont'd)

\begin{tabular}{|c|c|c|c|}
\hline $\begin{array}{l}\text { Stream } \\
\text { Label }\end{array}$ & $\begin{array}{l}\text { SRS East } \\
\text { (ft) }\end{array}$ & $\begin{array}{l}\text { SRS North } \\
\text { (ft) }\end{array}$ & $\begin{array}{c}\text { Elevatior } \\
\text { (ft) }\end{array}$ \\
\hline $4 \mathrm{Mile} \mathrm{Br}$ & 58705.2 & 67886.7 & 211.3 \\
\hline 4Mile_Br & 58760.0 & 67817.2 & 211.6 \\
\hline 4Mile_Br & 58799.1 & 67776.5 & 211.7 \\
\hline 4Mile_Br & 58863.3 & 67747.2 & 211.9 \\
\hline 4Mile_Br & 58911.9 & 67733.9 & 212.0 \\
\hline Old__Eff & 53093.4 & 72547.3 & 189.9 \\
\hline Old_Eff & 53115.3 & $72575.5^{\circ}$ & 190.0 \\
\hline OldEfE & 53122.5 & 72604.9 & 190.0 \\
\hline Old_Eff & 53135.1 & 72630.4 & 190.0 \\
\hline Old_Eff & 53156.6 & 72658.3 & 190.2 \\
\hline Old_Eff & 53189.8 & 72679.7 & 190.4 \\
\hline OId_Eff & 53221.2 & 72700.6 & 190.5 \\
\hline Old_Eff & 53261.6 & 72723.4 & 190.8 \\
\hline Old_Eff & 53283.4 & 72739.2 & 190.9 \\
\hline Old_Eff & 53286.7 & 72764.2 & 191.0 \\
\hline Old_Eff & 53278.6 & 72839.3 & 192.0 \\
\hline Old_Eff & 53289.0 & 72907.8 & 193.0 \\
\hline old_Eff & 53299.9 & 72970.1 & 194.0 \\
\hline Old_Eff & 53327.3 & 73072.9 & 195.0 \\
\hline Old_Eff & 53346.3 & 73112.7 & 196.0 \\
\hline Old_Eff & 53399.8 & 73172.6 & 197.0 \\
\hline Old_Eff & 53427.1 & 73199.9 & 198.0 \\
\hline Old_Eff & 53451.5 & 73223.8 & 199.0 \\
\hline Old_Eff & 53463.3 & 73234.7 & 200.0 \\
\hline Old_Eff & 53494.1 & 73266.7 & 201.0 \\
\hline Old_Eff & 53535.4 & 73299.6 & 202.0 \\
\hline Old_Eff & 53553.9 & 73310.0 & 203.0 \\
\hline Old_Eff & 53568.1 & 73317.5 & 204.0 \\
\hline Old_Eff & 53582.5 & 73325.9 & 205.0 \\
\hline Old_Eff & 53645.6 & 73353.1 & 206.0 \\
\hline Old_Eff & 53783.5 & 73384.2 & 207.0 \\
\hline Old_Eff & 53876.6 & 73425.9 & 208.0 \\
\hline Old_EfE & 53967.2 & 73477.9 & 208.8 \\
\hline Old_Eff & 53981.3 & 73505.4 & 209.0 \\
\hline Old_Eff & 53997.3 & 73560.0 & 209.5 \\
\hline Old_Eff & 53998.1 & 73622.6 & 210.0 \\
\hline Old_Eff & 54006.0 & 73647.6 & 211.0 \\
\hline Old_Eff & 54017.8 & 73687.4 & 212.0 \\
\hline Old_Eff & 54017.9 & 73716.3 & 213.0 \\
\hline Old_Eff & 54015.3 & 73740.4 & 214.0 \\
\hline Old_Eff & 54018.4 & 73756.6 & 215.0 \\
\hline NewRock1 & 53463.3 & 73234.7 & 200.0 \\
\hline NewRock1 & 53470.1 & 73271.3 & 201.0 \\
\hline NewRock1 & 53469.4 & 73317.2 & 202.0 \\
\hline NewRock1 & 53468.9 & 73358.5 & 203.0 \\
\hline NewRockI & 53473.5 & 73393.1 & 204.0 \\
\hline NewRock1. & 53481.6 & 73413.7 & 205.0 \\
\hline NewRock1 & 53514.1 & 73467.5 & 208.0 \\
\hline NewRock1 & 53527.0 & 73527.9 & 210.0 \\
\hline NewRock1 & 53549.6 & 73567.7 & 215.0 \\
\hline NewRock1 & 53592.2 & 73621.4 & 220.0 \\
\hline NewRock2 & 53493.5 & 73266.9 & 201.0 \\
\hline NewRock2 & 53532.7 & 73308.3 & 202.0 \\
\hline
\end{tabular}


Table A2. (cont'd)

\begin{tabular}{cccc}
$\begin{array}{c}\text { Stream } \\
\text { Label }\end{array}$ & $\begin{array}{c}\text { SRS East } \\
\text { (ft) }\end{array}$ & $\begin{array}{c}\text { SRS North } \\
\text { (ft) }\end{array}$ & $\begin{array}{c}\text { Elevation } \\
\text { (ft) }\end{array}$ \\
\hline NewRock2 & 53554.3 & 73349.1 & 203.0 \\
NewRock2 & 53564.6 & 73394.2 & 204.0 \\
NewRock2 & 53568.4 & 73424.3 & 205.0 \\
NewRock2 & 53570.1 & 73450.3 & 210.0 \\
NewRock2 & 53571.7 & 73527.3 & 215.0 \\
NewRock2 & 53591.9 & 73621.9 & 220.0
\end{tabular}


Table A3. Laboratory hydraulic conductivity as a function of mud fraction for SRS Tertiary-aged sediments.

\begin{tabular}{|c|c|c|c|}
\hline \multicolumn{2}{|c|}{ Bledsoe et } & \multicolumn{2}{|c|}{ a1. (1990) } \\
\hline ID & $\mathrm{KV}(\mathrm{ft} / \mathrm{d})$ & $K h(f t / d)$ & $\% \operatorname{San} d$ \\
\hline 2 & $4.82 e-4$ & $8.79 e-2$ & 47.0 \\
\hline 13 & $3.40 e-2$ & $1.84 e-2$ & 87.5 \\
\hline 14 & $1.50 \mathrm{e}-3$ & $4.73 e-2$ & 88.5 \\
\hline 28 & $1.28 e-5$ & $1.02 \mathrm{e}-4$ & 2.0 \\
\hline 35 & $3.40 e-5$ & $7.94 e^{-3}$ & 78.0 \\
\hline 36 & $9.64 e-3$ & $9.92 e-2$ & 78.5 \\
\hline 43 & $3.40 e-1$ & $1.45 e+0$ & 84.0 \\
\hline 54 & $9.64 e-5$ & $1.13 e-4$ & 23.5 \\
\hline 59 & $9.64 e-2$ & & 88.5 \\
\hline 60 & $1.73 e-2$ & & 16.5 \\
\hline 67 & $5.16 e-5$ & $3.23 e-1$ & 12.0 \\
\hline 77 & $1.79 e-4$ & & 14.5 \\
\hline 88 & $9.58 e-4$ & $8.70 e-4$ & 48.0 \\
\hline 1 & $1.59 e-1$ & $1.50 \mathrm{e}-1$ & 86.0 \\
\hline 8 & $1.28 e-1$ & $6.80 e-4$ & 74.5 \\
\hline 31 & $7.65 e-5$ & $5.67 e-5$ & 65.0 \\
\hline 41 & $2.58 e-3$ & $3.12 e-3$ & 54.5 \\
\hline 42 & $1.90 e-3$ & $1.64 e-2$ & 27.5 \\
\hline 81 & $5.70 e-4$ & $5.24 e-4$ & 68.5 \\
\hline 3 & & $1.45 e-3$ & 62.0 \\
\hline 4 & $7.51 e-6$ & & 72.5 \\
\hline 9 & $7.37 e-4$ & $2.32 e-4$ & 58.5 \\
\hline 15 & $1.13 e-3$ & $7.65 e-2$ & 74.0 \\
\hline 16 & $1.05 e-5$ & $4.25 e-5$ & 12.5 \\
\hline 17 & $3.40 e-6$ & & 10.0 \\
\hline 32 & $3.97 e-2$ & $8.79 e-2$ & 90.5 \\
\hline 33 & $9.07 e-5$ & $1.05 e-4$ & .12 .5 \\
\hline 37 & $3.97 e-5$ & $5.95 e-5$ & 44.5 \\
\hline 44 & $5.39 e-2$ & $6.80 e-1$ & 58.0 \\
\hline 50 & 1. $42 e-4$ & $1.22 e^{-4}$ & 3.0 \\
\hline 51 & $1.02 \mathrm{e}-3$ & & \\
\hline 55 & $4.25 e-5$ & $3.69 e-5$ & 4.5 \\
\hline 56 & $3.40 e-5$ & $1.13 e-1$ & 38.0 \\
\hline 61 & $6.07 e-5$ & $1.02 e-4$ & 12.0 \\
\hline 68 & $1.17 e-1$ & $1.07 e-1$ & 87.5 \\
\hline 71 & $7.85 e-3$ & & 18.0 \\
\hline 72 & $7.03 e-5$ & $7.46 e-5$ & 14.0 \\
\hline 78 & $9.75 e-5$ & $1.11 \mathrm{e}-4$ & 13.5 \\
\hline 82 & $2.86 e-4$ & $1.11 e-4$ & 66.0 \\
\hline 89 & $1.71 e-4$ & $1.75 e-4$ & 49.0 \\
\hline 90 & $8.28 e-5$ & $9.89 e-5$ & 0.0 \\
\hline 7 & $5.67 e-1$ & $4.82 e-1$ & 82.0 \\
\hline 12 & $1.16 \mathrm{e}-3$ & $4.82 e-3$ & 75.0 \\
\hline 40 & $9.64 e-5$ & $3.12 e-4$ & 68.0 \\
\hline 48 & $4.82 e-4$ & $9.64 \mathrm{e}-4$ & 80.5 \\
\hline 49 & $3.69 e-4$ & $1.87 e-4$ & 75.5 \\
\hline 53 & $3.69 e-4$ & & 25.5 \\
\hline 65 & $1.19 e-1$ & $2.48 e+0$ & 76.5 \\
\hline 66 & $2.24 e-4$ & $3.15 e-1$ & 80.0 \\
\hline 76 & $9.75 e-5$ & $1.11 e-4$ & 27.5 \\
\hline
\end{tabular}


Table A3. (cont'd)

\begin{tabular}{|c|c|c|c|c|}
\hline Riha & (1993) & & & \\
\hline Sample & fsand & $\mathrm{Kv}(\mathrm{cm} / \mathrm{s})$ & $\mathrm{Kh}(\mathrm{cm} / \mathrm{s})$ & \\
\hline IDS_2 & 36.3 & $3.5 e-8$ & $4.2 e-8$ & \\
\hline IDS_3 & 78.3 & $3.3 e-4$ & $7.8 e-5$ & \\
\hline IDS_4 & 91.4 & $1.5 e-3$ & & \\
\hline IDS_5 & 90.4 & $5.5 e-4$ & & \\
\hline IDS_6 & 30.1 & $4.0 e-4$ & & \\
\hline IDS_ 7 & 93.8 & $1.1 e-3$ & & \\
\hline IDS_8 & 44 & $4.0 e-7$ & $3: 7 e-7$ & \\
\hline IDS_9 & 80.3 & $5.6 e-4$ & & \\
\hline IDS_10 & 72.6 & $4.0 e-5$ & $1.9 e-5$ & \\
\hline IDS_11 & 92.2 & $1.4 e-3$ & & \\
\hline IDS_12 & 48.1 & $6.2 e-9$ & $1.2 \mathrm{e}-8$ & \\
\hline IDS_13 & 80.8 & $3.4 e-7$ & $3.4 e-7$ & \\
\hline IDS_14 & 68.2 & $4.0 e-7$ & $5.5 e-7$ & \\
\hline IDS_15 & 93.3 & $4.3 e-5$ & $4.5 e-5$ & \\
\hline IDS_I6 & 50.8 & $1.9 e-7$ & $5.6 e-6$ & \\
\hline IDS_17 & 93.1 & $2.5 e-4$ & $8.5 e-5$ & \\
\hline IDS_18 & 95.6 & $3.8 e-4$ & $1.2 e-4$ & \\
\hline MWME_1 & 89. & $1.2 e-3$ & & \\
\hline MWMF_2 & 90. & $2.9 e-3$ & & \\
\hline MWMF_3 & 61. & $1.9 e-4$ & & \\
\hline MWMF_4 & 77.5 & $1.1 e-4$ & & . \\
\hline MUIMF_5 & 58. & $5.0 e-5$ & & \\
\hline MUMF_6 & 76. & $1.7 e-4$ & & \\
\hline MWMF_7 & 70. & $1.0 e-4$ & & \\
\hline MWMF_8 & 79.5 & $1.3 e-3$ & & \\
\hline RUST & (1995) & & & \\
\hline Boring & Unit & smud & $\mathrm{KV}(\mathrm{cm} / \mathrm{s})$ & $\mathrm{Kh}(\mathrm{cm} / \mathrm{s})$ \\
\hline BGO003A & Ellenton & 50 & $5 . e-8$ & $8.1 e_{r} 8$ \\
\hline BGO003A & Greenclay & 78 & $4 . e-9$ & $7.4 e-9$ \\
\hline $\mathrm{BGO} 003 \mathrm{C}$ & Tanclay & 50 & $2.4 e-8$ & $3.1 e-6$ \\
\hline BG0051AA & Ellenton & 60 & $8 . e-9$ & $3.9 e-9$ \\
\hline BGO051B & Greenclay & 51 & $5.8 e-9$ & $8 . e-9$ \\
\hline BGO051B & Tanclay & 97 & $3.9 e-9$ & $6.1 e-9$ \\
\hline BGO052A & Ellenton & 98 & $3.8 e-9$ & $4 . e-9$ \\
\hline BGO052A & Ǵreenclay & 58 & $8.9 e-9$ & $1.5 e-8$ \\
\hline BGO052A & Tanclay & 99 & $4.3 e-9$ & $1.2 e-8$ \\
\hline OFS001SB & Tanclay & - & $1.2 \mathrm{e}-8$ & - \\
\hline OFSO03SB & Tanclay & 54 & $2.4 e-8$ & $6 . e-5$ \\
\hline OFS003SB & Greenclay & 89 & $1.7 e-9$ & $2.8 e-9$ \\
\hline OFS004SB & Tanclay & 32 & $2.2 e-7$ & $1.9 e-6$ \\
\hline OFSO04SB & Greenclay & 60 & $4 \cdot e-9$ & $2.3 e-8$ \\
\hline OFS005SB & Tanclay & 10 & 5.e-4 & $5 \cdot e-4$ \\
\hline OFS005SB & Greenclay & 62 & $1.6 e-9$ & $6.3 e-9$ \\
\hline
\end{tabular}


Table A3. (cont'd)

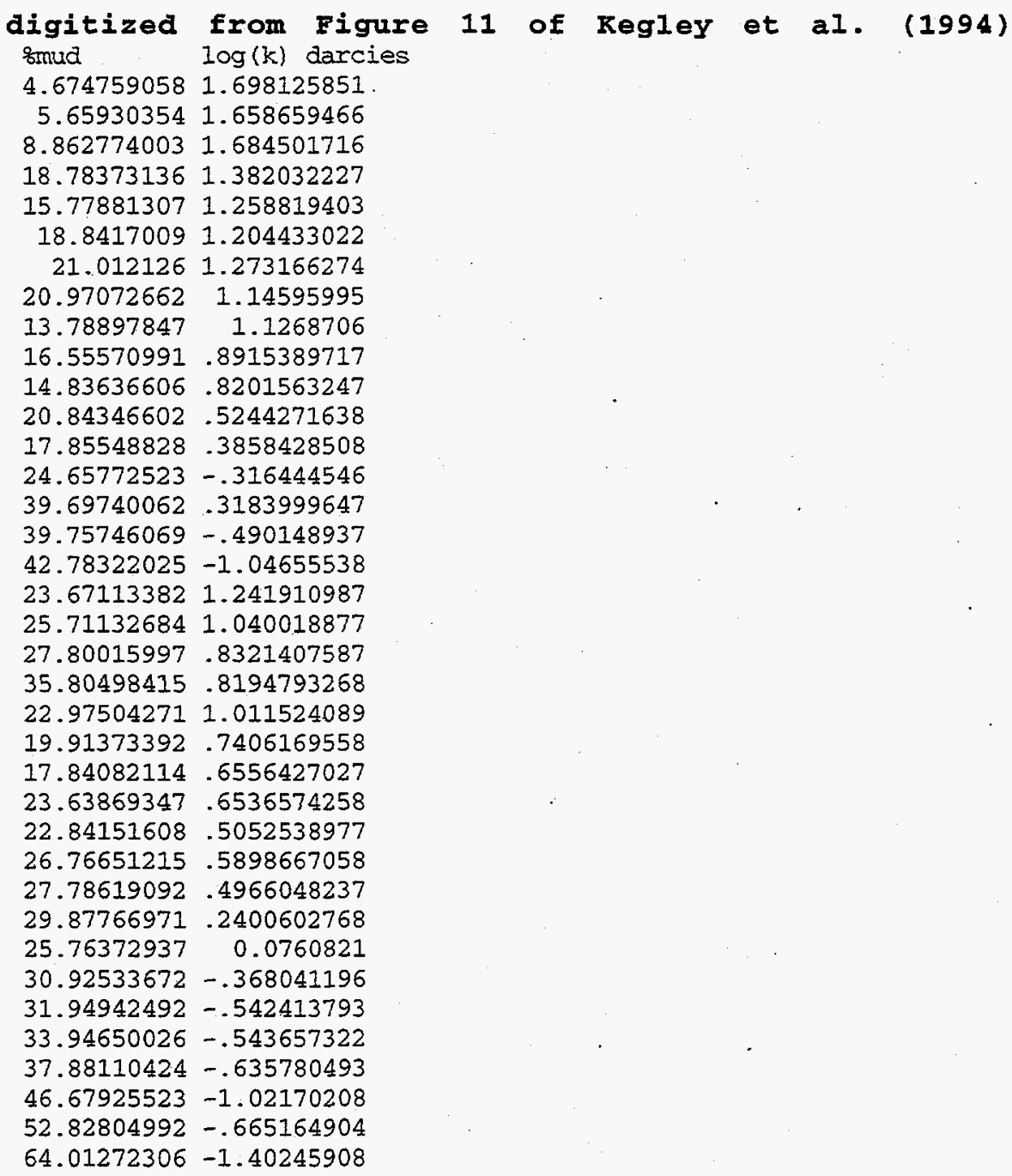

\section{other}

Boring

HIW2A

HIW2A

FIW1MC

FIW2MA

FIW2MA

HIWIMC

$\mathrm{HCH} 2$

$\mathrm{HCH} 2$

$\mathrm{HCH} 3$

$\mathrm{HCH} 3$

$\mathrm{HCH} I$

$\mathrm{HCH} 1$

$\mathrm{HCH} 1$

$\mathrm{FCH} 2$

FCH2

$\mathrm{FCH} 2$

$\mathrm{HCH} 2$

$\mathrm{HCH} 3$

$8 \mathrm{~F}$ ines
86
26
85
87
48
18
64
76
87
22
8
13
83
58
35
20
12
37

$\mathrm{KV}(\mathrm{cm} / \mathrm{s}) \quad \mathrm{Kh}(\mathrm{cm} / \mathrm{s})$ 3. $60 \mathrm{E}-09$

1. $00 \mathrm{E}-07$

1. $50 \mathrm{E}-08$

$1.38 \mathrm{E}-08$

$7.40 \mathrm{E}-09$

$1.90 \mathrm{E}-07$

$5.17 \mathrm{E}-08$

1.10E-07

$5.43 E-07$

3.89E-07

$8.03 E-05$

$1.52 \mathrm{E}-05$

1. $60 \mathrm{E}-08$

$8.39 E-09$

$6.84 \mathrm{E}-09$

3. $33 E-08$

4. $84 \mathrm{E}-05$

1. $69 \mathrm{E}-06$
4.00E-07

$1.20 \mathrm{E}-07$

$5.30 \mathrm{E}-07$

8. $00 \mathrm{E}-06$

1. $50 \mathrm{E}-08$

5. $00 \mathrm{E}-06$

$6.20 \mathrm{E}-08$

1. $63 \mathrm{E}-07$

$7.36 \mathrm{E}-07$

4. $10 \mathrm{E}-07$

$9.07 E-05$

3. $54 \mathrm{E}-05$

1. $91 \mathrm{E}-08$

$7.59 \mathrm{E}-09$

$8.99 \mathrm{E}-09$

7. $94 \mathrm{E}-08$

$6.31 E-05$

3. $88 \mathrm{E}-06$
Reference

WSRC-RP-93-1575

WSRC-RP-93-1575

WSRC-RP-92-896

WSRC-RP-92-896

WSRC-RP-92-896

WSRC-RP-92-896

ATEC (1992)

ATEC (1992)

ATEC (1992)

ATEC (1992)

ATEC (1992)

ATEC (1992)

ATEC (1992)

ATEC (1992)

ATEC (1992)

ATEC (1992)

ATEC (1992)

ATEC (1992) 
Table A3. (cont'd)

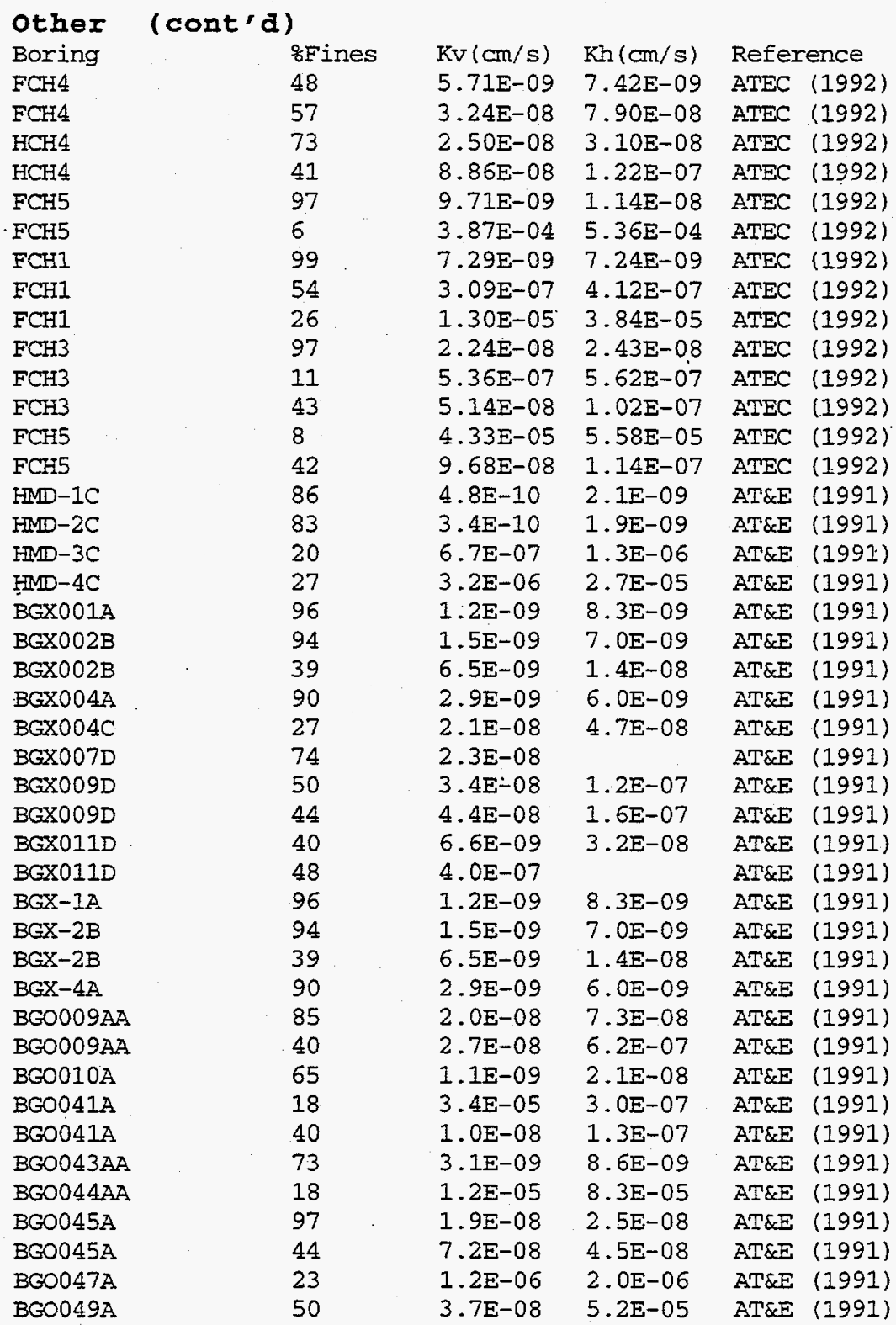


Table A4. Time-averaged well hydraulic head data for the "upper" aquifer zone within the Upper Three Runs aquifer.

\begin{tabular}{|c|c|c|c|c|}
\hline \multicolumn{2}{|c|}{$\begin{array}{l}\text { Well } \\
\text { Label }\end{array}$} & $\begin{array}{c}\text { SRS East } \\
(\mathrm{ft})\end{array}$ & $\begin{array}{l}\text { SRS North } \\
\text { (ft) }\end{array}$ & $\begin{array}{c}\text { Elevation } \\
\text { (ft) }\end{array}$ \\
\hline$B G$ & 52 & 55524.0 & 75910.0 & 229.5 \\
\hline BG & 53 & 55073.0 & 76157.0 & 229.3 \\
\hline BG & 54 & 54830.0 & 75837.0 & 228.5 \\
\hline BG & 55 & 54590.0 & 75525.0 & 227.1 \\
\hline BG & 56 & 54481.0 & 75206.0 & 227.6 \\
\hline BG & 57 & 54820.0 & 75000.0 & 225.9 \\
\hline BG & 58 & 55162.0 & 74790.0 & 227.3 \\
\hline BG & 59 & 55508.0 & 74593.0 & 230.0 \\
\hline BG & 60 & 55850.0 & 74386.0 & 231.0 \\
\hline BG & 61 & 56360.0 & 74075.0 & 233.1 \\
\hline BG & 62 & 56530.0 & 73971.0 & 234.3 \\
\hline BG & 63 & 56870.0 & 73754.0 & 236.6 \\
\hline BG & 64 & 57212.0 & 73547.0 & 239.4 \\
\hline BG & 65 & 57552.0 & 73340.0 & 237.4 \\
\hline BG & 66 & 57805.0 & 73585.0 & 236.5 \\
\hline BG. & 67 & 57902.0 & 73954.0 & 236.7 \\
\hline BG & 104 & 59888.0 & 77038.0 & 224.6 \\
\hline BG & 107 & 60120.0 & 74803.0 & 235.8 \\
\hline BG & 108 & 59827.0 & 74383.0 & 238.8 \\
\hline BG & 109 & 59626.0 & 73926.0 & 240.4 \\
\hline BG & 110 & 59277.0 & 73354.0 & 241.4 \\
\hline BGO & 1D & 58779.0 & 73737.0 & 238.6 \\
\hline$B G O$ & 2D & 58809.0 & 74552.0 & 238.6 \\
\hline BGO & 3D & 58809.0 & 75351.0 & 235.8 \\
\hline BGO & $4 \mathrm{D}$ & 58803.0 & 76150.0 & 232.4 \\
\hline BGO & 5D & 58784.0 & 76477.0 & 231.3 \\
\hline BGO & 6D & 58297.0 & 76487.0 & 231.5 \\
\hline BGO & $7 \mathrm{D}$ & 57917.0 & 76494.0 & 234.2 \\
\hline BGO & 8D & 57617.0 & 76588.0 & 234.4 \\
\hline BGO & $9 D$ & 57478.0 & 76811.0 & 231.8 \\
\hline BGO & $10 D$ & 57030.0 & 76805.0 & 231.9 \\
\hline BGO & IODR & 57073.0 & 76804.0 & 232.5 \\
\hline BGO & $11 D$ & 56651.0 & 76805.0 & 231.0 \\
\hline BGO & $12 \mathrm{D}$ & 56231.0 & 76805.0 & 230.8 \\
\hline BGO & $13 D$ & 55840.0 & 76805.0 & 230.0 \\
\hline BGO & $14 \mathrm{DR}$ & 55789.0 & 76322.0 & 231.7 \\
\hline $\mathrm{BGO}$ & $15 \mathrm{D}$ & 55859.0 & 75973.0 & 229.6 \\
\hline BGO & $16 \mathrm{D}$ & 56202.0 & 75751.0 & 230.7 \\
\hline BGO & 17D & 56399.0 & 75599.0 & 230.7 \\
\hline BGO & $17 \mathrm{DR}$ & 56407.0 & 75604.0 & 232.9 \\
\hline BGO & $18 \mathrm{D}$ & 56711.0 & 75600.0 & 231.9 \\
\hline BGO & $19 D$ & 56997.0 & 75350.0 & 232.1 \\
\hline BGO & $20 D$ & 57113.0 & 74962.0 & 234.1 \\
\hline BGO & $21 D$ & 57470.0 & 74688.0 & 234.7 \\
\hline BGO & $22 \mathrm{D}$ & 57817.0 & 74482.0 & 232.4 \\
\hline BGO & $22 \mathrm{DR}$ & 57831.0 & 74471.0 & 237.9 \\
\hline BGO & $23 D$ & 58133.0 & 74238.0 & 235.9 \\
\hline BGO & $24 \mathrm{D}$ & 58438.0 & 74012.0 & 236.7 \\
\hline BGO & $26 \mathrm{D}$ & 55015.0 & 76128.0 & 227.7 \\
\hline BGO & $27 \mathrm{D}$ & 54680.0 & 75677.0 & 227.4 \\
\hline BGO & $28 D$ & 54457.0 & 75348.0 & 226.1 \\
\hline BGO & $29 D$ & 54099.0 & 75592.0 & 227.5 \\
\hline
\end{tabular}


Table A4. (cont'd)

WeIl. SRS East SRS North Elevation

\begin{tabular}{|c|c|c|c|c|}
\hline & bel & $(\mathrm{ft})$ & (Et) & (Et) \\
\hline BGO & $30 D$ & 54499.0 & 75187.0 & 225.7 \\
\hline BGO & $31 D$ & 54841.0 & 74985.0 & 226.6 \\
\hline BGO & $32 \mathrm{D}$ & 55250.0 & 74727.0 & 227.5 \\
\hline$B G O$ & $33 D$ & 55695.0 & 74468.0 & 230.2 \\
\hline$B G O$ & $34 \mathrm{D}$ & 56082.0 & 74228.0 & 232.8 \\
\hline BGO & $35 \mathrm{D}$ & 56556.0. & 73946.0 & 234.3 \\
\hline $\mathrm{BGO}$ & $36 \mathrm{D}$ & 56888.0 & 73743.0 & 236.4 \\
\hline BGO & $37 D$ & 57292.0 & 73490.0 & 237.7 \\
\hline $\mathrm{BGO}$ & $38 \mathrm{D}$ & 57557.0 & 73329.0 & 235.3 \\
\hline BGO & $39 D$ & 57831.0 & 73583.0 & 235.0 \\
\hline BGO & $40 D$ & 54638.0 & 76125.0 & 223.6 \\
\hline BGO & $44 \mathrm{D}$ & 57910.0 & 76759.0 & 232.7 \\
\hline $\mathrm{BGO}$ & $45 D$ & 54585.0 & 75854.0 & 228.8 \\
\hline BGO & $46 D$ & 54420.0 & 75033.0 & 226.4 \\
\hline BGO & $47 D$ & 54922.0 & 74739.0 & 227.4 \\
\hline BGO & $48 D$ & 55121.0 & 74586.0 & 227.8 \\
\hline BGO & $49 D$ & 56198.0 & 73931.0 & 235.8 \\
\hline BGO & $50 \mathrm{D}$ & 54209.0 & 75181.0 & 226.2 \\
\hline BGX & ID & 58608.0 & 76809.0 & 230.0 \\
\hline BGX & $9 \mathrm{D}$ & 59522.0 & 76936.0 & 227.3 \\
\hline BGX & $10 D$ & 59765.0 & 76183.0 & 226.6 \\
\hline BGX & $11 D$ & 59581.0 & 75300.0 & 236.8 \\
\hline BGX & $12 \mathrm{D}$ & 59674.0 & 74410.0 & 240.4 \\
\hline $\mathrm{BRR}$ & 1D & 50588.0 & 77365.0 & 216.6 \\
\hline $\mathrm{BRR}$ & $2 \mathrm{D}$ & 50306.0 & 77431.0 & 215.4 \\
\hline $\mathrm{BRR}$ & $3 D$ & 50203.0 & 77398.0 & 215.1 \\
\hline BRR & $4 D$ & 50104.0 & 77360.0 & 214.8 \\
\hline $\mathrm{BRR}$ & $5 D$ & 50009.0 & 77266.0 & 215.1 \\
\hline FAC & 3 & 55322.0 & 78018.0 & 230.5 \\
\hline FAC & 4 & 55472.0 & 78223.0 & 228.9 \\
\hline FAC & 5 & 55241.0 & 77960.0 & 224.3 \\
\hline FAC & $5 P$ & 55314.0 & 78175.0 & 230.6 \\
\hline FAC & 7 & 55356.0 & 78123.0 & 221.8 \\
\hline FAC & 8 & 55366.0 & 78090.0 & 226.5 \\
\hline FAI & 1 & 53756.0 & 78115.0 & 218.7 \\
\hline FAI & 2 & 53757.0 & 78231.0 & 217.1 \\
\hline$F C A$ & IN & 53675.0 & 79037.0 & 299.2 \\
\hline FCA & $2 \mathrm{C}$ & 53712.0 & 78296.0 & 298.0 \\
\hline FCA & $2 \mathrm{D}$ & 53715.0 & 78295.0 & 225.4 \\
\hline $\mathrm{FCA}$ & $9 D$ & 53733.0 & 78600.0 & 225.6 \\
\hline FCA & $10 \mathrm{~A}$ & 53571.0 & 78640.0 & 225.3 \\
\hline$F C A$ & $10 \mathrm{C}$ & 53717.0 & 78642.0 & 302.3 \\
\hline FCA & $10 \mathrm{D}$ & 53732.0 & 78640.0 & 226.5 \\
\hline FCA & $16 \mathrm{~A}$ & 53568.0 & 78899.0 & 225.2 \\
\hline$F C A$ & $16 \mathrm{D}$ & 53719.0 & 78898.0 & 225.2 \\
\hline$F C A$ & $16 \mathrm{~T}$ & 53579.0 & 78898.0 & 297. \\
\hline$F C A$ & 19D & 53719.0 & 78271.0 & 217. \\
\hline$F C B$ & 2 & 55046.0 & 76679.0 & 231. \\
\hline FCB & 3 & 54874.0 & 76427.0 & 223. \\
\hline FCE & 5 & 54773.0 & 76492.0 & 228. \\
\hline $\mathrm{FCB}$ & 6 & 54733.0 & 76582.0 & 228. \\
\hline FET & 1D & 53299.0 & 76165.0 & 223. \\
\hline FET & $2 \mathrm{D}$ & 52981.0 & 76045.0 & 222 . \\
\hline
\end{tabular}


Table A4. (cont'd)

\begin{tabular}{|c|c|c|c|c|}
\hline \multicolumn{2}{|c|}{$\begin{array}{l}\text { Wel1 } \\
\text { Label }\end{array}$} & $\begin{array}{l}\text { SRS East } \\
\text { (ft) }\end{array}$ & $\begin{array}{l}\text { SRS North } \\
\text { (ft) }\end{array}$ & $\begin{array}{c}\text { Elevation } \\
\text { (ft) }\end{array}$ \\
\hline$F E T$ & $3 D$ & 53025.0 & 75961.0 & 222.0 \\
\hline FET & $4 D$ & 53149.0 & 75959.0 & 222.6 \\
\hline FSB & 76 & 51388.0 & 76141.0 & 218.3 \\
\hline FSB & 77 & 50713.0 & 75129.0 & 212.7 \\
\hline FSB & 78 & 50164.0 & 74764.0 & 209.2 \\
\hline FSB & 79 & 50139.0 & 73663.0 & 202.0 \\
\hline FSB & $87 \mathrm{D}$ & 50081.0 & 75586.0 & 213.5 \\
\hline FSB & $88 \mathrm{D}$ & 51527.0 & 75621.0 & 215.5 \\
\hline FSB & $89 \mathrm{D}$ & 51335.0 & 75548.0 & 214.9 \\
\hline FSB & $90 D$ & 51140.0 & 75376.0 & 214.5 \\
\hline FSB & 91D & 50946.0 & 75207.0 & 212.9 \\
\hline FSB & $92 \mathrm{D}$ & 50557.0 & 75045.0 & 211.5 \\
\hline FSB & $93 D$ & 50452.0 & 74888.0 & 210.8 \\
\hline FSB & $94 \mathrm{DR}$ & 50162.0 & 74869.0 & 210.6 \\
\hline FSB & $95 \mathrm{D}$ & 50008.0 & 74977.0 & 209.7 \\
\hline FSB & $95 \mathrm{DR}$ & 49996.0 & 74991.0 & 210.6 \\
\hline FSB & 97D & 49975.0 & 75188.0 & 210.5 \\
\hline FSB & $98 \mathrm{D}$ & 50111.0 & 75371.0 & 212.9 \\
\hline FSB & $99 D$ & 50326.0 & 75691.0 & 211.8 \\
\hline FSB] & $104 \mathrm{D}$ & 49255.0 & 73865.0 & 203.7 \\
\hline FSB] & $105 \mathrm{D}$ & 49833.0 & 75244.0 & 208.5 \\
\hline FSB] & 105DR & 49841.0 & 75258.0 & 211.4 \\
\hline FSB] & $106 \mathrm{D}$ & 50636.0 & 74193.0 & 206.9 \\
\hline FSB 1 & 1070 & 51149.0 & 75177.0 & 213.2 \\
\hline FSBI & $108 D$ & 51142.0 & 76260.0 & 217.2 \\
\hline FSBI & 1090 & 50488.0 & 75855.0 & 213.1 \\
\hline FSBI & 1100 & 50141.0 & 74193.0 & 205.1 \\
\hline FSBI & 111D & 51515.0 & 75382.0 & 214.5 \\
\hline FSB] & $112 \mathrm{D}$ & 48780.0 & 74223.0 & 206.7 \\
\hline FSB1 & $113 D$ & 51098.0 & 74154.0 & 208.0 \\
\hline ESB1 & $114 \mathrm{D}$ & 52018.0 & 75278.0 & 217.4 \\
\hline FSB1 & $115 D$ & 49728.0 & 72504.0 & 191.8 \\
\hline FSB] & $116 D$ & 50629.0 & 72727.0 & 192.2 \\
\hline FSB] & 1170 & 50486.0 & 74070.0 & 205.5 \\
\hline FSB1 & $118 \mathrm{D}$ & 51276.0 & 74697.0 & 211.5 \\
\hline FSBI & $119 \mathrm{D}$ & 50600.0 & 74599.0 & 208.9 \\
\hline FSBI & $120 \mathrm{D}$ & 49163.0 & 75568.0 & 210.4 \\
\hline FSB1 & $121 \mathrm{DR}$ & 48429.0 & 75151.0 & 208.5 \\
\hline FSB1 & $122 \mathrm{D}$ & 48201.0 & 73865.0 & 204.3 \\
\hline FSB1 & $123 D$ & 51734.0 & 74562.0 & 212.7 \\
\hline FSL & $1 D$ & 52992.0 & 79063.0 & 225.2 \\
\hline FSL & $2 \mathrm{D}$ & 52790.0 & 78636.0 & 226.7 \\
\hline FSL & 3D & 52465.0 & 77765.0 & 224.2 \\
\hline FSL & $4 D$ & 52230.0 & 77452.0 & 218.9 \\
\hline FSL & $5 D$ & 51903.0 & 77047.0 & 222.4 \\
\hline FSL & $6 \mathrm{D}$ & 51727.0 & 76733.0 & 221.2 \\
\hline FSL & 7D & 51485.0 & 76327.0 & 220.5 \\
\hline FSL & 8D & 51513.0 & 76054.0 & 219.7 \\
\hline FSI & 9D & 51543.0 & 75768.0 & 218.6 \\
\hline FSS & 1D & 53897.0 & 75257.0 & 223.5 \\
\hline FSS & $2 \mathrm{D}$ & 53918.0 & 75103.0 & 223.0 \\
\hline FSS & $3 D$ & 53548.0 & 74960.0 & 220.7 \\
\hline iss & $4 \mathrm{D}$ & & 755370 & \\
\hline
\end{tabular}


Table A4. (cont'd)

\begin{tabular}{|c|c|c|c|c|}
\hline \multicolumn{2}{|c|}{$\begin{array}{l}\text { Well } \\
\text { Label }\end{array}$} & $\begin{array}{l}\text { SRS East } \\
\text { (ft) }\end{array}$ & $\begin{array}{c}\text { SRS North } \\
\text { (ft) }\end{array}$ & $\begin{array}{c}\text { Elevatior } \\
\text { (ft) }\end{array}$ \\
\hline FTF & 1 & 53179.0 & 77413.0 & 229.4 \\
\hline FTF & 2 & 53275.0 & 77336.0 & 225.3 \\
\hline FTF & 3 & 53244.0 & 77235.0 & 224.1 \\
\hline FTF & 4 & 53268.0 & 77132.0 & 224.4 \\
\hline FTF & 5 & 53168.0 & 77035.0 & 225.1 \\
\hline FTF & 6 & 53062.0 & 77151.0 & 22.4 .1 \\
\hline FTF & 8 & 53059.0 & 77336.0 & 227.5 \\
\hline FTF & 9 & 52769.0 & 77482.0 & 223.6 \\
\hline FTF & 10 & 52905.0 & 77336.0 & 223.8 \\
\hline FTF & 11 & 52748.0 & 77180.0 & 225.2 \\
\hline FTF & 12 & 52648.0 & 77321.0 & 226.8 \\
\hline FTF & 13 & 53098.0 & 76637.0 & 224.7 \\
\hline FTF & 15 & 53230.0 & 76732.0 & 226.1 \\
\hline FTF & 16 & 52879.0 & 76758.0 & 223.1 \\
\hline FTF & 17 & 52884.0 & 76872.0 & 223.0 \\
\hline FTF & 18 & 52879.0 & 76955.0 & 222.8 \\
\hline FTF & 19 & 52670.0 & 77139.0 & 222.2 \\
\hline FTF & 20 & 52500.0 & 77015.0 & 221.8 \\
\hline FTF & 21 & 52498.0 & 76866.0 & 222.8 \\
\hline FTF & 22 & 52494.0 & 76751.0 & 221.6 \\
\hline FTF & 23 & 52660.0 & 76611.0 & 222.0 \\
\hline FTF & $25 \mathrm{~A}$ & 52868.0 & 77308.0 & 223.3 \\
\hline FTF & 26 & 52875.0 & 77250.0 & 223.3 \\
\hline FTF & 27 & 52823.0 & 77227.0 & 223.4 \\
\hline HAC & 1 & 61415.0 & 72171.0 & 269.1 \\
\hline HAC & 2 & 61366.0 & 72220.0 & 268.6 \\
\hline $\mathrm{HAC}$ & 3 & 61313.0 & 72183.0 & 268.9 \\
\hline HAC & 4 & 61372.0 & 72120.0 & 269.2 \\
\hline HAP & 1 & 63398.0 & 71209.0 & 270.7 \\
\hline HAP & 2 & 63519.0 & 71122.0 & 270.1 \\
\hline $\mathrm{HC}$ & $1 E$ & 61864.0 & 71746.0 & 275.0 \\
\hline $\mathrm{HC}$ & $2 \mathrm{E}$ & $61861: 0$ & 71784.0 & 270.5 \\
\hline $\mathrm{HC}$ & $2 F$ & 61861.0 & 71780.0 & 274.3 \\
\hline $\mathrm{HC}$ & $4 B$ & 63408.0 & 71596.0 & 268.0 \\
\hline $\mathrm{HC}$ & $5 B$ & 61705.0 & 73266.0 & 256.1 \\
\hline $\mathrm{HC}$ & $6 \mathrm{~B}$ & 62070.0 & 72150.0 & 268.9 \\
\hline $\mathrm{HC}$ & $11 \mathrm{C}$ & 62131.0 & 74496.0 & 236.6 \\
\hline $\mathrm{HCA}$ & 1 & 63109.0 & 72521.0 & 268.9 \\
\hline $\mathrm{HCA}$ & 3 & 63108.0 & 72651.0 & 268.7 \\
\hline $\mathrm{HCA}$ & 4 & 62942.0 & 72523.0 & 268.6 \\
\hline $\mathrm{HCB}$ & 1 & 63921.0 & 71426.0 & 262.9 \\
\hline $\mathrm{HCB}$ & 2 & 63797.0 & 71289.0 & 267.8 \\
\hline $\mathrm{HCB}$ & 3 & 63919.0 & 71098.0 & 266.1 \\
\hline HET & 1D & 60546.0 & 71948.0 & 267.4 \\
\hline HET & $2 \mathrm{D}$ & 60094.0 & 72006.0 & 258.2 \\
\hline HET & 3D & 60110.0 & 72093.0 & 258.6 \\
\hline HET & $4 D$ & 60166.0 & 72178.0 & 259.0 \\
\hline HR3 & 11 & 60146.0 & 71402.0 & 259.3 \\
\hline HR3 & 13 & 60065.0 & 71649.0 & 258.1 \\
\hline HR8 & 11 & 59559.0 & 71945.0 & 245.8 \\
\hline HR8 & 12 & 59330.0 & 71780.0 & 239.3 \\
\hline HR8 & 13 & 59300.0 & 71559.0 & 237.8 \\
\hline HR8 & 14 & 596120 & 714310 & 244 \\
\hline
\end{tabular}


Table A4. (cont'd)

\begin{tabular}{|c|c|c|c|}
\hline $\begin{array}{l}\text { Well } \\
\text { LabeI }\end{array}$ & $\begin{array}{c}\text { SRS East } \\
\text { (ft) }\end{array}$ & $\begin{array}{l}\text { SRS North } \\
\text { (ft) }\end{array}$ & $\begin{array}{c}\text { Elevatior } \\
\text { (ft) }\end{array}$ \\
\hline HSB 65 & 58432.0 & 72425.0 & 234.3 \\
\hline $\mathrm{HSB} \quad 65 \mathrm{C}$ & 58447.0 & 72439.0 & 233.2 \\
\hline HSB 66 & 56928.0 & 72429.0 & 226.9 \\
\hline HSB 67 & 58424.0 & 71505.0 & 225.2 \\
\hline HSB 68 & 56901.0 & 71528.0 & 224.4 \\
\hline HSB 69 & 56475.0 & 71546.0 & 220.7 \\
\hline HSB 70 & 55758.0 & 72606.0 & 227.5 \\
\hline HSB 71 & 55279.0 & 72875.0 & 225.1 \\
\hline $\mathrm{HSB} 83 \mathrm{D}$ & 58601.0 & 71628.0 & 225.8 \\
\hline $\mathrm{HSB} \quad 8 \triangle \mathrm{D}$ & 56349.0 & 71583.0 & 219.8 \\
\hline $\mathrm{HSB} 85 \mathrm{C}$ & 58947.0 & 73802.0 & 239.0 \\
\hline HSB 86D & 55996.0 & 72522.0 & 225.9 \\
\hline HSB100D & 58796.0 & 72073.0 & 233.3 \\
\hline HSB101D & 58594.0 & 71997.0 & 230.8 \\
\hline HSB102D & 58393.0 & 71952.0 & 228.0 \\
\hline HSB103D & 58315.0 & 71588.0 & 226.0 \\
\hline HSB10 $4 \mathrm{D}$ & 58075.0 & 71370.0 & 225.4 \\
\hline HSB105D & 57877.0 & 71454.0 & 225.8 \\
\hline HSB106D & 57644.0 & 71727.0 & 226.3 \\
\hline HSB107D & 57412.0 & 71696.0 & 225.1 \\
\hline HSB108D & 57145.0 & 71688.0 & 223.9 \\
\hline FSB109D & 56885.0 & 71685.0 & 223.4 \\
\hline HSB110D & 56672.0 & 71785.0 & 222.8 \\
\hline HSB111D & 56494.0 & 71926.0 & 222.6 \\
\hline HSB111E & 56487.0 & 71932.0 & $222: 7$ \\
\hline HSB112D & 56408.0 & 72161.0 & 223.7 \\
\hline HSB112E & 56399.0 & 72166.0 & $223 ! 6$ \\
\hline HSB113D & 56164.0 & 72302.0 & 223.6 \\
\hline HSB114D & 56104.0 & 72474.0 & 224.6 \\
\hline HSB115D & 56039.0 & 72662.0 & 225.5 \\
\hline HSB116D & 55988.0 & 72898.0 & 226.4 \\
\hline HSB117D & 55155.0 & 72747.0 & 224.8 \\
\hline HSB125D & 58584.0 & 71498.0 & 221.6 \\
\hline HSB126D & 57169.0 & 70633.0 & 204.9 \\
\hline HSB $127 D$ & 56788.0 & 71218.0 & 218.5 \\
\hline HSB129D & 55103.0 & 71837.0 & 208.5 \\
\hline HSB13OD & 54651.0 & 70757.0 & 200.1 \\
\hline HSB131D & 56891.0 & 70365.0 & 205.2 \\
\hline HSB132D & 58799.0 & 71469.0 & 221.7 \\
\hline HSB133D & 59102.0 & 71943.0 & 234.8 \\
\hline HSB134D & 58296.0 & 71217.0 & 222.5 \\
\hline HSB135D & 56552.0 & 71396.0 & 218.6 \\
\hline HSB136D & 55941.0 & 71906.0 & 221.5 \\
\hline HSB $137 D$ & 55696.0 & 72278.0 & 223.0 \\
\hline HSB138D & 55260.0 & 73160.0 & 224.0 \\
\hline HSB139D & 57384.0 & 71133.0 & 223.3 \\
\hline HSB14OD & 56560.0 & 70036.0 & 215.4 \\
\hline HSB141D & 59170.0 & 71184.0 & 243.5 \\
\hline HSB $142 \mathrm{D}$ & 53493.0 & 73113.0 & 198.3 \\
\hline HSB143D & 52774.0 & 73754.0 & 213.9 \\
\hline HSB145D & 57753.0 & 71088.0 & 221.7 \\
\hline HSB146D & 58493.0 & 70469.0 & 223.0 \\
\hline HSB147D & 55804.0 & 73827.0 & 234.0 \\
\hline
\end{tabular}


Table A4. (cont'd)

\begin{tabular}{|c|c|c|c|c|}
\hline \multicolumn{2}{|c|}{$\begin{array}{l}\text { Well } \\
\text { Label }\end{array}$} & $\begin{array}{l}\text { SRS East } \\
\text { (ft) }\end{array}$ & $\begin{array}{l}\text { SRS North } \\
\text { (ft) }\end{array}$ & $\begin{array}{c}\text { Elevati } \\
\text { (ft) }\end{array}$ \\
\hline \multicolumn{2}{|c|}{ HSB 148D } & 55355.0 & 70160.0 & 214.9 \\
\hline \multicolumn{2}{|c|}{ HSB149D } & 57286.0 & 71338.0 & 224.5 \\
\hline \multicolumn{2}{|c|}{ HSB150D } & 58692.0 & 71692.0 & 228.1 \\
\hline \multicolumn{2}{|c|}{ HSB151D } & 54026.0 & 72997.0 & 208.0 \\
\hline \multicolumn{2}{|c|}{$\mathrm{HSB} 152 \mathrm{D}$} & 54362.0 & 72011.0 & 206.4 \\
\hline HSL & $1 D$ & 58925.0 & 72179.0 & 235.6 \\
\hline HSL & $2 \mathrm{D}$ & 59423.0 & 72190.0 & 242.1 \\
\hline HSL & $3 \mathrm{D}$ & 59770.0 & 72251.0 & 250.0 \\
\hline HSL & $4 \mathrm{D}$ & 60171.0 & 72453.0 & 261.5 \\
\hline HSL & $5 \mathrm{D}$ & 60339.0 & 72562.0 & 263.8 \\
\hline HSI & $6 \mathrm{D}$ & 60531.0 & 72659.0 & 260.6 \\
\hline HSL & $7 \mathrm{D}$ & 60723.0 & 72674.0 & 260.3 \\
\hline HSI & $8 D$ & 61117.0 & 72688.0 & 261.5 \\
\hline HSS & 1D & 64675.0 & 67610.0 & 268.6 \\
\hline HSS & $2 \mathrm{D}$ & 64785.0 & 67355.0 & 267.2 \\
\hline HSS & $3 \mathrm{D}$ & 64709.0 & 68257.0 & 281.5 \\
\hline $\mathrm{HTF}$ & 1 & 62067.0 & 71745.0 & 271.8 \\
\hline HTF & 2 & 62175.0 & 71610.0 & 273.0 \\
\hline HTF & 4 & 61942.0 & 71630.0 & 272.5 \\
\hline HTF & 5 & 62110.0 & 71390.0 & 277.6 \\
\hline $\mathrm{HTF}$ & 6 & 62228.0 & 71259.0 & 276.4 \\
\hline HTF & 7 & 62112.0 & 71130.0 & 275.6 \\
\hline $\mathrm{HTF}$ & 8 & 61965.0 & 71270.0 & 274.5 \\
\hline HTF & 9 & 61698.0 & 71652.0 & 271.5 \\
\hline $\mathrm{HTF}$ & 10 & 61838.0 & 71520.0 & 270.8 \\
\hline HTF & 11 & 61722.0 & 71398.0 & 271.6 \\
\hline $\mathrm{HTF}$ & 12 & 61593.0 & 71520.0 & 270.7 \\
\hline $\mathrm{HTF}$ & 13 & 61586.0 & 71856.0 & 273.4 \\
\hline $\mathrm{HTF}$ & 14 & 61462.0 & 71858.0 & 273.2 \\
\hline HTF & 15 & 61353.0 & 71700.0 & .272 .8 \\
\hline $\mathrm{HTF}$ & 16 & 61950.0 & 72150.0 & 269.0 \\
\hline HTF & 17 & 61188.0 & 72600.0 & 262.8 \\
\hline HTF & 18 & 61223.0 & 71771.0 & 270.5 \\
\hline HTF & 19 & 61079.0 & 71902.0 & 268.5 \\
\hline $\mathrm{HTF}$ & 20 & 61086.0 & 72073.0 & 267.3 \\
\hline HTF & 21 & 61261.0 & 71998.0 & 268.5 \\
\hline HTF & 22 & 62553.0 & 71363.0 & 273.9 \\
\hline $\mathrm{HTF}$ & 23 & 62670.0 & 71363.0 & 274.1 \\
\hline HTF & 24 & 62775.0 & 71362.0 & 273.9 \\
\hline $\mathrm{HTF}$ & 25 & 62902.0 & 71224.0 & 273.9 \\
\hline HTF & 26 & 62815.0 & 71090.0 & 274.0 \\
\hline HTF & 27 & 62660.0 & 71057.0 & 274.2 \\
\hline HTF & 28 & 62515.0 & 71080.0 & 275.7 \\
\hline HTF & 29 & 62414.0 & 71229.0 & 274.2 \\
\hline HTF & 31 & 62662.0 & 70747.0 & 274.6 \\
\hline $\mathrm{HTF}$ & 32 & 62807.0 & 70880.0 & 273.9 \\
\hline $\mathrm{HTF}$ & 34 & 61978.0 & 71144.0 & 272.6 \\
\hline MGA & 36 & 57891.0 & 73904.0 & 238.4 \\
\hline MGC & 9 & 55610.0 & 75372.0 & 229.6 \\
\hline MGC & 11 & 55770.0 & 75252.0 & 232.2 \\
\hline MGC & 23 & 56726.0 & 74528.0 & 236.4 \\
\hline MGC & 32 & 57448.0 & 73982.0 & 245.7 \\
\hline MGE & 9 & 55489.0 & 75215.0 & 229.7 \\
\hline
\end{tabular}


Table A4. (cont'd)

\begin{tabular}{|c|c|c|c|c|}
\hline & $\begin{array}{l}11 \\
\text { bel }\end{array}$ & $\begin{array}{c}\text { SRS East } \\
\text { (ft) }\end{array}$ & $\begin{array}{c}\text { SRS North } \\
\text { (ft) }\end{array}$ & $\begin{array}{c}\text { Elevatior } \\
\text { (ft) }\end{array}$ \\
\hline MGE & 2.1 & 56446.0 & 74487.0 & 235.1 \\
\hline MGG & 15 & 55851.0 & 74699.0 & 233.1 \\
\hline MGG & 19 & 56174.0 & 74456.0 & 232.9 \\
\hline MGG & 23 & 56491.0 & 74214.0 & 235.8 \\
\hline MGG & 28 & 56895.0 & 73905.0 & 237.2 \\
\hline MGG & 36 & 57541.0 & 73413.0 & 238.8 \\
\hline NBG & 1 & 53879.0 & 79300.0 & 224.1 \\
\hline NBG & 2 & 53958.0 & 79099.0 & 224.8 \\
\hline NBG & 3 & 54068.0 & 78939.0 & 218.1 \\
\hline NBG & 4 & 54329.0 & 78942.0 & 217.1 \\
\hline NBG & 5 & 54515.0 & 78943.0 & 217.6 \\
\hline $\mathrm{P}$ & $27 \mathrm{D}$ & 64008.0 & 70376.0 & 266.9 \\
\hline SBG & 1 & 63749.0 & 74619.0 & 237.8 \\
\hline SBG & 2 & 64939.0 & 74570.0 & 237.6 \\
\hline SBG & 3 & 65265.0 & 73699.0 & 236.9 \\
\hline SBG & 4 & 65010.0 & 72399.0 & 240.6 \\
\hline SBG & 5 & 64499.0 & 72208.0 & 249.1 \\
\hline SBG & 6 & 63860.0 & 73599.0 & 244.2 \\
\hline SCA & 2 & 64697.0 & 73850.0 & 242.2 \\
\hline SCA & 3 & 64571.0 & 73959.0 & 241.3 \\
\hline $\mathrm{SCA}$ & $3 A$ & 64571.0 & 73965.0 & 270.9 \\
\hline SCA & 4 & 64563.0 & 73856.0 & 241.7 \\
\hline SCA & $4 A$ & 64567.0 & 73855.0 & 269.1 \\
\hline SCA & 5 & 64630.0 & 74092.0 & 242.0 \\
\hline$S C A$ & 6 & 64637.0 & 73706.0 & 242.2 \\
\hline SLP & 1 & 64449.0 & 72958.0 & 244.8 \\
\hline SLP & 2 & 64529.0 & 72863.0 & 244.4 \\
\hline YSC & $1 \mathrm{C}$ & 65855.0 & 78186.0 & 217.5 \\
\hline YSC & $2 \mathrm{D}$ & 66130.0 & 78320.0 & 217.1 \\
\hline $\mathbf{Z}$ & 2 & 53181.0 & 74785.0 & 218.1 \\
\hline $\mathrm{z}$ & 3 & 51328.0 & 75086.0 & 212.2 \\
\hline $\mathrm{z}$ & 8 & 51584.0 & 76640.0 & 218.0 \\
\hline $\mathrm{Z}$ & 9 & 50570.0 & 77732.0 & 214.8 \\
\hline $\mathrm{z}$ & 11 & 61750.0 & 72539.0 & 296.4 \\
\hline $\mathrm{z}$ & 12 & 61400.0 & 71198.0 & 274.4 \\
\hline $\mathrm{z}$ & 13 & 62203.0 & 70785.0 & 274.6 \\
\hline $\mathrm{Z}$ & 15 & 63419.0 & 72802.0 & 263.7 \\
\hline ZBG & 1 & 65584.0 & 76584.0 & 234.1 \\
\hline ZBG & $1 \mathrm{~A}$ & 65598.0 & 76588.0 & 279.7 \\
\hline ZBG & 2 & 67472.0 & 76170.0 & 221.5 \\
\hline ZDT & 1 & 65114.0 & 71644.0 & 239.5 \\
\hline $\mathrm{ZDT}$ & 2 & 65059.0 & 71696.0 & 241.1 \\
\hline $\mathrm{ZW}$ & 4 & 56556.0 & 77667.0 & 232.6 \\
\hline $\mathrm{ZW}$ & 5 & 54708.0 & 75767.0 & 227.5 \\
\hline $\mathrm{ZW}$ & 7 & 60300.0 & 72399.0 & 265.8 \\
\hline$Z W$ & 8 & 63801.0 & 70800.0 & 270.8 \\
\hline$Z W$ & 9 & 61400.0 & 73198.0 & 251.9 \\
\hline $\mathrm{ZW}$ & 10 & 63401.0 & 73212.0 & 249.7 \\
\hline $\mathrm{CC}-$ & & 54065.0 & 73295.0 & 214.9 \\
\hline $\mathrm{CC}-$ & & 54390.0 & 73060.0 & 216.4 \\
\hline $\mathrm{CC}-$ & & 54710.0 & 72820.0 & 220.0 \\
\hline GG- & & 54470.0 & 72495.0 & 207.8 \\
\hline GG- & & 54793.0 & 72260.0 & 211.8 \\
\hline
\end{tabular}


Table A4. (cont'd)

\begin{tabular}{lccc}
$\begin{array}{c}\text { WeIl } \\
\text { Labe1 }\end{array}$ & $\begin{array}{c}\text { SRS East } \\
\text { (ft) }\end{array}$ & $\begin{array}{c}\text { SRS North } \\
\text { (ft) }\end{array}$ & $\begin{array}{c}\text { Elevation } \\
\text { (ft) }\end{array}$ \\
\hline M-5 & 54690.0 & 74820.0 & 228.6 \\
M-9 & 55020.0 & 74590.0 & 228.0 \\
M-17 & 55650.0 & 74100.0 & 235.0 \\
M-21 & 55985.0 & 73870.0 & 237.9 \\
Q-5 & 54470.0 & 74500.0 & 226.0 \\
Q-9 & 54775.0 & 74260.0 & 226.9 \\
Q-13 & 55100.0 & 74020.0 & 227.4 \\
Q-17 & 55425.0 & 73780.0 & 241.6 \\
Q-21 & 55745.0 & 73540.0 & 233.1 \\
S-3 & 54070.0 & 74492.0 & 224.0 \\
S-4 & 53678.0 & 74319.0 & 222.1 \\
S-5 & 53370.0 & 73913.0 & 221.0 \\
S-6 & 53222.0 & 73440.0 & 204.6 \\
S-9 & 53785.0 & 74919.0 & 226.1 \\
S-15 & 53930.0 & 75381.0 & 231.5 \\
S-16 & 53491.0 & 75223.0 & 226.2 \\
U-5 & 54219.0 & 74176.0 & 223.0 \\
U-9 & 54540.0 & 73945.0 & 223.8 \\
U-13 & 54863.0 & 73700.0 & 232.4 \\
U-17 & 55185.0 & 73470.0 & 226.2 \\
U-21 & 55506.0 & 73225.0 & 227.3 \\
Y-7 & 54140.0 & 73730.0 & 218.2 \\
Y-9 & 54300.0 & 73615.0 & 220.8 \\
Y-13 & 54625.0 & 73380.0 & 223.2 \\
Y-17 & 54950.0 & 73140.0 & 224.7 \\
Y-21 & 55270.0 & 72900.0 & 224.0
\end{tabular}


Table A5. Time-averaged well hydraulic head data for the "lower" aquifer zone within the Upper Three Runs aquifer.

\begin{tabular}{|c|c|c|c|c|}
\hline \multicolumn{2}{|c|}{$\begin{array}{l}\text { Well } \\
\text { Label }\end{array}$} & $\begin{array}{c}\text { SRS East } \\
\text { (Et) }\end{array}$ & $\begin{array}{c}\text { SRS North } \\
(f t)\end{array}$ & $\begin{array}{r}\text { Elevati } \\
(f t)\end{array}$ \\
\hline$B G$ & 91 & 56649.0 & 78031.0 & 219.1 \\
\hline$B G$ & 92 & 56828.0 & 79019.0 & 209.0 \\
\hline$B G$ & 93 & 57160.0 & 79930.0 & 201.1 \\
\hline BG & 94 & 57494.0 & 80867.0 & 191.4 \\
\hline$B G$ & 95 & 58407.0 & 80059.0. & 193.3 \\
\hline BG & 96 & 58297.0 & $79396.0^{\circ}$ & 198.5 \\
\hline BG . & 101 & 59277.0 & 78740.0 & 195.7 \\
\hline BG & 103 & 59752.0 & 77883.0 & 200.4 \\
\hline$B G$ & 122 & 56789.0 & 78581.0 & 211.3 \\
\hline BGO & $5 c$ & 58794.0 & 76476.0 & 216.6 \\
\hline BGO & $6 \mathrm{~B}$ & 58346.0 & 76553.0 & 219.7 \\
\hline BGO & $6 \mathrm{C}$ & 58307.0 & 76487.0 & 220.1 \\
\hline BGO & $8 C$ & 57618.0 & 76579.0 & 225.4 \\
\hline BGO & $10 B$ & 56978.0 & 76982.0 & 220.9 \\
\hline BGO & $10 \mathrm{C}$ & 57041.0 & 76805.0 & 220.2 \\
\hline BGO & $12 \mathrm{C}$ & 56241.0 & 76805.0 & 220.0 \\
\hline BGO & $12 \mathrm{CR}$ & 56215.0 & 76806.0 & 222.4 \\
\hline BGO & $13 \mathrm{DR}$ & 55840.0 & 76824.0 & 232.2 \\
\hline BGO & $14 \mathrm{C}$ & 55839.0 & 76367.0 & 221.0 \\
\hline BGO & $14 \mathrm{CR}$ & 55789.0 & 76337.0 & 224.9 \\
\hline BGO & $16 \mathrm{~B}$ & 56183.0 & 75767.0 & 220.3 \\
\hline BGO & $27 \mathrm{C}$ & 54671.0 & 75666.0 & 220.3 \\
\hline BGO & $29 \mathrm{C}$ & 54099.0 & 75577.0 & 223.9 \\
\hline BGO & $30 \mathrm{C}$ & 54512.0 & 75181.0 & 219.1 \\
\hline BGO & $31 \mathrm{C}$ & 54816.0 & 74978.0 & 225.5 \\
\hline BGO & $33 C$ & 55681.0 & 74479.0 & 224.9 \\
\hline BGO & $35 \mathrm{C}$ & 56545.0 & 73953.0 & 228.3 \\
\hline BGO & $37 c$ & 57279.0 & 73498.0 & 229.1 \\
\hline BGO & $42 \mathrm{C}$ & 55522.0 & 76404.0 & 224.4 \\
\hline BGO & $43 C R$ & 56237.0 & 77035.0 & 226.6 \\
\hline BGO & $43 D$ & 56238.0 & 77056.0 & 232.3 \\
\hline BGO & $44 B$ & 57865.0 & 76756.0 & 221.9 \\
\hline BGO & $44 C$ & 57894.0 & 76757.0 & 221.7 \\
\hline BGO & $45 \mathrm{~B}$ & 54563.0 & 75840.0 & 220.6 \\
\hline BGO & $45 \mathrm{C}$ & 54577.0 & 75835.0 & 223.9 \\
\hline BGO & $46 \mathrm{~B}$ & 54444.0 & 75012.0 & 218.9 \\
\hline BGO & $46 \mathrm{C}$ & 54433.0 & 75022.0 & 221.1 \\
\hline BGO & $47 C$ & 54933.0 & 74752.0 & 223.7 \\
\hline BGO & $48 \mathrm{C}$ & 55124.0 & 74599.0 & 224.5 \\
\hline BGO & $49 C$ & 56202.0 & 73917.0 & 229.0 \\
\hline BGO & $50 \mathrm{C}$ & 54197.0 & 75190.0 & 219.5 \\
\hline$B G X$ & $1 \mathrm{C}$ & 58599.0 & 76820.0 & 216.9 \\
\hline$B G X$ & $2 B$ & 58256.0 & 77203.0 & 213.3 \\
\hline BGX & $2 D$ & 58265.0 & 77192.0 & 216.3 \\
\hline$B G X$ & $3 D$ & 57780.0 & 77577.0 & 216.1 \\
\hline$B G X$ & $4 \mathrm{C}$ & 57202.0 & 77886.0 & 215.9 \\
\hline BGX & $4 D$ & 57186.0 & 77893.0 & 217.0 \\
\hline BGX & $5 D$ & 57308.0 & 78402.0 & 210.6 \\
\hline$B G X$ & $6 D$ & 57524.0 & 78740.0 & 207.6 \\
\hline$B G X$ & $7 D$ & 58312.0 & 78349.0 & 207.7 \\
\hline BGX & $8 D R$ & 58942.0 & 77589.0 & 206.5 \\
\hline BGX & $12 \mathrm{C}$ & 59675.0 & 74427.0 & 235.7 \\
\hline
\end{tabular}


Table A5. (cont'd)

\begin{tabular}{|c|c|c|c|c|}
\hline \multicolumn{2}{|c|}{$\begin{array}{l}\text { Well } \\
\text { Label }\end{array}$} & $\begin{array}{c}\text { SRS East } \\
\text { (ft) }\end{array}$ & $\begin{array}{l}\text { SRS North } \\
\text { (ft) }\end{array}$ & $\begin{array}{c}\text { Elevation } \\
\text { (ft) }\end{array}$ \\
\hline$\overline{F A C}$ & 4 & 55472.0 & 78223.0 & 228.9 \\
\hline FBP & $1 \mathrm{~A}$ & 51080.0 & 78893.0 & 206.8 \\
\hline FBP & 4 & 51368.0 & 79320.0 & 211.6 \\
\hline FNB & 1 & 54271.0 & 80151.0 & 210.8 \\
\hline$F N B$ & 2 & 54362.0 & 80442.0 & 207.0 \\
\hline FNB & 3 & 54105.0 & 80553.0 & 209.2 \\
\hline FNB & 4 & 53843.0 & 80409.0 & 213.1 \\
\hline FSB & $76 \mathrm{C}$ & 51396.0 & 76112.0 & 212.7 \\
\hline FSB & $78 \mathrm{C}$ & 50170.0 & 74772.0 & 207.7 \\
\hline FSB & $79 C$ & 50171.0 & 73668.0 & 196.6 \\
\hline FSB & $87 \mathrm{C}$ & 50093.0 & 75591.0 & 208.4 \\
\hline FSB & $88 \mathrm{C}$ & 51518.0 & 75619.0 & 211.9 \\
\hline FSB & $89 \mathrm{C}$ & 51345.0 & 75553.0 & 211.4 \\
\hline FSB & $90 \mathrm{C}$ & 51148.0 & 75382.0 & 210.3 \\
\hline FSB & $91 \mathrm{C}$ & 50953.0 & 75213.0 & 210.3 \\
\hline FSB & $93 \mathrm{C}$ & 50458.0 & 74897.0 & 208.4 \\
\hline FSB & $94 \mathrm{C}$ & 50180.0 & 74869.0 & 207.7 \\
\hline FSB & $95 \mathrm{C}$ & 50016.0 & 74971.0 & 205.9 \\
\hline FSB & $95 \mathrm{CR}$ & 49987.0 & 75001.0 & 208.2 \\
\hline FSB & $97 \mathrm{C}$ & 49970.0 & 75179.0 & 207.7 \\
\hline FSB & $98 \mathrm{C}$ & 50116.0 & 75381.0 & 209.2 \\
\hline FSB & $99 \mathrm{C}$ & 50320.0 & 75683.0 & 209.2 \\
\hline FSB & $102 \mathrm{C}$ & 50834.0 & 73582.0 & 195.1 \\
\hline FSB & $103 C$ & 49651.0 & 74210.0 & 202.3 \\
\hline FSB & $104 \mathrm{C}$ & 49248.0 & 73872.0 & 200.5 \\
\hline FSB & $105 C$ & 49828.0 & 75234.0 & 207.2 \\
\hline FSB & $106 \mathrm{C}$ & 50651.0 & 74190.0 & 201.1 \\
\hline FSB & $107 \mathrm{C}$ & 51158.0 & 75184.0 & 209.7 \\
\hline FSB & $110 \mathrm{C}$ & 50150.0 & 74190.0 & 201.6 \\
\hline FSB & L11C & 51526.0 & 75383.0 & 211.1 \\
\hline FSB & $112 \mathrm{C}$ & 48794.0 & 74227.0 & 202.6 \\
\hline FSB & $113 C$ & 51084.0 & 74160.0 & 203.1 \\
\hline FSB & L14C & 52033.0 & 75288.0 & 213.8 \\
\hline FSB & $15 C$ & 49736.0 & 72515.0 & 184.2 \\
\hline FSB & $\mathrm{L16C}$ & 50645.0 & 72725.0 & 189.6 \\
\hline FSB & $20 \mathrm{C}$ & 49171.0 & 75549.0 & 206.8 \\
\hline FSB & $21 \mathrm{C}$ & 48413.0 & 75155.0 & 205.0 \\
\hline FSB & $22 \mathrm{C}$ & 48195.0 & 73881.0 & 200.5 \\
\hline FSB & $L 23 C$ & 51750.0 & 74566.0 & 210.8 \\
\hline $\mathrm{HC}$ & $1 \mathrm{~B}$ & 61877.0 & 71745.0 & 254.9 \\
\hline $\mathrm{HC}$ & $2 \mathrm{C}$ & 61872.0 & 71784.0 & 254.2 \\
\hline $\mathrm{HC}$ & $2 \mathrm{D}$ & 61866.0 & 71784.0 & 256.3 \\
\hline $\mathrm{HC}$ & $4 \mathrm{~A}$ & 63409.0 & 71606.0 & 244.7 \\
\hline $\mathrm{HC}$ & $5 A$ & 61710.0 & 73265.0 & 213.8 \\
\hline $\mathrm{HC}$ & $6 \mathrm{~A}$ & 62060.0 & 72150.0 & 252.2 \\
\hline $\mathrm{HC}$ & $10 B$ & 61600.0 & 75801.0 & 208.4 \\
\hline $\mathrm{HC}$ & $12 B$ & 59488.0 & 73186.0 & 241.6 \\
\hline HMD & 1D & 56973.0 & 78731.0 & 210.9 \\
\hline HMD & $2 \mathrm{D}$ & 57269.0 & 79665.0 & 202.3 \\
\hline HMD & 3D & 57745.0 & 79578.0 & 201.8 \\
\hline HMD & $4 D$ & 58188.0 & 79160.0 & 201.9 \\
\hline HSB & $65 B$ & 58439.0 & 72445.0 & 224.7 \\
\hline HSB & $68 B$ & 56882.0 & 71525.0 & 217.8 \\
\hline
\end{tabular}


Table A5. (cont'd)

\begin{tabular}{|c|c|c|c|}
\hline $\begin{array}{l}\text { Well } \\
\text { LabeI }\end{array}$ & $\begin{array}{l}\text { SRS East } \\
\text { (ft) }\end{array}$ & $\begin{array}{l}\text { SRS North } \\
(\mathrm{ft})\end{array}$ & $\begin{array}{c}\text { Elevatior } \\
(\mathrm{ft})\end{array}$ \\
\hline HSB $68 \mathrm{C}$ & 56872.0 & 71524.0 & 218.6 \\
\hline HSB $70 \mathrm{C}$ & 55757.0 & 72597.0 & 223.9 \\
\hline HSB $71 \mathrm{C}$ & 55281.0 & 72866.0 & 223.1 \\
\hline HSB $83 B$ & 58594.0 & 71639.0 & 223.2 \\
\hline HSB $83 C$ & 58614.0 & 71636.0 & 225.1 \\
\hline $\mathrm{HSB} \quad 84 \mathrm{~B}$ & 56352.0 & 71603.0 & 211.2 \\
\hline $\mathrm{HSB} 84 \mathrm{C}$ & 56360.0 & 71597.0 & 214.5 \\
\hline HSB $85 B$ & 58953.0 & 73789.0 & 233.9 \\
\hline $\mathrm{HSB} \quad 86 \mathrm{~B}$ & 55976.0 & 72519.0 & 223.0 \\
\hline HSB $86 C$ & 55984.0 & 72529.0 & 225.8 \\
\hline HSB $100 \mathrm{C}$ & 58806.0 & 72077.0 & 226.3 \\
\hline HSB101C & 58604.0 & 72001.0 & 225.3 \\
\hline $\mathrm{HSB} 102 \mathrm{C}$ & 58399.0 & 71960.0 & 224.6 \\
\hline HSB103C & 58323.0 & 71593.0 & 223.6 \\
\hline HSB $104 \mathrm{C}$ & 58082.0 & 71376.0 & 220.6 \\
\hline HSB105C & 57883.0 & 71447.0 & 219.7 \\
\hline HSB106C & 57651.0 & 71720.0 & 221.8 \\
\hline HSB107C & 57432.0 & 71698.0 & 219.5 \\
\hline HSB108C & 57155.0 & 71688.0 & 218.9 \\
\hline HSB109C & 56895.0 & 71684.0 & 219.0 \\
\hline HSB110C & 56680.0 & 71779.0 & 219.4 \\
\hline HSB111C & 56501.0 & 71919.0 & 220.7 \\
\hline HSB112C & 56417.0 & 72156.0 & 222.1 \\
\hline HSB113C & 56160.0 & 72312.0 & 222.6 \\
\hline HSB114C & 56107.0 & 72464.0 & 224.4 \\
\hline $\mathrm{HSB} 115 \mathrm{C}$ & 56043.0 & 72653.0 & 225.2 \\
\hline HSB116C & 55989.0 & 72888.0 & 225.8 \\
\hline HSB117C & 55162.0 & 72740.0 & 222.6 \\
\hline HSB125C & 58592.0 & 71503.0 & 223.4 \\
\hline HSB126C & 57178.0 & 70627.0 & 203.6 \\
\hline $\mathrm{HSB} 127 \mathrm{C}$ & 56792.0 & 71210.0 & 210.1 \\
\hline HSB129C & $55110: 0$ & 71830.0 & 205.4 \\
\hline $\mathrm{HSB} 130 \mathrm{C}$ & 54643.0 & 70762.0 & 199.7 \\
\hline HSB131C & 56894.0 & 70374.0 & $203: 4$ \\
\hline HSB132C & 58787.0 & 71472.0 & 222.1 \\
\hline HSB133C & 59110.0 & 71949.0 & 230.4 \\
\hline HSB134C & 58289.0 & 71210.0 & 220.8 \\
\hline HSB135C & 56560.0 & 71390.0 & 206.5 \\
\hline HSB136C & 55949.0 & 71900.0 & 217.8 \\
\hline $\mathrm{HSB} 137 \mathrm{C}$ & 55700.0 & 72269.0 & 220.9 \\
\hline HSB139C & 57374.0 & 71129.0 & 214.5 \\
\hline HSB140C & 56551.0 & 70049.0 & 206.2 \\
\hline HSB141C & 59170.0 & 71196.0 & 229.6 \\
\hline HSB142C & 53505.0 & 73119.0 & 198.9 \\
\hline HSB143C & 52773.0 & 73738.0 & 210.0 \\
\hline $\mathrm{HSB} 145 \mathrm{C}$ & 57769.0 & 71098.0 & 214.0 \\
\hline $\mathrm{HSB} 146 \mathrm{C}$ & 58473.0 & 70471.0 & 210.2 \\
\hline HSB148C & 55344.0 & 70151.0 & 202.0 \\
\hline HSB151C & 54014.0 & 72997.0 & 208.7 \\
\hline HSB152C & 54346.0 & 72012.0 & 199.2 \\
\hline P $\quad 27 \mathrm{C}$ & 64004.0 & 70391.0 & 245.2 \\
\hline SBG 2 & 64939.0 & 74570.0 & 237.6 \\
\hline YSC & 65901.0 & 77059.0 & 227.5 \\
\hline
\end{tabular}


Table A5. (cont'd)

\begin{tabular}{lcccc}
$\begin{array}{l}\text { Well } \\
\text { Label }\end{array}$ & $\begin{array}{c}\text { SRS East } \\
\text { (ft) }\end{array}$ & $\begin{array}{c}\text { SRS North } \\
\text { (ft) }\end{array}$ & $\begin{array}{c}\text { Elevation } \\
\text { (ft) }\end{array}$ \\
\hline $\mathrm{ZW} \quad 2$ & 54388.0 & 80701.0 & 207.1 \\
$\mathrm{ZW}$ & 3 & 57078.0 & 80746.0 & 201.1 \\
$\mathrm{~S}-6$ & & 53222.0 & 73440.0 & 204.6
\end{tabular}


Table A6. Time-averaged well hydraulic head data for the Gordon aquifer.

\begin{tabular}{|c|c|c|c|c|}
\hline \multicolumn{2}{|c|}{$\begin{array}{l}\text { Well } \\
\text { Label }\end{array}$} & $\begin{array}{c}\text { SRS East } \\
\text { (ft) }\end{array}$ & $\begin{array}{c}\text { SRS North } \\
(f t)\end{array}$ & $\begin{array}{c}\text { Elevation } \\
\text { (ft) }\end{array}$ \\
\hline BGO & $6 A$ & 58316.0 & 76487.0 & 159.0 \\
\hline $\mathrm{BGO}$ & $8 A$ & 57618.0 & 76569.0 & 160.5 \\
\hline BGO & $8 A R$ & 57617.0 & 76598.0 & 160.2 \\
\hline BGO & 9AA & 57371.0 & 76975.0 & 157.7 \\
\hline BGO & $10 \mathrm{~A}$ & 57050.0 & 76805.0 & 169.0 \\
\hline BGO & $10 \mathrm{AA}$ & 56990.0 & 76997.0 & 157.9 \\
\hline $\mathrm{BGO}$ & IOAR & 57063.0 & 76806.0 & .158 .6 \\
\hline BGO & $12 \mathrm{~A}$ & 56250.0 & 76804.0 & 181.0 \\
\hline BGO & $12 \mathrm{AR}$ & 56259.0 & 76803.0 & 158.0 \\
\hline BGO & $14 \mathrm{~A}$ & 55838.0 & 76377.0 & 157.7 \\
\hline BGO & 14AR & 55788.0 & 76351.0 & 159.7 \\
\hline BGO & $16 \mathrm{~A}$ & 56194.0 & 75757.0 & 160.7 \\
\hline BGO & 16AR & 56217.0 & 75743.0 & 161.3 \\
\hline BGO & $18 \mathrm{~A}$ & 56699.0 & 75599.0 & 160.8 \\
\hline BGO & $25 A$ & 55668.0 & 76158.0 & 160.3 \\
\hline BGO & $26 \mathrm{~A}$ & 55014.0 & 76144.0 & 159.5 \\
\hline BGO & $29 A$ & 54103.0 & 75560.0 & 159.5 \\
\hline BGO & $41 \mathrm{~A}$ & 55403.0 & 76469.0 & 158.6 \\
\hline BGO & $43 A$ & 56253.0 & 77061.0 & 158.5 \\
\hline BGO & $43 A \mathrm{~A}$ & 56268.0 & 77066.0 & 156.8 \\
\hline BGO & $44 \mathrm{~A}$ & 57851.0 & 76755.0 & 158.6 \\
\hline BGO & $44 \mathrm{AA}$ & 57880.0 & 76757.0 & 158.7 \\
\hline BGO & $45 A$ & 54550.0 & 75830.0 & 160.9 \\
\hline BGO & $47 \mathrm{~A}$ & 54914.0 & 74728.0 & 162.7 \\
\hline BGO & $49 A$ & 56205.0 & 73902.0 & 165.6 \\
\hline BGO & $50 \mathrm{~A}$ & 54179.0 & 75201.0 & 160.1 \\
\hline BGX & $1 A$ & 58590.0 & 76831.0 & 161.5 \\
\hline$B G X$ & $4 A$ & 57215.0 & 77879.0 & 155.4 \\
\hline ESB & $76 \mathrm{~A}$ & 51391.0 & 76131.0 & 154.6 \\
\hline ESB & $76 \mathrm{~B}$ & 51394.0 & 76122.0 & .151 .1 \\
\hline FSB & $78 \mathrm{~A}$ & 50172.0 & 74757.0 & 155.3 \\
\hline FSB & $78 B$ & 50178.0 & 74765.0 & 153.7 \\
\hline FSB & $79 A$ & 50149.0 & 73664.0 & 157.4 \\
\hline FSB & $79 B$ & 50159.0 & 73666.0 & 157.2 \\
\hline FSB & $87 \mathrm{~A}$ & 50115.0 & 75601.0 & 153.3 \\
\hline ESB & $87 B$ & 50104.0 & 75597.0 & 150.4 \\
\hline FSB & $96 \mathrm{~A}$ & 49778.0 & 74882.0 & 152.1 \\
\hline FSB & $96 \mathrm{AR}$ & 49746.0 & 74914.0 & 153.1 \\
\hline FSB & $97 \mathrm{~A}$ & 49965.0 & 75171.0 & 151.6 \\
\hline FSB & $98 \mathrm{~A}$ & 50121.0 & 75389.0 & 150.4 \\
\hline FSB & 98AR & 50105.0 & 75362.0 & 152.0 \\
\hline FSB & $99 A$ & 50314.0 & 75675.0 & 150.2 \\
\hline FSB & $100 A$ & 50958.0 & 75534.0 & 150.9 \\
\hline FSB & $101 \mathrm{~A}$ & 51191.0 & 75719.0 & 151.0 \\
\hline FSB & $112 \mathrm{~A}$ & 48809.0 & 74231.0 & 153.6 \\
\hline FSB & $113 A$ & 51068.0 & $7 \overline{4} 167.0$ & 158.6 \\
\hline FSB & $114 \mathrm{~A}$ & 52046.0 & 75297.0 & 155.5 \\
\hline FSB & $120 A$ & 49175.0 & 75538.0 & 148.3 \\
\hline $\mathrm{HC}$ & $1 \mathrm{~A}$ & 61867.0 & 71755.0 & 175.8 \\
\hline $\mathrm{HC}$ & $2 A$ & 61866.0 & 71794.0 & 176.3 \\
\hline $\mathrm{HC}$ & $2 \mathrm{~B}$ & 61876.0 & 71785.0 & 176.0 \\
\hline $\mathrm{HSB}$ & $65 \mathrm{~A}$ & 58436.0 & 72436.0 & 170.4 \\
\hline FSB & $68 \mathrm{~A}$ & 56892.0 & 71526.0 & 171.0 \\
\hline
\end{tabular}


Table A6. (cont'd)

\begin{tabular}{lccc}
$\begin{array}{c}\text { Well } \\
\text { Label }\end{array}$ & $\begin{array}{c}\text { SRS East } \\
\text { (ft) }\end{array}$ & $\begin{array}{c}\text { SRS North } \\
\text { (ft) }\end{array}$ & $\begin{array}{c}\text { Elevation } \\
\text { (ft) }\end{array}$ \\
\hline HSB 69A & 56465.0 & 71549.0 & 171.4 \\
HSB 83A & 58606.0 & 71648.0 & 172.5 \\
HSB 84A & 56359.0 & 71586.0 & 171.2 \\
HSB 85A & 58943.0 & 73791.0 & 168.3 \\
HSB 86A & 55985.0 & 72520.0 & 167.8 \\
HSB117A & 55170.0 & 72733.0 & 166.3 \\
HSB118A & 55775.0 & 72696.0 & 166.8 \\
HSB119A & 56100.0 & 73082.0 & 166.2 \\
HSB120A & 56431.0 & 73395.0 & 165.6 \\
HSB121A & 57389.0 & 72024.0 & 170.8 \\
HSB122A & 57747.0 & 72195.0 & 170.5 \\
HSB123A & 58124.0 & 72189.0 & 171.8 \\
HSB124A & 58514.0 & 72199.0 & 191.7 \\
HSB124AR & 58531.0 & 72202.0 & 172.4 \\
HSB139A & 57365.0 & 71127.0 & 172.8 \\
HSB140A & 56535.0 & 70050.0 & 175.8 \\
HSB141A & 59168.0 & 71213.0 & 175.0 \\
HSB144A & 56200.0 & 71892.0 & 170.9 \\
HSB146A & 58454.0 & 70478.0 & 176.1 \\
P 27B & 64000.0 & 70405.0 & 181.2 \\
YSC 1A & 65438.0 & 78039.0 & 161.3 \\
YSC 2A & 66100.0 & 78311.0 & 162.6 \\
YSC 5A & 67134.0 & 74295.0 & 180.5
\end{tabular}


Table A7. Hydraulic head data used to create a head contour map for the "upper" aquifer zone (Figure 14).

\begin{tabular}{|c|c|c|c|c|}
\hline \multicolumn{2}{|c|}{$\begin{array}{l}\text { Well } \\
\text { LabeI }\end{array}$} & $\begin{array}{c}\text { SRS East } \\
\text { (ft) }\end{array}$ & $\begin{array}{l}\text { SRS North } \\
\text { (ft) }\end{array}$ & $\begin{array}{l}\text { Head } \\
(\mathrm{ft})\end{array}$ \\
\hline BG & 52 & 55524.0 & 75910.0 & 229.5 \\
\hline BG & 53 & 55073.0 & 76157.0 & 229.3 \\
\hline BG & 54 & 54830.0 & 75837.0 & 228.5 \\
\hline BG & 55 & 54590.0 & 75525.0 & 227.1 \\
\hline BG & 56 & 54481.0 & 75206.0 & 227.6 \\
\hline$B G$ & 57 & 54820.0 & 75000.0 & 225.9 \\
\hline BG & 58 & 55162.0 & 74790.0 & 227.3 \\
\hline$B G$ & 59 & 55508.0 & 74593.0 & 230.0 \\
\hline BG & 60 & 55850.0 & 74386.0 & 231.0 \\
\hline$B G$ & 61 & 56360.0 & 74075.0 & 233.1 \\
\hline BG & 62 & 56530.0 & 73971.0 & 234.3 \\
\hline BG & 63 & 56870.0 & 73754.0 & 236.6 \\
\hline BG & 64 & 57212.0 & 73547.0 & 239.4 \\
\hline BG & 65 & 57552.0 & 73340.0 & 237.4 \\
\hline BG & 66 & 57805.0 & 73585.0 & 236.5 \\
\hline BG & 67 & 57902.0 & 73954.0 & 236.7 \\
\hline BG & 104 & 59888.0 & 77038.0 & 224.6 \\
\hline$B G$ & 107 & 60120.0 & 74803.0 & 235.8 \\
\hline$B G$ & 108 & 59827.0 & 74383.0 & 238.8 \\
\hline$B G$ & 109 & 59626.0 & 73926.0 & 240.4 \\
\hline$B G$ & 110 & 59277.0 & 73354.0 & 241.4 \\
\hline $\mathrm{BGO}$ & $1 D$ & 58779.0 & 73737.0 & 238.6 \\
\hline BGO & 2D & 58809.0 & 74552.0 & 238.6 \\
\hline $\mathrm{BGO}$ & $3 D$ & 58809.0 & 75351.0 & 235.8 \\
\hline $\mathrm{BGO}$ & 4D & 58803.0 & 76150.0 & 232.4 \\
\hline $\mathrm{BGO}$ & 5D & 58784.0 & 76477.0 & 231.3 \\
\hline BGO & 6D & 58297.0 & 76487.0 & $231: 5$ \\
\hline$B G O$ & 7D & 57917.0 & 76494.0 & 234.2 \\
\hline BGO & 8D & 57617.0 & 76588.0 & 234.4 \\
\hline $\mathrm{BGO}$ & $9 D$ & 57478.0 & 76811.0 & 231.8 \\
\hline$B G O$ & $10 D$ & 57030.0 & 76805.0 & 231.9 \\
\hline BGO & $10 D R$ & 57073.0 & 76804.0 & 232.5 \\
\hline BGO & $11 D$ & 56651.0 & 76805.0 & 231.0 \\
\hline BGO & $12 \mathrm{D}$ & 56231.0 & 76805.0 & 230.8 \\
\hline $\mathrm{BGO}$ & $13 D$ & 55840.0 & 76805.0 & 230.0 \\
\hline$B G O$ & $14 \mathrm{DR}$ & 55789.0 & 76322.0 & 231.7 \\
\hline $\mathrm{BGO}$ & $15 D$ & 55859.0 & 75973.0 & 229.6 \\
\hline BGO & $16 D$ & 56202.0 & 75751.0 & 230.7 \\
\hline $\mathrm{BGO}$ & $17 D$ & 56399.0 & 75599.0 & 230.7 \\
\hline $\mathrm{BGO}$ & $17 \mathrm{DR}$ & 56407.0 & 75604.0 & 232.9 \\
\hline BGO & $18 D$ & 56711.0 & 75600.0 & 231.9 \\
\hline BGO & $19 D$ & 56997.0 & 75350.0 & 232.1 \\
\hline BGO & 200 & 57113.0 & 74962.0 & 234.1 \\
\hline $\mathrm{BGO}$ & 210 & 57470.0 & 74688.0 & 234.7 \\
\hline $\mathrm{BGO}$ & $22 \mathrm{D}$ & 57817.0 & 74482.0 & 232.4 \\
\hline BGO & $22 \mathrm{DR}$ & 57831.0 & 74471.0 & 237.9 \\
\hline BGO & $23 D$ & 58133.0 & 74238.0 & 235.9 \\
\hline $\mathrm{BGO}$ & $24 \mathrm{D}$ & 58438.0 & 740.12 .0 & 236.7 \\
\hline BGO & $26 \mathrm{D}$ & 55015.0 & 76128.0 & 227.7 \\
\hline BGO & $27 \mathrm{D}$ & 54680.0 & 75677.0 & 227.4 \\
\hline BGO & $28 \mathrm{D}$ & 54457.0 & 75348.0 & 226.1 \\
\hline $\mathrm{BGO}$ & $29 D$ & 54099.0 & 75592.0 & 227. \\
\hline
\end{tabular}


Table A7. (cont'd)

\begin{tabular}{|c|c|c|c|c|c|c|}
\hline & $\begin{array}{l}\text { ll. } \\
\text { abel }\end{array}$ & $\begin{array}{c}\text { SRS East } \\
\text { (ft) }\end{array}$ & $\begin{array}{c}\text { SRS North } \\
\text { (ft) }\end{array}$ & $\begin{array}{l}\text { Head } \\
(f t)\end{array}$ & & \\
\hline BGO & $30 D$ & 54499.0 & 75187.0 & 225.7 & & , \\
\hline BGO & $31 D$ & 54841.0 & 74985.0 & 226.6 & & \\
\hline BGO & $32 \mathrm{D}$ & 55250.0 & 74727.0 & 227.5 & & \\
\hline BGO & $33 D$ & 55695.0 & 74468.0 & 230.2 & & \\
\hline BGO & $34 D$ & 56082.0 & 74228.0 & 232.8 & & \\
\hline BGO & $35 D$ & 56556.0 & 73946.0 & 234.3 & & \\
\hline BGO & $36 D$ & 56888.0 & $73743.0^{\circ}$ & 236.4 & & \\
\hline BGO & $37 D$ & 57292.0 & 73490.0 & 237.7 & & \\
\hline BGO & $38 D$ & 57557.0 & 73329.0 & 235.3 & & \\
\hline BGO & $39 D$ & 57831.0 & 73583.0 & 235.0 & & \\
\hline BGO & $40 D$ & 54638.0 & 76125.0 & 223.6 & & \\
\hline BGO & $44 \mathrm{D}$ & 57910.0 & 76759.0 & 232.7 & & \\
\hline BGO & $45 D$ & 54585.0 & 75854.0 & 228.8 & & \\
\hline BGO & $46 D$ & 54420.0 & 75033.0 & 226.4 & & \\
\hline BGO & $47 D$ & 54922.0 & 74739.0 & 227.4 & & \\
\hline BGO & $48 D$ & 55121.0 & 74586.0 & 227.8 & & \\
\hline BGO & $49 D$ & 56198.0 & 73931.0 & 235.8 & & \\
\hline BGO & $50 D$ & 54209.0 & 75181.0 & 226.2 & & \\
\hline$B G X$ & ID & 58608.0 & 76809.0 & 230.0 & & \\
\hline BGX & $9 D$ & 59522.0 & 76936.0 & 227.3 & & \\
\hline$B G X$ & $10 D$ & 59765.0 & 76183.0 & 226.6 & $\cdot$ & \\
\hline BGX & $11 D$ & 59581.0 & 75300.0 & 236.8 & & \\
\hline$B G X$ & $12 \mathrm{D}$ & 59674.0 & 74410.0 & 240.4 & & : \\
\hline$B R R$ & - $1 \mathrm{D}$ & 50588.0 & 77365.0 & 216.6 & & \\
\hline BRR & $2 \mathrm{D}$ & 50306.0 & 77431.0 & 215.4 & & \\
\hline BRR & $3 \mathrm{D}$ & 50203.0 & 77398.0 & 215.1 & & \\
\hline BRR & $4 \mathrm{D}$ & 50104.0 & 77360.0 & 214.8 & & \\
\hline BRR & $5 \mathrm{D}$ & 50009.0 & 77266.0 & 215.1 & & \\
\hline FAC & 3 & 55322.0 & 78018.0 & 230.5 & & \\
\hline FAC & 4 & 55472.0 & 78223.0 & 228.9 & & \\
\hline FAC & 5 & 55241.0 & 77960.0 & 224.3 & & \\
\hline FAC & $5 P$ & 55314.0 & 78175.0 & 230.6 & & \\
\hline FAC & 7 & 55356.0 & 78123.0 & 221.8 & & \\
\hline FAC & 8 & 55366.0 & 78090.0 & 226.5 & & \\
\hline FAL & 1 & 53756.0 & 78115.0 & 218.7 & & \\
\hline FAL & 2 & 53757.0 & 78231.0 & 217.1 & & \\
\hline$F C A$ & $1 \mathrm{~N}$ & & & 53675.0 & 79037.0 & 299.2 \\
\hline FCA & $2 \mathrm{C}$ & & & 53712.0 & 78296.0 & 298.0 \\
\hline$F C A$ & $2 \mathrm{D}$ & 53715.0 & 78295.0 & 225.4 & & \\
\hline FCA & $9 D$ & 53733.0 & 78600.0 & 225.6 & & \\
\hline FCA & $10 \mathrm{~A}$ & 53571.0 & 78640.0 & 225.3 & & \\
\hline$F C A$ & $10 \mathrm{C}$ & & & 53717.0 & 78642.0 & 302.3 \\
\hline FCA & $10 D$ & 53732.0 & 78640.0 & 226.5 & & \\
\hline$F C A$ & $16 \mathrm{~A}$ & 53568.0 & 78899.0 & 225.2 & & \\
\hline FCA & $16 \mathrm{D}$ & 53719.0 & 78898.0 & 225.2 & & \\
\hline $\mathrm{FCA}$ & $16 \mathrm{~T}$ & & & 53579.0 & 78898.0 & 297.6 \\
\hline FCA & $19 D$ & 53719.0 & 78271.0 & 217.0 & & \\
\hline$F C B$ & 2 & 55046.0 & 76679.0 & 231.0 & & \\
\hline$F C B$ & 3 & 54874.0 & 76427.0 & 223.2 & & \\
\hline$F C B$ & 5 & 54773.0 & 76492.0 & 228.5 & & \\
\hline$F C B$ & 6 & 54733.0 & 76582.0 & 228.9 & & \\
\hline FET & 1D & 53299.0 & 76165.0 & 223.4 & & \\
\hline FET & $2 \mathrm{D}$ & 52981.0 & 76045.0 & 222.0 & & \\
\hline
\end{tabular}


Table A7. (cont'd)

\begin{tabular}{|c|c|c|c|c|}
\hline \multicolumn{2}{|c|}{$\begin{array}{l}\text { Wel1 } \\
\text { Label }\end{array}$} & $\begin{array}{c}\text { SRS East } \\
\text { (ft) }\end{array}$ & $\begin{array}{c}\text { SRS North } \\
\text { (ft) }\end{array}$ & $\begin{array}{l}\text { Head } \\
(f t)\end{array}$ \\
\hline FET & $3 D$ & 53025.0 & 75961.0 & 222.0 \\
\hline FET & $4 D$ & 53149.0 & 75959.0 & 222.6 \\
\hline FSB & 76 & 51388.0 & 76141.0 & 218.3 \\
\hline FSB & 77 & 50713.0 & 75129.0 & 212.7 \\
\hline FSB & 78 & 50164.0 & 74764.0 & 209.2 \\
\hline FSB & 79 & 50139.0 & 73663.0 & 202.0 \\
\hline FSB & 87D & 50081.0 & 75586.0 & 213.5 \\
\hline FSB & $88 D$ & 51527.0 & 75621.0 & 215.5 \\
\hline FSB & $89 D$ & 51335.0 & 75548.0 & 214.9 \\
\hline FSB & $90 D$ & 51140.0 & 75376.0 & 214.5 \\
\hline FSB & $91 D$ & 50946.0 & 75207.0 & 212.9 \\
\hline FSB & $92 \mathrm{D}$ & 50557.0 & 75045.0 & 211.5 \\
\hline FSB & $93 \mathrm{D}$ & 50452.0 & 74888.0 & 210.8 \\
\hline FSB & $94 \mathrm{DR}$ & 50162.0 & 74869.0 & 210.6 \\
\hline FSB & $95 \mathrm{D}$ & 50008.0 & 74977.0 & 209.7 \\
\hline FSB & 95DR & 49996.0 & 74991.0 & 210.6 \\
\hline FSB & $97 \mathrm{D}$ & 49975.0 & 75188.0 & 210.5 \\
\hline FSB & $98 \mathrm{D}$ & 50111.0 & 75371.0 & 212.9 \\
\hline FSB & $99 D$ & 50326.0 & 75691.0 & 211.8 \\
\hline FSB1 & $.04 D$ & 49255.0 & 73865.0 & 203.7 \\
\hline FSB] & $.05 D$ & 49833.0 & 75244.0 & 208.5 \\
\hline FSB] & $.05 D R$ & 49841.0 & 75258.0 & 211.4 \\
\hline FSBI & $.06 \mathrm{D}$ & 50636.0 & 74193.0 & 206.9 \\
\hline FSBI & $.07 D$ & 51149.0 & 75177.0 & 213.2 \\
\hline FSBI & $.08 \mathrm{D}$ & 51142.0 & 76260.0 & 217.2 \\
\hline FSBI & $.09 D$ & 50488.0 & 75855.0 & 213.1 \\
\hline FSB1 & 100 & 50141.0 & 74193.0 & 205.1 \\
\hline FSBI & $11 D$ & 51515.0 & 75382.0 & 214.5 \\
\hline FSBI & $12 \mathrm{D}$ & 48780.0 & 74223.0 & 206.7 \\
\hline FSBI & $13 \mathrm{D}$ & 51098.0 & 74154.0 & 208.0 \\
\hline FSB] & $14 D$ & 52018.0 & 75278.0 & 217.4 \\
\hline FSB] & $15 \mathrm{D}$ & 49728.0 & 72504.0 & 191.8 \\
\hline FSB1 & $16 \mathrm{D}$ & 50629.0 & 72727.0 & 192.2 \\
\hline FSB1 & $17 \mathrm{D}$ & 50486.0 & 74070.0 & 205.5 \\
\hline FSB1 & $18 D$ & 51276.0 & 74697.0 & 211.5 \\
\hline FSB1 & $19 D$ & 50600.0 & 74599.0 & 208.9 \\
\hline FSB1 & $20 D$ & 49163.0 & 75568.0 & 210.4 \\
\hline FSB1 & $21 \mathrm{DR}$ & 48429.0 & 75151.0 & 208.5 \\
\hline FSB1 & $22 \mathrm{D}$ & 48201.0 & 73865.0 & 204.3 \\
\hline FSB1 & $23 D$ & 51734.0 & 74562.0 & 212.7 \\
\hline FSL & $1 D$ & 52992.0 & 79063.0 & 225.2 \\
\hline FSL & $2 \mathrm{D}$ & 52790.0 & 78636.0 & 226.7 \\
\hline FSL & $3 D$ & 52465.0 & 77765.0 & 224.2 \\
\hline FSL & $4 D$ & 52230.0 & 77452.0 & 218.9 \\
\hline FSL & $5 D$ & 51903.0 & 77047.0 & 222.4 \\
\hline FSL & $6 D$ & 51727.0 & 76733.0 & 221.2 \\
\hline FSL & $7 D$ & 51485.0 & 76327.0 & 220.5 \\
\hline FSL & $8 D$ & 51513.0 & 76054.0 & 219.7 \\
\hline FSL & $9 D$ & 51543.0 & 75768.0 & 218.6 \\
\hline FSS & ID & 53897.0 & 75257.0 & 223.5 \\
\hline FSS & $2 \mathrm{D}$ & 53918.0 & 75103.0 & 223.0 \\
\hline FSS & $3 D$ & 53548.0 & 74960.0 & 220.7 \\
\hline FSS & $4 D$ & 52876.0 & 75537.0 & 218.3 \\
\hline
\end{tabular}


Table A7. (cont'd)

\begin{tabular}{|c|c|c|c|c|}
\hline \multicolumn{2}{|c|}{$\begin{array}{l}\text { Well } \\
\text { Label }\end{array}$} & $\begin{array}{c}\text { SRS East } \\
\text { (It) }\end{array}$ & $\begin{array}{l}\text { SRS North } \\
\text { (ft) }\end{array}$ & $\begin{array}{l}\text { Head } \\
\text { (ft) }\end{array}$ \\
\hline FTF & 1 & 53179.0 & 77413.0 & 229.4 \\
\hline FTF & 2 & 53275.0 & 77336.0 & 225.3 \\
\hline FTF & 3 & 53244.0 & 77235.0 & 224.1 \\
\hline FTF & 4 & 53268.0 & 77132.0 & 224.4 \\
\hline FTF & 5 & 53168.0 & 77035.0 & 225.1 \\
\hline FTF & 6 & 53062.0 & 77151.0 & 224.1 \\
\hline FTF & 8 & 53059.0 & 77336.0 & 227.5 \\
\hline FTE & 9 & 52769.0 & 77482.0 & 223.6 \\
\hline FTF & 10 & 52905.0 & 77336.0 & 223.8 \\
\hline FTF & 11 & 52748.0 & 77180.0 & 225.2 \\
\hline FTF & 12 & 52648.0 & 77321.0 & 226.8 \\
\hline FTF & 13 & 53098.0 & 76637.0 & 224.7 \\
\hline FTF & 15 & 53230.0 & 76732.0 & 226.1 \\
\hline FTF & 16 & 52879.0 & 76758.0 & 223.1 \\
\hline FTE & 17 & 52884.0 & 76872.0 & 223.0 \\
\hline FTF & 18 & 52879.0 & 76955.0 & 222.8 \\
\hline FTF & 19 & 52670.0 & 77139.0 & 222.2 \\
\hline FTF & 20 & 52500.0 & 77015.0 & 221.8 \\
\hline FTF & 21 & 52498.0 & 76866.0 & 222.8 \\
\hline FTF & 22 & 52494.0 & 76751.0 & 221.6 \\
\hline FTF & 23 & 52660.0 & 76611.0 & 222.0 \\
\hline FTF & $25 \mathrm{~A}$ & 52868.0 & 77308.0 & $223: 3$ \\
\hline FTF & 26 & 52875.0 & 77250.0 & 223.3 \\
\hline FTF & 27 & 52823.0 & 77227.0 & 223.4 \\
\hline HAC & 1 & 61415.0 & 72171.0 & 269.1 \\
\hline HAC & 2 & 61366.0 & 72220.0 & 268.6 \\
\hline $\mathrm{HAC}$ & 3 & 61313.0 & 72183.0 & 268.9 \\
\hline $\mathrm{HAC}$ & 4 & 61372.0 & 72120.0 & 269.2 \\
\hline $\mathrm{HAP}$ & 1 & 63398.0 & 71209.0 & 270.7 \\
\hline HAP & 2 & 63519.0 & 71122.0 & 270.1 \\
\hline $\mathrm{HC}$ & $1 \mathrm{E}$ & 61864.0 & 71746.0 & 275.0 \\
\hline $\mathrm{HC}$ & $2 E$ & 61861.0 & 71784.0 & 270.5 \\
\hline $\mathrm{HC}$ & $2 F$ & 61861.0 & 71780.0 & 274.3 \\
\hline $\mathrm{HC}$ & $4 B$ & 63408.0 & 71596.0 & 268.0 \\
\hline $\mathrm{HC}$ & $5 B$ & 61705.0 & 73266.0 & 256.1 \\
\hline $\mathrm{HC}$ & $6 \mathrm{~B}$ & 62070.0 & 72150.0 & 268.9 \\
\hline $\mathrm{HC}$ & $11 C$ & 62131.0 & 74496.0 & 236.6 \\
\hline $\mathrm{HCA}$ & 1 & 63109.0 & 72521.0 & 268.9 \\
\hline $\mathrm{HCA}$ & 3 & 63108.0 & 72651.0 & 268.7 \\
\hline $\mathrm{HCA}$ & 4 & 62942.0 & 72523.0 & 268.6 \\
\hline $\mathrm{HCB}$ & 1 & 63921.0 & 71426.0 & 262.9 \\
\hline $\mathrm{HCB}$ & 2 & 63797.0 & 71289.0 & 267.8 \\
\hline $\mathrm{HCB}$ & 3 & 63919.0 & 71098.0 & 266.1 \\
\hline HET & 1D & 60546.0 & 71948.0 & 267.4 \\
\hline HET & $2 \mathrm{D}$ & 60094.0 & 72006.0 & 258.2 \\
\hline HET & 3D & 60110.0 & 72093.0 & 258.6 \\
\hline HET & $4 \mathrm{D}$ & 60166.0 & 72178.0 & 259.0 \\
\hline HR3 & 11 & 60146.0 & 71402.0 & 259.3 \\
\hline HR3 & 13 & 60065.0 & 71649.0 & 258.1 \\
\hline HR8 & 11 & 59559.0 & 71945.0 & 245.8 \\
\hline HR8 & 12 & 59330.0 & 71780.0 & 239.3 \\
\hline HR8 & 13 & 59300.0 & 71559.0 & 237.8 \\
\hline$R$ & 14 & 59612.0 & 71431.0 & 244. \\
\hline
\end{tabular}


Table A7. (cont'd)

\begin{tabular}{|c|c|c|c|c|}
\hline \multicolumn{2}{|c|}{$\begin{array}{l}\text { Well } \\
\text { Label }\end{array}$} & $\begin{array}{c}\text { SRS East } \\
(\mathrm{ft})\end{array}$ & $\begin{array}{l}\text { SRS North } \\
\text { (ft) }\end{array}$ & $\begin{array}{r}\text { Head } \\
(f t) \\
\end{array}$ \\
\hline HSB & 65 & 58432.0 & 72425.0 & 234.3 \\
\hline HSB & $65 \mathrm{C}$ & 58447.0 & 72439.0 & 233.2 \\
\hline HSB & 66 & 56928.0 & 72429.0 & 226.9 \\
\hline HSB & 67 & 58424.0 & 71505.0 & 225.2 \\
\hline $\mathrm{HSB}$ & 68 & 56901.0 & 7.1528 .0 & 224.4 \\
\hline $\mathrm{HSB}$ & 69 & 56475.0 & 71546.0 & 220.7 \\
\hline HSB & 70 & 55758.0 & 72606.0 & 227.5 \\
\hline HSB & 71 & 55279.0 & 72875.0 & 225.1 \\
\hline HSB & $83 D$ & 58601.0 & 71628.0 & 225.8 \\
\hline HSB & $84 D$ & 56349.0 & 71583.0 & 219.8 \\
\hline HSB & $85 C$ & 58947.0 & 73802.0 & 239.0 \\
\hline HSB & $86 \mathrm{D}$ & 55996.0 & 72522.0 & 225.9 \\
\hline HSB] & $3100 \mathrm{D}$ & 58796.0 & 72073.0 & 233.3 \\
\hline HSB] & 3101D & 58594.0 & 71997.0 & 230.8 \\
\hline HSB & $3102 \mathrm{D}$ & 58393.0 & 71952.0 & 228.0 \\
\hline HSB] & 3103D & 58315.0 & 71588.0 & 226.0 \\
\hline HSB] & $3104 \mathrm{D}$ & 58075.0 & 71370.0 & 225.4 \\
\hline HSB] & 3105D & 57877.0 & 71454.0 & 225.8 \\
\hline HSB] & $3106 \mathrm{D}$ & 57644.0 & 71727.0 & 226.3 \\
\hline HSB] & 3107D & 57412.0 & 71696.0 & 225.1 \\
\hline HSB] & 3108D & 57145.0 & 71688.0 & 223.9 \\
\hline HSB] & $3109 D$ & 56885.0 & 71685.0 & 223.4 \\
\hline HSB] & $3110 \mathrm{D}$ & 56672.0 & 71785.0 & 222.8 \\
\hline HSB] & 3111D & 56494.0 & 71926.0 & 222.6 \\
\hline HSB] & $3111 E$ & 56487.0 & 71932.0 & 222.7 \\
\hline HSB] & $3112 D$ & 56408.0 & 72161.0 & 223.7 \\
\hline HSB] & $3112 \mathrm{E}$ & 56399.0 & 72166.0 & $223^{\prime} .6$ \\
\hline HSB] & 3113D & 56164.0 & 72302.0 & 223.6 \\
\hline HSB] & $3114 \mathrm{D}$ & 56104.0 & 72474.0 & 224.6 \\
\hline HSB] & $3115 D$ & 56039.0 & 72662.0 & 225.5 \\
\hline HSB] & $3116 D$ & 55988.0 & 72898.0 & 226.4 \\
\hline HSB] & 3117D. & 55155.0 & 72747.0 & 224.8 \\
\hline HSB] & $3125 D$ & 58584.0 & 71498.0 & 221.6 \\
\hline HSB] & $3126 \mathrm{D}$ & 57169.0 & 70633.0 & 204.9 \\
\hline HSB] & $3127 D$ & 56788.0 & 71218.0 & 218.5 \\
\hline HSB] & 31290 & 55103.0 & 71837.0 & 208.5 \\
\hline HSB] & $3130 D$ & 54651.0 & 70757.0 & 200.1 \\
\hline HSB] & 3131D & 56891.0 & 70365.0 & 205.2 \\
\hline HSB] & $3132 D$ & 58799.0 & 71469.0 & 221.7 \\
\hline HSB] & $3133 D$ & 59102.0 & 71943.0 & 234.8 \\
\hline HSB? & $3134 \mathrm{D}$ & 58296.0 & 71217.0 & 222.5 \\
\hline HSB] & $3135 D$ & 56552.0 & 71396.0 & 218.6 \\
\hline HSB] & $3136 D$ & 55941.0 & 71906.0 & 221.5 \\
\hline HSB] & $3137 D$ & 55696.0 & 72278.0 & 223.0 \\
\hline HSB] & $3138 D$ & 55260.0 & 73160.0 & 224.0 \\
\hline HSB & 3139D & 57384.0 & 71133.0 & 223.3 \\
\hline HSB] & $3140 D$ & 56560.0 & 70036.0 & 215.4 \\
\hline HSB] & $3141 D$ & 59170.0 & 71184.0 & 243.5 \\
\hline HSB & $3142 D$ & 53493.0 & 73113.0 & 198.3 \\
\hline $\mathrm{HSB}$ & $3143 D$ & 52774.0 & 73754.0 & 213.9 \\
\hline HSB & $3145 D$ & 57753.0 & 71088.0 & 221.7 \\
\hline HSB] & $3146 D$ & 58493.0 & 70469.0 & 223.0 \\
\hline & & & & \\
\hline
\end{tabular}


Table A7. (cont'd)

\begin{tabular}{|c|c|c|c|c|}
\hline \multicolumn{2}{|c|}{$\begin{array}{l}\text { Well } \\
\text { Label }\end{array}$} & $\begin{array}{l}\text { SRS East } \\
(\mathrm{ft})\end{array}$ & $\begin{array}{c}\text { SRS North } \\
\text { (ft) }\end{array}$ & $\begin{array}{l}\text { Head } \\
(\mathrm{ft})\end{array}$ \\
\hline \multicolumn{2}{|c|}{ HSB148D } & 55355.0 & 70160.0 & 214.9 \\
\hline \multicolumn{2}{|c|}{ HSB149D } & 57286.0 & 71338.0 & 224.5 \\
\hline \multicolumn{2}{|c|}{ HSB150D } & 58692.0 & 71692.0 & 228.1 \\
\hline \multicolumn{2}{|c|}{ HSB151D } & 54026.0 & 72997.0 & 208.0 \\
\hline \multicolumn{2}{|c|}{$\mathrm{HSB} 152 \mathrm{D}$} & 54362.0 & 72011.0 & 206.4 \\
\hline HSL & ID & 58925.0 & 72179.0 & 235.6 \\
\hline HSL & $2 \mathrm{D}$ & 59423.0 & 72190.0 & 242.1 \\
\hline HSL & $3 D$ & 59770.0 & 72251.0 & 250 . \\
\hline HSL & $4 D$ & 60171.0 & 72453.0 & 261.5 \\
\hline HSL & $5 \mathrm{D}$ & 60339.0 & 72562.0 & 263.8 \\
\hline HSL & $6 \mathrm{D}$ & 60531.0 & 72659.0 & 260. \\
\hline HSL & $7 D$ & 60723.0 & 72674.0 & 260 \\
\hline HSL & $8 D$ & 61117.0 & 72688.0 & 261.5 \\
\hline HSS & $1 D$ & 64675.0 & 67610.0 & 268.6 \\
\hline HSS & $2 \mathrm{D}$ & 64785.0 & 67355.0 & 267.2 \\
\hline HSS & $3 \mathrm{D}$ & 64709.0 & 68257.0 & 281. \\
\hline HTF & 1 & 62067.0 & 71745.0 & 271.8 \\
\hline HTF & 2 & 62175.0 & 71610.0 & 273. \\
\hline HTF & 4 & 61942.0 & 71630.0 & 272 . \\
\hline HTF & 5 & 62110.0 & 71390.0 & 277. \\
\hline HTF & 6 & 62228.0 & 71259.0 & 276. \\
\hline HTF & 7 & 62112.0 & 71130.0 & 275 . \\
\hline HTF & 8 & 61965.0 & 71270.0 & 274 . \\
\hline HTF & 9 & 61698.0 & 71652.0 & 271. \\
\hline HTE $]$ & 10 & 61838.0 & 71520.0 & 270. \\
\hline HTF $]$ & 11 & 61722.0 & 71398.0 & 271. \\
\hline HTF 1 & 12 & 61593.0 & 71520.0 & 270 . \\
\hline HTF 1 & 13 & 61586.0 & 71856.0 & 273 . \\
\hline HTF $]$ & 14 & 61462.0 & 71858.0 & 273 \\
\hline HTF 1 & 15 & 61353.0 & 71700.0 & 272 . \\
\hline HTF 1 & 16 & 61950.0 & 72150.0 & 269. \\
\hline HTF 1 & 17 & 61188.0 & 72600.0 & 262. \\
\hline HTF 1 & 18 & 61223.0 & 71771.0 & 270 . \\
\hline HTF 1 & 19 & 61079.0 & 71902.0 & 268. \\
\hline HTF 2 & 20 & 61086.0 & 72073.0 & 267. \\
\hline HTF 2 & 21 & 61261.0 & 71998.0 & 268 . \\
\hline HTF 2 & 22 & 62553.0 & 71363.0 & 273 . \\
\hline HTF & 23 & 62670.0 & 71363.0 & 274 . \\
\hline HTF 2 & 24 & 62775.0 & 71362.0 & 273 . \\
\hline HTF 2 & 25 & 62902.0 & 71224.0 & 273 . \\
\hline HTF 2 & 26 & 62815.0 & 71090.0 & 274 . \\
\hline HTF 2 & 27 & 62660.0 & 71057.0 & 274 . \\
\hline HTF 2 & 28 & 62515.0 & 71080.0 & 275 . \\
\hline HTF 2 & 29 & 62414.0 & 71229.0 & 274 . \\
\hline $\mathrm{HTF} 3$ & 31 & 62662.0 & 70747.0 & 274 . \\
\hline HTF & 32 & 62807.0 & 70880.0 & 273 . \\
\hline HTF 3 & 34 & 61978.0 & 71144.0 & 272 . \\
\hline MGA & 36 & 57891.0 & 73904.0 & 238. \\
\hline MGC & 9 & 55610.0 & 75372.0 & 229 . \\
\hline MGC ? & 11 & 55770.0 & 75252.0 & 232 . \\
\hline MGC 2 & 23 & 56726.0 & 74528.0 & 236. \\
\hline MGC & 32 & 57448.0 & 73982.0 & 245 . \\
\hline MGE & 9 & 55489.0 & 75215.0 & 229. \\
\hline
\end{tabular}


Table A7. (cont'd)

\begin{tabular}{|c|c|c|c|c|}
\hline \multicolumn{2}{|c|}{$\begin{array}{l}\text { Well } \\
\text { Label }\end{array}$} & \multirow{2}{*}{$\begin{array}{c}\text { SRS East } \\
( \pm t) \\
56446.0\end{array}$} & \multirow{2}{*}{$\begin{array}{l}\text { SRS North } \\
\frac{(f t)}{74487.0}\end{array}$} & \multirow{2}{*}{$\begin{array}{l}\begin{array}{c}\text { Head } \\
\text { (ft) }\end{array} \\
235.1\end{array}$} \\
\hline MGE & 21 & & & \\
\hline MGG & 15 & 55851.0 & 74699.0 & 233.1 \\
\hline MGG & 19 & 56174.0 & 74456.0 & 232.9 \\
\hline MGG & 23 & 56491.0 & 74214.0 & 235.8 \\
\hline MGG & 28 & 56895.0 & 73905.0 & 237.2 \\
\hline MGG & 36 & 57541.0 & 73413.0 & 238.8 \\
\hline NBG & 1 & 53879.0 & 79300.0 & 224.1 \\
\hline NBG & 2 & 53958.0 & 79099.0 & 224.8 \\
\hline NBG & 3 & 54068.0 & 78939.0 & 218.1 \\
\hline NBG & 4 & 54329.0 & 78942.0 & 217.1 \\
\hline NBG & 5 & 54515.0 & 78943.0 & 217.6 \\
\hline $\mathrm{P}$ & $27 D$ & 64008.0 & 70376.0 & 266.9 \\
\hline SBG & 1 & 63749.0 & 74619.0 & 237.8 \\
\hline SBG & 2 & 64939.0 & 74570.0 & 237.6 \\
\hline SBG & 3 & 65265.0 & 73699.0 & 236.9 \\
\hline SBG & 4 & 65010.0 & 72399.0 & 240.6 \\
\hline SBG & 5 & 64499.0 & 72208.0 & 249.1 \\
\hline SBG & 6 & 63860.0 & 73599.0 & 244.2 \\
\hline SCA & 2 & 64697.0 & 73850.0 & 242.2 \\
\hline $\mathrm{SCA}$ & 3 & 64571.0 & 73959.0 & $241: 3$ \\
\hline SCA & $3 A$ & 64571.0 & 73965.0 & 270.9 \\
\hline $\mathrm{SCA}$ & 4 & 64563.0 & 73856.0 & 241.7 \\
\hline$S C A$ & $4 \mathrm{~A}$ & 64567.0 & 73855.0 & 269.1 \\
\hline $\mathrm{SCA}$ & 5 & 64630.0 & 74092.0 & 242.0 \\
\hline$S C A$ & 6 & 64637.0 & 73706.0 & 242.2 \\
\hline SLP & 1. & 64449.0 & 72958.0 & 244.8 \\
\hline SLP & 2 & 64529.0 & 72863.0 & 244.4 \\
\hline YSC & $1 \mathrm{C}$ & 65855.0 & 78186.0 & 217.5 \\
\hline YSC & $2 \mathrm{D}$ & 66130.0 & 78320.0 & 217.1 \\
\hline $\mathrm{Z}$ & 2 & 53181.0 & 74785.0 & 218.1 \\
\hline $\mathrm{z}$ & 3 & 51328.0 & 75086.0 & 212.2 \\
\hline $\mathrm{z}$ & 8 & 51584.0 & 76640.0 & 218.0 \\
\hline $\mathrm{z}$ & 9 & 50570.0 & 77732.0 & 214.8 \\
\hline $\mathrm{z}$ & 11 & 61750.0 & 72539.0 & 296.4 \\
\hline $\mathrm{Z}$ & 12 & 61400.0 & 71198.0 & 274.4 \\
\hline $\mathrm{z}$ & 13 & 62203.0 & 70785.0 & 274.6 \\
\hline z & 15 & 63419.0 & 72802.0 & 263.7 \\
\hline $\mathrm{ZBG}$ & 1 & 65584.0 & 76584.0 & 234.1 \\
\hline ZBG & $1 \mathrm{~A}$ & 65598.0 & 76588.0 & 279.7 \\
\hline $\mathrm{ZBG}$ & 2 & 67472.0 & 76170.0 & 221.5 \\
\hline ZDT & 1 & 65114.0 & 71644.0 & 239.5 \\
\hline ZDT & 2 & 65059.0 & 71696.0 & 241.1 \\
\hline $\mathrm{ZW}$ & 4 & 56556.0 & 77667.0 & 232.6 \\
\hline $\mathrm{zW}$ & 5 & 54708.0 & 75767.0 & 227.5 \\
\hline$Z W$ & 7 & 60300.0 & 72399.0 & 265.8 \\
\hline $\mathrm{ZW}$ & 8 & 63801.0 & 70800.0 & 270.8 \\
\hline $\mathrm{ZW}$ & 9 & 61400.0 & 73198.0 & 251.9 \\
\hline $\mathrm{ZW}$ & 10 & 63401.0 & 73212.0 & 249.7 \\
\hline $\mathrm{CC}-$ & & 54065.0 & 73295.0 & 214.9 \\
\hline $\mathrm{CC}-$ & & 54390.0 & 73060.0 & 216.4 \\
\hline $\mathrm{CC}-$ & & 54710.0 & 72820.0 & 220.0 \\
\hline GG- & & 54470.0 & 72495.0 & 207.8 \\
\hline GG- & & 54793.0 & 72260.0 & 211.8 \\
\hline
\end{tabular}


Table A7. (cont'd)

\begin{tabular}{lccc} 
Well & SRS East & SRS North & Head \\
Label & (ft) & (ft) & (ft) \\
\hline M-5 & 54690.0 & 74820.0 & 228.6 \\
M-9 & 55020.0 & 74590.0 & 228.0 \\
M-17 & 55650.0 & 74100.0 & 235.0 \\
M-21 & 55985.0 & 73870.0 & 237.9 \\
Q-5 & 54470.0 & 74500.0 & 226.0 \\
Q-9 & 54775.0 & 74260.0 & 226.9 \\
Q-13 & 55100.0 & 74020.0 & 227.4 \\
Q-17 & 55425.0 & 73780.0 & 241.6 \\
Q-21 & 55745.0 & 73540.0 & 233.1 \\
S-3 & 54070.0 & 74492.0 & 224.0 \\
S-4 & 53678.0 & 74319.0 & 222.1 \\
S-5 & 53370.0 & 73913.0 & 221.0 \\
S-6 & 53222.0 & 73440.0 & 204.6 \\
S-9 & 53785.0 & 74919.0 & 226.1 \\
S-15 & 53930.0 & 75381.0 & 231.5 \\
S-16. & 53491.0 & 75223.0 & 226.2 \\
U-5 & 54219.0 & 74176.0 & 223.0 \\
U-9 & 54540.0 & 73945.0 & 223.8 \\
U-13 & 54863.0 & 73700.0 & 232.4 \\
U-17 & 55185.0 & 73470.0 & 226.2 \\
U-21 & 55506.0 & 73225.0 & 227.3 \\
Y-7 & 54140.0 & 73730.0 & 218.2 \\
Y-9 & 54300.0 & 73615.0 & 220.8 \\
Y-13 & 54625.0 & 73380.0 & 223.2 \\
Y-17 & 54950.0 & 73140.0 & 224.7 \\
Y-21 & 55270.0 & 72900.0 & 224.0 \\
4Mile_Br & 49884.0 & 72820.2 & 180.0 \\
4Mile_Br & 49963.2 & 72807.8 & 180.1 \\
4Mile_Br & 50029.3 .0 & 72800.3 & 180.3 \\
4Mile_Br & 50094.4 & 72804.4 & 180.4 \\
4Mile_Br & 50156.5 & 72814.8 & 180.5 \\
4Mile_Br & 50213.9 & 72829.3 & 180.6 \\
4Mile_Br & 50266.4 & 72845.2 & 180.7 \\
4Mile_Br & 50312.7 & 72847.3 & 180.8 \\
4Mile_Br & 50359.3 & 72852.2 & 180.9 \\
4Mile_Br & 50404.7 & 72852.2 & 181.0 \\
4Mile_Br & 50481.1 & 72869.6 & 181.1 \\
4Mile_Br & 50570.8 & 72884.1 & 181.3 \\
4Mile_Br & 50615.8 & 72896.9 & 181.4 \\
4Mile_Br & 50670.4 & 72916.1 & 181.5 \\
4Mile_Br & 50729.8 & 72931.6 & 181.6 \\
4Mile_Br & 50781.0 & 72948.4 & 181.7 \\
4Mile_Br & 50847.4 & 72971.2 & 181.8 \\
4Mile_Br & 50896.9 & 72994.3 & 181.9 \\
4Mile_Br & 50926.4 & 73005.5 & 182.0 \\
4Mile_Br & 50974.7 & 73032.5 & 182.1 \\
4Mile_Br & 51021.0 & 73058.6 & 182.2 \\
4Mile_Br & 51076.3 & 73086.1 & 182.3 \\
4Mile_Br & 51118.2 & 73101.0 & 182.4 \\
4Mile_Br & 51156.1 & 73111.9 & 182.4 \\
4Mile_Br & 51209.5 & 73113.9 & 182.5 \\
4Mile_Br & 51254.2 & 73116.1 & 182.6 \\
4Mile_Br & 51301.0 & 73117.6 & 182.7
\end{tabular}


Table A7. (cont'd)

\begin{tabular}{|c|c|c|c|}
\hline $\begin{array}{l}\text { Well. } \\
\text { Label }\end{array}$ & $\begin{array}{c}\text { SRS East } \\
(\mathrm{ft})\end{array}$ & $\begin{array}{l}\text { SRS North } \\
\text { (ft) }\end{array}$ & $\begin{array}{l}\text { Head } \\
(\mathrm{Et})\end{array}$ \\
\hline 4Mile_Br & 51341.6 & 73101.1 & 182.8 \\
\hline 4Mile_Br & 51373.5 & 73094.0 & 182.8 \\
\hline 4Mile_Br & 51403.9 & 73091.6 & 182.9 \\
\hline 4Mile_Br & 51442.9 & 73074.4 & 183.0 \\
\hline 4Mile_Br & 51488.1 & 73063.5 & 183.1 \\
\hline 4Mile_Br & 51559.4 . & 73057.5 & 183.2 \\
\hline 4Mile_Br & 51616.1 & 73055.1 & 183.3 \\
\hline 4Mile_Br & 51653.2 & 73057.8 & 183.4 \\
\hline 4Mile_Br & 51685.0 & 73062.6 & 183.4 \\
\hline 4Mile_Br & 51747.9 & 73052.1 & 183.6 \\
\hline 4Mile_Br & 51788.8 & 73046.8 & 183.6 \\
\hline 4Mile_Br & 51843.4 & 73032.0 & 183.7 \\
\hline 4Mile_Br & 51895.0 & 73023.1 & 183.8 \\
\hline 4Mile_Br & 51944.1 & 73011.2 & 183.9 \\
\hline 4Mile_Br & 51982.2 & 73008.6 & 184.0 \\
\hline 4Mile_Br & 52022.8 & 73008.2 & 184.1 \\
\hline 4Mile_Br & 52085.0 & 72993.5 & 184.2 \\
\hline 4Mile_Br & 52149.6 & 72979.0 & 184.3 \\
\hline 4Mile_Br & 52225.0 & 72969.6 & 184.4 \\
\hline $4 \mathrm{Mile}$ & 52263.9 & 72959.8 & 184.5 \\
\hline 4Mile_Br & 52296.2 & 72960.0 & 184.6 \\
\hline 4Mile_Br & 52329.5 & 72945.9 & 184.6 \\
\hline $4 \mathrm{Mile}$ & 52365.2 & 72944.7 & 184.7 \\
\hline 4Mile_Br & 52398.7 & 72934.2 & 184.7 \\
\hline $4 \mathrm{Mile}$ _Br & 52439.4 & 72932.9 & 184.8 \\
\hline 4Mile_Br & 52472.9 & 72918.5 & 184.9 \\
\hline 4Mile_Br & 52537.9 & 72904.4 & 185. \\
\hline 4Mile_Br & 52584.6 & 72891.5 & 185.1 \\
\hline 4Mile_Br & 52619.1 & 72874.2 & 185.1 \\
\hline 4Mile_Br & 52679.8 & 72832.6 & 185.3 \\
\hline 4Mile_Br & 52747.9 & 72774.8 & 185. \\
\hline 4Mile_Br & 52776.4 & 72737.6 & 185.5 \\
\hline $4 \mathrm{Mile}$ _Br & 52819.9 & 72699.6 & \\
\hline 4Mile_Br & 52847.2 & 72675.8 & $185 .^{\circ}$ \\
\hline 4Mile_Br & 52890.9 & 72658.5 & $185 .^{\circ}$ \\
\hline 4Mile_Br & 52936.6 & 72630.3 & 185.8 \\
\hline 4Mile_Br & 52995.8 & 72593.8 & \\
\hline $4 \mathrm{Mile}$ _Br & 53019.6 & 72583.0 & 186. \\
\hline 4Mile_Br & 53045.9 & 72575.7 & 186.2 \\
\hline 4Mile_Br & 53084.2 & 72564.0 & 186.6 \\
\hline 4Mile_Br & 53122.8 & 72540.2 & 187.0 \\
\hline 4 Mile_Br & 53163.8 & 72527.4 & 187. \\
\hline $4 \mathrm{Mile}$ Br & 53198.7 & 72513.9 & 187. \\
\hline 4Mile_Br & 53230.4 & 72500.8 & 188.0 \\
\hline 4Mile_Br & 53270.5 & 72484.4 & 189.1 \\
\hline $4 \mathrm{Mile}$ _Br & 53300.4 & 72471.1 & 190. \\
\hline 4Mile_Br & 53365.3 & 72423.0 & 190.2 \\
\hline 4Mile_Br & 53422.6 & 72372.8 & 190.3 \\
\hline 4Mile_Br & 53442.4 & 72354.9 & 190.4 \\
\hline 4Mile_Br & 53480.7 & 72340.3 & 190.4 \\
\hline 4Mile_Br & 53529.7 & 72301.9 & 190. \\
\hline 4Mile_Br & 53585.3 & 72258.2 & \\
\hline 4Mile_Br & 53652.3 & 72204.3 & \\
\hline
\end{tabular}


Table A7. (cont'd)

\begin{tabular}{|c|c|c|c|}
\hline $\begin{array}{l}\text { Well } \\
\text { Label }\end{array}$ & $\begin{array}{c}\text { SRS East } \\
\text { (ft) }\end{array}$ & $\begin{array}{c}\text { SRS North } \\
\text { (ft) }\end{array}$ & $\begin{array}{r}\text { Head } \\
(f t)\end{array}$ \\
\hline 4Mile_Br & 53697.4 & 72172.5 & 191.0 \\
\hline 4Mile_Br & 53741.1 & 72133.4 & 191.1 \\
\hline 4Mile_Br & 53780.8 & 72088.7 & 191.2 \\
\hline 4Mile_Br & 53796.6 & 72069.9 & 191.3 \\
\hline 4Mile_Br & 53803.6 & 72040.7 & 191.3 \\
\hline 4Mile_Br & 53832.5 & 71977.4 & 191.4 \\
\hline $4 \mathrm{Mile}$ B $\mathrm{Br}$ & 53841.1 & 71943.6 & 191.5 \\
\hline 4Mile_Br & 53860.6 & 71911.3 & 191.6 \\
\hline 4Mile_Br & 53863.9 & 71899.7 & 191.6 \\
\hline 4Mile_Br & 53884.0 & 71886.7 & 191.7 \\
\hline 4Mile_Br & 53900.2 & 71857.0 & 191.7 \\
\hline $4 \mathrm{Mile} \mathrm{Br}$ & 53942.3 & 71808.9 & 191.8 \\
\hline 4Mile_Br & 53976.6 & 71778.1 & 191.9 \\
\hline 4Mile_Br & 54002.5 & 71758.8 & 192.0 \\
\hline 4Mile_Br & 54043.1 & 71735.9 & 192.1 \\
\hline 4Mile_Br & 54060.4 & 71721.0 & 192.2 \\
\hline 4Mile_Br & 54099.0 & 71701.8 & 192.3 \\
\hline 4Mile_Br & 54156.8 & 71663.4 & 192.5 \\
\hline 4Mile_Br & 54213.0 & 71634.9 & 192.7 \\
\hline 4Mile_Br & 54272.0 & 71591.5 & 192.9 \\
\hline 4Mile_Br & 54343.1 & 71563.3 & 193.1 \\
\hline 4Mile_Br & 54409.3 & 71534.9 & 193.3 \\
\hline 4Mile_Br & 54479.6 & 71493.9 & 193.5 \\
\hline 4Mile_Br & 54555.6 & 71446.2 & 193.7 \\
\hline 4Mile_Br & 54605.3 & 71415.0 & 193.9 \\
\hline 4Mile_Br & 54633.1 & 71395.7 & 194.0 \\
\hline 4Mile_Br & 54705.9 & 71347.9 & 194.3 \\
\hline 4Mile_Br & 54762.3 & 71307.2 & 194.6 \\
\hline 4Mile_Br & 54793.7 & 71285.1 & 194.7 \\
\hline 4Mile_Br & 54855.2 & 71193.5 & 195.1 \\
\hline 4Mile_Br & 54889.4 & 71144.6 & 195.3 \\
\hline 4Mile_Br & 54935.9 & 71089.0 & 195.6 \\
\hline 4Mile_Br & 54989.8 & 71037.5 & 195.9 \\
\hline $4 \mathrm{Mile} \mathrm{Br}$ & 55013.0 & 71014.5 & 196.0 \\
\hline 4Mile_Br & 55061.7 & 70959.2 & 196.2 \\
\hline 4Mile_Br & 55126.7 & 70934.2 & 196.5 \\
\hline 4Mile_Br & 55159.8 & 70917.8 & 196.7 \\
\hline 4Mile_Br & 55215.6 & 70874.7 & 196.9 \\
\hline 4Mile_Br & 55280.0 & 70848.4 & 197.2 \\
\hline 4Mile_Br & 55372.3 & 70857.5 & 197.5 \\
\hline 4Mile_Br & 55450.6 & 70862.4 & 197.8 \\
\hline 4Mile_Br & 55498.7 & 70863.0 & 198.0 \\
\hline 4Mile_Br & 55557.6 & $70871 . .5$ & 198.1 \\
\hline 4Mile_Br & 55603.8 & 70880.6 & 198.2 \\
\hline 4Mile_Br & 55659.9 & 70875.0 & 198.3 \\
\hline 4Mile_Br & 55713.8 & 70852.4 & 198.4 \\
\hline 4 Mile_Br & 55782.9 & 70848.1 & 198.5 \\
\hline 4Mile_Br & 55859.7 & 70814.2 & 198.6 \\
\hline 4Mile_Br & 55912.6 & 70790.3 & 198.7 \\
\hline 4Mile_Br & 56015.1 & 70771.7 & 198.9 \\
\hline 4Mile_Br & 56090.8 & 70749.1 & 199.0 \\
\hline 4Mile_Br & 56143.7 & 70735.9 & 199.1 \\
\hline 4Mile_Br & 56177.0 & 70737.8 & 199.2 \\
\hline
\end{tabular}


Table A7. (cont'd)

\begin{tabular}{|c|c|c|c|}
\hline $\begin{array}{l}\text { Well } \\
\text { Label }\end{array}$ & $\begin{array}{c}\text { SRS East } \\
\text { (ft) }\end{array}$ & $\begin{array}{c}\text { SRS North } \\
\text { (ft) }\end{array}$ & $\begin{array}{l}\text { Head } \\
(\mathrm{ft})\end{array}$ \\
\hline 4Mile_Br & 56234.0 & 70721.8 & 199.3 \\
\hline 4Mile_Br & 56330.0 & 70688.2 & 199. \\
\hline 4Mile_Br & 56400.8 & 70660.8 & 199. \\
\hline 4Mile_Br & 56463.6 & 70629.9 & 199 \\
\hline 4Mile_Br & 56555.9 & 70592.3 & 199.9 \\
\hline $4 \mathrm{Mile} B \mathrm{Br}$ & 56634.3 & 70562.1 & 200.0 \\
\hline 4Mile_Br & 56712.4 & 70542.6 & 200.2 \\
\hline 4Mile_Br & 56793.6 & 70519.6 & 200.5 \\
\hline $4 \mathrm{Mile} \mathrm{Br}$ & 56865.3 & 70507.2 & 200.6 \\
\hline 4Mile_Br & 56906.4 & 70491.2 & 200.8 \\
\hline 4Mile_Br & 56954.6 & 70.484 .6 & 200.9 \\
\hline 4Mile_Br & 56993.1 & 70458.7 & 201.0 \\
\hline 4Mile_Br & 57092.5 & 70386.0 & 201.4 \\
\hline 4Mile_Br & 57149.5 & 70338.1 & 201.6 \\
\hline 4Mile_Br & 57171.6 & 70317.5 & 201.6 \\
\hline 4Mile_Br & 57205.8 & 70287.9 & 201.8 \\
\hline $4 \mathrm{Mile} \mathrm{Br}$ & 57249.5 & 70271.1 & 201.9 \\
\hline 4Mile_Br & 57287.6 & 70266.0 & 202.0 \\
\hline 4Mile_Br & 57309.4 & 70257.2 & 202.1 \\
\hline \Mile_Br & 57322.4 & 70242.9 & 202.2 \\
\hline 4Mile_Br & 57353.6 & 70227.2 & 202. \\
\hline 4Mile_Br & 57361.0 & 70205.9 & 202.5 \\
\hline 4Mile_Br & 57370.3 & 70178.8 & 202. \\
\hline 4Mile_Br & 57366.4 & 70141.3 & 203. \\
\hline $4 \mathrm{Mile}$ Br & 57359.6 & 70127.9 & 203. \\
\hline 4Mile_Br & 57341.9 & 70107.2 & 203. \\
\hline 4Mile_Br & 57330.0 & 70070.4 & 203. \\
\hline 4Mile_Br & 57325.5 & 70039.9 & \\
\hline 4Mile_Br & 57317.1 & 69997.5 & 204. \\
\hline 4Mile_Br & 57314.1 & 69982.7 & 204. \\
\hline 4Mile_Br & 57305.0 & 69951.2 & 204. \\
\hline 4Mile_Br & $57309: 5$ & 69899.4 & \\
\hline 4Mile_Br & 57318.6 & 69840.3 & 204. \\
\hline 4Mile_Br & 57329.0 & 69773.8 & 205. \\
\hline 4Mile_Br & 57339.4 & 69739.5 & 205. \\
\hline $4 \mathrm{Mile}$ Br & 57361.8 & 69707.9 & \\
\hline 4Mile_Br & 57376.4 & 69663.2 & 205. \\
\hline 4Mile_Br & 57390.7 & 69643.3 & 205. \\
\hline 4Mile_Br & 57408.3 & 69624.4 & 205. \\
\hline 4Mile_Br & 57422.9 & 69599.6 & 205. \\
\hline $4 \mathrm{Mile}$ & 57447.1 & 69577.4 & 205. \\
\hline 4Mile_Br & 57456.1 & 69563.2 & 206. \\
\hline 4Mile_Br & 57471.1 & 69544.1 & 206. \\
\hline 4Mile_Br & 57516.6 & 69519.2 & 206. \\
\hline $4 \mathrm{Mile}$ Br & 57551.2 & 69490.2 & 206. \\
\hline 4Mile_Br & 57603.3 & 69477.5 & 206 . \\
\hline 4Mile_Br & 57668.6 & 69451.4 & 206. \\
\hline 4Mile_Br & 57729.7 & 69426.7 & 206. \\
\hline 4Mile_Br & 57765.0 & 69415.5 & 206. \\
\hline 4Mile_Br & 57805.5 & 69410.8 & 206. \\
\hline 4Mile_Br & 57843.9 & 69392.5 & 206. \\
\hline 4Mile_Br & 57939.8 & 69374.1 & \\
\hline & & & \\
\hline
\end{tabular}


Table A7. (cont'd)

\begin{tabular}{|c|c|c|c|}
\hline $\begin{array}{l}\text { Well } \\
\text { Label }\end{array}$ & $\begin{array}{c}\text { SRS East } \\
\text { (ft) }\end{array}$ & $\begin{array}{l}\text { SRS North } \\
\text { (ft) }\end{array}$ & $\begin{array}{l}\text { Head } \\
(f t)\end{array}$ \\
\hline 4Mile_Br & 58043.2 & 69353.3 & 207.3 \\
\hline 4Mile_Br & 58097.9 & 69345.3 & 207.4 \\
\hline $4 \mathrm{Mile} \mathrm{Br}$ & 58145.1 & 69312.3 & 207.6 \\
\hline 4Mile_Br & 58174.9 & 69265.3 & 207.7 \\
\hline 4Mile_Br & 58201.5 & 69217.7 & 207.8 \\
\hline 4Mile_Br & 58230.9 & 69163.8 & 207.9 \\
\hline 4Mile_Br & 58260.3 & 69114.8 & 208.0 \\
\hline 4Mile_Br & 58301.1 & 69033.0 & 208.2 \\
\hline $4 \mathrm{Mile \_ Br}$ & 58328.3 & 68965.3 & 208.4 \\
\hline 4Mile_Br & 58364.6 & 68892.5 & 208.6 \\
\hline 4Mile_Br & 58392.6 & 68824.5 & 208.7 \\
\hline 4Mile_BI & 58416.4 & 68737.0 & 208.9 \\
\hline 4Mile_Br & 58438.7 & 68695.9 & 209.1 \\
\hline 4Mile_Br & 58472.3 & 68657.1 & 209.2 \\
\hline 4Mile_Br & 58492.1 & 68611.0 & 209.3 \\
\hline $4 \mathrm{Mile} B \mathrm{Br}$ & 58531.2 & 68551.2 & 209.4 \\
\hline 4Mile_Br & 58567.9 & 68490.5 & 209.6 \\
\hline 4Mile_Br & 58597.2 & 68415.0 & 209.8 \\
\hline $4 \mathrm{Mile} \mathrm{Br}$ & 58622.8 & 68330.8 & 210.0 \\
\hline 4Mile_Br & 58626.5 & 68244.6 & 210.2 \\
\hline 4Mile_Br & 58626.3 & 68151.2 & 210.5 \\
\hline $4 \mathrm{Mile}$ & 58624.3 & 68075.4 & 210.7 \\
\hline 4Mile_Br & 58632.7 & 68006.0 & 210.9 \\
\hline $4 \mathrm{Mile}$ _Br & 58643.2 & 67964.6 & 211.0 \\
\hline 4Mile_Br & 58681.6 & 67926.2 & $211: 2$ \\
\hline 4Mile_Br & 58705.2 & 67886.7 & 211.3 \\
\hline 4Mile_Br & 58760.0 & 67817.2 & $211^{\prime} .6$ \\
\hline 4Mile_BI & 58799.1 & 67776.5 & 211.7 \\
\hline 4Mile_BI & 58863.3 & 67747.2 & 211.9 \\
\hline 4Mile_Br & 58911.9 & 67733.9 & 212.0 \\
\hline Old_Eff & 53093.4 & 72547.3 & 189.9 \\
\hline Old_Eff & 53115.3 & 72575.5 & 190. \\
\hline old_Eff & 53122.5 & 72604.9 & 190. \\
\hline Old_Eff & 53135.1 & 72630.4 & 190. \\
\hline Old_Eff & 53156.6 & 72658.3 & 190.2 \\
\hline Old_Eff & 53189.8 & 72679.7 & 190. \\
\hline Old_Eff & 53221.2 & 72700.6 & 190. \\
\hline old_Eff & 53261.6 & 72723.4 & 190.8 \\
\hline Old_Eff & 53283.4 & 72739.2 & 190.9 \\
\hline Old_Eff & 53286.7 & 72764.2 & 191.0 \\
\hline Old_Eff & 53278.6 & 72839.3 & 192.0 \\
\hline Old_Eff & 53289.0 & 72907.8 & 193.0 \\
\hline Old_Eff & 53299.9 & 72970.1 & 194.0 \\
\hline Old_Eff & 53327.3 & 73072.9 & 195. \\
\hline Old_Eff & 53346.3 & 73112.7 & 196.0 \\
\hline Old_Eff & 53399.8 & 73172.6 & 197. \\
\hline Old_Eff & 53427.1 & 73199.9 & 198. \\
\hline Old_Eff & 53451.5 & 73223.8 & 199. \\
\hline Old_Eff & 53463.3 & 73234.7 & 200 \\
\hline old_Eff & 53494.1 & 73266.7 & 201. \\
\hline Old_Eff & 53535.4 & 73299.6 & 202 . \\
\hline & & & \\
\hline & & & \\
\hline
\end{tabular}


Table A7. (cont'd)

\begin{tabular}{|c|c|c|c|c|c|}
\hline $\begin{array}{l}\text { Well } \\
\text { Label }\end{array}$ & $\begin{array}{l}\text { SRS East } \\
(\mathrm{ft})\end{array}$ & $\begin{array}{l}\text { SRS North } \\
\text { (ft) }\end{array}$ & $\begin{array}{l}\text { Head } \\
(f t)\end{array}$ & & \\
\hline Old_Eff & 53582.5 & .73325 .9 & 205.0 & & \\
\hline old_Eff & 53645.6 & 73353.1 & 206.0 & & \\
\hline Old_Eff & 53783.5 & 73384.2 & 207.0 & & \\
\hline Old_Eff & 53876.6 & 73425.9 & 208.0 & & \\
\hline Old_Eff & 53967.2 & 73477.9 & 208.8 & & \\
\hline Old_Eff & 53981.3 & 73505.4 & 209.0 & & \\
\hline Old_Eff & 53997.3 & 73560.0 & 209.5 & & \\
\hline Old_Eff & 53998.1 & 73622.6 & 210.0 & & \\
\hline Old_Eff & 54006.0 & 73647.6 & 211.0 & & \\
\hline Old_Eff & 54017.8 & 73687.4 & 2.12 .0 & & \\
\hline Old_Eff & 54017.9 & 73716.3 & 213.0 & & \\
\hline Old_Eff & 54015.3 & 73740.4 & 214.0 & & \\
\hline Old_Eff & 54018.4 & 73756.6 & 215.0 & & \\
\hline Old_Eff & & & 54026.7 & 73786.6 & 216.0 \\
\hline Old_Eff & & & 54029.8 & 73811.1 & 217.0 \\
\hline Old_Eff & & & 54033.8 & 73833.6 & 218.0 \\
\hline OId_Eff & & & 54032.6 & $73857: 3$ & 219.0 \\
\hline Old_Eff & & & 54028.4 & 73873.2 & 220.0 \\
\hline Old_Eff & & & 54028.6 & 73896.5 & 221.0 \\
\hline Old_Eff & & & 54034.0 & 73938.8 & 222.0 \\
\hline Old_Eff & & & 54044.2 & 73976.3 & 222.5 \\
\hline Old_Eff & & & 54040.3 & 74018.4 & 223.0 \\
\hline Old_Eff & & & 54042.9 & 74064.2 & 224.0 \\
\hline Old_Eff & & & 54047.6 & 74081.6 & 225.0 \\
\hline Old_Eff & & & 54059.0 & 74108.1 & 226.0 \\
\hline Old_Eff & & & 54068.8 & 74131.7 & 227.0 \\
\hline Old_Eff & & & 54102.1 & 74202.2 & 228.0 \\
\hline Old_Eff & & & 54132.3 & 74247.2 & 229.0 \\
\hline Old_Eff & & & 54151.7 & 74273.4 & 230.0 \\
\hline Old_Eff & & & 54166.8 & .74294 .2 & 231.0 \\
\hline Old_Eff & & & 54193.1 & 74322.5 & 232.0 \\
\hline Old_Eff & & & 54216.4 & 74345.7 & 233.0 \\
\hline Old_Eff & & & 54302.4 & 74423.3 & 234.0 \\
\hline OId_Eff & & & 54363.2 & 74495.6 & 235.0 \\
\hline Old_Eff & & & 54374.1 & 74518.0 & 236.0 \\
\hline Old_Eff & & & 54374.7 & 74568.8 & 237.0 \\
\hline Old_Eff & & & 54366.0 & 74614.9 & 238.0 \\
\hline Old_Eff & & & 54365.5 & 74683.2 & 239.0 \\
\hline Old_Eff & & & 54352.0 & 74721.4 & 240.0 \\
\hline Old_Eff & & & 54296.5 & 74853.3 & 241.0 \\
\hline Old_Eff & & & 54282.2 & 74904.8 & 242.0 \\
\hline Old_Eff & & & 54233.1 & 74984.7 & 243.0 \\
\hline Old_Eff & & & 54208.0 & 75036.3 & 244.0 \\
\hline Old_Eff & & & 54201.4 & 75051.8 & 245.0 \\
\hline Old_Eff & & & 54194.6 & 75065.1 & 246.0 \\
\hline Old_Eff & & & 54181.4 & 75094.6 & 247.0 \\
\hline Old_Eff & & & 54147.6 & 75134.8 & 248.0 \\
\hline Old_Eff & & & 54119.4 & 75179.7 & 249.0 \\
\hline OId_Eff & & & 54112.9 & 75198.5 & 250.0 \\
\hline NewRock1 & 53463.3 & 73234.7 & 200.0 & & \\
\hline NewRock1 & 53470.1 & 73271.3 & 201.0 & & \\
\hline NewRock1 & 53469.4 & 73317.2 & 202.0 & & \\
\hline NewRock1 & 53468.9 & 73358.5 & 203.0 & & \\
\hline
\end{tabular}


Table A7. (cont'd)

\begin{tabular}{|c|c|c|c|c|c|c|}
\hline $\begin{array}{l}\text { Wel1 } \\
\text { Label }\end{array}$ & $\begin{array}{c}\text { SRS East } \\
(f t)\end{array}$ & $\begin{array}{c}\text { SRS North } \\
(f t)\end{array}$ & $\begin{array}{r}\text { Head } \\
(f t)\end{array}$ & & & \\
\hline NewRock1 & 53473.5 & 73393.1 & 204.0 & & & \\
\hline NewRock1 & 53481.6 & 73413.7 & 205.0 & & & \\
\hline NewRock1 & 53514.1 & 73467.5 & 208.0 & & & \\
\hline NewRockI & 53527.0 & 73527.9 & 210.0 & & & \\
\hline NewRock1 & 53549.6 & 73567.7 & 215.0 & & & \\
\hline NewRock1 & 53592.2 & 73621.4 & 220.0 & & & \\
\hline NewRock1 & & & & 53617.0 & 73707.2 & 225.0 \\
\hline NewRock1 & & & & 53640.2 & 73784.2 & 230.0 \\
\hline NewRockI & & & & 53664.9 & 73870.0 & 240.0 \\
\hline NewRock1 & & & & 53678.9 & 73915.9 & 242.5 \\
\hline NewRock2 & 53493.5 & 73266.9 & 201.0 & & & \\
\hline NewRock2 & 53532.7 & 73308.3 & $202 . c$ & & & \\
\hline NewRock2 & 53554.3 & 73349.1 & 203.0 & & & \\
\hline NewRock2 & 53564.6 & 73394.2 & 204.0 & & & \\
\hline NewRock2 & 53568.4 & 73424.3 & 205.0 & & . & \\
\hline NewRock2 & 53570.1 & 73450.3 & 210.0 & & & \\
\hline NewRock2 & 53571.7 & 73527.3 & 215.0 & & $\cdot$ & \\
\hline NewRock2 & 53591.9 & 73621.9 & 220.0 & & & \\
\hline NewConcr & & & & 53682.5 & 73922.9 & 244.7 \\
\hline NewConcr & & & & 54095.2 & 75317.4 & 247.7 \\
\hline PseudoDa & 51750 . & 72850 . & 185. & 185 & & \\
\hline PseudoDa & 51942. & 72740 & 186. & $18^{\prime}$ & & \\
\hline PseudoDa & 52100 . & 72600 & 187.5 & 190 & & \\
\hline PseudoDa & 52368 . & 72425 . & 191. & 191 & & \\
\hline PseudoDa & 52690 . & 72190. & 194. & 192 & & \\
\hline PseudoDa & 52966 . & 71990. & 195. & 193 & & \\
\hline PseudoDa & 53300 . & 71750. & 196. & 195 & & \\
\hline PseudoDa & 53589. & 71523. & 197. & 196 & & \\
\hline PseudoDa & 53917 . & 71285 . & 198. & 197 & & \\
\hline PseudoDa & 54270 & 71031. & 199. & 198 & 75 & \\
\hline
\end{tabular}


Table A8. Hydraulic head data used to create a head contour map for the "lower" aquifer zone (Figure 15).

\begin{tabular}{|c|c|c|c|c|}
\hline \multicolumn{2}{|c|}{$\begin{array}{l}\text { Well } \\
\text { Label }\end{array}$} & $\begin{array}{c}\text { SRS East } \\
( \pm t)\end{array}$ & $\begin{array}{l}\text { SRS North } \\
\text { (ft) }\end{array}$ & $\begin{array}{l}\text { Head } \\
(f t)\end{array}$ \\
\hline BG & 91 & 56649.0 & 78031.0 & 219.1 \\
\hline BG & 92 & 56828.0 & 79019.0 & 209.0 \\
\hline BG & 93 & 57160.0 & 79930.0 & 201. \\
\hline BG & 94 & 57494.0 & 80867.0 & 191 \\
\hline BG & 95 & 58407.0 & 80059.0 & 193 \\
\hline BG & 96 & 58297.0 & 79396.0 & 198 \\
\hline$B G$ & 101 & 59277.0 & 78740.0 & \\
\hline BG & 103 & 59752.0 & 77883.0 & 200 \\
\hline BG & 122 & 56789.0 & 78581.0 & 211 \\
\hline BGO & $5 c$ & 58794.0 & 76476.0 & 216 \\
\hline BGO & $6 \mathrm{~B}$ & 58346.0 & 76553.0 & \\
\hline BGO & $6 \mathrm{C}$ & 58307.0 & 76487.0 & 220 \\
\hline BGO & $8 C$ & 57618.0 & 76579.0 & 225 \\
\hline BGO & $10 \mathrm{~B}$ & 56978.0 & 76982.0 & 220 \\
\hline BGO & $10 \mathrm{C}$ & 57041.0 & 76805.0 & 220 \\
\hline BGO & $12 \mathrm{C}$ & 56241.0 & 76805.0 & 220 \\
\hline$B G O$ & $12 \mathrm{CR}$ & 56215.0 & 76806.0 & 222 \\
\hline BGO & $13 \mathrm{DR}$ & 55840.0 & 76824.0 & 232 \\
\hline BGO & $14 \mathrm{C}$ & 55839.0 & 76367.0 & 221 \\
\hline BGO & $14 \mathrm{CR}$ & 55789.0 & 76337.0 & 224 \\
\hline BGO & $16 \mathrm{~B}$ & 56183.0 & 75767.0 & 220 \\
\hline BGO & $27 \mathrm{C}$ & 54671.0 & 75666.0 & 220 \\
\hline BGO & $29 \mathrm{C}$ & 54099.0 & 75577.0 & 223 \\
\hline BGO & $30 \mathrm{C}$ & 54512.0 & 75181.0 & \\
\hline BGO & $31 \mathrm{C}$ & 54816.0 & 74978.0 & 225 \\
\hline BGO & $33 c$ & 55681.0 & 74479.0 & 224 \\
\hline BGO & $35 \mathrm{C}$ & 56545.0 & 73953.0 & 228 \\
\hline BGO & $37 c$ & 57279.0 & 73498.0 & \\
\hline BGO & $42 \mathrm{C}$ & 55522.0 & 76404.0 & 224 \\
\hline BGO & $43 \mathrm{CR}$ & 56237.0 & 77035.0 & 226 \\
\hline BGO & $43 \mathrm{D}$ & 56238.0 & 77056.0 & 232 \\
\hline BGO & $44 \mathrm{~B}$ & 57865.0 & 76756.0 & 221 \\
\hline BGO & $44 \mathrm{C}$ & 57894.0 & 76757.0 & 221 \\
\hline BGO & $45 B$ & 54563.0 & 75840.0 & 220 \\
\hline BGO & $45 \mathrm{C}$ & 54577.0 & 75835.0 & 223 \\
\hline BGO & $46 \mathrm{~B}$ & 54444.0 & 75012.0 & 218 \\
\hline BGO & $46 \mathrm{C}$ & 54433.0 & 75022.0 & 221 \\
\hline BGO & $47 \mathrm{C}$ & 54933.0 & 74752.0 & 223 \\
\hline BGO & $48 \mathrm{C}$ & 55124.0 & 74599.0 & 224 \\
\hline BGO & $49 \mathrm{C}$ & 56202.0 & 73917.0 & 229 \\
\hline BGO & $50 \mathrm{C}$ & 54197.0 & 75190.0 & 219 \\
\hline$B G X$ & $1 \mathrm{C}$ & 58599.0 & 76820.0 & 216 \\
\hline BGX & $2 \mathrm{~B}$ & 58256.0 & 77203.0 & 213 \\
\hline$B G X$ & 2D & 58265.0 & 77192.0 & 216 \\
\hline$B G X$ & 3D & 57780.0 & 77577.0 & 216 \\
\hline BGX & $4 \mathrm{C}$ & 57202.0 & 77886.0 & 215 \\
\hline $\mathrm{BGX}$ & $4 \mathrm{D}$ & 57186.0 & 77893.0 & 217 \\
\hline$B G X$ & 5D & 57308.0 & 78402.0 & 210 \\
\hline BGX & 6D & 57524.0 & 78740.0 & 207 \\
\hline $\mathrm{BGX}$ & 7D & 58312.0 & 78349.0 & 207 \\
\hline$B G X$ & 8DR & 58942.0 & 77589.0 & 206 \\
\hline BGX & $12 \mathrm{C}$ & 59675.0 & $74 \leq 27.0$ & 235 \\
\hline
\end{tabular}


Table A8. (cont'd)

\begin{tabular}{|c|c|c|c|c|}
\hline \multicolumn{2}{|c|}{$\begin{array}{l}\text { Well } \\
\text { Label }\end{array}$} & $\begin{array}{c}\text { SRS East } \\
(\mathrm{ft})\end{array}$ & $\begin{array}{l}\text { SRS North } \\
\text { (ft) }\end{array}$ & $\begin{array}{l}\text { Head } \\
(\mathrm{ft})\end{array}$ \\
\hline FAC & 4 & 55472.0 & 78223.0 & 228.9 \\
\hline FBP & $I A$ & 51080.0 & 78893.0 & 206.8 \\
\hline FBP & 4 & 51368.0 & 79320.0 & 211.6 \\
\hline FNB & 1 & 54271.0 & 80151.0 & 210. \\
\hline FNB & 2 & 54362.0 & 80442.0 & 207.0 \\
\hline FNB & 3 & 54105.0 & 80553.0 & 209.2 \\
\hline FNB & 4 & 53843.0 & 80409.0 & 213.1 \\
\hline FSB & $.76 \mathrm{C}$ & 51396.0 & 76112.0 & 212.7 \\
\hline FSB & $78 \mathrm{C}$ & 50170.0 & 74772.0 & 207.7 \\
\hline FSB & 790 & 50171.0 & 73668.0 & 196.6 \\
\hline FSB & $87 C$ & 50093.0 & 75591.0 & 208.4 \\
\hline FSB & $88 \mathrm{C}$ & 51518.0 & 75619.0 & 211.9 \\
\hline FSB & $89 \mathrm{C}$ & 51345.0 & 75553.0 & $211: 4$ \\
\hline FSB & $90 \mathrm{C}$ & 51148.0 & 75382.0 & 210.3 \\
\hline FSB & $91 \mathrm{C}$ & 50953.0 & 75213.0 & 210.3 \\
\hline FSB & $93 C$ & 50458.0 & 74897.0 & 208.4 \\
\hline FSB & $94 \mathrm{C}$ & 50180.0 & 74869.0 & 207.7 \\
\hline FSB & $95 C$ & 50016.0 & 74971.0 & 205.9 \\
\hline FSB & $95 \mathrm{CR}$ & 49987.0 & 75001.0 & 208.2 \\
\hline FSB & $97 \mathrm{C}$ & 49970.0 & 75179.0 & 207.7 \\
\hline FSB & $98 \mathrm{C}$ & 50116.0 & 75381.0 & 209.2 \\
\hline FSB & $99 \mathrm{C}$ & 50320.0 & 75683.0 & 209.2 \\
\hline FSB & $102 \mathrm{C}$ & .50834 .0 & 73582.0 & 195.1 \\
\hline FSB & $103 \mathrm{C}$ & 49651.0 & 74210.0 & 202.3 \\
\hline FSB & $104 \mathrm{C}$ & 49248.0 & 73872.0 & 200.5 \\
\hline FSB & $105 \mathrm{C}$ & 49828.0 & 75234.0 & 207.2 \\
\hline FSB & $106 \mathrm{C}$ & 50651.0 & 74190.0 & 201.1 \\
\hline FSB & $107 \mathrm{C}$ & 51158.0 & 75184.0 & 209.7 \\
\hline FSB & $110 \mathrm{C}$ & 50150.0 & 74190.0 & 201.6 \\
\hline FSB & $111 \mathrm{C}$ & 51526.0 & 75383.0 & 211. \\
\hline FSB & $112 \mathrm{C}$ & 48794.0 & 74227.0 & 202.6 \\
\hline FSB & $113 \mathrm{C}$ & 51084.0 & 74160.0 & 203. \\
\hline FSB & $114 \mathrm{C}$ & 52033.0 & 75288.0 & 213.8 \\
\hline FSB & $115 \mathrm{C}$ & 49736.0 & 72515.0 & 184.2 \\
\hline FSB & $116 \mathrm{C}$ & 50645.0 & 72725.0 & 189.6 \\
\hline FSB & $120 \mathrm{C}$ & 49171.0 & 75549.0 & 206.8 \\
\hline FSB & $121 \mathrm{C}$ & 48413.0 & 75155.0 & 205. \\
\hline FSB & $122 \mathrm{C}$ & 48195.0 & 73881.0 & 200 \\
\hline FSB & $123 \mathrm{C}$ & 51750.0 & 74566.0 & 210.8 \\
\hline $\mathrm{HC}$ & $1 \mathrm{~B}$ & 61877.0 & 71745.0 & 254.9 \\
\hline $\mathrm{HC}$ & $2 \mathrm{C}$ & 61872.0 & 71784.0 & 254.2 \\
\hline $\mathrm{HC}$ & $2 \mathrm{D}$ & 61866.0 & 71784.0 & 256.3 \\
\hline $\mathrm{HC}$ & $4 \mathrm{~A}$ & 63409.0 & 71606.0 & 244.7 \\
\hline $\mathrm{HC}$ & $5 A$ & 61710.0 & 73265.0 & 213.8 \\
\hline $\mathrm{HC}$ & $6 \mathrm{~A}$ & 62060.0 & 72150.0 & 252.2 \\
\hline $\mathrm{HC}$ & $10 B$ & 61600.0 & 75801.0 & 208.4 \\
\hline $\mathrm{HC}$ & $12 B$ & 59488.0 & 73186.0 & 241.6 \\
\hline HMD & 1D & 56973.0 & 78731.0 & 210.5 \\
\hline HMD & $2 \mathrm{D}$ & 57269.0 & 79665.0 & 202. \\
\hline HMD & $3 D$ & 57745.0 & 79578.0 & 201.8 \\
\hline HMD & $4 \mathrm{D}$ & 58188.0 & 79160.0 & 201.5 \\
\hline HSB & $65 B$ & 58439.0 & 72445.0 & \\
\hline & & & & \\
\hline
\end{tabular}


Table A8. (cont'd)

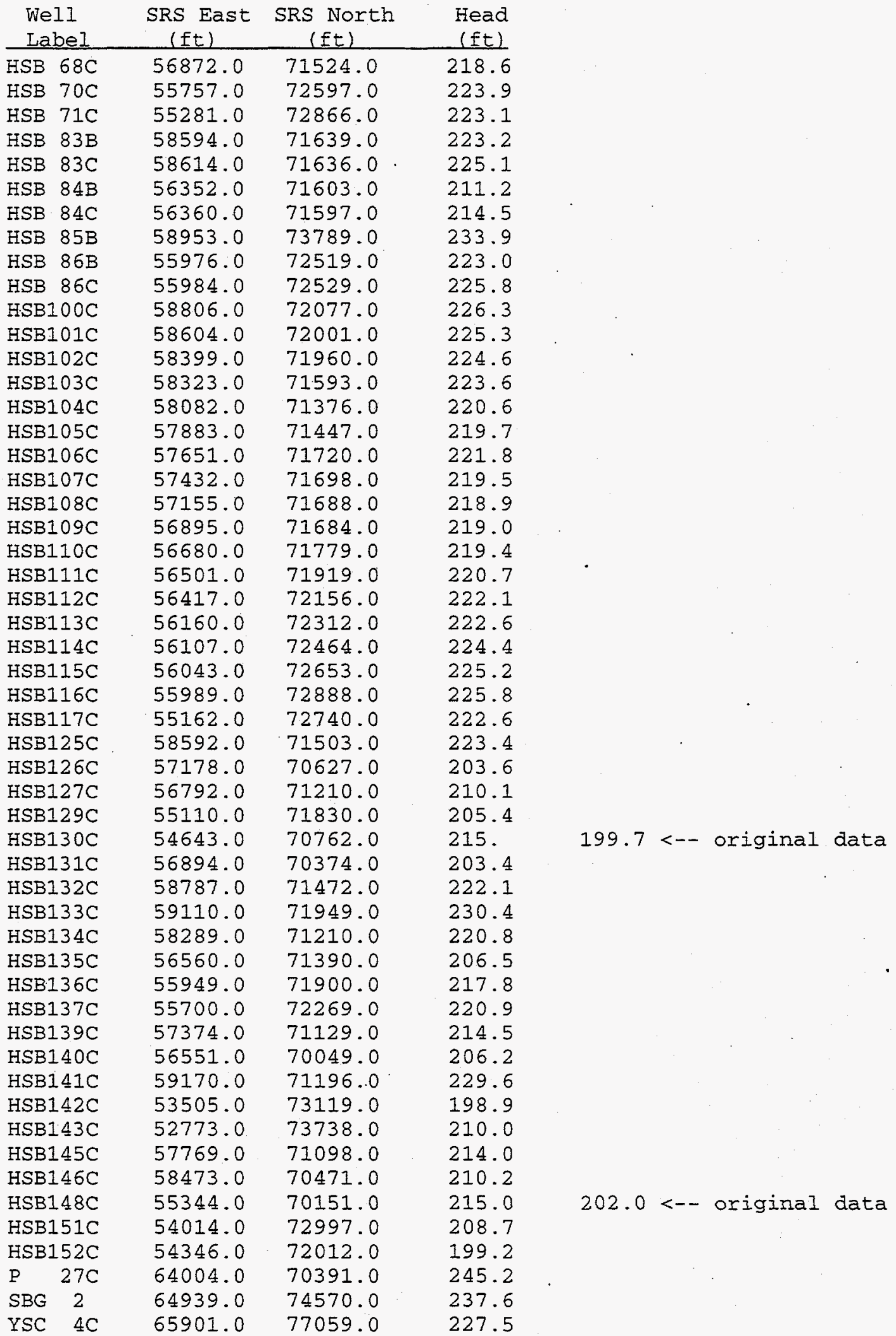


Table A8. (cont'd)

\begin{tabular}{|c|c|c|c|c|c|}
\hline $\begin{array}{l}\text { Wel1 } \\
\text { LabeI }\end{array}$ & $\begin{array}{c}\text { SRS East } \\
(f t)\end{array}$ & $\begin{array}{l}\text { SRS North } \\
(f t)\end{array}$ & $\begin{array}{l}\text { Head } \\
\text { (ft) }\end{array}$ & & \\
\hline $\mathrm{ZW} \quad 2$ & 54388.0 & 80701.0 & 207.1 & & \\
\hline$Z W$ & 57078.0 & 80746.0 & 201.1 & & \\
\hline$S-6$ & 53222.0 & 73440.0 & 204.6 & & \\
\hline 4Mile_Br & 50029.3 & 72800.3 & 185.3 & 180.3 & added 5 ' \\
\hline $4 \mathrm{Mi} l e \_\mathrm{Br}$ & 50312.7 & 72847.3 & 185.8 & 180.8 & \\
\hline $4 \mathrm{Mile}$ eBr & 50615.8 & 72896.9 & 186.4 & 181.4 & \\
\hline 4Mile_Br & 50896.9 & 72994.3 & 186.9 & 181.9 & $\mathrm{v}$ \\
\hline $4 \mathrm{Mile} \mathrm{Br}$ & 51118.2 & 73101.0 & 187.4 & 182.4 & \\
\hline 4Mile_Br & 51341.6 & 73101.1 & 187.8 & 182.8 & \\
\hline 4Mile_Br & 51559.4 & 73057.5 & 188.2 & 183.2 & \\
\hline $4 \mathrm{Mile} \mathrm{Br}$ & 51788.8 & 73046.8 & 188.6 & 183.6 & \\
\hline 4Mile_Br & 52022.8 & 73008.2 & 189.1 & 184.1 & \\
\hline 4Mile_Br & 52296.2 & 72960.0 & 189.6 & 184.6 & \\
\hline $4 \mathrm{Mile} \mathrm{Mr}$ & 52472.9 & 72918.5 & 189.9 & 184.9 & \\
\hline 4Mile_Br & 52747.9 & 72774.8 & 190.4 & 185.4 & \\
\hline 4Mile_Br & 52936.6 & 72630.3 & 190.8 & 185.8 & \\
\hline 4Mile_Br & 53122.8 & 72540.2 & 193.0 & 187.0 & \\
\hline $4 \mathrm{Mile} \mathrm{Br}$ & 53300.4 & 72471.1 & 195.0 & 190.0 & \\
\hline $4 \mathrm{Mile}$ ler & 53529.7 & 72301.9 & 195.6 & 190.6 & \\
\hline $4 \mathrm{Mile} B \mathrm{Br}$ & 53780.8 & 72088.7 & 196.2 & 191.2 & \\
\hline 4Mile_Br & 53860.6 & 71911.3 & 196.6 & 191.6 & \\
\hline $4 \mathrm{Mile} \mathrm{Br}$ & 53976.6 & 71778.1 & $196: 9$ & 191.9 & \\
\hline $4 \mathrm{Mile} B \mathrm{Br}$ & 54156.8 & 71663.4 & $197: 5$ & 192.5 & \\
\hline $4 \mathrm{Mile} \mathrm{Br}$ & 54479.6 & 71493.9 & 198.5 & 193.5 & \\
\hline 4Mile_Br & 54762.3 & 71307.2 & 199.6 & 194.6 & \\
\hline $4 \mathrm{Mile} \mathrm{Br}$ & 54989.8 & .71037 .5 & 200.9 & 195.9 & \\
\hline 4Mile_Br & 55215.6 & 70874.7 & 201.9 & 196.9 & \\
\hline 4Mile_Br & 55557.6 & 70871.5 & 203.1 & 198.1 & \\
\hline 4Mile_Br & 55859.7 & 70814.2 & 203.6 & 198.6 & \\
\hline 4Mile_Br & 56177.0 & 70737.8 & 204.2 & 199.2 & \\
\hline 4Mile_Br & 56555.9 & 70592.3 & 204.9 & 199.9 & \\
\hline $4 \mathrm{Mile} \mathrm{Br}$ & 56906.4 & 70491.2 & 205.8 & 200.8 & \\
\hline PseudoDa & 51750. & 72850 & 190. & 185. & \\
\hline PseudoDa & 51942 . & 72740 . & 195. & 187.5 & \\
\hline PseudoDa & 52100 & 72600 . & 205 . & 190. & \\
\hline PseudoDa & 52368 . & 72425 . & 215 . & 191.25 & \\
\hline PseudoDa & 52690 . & 72190 . & 215 . & 192.5 & . \\
\hline PseudoDa & 52966 . & 71990. & 215 . & 193.75 & \\
\hline PseudoDa & 53300 & 71750 . & 215 . & 195. & \\
\hline PseudoDa & 53589 . & 71523. & 215 . & 196.25 & \\
\hline PseudoDa & 53917 . & 71285. & 215 . & 197.5 & \\
\hline PseudoDa & 54270 . & 71031. & 215 . & 198.75 & \\
\hline
\end{tabular}


Table A9. Hydraulic head data used to create a head contour map for the Gordon aquifer (Figure 16).

\begin{tabular}{|c|c|c|c|c|}
\hline \multicolumn{2}{|c|}{$\begin{array}{l}\text { Well } \\
\text { Label }\end{array}$} & $\begin{array}{c}\text { SRS East } \\
\text { (It) }\end{array}$ & $\begin{array}{c}\text { SRS North } \\
\text { (ft) }\end{array}$ & $\begin{array}{l}\text { Head } \\
\text { (ft) }\end{array}$ \\
\hline $\mathrm{BGO}$ & $6 A$ & 58316.0 & 76487.0 & 159.0 \\
\hline BGO & $8 \mathrm{~A}$ & 57618.0 & 76569.0 & 160.5 \\
\hline BGO & $8 A R$ & 57617.0 & 76598.0 & 160.2 \\
\hline BGO & $9 A A$ & 57371.0 & 76975.0 & 157.7 \\
\hline BGO & $10 \mathrm{~A}$ & 57050.0 & 76805.0 & 169.0 \\
\hline BGO & $10 A A$ & 56990.0 & 76997.0 & 157.9 \\
\hline BGO & $10 \mathrm{AR}$ & 57063.0 & 76806.0 & 158.6 \\
\hline BGO & $12 \mathrm{~A}$ & 56250.0 & 76804.0 & 181.0 \\
\hline BGO & $12 \mathrm{AR}$ & 56259.0 & 76803.0 & 158.0 \\
\hline BGO & $14 \mathrm{~A}$ & 55838.0 & 76377.0 & 157.7 \\
\hline BGO & $14 \mathrm{AR}$ & 55788.0 & 76351.0 & 159.7 \\
\hline BGO & $16 \mathrm{~A}$ & 56194.0 & 75757.0 & 160.7 \\
\hline $\mathrm{BGO}$ & $16 \mathrm{AR}$ & 56217.0 & 75743.0 & 161.3 \\
\hline BGO & $18 \mathrm{~A}$ & 56699.0 & 75599.0 & 160.8 \\
\hline BGO & $25 \mathrm{~A}$ & 55668.0 & 76158.0 & 160.3 \\
\hline BGO & $26 \mathrm{~A}$ & 55014.0 & 76144.0 & 159.5 \\
\hline BGO & $29 A$ & 54103.0 & 75560.0 & 159.5 \\
\hline BGO & $41 \mathrm{~A}$ & 55403.0 & 76469.0 & 158.6 \\
\hline BGO & $43 \mathrm{~A}$ & 56253.0 & 77061.0 & 158.5 \\
\hline BGO & $43 A A$ & 56268.0 & 77066.0 & 156.8 \\
\hline BGO & $44 \mathrm{~A}$ & 57851.0 & 76755.0 & 158.6 \\
\hline BGO & $44 \mathrm{AA}$ & 57880.0 & 76757.0 & 158.7 \\
\hline BGO & $45 \mathrm{~A}$ & 54550.0 & 75830.0 & 160.9 \\
\hline BGO & $47 \mathrm{~A}$ & 54914.0 & 74728.0 & 162.7 \\
\hline BGO & $49 A$ & 56205.0 & 73902.0 & 165,6 \\
\hline BGO & $50 A$ & 54179.0 & 75201.0 & 160.1 \\
\hline$B G X$ & $1 A$ & 58590.0 & 76831.0 & 161.5 \\
\hline BGX & $4 \mathrm{~A}$ & 57215.0 & 77879.0 & 155.4 \\
\hline FSB & $76 \mathrm{~A}$ & 51391.0 & 76131.0 & 154.6 \\
\hline FSB & $76 \mathrm{~B}$ & 51394.0 & 76122.0 & 151.1 \\
\hline FSB & $78 \mathrm{~A}$. & 50172.0 & 74757.0 & 155.3 \\
\hline FSB & $78 B$ & 50178.0 & 74765.0 & 153.7 \\
\hline FSB & $79 A$ & 50149.0 & 73664.0 & 157.4 \\
\hline FSB & $79 B$ & 50159.0 & 73666.0 & 157.2 \\
\hline FSB & $87 \mathrm{~A}$ & 50115.0 & 75601.0 & 153.3 \\
\hline FSB & $87 \mathrm{~B}$ & 50104.0 & 75597.0 & 150.4 \\
\hline FSB & $96 \mathrm{~A}$ & 49778.0 & 74882.0 & 152.1 \\
\hline FSB & $96 \mathrm{AR}$ & 49746.0 & 74914.0 & 153.1 \\
\hline FSB & $97 A$ & 49965.0 & 75171.0 & 151.6 \\
\hline FSB & $98 \mathrm{~A}$ & 50121.0 & 75389.0 & 150.4 \\
\hline FSB & 98AR & 50105.0 & 75362.0 & 152.0 \\
\hline FSB & $99 A$ & 50314.0 & 75675.0 & 150.2 \\
\hline FSB1 & $.00 A$ & 50958.0 & 75534.0 & 150.9 \\
\hline FSB] & $01 \mathrm{~A}$ & 51191.0 & 75719.0 & 151.0 \\
\hline FSB1 & $12 \mathrm{~A}$ & 48809.0 & 74231.0 & 153.6 \\
\hline FSB] & $13 A$ & 51068.0 & 74167.0 & 158.6 \\
\hline FSBI & $14 \mathrm{~A}$ & 52046.0 & 75297.0 & 155.5 \\
\hline FSB] & $20 A$ & 49175.0 & 75538.0 & 148.3 \\
\hline $\mathrm{HC}$ & $1 \mathrm{~A}$ & 61867.0 & 71755.0 & 175.8 \\
\hline $\mathrm{HC}$ & $2 \mathrm{~A}$ & 61866.0 & 71794.0 & 176.3 \\
\hline $\mathrm{HC}$ & $2 B$ & 61876.0 & 71785.0 & 176.0 \\
\hline $\mathrm{HSB}$ & $65 A$ & 58436.0 & 72436.0 & 170.4 \\
\hline
\end{tabular}


Table A9. (cont'd)

\begin{tabular}{lccc}
$\begin{array}{c}\text { Well } \\
\text { Label }\end{array}$ & $\begin{array}{c}\text { SRS East } \\
\text { (ft) }\end{array}$ & $\begin{array}{c}\text { SRS North } \\
\text { (ft) }\end{array}$ & $\begin{array}{c}\text { Head } \\
\text { (ft) }\end{array}$ \\
\hline HSB 68A & 56892.0 & 71526.0 & 171.0 \\
HSB 69A & 56465.0 & 71549.0 & 171.4 \\
HSB 83A & 58606.0 & 71648.0 & 172.5 \\
HSB 84A & 56359.0 & 71586.0 & 171.2 \\
HSB 85A & 58943.0 & 73791.0 & 168.3 \\
HSB 86A & 55985.0 & 72520.0 & 167.8 \\
HSB117A & 55170.0 & 72733.0 & 166.3 \\
HSB118A & 55775.0 & 72696.0 & 166.8 \\
HSB119A & 56100.0 & 73082.0 & 166.2 \\
HSB120A & 56431.0 & 73395.0 & 165.6 \\
HSB121A & 57389.0 & 72024.0 & 170.8 \\
HSB122A & 57747.0 & 72195.0 & 170.5 \\
HSB123A & 58124.0 & 72189.0 & 171.8 \\
HSB124A & 58514.0 & 72199.0 & 191.7 \\
HSB124AR & 58531.0 & 72202.0 & 172.4 \\
HSB139A & 57365.0 & 71127.0 & 172.8 \\
HSB140A & 56535.0 & 70050.0 & 175.8 \\
HSB141A & 59168.0 & 71213.0 & 175.0 \\
HSB144A & 56200.0 & 71892.0 & 170.9 \\
HSB146A & 58454.0 & 70478.0 & 176.1 \\
P 27B & 64000.0 & 70405.0 & 181.2 \\
YSC 1A & 65438.0 & 78039.0 & 161.3 \\
YSC 2A & 66100.0 & 78311.0 & 162.6 \\
YSC 5A & 67134.0 & 74295.0 & 180.5
\end{tabular}


Table A10. Hydraulic head targets used to calibrate flow model and residuals.

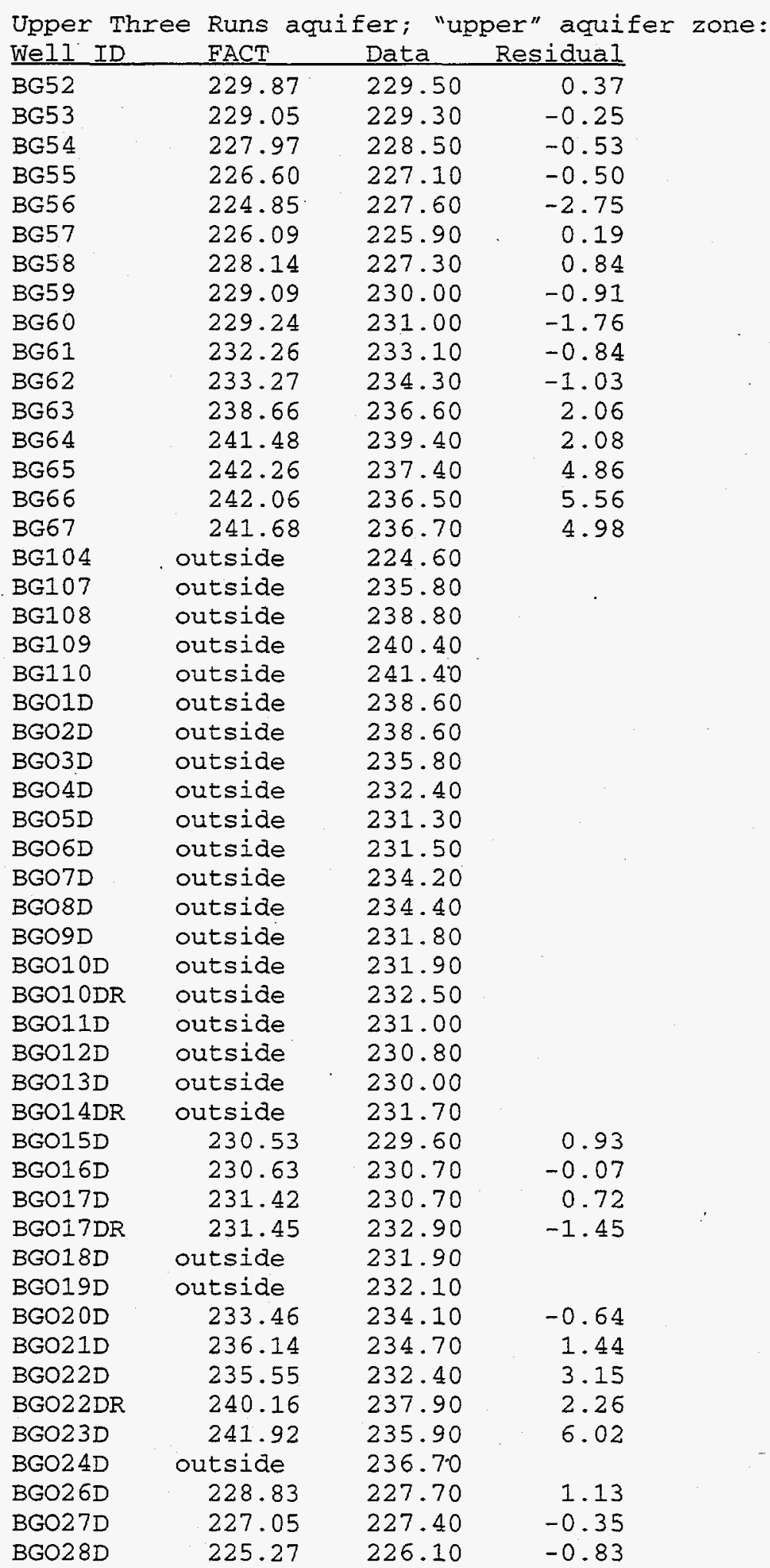


Table A10. (cont'd)

\begin{tabular}{|c|c|c|c|}
\hline Well ID & FACT & Data & Residual \\
\hline $\mathrm{BGO} 29 \mathrm{D}$ & 224.33 & 227.50 & -3.17 \\
\hline BGO30D & 224.87 & 225.70 & -0.83 \\
\hline BG031D & 226.15 & 226.60 & -0.45 \\
\hline $\mathrm{BGO} 32 \mathrm{D}$ & 227.86 & 227.50 & 0.36 \\
\hline BGO33D & 229.14 & 230.20 & -1.06 \\
\hline BG034D & 229.30 & 232.80 & -3.50 \\
\hline BGO35D & 233.76 & 234.30 & -0.54 \\
\hline $\mathrm{BGO36D}$ & 238.84 & 236.40 & 2.44 \\
\hline $\mathrm{BGO} 37 \mathrm{D}$ & 241.46 & 237.70 & 3.76 \\
\hline BGO38D & 241.61 & 235.30 & 6.31 \\
\hline BGO39D & 241.99 & 235.00 & 6.99 \\
\hline BGO4OD & 227.39 & 223.60 & 3.79 \\
\hline $\mathrm{BGO} 44 \mathrm{D}$ & outside & 232.70 & \\
\hline BGO45D & 226.86 & 228.80 & -1.94 \\
\hline BGO46D & 223.72 & 226.40 & -2.68 \\
\hline$B G O 47 D$ & 225.19 & 227.40 & -2.21 \\
\hline BGO48D & 225.38 & 227.80 & -2.42 \\
\hline BGO49D & 230.29 & 235.80 & -5.51 \\
\hline BGO50D & 223.28 & 226.20 & -2.92 \\
\hline BGX1D & outside & 230.00 & \\
\hline BGX9D & outside & 227.30 & \\
\hline BGX1OD & outside & 226.60 & \\
\hline BGX11D & outside & 236.80 & \\
\hline$B G X 12 D$ & outside & 240.40 & \\
\hline BRR1D & outside & 216.60 & \\
\hline BRR2D & outside & 215.40 & \\
\hline BRR3D & outside & 215.10 & \\
\hline BRR4D & outside & 214.80 & \\
\hline BRR5D & outside & 215.10 & \\
\hline FAC3 & outside & 230.50 & \\
\hline FAC4 & outside & 228.90 & \\
\hline FAC5 & outside & 224.30 & \\
\hline FAC5P & outside & 230.60 & \\
\hline $\mathrm{FAC7}$ & outside & 221.80 & \\
\hline FAC 8 & outside & 226.50 & \\
\hline FAL1 & outside & 218.70 & \\
\hline FAL2 & outside & 217.10 & \\
\hline FCA1N & outside & 299.20 & \\
\hline FCA2C & outside & 298.00 & \\
\hline FCA2D & outside & 225.40 & \\
\hline FCA9D & outside & 225.60 & \\
\hline FCA10A & outside & 225.30 & \\
\hline FCA10C & outside & 302.30 & \\
\hline FCA10D & outside & 226.50 & \\
\hline FCA16A & outside & 225.20 & \\
\hline FCA16D & outside & 225.20 & \\
\hline FCA16T & outside & 297.60 & \\
\hline FCA19D & outside & 217.00 & \\
\hline FCB2 & 230.27 & 231.00 & -0.73 \\
\hline FCB3 & 228.38 & 223.20 & 5.18 \\
\hline FCB5 & 228.75 & 228.50 & 0.25 \\
\hline FCB6 & 228.90 & 228.90 & 0.00 \\
\hline FET1D & 223.02 & 223.40 & -0.38 \\
\hline
\end{tabular}


Table A10. (cont'd)

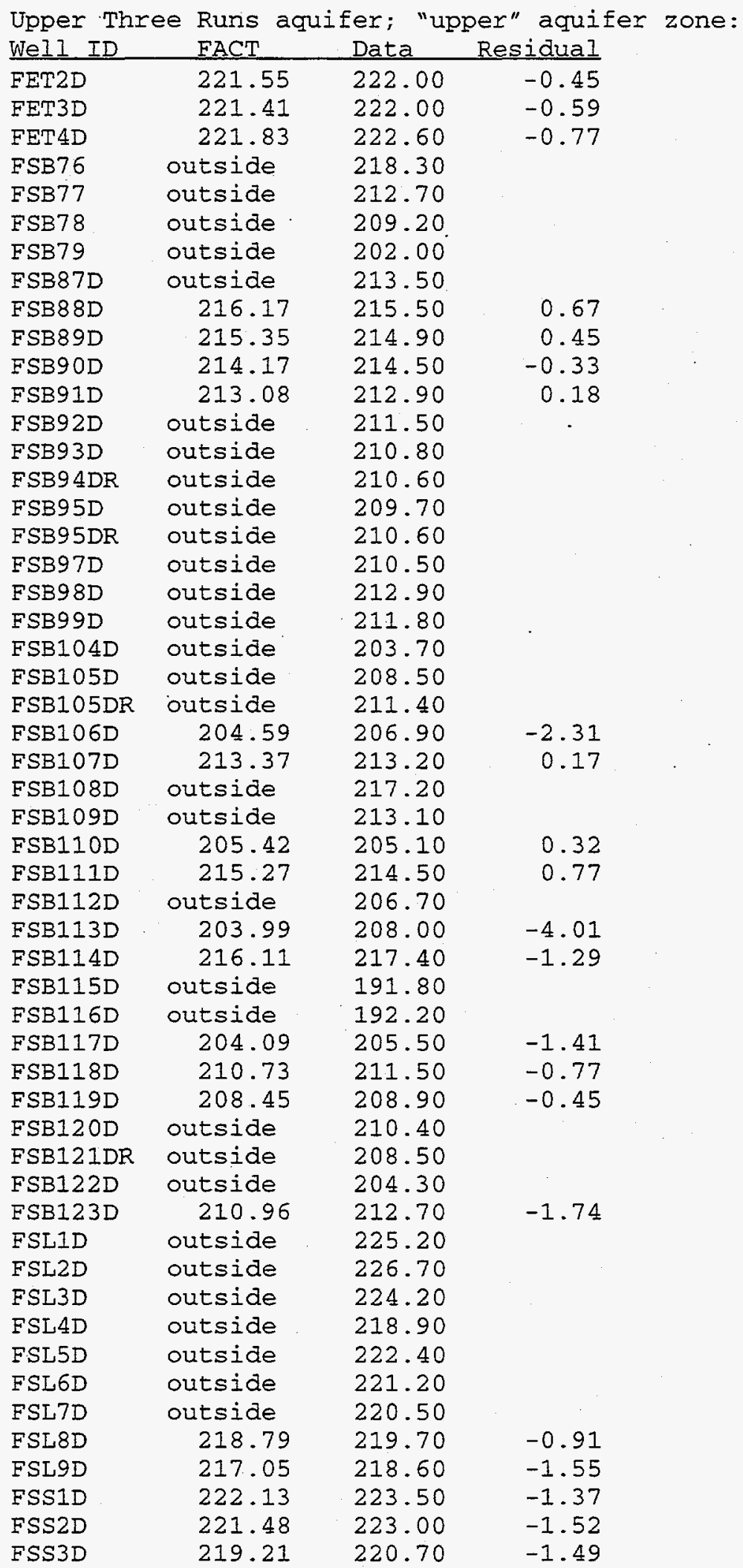


Table A10. (cont'd)

Upper Three Runs aquifer; "upper" aquifer zone:

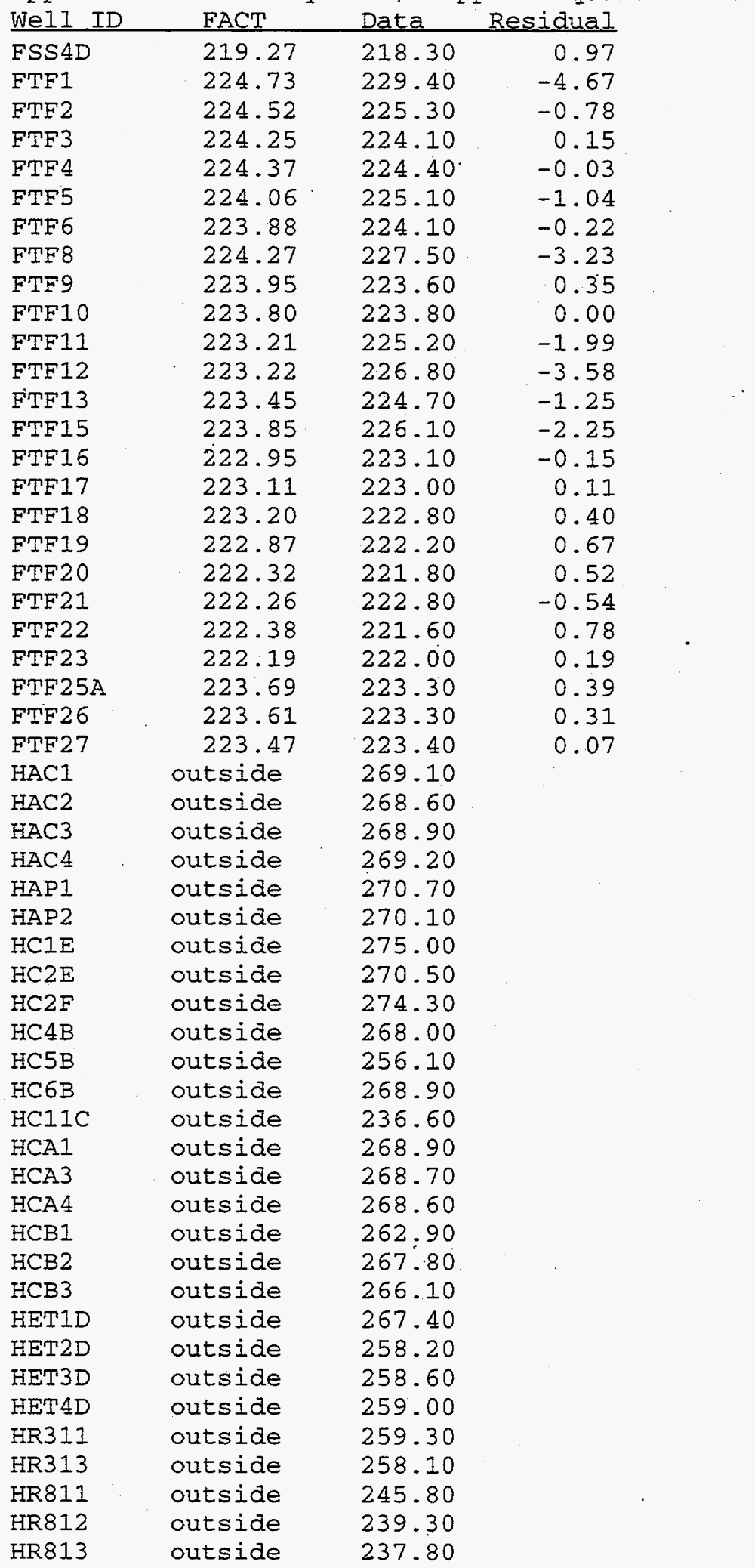


Table A10. (cont'd)

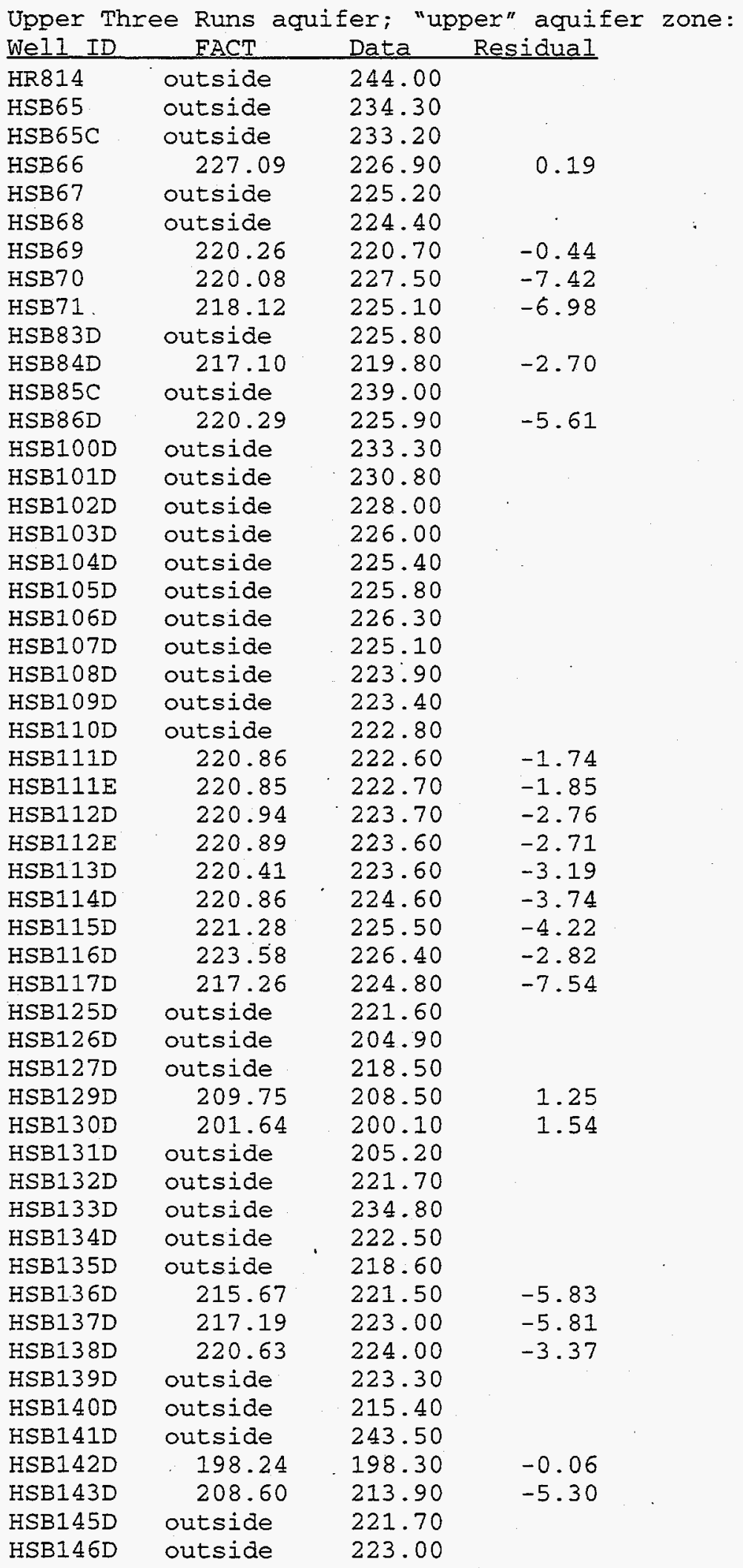


Table A10. (cont'd)

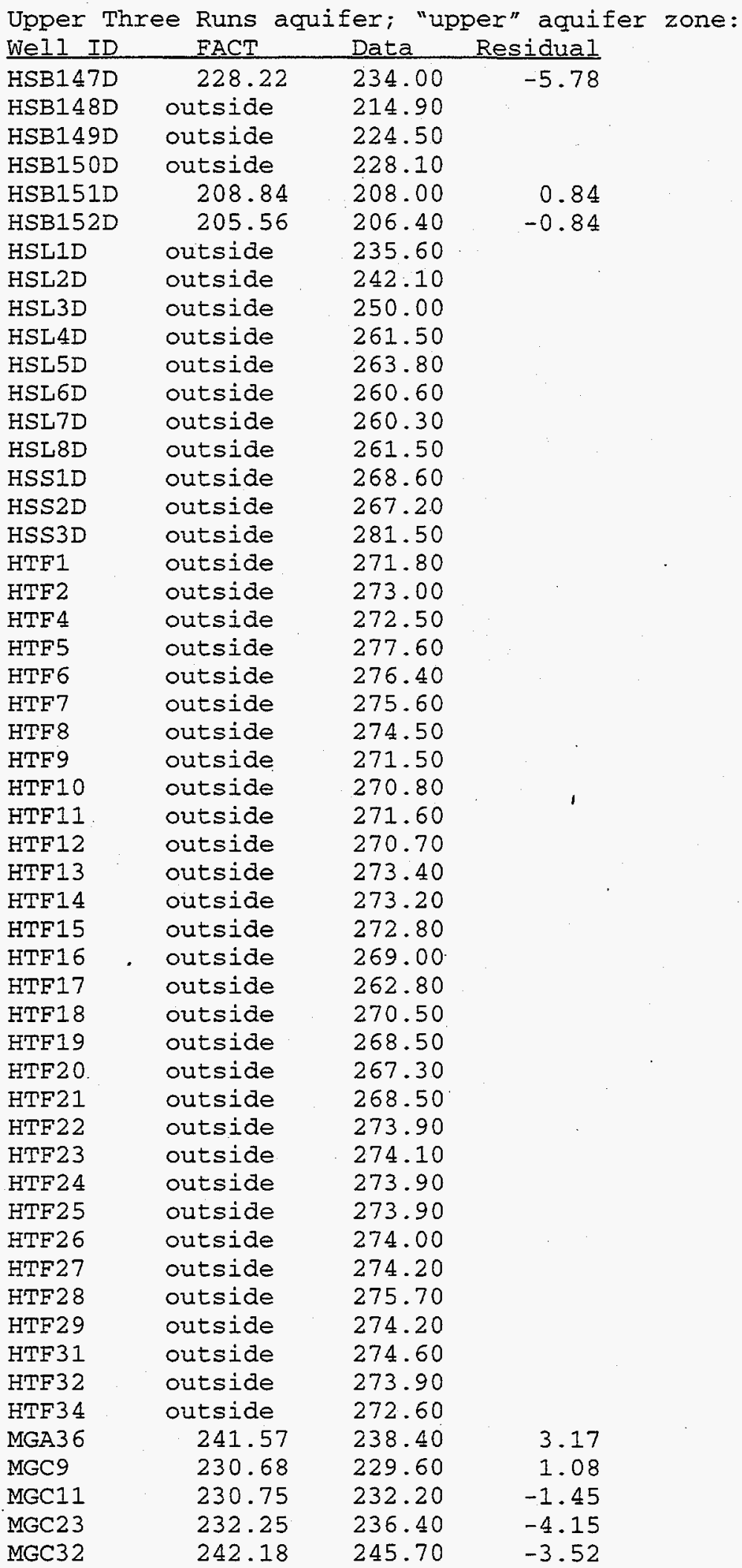


Table A10. (cont'd)

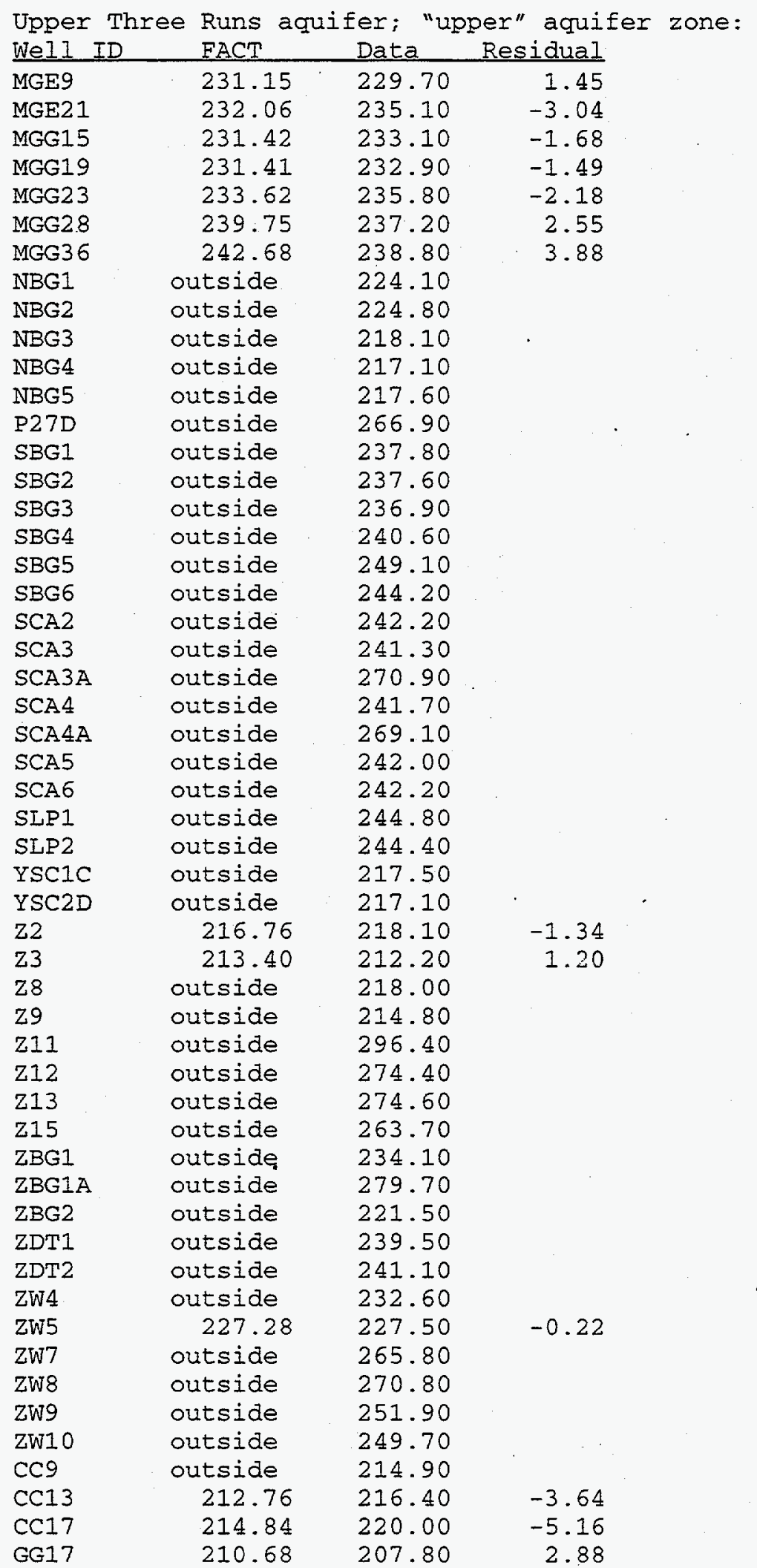


Table A10. (cont'd)

$\begin{array}{llll}\text { Upper Three Runs aquifer; "upper" aquifer zone: } \\ \text { Wel1 ID } & \text { FACT } & \text { Data } & \text { Residual } \\ \text { GG21 } & 212.30 & 211.80 & 0.50 \\ \text { M5 } & 224.75 & 228.60 & -3.85 \\ \text { M9 } & 226.14 & 228.00 & -1.86 \\ \text { M17 } & 228.17 & 235.00 & -6.83 \\ \text { M21 } & 230.83 & 237.90 & -7.07 \\ \text { Q5 } & 221.39 & 226.00 & -4.61 \\ \text { Q9 } & 223.07 & 226.90 & -3.83 \\ \text { Q13 } & 224.20 & 227.40 & -3.20 \\ \text { Q17 } & 231.63 & 241.60 & -9.97 \\ \text { Q21 } & 226.93 & 233.10 & -6.17 \\ \text { S3 } & 219.14 & 224.00 & -4.86 \\ \text { S4 } & 216.51 & 222.10 & -5.59 \\ \text { S5 } & \text { outside } & 221.00 & \\ \text { S6 } & 206.49 & 204.60 & 1.89 \\ \text { S9 } & 220.06 & 226.10 & -6.04 \\ \text { S15 } & 222.82 & 231.50 & -8.68 \\ \text { S16 } & 220.23 & 226.20 & -5.97 \\ \text { U5 } & 218.20 & 223.00 & -4.80 \\ \text { U9 } & 219.12 & 223.80 & -4.68 \\ \text { U13 } & 220.77 & 232.40 & -11.63 \\ \text { U17 } & 222.17 & 226.20 & -4.03 \\ \text { U21 } & 223.06 & 227.3 .0 & -4.24 \\ \text { Y7 } & 213.68 & 218.20 & -4.52 \\ \text { Y9 } & 214.42 & 220.80 & -6.38 \\ \text { Y13 } & 215.84 & 223.20 & -7.36 \\ \text { Y17 } & 217.75 & 224.70 & -6.95 \\ \text { Y21 } & 219.18 & 224.00 & -4.82 \\ & & & \end{array}$

Upper Three Runs aquifer; "Iower" aquifer zone:

\begin{tabular}{lcll} 
We11 ID & FACT & Data & Residual \\
\hline BG91 & outside & 219.10 & \\
BG92 & outside & 209.00 & \\
BG93 & outside & 201.10 & \\
BG94 & outside & 191.40 & \\
BG95 & outside & 193.30 & \\
BG96 & outside & 198.50 & \\
BG101 & outside & 195.70 & \\
BG103 & outside & 200.40 & \\
BG122 & outside & 211.30 & \\
BG05C & outside & 216.60 & \\
BG06B & outside & 219.70 & \\
BG06C & outside & 220.10 & \\
BG08C & outside & 225.40 & \\
BGO10B & outside & 220.90 & \\
BG010C & outside & 220.20 & \\
BG012C & outside & 220.00 & \\
BG012CR & outside & 222.40 & \\
BG013DR & outside & 232.20 & \\
BG014C & outside & 221.00 & \\
BG014CR & outside & 224.90 & \\
BGO16B & 220.89 & 220.30 & 0.59 \\
BGO27C & 222.86 & 220.30 & 2.56
\end{tabular}


Table A10. (cont'd)

\begin{tabular}{|c|c|c|c|}
\hline $\begin{array}{l}\text { Upper Th } \\
\text { Well ID }\end{array}$ & $\begin{array}{l}e \text { Runs a } \\
\text { FACT }\end{array}$ & Data & $\begin{array}{l}\text { jer" aqui } \\
\text { Residual }\end{array}$ \\
\hline $\mathrm{BGO} 29 \mathrm{C}$ & 221.01 & 223.90 & -2.89 \\
\hline$B G 030 \mathrm{C}$ & 220.53 & 219.10 & 1.43 \\
\hline$B G 031 C$ & 220.62 & 225.50 & -4.88 \\
\hline$B G 033 C$ & 222.06 & 224.90 & -2.84 \\
\hline BGO35C & 224.77 & 228.30 & -3.53 \\
\hline BGO37C & 226.81 & 229.10 & -2.29 \\
\hline $\mathrm{BGO} 42 \mathrm{C}$ & outside & 224.40 & \\
\hline $\mathrm{BGO} 43 \mathrm{CR}$ & outside & 226.60 & \\
\hline $\mathrm{BGO43D}$ & outside & 232.30 & \\
\hline BGO44B & outside & 221.90 & \\
\hline $\mathrm{BGO} 44 \mathrm{C}$ & outside & 221.70 & \\
\hline $\mathrm{BGO} 45 \mathrm{~B}$ & 223.22 & 220.60 & 2.62 \\
\hline BGO $45 \mathrm{C}$ & 223.57 & 223.90 & -0.33 \\
\hline $\mathrm{BGO} 46 \mathrm{~B}$ & 218.71 & 218.90 & -0.19 \\
\hline $\mathrm{BGO} 46 \mathrm{C}$ & 219.49 & 221.10 & -1.61 \\
\hline BGO $47 \mathrm{C}$ & 220.39 & 223.70 & -3.31 \\
\hline BGO48C & 220.51 & 224.50 & -3.99 \\
\hline BGO $49 \mathrm{C}$ & 224.01 & 229.00 & -4.99 \\
\hline BGO5OC & 219.27 & 219.50 & -0.23 \\
\hline BGX1C & outside & 216.90 & \\
\hline$B G X 2 B$ & outside & 213.30 & . \\
\hline BGX2D & outside & 216.30 & \\
\hline$B G \times 3 D$ & outside & 216.10 & \\
\hline BGX4C & outside & 215.90 & \\
\hline$B G X 4 D$ & outside & 217.00 & \\
\hline$B G \times 5 D$ & outside & 210.60 & \\
\hline$B G \times 6 D$ & outside & 207.60 & \\
\hline BGX7D & outside & 207.70 & \\
\hline BGX8DR & outside & 206.50 & \\
\hline $\mathrm{BGX} 12 \mathrm{C}$ & outside & 235.70 & \\
\hline FAC4 & outside & 228.90 & \\
\hline FBP1A & outside & 206.80 & \\
\hline FBP4 & outside & 211.60 & \\
\hline FNB1 & outside & 210.80 & \\
\hline FNB2 & outside & 207.00 & \\
\hline FNB3 & outside & 209.20 & - \\
\hline FNB4 & outside & 213.10 & \\
\hline FSB $76 C$ & outside & 212.70 & \\
\hline FSB78C & outside & 207.70 & \\
\hline FSB79C & outside & 196.60 & \\
\hline FSB87C & outside & 208.40 & \\
\hline FSB88C & 213.23 & 211.90 & 1.33 \\
\hline FSB $89 C$ & 212.65 & 211.40 & 1.25 \\
\hline FSB9OC & 212.43 & 210.30 & 2.13 \\
\hline FSB91C & 210.63 & 210.30 & 0.33 \\
\hline FSB93C & outside & 208.40 & \\
\hline FSB94C & outside & 207.70 & \\
\hline FSB95C & outside & 205.90 & \\
\hline FSB95CR & outside & 208.20 & \\
\hline FSB97C & outside & 207.70 & \\
\hline FSB98C & outside & 209.20 & \\
\hline FSB99C & outside & 209.20 & \\
\hline FSB102C & 194.63 & 195.10 & -0.47 \\
\hline
\end{tabular}


Table A10. (cont'd)

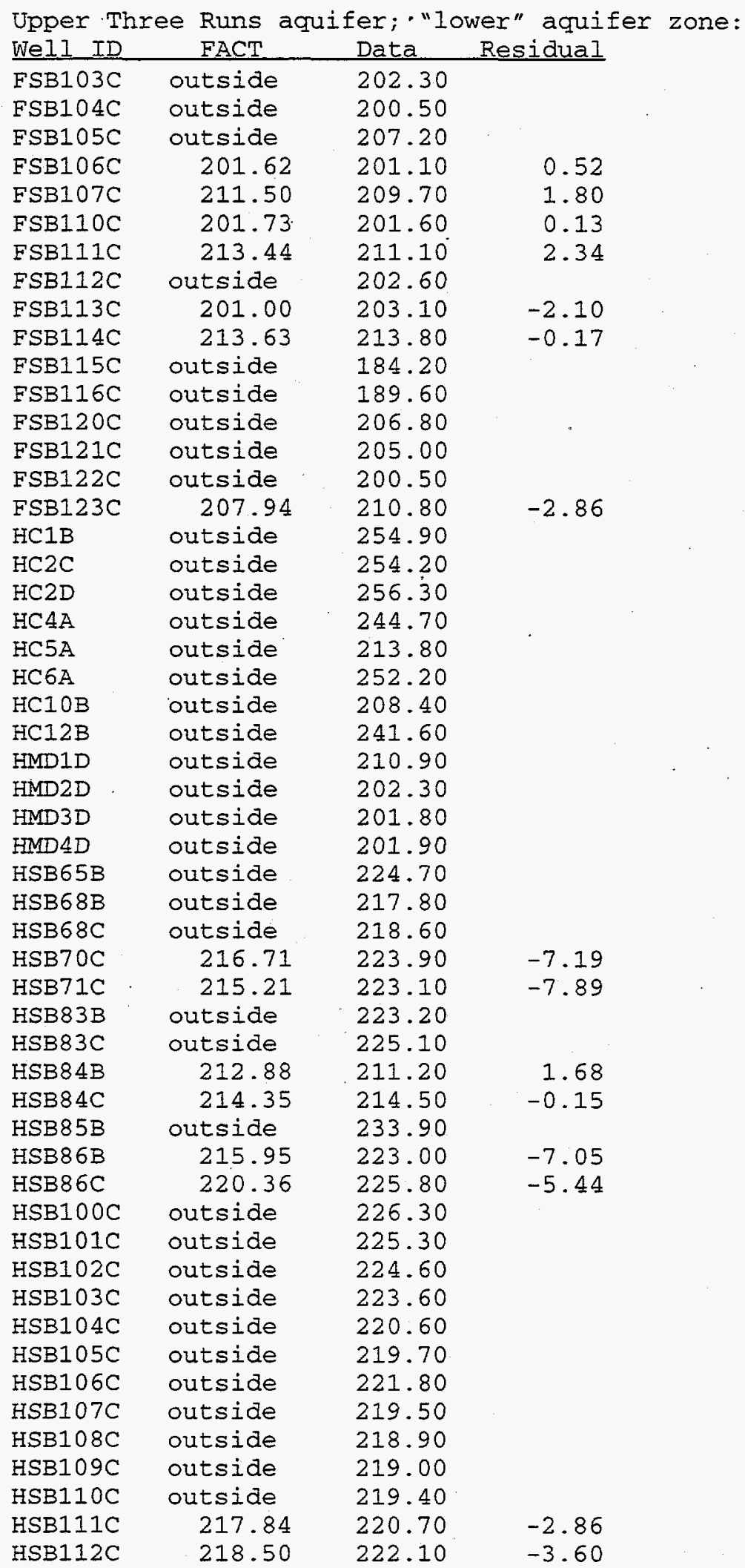


Table A10. (cont'd)

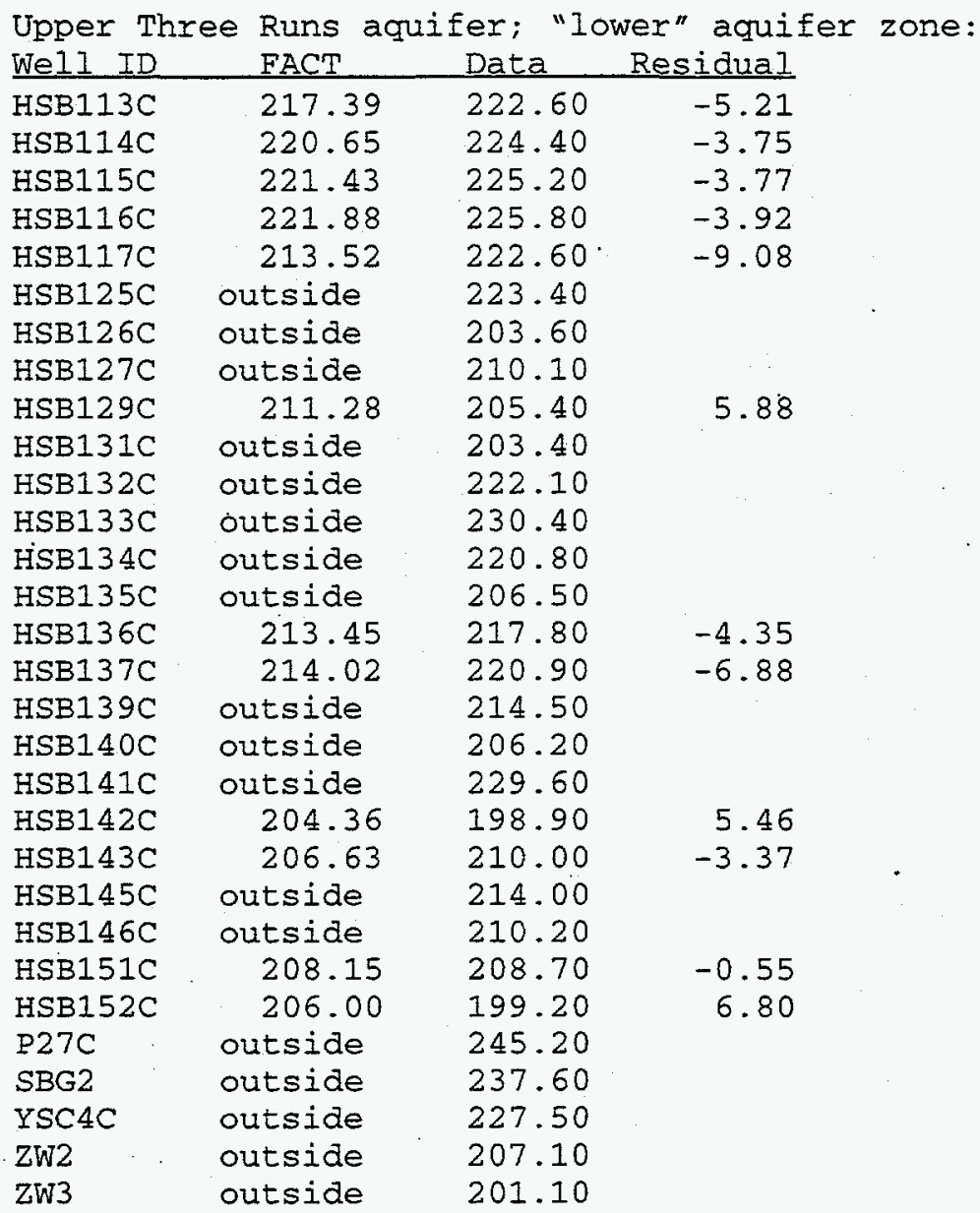

Gordon aquifer:

\begin{tabular}{|c|c|c|c|}
\hline WelI ID & FACT & Data & Residual \\
\hline BG06A & outside & 159.00 & \\
\hline BGO8A & outside & 160.50 & \\
\hline BGO8AR & outside & 160.20 & \\
\hline BGO9AA & outside & 157.70 & \\
\hline BGO10A & outside & 169.00 & \\
\hline BGO10AA & outside & .157 .90 & \\
\hline BGO10AR & outside & 158.60 & \\
\hline BGO12A & outside & 181.00 & \\
\hline BGO12AR & outside & 158.00 & \\
\hline BGO14A & outside & 157.70 & \\
\hline BGO14AR & outside & 159.70 & \\
\hline BG016A & 161.27 & 160.70 & 0.57 \\
\hline BGO16AR & 161.28 & 161.30 & -0.02 \\
\hline BGO18A & outside & 160.80 & \\
\hline $\mathrm{BGO} 25 \mathrm{~A}$ & 159.18 & 160.30 & -1.12 \\
\hline $\mathrm{BGO} 26 \mathrm{~A}$ & 159.09 & 159.50 & -0.41 \\
\hline $\mathrm{BGO} 29 \mathrm{~A}$ & 159.54 & 159.50 & 0.04 \\
\hline BGO41A & outside & 158.60 & \\
\hline BGO43A & outside & 158.50 & \\
\hline
\end{tabular}


Table A10. (cont'd)

Gordon aquifer:

\begin{tabular}{|c|c|c|c|}
\hline Wel I ID & FACT & Data & Residual \\
\hline $\mathrm{BG} 043 \mathrm{AA}$ & outside & 156.80 & \\
\hline $\mathrm{BGO} 44 \mathrm{~A}$ & outside & 158.60 & \\
\hline $\mathrm{BGO} 44 \mathrm{AA}$ & outside & 158.70 & \\
\hline BG045A & 159.53 & 160.90 & -1.37 \\
\hline $\mathrm{BGO} 47 \mathrm{~A}$ & 161.87 & 162.70 & -0.83 \\
\hline $\mathrm{BGO} 49 \mathrm{~A}$ & 164.73 & 165.60 & -0.87 \\
\hline $\mathrm{BG} 050 \mathrm{~A}$ & 160.12 & 160.10 & 0.02 \\
\hline BGX1A & outside & 161.50 & \\
\hline$B G X 4 A$ & outside & 155.40 & \\
\hline FSB76A & outside & 154.60 & \\
\hline FSB76B & outside & 151.10 & \\
\hline FSB78A & outside & 155.30 & \\
\hline FSB78B & outside & 153.70 & \\
\hline FSB79A & outside & 157.40 & \\
\hline FSB79B & outside & 157.20 & \\
\hline FSB87A & outside & 153.30 & \\
\hline FSB87B & outside & 150.40 & \\
\hline FSB96A & outside & 152.10 & \\
\hline FSB96AR & outside & 153.10 & \\
\hline FSB97A & outside & 151.60 & \\
\hline FSB98A & outside & 150.40 & \\
\hline FSB98AR & outside & 152.00 & \\
\hline FSB99A & outside & 150.20 & \\
\hline FSB100A & outside & 150.90 & \\
\hline FSB101A & 151.19 & 151.00 & 0.19 \\
\hline FSB112A & outside & 153.60 & \\
\hline FSB113A & 157.72 & 158.60 & -0.88 \\
\hline FSB114A & 156.06 & 155.50 & 0.56 \\
\hline FSB120A & outside & 148.30 & \\
\hline $\mathrm{HC} 1 \mathrm{~A}$ & outside & 175.80 & \\
\hline $\mathrm{HC} 2 \mathrm{~A}$ & outside & 176.30 & \\
\hline $\mathrm{HC} 2 \mathrm{~B}$ & outside & 176.00 & \\
\hline HSB65A & outside & 170.40 & \\
\hline HSB $68 \mathrm{~A}$ & outside & 171.00 & \\
\hline HSB69A & 171.45 & 171.40 & 0.05 \\
\hline HSB83A & outside & 172.50 & \\
\hline HSB $84 A$ & 171.24 & 171.20 & 0.04 \\
\hline HSB $85 A$ & outside & 168.30 & \\
\hline HSB8 6 A & 168.23 & 167.80 & 0.43 \\
\hline HSB117A & 167.02 & 166.30 & 0.72 \\
\hline HSB118A & 167.59 & 166.80 & 0.79 \\
\hline HSB119A & 166.80 & 166.20 & 0.60 \\
\hline $\mathrm{HSB} 120 \mathrm{~A}$ & 166.16 & 165.60 & 0.56 \\
\hline HSB121A & outside & 170.80 & \\
\hline $\mathrm{HSB} 122 \mathrm{~A}$ & outside & 170.50 & \\
\hline HSB123A & outside & 171.80 & \\
\hline HSB1 24A & outside & 191.70 & \\
\hline HSB1 24AR & outside & 172.40 & \\
\hline HSB139A & outside & 172.80 & \\
\hline HSB140A & outside & 175.80 & \\
\hline HSB141A & outside & 175.00 & \\
\hline HSB144A & 170.21 & 170.90 & -0.69 \\
\hline HSB146A & outside & 176.10 & \\
\hline
\end{tabular}


Table A10. (cont'd)

Gordon aquifer:

Well ID FACT

P27B

outside

YSC1A outside

YSC2A outside

YSC5A

outside

Data

Residual

181.20

161.30

162.60

180.50 


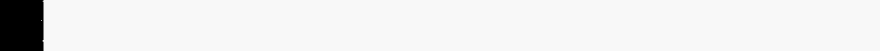

